


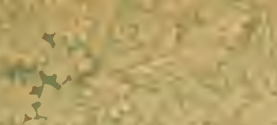

Thes

3.

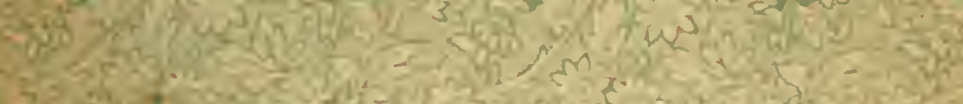

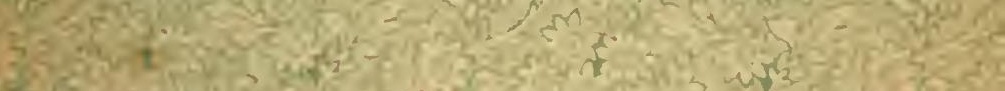

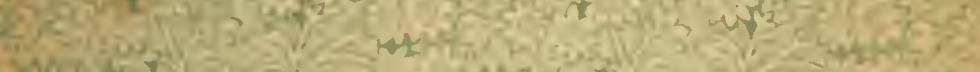

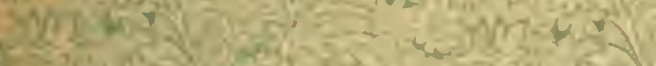

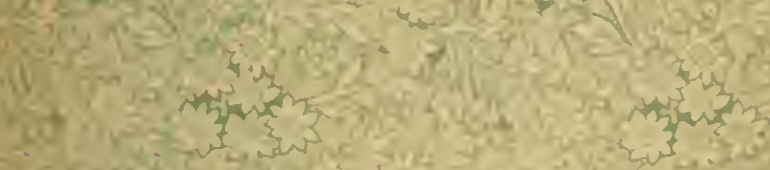

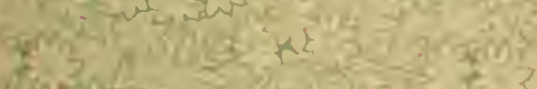

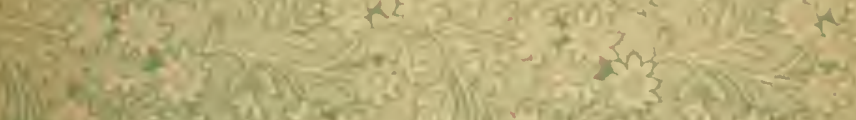

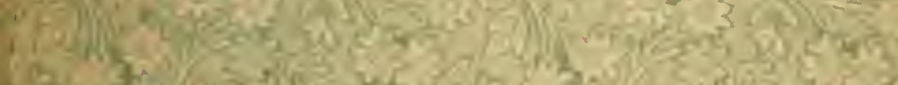

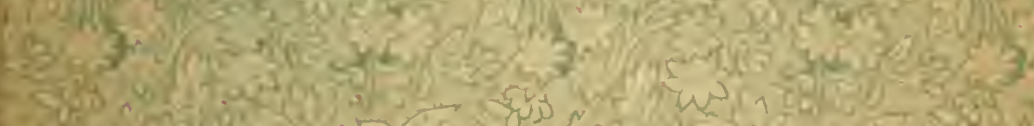

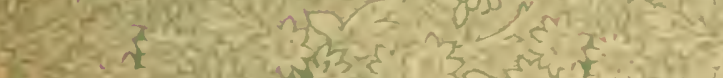

1.
3oints
a.

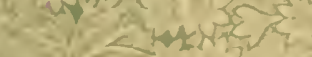

Non

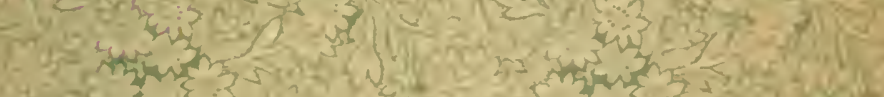

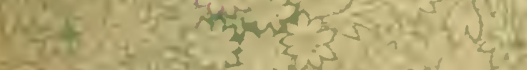

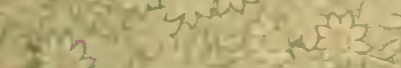

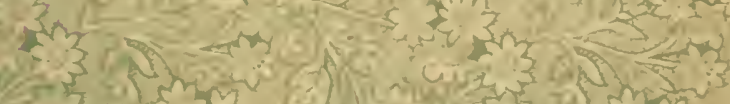
$7 x^{*}$

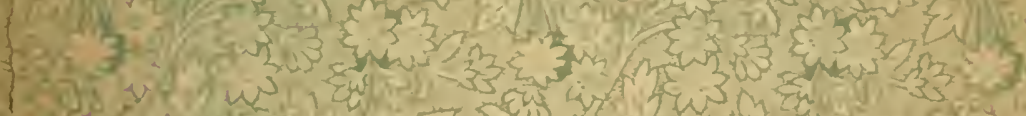

a

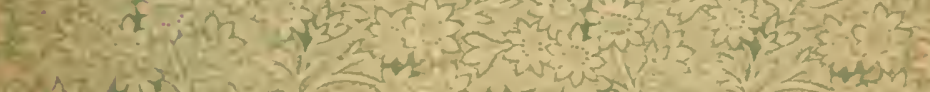

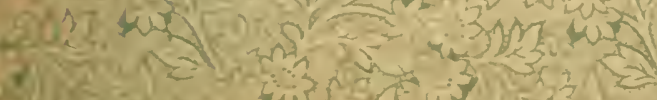

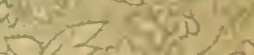
( 



\section{TALKS ON MANURES.}

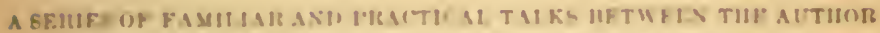

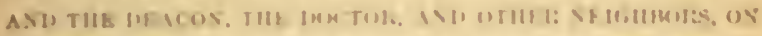

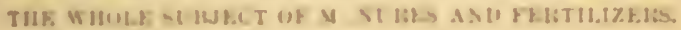

BY

JOSEPII HARRIS, M. S.

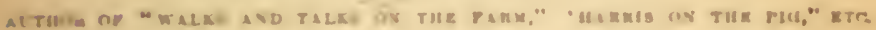

NEW AND ENLARTID EDITION,

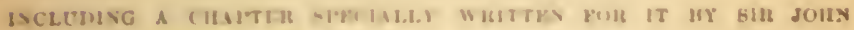

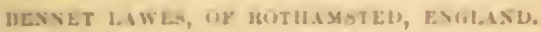

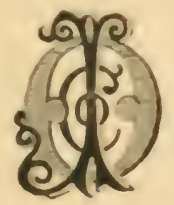

NE: IU:R K :

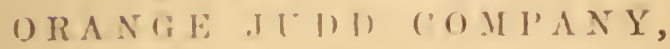


Eatered sccombng to. Act of rongruas, in the grar 1883, hy the

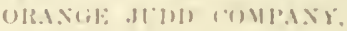

In the Ualce of the Libraran of Congrese, at Waytugton. 


\section{CON'T N T S.}

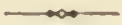

\section{CIIIJ'ER I.}

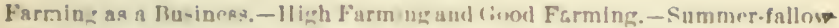

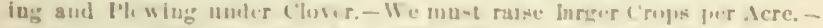

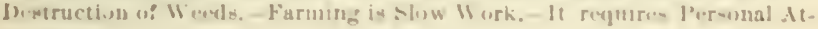
teutsun.

\section{LIINTEIS II.}

What is Manure:-The dedn tions given by the Ih acom and the louctor....

CHIIITE.R III.

Sumething alvout l'lant fired - III - ila on which planta grow contain it.-

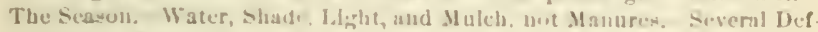

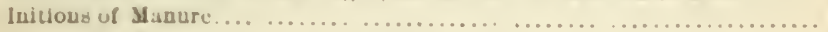

C'HAPTER IS.

Xis ural Mauure. -Acemulated l'hat foud in the sivil. - Exxha-tion of the

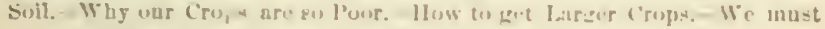
Drain, Cultibate thoroughly, aud Make Richer Manure................

(III'TELI:

Swamp-muck and l'cat a* Vaunre--Draining Swamplund.-C'omporition of

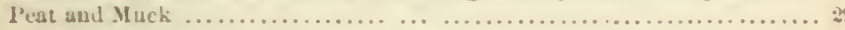

CIIAPTER VI.

What is Putential Ammunia.

CII.MPTER VII.

Tillage is Mlsnure,-The Iloctor"8 Lecture on Manure.

CHIITER VIII.

Summer-fallowing.-Mr. Lawea crop evry other yor.- Wheat aflur Bar-

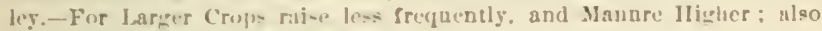

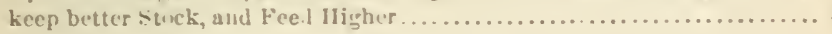

CHAINER IX.

How to Re-tore a Worn-out Farm-The Author's Farm.-Tillage renders the Plant-fend stured in the soil available.-Cultivated Lands contain less Plant-f oud, but are more prodnctive.-Grass alone will not make rich land. $3 \pi$

\section{CIIAPTER $X$.}

How to Makc Mannre. -We must get it ont of the Land................ II

\section{CHAPTER XI.}

The Value of the Manure depends npon the Food-rot upon the Animal.....

\section{CH.APTEI XII.}

Fonds which Make Rich Manure. - Table giving the composition of 31 kinds rif Foorl and the value of the Manure they yield.-Cotton-seed Cake.E.nolish and ferman Cluwer. - Nitrugenon matter in Rich and Puor Fonds.Mannre from Curn eompared with that frum straw................... 


\section{CH.IPTER XIII.}

llorse-manure and liarm yari Manure.-Why the one is richer than the othcr.- Amount of Munure from a llopse. Comprosition of Farm-yard Manure.- Ife draw and spread a tou to get is $10=$. of Nitrogen, l'hosphoric Acid, and Putasta................

\section{CH.I'TEK XIV.}

Fermentiug Yanure,- Compusition of Masure wben l'rests and in its stages

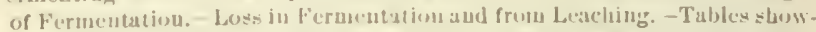
ing the compo-itlon of Minure at ditrereut stajes - Fermentuge makes Inunure more soluble...............................

chinetili xi:

Kecpiug Inume under 'oncr-1)r. Valekir's Experimeste-Manure Fer-

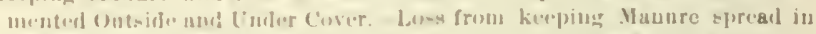

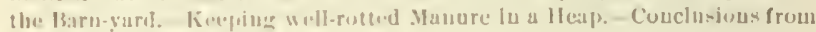
I)r. Vuelcker' \& Experument.-

\section{PIIAPTFI: XVI.}

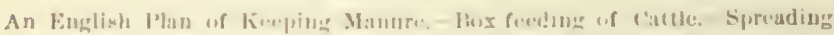

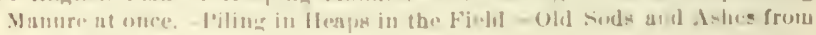
C'lusruel siul $4 . . . . . . . . .$. .

('HAITLI: XVII.

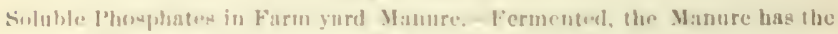
most. - were sil per cent. of the l'husphoric . Icid is suluble ............ is

CIIAPTER XIIII.

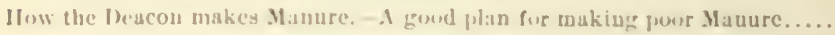
71 ('II.I!THE XIX.

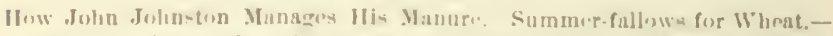

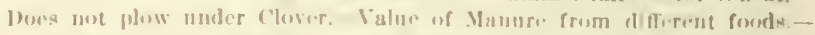

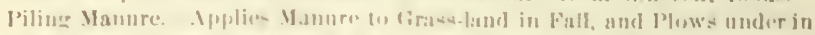

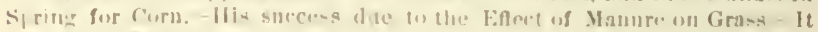
brunght in licd Clover.

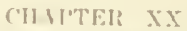

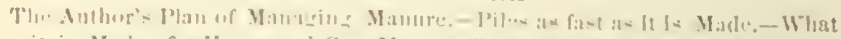

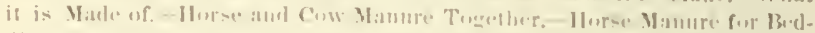

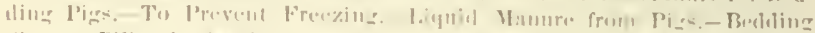

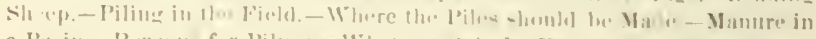

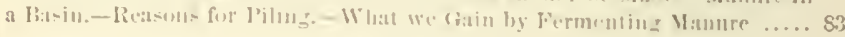

\section{CIIIPTEIR XIt}

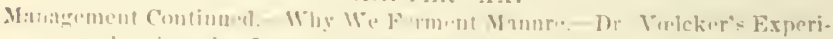

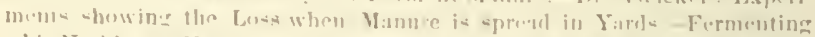

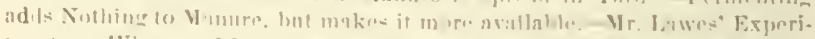

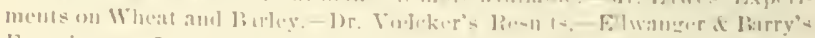
Experience. Las of Ammonia by Formenting-W Wa-te from leacling-

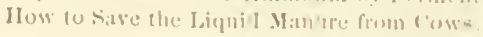

CII.IPTEI: XXIt.

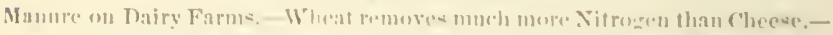

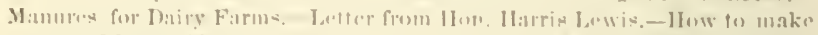

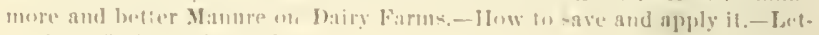

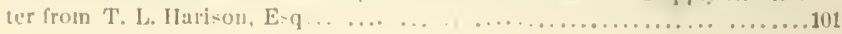




\section{('II.H'THil AXIII.}

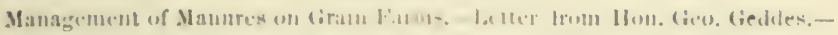

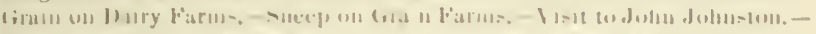

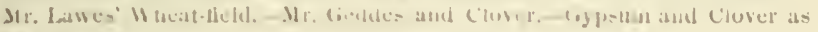
Minure. .......

\section{C'ILATIRE XIIS.}

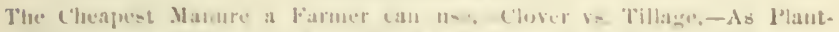

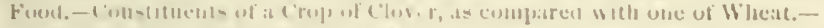

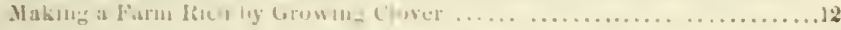

\section{(IINTER XXV.}

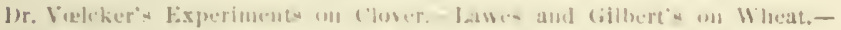

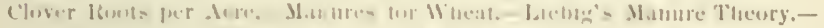

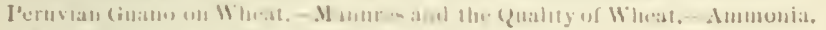

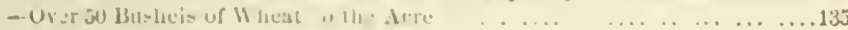

\section{CHAPEH: XXYT.}

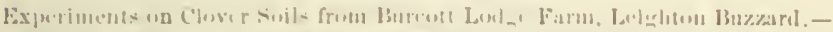

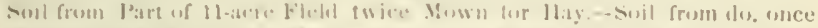

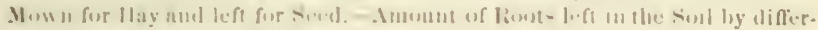

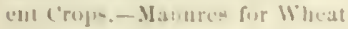

\section{CII.M'TEIR XIVII.}

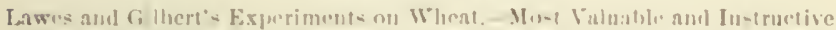

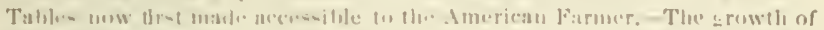

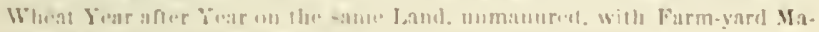

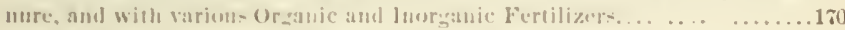

\section{IIITITFE XIIJ).}

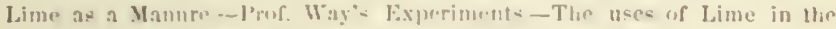

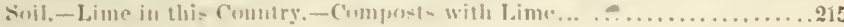

\section{CIIITTER XXIX.}

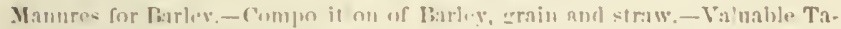

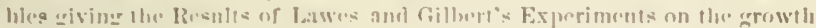

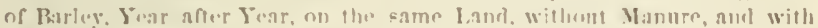

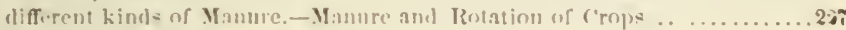

\section{CIIAPTER XXX.}

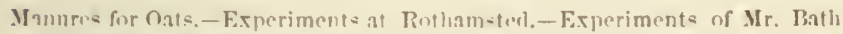
of Virminia - It Mormtum Farm...................

\section{CII.IPTER TEXI.}

Mamures for Potatnes. - Pernvian Ginano for Putatose, - Manure from different Fonds.-Eperiments at Moretur Farm.-Mr. IInner's Experiments...... 25

\section{CII.IPTEIR XXXII}

That Crops shonli Manure he Ippliwl in?-Jlow, and When?-Jolin J.

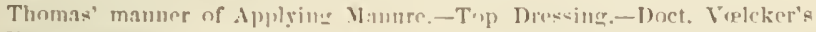

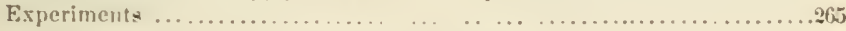

\section{CII.IPTER FXXII.}

Manures on Permanent M cadows anl I'astures,_Experimenls at Rothamsted.2T1 
(IIIPTE TXXIV.

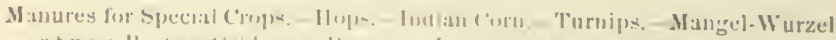

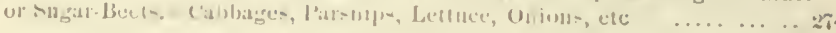

(HIITER XXXV.

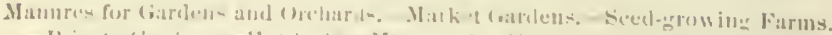

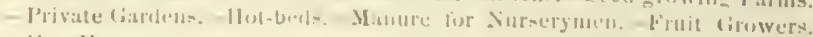
- Heu-Manure

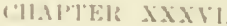

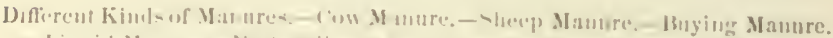

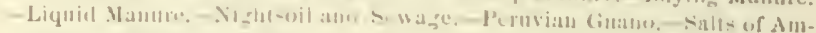
mown and Nirate of suda.

('II.H'TEl: XXXII,

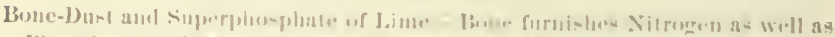

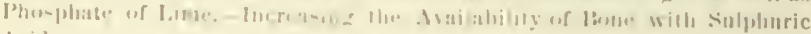
Acid $\ldots . . . . .$.

II.APTEl: XXXill.

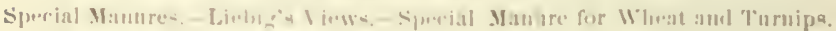
- Rouliam-bul lixprerimel

CIIITEIR XXXIX.

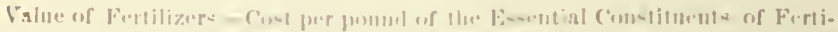

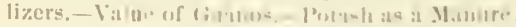

\section{CIIIPTI:H XI.}

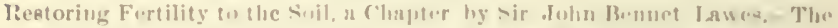

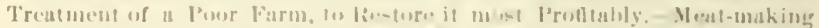

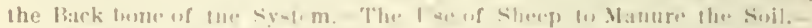

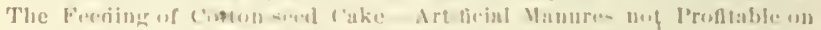

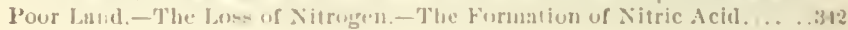

\section{MPI:XIX.}

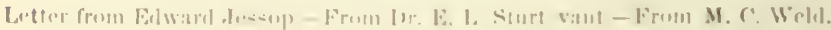

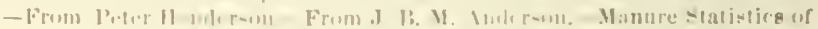

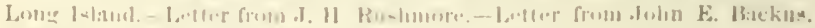

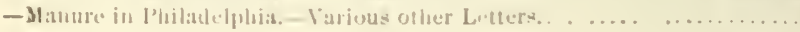


INTRODUCTION TO NEW AND FNLARAED EDITION.

Sir John Bennet Iawes kindly consenterl to write a Chajutr for the new edition of this work. The Deseon, the Dextor, the Siguire, Charlie aml mysolf all felt flattorerl and somewhat bashful at tinding onrsilves in such distingui-houl complany. I neerl not sily that this new ('hajuter from the ju+n of the most eminent English agrienltural investigator is worlly of a very careful sturly. I have read it again and agajn, ambl atch time with great and rem.wel interest. I could wish there wils mure of it. lBut to the intelligent and well-informel realer this Chapter will be valued not merely for what it contains, but for what it onits. A man who knew less would write more. sir Joln gexes stritight to the mark, and we have here his unature views on one of the mest important questions in agricultural science and praction.

Sir John deseritu's a trat of gumer land, and tells us that the cloapest motherl of improving and enriching it is, to keep a large breecling flock of sherp, and feed town sumerican cotton-

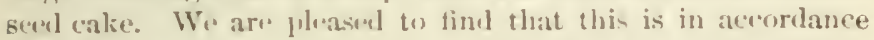
with the general toaching of our "Talks," as given in this bonk several years agu.

When this work was first publishenl, some of my friends expressed surporise that I did not recommond the more xiended use of artificial mimures. One thing is certain, since that time the use of superphosphate has been zreatly on the inerease. And it seens clas that its use must le profitable. Where I live, in Western New York, it is sown quite generally on winter whrat, and also on harley and oats in the spring. On corn and potatoes, its use is not so common. Whethrr this is because its application to these erols is not so easy, or because it does not pronluce so marked an increase in the yield per acre, I am umable to say.

Our winter wlyeat is sown liere the first, second, or (rarely) the third week in September. We sow from one and a half to twa and a quarter bushels per acre. It is almost invariably sown with a drill. The drill has a fertilizer attachment that distributes the superphosphate at the same time the wheat is (VII) 
sown. The superphosphate is not mixul with the wheat, lut it drops into the same tubes with the what, and is sown with it in the same trill mat $k$. In this way, the superphospluate is deposited where the roots of the young plants ean immediately find it. For barley and oats the same method is adopted.

It will be senen that the cost of sowing superphospliate on these crops is merely nominal. But for corn and potatoes, when planted in hills, the superphosphate must be dropped in the hill by hand, and, as we are almost always hurried at that season of the gear. we are impatient at anything which will delay plantingeren for a day. The boys want to go tishing!

This is, undosbtediy, one reason why superphosphate is not used so generally with us for eorn as for wheat, barley, and oats. Another reason may be, that one humeleel pounds of eorn will not sefl for anything like as much as one huuseled pounds of wheat, barley, and oats.

We are now buying a very gool superplospluate, made from Carolina rock phosphate, for about one and a half oents per pound. We usually drill in about two hundred penunds per acre at a cost of three dollars. Now, if this gives us an inerease of tive bushels of wheat pere ace. worth six dollars, we think it pays. It often does far bette' than this. Last yaar the wheat erop of Western New York was the lest in a third of a century, which is as far liak as I have had anything to do with farming here. Fom all I can learn, it is doubtful if the wheat crop of Western New York has eror averaged a larger yield per acre since the lanel was first enltivated after the remoral of the original forest. Something of this is due to better methouls of cultivation and tillage, and something, doulteless, to the general use of superphosphate, but nuch more to the favorable season.

The present rear our what crop turned out "xceelingly poor. Ifuntreds of ateres of wheat were plowed up, and the land resown, and hmolreds more would have been plewed up had it not been for the fact that the land was seeded with timnthy grase at the time of sowing the wheat, and with clover in the spriner. We do not like to lose our grass and elover.

Dry weather in the antmmn was the real cause of the poor yichl of wheat this year. True, we had a very trying winter, and a still more trying spring. followed by dry, enld weather. The season was rery baekwarl. We wes not able to sow anything in the fields before the first of May, and our whent ought to have been realy to harvest in July. On the first 
of May, many of our wheat-fielels, espucially on elay laurl. Ioukerl as liare as a naked fallow.

Therewas here and there, a grool fielıl of wheat. Is a rule, it wasen naturally moist land.or after a groul summer-fallow, sow early. I know of lnet one exception. A neighboring museres firm hal a very promising fielel of wheat, which was sown latr. But their land is rich and unusually well worked. It is, in fact. in the very highest conlition, and, though suwn late, the yums plants were enabled to make a gook strong growth in the autunne.

In such a dry seasom, the great point is, to get the seed to germinate, aul to furnish suftici'nt moisture and fool to enable the young plants to make a strong. vignrous growth of roots in the antumm. I do not say that two hundred pounds of superphosphate per acre, drilled in with the seerl, will always aceon. plish this object. But it is undoubtedly a great help. It eloes not furmish the nitrogen which the wheat roquires, but if it will stimulate the production of roots in the early autumn, the plants will be mueli more likely to fund a sufticient supply of nitrogen in the soil than plints with fewer and smaller roots.

In a season like the past. therefore, an applieation of two hundreal pounis of superphospliate per acre, costing three dollars, insteal of giving an increase of five or six bushels per aere, may gire us an iuelease of fiftern or twenty bushels per acre. That is to say, wring to the elry wather in the autumu, followed by severe weather in the winter, the weak plants on the unmanured land may either he killed out altogether, or injured to such an extent that the crop is harlly worth harvesting, while the wheat where the plosphate was sown may give us almost an average erop.

Sir John B. Lawes has somewhere compared the owuer of land to the owner of a coal mine. The owner ef the coal digs it and gets it $t$ o market in the hest way he can. The farmer's coal mine consists of plant food, and the object of the farmer is to get this food into such plants, or such parts of plants, as his eustomer's require. It is hardly worth while for the owner of the coal mine to trouble his heal about the exhaustion of the supply of coal. Iis true plan is to dig it as econcmieally as he ean, and got it into market. There is a good deal of coal in the world, and there is a good deal of plant food in the earth. As long a: the plant food lies dormant in the soil, it is of no value to man. The object of the farmer is to convert it into prolucts which man and animals require. 
Yining for coal is a very simple natter, hut low lost to get the greatest quantity of plant foul ont of the soil, with the least waste and the greatest profit, is a much more comples and difficult task. Plant food consists of a dozen or more ditfrent sulsstances. We have talkerl about them in the pages of this loxsk, and all I wislo to sily here is that some of them are mols more abundant, and mere realily obtinines, than others. The throe substances mosit lificicult to gret at arr: nutric aciol, phosphoric acid and putash. All the ses sthestances are in the soil, lent seme soils contain much more tham others, ant their relative propertion varies emosilferably. The substanee which is of the erreatest ingurtance, is nitric andil. As at rule. the fertility of a soil is in propertion to the amount of nitsie acid which beromes availalole for the use of plants during the erowing

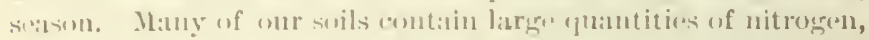
unitenl with ardmen, hut the plints in not take it up in this

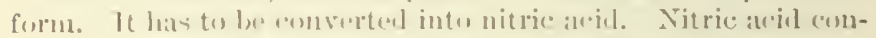

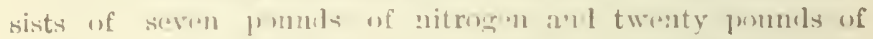

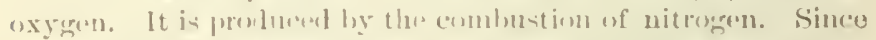

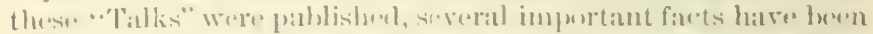

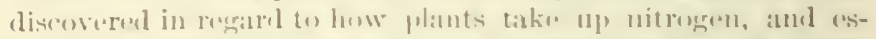

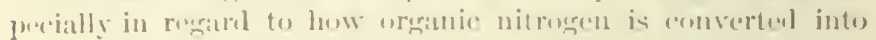
nitrie aciul. It is bromglt abunt throurh the action of a minute funderid plint. Ther: are sederal thinges neressiry for the

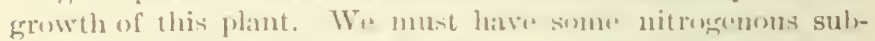
stancer, a mexlerate dexpe of heat, way from siventy to one

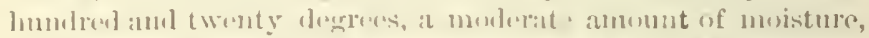
and plenty of oxyenen. Sllawle is alsu favorable. If tous hot or

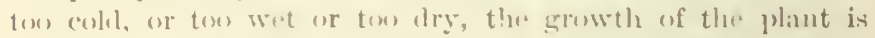
checked, and the formution of nitric arisl sucremeled. The presence of lime, or of som alliali, is also necessity for the grewth of this fumens and the production of nitric acid. The nitric aceis muites with the lime, and forms nitrate of lime, or wit! serla (1) form nitrat of serla, a." with potash to form nitrate of potash, or salt-petre. A water-legened suil, ly exc-ducli.re the oxyeren, destruys this plant. hence cons of the arlvantares of mulerelraning. I have said that shate is farorable to the growth of this fungus, and this fact explains and confirms the common idea that shade is manure.

The great objoet of arriculture is to convert the nitrogen of our soils, or of green crops plowet muler, or of manure, into nitric acid, and then to convert this nitric aciul into profitable prolnets with as little loss as pussilule. Nitrogen, or rather 


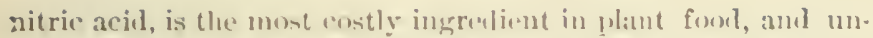
fortunately it is very "asily wishled ont of tho suil aml lost. Perliaps it is alsolutely impusilule to ('ntirely prevent all loss from leaching: lont it is entatinly woll worth onr while to mol, r. stand the subject, and tukn w axilly whatc wo ar foing. In a new country. whore litul is choste, it may lus more grofitable

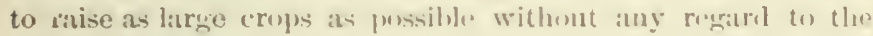
loss of nitric acid. But this emolition of thingst dens not lasit leng, and it very som locomes dosirable to iulopt lasi wastoful processes.

In Lawes and (iilbort's "xperiments, ther is a grast loss of nitric aciul from drainare. Ir no ease hits ats much nitrogen been obtainul in the increasid ('ropt ats was applierl in the manure. There is always a lusis and probably always will he. But

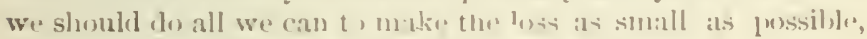
consistent with the promluetion of protitalule crops.

Thereare many ways of lessoning this losis of nitrie arejel. Our farmers sow superphespluate with their whent in the autumn, and this stimulates, we think, the enrwwh of rests, which ramify in all direetions thrmegle the soil. This increasen growth of rout lorings th. plant in contart with a larger feeding surface, and enables it to take up nore nitric acid from its solution in the soil. soch is also the case during the winter and rarly spring. when a good deal of water permeates throwgh the soil. The applination of superphospliate,

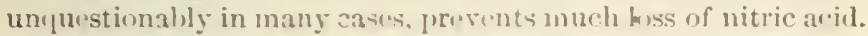
It Ioes this by giving us a much grouter growth of wlueat.

I was at Rothansted in $18 \% 9$, anl witnesicel the injurious effoct of an txcessive rainfall, in washing (unt of the soil nitrate of snta and silts of ammonia, which wer. sown with the wheat in the autumn. It was an excerlingly wet season, and the loss of mitrates on all the diffurent juluts was very great. But where the nitrates or salts of ammonia were sown in the spring. while the crops wero growing, the loss was not nearly so great as when sown in the autumn.

The sight of that wheat field improssed me, as nothing else could, with the inportance of guarding against the luss of arailahle nitrogen from leaching, and it has changed my practice in two or three important respects. I realize, as never before, the impurtance of applying manure to crops. rather than to the land. I mean l,y this, that the object of applying manure is, not simply to make land rich, but to make crops grow. Manure is a costly and raluable article, and we want to convert 
it into plants, with as little delay as possible, which will, dirextly or inclirectly, bring in some money.

Our elinate is viry different from that of England. Is a rule, we seldom have enough rain, from the time com is plauted until it is harvesterl, to more than saturate the gromul on our upland soils. This year is an exeeptum. On Sunday night, May 20, 1N83, we hat a northeast storm which erntinued three days. During these three diys, from three to five inches of rain fell, and for the first tim in many years, at this seasom, my underdrains dischareel water to their full rapacity. Had nitrate of sola beem sown on latre lamel previous to this rain, much of it would, dombless. have luen lost by learhing. This, howevere, is an exreptional case. My mulerilrains usually do not commence to disentre. Waler before the tirst of Derember, or continue later than the first of liay. To guard against loss of nitrogen ly leaching. therefore, we should ain to kexp rich land oecupial by some crop, during the winter and early spring, and the earlier the croln is sown in the antumu or late summer. the better, so that the routs will the more completely fill the gromul and take up all the available nitrogen within their reach. I have sail that this illa had molified my own practice. I grow a considerable (puantity of garden vegutables, principally for sect. It is neessary to make the land very rich. The plan I have adopted to guard arrainst the loss of nitrogen is this: As soon as the lant is clearell of any crop, after it is too late to sow turnipss. I sow it with rye at the rate of one and a half to two bushels per acre. On this rich land, especially on the moist low land, the rye makes a great growth during our warm autum weather. The ryo cherks the growth of weals. and furnishes a consildrablo amount of succulent food for shreep, duriag the atrtumn or in the spring. If not noested for ford, it can be turued umler in the spring for manure. It unquestionably prevents the luss of considerable nitrie acid from leaching during the winter and early spring.

Buckwheat, or millet, is sometinxs sown on such land for plowing umder as manure. hut as these crops are killed out ly the winter, they eammot prevent the loss of nitric acid during the winter and spring montlss. It is only on musually rieh land that such precantions are particularly necessary. It has been thought that these experinemts of Lawes and filbort afford a strong argument against the nse of summer-fallows. I do not think so. A smmmer-fallow, in this country, is nsually a piece of l:me which has been seeded down one, two, and 
sometimes three sears, with red elover. The lamel is plowed in May or June, and oceasionally in July, and is afturwarils sown to winter wheat in September. The treatment of the smmmerfallow varies in different localities and on different farms.

Sometimes the land is only plowed onee. The elover, or serl, is plowed under dewp and well, and the after-treatment consists in keepinge the surfaces soil free from werels, hy the frequent use of the harrow, roller, cultivatur or gang-plow. In other cases, especially on heary clay land, the first plowing is done early in the spring. and when the sod is sutficiently rotted, the land is cross-plowed. and afterwards marle tine and mellow by the use of the roller, harrow, amel cultivator. Just before sowing the wheat, many goml. old-fashioned farmers, plow the laud again. But in this section, a summer-fallow, plowed two or three tines during the summer, is becoming more and more rare erery year.

Those farmers who summer-fallow at all, as a rule. plow the ir land but onee, and eontent themselse's with mere surfitee eultivation afterwarcls. It is undoubtedly true, alse), tliat summer fallows of all zinds are ly no means as common as formerly. This fact may be consilereel an argument against the use of summer-fallowing; hut it is not conclusive in my" mind. Patient waiting is nut a characteristic of the age. We are inclined to take risks. We prefer to sow our land to oats, or barley, and run the chance of getting a good wheat crop after it, rather than to spend sereral months in cleaning and mellowing the land, simply to grow one crop of wheat.

It has always seemed to me entirely unnecessary to urge farmers mot to smmmer-fallow. We all naturally prefer to see the land oceupied by a goud paying crop, rather than to spend time, money, and labor. in preparing it to proluce a crop twelve or fifteen months afterward.s. Tet some of the agricultural editors and many of the agricultural writers, seem to take delight iu deriding the old-fashioned summer-fallow. The fact that Lawes and Gilbert in England find that. when land contains considerable nitric acid, the water which percolates through the soil to the underirains beneath, contains more nitrate of lime when the land is not occupied hy a crop, than when the roots of growing plants fill the soil, is deemed positive proof that summer-fallowing is a wasteful practice.

If we summer-fallowed for a spring crup, as I have sometimes done, it is quite prubable that there would be a loss of nitrogen. But, as I have said before, it is very sehlom that any 
water passi's through the soil from the time we commence summor-fallow until the wheat is suwn in the autumn, or for many wethis afterwarls. The nitrugen, which is converted into nitric aceid by the agency of a good summer-fallow, is no more liable to be washed out of the soil after the field is sown to what in the antumn, thim if we applied the nitrogen in the form of some reillily available manure.

I still belicre in summer fallows. If I hat my life to live

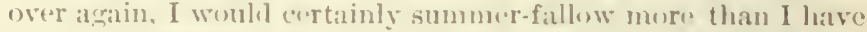
done. I have been an agrieulteral writer for ons-thirs of a century, and have persistently adveraterl the mure extemderl use of the sumener-fallow. I have mothing to take lack, unless it is what I lave sail] in referenc. to " fall-fallowing." ['ossibly this practiec may restit in losis, thomgh I do not think so).

A good summer-fallow, on rather heavy elay land, if the eonditions are utherwise faveralbe, is pretty sure to give us a good

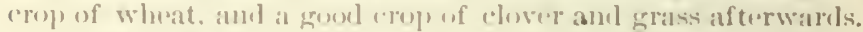
Of course, a farmer who hat nice, clean sindy soil, will net think of summer-fallowing it. Such suils are easily workert, and it is not a dint enlt inater to kerp them elean witlout sumner-fallowing. Such suls. howerer, soldone contain a large store of unavilible plint forml, and instead of summer. falluwing. we had hettor manure. On such solls artificial manures are often very profitalle. thworh barn-yarel manure, or thro droppings of animals fecting on the land, shonld be the prime basis of all attempts to maintain. or inerease, the produrtivenriss of silell suils.

Since this lusk was first publishuel, I do not know of any new ficts in resand to the inpurtant question of, how best to manalye amd apply our harn-yard manure, su ats to make it more immediately aretive and availatule. It is uncpurstionaluy true, that the sinme anosunt of nitrogen in harn-yarl manure, will not produce su great an efferet ats its theresetical value would inrlieate. There ean he no dould, lewwerer. that the better we foed ond animals, and the more carefully we save the liquicls, the more valuable ame aretise will lne the manture.

There (onversion of the inert nitrogen of manures and seils,

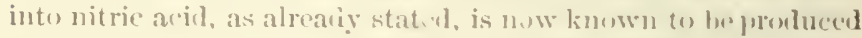
by a minute fungus. I hopue it will be femul that we can introduce this lueterinm into onr manure piles, in such a way as to greatly aid the conversion of inert nitrogen into nitrates.

Experinents have been made, and are still entinued, at Wuburn, under the auspicess of the Royil Agricultural Society 
of England, to ascertain, anong other things, whetluer manurw

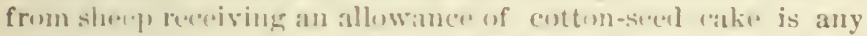
richer than thit from shcep, otherwise feel alike, hut having, msteiul ef eotton-serel calie, the same amount of corn meal. We know that such maunre contains more nitrugen, amd other plant foxsl. than that from the corn meal. But the experiments so far. though they latre lewen continuend for sereral years, do not show any striking superiority of the manure from cottunseedl cake over that from corn meal. I sia the wheat on these ditrerently manureil plots in 1889. Dr. Volcker and 1)r, Gilbert, told me that. one of two plots wils drussinl with the cotton-seed manure, and the other with the corn meal manure, and they wanted me to siy which was the rent fromising crop. I believe the one I siall was the better, was the cottenseed plot. But the difference wis very slight. The truth is that such experiments must lue contmuen] formany years before thes will prove anytinge. As I sail hefore, we know that the manure from the cottum-sond cale is richer in nitrogen than that from the corn meal : but we also know that this nitrogen will wot produce si) great an effert, as a much smaller amount of nitrogen in salts of ammonia, or nitrate of somla.

In going over these "xperinnents, I was struck with the heal:hy and vigorous appurance of une of the plots of wheat, and asked how it wat manured. Dr. Vusklier called out, "chover, Mr. Harris, clewer." In Englaml, as in America, it requires rery little observation and experience to convises any one of the value of chror. After what I have said, and what the Deacon, the Doctor, Charley and thr. Syutre lave sairl, in the pages of this book, I hope no one will think that I do not appreciate the great value of red clover as a means of enriching our land. Dr. Fosleker evidently thought I was skeptical on this point. 1 an mot. I lave great faith in the benefits in be lerived from the growth of clover. But I do not think it originates fertility : it does not get nitrogen from the atmosphere. Or at any rate. we have nu evidence of it. The facts are all the other way. We have discussed this question at considerable length in the pages of this book. and it is not necessary to say more on the subject. I would, lowerer, particularly urge farmors. especially those who are using phosphates freely, to grow as much clorer as possible, and feed it out on the farm, or plow it under for manure.

The question is frequently askid, whether the use of phosphates will ultimately imporerish our farms. It may, oi it may 


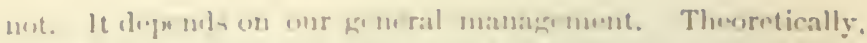

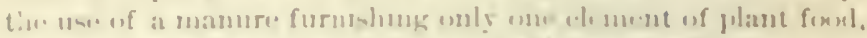

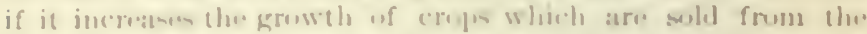

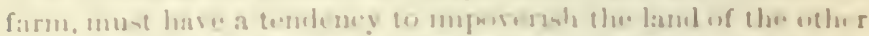

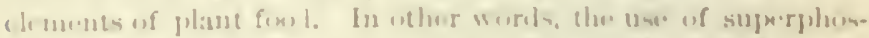

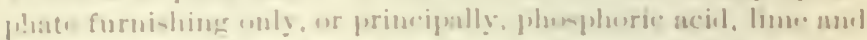

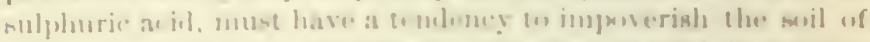

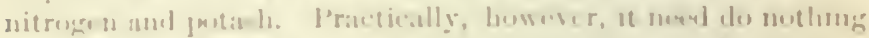
of the kimel. If the lamel is woll cultusaterl. amel if aur low.

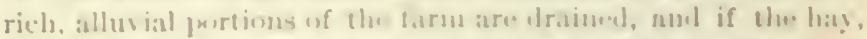

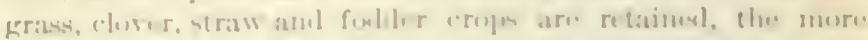

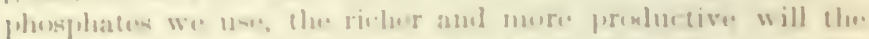

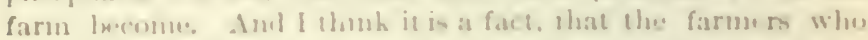

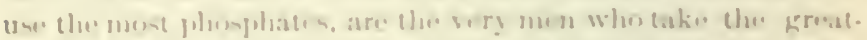

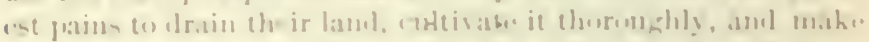
the most mamure. It foll own. the refore, that the use of plussphate:s is a mattemal In'tse fit.

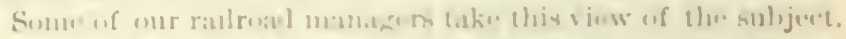

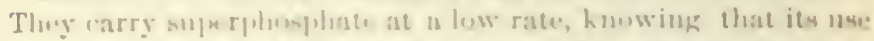
will increase the fretght the wh r wis. In onler worels, they

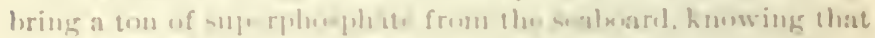

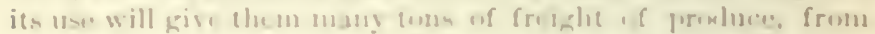

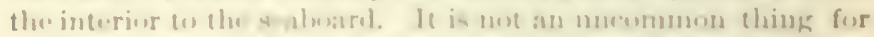

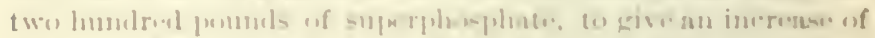

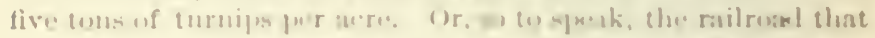

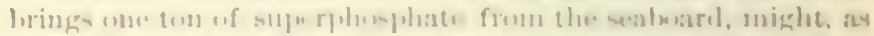

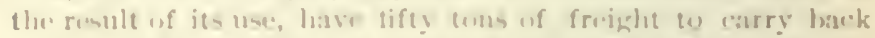

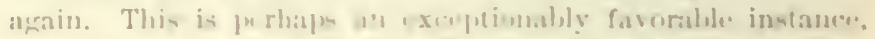

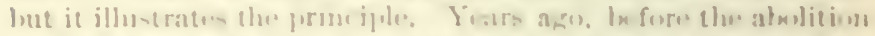
of tolls on the Engliah turmpihe roals, carriage logaled with

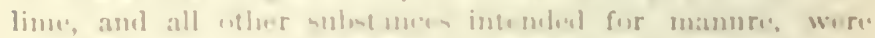

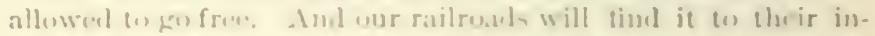
t.rist to transport mamures of all kinds, at a merely mominal ratı:

Many pupple. will he surpiria ol at the recommendation of fir

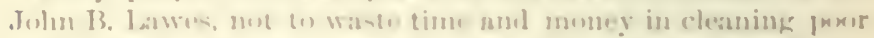
land, before sodiug it down to grast. Ho thinks that if the

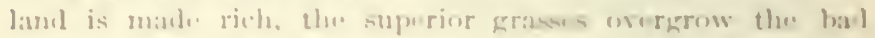

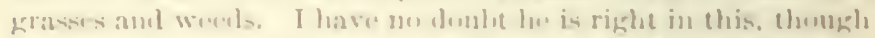

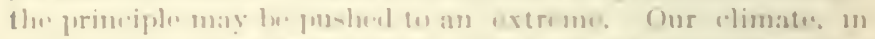

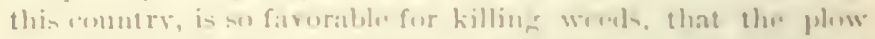

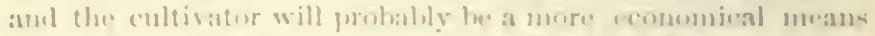
of mating our lame clean, than the liloral use of exprensive 


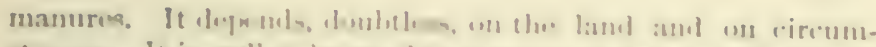

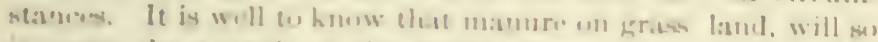

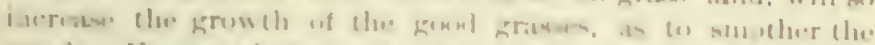

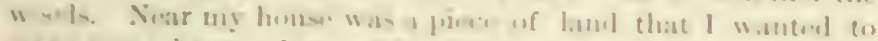

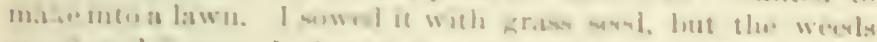

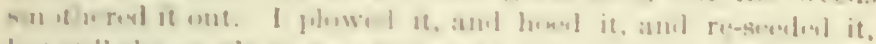

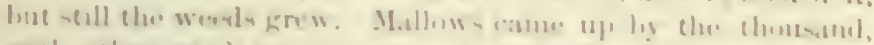

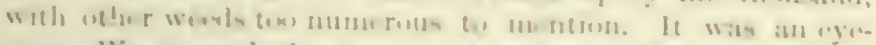

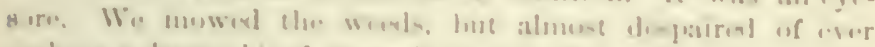

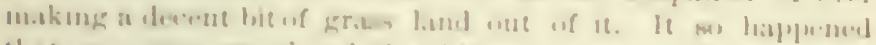

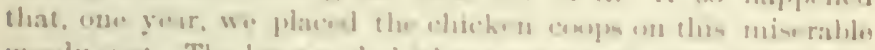

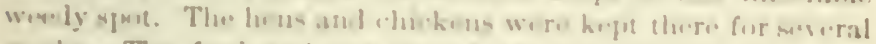

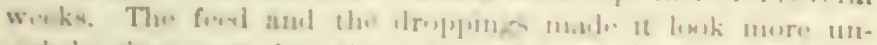

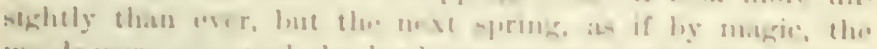

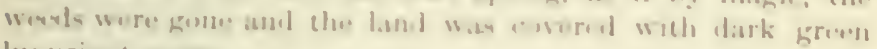
luxuriant geras,

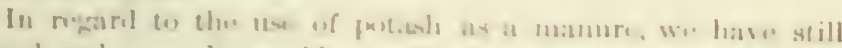

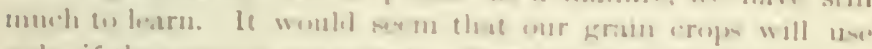

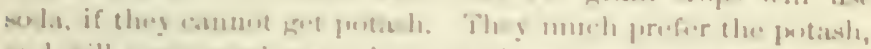
and will forow mu h more luxiruatls where, in the suil ur ma-

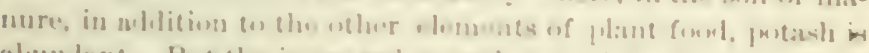

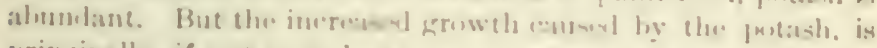

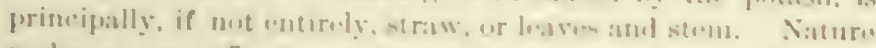

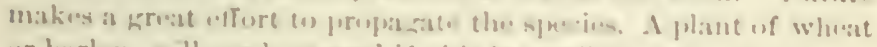

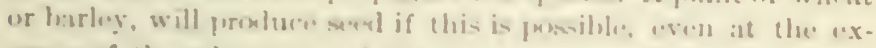

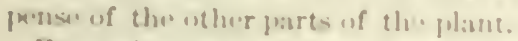

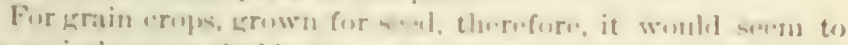

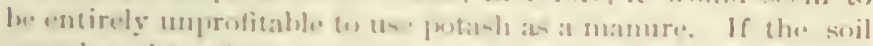

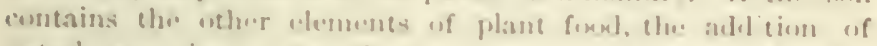

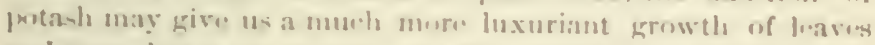

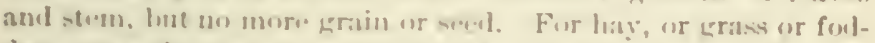

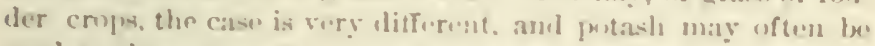

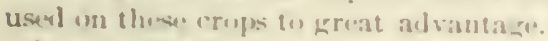

I am inclinml to think that (onsideral, nitrate of sorla will Sot he userl in this ramutry for manure. I domot suppose it will pay as a rule, on wheat, corn and uther standarel grain erojs. But tho gariliner, seml grower, and surseryman, will fiml out how to use it with grint profit. Our murwirymen say that they annot use artificial manures with any alvantage. It ju mo. doubterly true thast a lrusing of supurphowplate. Srown on a

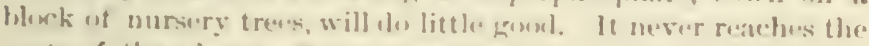

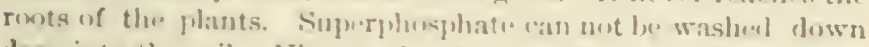
derp into the soil. Nitrate of souta is readily earriod dewn, as 
deep as the watror sinks. For (rees, therefore, it would seem desirable to apply the superhespluate hefore they are planted,

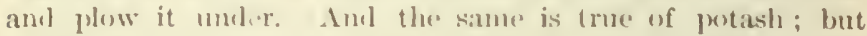
nitrate of suda womld be better applienl as a top-dressing every yoar, early in the spring.

The most discouraging fatt, in Läwes' and Gilloert's "xperiments, is ther great luss of nitrogen. It would seem that, on an average, during the last forty years, alunt one-half the nitrugen is washed ont of the suil, or otherwise lest. I can not but hepe and lestieve that, at any rate in this country, there is no such less in practical agriculture. In Lawes' and Gilbert's "xperimentson wheat, this grain is grown year after year, on the same latsel. Forty anmual crops have been removiol. No clover is sown with the wheat, and great patins are taken to keepthe land clean. The erop) is losed while growing. and the

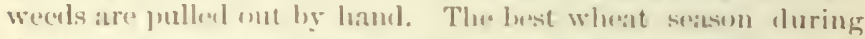
the forty gears, was the yerar lstiis. The perest, that of 18i9; and it so happene. that after an absente. of thirty gears, I was at kethamsted duriug this purer year of 1469. The first thing that struck me, in lowking at the experionental wheat, was the ragred alpestrance of the crop). My uwn wheat crop was being

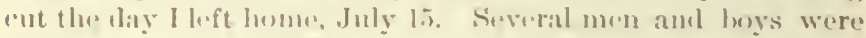
pulling weenli out of the experimental wheat, two werks latter. Had the werels beens suffered to grow, Sir John lbennet Lawes

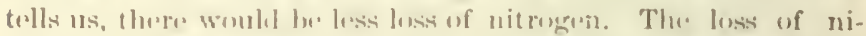
trogen in 1sfi3. was about twenty-foll pommls jer acre, and in 1879) tifty jomuls per acre-the amount of available nitrogen, applind in each year, being eighty-seven pounds per acre. As I said lufere, the wheat in 1879 haxl to ine a raggerl lewe. It was thin on the gromel. There wre not plints enomgh to take up and evaporate the lavge amount of water which foll during the wet season. Such a condition of things raprely aceurs in this rountry. WFo sow timothy with our wintor wheat, in the autumn, and rod clover in the spring. After the wheat is harrested, we frequently have a heary growth of clover in the autumn. In such circumstances I helinve there woulel be comparatively little less of nitrugen.

In the summer-fallow experiments, which have unw heen continued for twenty-seven years. lhere has leen a great loss of nitrogen. The sime remarlis apply to this ease. No one ever alverates summer-fallowing lami erery other year. and sowing nothing lut wheat. When we summer-fallow a piece of lind for wheat, we seel it down with grass and clover. 
There is, as a rule, very little loss of nitrogen ly drainage while the wheat is growing on the ground. lut after the wheat is cut, the grass and elover are pretty sure to take up all the avalable nitrogeu within the range of their ronts. This smmuer-fallow experiment, instead of atfording an argument against the use of summer-fallowing, is an argument in its favor. The summer-fallow, by exposing the soil to the dexompuning intluences of the atmosphere, converts more or less of the inert nitrogenous corganic matter into anmonia and nitric acil. This is precisely what a farmer wants. It is just what the wheat erop needs. But we must be very cariful, when wo rendir the nitrogen soluble, to have sume plant reably to take it up, and uot let it be washeel ont of the seil during the winter and early spring.

We have much proor land in the Unitrol states, and an immense area of goxel lame. The poor land will be need to grow timber, or be inpruved by (nonverting more or less of it, gramlually, into pasture, and stocking it with sheep and eattle. Tho

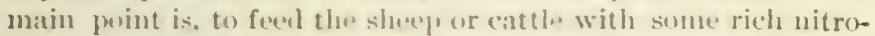
genous foml, such as enton-seerl cake, malt-sprouts, bran, shorts, mill-fredl, refuse leans, or bean-meal male from beins injured by the weevil, or loug. In short, the wwer of such land must buy such fonl as will furnish the most nutriment and make the richest manure at the least cost-taking both of these objucts inte consiluration. He will also huy more or less artifieial manures. to be used for the production of folder crops, such as corn. millet, Hungarian grass, ete. And, as soon as a portion of the land ean be made rich enough, he will grow more or less mangul wurzels. sugar leets, turnips, and other reot crops. Superphosphate will be fouml aelmirably adapted for this purpose, and two. three. or four hundred pounds of cheap potash salts, per acre. can frequently be used on follter erops, in connectiom with two or three hundred pounds of superphosphate, with consiclerable profit. The whole subjoct is well worthy of careful study. Never in the history of the world has there been a granler oplortunity for the application of science to the improvement of agriculture than now.

On the richer lands, the aim of the farmer will be to convert the plant food lying dormant in the soll into profitable crops. The main point is goorl tillage. In manr cases weeds now run away with half our crops and all our profits. The weeds which spring up after the grain crops are harrested, are not an unmixed evil. They retain the nitrogen and other plant food, and 
vlien turned under make matnure for the succerling crops. but weeds anong the growing crop are evil, and only an evil. Thorough plowing is the remedy, ateompanies by drainage where neederl.

Wo have an inmense mumber of farms (m) which there are

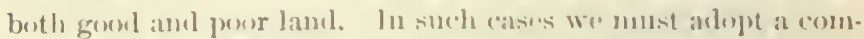

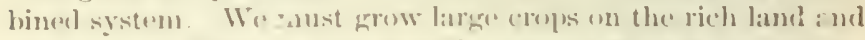
use them, at least in part. to make matume for the pourer portions of the farns. Drainage and gend tillage will convert much of onr low, alluvial lauks inter a gerferet mine of wealth. And mueh of our light. rolling limel consists of strong loan, abomeling in plant food. Such land renuires little more than thoromgh tillage. with perhates two hundred pounds of sil]er-

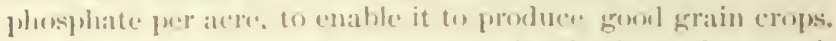

After all is satil amd lone. farming is a busimess that rengires not merely sedence, lut industry, (4)

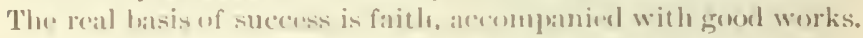
I eammet illustrate this better thatn by alluding tor me of my neiphbors, a strong. Itealthy, intelligent, observing ant enterprising (ientan. who commentenl lifo as a farm laturer, and is to-flay worth at last one humlred thomsand dollars, that he has wade, wot hy the alvane of suburban propurty. helt hy farming. pure and simple. He tirst rented a farme and then lesught it, and in a few years low bughtit another farm aljoining the first one, and would torlaty buy anotlere if lie found one

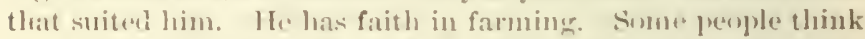
lu. "puns his land," ant, in fart. such is the cast. He kenpls goul teams, and good plows, and groul harrows, and groud rollers, and gruul cultivators, and grunl graude. Shorthorn eows. He acts ats though low lxelieverl, ats Sir John B. Ialwes says, that "the soil is a mine," out of which he digs money iferuns his land for all it is worth. If" raises whett, harley, wats, corn, putatoes, and hay, and when la can get a goul price for his timothy hay, he draws it to market and sells it. Throwgh tillage is the hasis of his sucess. Ho is now using phempluates for wheat, and will probably increase his heril of cows and make more mamre. He has grat faith in manure. lut acts as though la" hat still greater faith in good plowing, early sowing, and thorough cultivation. 


\section{PREFAOE TO FIRST EITTON.}

The Printers have fot our "Talks on Manures" in type; and the publishers want a I'reface.

The Deacon is lusy horing his corn; the Doctur is gone to Rice Lake, fishing: Charley is cultivating mangels: the Squire is hayingr, and I an here alone, with a prencil in hand and a shect of blank paper lefore me. I would far rather be at work. In fact, I have only just come in from the field.

Now, what shall I say" It will do no good to apologize for the deficiencies of the lonok. If the critics condescend to notice it at nll, nothing I ran say will jropitiald their faror, or moderate their censure. They are an indefrendent set of fellows! I linow them well I am an old editor myseli, and nothing would please me better than to sit down and write a slashing criticism of these "Talks on Manures."

I3ut I an denirul that pleasure. The critics have the floor.

All I will siy here, is, that the book is what it pretends to be. Some people seem to think that the "Deacon" is a fictitious character. Nothing of the kind. IIe is one of the oldest farmers in town, and lises on the farm next to me. I have the very highest respect for him. I baro tried to report him lully and correctly. Of my own share in the conversations I will say little, and of the Docur's nothing. II own riews are honestly giren. I hold $\mathrm{my}$ self responsible for them. I may contradict in one chapter what I hav' asserted in anotler. And sc, probubly, has the Deacon. I do not know whether this is or is not the ease. I know very well that on many questions "much can be said on hoth sides"-and rery likely the Deacon is sometimes on the south side of the fence anil $I$ on the north side: and in the next chapter you may find the Deacon on the north side, and where would! you have me go, except in the south side? We cannot see both sides of the fence, if hoth of us walk on the same side!

I fear some will be disappointed at not fincling a particular subject discussetl.

I have talkec' about those things which occupy my own thoughts. XXI 
There are some things not worth thinking about. There are others beyonil iny reach.

I have said nothing about manures for cotton or for the sugar. cane-not bectuse I feel no interest in the matter, but because I have hat no experience in the cultiration of these importint crops. I might have told what the crops contain, and could have given minute dircetions for furnishing in manure the exact quantity of plant-fond which the crops remove from the soil. But $I$ have no faith in such a system of furming. The few cotton-plunters I have hacl the pleasure of seeing were men of education and rare ability. I cannot undertike to oller them adviee. But I presume they will find that, if they desire to increase the growth of the cotton-plant, in uine cases wit of ten they can do it, providea the soil is properly workerl, hy supplying a manure contuining available nitrogen, phospluric acil, and potash. But the proper preportion of these ingrelients of plint-find must be ascertimed by experiment, and not from a mere analysis of the cotton plant.

I have much faith in artificial manures. They will do great things for Amerionn agrieulture- lirectly, and indirecty. Thei general use will liad to a higher system of farminte-to better conttivation, more rout and fodler crope, improred stock, higher feeding, and richer manure. But it has berom no part of my object to unduly extol the virtues of commereial manures. That may le left to the manuficturers.

My sympatly is with the farmer, and especially with the farmer of molerate means, who fimls that improved farming calls for more and more cipital. I wnuld like to eneourage such a man. And so, in point of fact, would the l)egeon, thourh lie often talks as theugh a man who irice in improre his farm will certainly come to poverty. Such men as the Deacon are useful neighloors if their doubts, and hear-shakings, and shoulder-shruggings leal a young and enthusiastic farmer in put more enerey, industry, and reomomy into his husiness. It is well to list. n to the Di:aeon-to hear all his objerlinus, and then to keep a sharp look-out for the dangers and ditticulties, and go-thatd. 


\section{TATKS ON MANURES.}

\section{I A P T R I.}

\section{FARIIING AS A BUSINESS.}

"Farmine is a poor businese," said the Deacon. "Tahe the enrn crop. Thirty lusheli fuer acere is a fair averitge, worth, is is centes per busluel, s.2.50. If we reckon that, for earts buslacl of corn, we get 100 lbs. of stallis, this wonld be a ton and a haif per acre, worth at \$.j per ton \$i.50."

Total receipts per acre for enrn crop..................

Expenses. - Preparing the land fur the crop.......... 500

$\$ 3000$

Plantiur and seed ................... 150

Cultivating, three times, twice in a row buth ways........................ 500

Ineing twice....................... 300

Cuttine un the eorn................... 150

Husking and drawing in the corn.......... \& 40

Drawing in the stilks, ete.............. 100

Shellins, and drawing to market.......... 200

Total co-t of the crop..........................

Profit per aere............................... $\overline{\$ s 00}$

"Anil from this," said the Deacon, " we have to deluct interest on lund ambl taxes. I tell you, farming is a ponr business."

"Yes," I replied, "poor farming is a tery poor business. But gool farming, if we bave good priecs, is as crood a business as I Want, and withal as pleasant. I goorl farmer raises ij bushels (j) 
of eorn per acre, instead of 30 . Ite woull get for his erop, incluling stalks............................... 00 Expenses. -Preparimg land for the crop...............5 00

Planting and seed.................... 150

Cultivating........................ 5 500

Hoeing........................... ; 300

Cutting up the corrt................... 150

Husking and drawing.................. 1000

Dritwing in ilıe stalks.................. 300

Shelling, etc....................... o $6(10$

Prolit per acre............................... \$ $\$$

Take another case, which astually oecurred in this neirhhorhond. The Julge is a good farmer, and particularly sucecssful in raising polatoes amel selliug them at at gered priece to lutels and private families. Ile cultivates very thoronghly, plants in hills, and puts a handful of aslies, plaster, and hem-minume, on the hill.

In 18\%3, his crop of Puachinlows was at the rate of 208 bushels per acre. Of these, 200 hush lis were sull all 60 ecnts per bustiel. There were 8 bushels of small putitors, worth s:y 12! cents per busiliel, to feed ont to stock.

Mr. Sloe, who lives on an a ljoining farm, hat three arres of Peachblow pot theses the same year. The yiel 1 was 100 bushels per acre-of which 25 bushels were mot litre enough for market, he got 5o ecents per husbel for tie other:

The accunt of the two eropls stamls as follow:

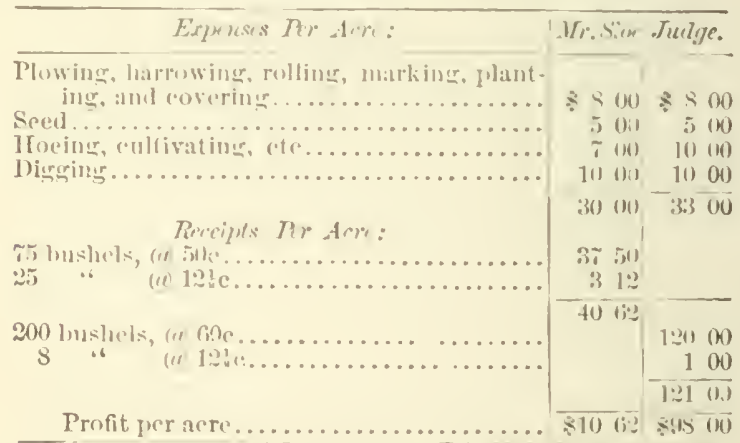

Since thrn, Mr. Slon loss been making and using more manure, and the gear before last (1Nia) his crop of potatoes averaged over 


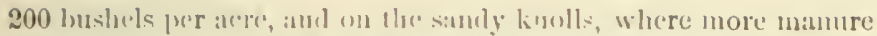

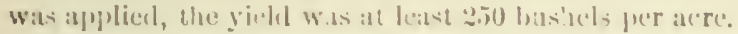

"Neverthel sns," siril the l) "au"en, "I do not believe in "high farming.' It wil: not juy."

"Posibly not," I replic.l. "It d. pencls on circumstinces; and these we will talk abuut presently. Iligh farming aims to get sarege cropis every year. Goul farming proiluces equally large crops per acre, hut not so many of them. 'Plis is what 1 am trying to (1) on my own farm. I am aiming to get 3.j busluels of wheat per

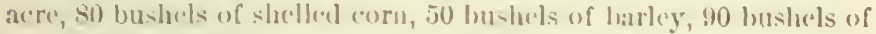
Oats, 300 bushels of molatues, and 1,200 bushrels of mangel-war\%el per acre, on the averilge. 1 can sie no waly of payiug hight wages except by raising large crops per acre. But if I get these large crops it dlos not necessirily follow that I am practising "ligh farminır.' "

To illustrate: Suppose I slumbl sucecel in aretting sueh erops hy alopting the folluwing plan. I have a farm of nearly :300 acres, one yuarter of it heiner low, alluvial lanel, tou wet for cultivation, hut when elrained exeellent for pasturiug cows of for timotlyy meatows. I train this land, and affer it is draincel I clann u] some of the streams that llow into it or through it, and irrigate whererer I can make the water llow. So much for the low land.

The upland portion of the farm, emutaining say 200 acres, ex-

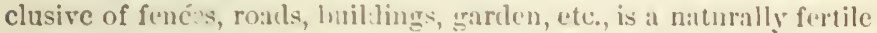
loam, as gool as the areraige whent land of Western New York. But it is, or was, badly "run down." It lad been what people call "worked to death;" althourh, i:s point of fact, it hat not been half-worked. Some suit it was " wheated to death," others that it had been "onted to denth," others that it hitl been "grassed to death," and one man sail to me, "That ficld has had slieep on it until they have gnawed crery purticle of vegutable matter ont of the soil, and it will not now prorluce emongh to pasture a tlock of geese." Aud he was not far from rirlit-notwitlistanding the farct that sheep are thouglit to be, an l are, the best animals to enrich land. But let me say, in passing, that I lave since raised on that s:me ficlil 50 bushels of barley per acre, 33 bushels of Dichl whrat, a great crop of clover, ancl last year, on a part of it, over 1,000 bushels of mangel-murzel per aere.

But this is a digression. Le's us earry nut the illustration. What does this upland portion of the farm need? It needs underdraining, thorough cultivation, an I plenty of manure. If I had plenty of manure, I coulel adongt hiqh farming. But where am I to ret plenty of manure for 200 reres of land? "Make it," sars the 
1)(e)n. Very good; but what slatl I make it of? "Make it nut of your straw and stalks and hoy." So I lo, but all the straw and stalks and hay raised on the farm when I bought it would not make as much manure as "high farming" requires for tive acres of land. Ant is this not true of half the farms in the United States to day ? What then, shall we du?

The best thing to (lo, theorctic illy, is this: Any land that is proelucing a fair crop of gratss or clower, let it lie. P'asture it or mow it for lay. If you have a finhl of clayey or stitr loamy land, break it up in the fall, an ? smmuner-fallow it llue next year, and sow it to wheat and secel it down with chorer. Lath it lie two or three years

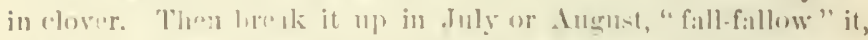
an 1 sow it with barley the neat spriag, and serel it down again with relover.

Samly or ligit lume, llat it will not pay to summer-fallow,

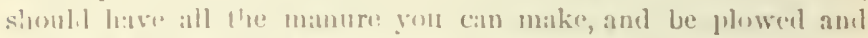
plant d with corn. C'altivate lhoroughly, anl eilher seenl it down with the (ort. in Alsplst, or s w it to barley or onts next spring, and s and it down with clover. I ay, theorefenlly this is the best plont to allopt. But practically it mily not he so, hecanse it may be

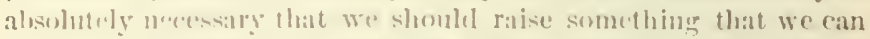

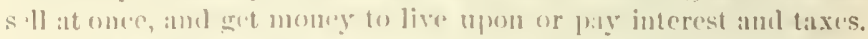

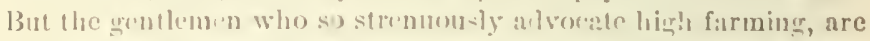

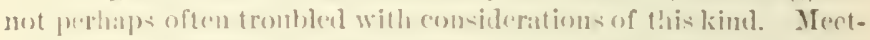
ing th m, therefore, on their own ground, I antend that in my ease "ligrl farming" would not bre as profitable as the plan hinted at albore.

The rich alluvial low lan 1 is to lu pisture l or mown the upland

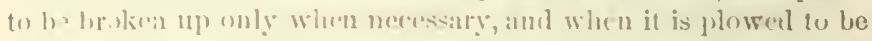
plowed well and worked thorenglily, and frot back again into cluver as soon as jussible. The lay ant pasture from the low lan 1 , and the duwer and straw and stillis from the upland, would cnalile us to kinp a grond many eowe aml sheep, with more or Jess pigse, aml tinere would lo a big pile of manure in the yarl every spring. And when this is one olotained, you can get along mach more pleasamly and profinably.

"But," I mav lo asked, "when you have got this pile of manure can unt you arloph hirle farming?" Xo. My manure pile would contain siy : bolums of elorer-hay ; 20 tons whest-straw; 25 fons

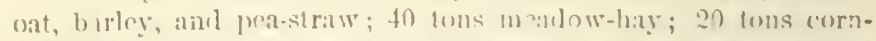
st:allis; 20 tons corn, oats, aud other grrain ; 120 tous mamgel-wurze] and turnips. 


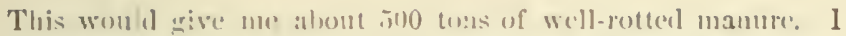
shoulh want 200 tons of this for the manterels and turmips, and the 300 tons I should want (1) top-liress 20 al'res of arras land intenderl for corngind protatoes tixe next yeatr. 11 pile of manure, theree

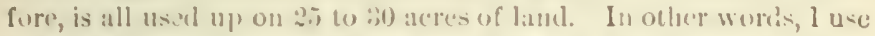
the unsolil profluer of 10 it res 10 manture one. lis this "hight farming?" I think in my viremustane e it is goot forming, hut it

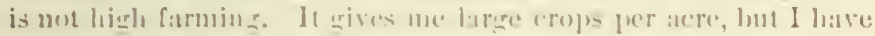
contuaratively fow acres ia erope that are sold from the farm.

"Ilish farmiag," if the term is to hase any dethote meaning at

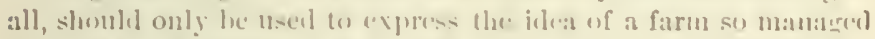

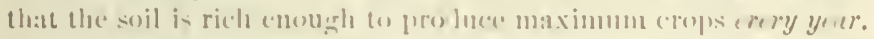
If you andogn the system of rot.tion yuite gemeral in this section-

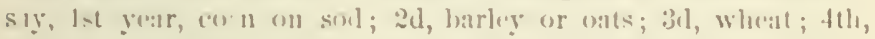

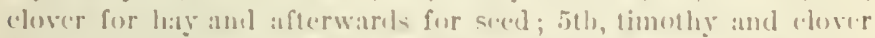

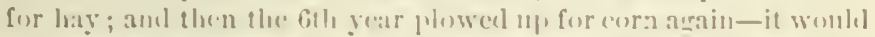

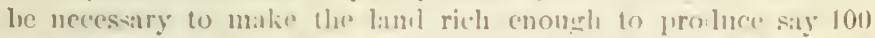

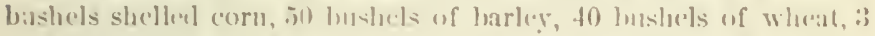

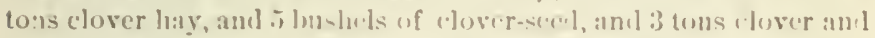
timutly-hay per acre. This would l, momernte hith farmmer. If

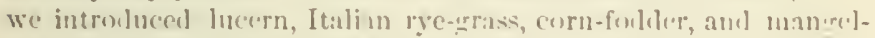
wurzel into the rotation, we should ne d still richer land to proluce a maximuin growth of these crops. In other words, we shombl need more manure.

The point I am ende:boring to eret at, is this: Where you want a farm to be self-suppurting-where you depend solely on the produere of the farm to supply manure-it is a sheer impossibility to alopt higli farming on the stente of your lend. I wint to raise just as larere erops per ace as the high farmers, lut there is no way of doing l'is, unleses we son ont-ide the farm for manure, withont ratising a smaller area of such erops as are sold from the farm.

I ilo mot wish any one to suppose that I am opposed to higl farm in :. There is oecasionally a farm where it may be practised with advantage, but it soms perfectly clear to my mind that as long as there is such an unlimited supply of letud, and such a limited supply of fertilizers, most of us will fin 1 it more profit:1h]e (o develop) the latent stores of plant-fool lying dormant in the soil rather than to buy manures. And it is cer'ain that you can not adopt him farming without either louying manure diretly; or buying foul to fee l tu animals that shall make manure on the farm.

And you must recollect that high farming requires an incrased 
supply of libbor, and birecl luclp is a luxury almost as costly is artiticial fertilizers.

We have heard superficial thinkers olject to agricultural papers on the ground that they were urging farmess to impove their land and produce larger crops, "white," say" they, "we are producing so much already tiat it will not sell for as much as it costs to produce it." My plan of improved agriculture docs not necessarily imply the procluction of any more wheat or of any more grain of any kinel that we sedl than we raise at present. I would simply rase it on fewer acres, and thus lessen the expense for seed, cultivation, latresting, ete. I womld raise 30 lushels of wheat per ace every third year, instead of 10 bushels crery year.

If we smmmer-fallowed and plowed under clover in orler to produee the 30 bushels of wheat once in three years, insteat of 10 bushels every year, no more produce of any linel woukl he raised. Bit my plan does not contemplate surh a result. On my own f:rm I seldom summer-fallow, an I never plow under cluver. I think I 'm enrich the f:m nearly as mulh hy feeding the clover to a :imals and returniner the manure to the land. The animals do not take oist more than from tive to ten per enent of the more valualse elements of plant-food from the cluser. And so my plan, while it produces as much anil no more grenin to scll, adds greatly to the fertility of the lame, and gires an increase: p production of beef, mutton, wool, butter, chese, and pork.

"But what is a man to do who is poor and has poor land?" If he has good heslth, is inclustrions, ecomomical, and is possessed of al fitir share of good common sense, lie need liave no dould as to being able to renovate his farm an limprove his ow fortune.

Fath in grool faming is the tirst rivplixite. If this is weak, it will be strengthemet by exereise. If youl have not fath, act as though you hatd.

Tork hard, but do not lon a druclue. A fow homrs' vigorous labor

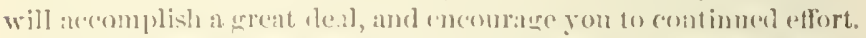
Bo prompt, systomatic, (cheerful, amol enthusiastic, Go folleal early and get me when you walke. But take sleeprenomgli. A man had

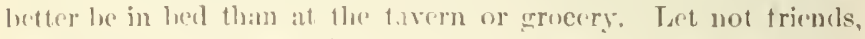
eren, keep gou ul late; " manners is manners, lut still gour elth's your ilth."

"Bat what has this to a with good firming?" More than chemistryand all the science of the seloools. Awrieulture is an art and must he followed as sucli. Science will help-loelp enormonsly -but it will never cmathle us to dispense with industry. Chemistry 
throws great light on the all of cooking, lunt a farmer's wife will roblst a turkey better than a Lieling.

When Mr. Janes 0 . Shellon, of Geneva, $N$. Y., boughth his farm, his entire crop of hay the tirst year wats if loalds. He kept stock, and bonght more or less grain and bran, and in eleven yoars from that time bis farm preduced $4: 30$ loids of hay, atloreded pasture for his large heril of shorthuru tautle, and produced quite as much gr.nin as when he tirst tork it.

Exeept in the neighborhond of large cities, "high farming " may not pry, owing to the face thit we have somuch land. But whether this is so or mot, there an be no doubt that the only protitahle system of farming is to latise large cropse on sllch hand ats we cultivate. Iligh farming gives us large crops, and meny of them. At present, while we haveso much lamel in proportion to population, we must, perisips, be content with l.ırere cropgs of grain, and few of them. We must alopt the slower but less expensive me:ms of enriching our land from natural someres, rather than the quiclicer, more artitial. and costly meats aloptel by many formers in En flan 1, ath hy marlet gar.leners, sec l-growers, and nurserymen in this comutry. Idibor is su hight that we can not affor.l fo ratis" it smill crop. If we sow but half the number of acres, and fombles the yiell, we shmul qual lruple our profits. I have made up ny mind to let the I mol lic in clorer thrce years, insten' of two. This will lessen the number of acres muler cultivation, and enable l!: $t$, bestow more eare in pl wing and eleaning it. Int the lanel will be richer, and produce bet!er crops. The atmosphere is (alpathle of supplying a certain quantity of ammonia to the soil in rains and dews every year, and by giving th. wheat (cop a three years supply instead of two years, we gitin so muel. Plaster the cluver, top-dress it in the fall, if you lave the manure, and stimulate its growth in every way possih], and consume all the clover on the land, or in the barn-yar.l. Do not sell a single ton; let not al weed grow, and the land will certainly improve.

The first object should be to destroy weeds. I do not know how it is in other sections, but with us the majority of farms are com. pletely overrun with weeds. They are eating out the life of the lan l, an l if something is not done in destroy them, even exorlitantly high prices can not make farming protitable. $\mathbf{A}$ farmer yesterday was contending that it did not pay to summer-fallow. He has taken a run-down farm, and a year ago last spring he plowed up ten acres of a field, and sowed it to barley and oats. The remaind re of the field he summer-fallowel, plowing it four times, and rolling and harrowing thoroughly after each plowing. After 
the barley and oats were ofl, he plowed the land once, harrowed it. and suwed Sed terranean wheat. On the sunmer-fallow he drilled in s)ieh! wheat. He has just threshed, and got 22 bushels per atere of liediterrancan wheat after the spring erop, at one plowing, and 26 busidels per atere of bital what on the summerfallow. This, he satid, would mot pay, ats it cost him $\$ 0$ per acere to summer-fallow, and he lest the une of the land for one sinson. Now this maty be all true, an I yet it is uo aromuent agaimst sum mer-fallowing. Wait a few years. Farming is slow work. Mr. George freddes remarkeel to we, when I told him I was trying to reuovite a run-down farm, "you will find it the work of ycur life." Wie ousht not to exprect a ligg (rope on poor, run-down land, simply by plowing it three or four time in as matuy montls. Time is repuirel for the chemical changers tos take place in the soil. But watch the efliet on the eleser for the next two years, and when the lon lis plowed atran, see if it is not in far better condition than

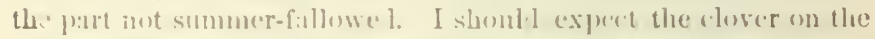
summer-falluw to be fully one-thirl better in quatity, and of het-

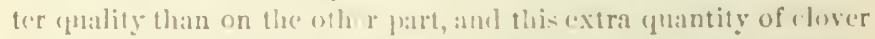
will make an 'xtra quatity of rom m inure, and thus we hase the means of going on with the work of improving the farm.

"Yer," said the Dortar, "anl tiucre will also be more clowerroms in the sil."

"But I ran not atford to wait for rlover, and summer-fallowius," writes an int lliment Ẍew York encotleman, a dear lover of grood stock, who h.: lougrht an exhaustrel New Enthand farm, "I must have a jurtion of it prorluciner enoul crops riglt otl." Very well. I farmer with plenty of money can do womlers in a shert time. Set a ging of ditchers to work, and put in underdrains wheremost neederl. Ilase teams anil plows ereugh te to the work rapilly: As soon as the land is clraned and plowed, put on a lewey roller. Then sow j00 lise of Peluri in enmono per acre broarleast, or its "cuivalent in some other fertilizer. Follow with a Shares' harrow. This will mellow the surface and corer the guano witlout disturbing the sod. Foilow with a forts-tootherl harrow, and roll again, if nected. working the land intil there is three or four inclues of fine, mellow surface snil. Then mark off the land in rows as straiglit as an arrow, and plint rorn. Cultirate thoroughly, ant kill erery weed. If the litehers ean not ket throngh until it is ton late to plant eorn, drill in heans on the last drained part of the field.

Another good crop to raise on a stock farm is corn-fodder. This can be dritled in from time to time as the land car be got 
ready. Put on balf a ton of guano per acre and harrow in aud then tuark ofl the ruws three feet ap)art, and trill in four husliels of corn yer atere. Cultivate thorumgliy, and expect a great ('rop). 135 thu last of July, the Ayrshire cows wi!l take kindly to the suce culent corn-fo liler, and with three or four yllart- of meal a day, it will enable each of them to make 10 lls. of loutt $\mathrm{r}$ a week.

For the pigs, s w a few ateren of peas. These will de well an sud-land, sown (arly or l.ul", or a port carly and a part late, as most convenient. Suw lormalanst and latrow in, jou llss, of l'e-

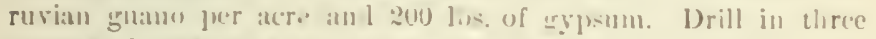

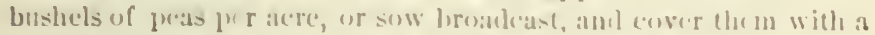
Shares' harrow. Crammeme to foed the couperen ats soun as the

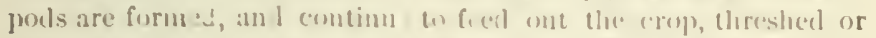
unthreshed, matil the mielelle of Noscmber. Lju to this time the bugs do complaratively little damage. The pigs will thrive wonderfully on this crop, and m the lle rie luest and be-n of manure.

I have little fath in . ay attempt to raise ruot erops on land not previously well prepret. But as is is ne esiry to have some maturel-wroel and Swede turnips for the drishire cows and

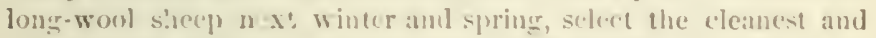
ricluest land that ean be fouml that wate under collivation last scason. If fall plowed, llie rlaners of sureess will be dombled. Pluw the land two or thre times, an I cultivate, latrow, and roll

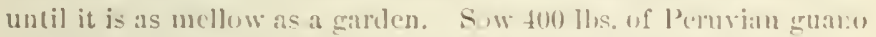

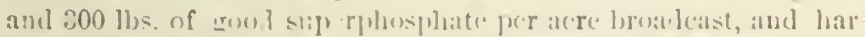

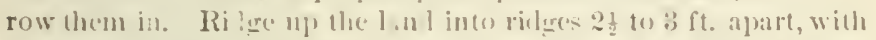
a double monlel-boarl plow. Roll down the ricleres with a light roller, and drill in the secd. Sow tho mangrel-wrzel iu May-the earlier the hetter-and the Swerles as soum afterwards as the land can be tboroughly prepared. B tter delay until Jume rather than sow on rough land.

The first point on such a farm will be to attend to the grass land. This affords the most lupeful alsence of eretting groot. returns the first rear. But no time is to be lost. Sow 500 llis. of Peruvian guano per acre on all the grass land and on t'uc cluver, witl 200 lbs. of rypsum in addition on the latter. If this is sown early enough, so that the spring rains dissolve it and wash it into the soil, erreat crops of griss mav be expected.

"But will it pay?" My friend in Nu York is a very enercetic and successful busines 3 man, and he has a real lore for farming, and I lave no sort of dombt that, takinir the New York business and the farm tunether, they will afford a rery handsome profit. Furthermore, I have no doubt that if, after lie has drained it, he 
would cover the whole farm with $500 \mathrm{lbs}$ of Peruvian guano per acre, or its equivalent, it would pay lim better than any other arricultural operation he is likely to engage in. By the time it was on the land the cost would amount to about porere. If he sells no more tratss or haty from the farm than le would sell if he did not use the gruano, this \$20 may very properly he added to the permanent capital invested in the farm. Amb in this aspect of the ease, I have no hesitation in saying it will pay a ligh rate of interest. Itis hill for labor will be as much in one ease as in the other: and if he uses the guanu he will probilnly dunble his erops. Ilis grass lands will earry twenty cows instead of ten, and if he raises the corn-fodder and ront-, he can probably keep thirty cows better than he could otherwise keep a duzen; and, having to keep a herdsman in either case, the cost of habor will nest be nuch increased. "But ron think it will not pay" "It will probably not pay him. I des not think $k$ is business would pry ne if I lived os my farm, anc? went to New York only once or twice at week. If there is one husiness above all others t'rat reguires constant attention, it is farming-and especinlly stuck-farming. But my friend is right in saying that he cannot afford to wait to enrich his land hy clover and summer-fallowing. Ilis land costs ton much; he has a large harn and everything requisite to kecp a large stoek of cattle and sheep. The intorest on farm and builelings, and the money expended in lithor, wuld run on while the dormant matter in the soil wats slowly beemine available. under the influence of good tillige. The litrge born must he filled at ouce, and the only way to do this is to apply manure with an unsparing hand. If he lived on the farm, I should lave no doulst that, by adopting this course, and by keeping improved stock, aud ferding liberally, he cumll make moner. Perhaps lee can find a man who will successfully mage the farm under his clirection, but the probahilities are that his present profit and pleasure will come from the grat. ification of his e:trly love for country life. 


\section{II $A$ I' 'I' E R I I.}

\section{WHAT IS MLNULE?}

"What is the good of asking such at question as that ?" said the Deacon ; "we all know what manure is."

"Wcll, then," I repliet, "tell us what it is?"

"It is anything that will muke erups growo better and bigger," replied the Deacon.

"That is not at had clefinition," saicl I; "but let us see if it is a true one. You have two rows of eabbage in the garden, and you water one row, and the plants grow bigger and better. Is vouter manure? You cover a plint with a hand-glass, and it grows bigger and better. Is a haud-rgliss manure? You shelter a few plants, and they grow higger and better. Is shelter manure? You put some pure sand round a few plants, and they grow bigger and better. Is pure sand manure" I think we shall hage to rejeet the Deacon's definition."

Let us hear what the Doctor has to say on the suliject.

"Manure," repliel the Doctor, "is the food of plants."

"That is a better definition," sai.1 1: "but this is really not answering the question. You say manure is plant-food. But what is plant-food ?"

"Plant-fuod," sail the Doctor, "is composed of twelre ele. ments, and, possibly, sometimes nne or two more, which we need not here talk about. Four of these elements are gases, oxygen, hyclrogen, carbon, and nitroen. When a plant or animal is burnt, these gases are driven off. The ashes which remain are composed of potas!., soda, lime, and magnesia; sulphuric acid, phosphoric acil, chlorine, and silica. In other words, the 'food of plants' is composed of four ormanic, or gaseous elements, anrl eight inorganic, or mineral elements, of which four have acid and four alkaline properties."

"Thank you, Doetor," said the Deacon, "I am glad to know what manure is. It is the fool of plants, and the fool of plants is composed of four gases, four acid and four alkaline elements. I seem to know all about it. All I have wanted to make my land rick was plenty of manure, and now I shall know where to get it-oxygen, hydrogen, carbon, and nitrogen; these four atmospheric elements. Then potash, sodia, magnesia, and lime. I know what these four are. Then stlphur, phosphorous, silica 
(sancl,) ant chlorine (sait). I shall soon have rich land and hic crops."

Charley, who has riently wome home from collegre, where he has been stmlying chemistry, looked at the I)atcon, and was evidently puzzled to understand him. Turning to the Doctor, Char. ley asked molestly if what the lonetor had said in regard to the composition of plant forl could not be sail of the composition of all our animils and plints.

"Certainly," replied the [noc(ur, "all our agrieultural plants

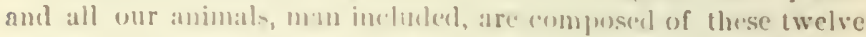
chements, oxyoren, hyilrugen, carbon, and nitrogen; phosphorus, sulphur, silis:i, rblurine, potish, sodit, magne-ia, and lime."

(Charley sibled something about lime, potash, and soda, not lieing "dements;" and something atwut siliea and chlorine not being fouml in :mimals.

"Yer," saibl I, " and he has left out iron, which is an important constituent of all our farm eropk and animals." Nither the Doc-

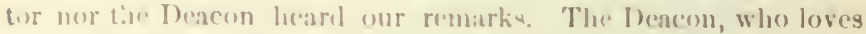
an argument, exclaimeel: "I thoneht 1 knew all ahout it. You told us that mamnere was the foul of plants, and that the food of plints was compesel of the mhove twelve elements; and now you tell us that man and beast, fruit and lluwer, grain atul grass, root, stem, amb liranch, all are eomponed or malk up of these same dozen elements. If I ask you what hreal is mate of, you say it is eompused of the dozen elements aforesil l. If I nsk what wheatstraw is made of, you answer, the dezen. If I ant what a thistle is male of, youl say llue dozen. There are a goud many milk weels in my strawerry patch, and I am glad to knww that the milk-weed and the strawberry are botle composet of the same dozen elements. Mamure is the fool of plants, and lhe foul of plants is cumposed of the above dozen flemente, and every plant and atuimal that we eat is also (omposerl of these same dozen r.lements, and so I suppose there is no ditference betwern an onion and an omelet, or between bread and milk, or between mangel-wurzel and manure."

"The differenee," replied the Dextur, "is nne of proportion. Mangels and mamure are hoth composet of the same elements. In fact, uangels make gond manure, and grool manure makes good mangels."

The Deacon and the Doctor sat down to a rame of backgammon, and Charley and I continued the conrersation more seriously. 


\section{H A I'T'E R III. \\ SOMETHIIG ABOLT IJIATT-FOOD.}

"The I) (x)(or in in the main correce" saill 1; "but he lues not fully an-werthe ytustion, "What is manure ?" Tosaly that manture

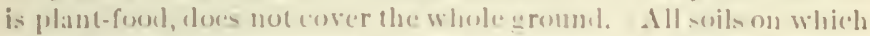
plant erow, romtain more or las plant-foml. I plant ran uot

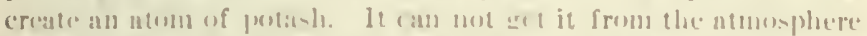
W0 thel potasls in the plant, and we humw that it ant it from the soil, and we are certain, therefore, that llie soil contains potash. Ant seof nll the other mineral clements of plants. A soil that will produce a thistle, or a pier-worl, (e)mtains plant-ford. And so the definition of the Doceter is leferetire, inasmand as it mabies no elistinction betwern snil an l nutanre. B, th contain plant-fonc."

"What is your definition of manure"" a-ken Churley; "it wonld sextm as thomeh we all kucw what manur. was. We have gest a ereat hesp of it in the sard, and it is frrmentiug nicely."

"Yes," I replis 1, "w " nre makiner mure mantre on the fatun this

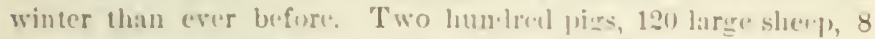
horses, 11 cows, and a lumelrod lueml of poultry make eon-julerable manure; and it is a groud cleal of wrork (1) rle:an out the pens, pilu the mantre, traw it to the finhl, and apyly it to the crops. We onglit to know somerhime alnumt it; lut we might work anong mamme all our lives, and not know what manure is. It any rate, we might not he able to detine it accurately. I will, howeser, try my hand at a definition.

"Let us assume that we have a fild that if free from starmant water at all seasons of the year; that the soil i= clean, mollww, and well workel s.ven inrli('s decp, and in gurnd order for putting in a crop. What the coming 'susmn' will be we know not. It may be what we call a hot, dry summer, or it may he cool and moist, or it my be partly one and partly the other. The 'season' is a great element of uncertainty in all our farming calculations; but we know that we shall have a season of some kind. We have the promise of seed-time and luarest, and we hare nerer known the promise to fail us. Crups, lowever, vary very much, accorling to the season; and it is necessary to bear this fact in mind. Let us say that the sun and heat, and rain and fors, or what we call 'the season,' is eapabte of proulucing 50 bushels of wheat per acre, but that the soil I have deseribed abore, dnes not produce over 20 hushels per acre. There is no mechanical defoct in the soil. The seed is gool, it is put in properly, aud at the right time, 
and in the best manmer. No weeds choke the wheat plants or rob them of their food; but that field does not produce as much wheat by 30 bushels per acre as the seuson is capable of producingr. Why? The answer is evident. Because the voleat plants do not find food enough in the soil. Now, anything that will furnish this food, anything that will eatuse that field to produce what the elimate or season is capable of producing, is manure. A gardener way increase his crops by artificial heat, or by an increased supply of water, but this is not manure. The effect is due to improved climatic conditions. It has nothin's to do with the question of manure. Te often read in the agricultural papers about 'shude as manurc.' We might just as well talk ahont sunlight as 'manure.' The effects olservel shonkl be referred to modifications of the climate or season; an l so in regard to mulehing. A good mulch may often produce a larger increase of growth than an application of manure. But mulch, proper, is not manure. It is climate. It checks (vaporation of moisture from the soil. We might as well speak of rain as manure as to call a mulch manure. In fact, an ordinary shower in simmer is little more than a mulch. It doe's not reach the roots of plants; and yet we see the effect of the shower imme liately in the inereased viror of the plants. They are full of sap, and the drooping leaves look refreshed. We saty the rain has revived them, amel so it has; but probably not a particle of the rain has enterel into the circulation of the plint. The rain checked evaporation from the soil and from the leares. A cool night refreshes the plants, and fills the leaves with sap, precisely in the same way. All these fertilizing effects, however, belong to climate. It is inaccurate to associate cither mulching, sunshine, shade, heat, dews, or rain, with the question of manure, though the effect may in certain cireumstances be precisely the same."

Charley evidently thought I was wandering from the point. "You think, then," said he, "manure is plant-food thit the so"t necds?"

"Yes," said I, "that is a very gool definition-rery gool, indeed, though not absolntely accurate, because minure is manure; whether a particular soil nee ls it or not." Cnobserved by us, the Deacon and the Doctor had been listening to our talk. - "I would like," said the Deacon, "to hear pnu give a hetter definition than Charley has given."-"MImure," suil I, "is anything containing an element or elements of plant-fool, which, if the soil needed it. woul: if supplied in sufficient quantity, and in an avalable condition, produce, accorling to soil, season, climate, and variety, a maximum erop." 


\section{I A P'I'E R I V.}

\section{NATURAL, IANURE.}

We often hear ahout "natur.ll" manure. I do not like the term, though I helieve it originated with me. It is not accurate; not definite enougir.

"I do not know what you mean by natural manure," said the Deacon, "unless it is the dropplunes of animals."- "To distinguish them, I suppose," saiu the Doctor, "from artiticial manures, such as superphospliate, sulphate of ammunia, and nitrate of soda.""No; that is not how I used the term. I few years ago, we used to hear much in regard to the 'exhaustion of soils.' I thouglit this phrase conveyed a wrong idea. When new land produces large crops, and when, after a few years, the erops get less and l ss, we were tol 1 that the farmers were exhansting their land. I said, no; the farmers are not exhausting the soil; they are merely exhausting the accumulated plant-food in the soil. In other words, they are using up the natural manure.

"Take my own farm. Fifty years ago, it was envered witl a heary growth of maple, becech, black walnut, oak, and other trees. These trees had shed annual crops of leaves for centuries. The leaves rot on the ground; the trees also, age after age. These leaves and other organic matter form what I have called natural manure. When the land is cleared up and plowed, this natural manure deeays more rapidly than when the land lies undisturbed; precisely as a manure-pile will ferment and decay more rapidly if turned necasionally, and exposed to the air. The plowing and enltivating renders this natural manure more readily available. The leares decompose, and furnish food for the growing cropr."

\section{EXHACSTION OF THE SOIL.}

"Tou think, then," said the Doctor, "that when a piece of land is cleared of the forest, harrowed, and sown to wheat; plowed and planted to corn, and the process repeated again and again, until the land no longer yiel'ls profitable crops, that it is the 'natural mamure,' and not the soil, that is exhausted?"

"I think the sril, at any rate, is not exhausted, and I can easily conceive of a case where even the natural manure is very far from being all used up."

"Why, then," asked the Deacon, "is the land so poor that it will scarcely support a sheep to the acre?" 
"Simply lecanse the natural manure an:l other plant-food which the soil contains is not in an avilable eondition. It lies dead and inert. It is not soluble, and the roots of the plants cannot get enough of it to enable them to thrive; and in addition to this, you will find as a matter of lact that these poor ' exhausted' farms are infested with weeds, which rob the growing crops of a liare part of the scanty supply of available plant-food."

"But thrse weeds," stid the Deacon, "are not remored from the farm. "Tley rot on the land ; notling is lost."

"True," said I, "but they, nevertheless, rob the growing crops of available plant-foml. The anmual supply of plant-food, instead of being used to grow useful niluts, is us ad t grow weeds."

"I mulertind that," side the Deacon, "but if the weeds are left on the land, and the usiful plants are sold, the farmer who keeps his lan I clain would exhemit his land faster than the careless furmer who lets his land lie mutil it is orrrmen with thistles, briars, and pirr-weed. Yon anricultural writers, whos are constantly urginer us to farm hetter and grow latrer crops, seem to overlook this point. As you know, I do not take much stock in chenical theories as applied to arriculture, but as you do, here is a little extract I cut from an agricultural paper, that seems to jrove that the better you work your land, and the larger erops you ratie, the sooner you exhaust your land."

The Deacon put on his spectacles, drew his chair nearer the lamp on the talle, and read the following:

"There is, on an averige, albout nue-fourth of a pounel of potash to every one lundred pounds of soil, and about one eighth of a pound of plowphoric acil, and me-sixtcenth of a pound of sulphuric acicl. If the potatues and tho topes are continually removed from the soil, it will soon exhaust the potash If the wheat and straw are removed, it will soon exhamst the pliosphate of lime; if corn and the stalks, it will soon exhaust the sulphuric acill. Unless there is a $r$ itation, or the material the plant requires is supplied from ahroad, four crops will som rum ont, though the suil will continue rich for other plants."

"Tlat extract," saicl I, "carriı's one back twenty-five years. We used to have article after article in this strain. Wo were told that "always taking meal out of the tuls soon comes to the bottom,' and always taking potash and phosphorie acid from the soil will soon exhaust the suplyly. But, muctic ily, there is realyy litt?e danger of our exhausting the land. It do s not par. The farmer's resourees will be exhatusted long before he can exhanst his f:trm." 
"Assuming," sitid the lloctor, who is fond of an arement, "that the above statement is trute, let us look at tiec facts. An acre of soil, 12 inches leerp, would weigh aloout 1,600 tons; and if, as the writer quoted ly the Deacon states, the soil contains 4 ozs. of potatsh in every $100 \mathrm{lls}$ of soil, it follows that an acre of soil, 12 inches ier $]$, contains $8,000 \mathrm{lbs}$. of potash. Now, potatoes contain about 20 per cent of dry matter, and this dry matter contains, say, 4 per cent of ash, hialf of which is potash. It follows, therefore, that 2.50 bushels of potitoes contain about 60 $1 \mathrm{ls}$ of potash. If we reckon that the tepss contitin $20 \mathrm{lbs}$, whore, or 80 lbs. in all, it follows that the acre of soil contains potast enough to grow an annuil crop of 250 linshels of potatoes per ate re for one hunired years."

"I know farmers," sairl Charley, "who de not get over 50 bushels of potateses per acre, and in that case the potash would last fire lundred years, as the weeds grown with the crop are left on the land, and do not, aceorling to the I) eacon, exhaust the soil."

"Grood for you, Clarley," said the Doxtor. "Now let us see about the phosphoric acid, of which the soil, accordiag to the above statemeat, contilius oily half as much as it contians of potash, or 4,000 lls. pur acre.

"A crop of wheat of 30 lumshels per aere," continued the Doctor, "contains in the grain about 26 lbs. of as's, and we will say that half of this ash is piosplurie acid, or 13 liss. Allowing that the straw, chaff, etc., contain ; lbs. more, we remore from the soil in a crop of wheat of 30 bushels per acre, $20 \mathrm{lb}$ of phosphoric acid, and so, accorcling to the above estimate, an acre of soil contains phosphoric acil to proluce annually a crop of wheat and straw of 30 bushels per acre for tero hundrea years.

"The writer of the paragraplu quoted by the Deacon," continued the Doctor, "selected the crops and elements best suited to his purpose, and yet, according to his own estimate, there is sufficient potash and phosphoric acid in the first 12 inches of the soil to enable us to raise unusually large crops until the next Centennial in $19 \pi 6$.

"But let us take another riew of the subject," continued the Doctor. "No intelligent farmer removes all the potatoes and tops, all the wheat, straw, and chaff, or all the corn and stalks from lis farm. According to Dr. Silisbury, a crop of corn of 75 busllels per acre removes from the enil 600 lbs. of ask, but the grain contains only 46 lus. The other $5.51 \mathrm{lhs}$. is contained in the stalks, etc., all of which are usually retained on the farm. It follows 
from this, that when only the grain is sold ull the farm, it takes more than thirteen (rops to remuse as much mineral matter from

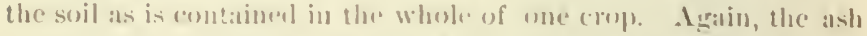

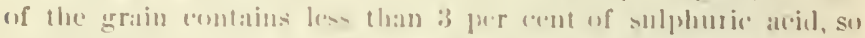

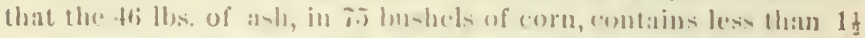
lls. of sulphuric acrid, and thus, if an at re of soil contains 2, 1000

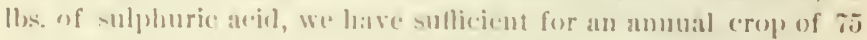
bushels par ace fer tifteen humbered years!

"As I stall before," comtiuutel the ")oetur, "intelligent farmers

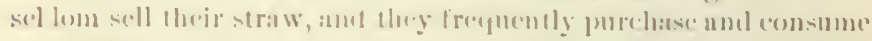

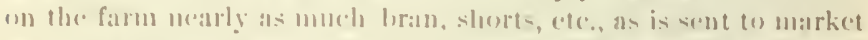
with the grain they sell. In the ' Nallural Ilistory of New York,

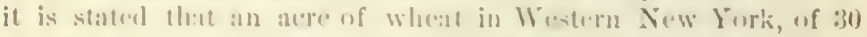

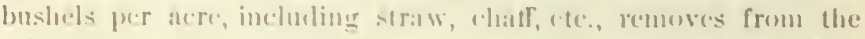

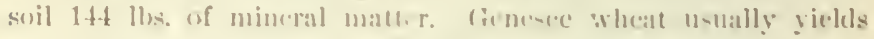

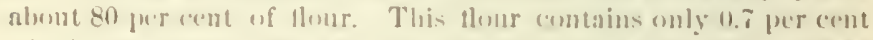
of mineral matter, while time midlling- remtain f jer cent; coarse

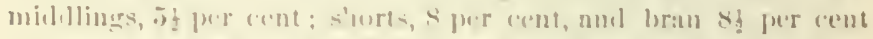
of mineral malter or :s sh. It follow $=$ from this, lhat out of the 144

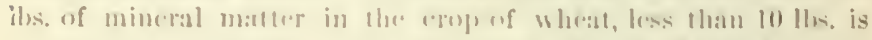

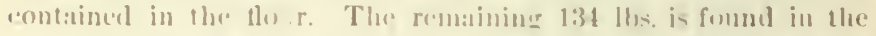
straw, rhatr, lıran, - furt-, wh., which a goud farmer is almost sure to fered ent on his farm. but exen if the farmer ferels out nome of his whent-bran, but sells it all with his wheat, the 30) hushels of wheat remove from the soil only 2t: lhe. of minersl matter; and it would take more than five cropge to remose as mush mineral matter as onc crope of whe:at and straw enutains. Allowing that half

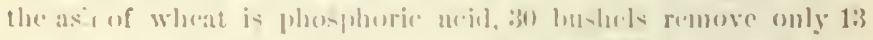

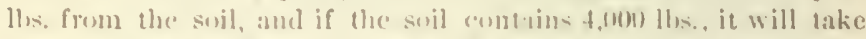

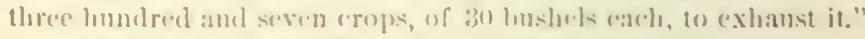

"That is to saly," s.iul charley, "if all the straw and chatf is retained on the farm, axd is returnel to the land without loss of phospherie ancil."

"Yes," said the Docter, "a 11 if :1ll tien hran and shorts, cte,

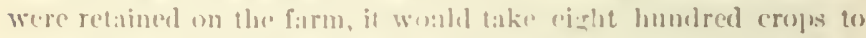

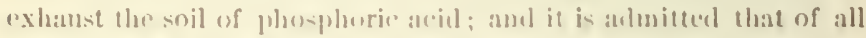

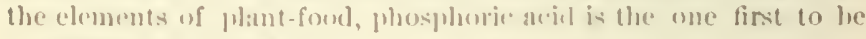
exhisisted from the snil."

I have sold some timully hay this winter, and propose to do so whenever the priee suits. But some uf my neirltbors, who do uot he-ilate to sell their own la:ty, thiuk I omelat not to du so, besause " "write for the papers"! It ought to sati-fy them to know that I brine back 30 ('wt. of liran for wery tom of hay I 


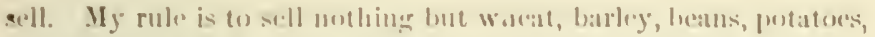

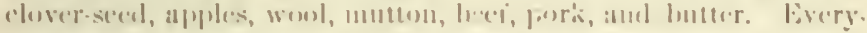

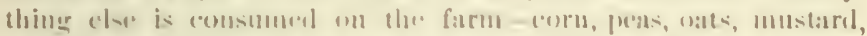

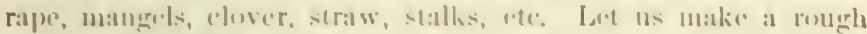

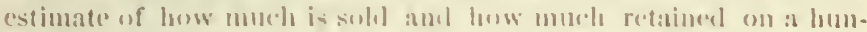

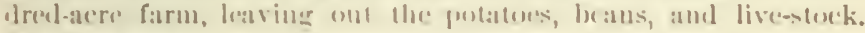

IVe have sigy:

silil.

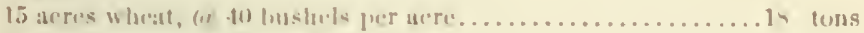

5 " harl(w, (ti ix) ". "

15) " eforersent, 4 " $"$.

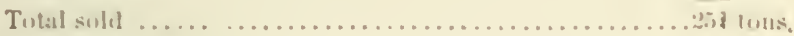

Retainied on t]a farm.

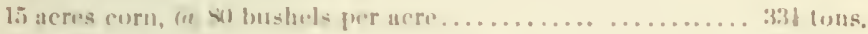

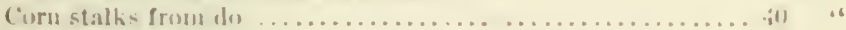

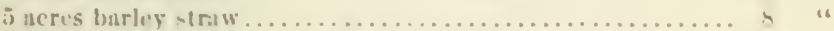

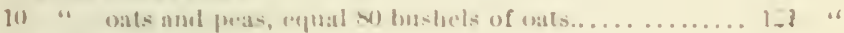

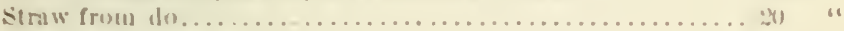

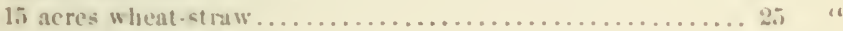

15 " clover-hat........................ "

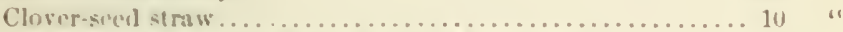

15 acres pasture and mendow, equal fll tons hay......... \&

5 " mustarl, erqual 10 toms hay. ................

5 " rape, equal 10 curs hay..................

5 " inangels, "25 tons per acre, equal to 3 tons dry...... 15 "

Leaves from do............................ 3 "

Total retalned on the farm .....................25: tous.

It would take a gond many years in exhaust any ortimary soil by such a course of eroppine. Execpt, perlaps, the sanely knolls, I think there is mot an are on my firm that would be colsansted in ten thousand years, and as some portims of the luw alluvial soil will grow crops without mamurc, thare will he an opporturity to give the poor, sandy knoljs more than their share of plant-fool. In this way, notwithstaniling the fact that we sell prouluce and bring nothing back, I brliere the whole farm will gradually increase in productiveness. The plunt-fond annually remiered arailable from the decomposition and disintegration of the inert organic and mincral matter in the soil, will be more than equal to that exportol from the farm. If the soil becomes deficient in anythiner, it is likely that it vill he in phosploates, aud a little superplosphate or lone-ilust migist at any rate be profitably ustel in the rape, mustarel, and inruips.

The proint in erond farming is to develop from the latent stores 
in the soil, and to acrumulate crough avilable plant-food for the production of the larges possihle yield of these? (ropss which we sell. In other words, we want enongle availalle plant-food ia the soil to grow 40 busluels of wheat and 30 bushels of barley. I think the farmer who raises 10 tons for every ton he sells, will som reach this point, and when once reaclsed, it is a comparatively a:sy matter to maintain this decrree of fertility.

\section{WHY OLL CROPS ARE SU POOR.}

"If the soil is so rich in plint-foorl," said the Deacon, "I again ask, why are our (ropls so poor?"

The Itacon s.id this very quietly. IIe di.l not seem to know that he lad asked one of the most important ruestions in the whole ranere of agricultural science. It is a fact that a soil maty contain enough plant-food to produce a thousand large cropss, and yet the erouss we ohtain from it may be so poor as hardly to pay the cost of rultivation. The plant-fool is there, lunt the plants camnot get at it. It is not in an avaliable conclition; it is not solulile. A rase is quoted by Prof. Jolmson, where a soil was analyzed, and found to contain to the depth of one foot 4,652 lhs. of nitrogen per acre, but only 6:3 lbs. of this was in an available enndition. And this is erpually true of phosplioric accid, potash, and other dements of plant-food. No matter low much plant-food there may he in the soil, the only portion that is of any immodiate value is the small amount that is annually available for the growth of 'rops.

\section{HOW TO GET LARGEIR CROPS.}

"I am tired of so much tallis about plant-food," saicl the Deacon; "what we want to know is low to make our land produce larger cropes of wheat, corn, oats, barley, potatoes, clover, and grass."

This is preciscly what I an trying to show. On my own farm, the three leading objocts are (1) to get the limd drained, (2) to make it clean and mollow, and (3) to get availalule nitrogen for the cereal crops. s "ter the first two objects are aceomplisherl, the measure of produtiveness will he determined by the amomt of arailable nitrogen in the soil. IIow to are avilibible nitrogen, therefore, is my chief and ultimate oljoet in all the operations on the farm, and it is here that seience ean locilp me. I know how to get nitrogen, but I want to get it in the cheapest way, and then to be sure that 1 do not waste it.

There is one fact fully estalblisher hy renested experiment and general experienee-that 80 lbs. of avilable nitrogen por acre, 
applied in manure, will almost invariahly give us a greatly inereased yield of grain cropss. I should expect, on my farm, that on land which, without manure, would give me 15 bushels of wheat per acre, such a dressing of manure would give me, in a favorable season, 3.5 or 40 busliels pere acre, willt a proportional increase of straw; and, in addition to this, there would be (onsiderable nitrogen left for the following cupp of chover. Is it not worth while making an carnest eflort to get this $80 \mathrm{llss}$. of avilibble nitrogen?

I have on my farm many acres of low, mucky land, bordering on the creek, that probably contain several thourand pounds of nitrogen per acre. So long as the land is surchured with water, this nitrogen, and other plant-ford, lies dormant. But drain it, and let in the air, and the oxegen decomposes the oreanic matter, and ammonia and nitric acid are produced. In other words, we get aveilable nitmgen and other plant-food, and the land hecomes capahle of producing larie cropls of corn and grass; and the cropes obtained from this low, rich land, will make manure for the poorer, upland portions of the farm.

\section{II A P 'T E R T.}

\section{SWAMP-MLCK OR PEAT AS MANLRE.}

"It would pay you," stid the Deacon, "to draw out 200 or 300 loads of muck from the swamp every year, and eompost it witl your manure."

This may or may not be the case. It depends on the composition of the muck, and how much labor it takes to handle it.

"What you should do," said the Doctor, " is to commence at the creek, and straighten it. Tilke a gang of men, and be with them with yourself, or get a good foreman to direct operations. Commence at $a$, and straighten the ereek to $b$, and from $b$ to $c$ (see map on next page). Throw all the rich, black muck in a heap by itself, separate from the samcl. You, or rour foreman, must he there, or you will not get this done. $\Lambda$ good ditcher will throw out a great mass of this loose muek and sand in a day; and you want him to dig, not think. You must to the thinking, and tell him which is muck, and which is only sand and dirt. When thrown up, this muck, in our dry, lot climate, will, in the course of a few 
montlus, part with a large amount of water, and it ean then be drawn to the barns and stables, and used for bedding, or for composting with manure. Or if you do not want to draw it to the barn, get some refuse lime from the lime-kiln, and mix it with the muck after it has been thrown up a few weeks, and is partially dry. Thurn over the heap, and put a fen bushels of lime to every cord of the muck, mixing the lime and muck together, leaving the heap in a compact form, and in good shaze, to shed the rain.

"When you have straigitened, and cleaned ont, and deepened the creek," continued the boctor, "commence at $z$ on the new creek, and cut a ditch through the swamp to $y$. Throw the muck on one side, and the sand on the other. This will give you some

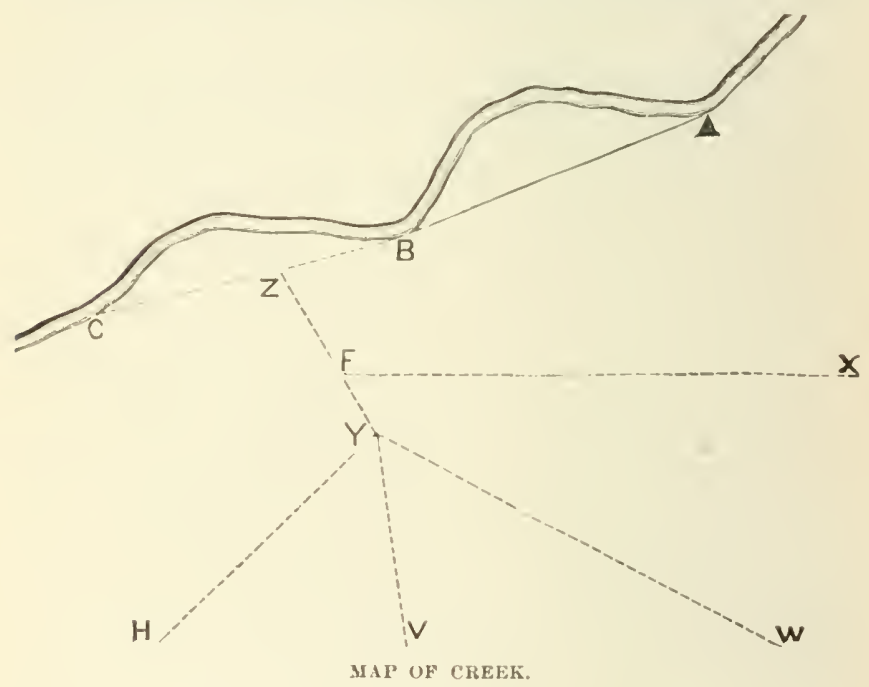

grood, rich muck, and at the same time drain your swamp. Then rut some under-druins from $y$ towards the higher land at $x, r$, and $h$, and from $f$ to $x$. These will drain your land, and set free the inert plant-food, and such crops of timothy as you will get from this swamp will astonish the natives, and your hill for medical attentance and quinine will sink to zoro."

The Doetor is right. There is money and health in the plan.

Prof. S. W. Johnson, as chemist to the Comn. State Ag. Society, made accurate analyses of 33 samples of peat and muck sent him by gentlemen from different parts of the State. The amount of 
potential ammonia in the chemically dry peat was found to vary from 0.58 in the poorest, to 4.06 fer eent in the richest samples. In other words, one deposit of muck may contain seren times as nueh nitrogen as another, and it would be well hefore sperding much money in drawing out muck for manure to send a sample of it to some good chemist. A bed of swamp-muck, easily accessibic, and containing 3 per cent of nitrogen, would be a mine of weath to any farmer. One ton of such muck, dry, would contain more nitrogen than 7 tons of straw.

"It would be eapital stutf," said the Deacon, "to put in your pig-pens io absorb the urine. It would make rich manure."

"That is so," said I, "and the weak point in my pig-hreceling is the want of suffieient struw. Pigs une up more becleing than any other animals. I have over 200 pirs, and I could use a ton of ary muck to each pig every winter to great advantage. The pens would be drier, the pirs healthier, and the manure richer."

The Doctor here interrupted us. "I see," said he, "that the average amount of ammonia in the $3: 3$ samples of dry peat analyzed by Professor Joinson is 2.07 per cent. I had no iclea that muck was sorich. Barn yard manure, or the manure from the horse stahle's in the cities, contains only lualf a per eent $(0.5)$ of ammonin, and it is an unusually rich manure that contains one per cent. We are safe in saying that a ton of dry muck, on the average, euntains at least twice as much potential ammonit as the average of our best and richest stable-manure."

\section{II $A$ P T E R V I.}

\section{WHAT IS POTENTIAL AMIONIA?}

"You say," said the Deaeon, "that dry muck contains twice as much 'potential ammoni, ' as manure?"

"Yes," said the Doetor, "it contains three or four times as much as the half-rotted straw and stalks you eall manure."

"But what do you mean," asked the Deacon, "by "potential ammonia?"

"It is a term," said the Doctor, "we used to hear much more frequently than we do now. Ammonia is eomposed of $14 \mathrm{lhs}$ of nitrogen and 3 lbs. of hỵdrogen; and if, on analysis, a guano or 
other manure was found to contain, in whatever form, 7 per cent of nitrogem, the elomist repurted that he found in it $8 \frac{1}{2}$ per eent of 'potential' ammonia. Dried blool contains no ammonia, but if it contained 14 per cent of nitrogen, the chemist would be justifiel in saying it coutained $1 \tilde{r}$ per cent of potential ammonia, from the fact that the dried blood, by fermentation, is capable of yielding this amount of ammonia. We say a ton of common horsemanure contains 10 or $12 \mathrm{lhs}$ of potential ammonia. If perfectly freshe, it may not contain a particle of ammonial bat it contains nitrogen enengli to procluee, hy fermentation, 10 or 12 lbs. of ammonia. And when it is saicl that (try swamp-muck routains, on the average, $2.0 \%$ ferent of potential ammonia, it simply means

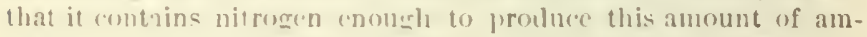
mouia. In proint of fact, I suppose wuck, when dug fresh from the stampl, (ontains no ammonlia. Ammonia is quite soluble in water, and if there was any ammunia in the swamp-muck, it

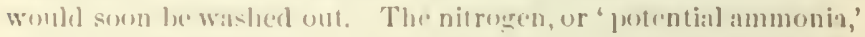
in the muck exists in an incm, insoluhle form, arel before the muck will yidel up this nitrugen to plants, it is necessiry, in some way, to forment or elecompose it. But this is a point we will discuss at a future meeting."

\section{I $\Lambda$ P'I E R V I I.}

\section{TILLAGE IS MANURE.}

The Doctor has been invitel to duliver a lecture on manure before our lecal farmers' ('lub. "The etymolugical meaning of the word manure," he said, " is hand hebor, from muin, hand, and outrer, to work. To manure the land originally meant to cultivate it, to hoc, to lig, to plow, to harrow, or stir it in any way so as to expose its particles to the oxyen of the atmospliere, ano thus render its latent elementi assimilable ly plants.

"When our first parent," he continued, " was sent forth from the Garden of Eden to till the ground from whence he was taken, he probably diul not know that the means neecssary to kill the thorms and thistles onluanced the productiveness of the soil, yet such was undoubtelly the calse. 
"The farmer fur centuries was simply a 'tiller of the gromnd.' Guano, though formet, accorling to some eminent athorities, long age's before the ereation of man, was not then known. The coprolites lay undisturbed in conmtless numbers in the lias, the greensand, an the sullisli cring. (harlenton phosphates were unknown. Superpho-phate, sulphate of ammonia, nitrate of solat, and kanit were not dreanuel of. Nothing was sibl about the mincral manure thenry, or the exhanstion of the soll. There were no frands in artificial furtilizers; no kixpriment stations. The earth, freshe from the hands of itm ('reator, needed only to he 'tickled with a lose to latlerl with a harvest.' Nothine was said ahout the value of the manure ob)ained from the (') sumution of

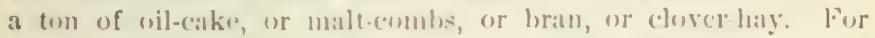
many centuries, the lowe, the spiule, and the ralie constituted Alam's whole stosek in trale.

"At lenerth," enutinued the Ductor, "a greal di-eosery was made. A Roman farmur-prohbilily a prominent firangre-sumbled on a mirlity truth. IItumring the land-that is, horing and cultirating it-inderensed its fortility. This was well known-had been known for ates, and ared ulou: lut this loman farmer, Stereutius, who was a clo=e observer, divenvered that the droppings of thimals hat the sime cflect as lineiner. No wonder these idolatrous people roted him a goul. Thry thought there would be no more old-fashionel manuring; no more hoeing.

"Of course they were mistaken," continued the Doctor, "our arable lanil will always need plowing and cultirating to kill weeds. Manure, in the sense in which we now use the term, is only a partial substitute for tillage, and tillare is only a partial substitute for manure; lut it is well to bear in mind that the worls mean the same thing, and the effects of both are, to a eertain extent, identical. Tillage is manure, and manure is tillage." 


\section{II A P ' T E I V I I I.}

\section{SUMAEIR-FALLOWING.}

This is not the place to discuss the merits, or demerits, of fallow. ing. But an intelligent Ohio farmer writes me:- "I see that you recommend fallow plowillg, what are your reasons? Granting that the immedinte result is an increased cropl, is not the land inpoverished "Will not the thorough cultivation of corn, or potatoes, answer as well?" And a distinguished farmer, of this State, in at recent communication expressed the same ideat-that summerfallowing would som imporerish the land. But if this is the case, the fault is not in the practice of summer-fallowing, hut in growing too many grain crops, and selling them, insteat of consuming them on the farm. Take a wo fiekds; summer-fallow one, and sow it to wheat. Plant hle other to corn, and sow wheat after it in the fall. You get, say 3.j lushels of wheat per acre from the summer-fallow. From the other field you cret, say, 30 bushels of slielled corn per acre, and 10 bushels of wheat afterwards. Now, where a farmer is in the labbit of selling all his wheat, and comsuming all his ecorn on the farm, it is evident that the practice of summer-fallowing will impoverish the soil more rapidly than the system of growing corn followel by wheat-and for the simple reason that more wheat is sold from the farm. If no more grain is sold in one case than in the other, the summer-fallowing will not impoverish the soil any more than corn growing.

My idea of fallowing is this:-The soil and the atmospliere furnish, on gornd, well cultivate:l land, plant-food sullicient, say, for 15 bushels of wheat per are, exery yerr. It will be sometimes more, and sometincs less, according to the season and the eharacter of the soil, but on good, stroner limestone land this may be taken as about the averare. To grow whent erery year in crops of 15 bushels per acre, woukt impoverish the soil just as much as to summer-fallow and get 30 bushels of wheat every other year. It is the same thing in either case. But in summer-fallowing, we clean the land, and the profits from a erop of $: 30$ bushels per acre every other year, are much more than from two crops of 15 bushels every year. Yon know that Mr. Tawes has a field of about thirteen acres that he sows with wheat every year. On the plot that receives no manure of any kind, the crop, for twenty years, averaged $16 \pm$ bushels per atere. It is plowed twice every year, and 
the wheat is hand-hued in the spring to kenep it elean. $\Lambda$ few years agro, in a ticld adjoininer this cxperimental wheat fichl, and that is of the sime character of lind, he mate the following experiment. The land, after whent, wats fithowed, and then sown to wheat; then fallowed the next yeatr, and atrain sow to theat, and the next year it was sown to wheat after wheat. The following is the result eompared with the yiold of the continuously unmanured plot in the experimental field that is sown to wheat crery year:

1. YEA

Yo. 2-Wheat after wheat........15 bushels 34 pecks per acre.

2. Yrar-No. 1-Wheat after fallow......s\% " - " "

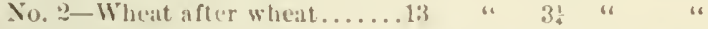

3. Ye.1R-No. 1-Fallow after wheat ..................... No crop.

No. 2-Wheat after wheat........15 bustels 3 ! pereks per acre.

4. YEak-No. 1-Wheat after fallow....... " " - " " "

Xo. 2-Wheat after wheat........21 " " "

5. YEAR-No. 1-Wheat after wheat.......1\%

No. 2-Wheat after wheat .......17

Taking the first four years, we have at total yield from the plot sown every year of 60 busluels 25 pecks, and from the two (rops altermately fallowed, a total yicld of 79 bushels. The next year. when wheat was sown after wheat on the land previumsly fallowed, the yield was almost identical with the yiele from the plot that has grown wheat after wheat for so inany years.

So far, these results do not indicate auy exlanstion from the practice of fallowing. On the other hand, they tend to show that we can get more wheat by sowing it every other year, than hy cropping it every year in succession. The reason for this may be found in the fact that in a fallow the land is more frepuently exposed to the atmosphere hy refeated plowings and harrowings; and it should be borne in mint that the effect of stirring the land is not necessarily in proportion to the total amount of stirring, but is according to the number of times that fresh particles of soil are exposed to the atmosphere. Two plowings and two harrowings in one week, will not do as much good as two plowings and two harrowings, at different times in the course of three or four mont'is. It is for this reason that I object, theoretically, to sowing wheat after barley. Te often plow the harley stuble twice, and spend consilerable labor in getting the land into goof condition; but it is generally all done in the course of ten days or two weeks. We (lo not get any adequate benefit for this lahor. We can kill weeds readily at this season. (Aurust), lut the stirring of the soil does not derelope the latent plant-focd to the extent it would if tho 
work was not necessarily done in such a limited period. I say theoretically, for in point of fact I do sow wheat after barley. I do so because it is very convenient, and because it is more inmediately profitable. I an satisfied, howerer, that in the end it would be more profitable to seed down the barley with clover.

We must raise larger crops; and to do this we must raise them less frequently. This is the key-note of the coming improved system of Anerican agriculture, in all sections where good land is worth less than one hundred dollars per acre. In the neighborhood of latge c1ties, and wherever land comminds a high price, we must keepl our farms in a high stiste of fertiity ly the purchase of manures or eattle foods. Those of th in the iuterior, where we can not hny manure, must raise fewer grain crops, and more clover. We must aim to raise 40 bushels of wheat, 50 bushels of barley, 80 bushels of oats, and 100 bushels of shelled coru, and 5 bushels of clover-seet per atere. That this ean be done on geod, well-clr ined land, from the unililed resources of the farm, I have no doubt. It may give us no more giain to sell than at present, but it will enahle us to proluce much more mutton, wool, beef, cheese, butter, and pork, than at present.

"But, then, will there be a demand for the meat, wool, etc.?" The present inclications are highly farorable. But we must aim to raise grod meat. The low-prieed beef and mutton sold in our markets are is unprofitalble to the consumer as they are to the producer. We must feed higher, and to do this to adrantage we must have improved stock. There is no prolit in farming withont good tillage, larerer crops, inproved stock, and higher feeding. The details will be moditie l by cireumstanees, hut the principles are the same wherever agri-culture is practised. 


\section{II $\Lambda$ I'T E R I I.}

\section{HOW TO RESTORE A WORN-OUT FARSI.}

I have never yet seen a "worn.out" or " exhlilusted farm." I know hlany farms that are "l'un down." I bought just such a farm a dezen or more years age, ind 1 have becin trying hard, ever since, to bring it up to a protitande stindard of productiveness-and an still erying, and expect to have to kecele on trying so long as I keep on farming. The truth is, there nevele was a farm so rich, that the farmer did not wi-ls it was richer.

I have succeded in making the larger part of my farm much more procluctive than it ever wals before, sisce it was cleared from the oririnal forest. But it is far from being as rich as I want it. The truth is, God sent us intw this world to work, and Ille has giren us plenty to do, if we will only do it. At any rate, this is true of farming. Ile has not given us land reaty to our hand. The man who first clearcel up my farm, had no easy tisk. IIC fairly earned all the geood erope he erer get from it. I liave never begrudged him one particle of the "natural manure" he tonk out of the land, in the form of wheat, corn, oats, and hay. On the dry, sandy knolls, he probably got out a geocl portion of this natural minure, but on the wetter and heavier portinns of the farm, he probably did not get out one-hundredth part of the watural manure which the land contained.

Now, when such a farm came into my possession, what was I to do with it?

"Tell us what you did," said the Doetor, "and then, perlaps, we can tell you what you ought to have done, and what you obght to have left undone."

"I made many mistakes."

"Amen," said the Deacun: "I am glad to hear you acknowl. elge it."

"Well," said the Doetor, " $i t$ is hetter to make mistakes in trying to do something, than to hug our self-esteen, and fold our hands in indolence. It has been said that erities are men who have failed in their undertakings. But I rather think the most disagreeable, and self-satisfied critics, are men who have lerer done anything, or tried to do anything, themselres."

The Deacon, who, though something of an old forgy, is a good deal of a man, and possessed of good commion sense, and much ex- 
perience, tonk these remarks kimlly. "Wrll," said he to me, "I most say that your farm hatsecertinly inproved, but you did things so ditlerently trom what we expeeted, that we could sot see what you were lliving at."

"I cem tell you what I have bech aiming at all along. 1st. To draie the wee pertions of the atrible land. 2d. To kill weeds, and make the soil mellow and cleam. "abl. Th make more manne."

"You have alio bought sume boncelust, superphosphate, and other artificial manures."

"True; and if 1 hat had more money I would have hought more manure. It would have faid well. I could have male my la bul as rich at it is mow in laalf the time."

I hatel to depend prineipally wh the natural resourees of the land. I gुot ont of the soil all I rould, ant? hept as much of it as possible on the farm. Wire of the mistakes I makle was, in lereaking up too much lamil, and putting in tom much wheat, barley, oats, peas, and

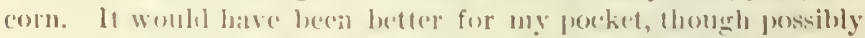
not so grood for the farm, if I hatel left more of the lamel in grass, amil also, if I had smonmer-fallowed more, amel sown less barley and oat: amil planterd less courn.

"I de net sere hew plowing up the errass land," sibil the Deacon, "could pesibly loe any leteer for the farm. You agricultural writcrs are always folling us thatl we plow too morels land, and do uon raise gral<s and clover enomght."

"What I metant lig saytug that it would have been better for my pocknt, thourli possibly not so groel for the farm, if I lad not plowed so mude land, may need explamation. The land had been only laalf enltivated, and was very foul. The grass and clever fiedle dicl not eive more than half a crop of hay, and the hay was poor in quality, ant mueh of it half thistles, and wher weeds. I plowed this limel, planted it en com, and cultivated it thoroughly. But the labor of keeping the eorn elenu was costly, and alsorbed a very large slice of the profits. But the corn yielded a far larger produce per acre than I should have got had the land lain in grass. And as all this produce wats consimed on the farm, we made more manure than if we had plowel less land."

I have great faitlu in the henefits of thorought tillage-or, in other words, of lireaking up, pulverizine, and "xposing the soil to the deempesing action of the atmospluere. I look upon a good, st rong soil ats a kind of strrchouse of plant-foud. But it is not an easy mitter to renter this plant-food soluble. If it were any less solube than it is, it would have all leached ont of the lancl centuries ago. Tuming over, and fining a manure-heap, if other concitions 
are favoralube, callse rapia] [ermentation with the formation of ear-

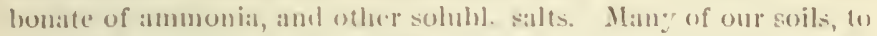

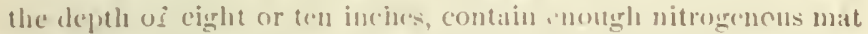
ter in un acr so produce two or three thousitual poumels of ammonia. Byy stirring $11 \cdot \mathrm{c}$ soil, amel exposing it to the atmosplece, a small portion of this nitrogen becomes annually avalable, and is taken up by the growing erops. And it is so with the other oleme ts of plant-food. Stirring the sult, then, is the bistis of agriculture. It has been sail that we must reimm to the soil as much plan'-fool as we take fro... it. If this were truc, nothing could be sold from the farm. What we shoukl aim to do, is to develop as mulh as possible of the plant-fond that lies laturt in the soil, and not to sell in the form of erops, elecese, wool, or animals, any more of this plant foul than we annually develop from the soil. In this way the "condition" of the soil rould rumain the same. If we scll lexs than we derelop, the condition of thes il will ianprove.

By "condition," I mean the amonnt of curiluble plant-food in the soil. Nearly all our farms are poorer In flant-food to-day than when first eleared of the original forest, or than they were ten, tifteen, or twenty years later. In other worls, the plints ancl animals that have heen sold from the farm, lave carried off a considcrable amount of plant-fond. We lave taken far more nitrogen, phosphoric acil, potish, rte., ont of the soil, than we have returned to it in the sliape of manure. Comsequently, the soil must contain less and less of plant food every year. And yet, while this is a selferident fact, it is, nevertheless, true that many of these self-same farms are more productive now than when first cleared, or at any rate more productive than they were twenty-five or thirty yciars a gao.

Sometime ago, the Deacon and I risited the farm of Mr. Dewey, of Monroe Co., N. Y. He is a good farmer. Ile does not practice "high farming" in the sanse in which I nse that term. His is a gnod cxample of what I term slow farming. He raises large crops, but comparatively few of them. On his farm of 300 acres, he raises 40 acres of wheat, 17 acres of Indian corn, and $2 ?$ acres of oatc, barley, potatnes, ronts, etc. In other words, he lias 80 acres in cropa, and 220 acres in grass - not permanent grass. Ile lets it lie in grass five, six, oven, or eight years, as he decms best, and then breaks it up, and plants it to corn. The land he intends to plant to corn next year, has been in grass for seren years. He will put pretty mucli all his manure on this land. After corn, it will be sown in oats, or barley; then sown to wheat, and seeded down again. It will throl lis $\mathrm{i}$ is griss three, four, five, six, or seven 
years, until he needs it again for corn, etc. This is "slow farniug," but it is also good farming-that is to say, it gives large yields per acre, and a good return for the labor expended.

The soil of this farm is richer to-day in availuble plant-food than when first cleared. It produces larger crops per acre.

Mr. D. called our attention to a fact that establishes this point. An old fence that had occupied the ground for many years was removed some years since, and the two fields thrown into one. Every time this field is in crops, it is easy to see where the old fence was, by the short straw aml poor growth on this strip, as compared with the land on each side which had been cultivated for years.

This is precisely the result that I should have expected. If Mr. D. was a poor farmer-if he croplyed his land frecuently, did not more than half-cultirate it, sold everything be raised, and drew back no manure-I think the old fence-strip would have given the best erops.

The strip of land on which the old fence stood in Mr. Dewey's fidi, contained more plint-fool than the soil on either side of it. But it was not arailable. It was not developed. It was latent, incrt, insoluhle, crucle, and undecomposed. It was so much dead eapital. The land on rither sile which had been cultivated for years, produced better crops. Thy ? Simply because the stirring of the soil hatd developed more plant-food than had been removed by the crops. If the stirring of the soil cleveloped $100 \mathrm{lbs}$. of plantfood a year, and only in lbs. wore carried off in the crops-25 lbs. being left on the land in the form of roots, stublele, etc.-the land, at the expiration of 40 years, would contain, provided none of it was lost, 1,000 lbs. more avriluble plint-food than the uncultivated strip. On the other liand, the latter would contain 3,000 lbs. more actuil plant-food ner acre than the lind which had heen cultivated -bnt it is $n$ an unarailable condition. It is dead eapital.

I do nut know that I make myself understood, thongh I would like to clo sc, because I am sure there is no point in s ientifie farming of greater importance. Mr. Gediles calls grass the "pivotal crop' of American agriculture. He deserves our thanks for the worl and the illea connected with it. Bnt I am inclined to think the pivot on which our agriculture stands and rotates, lies deeper than this. The grass crop ereates nothing-developes nothing. The matilled and unmanured grass lands of Herkimer County, in this State, are no richer to-day than they were 50 years ago. The pastures of Cheshire, England, except those that have been topdressed witls hones, or other manures, are no more productive thas 
they were eenturies back. Grass alone will not make rich land. It is a good "savings bank." It gathers up and saves plant-food from running to waste. It prays a good interest, and is a capital institution. But the real source of fertility must be looked for in the stores of phant-food lying dormant in the soit. Tillage, underuraining, and thorough cultivation, are the means by which we develop and render this plant-food avilable. Grass, clover, peas, or any other crop consumed on the farm, merely affords us the meaus of saving this plant-food and making it pay a good interest.

\section{$-$ \\ CHAP'TER X.}

\section{HOW TO MAKE MANURE.}

If we bave the necessary materials, it is not a difficult matter to make manure; in fact, the manure will make itself. We sometimes need to hasten the process, and to see that none of the fertilizing matter runs to waste. This is about all that we can do. We cannot create an atom of plint-food. It is ready formed to our bands; but we must know where to look for it, and how to get it in the easiest, cheapest, and best way, and how to save and use it. The science of manure-making is a profound study. It is intimately connected with nearly every branch of agriculture.

If weeds grow and decay on the land, they make manure. If we grow a crop of buckwheat, or spurry, or mustard, or rape, or clover, and mow it, and let it lie on the land, it makes manure; or if we plow it under, it forms manure; or if, after it is mown, we rake up the green crop, and put it $\mathrm{i}$ to a heap, it will ferment, heat will be produced by the slow combustion of a portion of the carbonaccous and nitrogenous matter, and the result will be a mass of material, which we should all recognize as "nanure." If, insteal of putting the crop into a heap and letting it ferment, we feed it to animals, the digestible carbonaceous and nitrogenous matter will be consumed to produce animal heat and to sustain the rital functions, and the refuse, or the solid and liquid droppings of the animals, will be manure.

If the crop rots on the ground, nothing is added to it. If it ferments, and gives out lieat, in a heap, nothing is added to it. If it 
is passed through an animal, and produces heat, nothing is added to it.

I have heard people say a farmer could not make manure unless he kept animals. We might with as much truth say a farmer cannot make ashes unless he keeps stoves; and it would be just as sensible to take a lot of stove's into the woods to make ashes, as it is to keep a lot of animsls merely to make manure. Yon can make the ashes by throwing the wool into a pile, and burning it; and you can make the manure ly throwing the material out of which the manure is to be made into a pile, and letting it ferment. On a farm where neither fond nor manure of any kind is purchased, the only way to make manure is to get it out of the hend.

"From the land and from the atmosphere," remarked the Doetor. "Plants get a large portion of the material of which they are composed from the atmosphere."

"Yes," l replied, "but it is principally carbonaceous matter, which is of little or no value as manure. $\Lambda$ small amount of ammonia and nitric acid are also brought to the soil by rains and dews, and a fresllyy-stirral soil may also sometimes absorb more or less ammonia from the atmosplicre: but while this is true, so far as making manure is concerned, we must look to the plantfool existing in the soil itself.

"Take such a farm as Mr. Deweỵ's, that we hare already referred to. No manure or food has been purchased; or at any rate, not one-tenth as much as has been sold, and yet the farm is more productive to-day than when it was first cleared of the forest. IIe has dereloped the manure from the siores of litent plant-food previously existing in the soil and this is the way farmers gen. erally make manure." 


\section{H A I'I E R X I.}

\section{THE VALUE OF MANURE DEPENDS ON THE FOOD- NOT ON THE ANIMLL.}

"If," said I, "you should put a ton of cut straw in a heap, wet it, and let it rot down into manure; and should place in another heap a ton of cut corn-fodder, and in another lieap a ton of cut cloverhay, wet them, and let them also rot down inte manure; and in another heap a ton of pulpedeturnips, and in another heap a ton of corn-meal, and in anotleer locap a ton of bran, and in another a ton of malt-spronts, and let them be mixed with water, and so treated that they will ferment without loss of ammonia or other valuable plant-food, I think no one will say that all these different heaps of manure will have the same value. And if not, why not?"

"Bceause," sald Charley, "the ton of straw does not contain as much raluable plant-fond as the ton of corn-fodder, nor the ton of corn-fodiler as much as the ton of clover-hay."

"Now then," said I, "insteal of putting a ton of straw in one heap to rot, and a ton of corn-folder in another heap, and a ton of clover in another leap, we feed the ton of straw to a cow, and the ton of corn-fodder to another cow, and the ton of clover to anotiver cow, and save all the solid an l liquid excrements, will the manure made from the ton of straw be wortl as much as the manure made from the ton of corn-fodler or clover-hay?"

"No," said Charley.- "Certainly not," said the Doctor.-" I am not so sure about it," said the Deacon; "I think you will get more manure from the corn-fodder than from the straw or clover-hay."

"We are not talking about lulk," sail the Doctor, "but value." "Suppose, Deaenn," said he, "you were to shut up a lot of your Brahma hens, and feed them a ton of eorn-meal, and should also feed a ton of corn-meal made into slops to a lot of pigs, and should save all the liquill and solid excroments from the pigs, and all the manure from the hens, which would be worth the most ?"- "The hen-manure, of course," said the Deacon, who has great faith in this kind of "guano," as he calls it.

"And yet," said the Doctor, "you would probably not get more than half a ton of manure from the liens, while the liquid and solid excrements from the pigs, if the eorn-meal was made into a thin slop, would weigh two or three tons." 
"More, too," said the Deacon, "the way you feed your store pigs."

"Very well; and yet you say that the half ton of hen-manure made from it ton of corn is worth more than the two or three tons of pig-manure made from a ton of corn. You do not seem to think, after all; that mere bulk or weight adds anything to the value of the manure. Why then should you say that the manure from a ton of corn-fodder is worth more than from a ton of straw, because it is more bulky :"

"You, yourself," said the Deacon, "also say the manure from the ton of corn-fodder is worth more than from the ton of straw."- "True," said I "but not because it is more bulky. It is worth more because the ton of corn-fodder contains a greater quantity of valuable plant-fool than the ton of straw. The clover is still richer in this valuable plant-food, and the manure is much more valuable; in fuct, the manure from the ton of clover is worth as much as the manure from the ton of straw and the ton of cornfodtler together."

"I would like to see you prove that," said the Deacon, "for if it is true, I will sell no more clover-hay. I can't get as much for clover-hay in the market as I can for rye-straw."

"I will not attempt to prove it at present," said the Doctor; "but the evidence is so strong and so (onclusive that no rational man, who will sturly the subject, cau fail to be thoronghly convinced of its truth."

"The value of manure," sail I, "does not depend on the quantity of water which it contains, or on the quantity of sand, or silica, or on the amount of woody fibre or carbonaccous matter. These things add little or nothing to its fertilizing value, except in rare cases; and the sulphuric acid and lime are worth no more than the same quantity of sulphate of lime or gypsum, and the chlorine and sola are probably worth no more than so much common salt. The real chemical value of the manure, other things being equal, is in proportion to the nitrogen, phosphoric acid, and potash, that the manure contains.

"And the quantity of nitrogen, phosphoric acid, and potash found in the mantre is determined, other things being equal, by the quantity of the nitrogen, phosphoric acid, and potash contained in the food consumed by the animals making the manure." 


\section{H A P T E R X I I .}

\section{FOODS WHICH MAKE RICH MANURE.}

The amount of nitrogen, phosphorie acid, and potash, contained in different foods, has been accurately determined by many able and reliable chemists.

The following tahle was prepared by Dr. J. B. Lawes, of Rothamsted, England, and was first published in this country in the "Genesee Farmer," for IIay, 1860. Since then, it has been repeatedly published in nearly all the leading agricultural journals of the world, and has given rise to much discussion. The following is the table, with some recent additions:

\begin{tabular}{|c|c|c|c|c|c|c|}
\hline & \multicolumn{5}{|c|}{ PER CENT. } & \\
\hline & 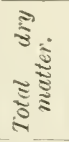 & 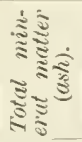 & 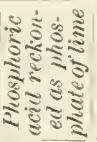 & 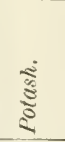 & 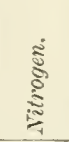 & 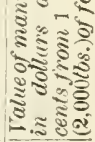 \\
\hline 1. Linseed cake........... & 88.0 & 7.00 & 1.52 & 1.65 & 4.75 & 19.72 \\
\hline 2. Cotton-seed cake*.. . . & 89.0 & 8.00 & 7.00 & 3.12 & 6.50 & $27.8 i$ \\
\hline 3. Rape-cake............ & 8.9 .0 & 8.60 & 5.75 & 1.76 & 5.00 & 21.01 \\
\hline 4. Linseed............. & $91) .0$ & 1.00 & $3: 38$ & 1.37 & 3.80 & 15.65 \\
\hline 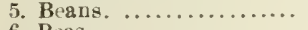 & 81.0 & 3.00 & 2.20 & 1.27 & 4.00 & 15.75 \\
\hline 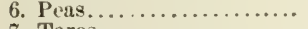 & 81.5 & 2.40 & 1.81 & 0.96 & 3.10 & 13.38 \\
\hline 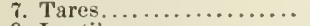 & 84.0 & 2.00 & 1.63 & 0.66 & 4.20 & $16 . \% 5$ \\
\hline 8. Lentils .............. & 89.11 & 3.00 & 1.89 & 0.96 & 4.30 & 16.51 \\
\hline 9. Malt-dust . . . . . . . . . . & 94.0 & 8.50 & 5.23 & 2.12 & 4.20 & $1 S .21$ \\
\hline 10. Lncnst beans ........... & 85.0 & 1.65 & & & 1.25 & 4.81 \\
\hline 11. Indian-meal........... & הIX. () & 1.30 & 1. 13 & 0.35 & 1.80 & 6.65 \\
\hline 12. Wheat. ................ & 8.5 .0 & 1.70 & $1 \times$ & 0.50 & 1.80 & 7.08 \\
\hline 13. Barley................ & 84.0 & 2.20 & 1.35 & 0.55 & 1. 6.5 & 6.32 \\
\hline 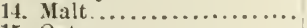 & 95.11 & 2.60 & $\left.1.6^{\prime}\right)$ & 0.65 & 1. 70 & 6.65 \\
\hline 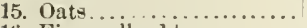 & 86.0 & 2.85 & 1.17 & 0.50 & 2.00 & 7.70 \\
\hline 16. Fine pollard $+\ldots \ldots \ldots \ldots$ & 86.0 & $5.1 i()$ & 6.41 & 1. $41 i$ & 2.60 & 13.53 \\
\hline 17. Coarse pollard $\neq \ldots \ldots$. & $86 \mathbf{0} .0$ & 6.20 & 7.52 & 1. 49 & 2.58 & $14.31 i$ \\
\hline 18. Wheat-bran. ........... & $86 i .0$ & (i. 60 & 7.95 & 1.45 & 2.55 & $14.5 !)$ \\
\hline 19. Clover-hay............. & 84.0 & 7.50 & 1.25 & 1.30 & 2.50 & 9.61 \\
\hline 20. Meadow-hay ............ & 81.0 & (i.0) & 0.89 & 1.50 & 1.50 & 6.43 \\
\hline 21. Bean-straw ........... & 82.5 & 5.55 & 0.90 & 1.11 & 0.90 & 3.87 \\
\hline 22. Pea-straw .... . . . . . . & $8 \geq .0$ & $5.9 \%$ & 0.85 & $0 . \$ 9$ & & 3.74 \\
\hline 23. Wheat-straw .......... & 84.0 & 5.00 & 0.55 & 0.65 & 0.60 & 2.14 \\
\hline 21. Barley-straw ........... & 85,0 & 450 & 0.37 & 0.63 & 0.50 & 2.25 \\
\hline 25. Oat-straw ............. & $8: 3.0$ & 5.50 & 0.48 & 0.93 & 0.60 & 2.911 \\
\hline 26. Mangel-wurzel. ........ & 12.5 & 1.00 & 0.09 & 0.25 & 0.25 & $1.0 \%$ \\
\hline 27. Swedish turnips........ & 11.0 & .68 & 0.13 & 0.18 & 0.22 & 91 \\
\hline 28. Common turmips ....... & 8.0 & .138 & 0.11 & 0.29 & 0.18 & $.8 t i$ \\
\hline 29. Potatoes........ .... & 24.0 & 1.00 & 0.32 & 0.43 & 0.3 .5 & 1.50 \\
\hline 3). Carrots $\ldots \ldots \ldots \ldots \ldots \ldots$ & 13.5 & .70 & 0.13 & 0.23 & 0.20 & .80 \\
\hline 31. Parsnips............. . & 15.0 & 1.00 & 0.42 & 0.36 & 0.22 & 1.14 \\
\hline
\end{tabular}

* The manure from a ton of undecorticated cotton-seed cake is worth \$15.74; that from a ton of cottun-seed, after being ground and sifted, is worth \$13.25. The grinding and sifting, in Mr. Lawev' experiments, removed about 8 percent of hinsk and cotton. Cotton-seed. So treatud. proved to be a verv rich and ecunomical food. 
Of all vegetable substances used for food, it will be seen that decorticated cotton-seed cake is the riciest in nitrogen, phosphoric acid, and potash, and eonsoquently makes the richest and most valuable manure. Accorling to Mr. Lawes' estimate, the manure from at ton of decorticated cotton-seel cake is worth $\$ 2 \pi .86$ in golkl.

Rape-eake comes next. Twenty-five to thirty years ago, rapecake, ground as tine as corn-neal, wals used quite extensively on many of the light-land farms of England as a manure for turnips, and not unfreyuently as a manure for wheat. Mr. Lawes used it for many years in lis experiments on turnips and on wheat.

Of late years, howerer, it has been fed to sheep and eattle. In other worts, it has been used, not as formerly, for manure alone, lut for fool first, and mature afterwarls. The oil and other carbonaceous matter which the eake contains is of little value for manure, while it is of great value as food. The animals take out this carbonacens matter, and leave nearly all the nitrogen, phosphorie arid, and potssh in the mamme. Farmers who had found it profitable to use on wheat and turnips for 11 :nure alone, found it still more profitable to use it first for food, ant then for manure afterwarls. Mr. Lawes, it will be seen, estimates the manure produecel from the consumption of a ton of rape-cake at $\$ 21.01$.

Linserd-oil calie comes next. Pure lineed-cake is excecdingly valualsle, both for food and manure. It is a favorite food with all eattle and sheep lorecters and feeders. It has a wonderful effect in improving the appearance of cattle and sheep. In English farmer thinks he eannot get along without "cake" for his calves, l:mbs, eattle, and slieep. In this country, it is not so extensively used, except by the breeders of improvel stock. It is so popular in England that the price is fully up to its iatrinsic value, and not unfrequently other foods, in proportion to the nutritive and manurial value, can be lought eheaper. This fact slows the value of a goot reputation. Linseed-cake, however, is often arlulterited, and farmers need to be cautious who they deal with. When pure, it will be seen that the manure made by the consumption of a ton of linsecii-rake is worth \$19. 2 ?.

Malt dust stands next on the list. This article is known by different names. In England, it is often called " malt-combs;" here it is known as "malt-sprots," or "malt-roots." In making barley into malt, the barley is soiked in water, and afterwards kept in a warm room until it germinates, and throws out sprouts and roots. It is then dried, and before the malt is used, these dried spronts and roots are sifted ont, and are soll for cattle-food. They weigh 
from 22 to 25 lbs. per bushel of 40 quarts. They are frequently mixed at the hreweries with the "grain-" and are sold to milkmen at the same price-from 12 to 15 cents per bushcl. Where their value is not known, they can, doubtless, be sometimes obtained at s mere nominal price. Milkisen, I believe, prefer the "grains" to the malt-dust. The latter, however, is a good food for sheep. It hats one advantage over brewer's "grains." The latter contain 76 per cent of water, while the malt-dust continins only 6 per cent of water. We can atford, therefore, to trinsport malt-dust to at greater listance than the grains. We do not want to carry vater many miles. There is another alvantage: brewer's grains soon ferment, and become sour; while the malt-clust, heing dry, will keep for any length of time. It will be seen that Mr. Lawes estimates the value of the manure left from the consumption of a ton of malt-clust at $\$ 18.21$.

Tares or vetches, lentils, linseed or flaxseed, beans, wheat, bran, midllings, fine mill-fee 1, undecorticute:l cotton-seed eake, peas, and cotton-sed, staad next on the list. The value of these for manure ranging from \$ $\$ 13.25$ to $\$ 16$. is per ton.

Then concs clover-liay. VIr. Lawes cestimates the value of the manure from the consumption of a ton of clover-hay at \$9.64. This is from carly cut clover-hay.

When clover is allowed to grow until it is nearly out of flower, the hay would not contain so much nitrogen, and would not be worth quite so much per ton for manure. When mixed with timothy or other grasses, or with weeds, it would not be so valuable. The above estimate is for the average quality of good pure English clover-hay. Our best farmers raise elover equally as gool; but I have seen much clover-bay that certainly would not come up to this standarel. Still, even our common clover-hay makes rich manure. In Woltl's Table, giren in the appendix, it will be seen that clover-hay contains only 1.97 per cent of nitrogen and 5.7 per cent of as'. Mr. Lawes' elover contains nore nitrogen and ash. This means richer land and a less mature condition of the crop.

The cereal grains, wheat, barley, oats, and Indian corn, stard next on the list, being worth from $\$ 6.32$ to $\$ \pi .70$ per ton for manure.

"Meadow-hay," which in the table is estimated as worth $\$ 6.43$ per ton for manure, is the hay from permanent meadows. It is a quite different article from the "English Meadow-has" of New England. It is, in fact, the perfection of hay. The mearlows are frequently top-dressed with composted manure or artificial fertilizers, 
and the hay is composed of a number of the best grasses, cut early and carefully cured. It will be noticed, however, that even this choice meadow-hay is not as valuable for manure as clover-hay.

English bean-straw is estimated as worth $\$ 3.87$ per ton for manure. The English "Lorse bean," which is the kind here alluded to, has a very stiff, coarse long straw, and looks an though it was much inferior as folder, to the straw of our ordinary white baans. See Wolff's table in the appendix.

Pea-straw is estimated at \$3. it per ton. When the peas are not allowed to grow until dead ripe, and when the straw is carefully enred, it makes capital fool for sheep. Taking the grain and straw together, it will be seen that peas are an unusually valuable crop to grow for the purpose of making rich manure.

The straw of oats, wheat, and barley, is worth from $\$ 2.25$ to $\$ 2.90$ per ton. Barley straw being the poorest for manure, and oat straw the richest.

Potatoes are wolth $\$ 1.50$ per ton, or nearly 5 cents a bushel for manure.

The mamurial value of roots raries from 80 cents a ton for earrote, to $\$ 1.07$ for inazgel-wurzel, and $\$ 1.14$ for parsmips.

I am very anxious t'at there should be no misapprehension as to the maning of these figures. I am sure they are well worth the eareful study of every intelligent farmer. Mr. Lawes has been eagaged in making experiments for over thirty years. There is no man more competent to speak with authority on such a subject. The figures showing the money ralue of the manure made from the different fools, are based on the amount of nitrogen, phosphoric acid, and potash, which they contain. Mr. Latres has been buying and using artificial manures for many years, and is quite eompetent to form a correct conchsion as to the cheapest sources of obtaining nitrogen, phosphoric acid, and potasls. He has eert:inly not overestimated their cost. They can not be bought at lower rates, either in England or America. But of course it does not follow from this that these manures are worth to the farmer the priee charged for them; that is a matter depending on many conditions. All that ean be said is, that if you are going to buy commereial manures, you will have to pay at least as mueh for the nitrogen, phosphoric acid, and potish, as the price fixed upon by Mr. Lawes. And you shomld recollect that there are other ingredients in the manme ob:ained from the food of animals, which are uot estimated as of any value in the table. For instanee, there is a large amount of earbonaceous mitter in the manure of animals, 
which, for some erops, is not without value, but which is not here taken into account.

Viewed from a farmer's stiml-point, the table of money values must be taken only in a comparative sense. It is not claimed that the manure lrom a ton of wheat-straw is worth \$2.68. Tuis may, or may not, be the case. But if the manure from an ton of wheatstraw is worth $\$ 2.68$, then the mamure from a ton of pea-straw is worth \$3. 4 , and the manure from a ton of corn-meal is worth $\$ 6.65$, and the manure from a ton of clover-lay is worth $\$ 9.654$, an 1 the manure from it ton of wheat-bran is worth $\$ 14.59$. If the manure from at ton of corn meal is nut worth s $86 .(i j)$, then the manure from a ton of bran is not worth $\$ 14.59$. If the manure from the ton of corn is worth mure than \$i.6.j, then the manure from a ton of bran is worth more than \$14.59. There need be no doubt on this point.

Settle in your own mind what the manure from a ton of any one of the foods mentioned is worth on your farm, and you can easily calculate what the manure is worth from all the others. If you say that the manure from in ton of wheat-stria is worth $\$ 1.34$, then the manure from a ton of Indian corn is worth \$...8:3, and the manture from a ton of bran is worth $\$ \tau .30$, and the mauure from a ton of clover-hay is worth \$ 4.82 .

In this section, howerer, few good farmers are willing to sell straw, though t'ey can get from $\$ 8.00$ to $\$ 10.00$ per ton for it. They think it must be cousumel on the farm, or used for bedding, or their land will run down. I do not say they are wrong, but I do say, that if a ton of straw is worth \$2.6\$ for manure alone, then a ton of clover-hay is worth $\$ 9.64$ for manure alone. This may be accepted as a general truth, and one which a farmer ean act upon. And so, too, in regard to the value of corn-meal, loran, and all the other articles giren in the table.

There is another point of great importance which shonld be mentioned in this connection. The nitrogen in the better elass of foods is worth more for mauture than the nitrogen in straw, cornstalks, and other coarse fodder. Nearly all the nitroren in grain, and other rich foods, is cligested by the animals, and is roided in solution in the urine. In other words, the nitrogen in the manure is in an actire and arailable condition. On the other hand, only about half the nitrogen in the coarse fodders and straw is digestible. The other half passes off in a crude and comparatively unavailable condition, in the solill excrement. In estimating the value of the manure from a ton of food, these facts should be remembered. 
I have said that if the manure from a ton of straw is worth $\$ 2.68$, the manure from a ton of corn is worth $\$ 6.65$; but I will not reverse the proposition, and say that it the manure from a ton of com is worth $\$ 6.65$, the mimure from a toa of straw is worth $\$ 2.68$. The manure from the grain is nearly all in an avalahle condition, while that from the straw is not. A pound of nitrogen in rich manure is worth more than a pound of nitrogen in poor manure. This is another reason why we should try to make rich manure.

\section{H $\triangle$ P I E R X I I I I.}

\section{HORSE MANLTE AND FARMITARD MANURE.}

The manure from horses is generally considered richer and better than that from cows. This is not always the case, though it is probably so as a rule. There are three principal reasons for this. 1st. The horse is usually fed more grain and hay than the cow. In other work, the foot of the horse is ustally richer in the valnable elements of plant-food than the ordinary food of the cow. 2l. The milk of the cow alsstracts consiclerable nitrogen, phosphorie ard, etc, from the food, and to this extent there is less of these valuable subtances in the excrements. 3d. The excrements of the cow contain much more watcr than those of the horse. And conserpently a ton of cow-dung, other things being equal, would not con'ain as much actual manure as a ton of horse-dinng.

Boussingault, who is eminently trustworthy, gives us the following interesting facts :

4 horse consumed in 24 hours, 20 lbs. of laay, 6 lbs. of oats, and $43 \mathrm{lbs}$. of water, and voided during the stme period, 3 lbs. 7 ozs. of urine, and $38 \mathrm{lbs} .2 \mathrm{ozs}$. of solicl excrements.

The solid exerements contained $2: 3 \frac{1}{2}$ lbs. of wa'er, and the urine 2 lis. 6 ozs. of watur.

Accorling to this, a horse, eating 20 lhs. of hay, and $6 \mathrm{lbs}$. of oats, per day, voids in a year nearly seven tons of solid exerements, and $1,25 \%$ libs. of urine.

It would scem that there must have heen some mistake in eollecting the urine, or what was probaluly the ease, that fome of it must have heen absorbed by the dung; for $3 \frac{1}{2}$ pints of urine per day is certainly much less than is usually voided by a lorse. 
Stockard gives the amount of urine voided by a horse in a year at 3,000 lbs.; a cow, 8,000 lus.; shecp, 380 lbs.; pig, 1,200 lbs.

Dr. Volcker, at the Royal Agricultural College, at Cirencester, England, made sone valuable investigations in regind to the composition of farm-yard manure, and the changes which take place during fermentation.

The manure was composed of horse, cow, and pig dung, mixed with the straw used for bedling in the stalls, pig-pens, sheds, etc

On the $3 \mathrm{~d}$ of November, 18.j4, a sample of what Dr. Volckes calls "Fresh Long Dung," was taken from the "manure-pit" fos analysis. It laal lain in the pit or heap about 14 days.

The following is the result of the analysis:

FRESII FARMIYARD MANURE.

HALF A TON, OR 1,000 LBS.

Water........................... efi1.7 lbs.

Organic matter.............................

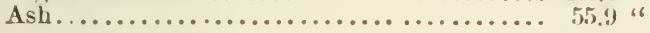

Nitrogen ................................... 1,000.0

"Before you go any farther," said the Deacon, "let me understand what these figures mean? Do you mean that a ton of manure contains only 12 lhs. of nitrogen, and $111 \mathrm{lhs}$. of ash, and that all the rest is carbonaceous matter and water, of little or no value"?-"That is it precisely, Deacon," said I, "and furthermore, a large part of the ash has very little fertilizing value, as will be seen from the folluwing:

DETAILED COMPOSITION OF TIL ASH OF FRESH BARY-YARD MANURE.

Soluble silica...................... 21.59

Insoluble silicious matter (sand) ................ 10.04

Phosphate of lime ................... 5.85

Oxide of iron, alumina, with phesphate........... 8.47

Containing phospleric acid................. 3.18

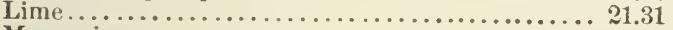

Magnesia........................... 276

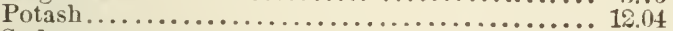

Sorla ..................................... 1.30

Chloride of sodium...................... 0.54

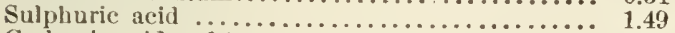

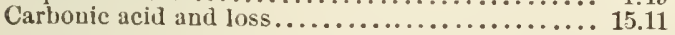

100.00

Nitrogen, phosphoric acid, and potash, are the most valuable ingredients in manure. It will be seen that a ton of fresh barn-yard manure. of probabiy gond average quality, contains:

Nitrogren....................... 12: lbs.

- Phosphoric acid ..................... $6 i_{2}^{1}$ "6

Potash................................ $13 \frac{1}{8}$ " 
I do not say that these are the only ingredients of any value in a ton of manure. Nearly all the other ingredients are indispensable to the growth of plants, and if we should use manures containing nothing but nitrogen, phosphoric acid, and potash, the time would come when the crops would fail, from lack of a sullicient quantity of, perhaps, mannesia, or lime, sulphuric acid, or soluble silica, or iron. But it is not necessitry to ulake provision for such a contingency. - would be a very exceptional case. Farmers who depend mainly on harn-yard mume, or on plowing under green crops for kecping up the fertility of the laud, may safely calculate that the value of the manure is in proportion to the amount of nitrogen, phosphoric acid, and potash, it contains.

We draw out a ton of fresh manure and spreal it on the land, therefore, in order to furnish the growing crops with 12 o lhs. of nitrogen, $6 \frac{1}{2}$ los. of phosphoric acid, and $13 \frac{1}{2} \mathrm{lbs}$. of potash. Less than $33 \mathrm{lbs}$. in all!

We cannot dispense with farm-yard manure. Te can seldom buy nitrogen, phosphoric acid, and potash, as cheaply as we can get them in home-made manures. But we should clearly understand the fact that we draw out 2,000 3lus. of matter in order to get $33 \mathrm{lbs}$ of these fertilizing ingredients. We should try to muke richer mumure. A ton of manure containing 60 lbs. of nitrogen, phosphoric acid, and potash, costs no more to draw out and spread, than a ton containing only $30 \mathrm{lbs}$, and it would be worth nearly or quite double the money.

Fiow to make richer manure we will not discuss at this time. It is a question of food. But it is worth while to enquire if we can 'not take such manure as we have, and reduce its weight and bulk without losing any of its nitrogen, phosphoric acid, and potash.

\section{II $A$ P T E P X I V.}

\section{FERIENTING MANURE.}

Dr. Voleker placed 2.898 lhs. of fresh mixed manure in a heap Nov. 3, 18.5t, and the next spring, April 30, it weigherl 2,026 lbs., a slurinkage in weight of 28.6 per cent. In other words 100 tons of sulh manure woull be relueed to less than ilt tons.

The heap was weig'led agrain, Angust 29,1 , and contained 1,994 1bs. It was again weighed Nov. 15 , and contained $1,97.1$ lbs 
The following table shows the composition of the heap when first put up, and also at the three subsequent periods:

TABLE SHOWLXG COMPOSTTION OF THE WHOLE IEAP ; FRESH FAIM-YAITD MAXTRE (NO. I.) EXPOSED-EXI'LES-ED IX LBS.

\begin{tabular}{|c|c|c|c|c|}
\hline & 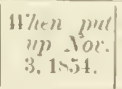 & $\begin{array}{l}1 p \text { ril } \\
1855 .\end{array}$ & Aigg. 23 & $\begin{array}{l}\text { Tov. } 15 \\
1 \times 55\end{array}$ \\
\hline Weight of manure iu lus......... & 2,335 & 2,026 & 1,991 & 1,974 \\
\hline $\begin{array}{l}\text { Amt. of water in the manure........ } \\
\text { Amt. of dry matter in tlie mantire... } \\
\text { Consisting of- }\end{array}$ & $\begin{array}{l}1,8 \div \ldots .1 \\
961.1\end{array}$ & $\begin{array}{r}1.3361 .1 \\
1649.9\end{array}$ & $\begin{array}{r}1,505.3 \\
4 \leqslant 5.7\end{array}$ & $\begin{array}{r}1.46655 \\
507.5\end{array}$ \\
\hline 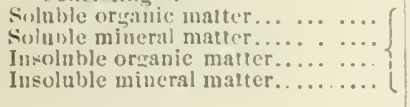 & $\begin{array}{r}70.25 \\
43.71 \\
731.07 \\
114.91 \\
\end{array}$ & $\begin{array}{r}86.51 \\
57 . \times 8 \\
359.74 \\
155.7\end{array}$ & $\begin{array}{r}58.93 \\
39.16 \\
24: 3.22 \\
147.49\end{array}$ & $\begin{array}{r}54.0 .4 \\
3(1.5 ! 9 \\
211.92 \\
201 .+55\end{array}$ \\
\hline Iusoluble mineral matter........... & 960.1 & $6 \times 41.9$ & 485.7 & 507.5 \\
\hline 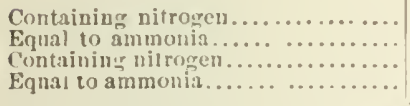 & $\begin{array}{r}4.2 .2 \\
5.22 \\
11.01 \\
1 \% .02\end{array}$ & $\begin{array}{r}6.07 \\
7.3 \% \\
12.07 \\
14.65\end{array}$ & $\begin{array}{r}3.7 t \\
4.51 \\
0.38 \\
11.40\end{array}$ & $\begin{array}{r}3.65 \\
4.36 \\
9.39 \\
11.39\end{array}$ \\
\hline $\begin{array}{l}\text { Total amonnt of nitrogen in manure. } \\
\text { Equal to ammonia. ............... }\end{array}$ & $\begin{array}{l}18.23 \\
22.14\end{array}$ & $\begin{array}{l}18.14 \\
2 \cdot .02\end{array}$ & $\begin{array}{l}13.14 \\
15.96\end{array}$ & $\begin{array}{l}13.03 \\
15.75\end{array}$ \\
\hline $\begin{array}{l}\text { The manure contains ammonia in } \\
\text { free state.... ..................... } \\
\text { The manure contains ammonia in } \\
\text { form oi salts, easily decomposed by }\end{array}$ & $.96 i$ & .15 & .20 & .11 \\
\hline Total amount of organic milters.... & $\begin{array}{r}2.49 \\
801.45\end{array}$ & $\begin{array}{l}1.71 \\
476.25\end{array}$ & 302.05 & 268.90 \\
\hline Total amount of minelul matters... & $15 \div .15$ & 213.65 & $186 .+15$ & 235.54 \\
\hline
\end{tabular}

"It will be remarked," says Dr. Vœlcker, "that in the first experimental period, the fermentation of the dung, as might liave been expected, proceeded most rilpidly, but that, notwithstanding, very little nitrogen was dissipated in the form of volatile ammonia ; and that on the whole, the loss which the manure sustained was inconsiderable when compared with the enormous waste to which it was subject in the subsequent warmer and more l'ainy seasons of the year. Thus we find at the end of April very nearly the same amount of nitrogen which is contained in the fresh; whercas, at the end of August, $2 \tau \supset$ per cent of the total nitrogen, or nearly one-third of the nitrogen in the manure, has been wasted in one way or the other.

"It is worthy of obserration," continues Dr. Vœlcker, "that, during a rell-regulated fermentation of dung, the loss in intrinsically valuable constituents is inconsiderable, and that in such a preparatory process the effic icy of the munure becomes grently enhanced. For certain purposes fresh dung can never take the 
place of well-rotted dung. * * The farmer will, therefore, always be compelled to submit a portion of home-made clung to fermentetion, and will find satisfaction in knowing that this proeess, when well regulated, is not atteaded with any serious depreciation of the value of the minule. In the foregving analyses he will find the direct proof that as long as heavy showers of rian are excluifed from manure-heaps, or the manure is kept in waterprofof pits, the most valuable fertilizing matters are presorvel."

This expriment of 1 r. Volckel proves conclusively that manure eam be kept in a rapid state of fermentation for six montls chring winter, with little loss of nitrogen or other fertilizing matter.

During fermentation a portion of the insoluble matter of the dung becomess soluble, and if the manure is then bept in a heily exposen to rain, there is a great loss of fertilizing matter. This is precisely what we should expet. We ferment manure to make it more readily avaliable as plant-food, and when we have attained our object, the manure should be applied to the land. We kepl winter apples in the cell ir until they get ripe. As soon as they are ripe, they should be caten, or the will rapdully decay. This is well understool. And it should he equally well known that manure, after it has been fermentirg in a heap for six montlis, cannot safely be kept for another six months exposed to the weather.

Tue following table sinws the eomposition of $100 \mathrm{lbs}$. of the farm-yaril manure, at different periods of the year :

COMIOOA1TION OF 100 LBR. OF FRESIX FARY-YAIB MINYIE (NO. T.) EXPOSED IN NATTRA1, STITE, AT DIFFERENT PERI)IS OF THE YEAR.

\begin{tabular}{|c|c|c|c|c|c|}
\hline & 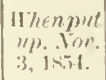 & $\begin{array}{c}F e b \text { 11, } \\
185.5 .\end{array}$ & $\begin{array}{c}1 \mathrm{~m} .30 \\
1855 .\end{array}$ & $\begin{array}{c}14 q .23 \\
1 \text { s.5. }\end{array}$ & $\begin{array}{c}\text { Nor. } 15, \\
1855 .\end{array}$ \\
\hline Water. . & (iti. 17 & 169. $\div 3$ & (i.). .9 .5 & (5.). 4 ! & 71.29 \\
\hline Soln & & $3 \times 1 i$ & $4.2 \%$ & 2.95 & 2.74 \\
\hline Solul & 1.51 & 2.97 & 2.86 & 1.97 & 1.97 \\
\hline Insoluble organic maller............ & $25.7 \%$ & 15.11 & [19.23 & $1 \cdot 2.20$ & 10.89 \\
\hline \multirow[t]{2}{*}{ Insoluble mineral matter........... } & 1.0 .5 & 1.90 & 6.199 & 7.39 & 10.21 \\
\hline & $100.0 \%$ & 100000 & 100.00 & 100.00 & 100.00 \\
\hline iner nitrogen & .149 & .27 & .30 & .19 & .18 \\
\hline Eya: & .141 & $3 !$ & .36 & .23 & .21 \\
\hline Coll & .111 & 17 & .59 & .47 & .47 \\
\hline Eyylua & 590 & .57 & $\pi 1$ & 62 & .57 \\
\hline Total & .613 & $\pi i$ & .80 & $.6 f^{6}$ & .65 \\
\hline Equal to ammonia. & .740 & $.89)$ & $1.1 \%$ & .85 & $\pi 8$ \\
\hline Ammonia in a free state.......... & .034 & 019 & .0012 & .010 & .006 \\
\hline Ammonia in form of salts easily de- & & & & & \\
\hline comp & .088 & mil & .085 & $.0: 38$ & .011 \\
\hline Total amt. of o & $2<21$ & จ...31) & $2: 3,59$ & 1.5 .15 & $1: 6 i 3$ \\
\hline 'Total ant. of mineral substa & 5.59 & $7.5 \%$ & $10 . \pi 5$ & !):34 & j. 02 \\
\hline
\end{tabular}

It will be seen that two-lhirds of the fresh manure is water. After fermenting in an exposed heap for six inonths, it still con. 
tains about the same pereentuge of watte. When kejt in the hialp until dugust, the pereentige of water is much greatter. Of lour tons of such manure, three tons are water.

Of Sitrogen, the most viluable ingredient of the manure, the fresh dung, contained 0.64 jer cent; after fermenting six montis, it contained 0.89 per cent. Six months later, it contained $0.6 j$ per cent, or about the sime amomint as the fresh minure.

Of mineral matter, or ash, this frish farm-yard mauure (omtained 5.59 per cent; of which 1.54 was soluble in water, and 4.05 insoluble. After fermenting in tile heap for six months, the matnure contained 10.j.j per cent of as h, of which 2.86 wits soluble, and i.69 insoluble. Six months later, the soluble ash had decreased to $1.9 \mathrm{r}$ per cent.

The following table shows the composition of the manure, at different periods, in the dry st ite. In uther words, supposing all the water to be removed from the manme, its eromposition would be as follows:

COMPOSITIOX OF FRESH FATM YARD MANURE (No. 1.) EAIOSED. CALCELATED DRT.

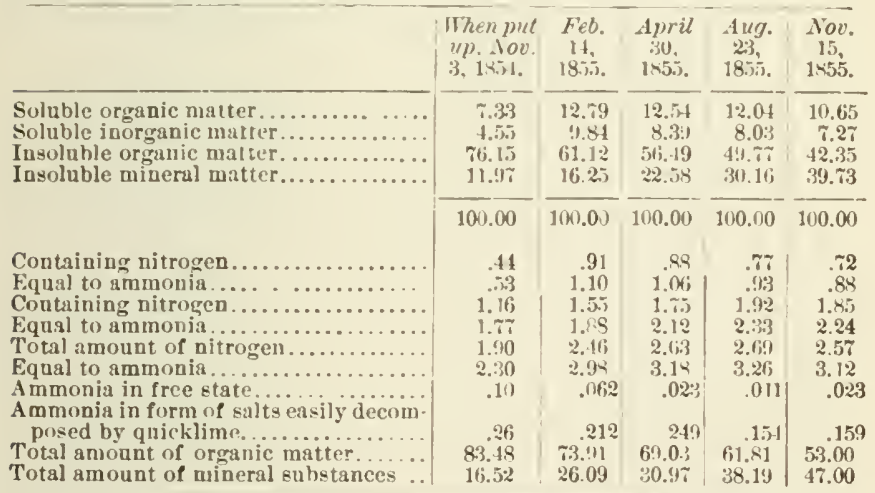

"A comparison of these different analyses," says Dr. Vœelcker, "points out clearly the changes which fresh farm-yard manure undergoes on keeping in a heap, exposed to the influence of the weather during a period of twelve months and twelve days.

"1. It will be perceiverl that the proportion of organic matter steadily diminishes from month to month, until the original percentage of organic matter in the dry manure, amounting to 83.48 per cent, becomes reduced to 53 per rent.

" 2 On the other hand, the total pereentage of mineral matter rises as steadily as that of the organic matter falls. 
"3. It will be seen that the loss in organic matter affects the percentage of insoluble organic matters more than the percentage of soluble organic substances.

"4. The percentige of soluble organic natters, indeed, increased considerably during the first experimental period ; it rose, namely, from 7.33 per cent to 12.79 per cent. Examineel again on the 30 th of A pril, very nearly the same pereentage of soluble urganic matter, as on February the 14th, was found. The August analysis shows but a slight decrease in the percentage of soluble crganic matters, while there is a decrease of 2 per cent of soluble organic matters when the Norember analysis is compared with the February analysis.

" 5 . The soluble mineral matters in this manure rise or fall in the different "xperimental periods in the same orter as the soluble organic matters. Thus, in Felnruary, 9.84 per cent of soluble mineral matters were fomt, whilst the manure contained only 4.55 jer cent, when put up into a heap in November, 185t. Gradually, however, the proportion of soluble mineral matters again dimmished, and hecame reduced to 7.27 per cent, on the examination of the manure in Novemher, 18.5i.

"6. A similar regularity will be observed in the percentage of nitrogen contained in the soluble organic matters.

"In the insoluble organic matters, the percentage of nitrogen regularly increased from Norember, 1854, up to the 23d of August, notwithstanding the rapid diminution of the percentage of insoluble organic matter. For the last experimental period, the percentage of nitrogen in the insoluble matter is nearly the same as on August 23d.

"8. With respect to the total perecntage of nitrogen in the fresh manure, examined at different periods of the year, it will be seen that the February manure contains about one-half per cent more of nitrogen than the manure in a perfectly fresh state. On the 30 th of $\mathrm{April}$, the percentage of nitrogen again slightly increased; on August 233, it remained stationary, and had sunk but very litthe when last examined on the 15th of November, 1855 .

"This series of analyses thus shows that fresh farm-yard manure rapilly becomes more solulle in water, but that this desirable change is realized at the expense of a large proportion of organic matters. It likewise proves, in an unmistakable manner, that there is no advantage in kecping farm-yart manure for ton long a period; for, after Fehruary, neither the percentage of soluble organie, nor that of sulnble mineral matter, has become greater, 
and the pereentage of nitrogen in the manure of $\Lambda$ pril and $A$ ugust is only a very little higher than in February."

"Before you go any further," said the Deacon, "answer me this question: Suppose 1 take five tons of farm-yarl manure, and put it in a heap on the $3 d$ of November, tell me, 1st, what that heap will contain when first made; $2 \mathrm{~d}$, what the heap will contain April 30th ; and, 3.1, what the heap will contain August 23d."

Here is the table:

CONTENTS OF A HEAP OF MANURE AT DIFFERENT JERIOD8, EXPOEED TO RALN, ETC.

\begin{tabular}{|c|c|c|c|c|}
\hline • & $\left|\begin{array}{c}\text { When put } \\
\text { up. lov. } \\
3 .\end{array}\right|$ & April 30. & Aug. 23. & Tov. 15 \\
\hline Total weight of manure in heap ... & $10.0 ; 10$ & $\pi .138$ & $\div .125$ & 6.954 \\
\hline Water in the heap of manure.. ... & $6 .(i 1 \%$ & $4.0 \%$ & 5.3114 & 5,167 \\
\hline Total organic matter . ............... & 2,421 & $1,6 \tilde{R}$ & $1,0.4$ & $! 17$ \\
\hline c matter............. & $55: 3$ & 753 & 6ij & 840 \\
\hline Total nitr & 61.3 & (i)3.9 & fti. 3 & +6.0 \\
\hline is matter... & 218 & 305 & $20 \%$ & 193 \\
\hline nic malter & $2,5 i t i$ & $1,3 \div 3$ & $85 \%$ & 7.57 \\
\hline Soln & 151 & 20 & & $1: 3$ \\
\hline 1 matter ....... & $4 \longdiv { 5 }$ & 519 & & $\pi 10$ \\
\hline le matter.... & 14.9 & 21.4 & $1: 3.2$ & 12.9 \\
\hline Nitrogen in in=oluble matter... & 49.1 & 42.5 & 33.1 & 33.1 \\
\hline
\end{tabular}

The Deacon put on his spectacles and studied the above table carefully for some time. "That tells the whole story"" said he, "you put five tons of fresh manure in a lieap, it ferments and gets warm, and nearly one ton of water is driven off by the heat."

"Yes," said the Doctor, "you see that over half a ton $(1,146 \mathrm{lbs}$. of dry organic matter has been slowly burnt up in the heap; giving out as much heat as half a ton of coal burnt in a store. But this is not all. The manure is cooked, and steamed, and softened by the process. The organic matter burnt up is of no value. There is little or no loss of nitrogen. The lieap contained 64.3 lhs. of nitrogen when put up, and $63.9 \mathrm{lbs}$. after fe menting six months. Aud it is evident that the manure is in much more actire and available condition than if it had been applied to the land in the fresl state. There was $14.9 \mathrm{lbs}$. of nitrogen in a solulle condition in the fresh manure, and $21.4 \mathrm{lbs}$. in the fermented mannre. And what is equally important, you will notice that there is $154 \mathrm{lbs}$. of soluble ash in the heap of fresh manure, an $1204 \mathrm{lbs}$. in the heap of fermented manure. In other words, 50 lbs. of the insoluble mineral matter had, by the fermentation of the manure, been rendered soluble, and consequently immediately avaitable as plantfood. This is a very important fact."

The Doctor is right. There is clearly a great advantage in fermenting manure, provided it is done in such a manner as to pre. 
vent loss. We have not only less manure to draw out and spread, but the plant-food which it contains, is more soluble and active.

The table we have given shows that there is little or no loss of valuable constituents, even when maure is fermented in the open air and exposed to ordinary rain and snows during an English winter. But it also shows that when the manure has been fer. mented for six months, and is then turned and left exposed to the rain of spring and summer, the loss is very considerable.

The five tons (10,000 lbs.,) of fresh manure placed in a heap on the 3 d of November, are redueed to 7,133 lbs. hy the 30 th of April. Of this 4,707 llos. is water. By the $2: 3 d$ of August, the heap is re. duced to $7,025 \mathrm{lbs}$, of which $5,30 \div \mathrm{lbs}$. is water. There is nearly 600 lbs. more water in the heap in August than in April.

()f total nitrogen in the heap, there is $64.3 \mathrm{ll}$ s. in the fresh manure, 6:3.9 Hos. in April, and only 46.3 lbs, in August. 'This is a great loss, and there is no compensating gain.

We baveseen that, when five tons of manure is fermented for six months, in winter, the nitrogen in t':e soluble organie matter is increased from $14.9 \mathrm{lbs}$. to $21.4 \mathrm{ll} \mathrm{s}$. This is a decided advantage. But when the manure is kept for another six months, this soluble nitrogen is lecreased from 21.4 lhs. to $13.2 \mathrm{lls}$. We lose over 8 lbs. of the most active and availahle nitrogen.

And the same remarks will apply to the valuable soluble mineral matter. In the fire tons of fresh manme there is 154 lbs. of soluble mincral matter. By fermenting the heap six months, we get 204 llos., but by keeping the manure six months longer, the soluble mineral matter is reduced to 138 lbs. We lose $66 \mathrm{lbs}$. of valuable soluble mineral matter.

By fermenting manure for six months in winter, we greatly im. prove its condition: ly keeping it six months longer, we lose largely of the very best and most active parts of the manure. 


\section{H A P T E R X V.}

\section{KEEPING MANURE LNDER COYER.}

Dr. Volcker, at the same time he made the experiments alluded to in the preceding chapter, flacel another heap of manure under cucer, in al shed. It was the samse kind of manure, and was treated precisely as the other-the only difference heing that one heap was exposed to the rain, and the other not. The following tible gives the results of the weighings of the heap at ditferent times, and also the percentuge of loss:

MANURE FERMENTED UNDER COVER IN SHED.

TABLE BHOWING TUE ACTUAL WEIGHINGS. AND IERCENTAGE OF LOSG IN WEIGIT, OF EXPERIMENTAL HEAP (NO, H.) FRESII F.RM YARD MAXURE UXDER

BEED, AT DIFFERENT PERIODS OF THE YEAR.

\begin{tabular}{|c|c|c|c|}
\hline & $\begin{array}{c}\text { Weight } \\
\text { of } \\
\text { Holume } \\
\text { in Lls. }\end{array}$ & \begin{tabular}{|} 
Loss in \\
oriyinal \\
ceighl \\
in Lbs.
\end{tabular} & $\begin{array}{l}\text { Percen: } \\
\text { agye of } \\
\text { Loss. }\end{array}$ \\
\hline 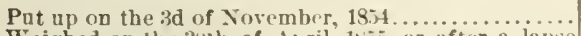 & $3,2: 58$ & & \\
\hline $\begin{array}{l}\text { Weighed on the } 3 \text { ith of April, 1sjs. or after a lapse } \\
\text { of } 6 \text { months.... }\end{array}$ & 1.613 & 1,645 & 50.4 \\
\hline 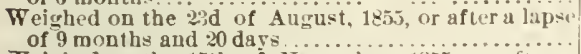 & $1,29 \pi$ & 1,961 & 60,0 \\
\hline 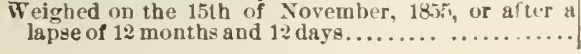 & 1.235 & 2,023 & 62.1 \\
\hline
\end{tabular}

It will be seen that 100 tons of manure, kept in a heap under cover for six months, would be reluced to 49.6-10 tons. Whereas, when the same manure was fermented for the same length of time in the open air, the 100 tons was reduced to only i1.4-10 tons. The difference is due principally to the fuet that the heap exposed contained more water, derived from rain and snow, than the heap kept under cover. This, of course, is what we should expect. Let us look at the results of I)r. V'eleker's analyses: 
TABLE SUOWIVG TIE COMPOATION OF EXPERIMENTAL HEAP (NO. I.) FIERH FARMIARD MANUIBE UNDEIK SIIED, IN NATL:AL, STATE AT DIFFERENT

I'EKIODS OF TIIE YEAR.

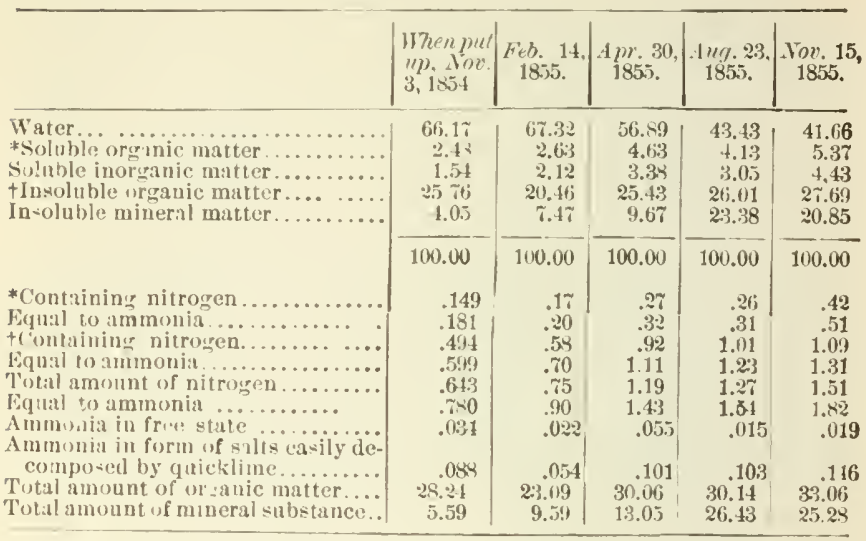

TABLE SIIOWINO TIE COMPOSITION OF EXPERIMENTAL IIEAP (NO. II.) FRESH FARM YARD MANURE CNDEK SIIED, CALCULATED DRY, AT DIFFERENT PERIODS OF THE YEAR.

\begin{tabular}{|c|c|c|c|c|c|}
\hline & $\begin{array}{l}\text { When put } \\
\text { up, Nox. } \\
3,1854 .\end{array}$ & $\begin{array}{c}F+b .14 \\
185 .\end{array}$ & $\begin{array}{c}\text { A pr. } 30 . \\
1855 .\end{array}$ & $\underset{1855 .}{A u g .23 .}$ & $\begin{array}{c}\text { Tov. } 15, \\
1855 .\end{array}$ \\
\hline $\begin{array}{l}\text { *Soluble organic matter.. } \ldots \ldots \ldots \\
\text { Soluble inorganic matter.......... } \\
\text { tInsoluble organic matter......... } \\
\text { Insolnble mineral matter......... }\end{array}$ & $\begin{array}{r}7.33 \\
4.55 \\
71.15 \\
11.97\end{array}$ & $\begin{array}{r}8.04 \\
6.49 \\
62.690 \\
22.89\end{array}$ & $\begin{array}{r}10.74 \\
7.81 \\
58.99 \\
22.43\end{array}$ & $\begin{array}{r}7.30 \\
5.39 \\
45.67 \\
41.34\end{array}$ & $\begin{array}{r}9.20 \\
7.59 \\
47.46 \\
35.75\end{array}$ \\
\hline & 100.00 & 100.00 & 100.00 & 100.00 & 100.00 \\
\hline 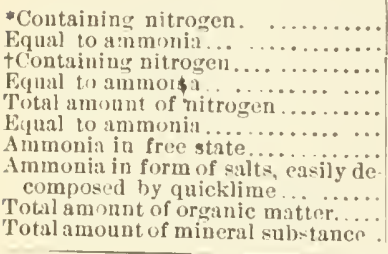 & $\begin{array}{r}.41 \\
.53 \\
1.46 \\
1.76 \\
1.90 \\
2.30 \\
.10 \\
.26 \\
83.48 \\
16.52\end{array}$ & $\begin{array}{r}.53 \\
.60 \\
1.77 \\
2.14 \\
2.30 \\
2.80 \\
.074\end{array}$ & $\begin{array}{r}.63 \\
.77 \\
2.14 \\
2.59 \\
2.77 \\
3.35 \\
.127 \\
.231 \\
69.73 \\
3027\end{array}$ & $\begin{array}{c}.46 \\
.56 \\
1.78 \\
2.16 \\
2.21 \\
2.72 \\
.026\end{array}$ & $\begin{array}{c}.72 \\
.89 \\
1.88 \\
2.0 \\
2.60 \\
3.08 \\
.032\end{array}$ \\
\hline
\end{tabular}

The above analyses are of value to those who buy fresh and fermented manure. They can form some idea of what they are getting. If they buy a ton of fres' manure in November, they get 129 lbs. of nitrogen, and 30 lbs, of soluble mineral matter. If 
they buy a ton of the same manure that has been kept under eover until February, they get, nitronen, 15 los.; soluble minerals, 42. lbs. In April, they get, nitrogren, 23 lbs.; soluble minerals, $6 \sigma^{2}$ lbs. In August, they gret, nitrogen, $25 \frac{1}{2}$ lbs. ; soluble minerals, 61 lbs. In November, when the minure is over one year old, they get, in a tom, nitrogen, $30 \frac{1}{16}$ lbs. ; soluble miner:ls, $88 \frac{1}{2} \mathrm{lbs}$.

When manure hits not been exposed, it is clear that a purchaser can atiord to jay considerably more for a tou of rotted nanure than for a ton of fresh mauure. But waiving this point for the present, let us see how the matter stands with the farmer who makes and uses the manure. What does he gain by keeping and iermenting the manure under corer?

The following table shows the weirht and composition of the entire heap of manure, kept under corer, at different times :

TABLE SHOWLYG C MPOLTION OF ENTIIE EXPEIMYETAL UEAP (NO. II.) FRESH FARM-YARD TANTRE, CNDER. SIIED.

\begin{tabular}{|c|c|c|c|c|}
\hline & $\begin{array}{l}\text { Then put } \\
\text { up. Yov. } \\
3,1554 .\end{array}$ & $\begin{array}{l}\text { April } 30 \\
1855 .\end{array}$ & $\begin{array}{c}\text { Aug. 23, } \\
1655 .\end{array}$ & $\begin{array}{l}\text { Nov, } 15 \\
1855\end{array}$ \\
\hline 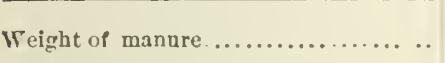 & $\begin{array}{r}\text { thos. } \\
3.258 .\end{array}$ & $\begin{array}{r}\text { ths. } \\
1,613 .\end{array}$ & $\begin{array}{r}\text { fto. } \\
1,29 \%\end{array}$ & $\begin{array}{r}\text { fos. } \\
1,225 .\end{array}$ \\
\hline $\begin{array}{l}\text { Amount of water in the manure......... } \\
\text { Amount of dry matter................. } \\
\text { *Consisting of soluble organic matter... } \\
\text { Soluble mineral matter........... } \\
\text { tInsoluble organic matter........ } \\
\text { Insoluble mineral matter......... }\end{array}$ & $\begin{array}{r}2.15 \% \\
1,102 . \\
80 . \pi 1 \\
50.11 \\
83 \% .1 \% \\
131.92\end{array}$ & $\begin{array}{r}91 \% .6 \\
69.5 .4 \\
7.68 \\
5.51 \\
410.21 \\
155.97\end{array}$ & $\begin{array}{r}56 ; 3.2 \\
733.8 \\
53.56 \\
39.55 \\
337.32 \\
303.37\end{array}$ & $\begin{array}{r}514.5 \\
720.5 \\
66.28 \\
54.68 \\
311.97 \\
257.57\end{array}$ \\
\hline & 1,102 & 695.4 & ซ33.8 & 720.5 \\
\hline 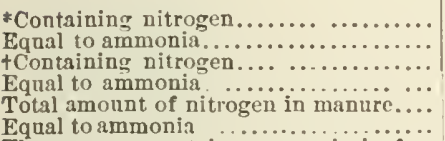 & $\begin{array}{r}4.85 \\
5.82 \\
16.08 \\
19.5 \\
20.93 \\
25.40\end{array}$ & $\begin{array}{r}4.38 \\
5.33 \\
14.88 \\
17.46 \\
19.26 \\
22.79\end{array}$ & $\begin{array}{r}3.46 \\
4.20 \\
13.18 \\
15.8 \\
16.54 \\
20.03\end{array}$ & $\begin{array}{r}5.25 \\
6.37 \\
13.51 \\
1641 \\
18.79 \\
22.81\end{array}$ \\
\hline $\begin{array}{l}\text { The manure contains ammonia in free } \\
\text { state........................... } \\
\text { The manure contains ammonia in form }\end{array}$ & 1.10 & .88 & .19 & .23 \\
\hline 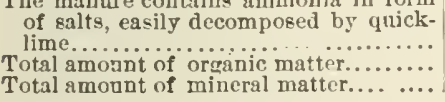 & $\begin{array}{r}286 \\
919.94 \\
1 \times 2.06\end{array}$ & $\begin{array}{r}1.62 \\
481.92 \\
210.48\end{array}$ & $\begin{array}{r}1.33 \\
390.89 \\
342.92\end{array}$ & $\begin{array}{r}1.80 \\
408.25 \\
312.35\end{array}$ \\
\hline
\end{tabular}

This is the table, as given by Dr. Tœlcker. For the sake of comparison, we will figure out what the changes would be in a heap of five tons $(10,000$ lbs.) of manure, when fermented under cover, preciscly in the same wy as we dict with the beap fermented in the open air, exposed to the rain. The following is the table : 
CONTENTS OP A HEAP OF MAYUIE AT DIFFEIEXT IERIOUS. FERMENTEN UNUEA covkik.

\begin{tabular}{|c|c|c|c|c|}
\hline & $\begin{array}{l}\text { When put } \\
\text { up. . . oc'.3. }\end{array}$ & April :30. & Aug. 23. & Nor. 15. \\
\hline Total weight of manure in heap... & $\begin{array}{c}\text { tts: } \\
\text { 10.00i0 }\end{array}$ & 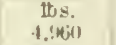 & $\begin{array}{l}\text { thes. } \\
4,1410\end{array}$ & $\begin{array}{l}\text { thes. } \\
3, \pi ! \cdot 0)\end{array}$ \\
\hline Watcr in rle leaply of manuri...... & ti.tb1 & 2,422 & 1.337 & 1.579 \\
\hline Total organtc matte............ . & $2.8 \div 4$ & 1,430 & 1,205 & 1,253 \\
\hline Total inorganic uistler... ........... & 5,34 & i.46 & 1,056 & 9.8 \\
\hline Total nitrogen in heap............. & 61.3 & 59 & 50.8 & 57.2 \\
\hline Total sululbe organic malter........ & 218 & 230 & $16 . j$ & 203.5 \\
\hline Insoluble organte maltur..... & $2,5 i 1 ;$ & 1,2150 & 1.010 & 1,049 \\
\hline Soluble mineral malter. & 1,1 & 11,7 & 122 & 168 \\
\hline Iusoluble mincral matter & 4115 & $4: 9$ & $9: 35$ & 790 \\
\hline Nitrugen in solubles matlor ... & 14.1 & 13.4 & 10.1 & 15.9 \\
\hline Nirrugen in insoluble & $4 \% .4$ & $15.1 i$ & 411.4 & 11.3 \\
\hline 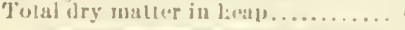 & 3.283 & $2,10: 34$ & $2,2(i)$ & 2,211 \\
\hline
\end{tabular}

It will be seen that the heap of manure kept under cover containel, on the \&:0th of A pril, liss solnb]e organic matter, less soluble mincral matter, less soluble nitrogenous matter, and hos total nitrogen than the heap of manure exposed to the weither. This is precisely what I should hatre expectul. The heap of manure in the slued probalily fermented more ripilly than the heap out of doors, and there was not wilur eno'bh in the manure to retain the carbonate of ammonia, or to favor the production of organic acids. The heap acus too dry. If it could have riveived enomgh of the liquicl from the stables to hatre kept it moderately moist, the result would have been very dillierent.

We will pestpone further endicleration of this point at oresent, and look at the results of another of Dr. Tolekrr's interesting experiments.

Dr. Verkeker wished to astertain the itferet of three common metluels of managing mianuri:

1st. Keeping it in a heep in the open air in the barn-yard, or fiel: 1 .

2d. Kicejing it in a heap nnder cover in a s'sed.

3d. Keeping it spreud ont over the barn-yard.

"You say these are common methods of managing manure," remarked the Deacon, "but I nerer knew any one in this country" take the troable to spread manure orer the yarl."

"Perhajs nut," I replied, "lut yon have known a good many farmers who alopt this very methol of keeping their mannre. They do not spreal it-lut they let it lie spreasl out over the rards, just wherever it happens to he."

Let us see what the effiet of this treatment is on the composition and value of the manure.

We have examined the eflect of keeping manure in a heap in 
the open air, and also of keeping it in a lieap under cover. Now let us see how these methods compare with the practice of lear jug it exposed to the ratus, spread out in the yard.

On the 3rd of November, 18.5, Dr. Velcker weighed out 1,652 Ifs. of manure sinilar to fluat used in the preceding experinents, aud spreaul it out in the yart. It was weiglod $A_{p}$ ril 30 , aucl again Aurust 2:3, anıl Noveunber 1j.

The following lable grites the actual weight of the monure at the different periods, also the actual amount of the water, orgatic matter, ash, nitrogen, etc. :

TABLE BHOWING TIIE W'EIGIT ANU COMPOSITION OF EXTILE MASA OF EXPEIR-

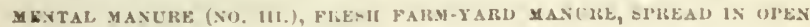
YALI) AT DIFFEILAT PELLOD OF TIE YEAR. IN SATUIAL STATE.

Weiglit of manure...

\begin{tabular}{|c|c|c|c|}
\hline $\begin{array}{l}157 \text { en puf } \\
\text { up. Jor. } \\
\text { 3. ixil. }\end{array}$ & $\begin{array}{l}\text { 1pril :30, } \\
\text { lsis. }\end{array}$ & $\begin{array}{c}\text { Aug.? } \\
\text { lisiv. }\end{array}$ & $\begin{array}{l}\text { Yor } 1 \text { 1. } \\
18 j^{2}\end{array}$ \\
\hline $\begin{array}{c}00 \\
1,65.3\end{array}$ & $\begin{array}{l}\text { th: } \\
1,4: 9 .\end{array}$ & $\begin{array}{l}\text { th:s. } \\
1,012 .\end{array}$ & $\begin{array}{l}\text { This. } \\
9.0 .\end{array}$ \\
\hline 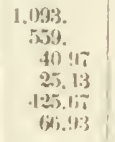 & $\begin{array}{c}1.118 . \\
2 \times .5 \\
16.55 \\
11.41 \\
163.7 .4 \\
90.75\end{array}$ & $\begin{array}{r}701.3 \\
302.1 \\
4.46 \\
6.4 i \\
10 t .41 \\
1=4.16\end{array}$ & $\begin{array}{r}622.8 \\
3 \div 7.2 \\
3.9 .3 \\
5.52 \\
91.15 \\
223.24\end{array}$ \\
\hline $55 \% .0$ & $2 \times 5.50$ & $302 . \pi 11$ & $32 \div .20$ \\
\hline $\begin{array}{r}3.29 \\
3.413 \\
6.21 \\
7.51 \\
9.19 \\
11.52\end{array}$ & $\begin{array}{l}1.19 \\
1.11 \\
6.51 \\
i .91 \\
7.70 \\
9.31\end{array}$ & $\begin{array}{l}.60 \\
.73 \\
3.44 \\
4.29 \\
4.14 \\
5.02\end{array}$ & $\begin{array}{r}.32 \\
.39 \\
3.56 \\
1.25 \\
3.88 \\
1.61\end{array}$ \\
\hline .5i & 14 & .13 & .00 .55 \\
\hline $\begin{array}{r}1.45 \\
4 i 6.614 \\
! r 3.365\end{array}$ & $\begin{array}{r}.62 \\
1.0 .31 \\
105.16\end{array}$ & $\begin{array}{l}111.75 \\
190.93\end{array}$ & $\begin{array}{r}.28 \\
98.40 \\
228.80\end{array}$ \\
\hline
\end{tabular}

Amount of waler in the mantre........

Amount of dry matler..................

- Consisting of soluble oribitie malter... Soluble mineral matter........... tInsolnble organic mitter.......... Insoluble mineral malter.........

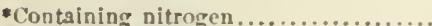

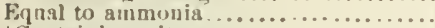
+Containing nitrogt ${ }^{2} \ldots \ldots \ldots \ldots \ldots \ldots \ldots$

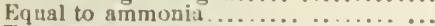
Total amount of nitrogen in manure...

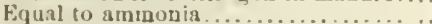

Thu manure coulains ammouia in free

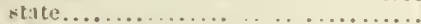

The manure entains ammonia in form of salts, easily d'composed by quick-

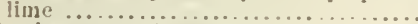

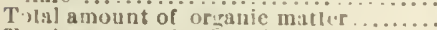
Tolal aronnt of mineral matter.........

"One moment," said the Deacon. "These tibles are a little confusing. The table you have just given shows the actual weight of the manure in the heap, and what it contained at different periods."- "Yes," said I, "and the table following shows what $100 \mathrm{lbs}$ of this manure, spread ont in the rard, contained at the different dates mentioned. It shows how greatly manure deterin. rates by being exposed to rain, spreat ont on the surface of the yarl. The table merits careful study:" 
TABLE SIOWING COMPOSITION OF ESPERIMENTAL IIEAP (NO. III.), FRESH FARM YARD MANURE, SPREAD IN OPEN TARD, AT DIFFERENT PERIODS OF THE TEAR. IN NATURAL STATE,

\begin{tabular}{|c|c|c|c|c|}
\hline & $\begin{array}{l}\text { When put } \\
u p, \text { tov } \\
3,1854 .\end{array}$ & $\begin{array}{c}\text { April } 30 \\
1555 .\end{array}$ & $\begin{array}{c}\text { Aug. } 23, \\
1855 .\end{array}$ & $\begin{array}{c}1 \mathrm{Tco} .15 \\
1855 .\end{array}$ \\
\hline 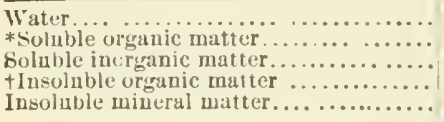 & $\begin{array}{r}6+i .17 \\
2.18 \\
1.54 \\
25.76 \\
1.05\end{array}$ & $\begin{array}{r}80.02 \\
1.16 \\
1.01 \\
11.46 \\
6.535\end{array}$ & $\begin{array}{r}70.09 \\
.49 \\
.64 \\
10.56 \\
18.22\end{array}$ & $\begin{array}{r}65.56 \\
.42 \\
.5 \% \\
9.94 \\
23.51\end{array}$ \\
\hline & 100.00 & 100.00 & 100.00 & 100.00 \\
\hline 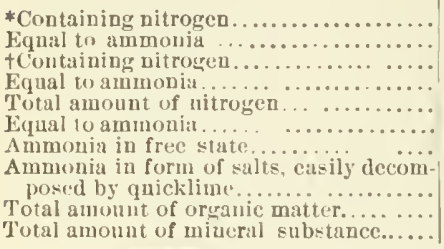 & $\begin{array}{l}.14 ! \\
.181 \\
.4 ! 1 \\
.59 ! \\
.613 \\
. .81 ! \\
.034 \\
.0 .8 \\
28.24 \\
5.54\end{array}$ & $\begin{array}{c}.08 \\
.1 .9 \\
.45 \\
.54 \\
.55 \\
.63 \\
.010 \\
.045 \\
12.6 \% 2 \\
7.26\end{array}$ & $\begin{array}{c}.06 \\
.0 \% \\
.35 \\
.42 \\
.11 \\
.4 ! \\
.012 \\
.051 \\
11.05 \\
18.86\end{array}$ & $\begin{array}{c}.03 \\
.036 \\
.36 \\
.46 \\
.33 \\
.1 ! 6 \\
.0006 \\
.030 \\
10.36 \\
24.03\end{array}$ \\
\hline
\end{tabular}

The following table shows the composition of the manure, calculated dry :

PABLE SHOWIX COMPOSITION OF EXPEIMENTAL HEAP (XO. II.), FRESH FARY YARD MANLRE, SPIEAD IS OPEX TARD, AT DIFFERENT PERIODS OF TUE YEAR, CALCCLATED DRY.

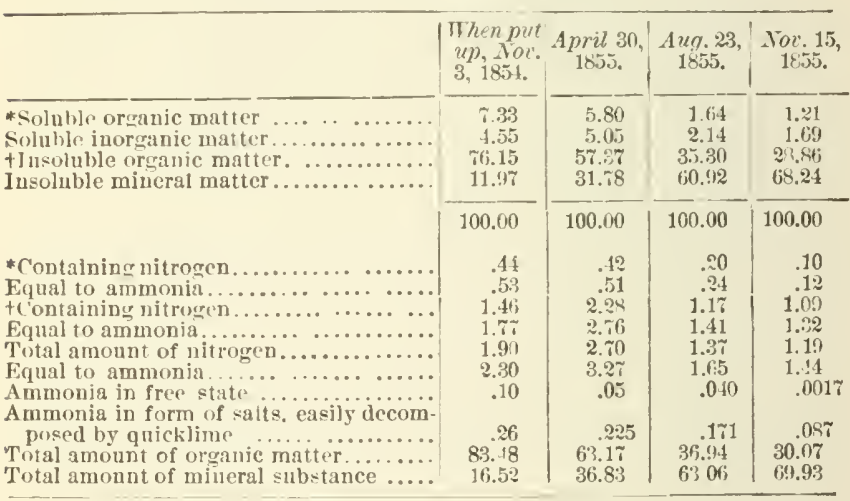

I have made out the following table, showing what would he the changes in a heap of 5 tons $(10,000$ lbs. of manure, spreacl out in the yarl, so that we can readily see the effectsof this method of 
management as emmared with the other two methods of keeping the manure in cempact heaps, one exposed, the other under cover.

The following is the table:

TONTENTS OF TEE MASS OF MANURE, SPIBEAD OUT IN FARY.YARD, AND EXPOSEI TO RAIX, ETC.

\begin{tabular}{|c|c|c|c|c|}
\hline & $\begin{array}{l}\text { When spread } \\
\text { ont, i oc. 3. }\end{array}$ & -1pril 30. & Aug 23. & Nov. 15. \\
\hline Total weight of manure......... & $\begin{array}{l}\text { tos. } \\
10.000\end{array}$ & $\begin{array}{l}\text { tos. } \\
8.6500\end{array}$ & $\begin{array}{l}\text { ths. } \\
6,1: 0\end{array}$ & $\begin{array}{l}\text { tbs. } \\
5.750\end{array}$ \\
\hline Water in the manure.............. & 6,6117 & $6,1,122$ & $1,29 \%$ & $3, \pi 71$ \\
\hline Total organic inaller............ & 2.424 & $1,00 \cdot 2$ & $67 \%$ & $5: 15$ \\
\hline Total inurganic matler........... & 559 & $6: 36$ & 1,155 & $1, \therefore 81$ \\
\hline Totथl nitrogen in manure......... & 64.3 & 45.9 & 25 & 22.1 \\
\hline Total suluble orgunic matter.... & 218 & 100 & 30 & 21 \\
\hline Iusuluble organic malter......... & $2,5,6$ & 932 & 617 & $5 \pi 1$ \\
\hline Soluble mineral matter .......... & 151 & $8 i$ & $3 !$ & 23 \\
\hline linsoluble mineral matter......... & 405 & 519 & 1,116 & 1,351 \\
\hline Nilregen in solinc] e matter........ & 11.9 & 6.9 & 3.6 & 1.7 \\
\hline Nitrogen in insoluble matter...... & 4.1 .4 & 39 & 21.4 & 20.7 \\
\hline
\end{tabular}

It is not necessary to make many remarks on this table. The facts speak for themselves. It will be seen that there is eonsiderable loss eren by letting the manure lie spread out until spring; but, scrious as this loss is, it is small compared to the loss sustainel by allowing the manure to lie exposed in the yard ciuring the summer.

In the five tons of fresh manure, we litre, November $3,64.3$ lhs. of vitrogen; April 30, we have 46 lbs.; August 23, only 25 lbs. This is a great loss of the most valualb]e constituent of the manure. Of soluble nimeral matter, the next most valuable ingredient, we have in the fire tons of fresh mannre, November 3,154 lbs.; April 30,87 lbs.; and August 23 , only 39 lbs. Of soluble nitrogen, the most actire and raluable part of the manure, we hare, Norember 3, nearly 15 lbs.; April 30, not quite 5 lbs.;

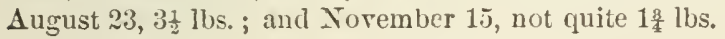

Dr. Tœlcker made still another experiment. He took 1,613 lbs. of vell-rotted dung (nixed manure from horses, cows, and pigs,) and kept it in a heap, exposed to the weather, from December 5 to April 30, August 23, and Norember 15, weighing it and analyzing it at these different dates. I think it is not necessary to give the results in detail. From the 5th of December to the 30th of April, there was no loss of nitrogen in the heap, and eomparatively little loss of soluble mineral matters; but from April 30 to August 23, there was considerable loss in both these valuable in gredients, which were washed out of the beap by rain. 
Dr. Voelcker draws the following conclusions from his experiments :

"Having described at length my experiments with farm-yard manure," lie says, "it may not he amiss to state briefly the more prominent and practically interesting points which have been developed in the course of this investigation. I wonld, therefore, olserve:

“1. Perfectly fresh farm yard manure contains but a small proportion of free ammonia.

"2. The nitrogen in freslı dung exists prineipally in the state of insoluble nitrogenized mitters.

“3. The solnhle organic and mineral constituents of dung are much more valuable fertilizers than the insoluble. Particular eare, therefore, should be bestowed upon the preservation of the liquid exerements of animals, and for the same reason the manure should be kept in perfectly water-proof pits of sufficient calpacity to render the setting up of dung-heaps in the corner of fields, as much as it is possible, unnecessary.

"4. Farm-yarl mamure, even in quite a fresh state, contains phosphate of lime, which is much more soluble than has litherto been susperted.

"5. The urine of the horse, cow, and pig, does not contain any appreciahle ruantity of phosphate of lime, whilst the drainings of dung-heaps contain consilerable quantitios of this valuable fertilizer. The drainings of dun r-lieaps, prortly for this reason, are more valuable than the urine of oHr clomestic animals, and, therefore, ought to be prevented by all available means from running to waste.

" 6 . The most effectual means of preventing loss in fertilizing matcers is to eart the manure direetly on the field whenever ciremustances allow this to he done.

" $\%$ On all soils with a molerate proportion of clay, no fear ned to be entertained of valuable fertilizing substances loeoming wasted if the manure cannot be plowed in at onee. Fresh, and even well-rotten, dung contains very little free ammonia; and since active fermentation, and with it the further evolution of free ammonia, is stopped by spreading out the manure on the fiold, valualhle volatile manuring matters ean not escape into the air by adopting this plan.

"As all soils with a moderite proportion of clay possess in a remarkahle degree the power of albsolbing and rotaining manuring matters, none of the saline and soluble organie constifuents are wasted even by a heavy fall of rain. It may, indeed, be questioned 
whether it is more advisible to plow in the manure at once, or to let it lie for some time on the surface, and to give the rain full opportunity to wash it into the soil.

"It appears to me a matter of the greatest importance to regulate the applicatiou of manure to our tields, si) that its constituents may become properly diluted and uniformly distributed anongrst a large mass of soil. By plowing in the manure at once, it ap)pears to me, this desirable end can not be rencheal so perfectly als by allowing the rain to wash in gractually the manure evenly spread on the surface of the ficlit.

"By adopting such a course, in case practical experience should confirm my theoretical reasoning, the oljection coild no longer be maintained that the land is not ready for carting matnure upon it. I am inclined to recommend, as a general rule: Cart the manure on the field, spread it at once, and wait for a favorable opportunity to plow it in. In the calse of clay soils, I have no lacsitation to say the manure may be spread even six months before it is plowed in, without losing a:ly appreciable quantit ${ }_{j}$ i: manuring matter.

"I am perfecty aware, that on stiff cliy land, farm-yard mak nure, more especially long dun'r, when plowe: in hefore the frost sets in, exercises a most beneficial action ly kecping the soil loose, and admitting the free access of frost, which pulverizes the land, and would, therefore, we no means reemmend to leave the mamme spread on the surface without plowing it in. All I wish to enforce is, that when no other choice is left hut either to set up the manure in a heap in a corner of the field, or to sjuread it on the field, without plowinir it in directly, to atopt the lattor plan. In the case of very linht sandy soils, it may perhaps not be alvisable to spread out the manure a long time before it is plowed in, since such soils do not possess the power of retaining manuring matters in any marked degree. On light sandy soils, I would suggest to manure wit'. well-fermented dung, shortly beforc the crop intended to be grown is sown.

"8. Well-rotteu dung contains, likewise, little free ammoni:l, but a very much larger proportion of soluble orçanic and saline mineral matters than fresh manure.

"9. Rotten dung is richer in nitrogen than fresh.

"10. Weight for weight, rotten dung is more valuable than fres'.

"11. In the fermentation of dung, a very considerable proportion of the organic matters in fresh manure is dissipated into the air in the form of carbonic acil ancl other gases. 
"12. Properly regulated, however, the fermentation of dung is not attended with any great loss of nitrogen, nor of saline mineral matters.

"13. During the fermentation of dung, ulmic, lumie, and other organie acids are formed, as well als gypsum, which fix the ammonis generated in the decompusition of the nitrugenized constituents of dung.

"14. During the fermentation of lung, the phosphate of lime which it contains is rendered more soluble than in fresh manure.

"15. In the interior an 1 heated portions of manure-heaps, ammonia is given off; but, on passing into the external and cold laycrs of dung-heaps, the free ammonis is retained in the heap.

"16. Ammonia is not given oll from the surface of well-rompressed dung-heaps, but on turning manme-heaps, it is wasted in appreciable quantities. Dung-heaps, for this reason, should not be turned more frequently than absolutely necessary.

"1\%. No adrantage appears to result from earrying on the fer mentation of lung too far, but erery disiclvantage.

"18. Farm-yard manure becomes deteriorated in value, when kept in heaps exposed to the weather, the more the longer it is kept.

"19. The loss in manuring matters, which is incurred in keepi:irg mature-heaps exposed to the weather, is not so much due to the volatilization of ammonia as to the removal of ammoniacal salts, soluble nitrogenized organic matters, ancl valuallele mineral matters, by the rain which falls in the perind during which the manure is kept.

" 20 . If rain is excluded from dung-heaps, or little rain falls at a time, the loss in ammonia is tritlingr, and no saline matters, of course, are removed; but, if much rin falls, especially if it deseends in heavy showers upon the dung-heap, a serious loss in ammonia, soluble organic matter, phosphlate of lime, and salts of potash is ineurred, and the mannre becomes rapidly deteriorated in value, whilst at the same time it is climinished in weight.

“ 21 . Well-rotten dung is more readily affected by the deteriorating intluence of rain than fresh manure.

“ 22. Practically speaking, all the essentially valualle manuring constituents are preserved by lieeping farm-yard manure under cover.

"2:. If the animals have been supplierl with plenty of litter, fresh dung contains an insufliepent gliantity of water to induce an active fermentation. In this case, fresh dung can not he properly 
fermented under cover, except water or liquid manure is pumped over the heap from time to time.

"Where much straw is used in the manufacture of dung, and 110 provision is male to supply the manure in the pit at any time with the requisite amount of moisture, it may not be advisable to put np a roof over the dung-pit. On the other himel, on farms where there is a de.ciency of straiw, so that the moisture of the excrements of our domestic animals is barely absorbed by the litter, the advantage of erecting a roof orer the dung-pit will be found very great.

"24. The worst method of making manure is to prouluce it by animals kept in open yards, since a larere proportion of valuable fertilizing matters is wasted in a short time; and after a lapse of twelve months, at least two-thirds of the substance of the manure is wasted, and only onc-third, inferior in quality to an cqual weight of fresh dune, is left hehind.

“25. The most rattional plan of keeping manure in heaps appears to me that adopted by Mr. Lawrence, of Cirencester, and described by him at lenetl in ILorton's " Cyclopeedia of Agriculture,' under the head of 'Manure.'"

\section{$+\infty$ \\ C II A P 'T E R X VI.}

\section{AN ENGLisH PLAN OF KEEPING MANURE.}

"I would like to kuow," said the Deacon, "how Mr. Lawrence manages his manure, especially as his method has received such high commendation."

Charley got the second rolume of "Morton's Cyclopædia of Agriculture," from the book shelres, and turned to the article on "Miture." He found that Mr. Lawrence adopted the "Box System" of feeling cattle, and used cut or chaffed straw for bedcing. And Mr. Lawrence claims that by this plan " manure will hare been made under the most perfect conditions." And "when the boxes are full at those periods of the year at which manure is required for the suecee ling crops, it will be most advantageously dis pose ? of by being trinsferred at once to the lan 1, and covered in."

"Good, said the Deacon, "I think he is right there." Charley continued, and read as follows :

"But there will be accumulations of manure requiring removal 
from the homestead at other seasons, at which it cannot be so applied, and when it must be stored for future use. The following has been found an effectual and economical mode of accomplisliing this; more particularly when cut litter is used, it saves the cost of repeated turnings, and effectually prevents the decomposition and waste of the most active and volatile principle.

"Some three or more spots are selectec. according to the size of the farm, in convenient positions for access to the land under t:llage, and by the side of the farm roads The sites fixed on are tien excavated about two feet uncier the surrounding surface. In the bottom is laid some three or four inches of earth to absorb any moisture, on which the manure is emptied from the carts. This is evenly spread, and well trodden as the heap is forming. As soon as this is about a foot above the ground level, to allow for sinking, the heap is gradually gathered in, until it is completed in the form of an ordinary steep roof, slightly rounded at the top by the final treading. In the course of building this un, about a bushel of salt, to two cart-loads of dung is sprinkled amongst it. The base laid out at any one time should not exceed that required by the manure ready for the complete formation of the heap as far as it goes; and within a day or two after such portion is built up, and it has settled into shape, a thin coat of earth in a moist state is plastered entirely over the surface. Under these conditions decomposition does not take place, in consequence of the exclusion of the air ; or at any rate to so limited an extent, that the ammonia is absorbed by the earth, for there is not a trace of it perceptible about the heap; though, when put together without such covering, this is perceptible enough to leeward at a luundred yards' distance.

"When heaps thus formed are resorted to in the autumn, either for the young seeds, or for plowing in on the stubbles after preparing for the succeeding root crop, the manure will be found undiminished in quantity and unimpaired in quality; in fact, simply consolidated. Decomposition then proceels within the soil, where all its results are appropriated, and rendered available for the succeeding cereal as well as the root crop.

"It would be inconvenient to plaster the heap, were the ridge, when settled, above six or seven feet from the ground level; the base may be formed about ten to twelre feet wide, and the ridge about nine feet from the base, which settles down to about seven feet; this may be extended to any length as further supplies of manure recuire removal. One man is sufficient to form the heap, and it is expedient to employ the same man for this service, who soon gets into the way of performing the work neatiy and quickly. 
It has been asked where a farmer is to get the earth to cover his heaps-it inay be answered, keep your roads scriped when they get muddy on the surface during rainy weather-in itself good economy-and leave this in small heaps beyond the margin of your roads. This, in the course of the year, will be found an ample provisiou for the purpose, for it is unnecessary to lay on a coat more than one or two inches in thickness, which shonld be done when in a moist state. At any rate, there will always be found an aceumulation on Leadlands that may be drawn upon if need be.

"Farmers who have not been in the habit of bestowing eare on the manufacture and subsequent preservation of their manure, and watching results, have no conception of the importance of this. A harrowful of such manure as has been described, would produce a greater weight of roots and corn, than that so griphically deseribed by the most talenteil and accomplished of our agricultural authors-as the contents of "neighbour Drychalf"s clungcart, that ereaking hearse, that is carrying to the field the dead body whose spirit lias departed.'

"There is a source of valuable and extremely useful manure on every farm, of which very few farmers avail themselves-the gathering together in one spot of all combustible waste and rubbish, the clippings of hedges, scouring of ditches, grassy accumulation on the sides of roads and fences, etc., combined with a good deal of carth. If these are carted at leisure times into a large eircle, or in two rows, to supply the fire kindled in the center, in a spot which is frequented by the laborers on the farm, with a three-pronged fork and a shovel attendant, and each passer-by is encouraged to add to the pile whenever he sees the smoke passing away so freely as to indicate rapid combustion, a rery large quantity of valuable ashes are collerted between March and Oetrober. In the latter month the fire should be allowed to go out; the ashes are then thrown into a long ridge, as high as they will stand, and thatehed while dry. This will be found an invaluabl store in April, May, and June, capable of supplying from twenty to forty bushels of ashes per acre, according to the care and inclustry of the collector, to "Irill with the seeds of the root crop."

The Deacon got sleepy before Charles finished reading. "We can not afford to be at so much trouble in this country," he said, and took up his liat and left.

The Deacon is not altogether wrong. Our climate is very different from that of England, and it is seldom that farmers need to draw out manure, and pile it in the field, except in winter, and 
then it is not necessary, I think, either to dig a pit or to cover the heap. Those who draw manure from the city in summer, may probably adopt some of Mr. Lawrence's suggestions with advantage.

The plan of collecting rubbish, brush, old wood, and sods, and convertiug them into ashes or charcoal, is one which we could often adopt with decided advintage. Our premises would be cleaner, and we should have less fungus to speck and erack our apples and pears, and, in addition, we should hare a quantity of ashes or burnt earth, that is not only a manure itself, but is specially useful to mix with moist superphosphate and other artificial manures, to make them dry enough and bulky enough to be easily and evenly distributed by the drill. Artificial manures, so mixed with these ashes, or dry, charred earth, are less likely to injure the seed than when sown with the seed in the drill-rows, unmixed with some such material. Sifted coal ashes are also very useful for this purpose.

\section{$\rightarrow \infty$ \\ C H A P T E R X VII.}

\section{SOLUBLE PIIOSPHATES IN FARMI TARD MANURE.}

There is one thing in these experiments of Dr. Voelcker's which deserves special attention, and that is the comparutively large amount of soluble phosphate of lime in the ash of farm-yard manure. I to not think the fact is generally known. In estimating the valne of animal mannres, as compared with artificial manures, it is usually assumed that the phosphates in the former are insoluble, and, therefore, of less value than the soluble plosphates in superphosphate of lime and other artificial manures.

Dr. Volcker found in the ash of fresh farm-yard manure, phosphoric acid equal to 12.23 per cent of phosphate of lime, and of this 5.35 was soluble phosphate of lime.

In the ash of well-rotted mantre, he found phosphoric acid equal to 12.11 per cent of plosphate of lime, and of this, $4 . \pi$ was soluble phosphate of lime.

"That is, indeed, an important faet," said the Doctor, "bnt I thonght Professor Volckel claime I that 'during the fermentation of lung, the phosphate of lime which it contains is rendered more soluble than in fresh manure." 
"Ile did say so," I replied, "and it maly be true, but the alhove figures do not seem to prove it. When he wrote the sentence you have quoted, he probably had reference to the fact that he found more soluble phosphate of lime in rotted manure thin in fresh mannre. Thus, he found in 5 tons of fresh and 5 tons of rotted manure, the following ingredients:

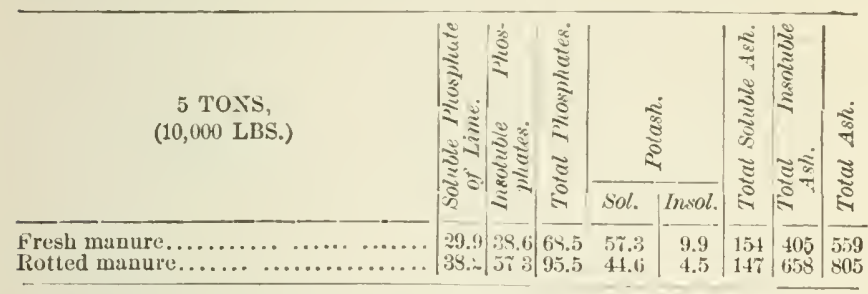

"It will be seen from the ahove figures that rotted manure contuins more soluble phosphate of lime the fresh manure.

"But it does not follow from this fact that any of the insoluble phosphates in fresh manure lave been rendered soluble during the fermentation of the manure.

"There are more insoluble phosphates in the rotted manure than in the fresh, but we do not conclude from this fact that any of the phosphates have been rendered insoluble during the process of fermentation-neither are we warranted in concluding that any of them have been rendered soluble, simply beeause we find more soluble phosp'ates in the rotted manure."

"Very true," said the Doctor, "but it has been shown that in the heap of manure, during fermentation, there was an actual increase of soluble mineral matter during the first six months, ancl, to say the least, it is highly probable that some of this increase of soluble mineral matter contai iel more or less soluble phosphates, and perhaps Dr. Voicker had some faets to show that such was the case, although he may not have published them. At any rate, he evidently thinks that the phosphates in manure are rendered more soiuble by fermentation."

"Perhaps," said I, "we can not do better than to let the matter rest in that form. I am merely anxious not to draw definite conclusions from the facts which the facts do not positively prove. I am strongly in favor of fermenting manure, and should be glad to have it shown that fermentation does actually convert insoluble phosphates into a soluble form."

There is one thing, however, that these experiments clearly prove, and that is, that there is a far larger quantity of solubie 
phosphates in mauure than is generally supposed. Of the total phosphoric acid in the fresh manure, 43 per cent is in a soluble condition; and in the rotted manure, 40 per cent is soluble.

This is an important fact, and one which is generally overlooked. It enhances the value of farm-yard or stable manure, as compared with artificial manures. But of this we may have more to say when we come to that part of the subject. I want to make one remark. I think there can be little doubt that the proportion of soluhle phosphates is greater in rich manure, made from grainfed animals, than in poor manure made principally from straw. In other worls, of $100 \mathrm{lhs}$. of total phosphoric acid, more of it wonld be in a soluble condition in the rich than in the poor manure.

\section{II A P T E R X T I I I.}

\section{HOW THE DEACON MAKES MANURE.}

"I think," said the Deacon, "you are talking too much about the science of manure making. Science is all well enough, but practice is better."

"That depends," said I, "on the practice. Suppose you tell us how you manage your manure."

"Well," said the Deacon, "I do not know much about plantfood, and nitrogen, and phosphoric acid, but I think manure is a good thing, and the more you have of it the better. I do not believe in your practice of spreading manure on the land and letting it lie exposed to the sun and winds. I want to draw it out in the spring and plow it under for corn. I think this long, coarse manure loosens the soil and makes it light, and warm, and porous. And then my plan saves labor. Hore than half of my manuse is handled but once. It is made in the yard and sheds, and lies there until it is drawn to the field in the spring. The manure from the cow and horse stables, and from the pig-pens, is thrown into the yard, and nothing is done to it except to level it down occasionally. In proportion to the stock kept, I think I make twice as much manure as you do."

"Yes," said I, "twice as much in bulk, but one load of my manure is worth four loads of your long, coarse manure, composed 
principally of corn-stalks, straw, and water. I think you are wise in not spending much time in piling and working over such manure."

The Deacon and I have a standing quarrel about manure. We differ on all points. He is a good man, but not what we call a good farmer. He cleared up his farm from the original forest, and he has always been content to receive what his land would give him. if he gets good crops, well, if not, his expenses are moderate, and he manages to make both ends meet. I tell him he could double his crops, and quadruple his profits, by better farming-but though he cannot disprove the facts, he is unwilling to make any change in his system of farming. And so he continues to make just as much manure as the crops he is obliged to feed ont leave in bis yards, and no more. He does not, in fact, muke any manure. He takes what comes, and gets it on to his lind with as little labor as possible.

It is 110 use arguing with such a man. And it certainly will not do to contend that his method of managing manure is all wrong. His error is in making such poor manure. But with such poor stuff as he has in his yard, I believe he is right to get rid of it with the least expense possible.

I presume, too, tlrat the Deacon is not altogether wrong in regard to the good mechanical effects of manure on undrained and indifferently cultivated land. I have no doubt that he bases his opinion on experience. The good effects of such manure as he makes most be largely due to its mechanical action-it can do little towards supplying the more important and valuable elements of plant-food.

I commend the Deacon's system of managing manure to all such as make a similar article. But $I$ think there is a more excellent way. Feed the stock better, make richer manure, and then it will pay to bestow a little labor in taking care of it. 


\section{H I P T E R X I X.}

\section{HOW JOHN JOHNSTON MANAGES HIS MANURE.}

One of the oldest and most successful farmers, in the State of New York, is John Johnston, of Genera. He has a farm on the borders of Seneca Lake. It is high, rolling land, but needed under draining. 'This has been thoroughly done-and done with great profit and advantage. The soil is a heavy elay loam. Mr. Johnston has been in the habit of summer-fallowing largely for wheat, generally plowing three, and sometimes four times. He has been a very successful wheat-grower, almost invariably obtaining large erops of wheat, both of grain and straw. The straw he feeds to sheep in winter, putting more straw in the racks than the sheep ean eat up elean, and using what they leave for belding. The shecp run in yards enclosed with ticht board fences, and have sheds under the barn to lie in at pleasure.

Although the soil is rather heary for Indian corn, Mr. Johnston succeeds in growing large crops of this great American cereal. Corn and stalks are both fed out on the farm. Mr. J. has not yet practisel cutting up his straw ard stallss into chinf.

The land is admirably adapted to the growth of red clover, and great crops of clover and timothy-hay are raised, and fed out on the farm. Gypsum, or plaster, is sown quite frecly on the elover in the spring. Comparatively few roots are raised-not to exceed an acre-and these only quite recently. The main crops are winter wheat, spring barley, Indian corn, elover, and timothy-liay, and clover-see!!

The materials for making manure, then, are wheat and barley straw, Inlian corn, corn-stalks, clover, and timothy-hay. These are all raised on the farm. But Mr. Johnston has for many jears purchased linseed-cil cake, to feed to his shcep and cattle.

This last fact musi not be overlookel. MIr. J. commenced to feed oil-cake when its value was little known here, and when he bought it for, I think, seven or cight dollars a ton. He continued to nse it eren when he had to pay fifty dollars per ton MIr. J. has great faith in manure-and it is a faith resting on good evidence and long experience. If he had not fed out so much oil-cake and clover-hay, he would not have found his manure so valuable.

"IIow much oil-cake does lie use?" asked the Deacon.

"He gives his sheep, on the average, about $1 \mathrm{lb}$. each per day." 
If he feeds out a ton of elorer-hily, two tons of straw, (for feed and bedding, and one ton of oil-cake, the manure obtained from this quantity of food and litter, would be worth, according to Mr. Lawes' table, given on page 4.5, $\$ 34.72$.

On the other hand, if he fed out one ton of corn, one ton of clover-hay, and two tons of straw, for feed and bedding, the manure would be worth \$21.6.\%.

If he fed one ton of corn, and three tons of straw, the manure would be worth only $\$ 14.69$.

He would get as much manure from the three tons of straw and one ton of corn, as from the two tons of straw, one ton of cloverhay, and one ton of oil-eake, while, as before said, the manure in the one case would be worth $\$ 14.69$, and in the other $\$ 34.72$.

In other words, a load of the good manure would be worth, when spread out on the land in the field or garden, more than two loads of the straw and corn manure.

To get the same amount of nitrogen, phosphoric acid, and potash, you have to spend more than twice the labor in cleaning out the stables or yards, more than twice the labor of throwing or wheeling it to the manure pile, more than twice the labor of turning the manure in the pile, more than twice the labor of loading it o: the carts or wagons, more than twice the labor of drawing it to the field, more than twice the labor of unloading it into heaps, and more than twice the labor of spreading it in the one case than in the other, and, after all, twenty tons of this poor manure would not produce as good an effect the first season as ten tons of the richer manure.

"Why so"? asked the Deacon.

"Simply because the poor manure is not so actire as the richer manure. It will not decompose so readily. Its nitrogen, phosphoric acid, and potush, are not so available. The twenty tons, $m a y$, in the long run, do as much good as the ten tons, but I rery much doubt it. At any rate, I would greatly prefer the ten tons of the good manure to twenty tons of the poor-even when spread out on the land, ready to plow under. What the difference would be in the valuc of the manure in the yard, you can figure for yourself. It would depend on the cost of handling, drawing, and spreading the extra ten tons."

The Deacon estimates the cost of loading, drawing, unloading, and spreading, at fifty cents a ton. This is probably not far out of the way, though much depends on the distance the manure has to be drawn, and also on the condition of the manure, etc. 
The four tons of feed and bedding will make, at a rough estimate about ten tons of manure.

This ten tons of straw and corn unanure, according to Mrr. Lawes' estimate, is worth, in the field. $\$ 14.69$ And if it costs fifty cents a load to get it on the land its vilue, in the yord, would be $\$ 9.69-$ or nearly ninety-seven cents a tou.

The ten tons of good manure, according to the same estimate, is worth, in the field, 4.2 .2 , and, ecnseruently, woul.l be worth, in the yord, \$29.72. In other words, a ton of poor manmre is worth, in the yard, ninety-seven cents a ton, and the good manure \$2 97.

And so in describing John Jolnston's method of managing manure, this fact must be borue in mind. It might not pay the Deacen to spend murbla lahor on unanure worth only ninety-seven cents a ton, while it might pay John Johnston to bestow some considerable time and libur on manure worth \$2.9 per ton.

"But is it really worth this sum?" asked the Deacon.

"In reply to that," said $I, "$ all I claim is that the figures are com. parative. If your manure, mate as ahove deseribed, is worth ninety-seven cents a ton in the yard, then .Joln Johnston's manure, made as stated, is certuinl!y worth, at least, $\$ 2.97$ per ton in the yart."

Of this there can be no doulst.

"If you think," I continued, "rour manure, so male, is worth only lualf as much as Mr. Lawes' estimate; in other words, if your ten tons of manure, insteal of being worth $\$ 14.69$ in the ficld, is worth only $\$ 535$; then John Jolnston's ten tons of manure, instead of being worth $\$ 34.72$ in the field, is worth only $\$ 17.36$."

"That looks a little more reasonable," said the Deacon, "John Johnston's manure, inst at of being worth $\$ 2.97$ per ton in the yard, is worth only $\$ 14$ per ton, and mine, instead of being worth ninetyseven cents a ton, is worth forty-eight and a half cents a ton."

The Deacon sat for a few minutes looking at these figures. "They do not seem so extravagantly high as I thought them at first," he sad, "and if you will reduce the firures in Mr. Lawes' table one-half all through, it will be much nearer the truth. I think my manure is worth forty-eight and a half cents a ton in the yard, and if your figures are correct, I suppose I must admit that John Johnston's manure is worth $\$ 1.48$ per ton in the yard."

I was very glad to get such an admission from the Deacon. He did not see that he had male a mistake in the figures, and so 1 got him to gro over the calculation again. 
"You take a pencil, Deacon," said I, "and write down the figures :

Manure from a ton of cil.calie .............. 19.72

Manure from a ton uf elover liay............. @ tit

Manure frum twu tons of straw............ 5.36;

$$
\text { ล:3 } \%
$$

"This would make aboit ten tons of manmre. We liare atreed

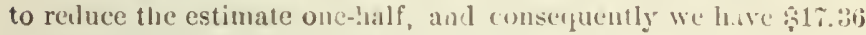
as the value of the ten tons "f manure."

"This is Juhn Johnston's manure. It is worth $\$ 1$. $\approx: ;$ jer tom in the ficld.

"It costs, we have estimated, 50 cents a ton to hanile tide manure, and consequeutly it is wortl in the yard st.2:3 per ton."

"This is less than we mate it before," silic the Deacon.

"Never mind that," said I, "the figures are correct. Now write down what your manure is worth :

Manure from 1 ton of corn.................

Manure from 3 tuns of straw............... 4.14

$\div 14.69$

"This will make about ten tons of manure. In this rase, as in the other, we are to reduee the estimate one-lialf. Comseguently, we have s.7.5 as the value of this ten tous of manure in the field, or r3t cents a ton. It costs, we lave estimited, 50 c'ents a ton to handle the manure, and, therefore, it is worth in the yurd, $23 \frac{1}{2}$ cents a tou."

"John Johnston's manure is worth in the yard, \$1.23 per ton. The Deacon's manure is worth in the yarl, 2: $\frac{1}{2}$ cents per ton."

"There is some mistake," exelaimed the Deacon, "you said, at first, that one load of John Johuston's manure was worth as much as two of my loads. Now jou make one load of his manure worth more than fire loads of my manure. This is absurcl."

"Not at all, Deacon," said I, "you made the firures yourself. You thought Mr. Lawes' estimate too high. Tou reduced it onehaif. The figures are correct, and you must accept the conclusion. If John Johnston's manure is only worth \$1.23 pir ton in the yard, yours, made from 1 ton of corn and 3 tons of straw, is only worth $23 \frac{1}{2}$ cents per ton."

"And now, Deacon," I continued, "while you have a pencil in your hand, I want you to make one more calculation. Assuming that MIr. Lawes' estimate is too himh, and we reduce it one-half. 
figure up what manure is worth when made from straw alone. You take 4 tons of wheat straw, feed out part, and use part for bedding. It will gire you about 10 tons of manure. And this 10 tons cost you 50 cents a ton to loal, draw out, and spread. Now figure :

"Four tons of straw is worth, for manure, according to Mr. Lawes' table, \$2.68 per ton. We have agreed to reduce the figures one half, and so the

10 tons of manure from the 4 tons of straw is worth...\$5.36

Drawing out 10 tons of manure at 50 cents......... 5.00

Valne of 10 tons of straw-manure in yard........... $\$ 0.36$

"In other words, if John Johnston's manure is worth only $\$ 1.23$ per ton in the yar!, the straw-made manure is worth on'y a little over $3 \frac{1}{2}$ ernts a ton in the yard."

"That is too absurd," sai 1 the Deacon.

"Very well," I replied, "for onee I am glad to arree with you. Bit if this is absurd, then it follows that IIr. Lawes" estimate of the value of certain fools for manure is not so extravagant as you supposed-which is precisely what I wished to prove."

"Yon have not told us how Mr. Johnston manages his manure," said the Deacon.

"There is nothing very remarkable abont it," I replied. "There are miny farmers in this neighborhood who adopt the same method. I think, however, John Johnston was the first to recommend it, and subjected himself to some criticism from some of the so-ealled seientific writers at the time.

"II is general plan is to leave the manure in the yards, basements, and she's, under the sheep, until spring. IIe usually sells his fat sheep in March. As soon as the sheep are removed, the manure is either thrown up into loose heaps in the yard, or drawn directly to the field, where it is to be used, and made into a heap there. The manure is not spread on the land until the autumn. It remains in the heaps or piles all summer, being usually turned once, and sometimes twice. The manure becomes thoroughly rotted."

Mr. Jolnston, like the Deacon, applies his manure to the corn crop. But the Deacon draws ont his fresh green manure in the spring, on sod-lund, and plows it under. Mr. Johnston, on the other hand, keeps his manure in a beap through the summer, 
spreads it on the sod in September, or the first week in Octoloer. Here it lies until next spring. The grass and clover grow up through manure, and the grass and manure are turned under next spring, and the land plinted to corn.

Mr. Johnston is thoroughly conrinced that lie gets far more benefit from the manure when applied on the surface, and left exposed for several months, than if he plowed it under at once.

I like to write and talk about John Johnston. I like to visit him. Ile is so delightfully enthusiastic, believes so thoroughly in good farmingr, and has been so emincutly suceessful, that al day spent in his company can not fail to encourage any farmer to runewed efforts in improving his soil. " Tou must drain," he wrote to me; "when I first commenced faming, I never male any money until I began to undelelrain." But it is not underdrainingr alone that is the cause of his eminent success. When he bought his farm, "near Genera," over fifty years agro, there was a pile of manure in the yard that had lain there year after year, until it was, as he said, "as black as my liat." The former owner regarded it as a nuisance, and a few montlis before young Jolnsion bought the farm, had given some darkies a cow on conclition that they would draw out this manure. They drew out six loads, took the eow-and that was the last seen of them. Johnston drew out this manure, raised a good erop of wheat, and that gave him a start. He says he has been askel a great many times to what he owes his success as a farmer, and be has replied that he could not tell whether it was "lung or ereclit." It was probably neither. It was the man-his intelligence, indistry, and grood common sense. That heap of black moukl was merely an instrument in bis hands that he conld turn to good accoint.

His first crop of wheat gave him "creclit," and this also he used to advantage. He believed that gool farming would pay, and it was this faith in a generous soil that made lim willing to spend the money olstained from the first crop of wheat in enriching the land, and to avail himself of his eredit. Had he lacked this faithhad he hoarded every sixpence he could bare ground out of the soil, who would have ever heard of John Johnston? He has been liberal with his crops and his animals, and has ever found them grateful. This is the real lesson which his life teaches.

He once wrote me he had something to show me. He did not tell me what it was, and when I got there, lue took me to a ficld of grass that was to be mown for hay. The field had been in winter wheat the year Defore. At the time of sowing the wheat, the 
whole field was seeled down with timothy. No clorel was sown either then or in the spring; hut after the wheat was sow $n$, he put on a slight dressiug of manure on two portions of the tield that he thought were poor. He tohl the math lo spread it cut of the wagron just as thin as he could distribute it evenly over the danel. It was at very light manuring, but the mante was rich, and thoronghly rotted. I do mot rerolleet whether the eflect of the manure wits particularly notiend on the wheat; lut on the grass, the following s]ring, the diet wals sufficiently striking. These two portions of the tield where the manure was spread were cotered with

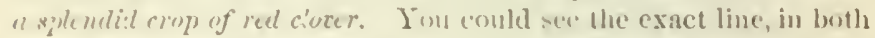
cass's, where the matumse reached. It looked quite curious. No cloresesect was sown, and yet there was as fine a crop of clover as une erulul desire.

On foukine into the matter more closely, we fomml that there was more or less elower all orer the fireld, hust where the moune Wats not userl, it could haplly he sien. The plants were small, and the timothy list the from view. Isut where the mame was userl, thesi plants of clover laad beren stimulated in their growth until they cowerest the ground. The leaves were broat and vigorus, while in the wher ease they were small, and almo:t driel up. This is probahly the richt explamblion. The manure dis not "hring in the clower;" it simply increased the growth of that al ready in t1,e soil. It shows the vathe of manure for grass.

This is what Mr. Juhnston wanted to show me. "I might have written and told you, lut you would not hate got a clear idlea of the matter." This is true. One hatd to sec the great luxurance of that piese of choser in fuПy appresectate the effert of the manure. Mr. J. said the manure on that grass was worth $\$ 30$ an acre-that is, on the three crops of grass, before the fichl is again plewerl. I lave un doubt that this is true, and that the future crops on the land will also he benefited-not directly from the mantare, perhaps, lut from the clorer-ronto in the suil. And if the tiold were pistured, the effect on future crops would be very decided. 


\section{II $\perp$ I' 'I' J: R I I.}

\section{MY OWN PLAN OF MANARING MANURE.}

One of the charms and the melvanbiges of anriculture is that a farmer must think for himself. 110 should studr principles, and

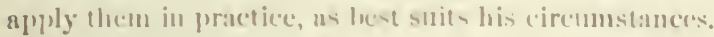

IIy own metho l of mantaging manure rives me many of the ndvantages chlinued for the 1) ancon's medhurl, and John Johnston's, also.

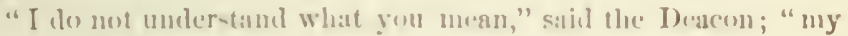
methonl ditliers esentially froun that of John Johnston."

"True," I replicd, "you use your winter-made manure in the spriug; while Iir. Johnston pilies lise, and gets it thoronghly fermented ; lut to do this, he has lo k(-1) it until the antumu, and it dees not benefit his rorn-trof, before: the next summer. He loses the use of his manure for an year."

I thiuk my methexl secures both these milvantages. I get my winter-malle manure formented and in gonel rondition, ant yet lase it ready for saring erops.

In the fir-t place, I shumlit remark thent my nsual plan is to cut

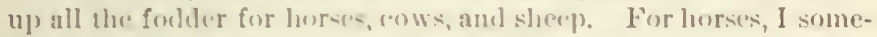
times nise bung straw for bedling, lut, as a rule, I prefer to run everything througle a ferel-cutter. Wie lo mut stram the food, and we let the cows and shep liave a liberal supply of cut corn-staliks and straw, and what they do not cat is thrown ont of the mangers and racks, and used for lechling.

I should state, tow, that 1 keep a good many pigs, seldom having less than jo liceding sows. My pigs are mostly sold at from two t1) four months ohl, lant wr probully areratge 150 luad the year round. A goml deal of my manure, therefore, comes from the pig-pens, and from two basement cellars, where my store hogs sleep in winter.

In addition to the pirs, we latve on the farm from 150 to 200 Cotswold and grale sheep; 10 cows, and 8 horses. These are our manure makers.

The raw material from which the manure is manufactured consists of whint, barley, rye, and oat-straw, corn-stalks, corn-fodder, cluver and timnthy-hay, clover seel-hay, hean-straw, pea-straw, potato-topıs, mancel-rurzel, turnips, rape, and mustard. These are all raiced on the farm; and, in addition to the home-grown oats, peas, and corn, we buy and feed out considerable quantities 


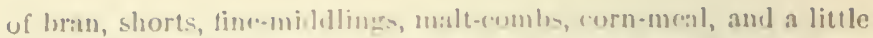
bil-catice. I sell what, rye, harley, ame a loser-secl, apples, and

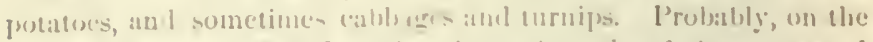
averign", fur each \$lun I renceis from the sible of these crops, I

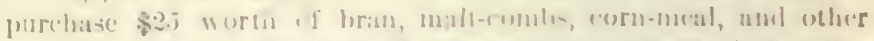

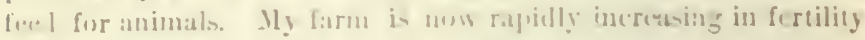

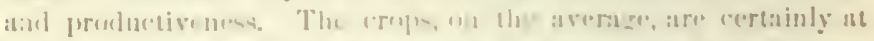

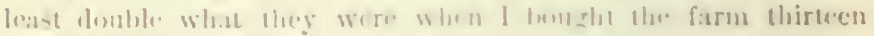

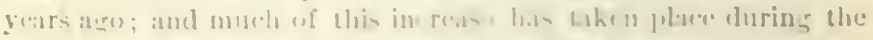

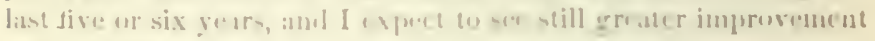
year hy yeir.

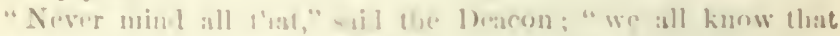

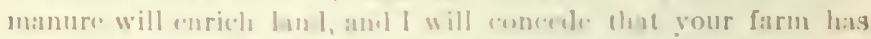

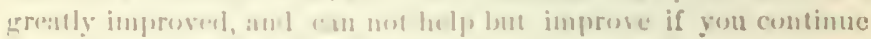

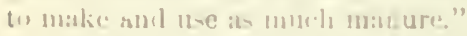

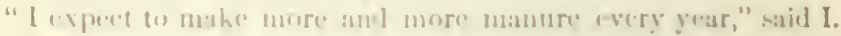
"Tlue larger llace erope, the more manure we can make; and the more minure we whe, the larer the cropse"

The reesl point of ditfere nee lwetweth my plon of managing ma-

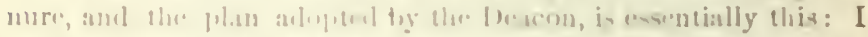

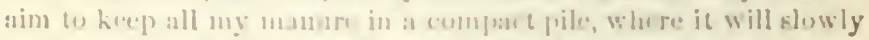

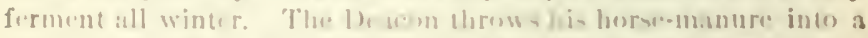

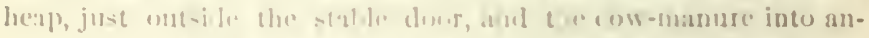

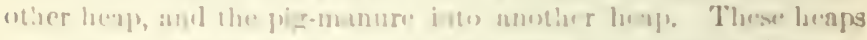

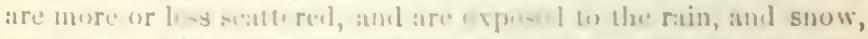

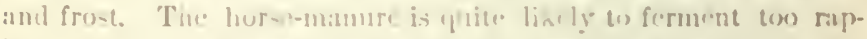

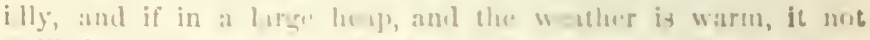

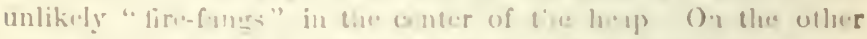
hand, the cow-manne lis a coll an l d ml, an I during the winter freere-into suli l lumpis.

I wherel or eart all my manure intu one eentr.l luap The main

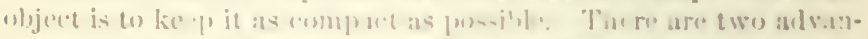

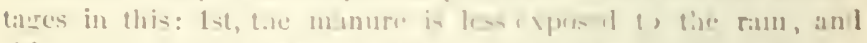

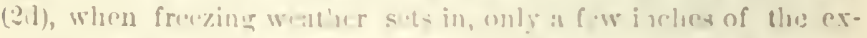
ternal portion of t'u lump is frum. In. I hive prutisel thes plan

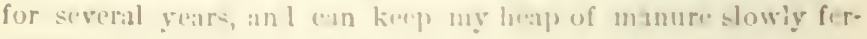
menting during l'u whale winler.

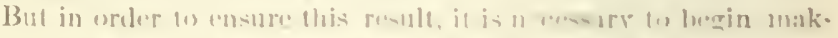

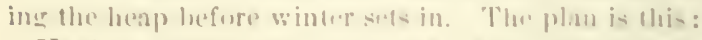

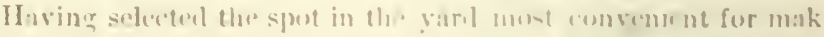

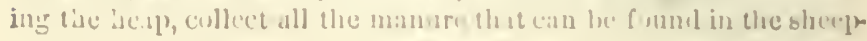




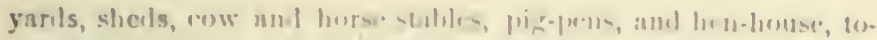

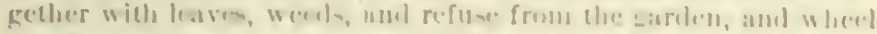

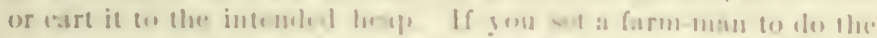
work, tell him you want fo mahe a loot-leel abum fir, fort higl, six

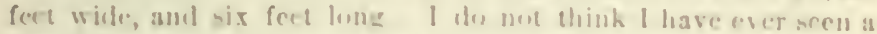

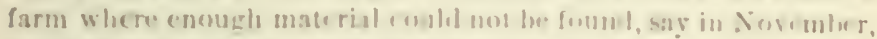
(1) mahe sueh a lieap. And this in all that is meded lf the mat-

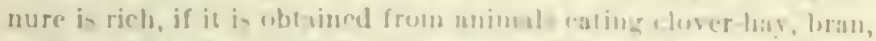
prain, or wher foml rich in nitrogen, if will -moll ferment. 13ut if the manure is guxor, consintiu laszely uf straw, it will lee very do-

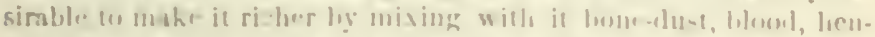
druppunz, womllen raes, clumber-lse, and animal matler of any kiml tlut bou ran limel.

The richer you can mahe the manure, the mese reanlily will it

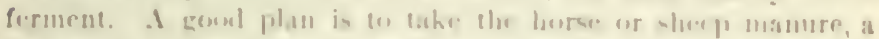

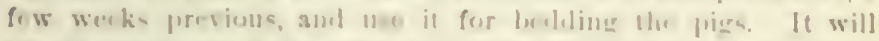
almorl, the liquide of the pige, and mahe riels manure, which will soun ferment whe n plued in a he:ap.

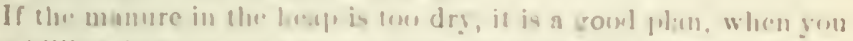
are killing hocs, to throw on as the manure alt the warm willer.

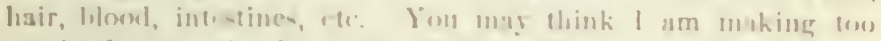

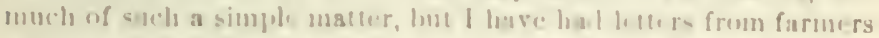
who have tried this plan of manugug momure, and the s ay llat

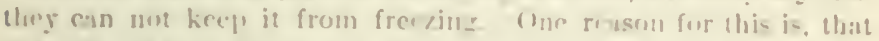
they In not sere the heyp enrly monels, and th not tahe pains to

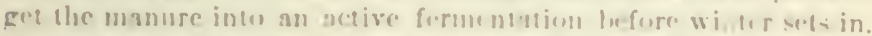

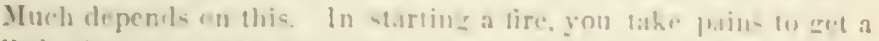
liete fine, llry woul, that will hur , realily, and whell the fire is

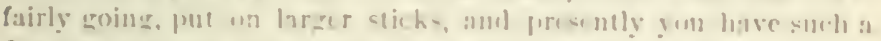

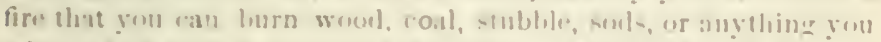
wish. Anl so it is with a monure-hrap). Fint the lire, er fermenItion, or, mure srictly speshing, putrefaction fairly starled, amd

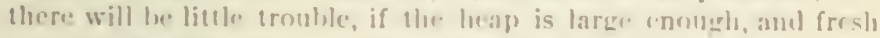
materiol ja alded from time in time, of coutinuine the fermu ntation all wimter.

Anutler point to be nlacervel, and experially in rold weather. is to kerp the sides of thw he ap straight, ame the tup lerel. You

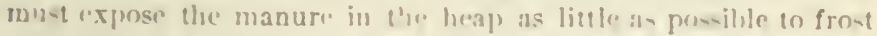
and inlel wind-. The rule sloulle lu in sproarl ivery wheel-liarrowful of manure as sorm as it is put on tlue limap. If left un-

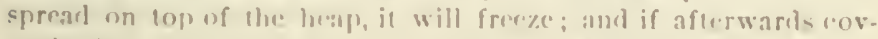
cred with other manure, it will reyuire cur-ieleralsle leat (1) milt it, an I thua raluce the temprerstur of the whole heap. 
It is far less work to manage a lieap of manure in this way than may be suppesed from my description of the plan. The trutl is, I find, in point of fact, that it is mot an easy thing to manage manure in this way ; and i lear not nne farmer in ten will suceed the first winter he undertakes it, unless he gires it his persunal attention. It is well worth tryins, however, hecause if your heaj) should freege mp, it will be, at any rate, in no worse conclition than if manared in the ordinary way ; and if you do succeed, "ven in part, you will lase manure in good condition for inmeliate use in the spring.

As I have saill hefore, I kerp a good many pigs. Now pigs, if forl on slops, void a large quantity of liquid mamure, and it is not always ensy to furnish straw enough to alsorb it. When straw and stalks are "ut into chatf, the'y will absorb much more liquid than when used whole. Fur this reasen we ustally cut all our straw and stalls. Wre also use the litter from the horse-stable for bubling the store hogs, aud also sometimes, when eomparatively dry, we use the refuse slueep betding for the sime purpose. Where the sheep haru is contigusus to the pirr-pens, and when the sheeple bedding (an be thrown at onee into the pigr-pens or cellar, it is well to nse bedding freely for the sheep and lambs, and remove it frefuenty throwing it into the pion-pens. I de not want my slre"p to be compelled to eat up) the straw and corn-stalks too (dose. I want them to prick out what they like, and then throw away what they leave in the trouthe for bedding. Sometimes we take out a tive-loushel hasketful of these direct from the tronghs, for lecdling young pirs, ur sows and pigs in the pens, but as at rule, we use them first for hedling the sheep, and then afterwards use the sheep bethling in the fattening or store prir-pens.

"Anl sometimes," remarlicd the Deacon, "you use a little long straw for your youne pirs to sle(p) on, so that they can bury themsedres in the straw and keep warm."

"True," I replicel, "and it is not a lad plan, lut we are not now talking about the management of pirs, hut low we treat our manure, and how we manage to have it ferment all winter."

$A$ good deal of onr pir-manure is, to horrow a plarase from the pomologists, "doulhle-workefl." It is herse or sheep-manure, used for bedding pigs and cows. It is saturated with urine, and is much richer in nitrogenous material than ordinary manure, and consecpuently will ferment or putrify much more rapjidly. I'sually lig-manure is consid"red "cold," or slugrish, but this double- 


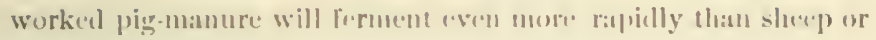
horse-manture ilone.

Unmixed eow-mamure is heavy and and, and when kept in a heal) by itself out of dours, is almost (ertion to freeze up solis during the winter.

We usually whecl out our cow-dune every liay, and spread on the manure leare.

This is one of the thines that meels attention. There will be a constant tendency to put all the cow-aluner torenther, instaid of mixing it with the liguter and more active manure from the horses, sherep, and piess. Spreal it out and cover it with some of the more strawy manure, which is nue -1 liable to freceze.

Shmlel it so happen-as will mos likely be the case-that on looking at your heap some unronine when the thermenueter is below z ro, you find thet several when-lyarrowfuls of manure that wer. put on the heap the diy loefore, were not sprea l, amel are now crusted ewer with ier, it will he well to hre.tk up the barrowfuls, "ven if necessury to 11 se a rowhir, and place the frozen lumps of manure on the outsile of the lae:tp), rather than (o) let them lieju the center of thr pile. Your aim should ba alw ty to keep the center of the heap warm and in a state of fermentation. Youldo not want the fire to gro ont, and it will uot go ont if the heap is properly manared, even shoull all the sidles anil top be erusted over with a layer of froz'n manure.

During very severe weather, and when the top is fruzen, it is a grood plan, when you are about to whene some frests manure on to the heap, 10 remove a portion of tice frozen crust on top of the lieap, near the center, and mike a bole for the fresh manure, which should be spreat and covered up.

When the heap is high enourh, say fire feet, we enmmener another heap alonesside. In doine this, our plen is tu clean out some of the sheep-sheds or pir-pens, where the mure has acenmulated for some time. This gives us much more than the daily supply. Place this manne on the ontside of the new heaj, and then take a quantity of hot, fermenting, monure from the middle of the old heap, and throw it into the center of the new heap, and then cover it up with the fresh manure. I would put in eight or ten bushels. or as much as will war:n up the center of the new heap, and start fermentation. The colder the weather, the more of this hot manure should you take from the old heap-the more the better. Fresh manure should he added to the old heap to fill up the hole made by the removal of the hot manure. 


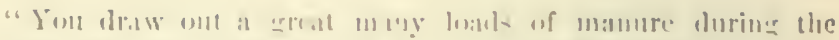

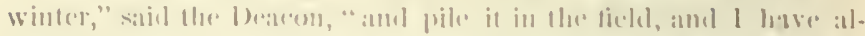

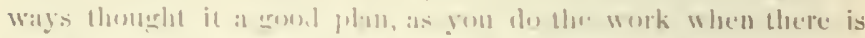

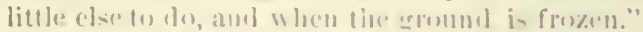

les, this is an improwement mu my ohl plan. I formorly used

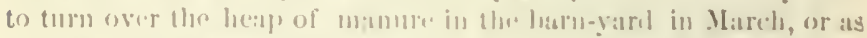

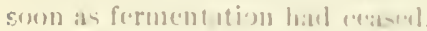

The objeret of turning the he tp) i- $(1-1$,$) (n) mix the manure and$

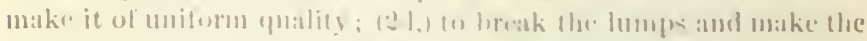

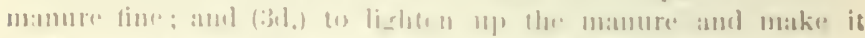

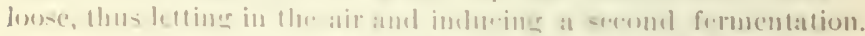

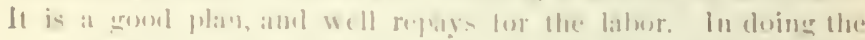

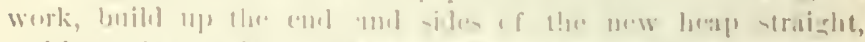

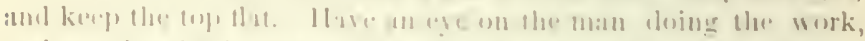

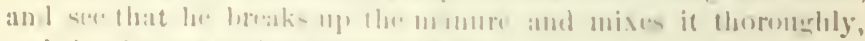

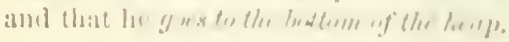

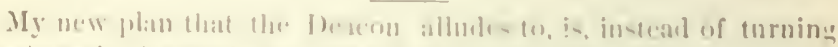

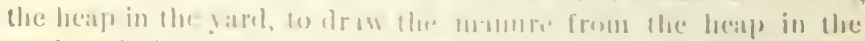

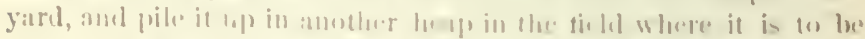

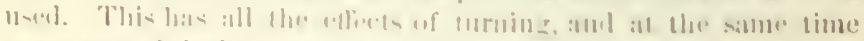

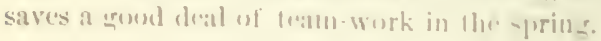

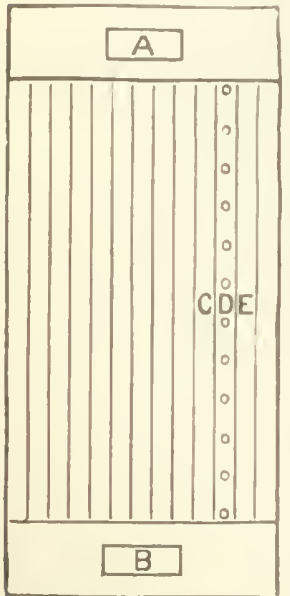

$A, B$, Wamure Heraps; $C$,

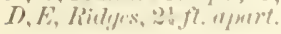

The luathion of the manurr-liesp in the

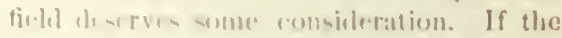

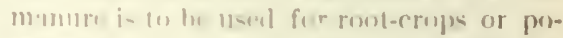

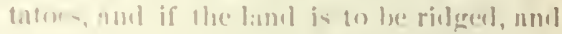
the matmere fout in the rislerses, Horn it wili

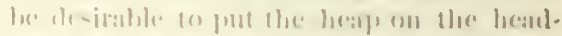
land, or, he tler still. (o) make (wor) heape,

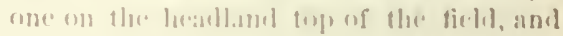

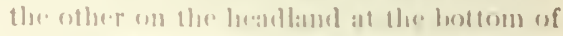
the fich, as - -

W1. slaw the manare with a cort, the horer walking lutwe 1$)$ lwo of the rilieres

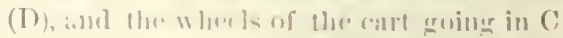
amb L. The manmo is pullorl ont at the bareli ond of the (allt inne small leaps, aheut five pares's apall:

"Thast is whall I whjeret w with you

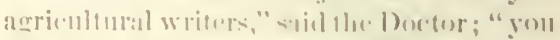

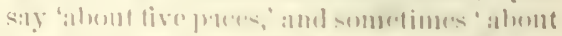

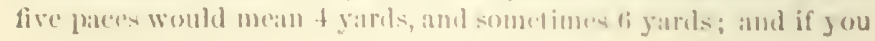




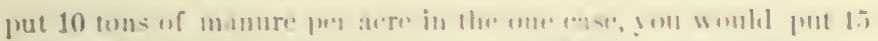

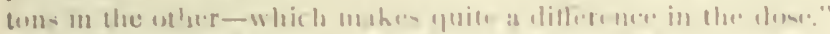

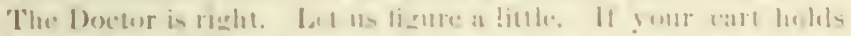

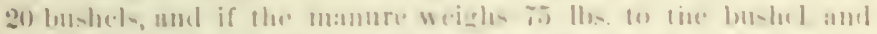

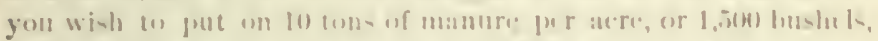

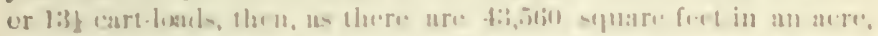

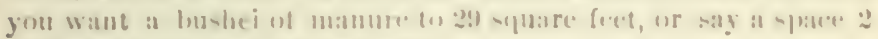
yarels lome, by mearly is feet wile.

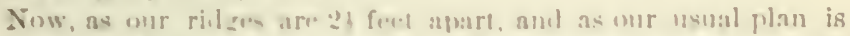
(1) manure is ribles al a lime, or $1 \geq 1$ fen 1 widle, a load of 20

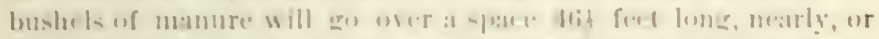

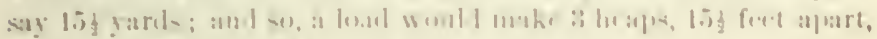

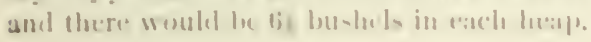

If the manure is to lu -qureal on the chrface of the land, there is

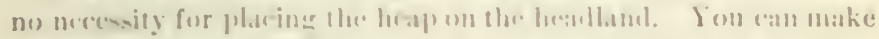

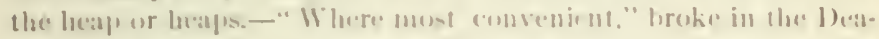

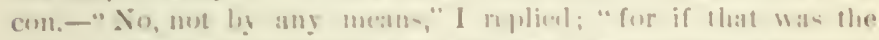

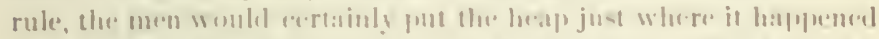

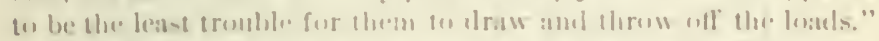

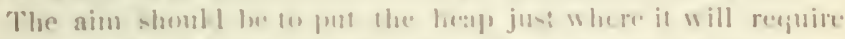

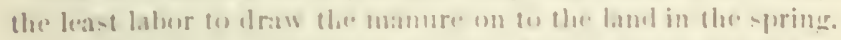

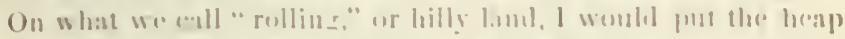

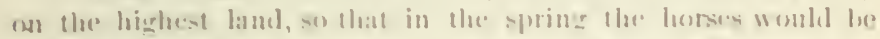
gring dewn hill with the full atsts or wasems. ()f course it would be very unwise to adeptet this plan if the manure was not

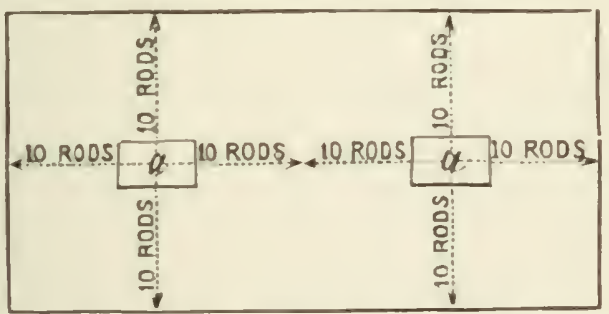

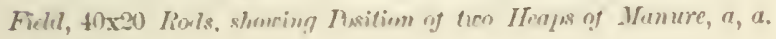

drawn from the yards until spring. when the land was soft; but I am nuw speaking of drawing out the manure in the wintor, when there is slejeline, or when lle eround is frozen. No farmer will oljuet tu a litte extra lolur fur the teams in the winter, if it will save work and time in the spring. 
If the land is level, then the lin:1] or heaps shomld he placed where the least distance will hate th be traveled in drawing the manure from the heapl to the land. If there is only one he.sp, the best point would be in the center of the fiekl. It two heaps, and the ficld is lonerer than it is broat, say $20 \mathrm{rots}$ wide, and 40 roils long, then the beaps should be male as slown on the previons page.

If the field is square, say $40 x+1)$ rods, and we can have four heaps of manure, then, other things beine efpual, the best points for the heaps are shown in the annexed figure:

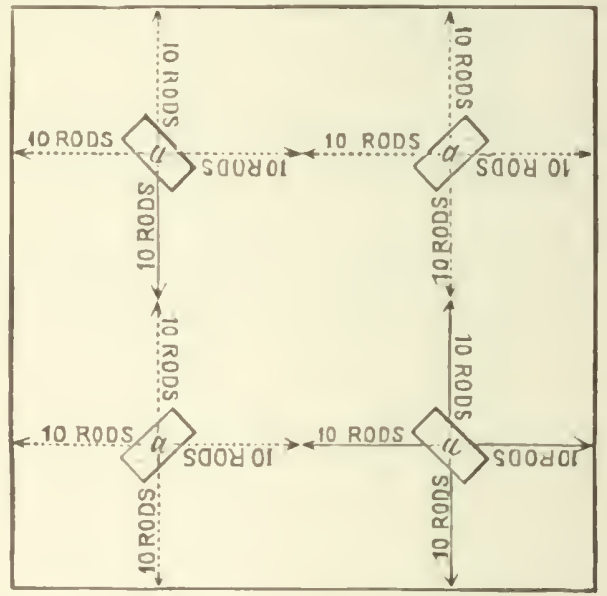

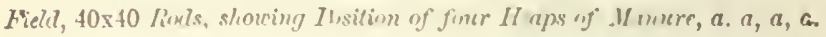

Having determinel where to make the heaps, the next question is in regard to size. We make one ahout $\times$ fert wide and 6 feet high, the length being determined ly the quantity of the mannre we have to draw. In (o)ld weather, it is well to finish the heap each tay as far as you go, so that the sloping side at the end of the heap will not be frozen during the night. Build up the sides square, so that the top of the heap shall be as liroad as the bottom. You will have to see that this is done, for the arerage farmman, if left to himself, will certainly narrow up the heap like the roof of a house. The reason he dues this is that he throws the manure from the load into the center of the heap, and he ean uot build up the sides straight and square withont getting on to the heap occastomally, and fll ling a layer round the outsides. If 
should be instructed, tor, to break nj the lumpk, and mix the ma. nure, workine it wser until it is lons." 'm t line. II there are any frozen masses of mannre, place them on the cust or suuth ontside, and not in the middle of the he:ip.

If there is any manure in the sluels, or basements, or collars, or pier-pens, clean it out, and draw it at once to the pile in the tiedel, ond mox it with the manure you are drawing from the licap in the yard

We generally draw whth two tams and three watons. We have one math to till the watron in the yarel, and iwo men to drive and unloal. Whin the man eomes back from the fireld, he places his empty waten ly the sil] of the heap in the yard, and takes off the horses and puts them (1) the loulded waron, and drives to the heap in the fich. If we have men and tenms enough, we

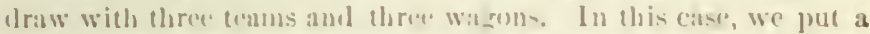
reliable man at the heap, who leclpe the drover (1) moload, and soes that the heap is built properly. "The driver helpe the man in the yard in loal up. In the iormur plan, we have two teams and three men; in the latter case, we have three tams and five men, and as we have two men lonling and unloaling, insteat of one, we onglat to draw out double the quantity of manure in a lay. If the weather is cold and winly, we put the hlankets on the horses under the harness, so that they will not he chilled while standing at the heap in the yart or tield. They will trot back lively with the cmpty wagn or sleigh, and the work will proceed briskly, and the manure be less exposed to the cold.

"You do not," saill the Doetor, "Aram the manure on to the lieap with a cart, and dump it, as I liave seen it done in Englind?"

I diel so a few years agn, ancl might do so agran if I was piling manure in the sprine, to he kept orer summer for use in the fall. The emmpression eaused by drawing the cart over the manure, has a tendency to exclude the air and thus retard fermentation. In the winter there is certainly no necessity for resorting to any means for checking termentation. In the spring or summer it naxy he well to compress the heap a little, but not more, I think, than can be done by the trampling of the workman in spreading the manure on the heap

"You do not," sail the Doctor, "adopt the old-fashioned Enclish plan of kecpine rour manure in a basin in the barn-yard, and yet I should think it has some advantages." 
"I practised it lecre," salid I, "for some ge"ars. I fluwed and

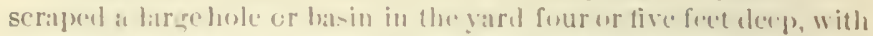

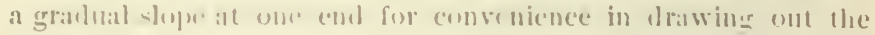
In:at-the ofluer siles being mueh stereper. I also made a tank at

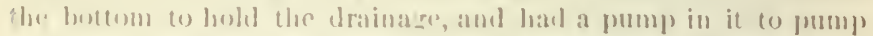

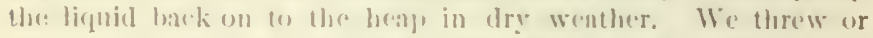
wheded the manure frem the stables and pier-gens into this basin, but I lid not like the flan, for two reasons: (1.) the matumre being

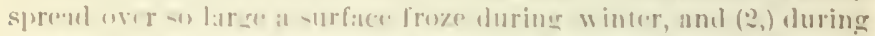

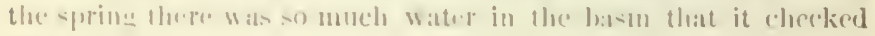
fermentution,"

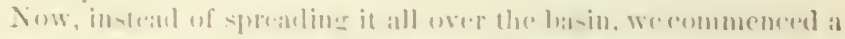

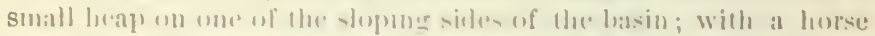

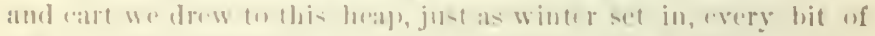

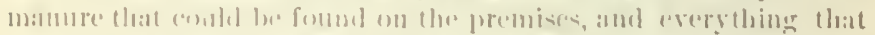

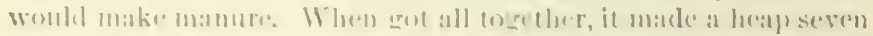

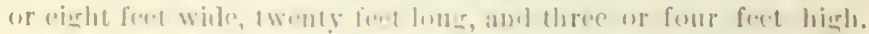

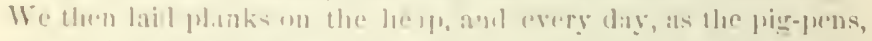

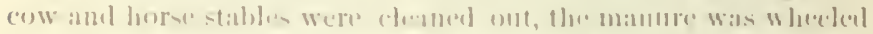

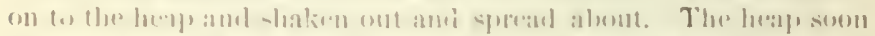

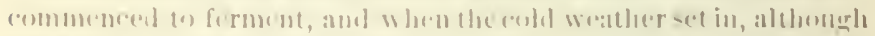
the sides and some partio of tae loge froze a little, the io-ide hept quite wurm. Little thimneys were formed in the heale, where the

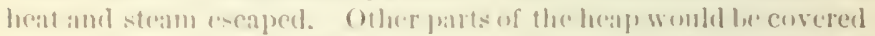
with at thin arust of frogen manure. By taking a few forkfuls of the latter, and placing them on the toje of the "chimneys," they checket the eseape of steam, and hat a tembency to distribute the heat to ohluer partio of the hasp. In this waty the formentation be came more enencral throurhome all the mass, and not so violent it any (1) smot.

"I3nt why be at all this trouhbe" -For severil reasons. First. It saves labor in the and. Two hunre work, in winter, will save three homes work in the spring. And three hours' work in the spring is worth more than four hours work in the winter. So that we save late the expense of hamlling the manure. 2d. When manure is allowed to lic scattered about ower large surface, it is liable to bawe much of its value washed out hy the rain. In a compact lexpe of this kind, the rain or snow that falls on it is not more than the manne needs to kerp it moist enough for formentation. 3d. There is as much fascinalion in this fermenting heap of mantre as there is in having meney in a sovings bank. One is

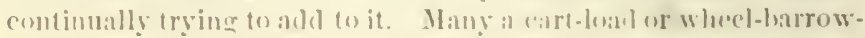
ful of material will be deposited that wembletherwise he alluwed 


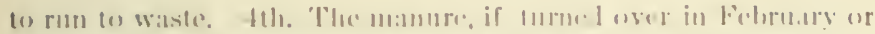

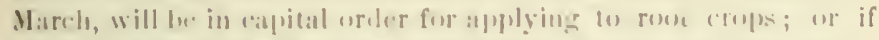

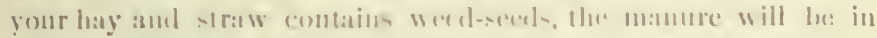

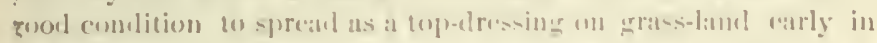

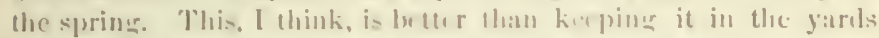

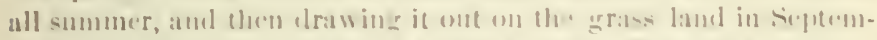

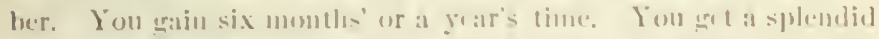
arrow lh of rich grass, and the ro l-rout sere ls will ererminate next

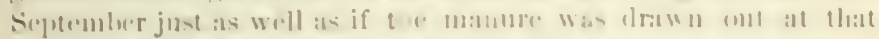

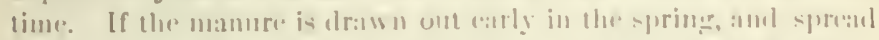

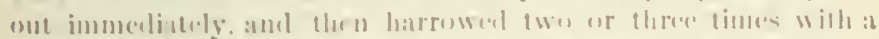

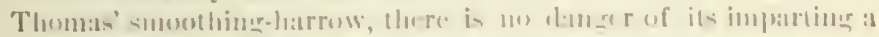

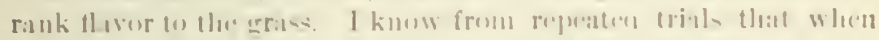

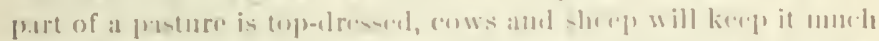

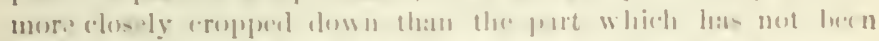

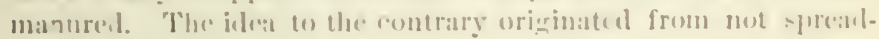
ing the mumre enolyly.

"But why forment the undunre at all? W"ly not draw it out

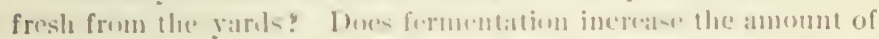

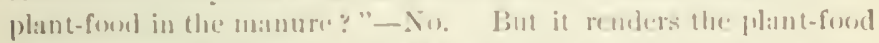
in the manure more immo liately availalile. It malies it more soluble. We ferment mamure for the sime reasun llat we de-

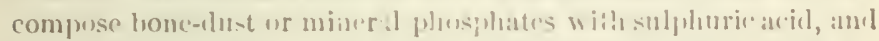
convert them into superphusphole, or for the sime reason that we griml our corn and eouk the me:al. These procesios and nothing to the amount of plant-foou in thr lunes or the nutriment in the corn. They unly in rease its avilibulity. So in formonting manure. When the linuil amel solicl acremants from well-fed animale, with the straw neressury to alsorb the liquid, are placed in a be p, fermentation sets in aul soun efferts very impurtant changes in the nature aml composition of the materials. The insoluble wouly tibre of the straw is leenmposcil and ronvertel into humic and ulmic acids. These are insululile; and when manure consists almost wholly of straw or cum stalles, there wombl he little gained by fermenting it. But when there is a conol propurtion of manure from well fell animals in the licap, carbonate of anmonia is formerl from the nitrogenous (ommponmes in the mamme, amel this ammonia unites with the humic and ulmic arids and forms humate and] ulmate of ammonia. Tlıcie ammoniacal salts are soluble in water-as the hrown color of the drainings of a manure heap suflicienily indieates.

Properly fermenter manture, therefore, of good quality. is a much more active anıl immediately useful fertilizer tnan fresh, un. 
f.rmented manure. There need lee no lons of ammonia from evalporation, and the mauure is far lesis hulky, amel costs far less lahor to draw out and spreall. The only luss that is likeng to occur is from leaching, and this must be specially guarded agrinst.

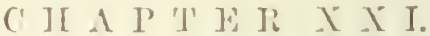

\section{THE MANAGLVENT OF MANLRLS-CONTIIED.}

\section{WHY U() WE FEIIMF.NT MANLliE?}

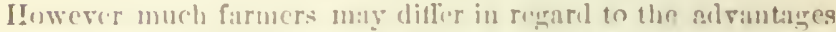
or disaclvantages of fermenting matnure, I hare never mel with one who contenderl that it was groul, eithes in therery or practire,

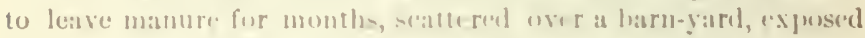
to the spring and antumn raim, and is the smmmer's sun and

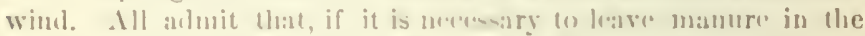

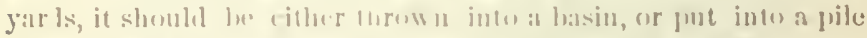

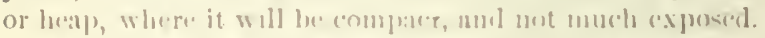

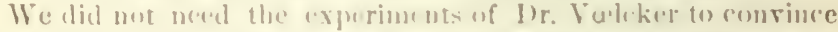
us that there was great waste in liaving mamure (xposed to the leaching action of our heavy rains. Wo disl ant know cexactly low much we low, but we knew it mu-l he consiblerahle. No one ad rorates the practice of exposing m.mure, and it is of mo use to dis cuss the matter. All will alunit thot it is unwi-e ambl wasteful to allow manure to lin seatlered and exposed ower the barm-yarts any lomger than is alsolutely menesiry.

We shombl cither draw it directly on the fichl and use it, or we shonld make it into a compact heap, "where it will not receive more rain than is needed to kerp it moist.

One reason for piling manure, there fore, is to preserve it from loss, until we wish to use it nu the lant.

"We all almit that," said the Jeacem, "but is there anything actually gained by fermenting it in the heap ? "- ln one sense, no; but in anotlacr, and very important sinse, yes. Whan we cook eorn-meal for our little piges, wr atd nothing to it. We have no more meal after it is cooked llan before. There are mu more stareh, or oil, or nitrogenous mathers in the meal, but we think the pigs cau digest the fool more rablily. And so, in fermonting 


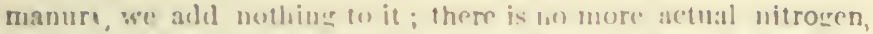

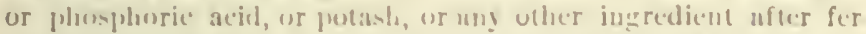
mentation than there was before, but the-e ingledients are rendereel more soluble, and ean 'xe more rapmly laken up by the p lants. In this seruse, therefore, there is a great gain.

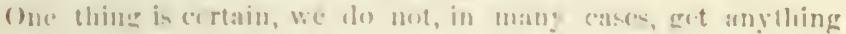
like as much beneit from onr mature as the ingredients it e vols tains would le:al u- (1) \& xpect.

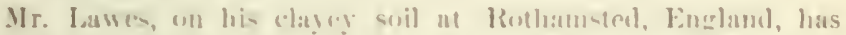

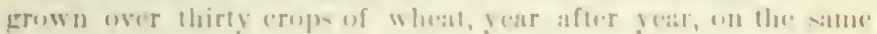

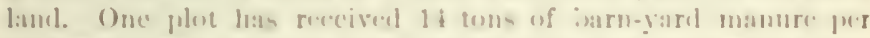
arere erery gear, and yet the produce from this plot is mo larger,

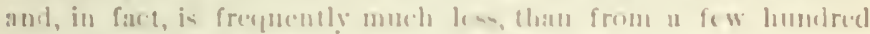
poumds of urtiticial manure containin far lew nitrogen.

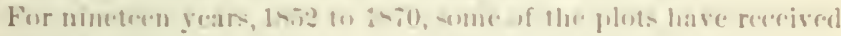
the san. manure year after year. The follewing show : the acer uge yirld for the nineteen year:

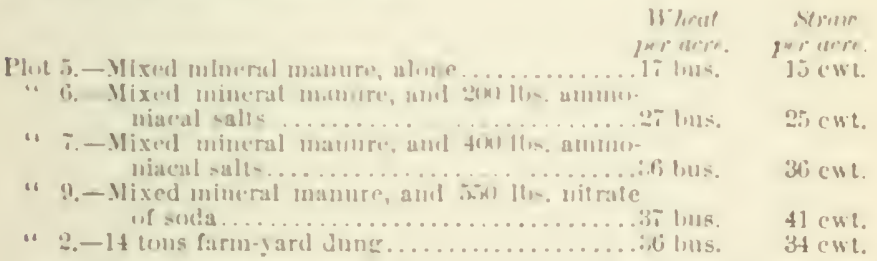

The 14 ions (31,360 l3m.) of farm-yart manure contained about 8,740 lhs. organic matter, sis lhs. mineral matter, and $2010 \mathrm{lls}$. nitrozen. The fou lbs. of ammuniasal salts, and the s.jo lls. nitrate of sula, carle eontained s:? lls. of nitrogen; and it will he secen that this s"2 lls.s of nitregen produeed us great an eflect as lhe 200 lhs. of nitrogen in Inrm-yaril manure.

Sinilar experiments have leen made on harley, with exen more striking results. The plue dressed with:300 lts superphospluate of lime, and 200 lfs. ammoniacal salts per acre, produced as large a crop as 14 tons of farmeyarl manure. The arerage yiclel of barley for nincteen irupse grown on the same land wath year was 48 luss. and $28 \mathrm{cwt}$ of straw per acre on both pi ts. In other words, 41 llıs. of nitrogen, in ammoniacal salts, produret is great an effect as 200 Ibs. of nitrogen in farm-rard manure! During the nimetern rears, we plot had receired 162.260 lhs. of oreanic matter. 16,4!2 lis. of mineral matter, and 3.800 lhs of introgen; while the other had receivul only 5,700 llis. mineral matter, and i:a llse. of nitrogenand yet one has produced as large a crop as the other. 
Why this difference? It will nut do to saly that more nitroge was applice in the farm-yard momnre than was neceled. MI Lawes silys: "For some years, an immont of almmoniat-Silts, con taining 82 lbs. of nitureren, was applicel to one series of plots (or barl(y), hut this was found to be too much, the croplegenerally

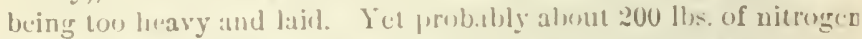
was illnually supplied in llac dung, lut whth it there was no over. luxurion $\%$, and wo more erep), than where 41 lhs. of nitrogen was el1pplial in the form of :1mmoniat or nitric ac.ill."

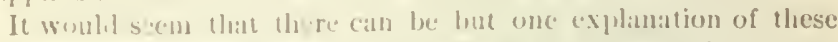

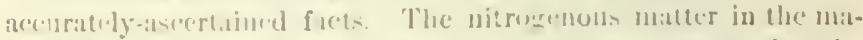
nure is not in an atrilablenen lition. It is in the manure, but the

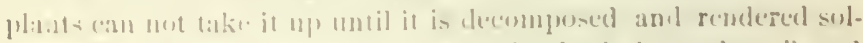

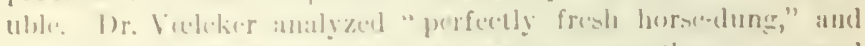
foumd that of fire ammonia there was not more than one pound in 1.7 tons! Ant ret there lis tons contained nitrogen enough to

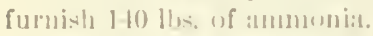

"But,' it may he anked, " will mot this frosh manure decompose

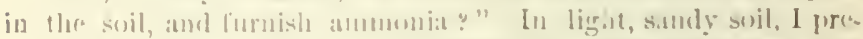

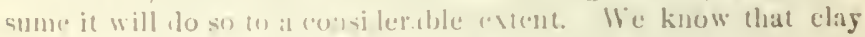
mixal with monur ret.re ls fermentation, hut sand mixed with mannese acerlerate lo rumentations. This, at any rate, is the case

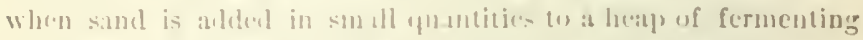

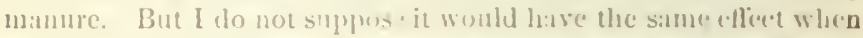
a small quantity of manure is mixed with a larese amonnt of sand,

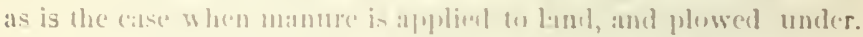
At any rate, pratlical farmer-, with allu, st contire unanimitr, think

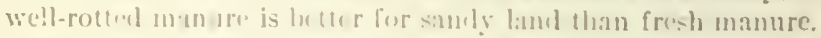

As to how rapidly, ur molher how slowly, manure derompesez in a rather heary hamy soil, the abose experiments of Mr. Lawes

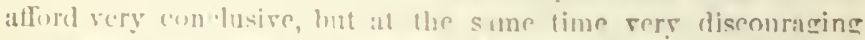

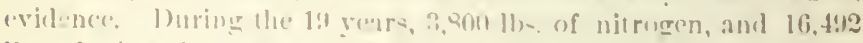
los. of mincral malter, in fles form of farm-garil manure, were applied to an are of land, and the 19 corps if barley in erain and

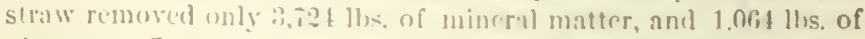
nitr gुet?. The soil uno entitins, unlese it lass drained away. 1,736 lbs. more nitrogen perace than it did wlen tlie esperiments commencell. And set 41 llse of nitrogen in an arailathe enndit on

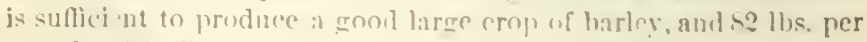
acre furnis'sed more than the plank conlli weranize.

"Those are verr interestingexperiments," said the Doetor, "and slow why it is that nur farmers end affort in pay a higloer price for nitrogen and phosphoric acid in sujerpliosizhate, and other ar 
tificial manures, than for the stunc annount of pitrogen amel fliosploric acjel in slable-matumse."

We whlt not direus this juint at present. What I want to as. certain is, whether we cau nut ind sume tucthesl of malsing our

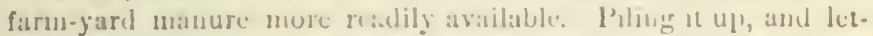
tiug th ferment, is one methoil of toing this, thourh I think other me thuds will yet he discoserel. I'ussibly it will be found that sprealing well-runcel manure on the surface of the land will be one of the mest practical amel simplest methoels of atecomplishing this oliject.

"We pile the manure, therefore," said Chatrley, "tirst, heesulse we de not wish it to lice exprosed to the rain in the yards,

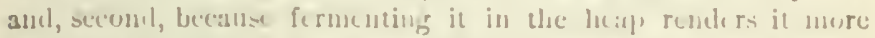

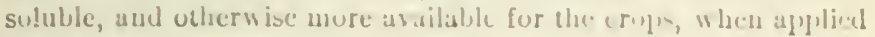
to the land."

That is it exactly, and another reason for piline mantare is, that

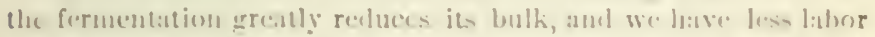

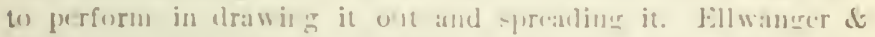
Barry, whe draw several lhousumb loud of stalife-manure crory

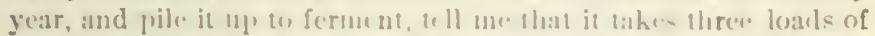

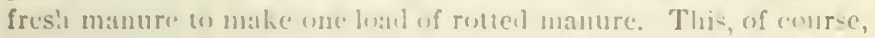

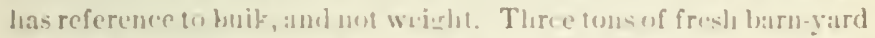

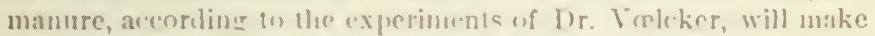
about two tons when we!l rollent. Even this is a trreat saving of lalwr, and the rulled manure catn he more ena-ily cpread, and unixed more thorouglaly with the soil-a peint of great impurtance.

"Another reason for fermenting manure," saiel the. Syutire, "is the de-truction of weet-cenels."

"Tluat is true," -aiel I, " aud a rery important reasun; lut I try not to think alwut this methot of killiner weet-sertse. It is at ereat deal better to kill the werds. There can he no doubt that a fermenting manure-leap will kill many of the weel-ecels, hut cnough will nisi:illy eseape to re-sepil the land."

It is fortunate, howerer, that the hest means in kill weed-seeds in the manure, are also the bust for rendering tlie manure mot efficient. I was talking to John Juhnston on this subject a fes days agn. He fold me how he jilent manure in his yarls.

"I enmmence," he said, "wlice the heep is intenced in her, and throw the manure on oue side, until the hare gromed is reached."

"What is the use of that?" I asket.

"If you do not do so," he replied, "there will be some portion of 
the uanure under the heals that will be so eompact that it will not ferment, and the weel-secel- will net be killedl."

"You think," sitd I, " that weed-secels casn he killed in this way." "

"I know they ran," he repliell," hur the heapl must he earefilly made, so that it will ferment erenty, and when the pile is turned, the bottom and sides should he thrown inte the center of the heap."

\section{LUSO UF AMMUNIA BY FERMENTING M.NLIBE.}

If youl throw a quantity of fresh lowr-1.-manure into a lewse heap,

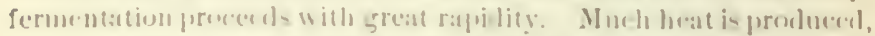
and if the manure is under cover, we there is not sain rmengh to

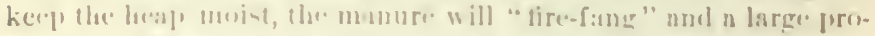

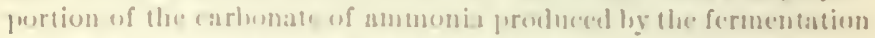

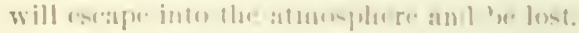

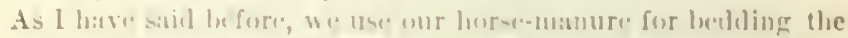
store and fattening piers. We throw the manure erery morning and evenuing, whe th the stable is clestacel ont, into an empty stall

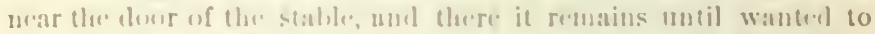
bed the pis. We timl it is mecesary to remove it frepuently, rspecially in the - 1 mumere as fermentation som sets in, and the escapn of the anumonit is defeeded by its well kuown pungent smedl. Throw this manure into the piperellar and let the pieg tramplo it down, and the re is we longer any aseape of ammonia. At any rate, I have newer fere roved any. Litmu paper will defect ammonia in an atmo-phere comtatuing only one serenty tive themsandth part of it; and, an I'rof. \&. WF. Iolnown once remarked, "It is certain that a healthy nowe is not far inferior in delieacy to bitmus paper." I ferel sure that an ammonia iseafes from thio borsemanure after it is trampled down hy the pigs, mlthougle i: contains an ablitional quantity of "futtrtial ammonia" from the

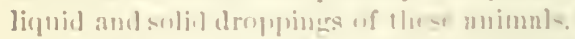

Watcr has a strong attratetion for ammonia. One galion of ice-

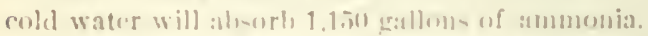

If the mamore, therefore, is mesterately moint, the ammonia is

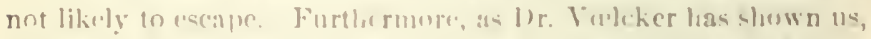
during the fermentation of the manne in al loap, ulmire aml humie, crenire and aprexerenic aceds are produced, and lhese unite with the ammonia and "fix" it-in other word the they (liange it from a volattile gas into a non-rolitile -alt.

If the herap of monure, therefore, is mojet enough anel laree

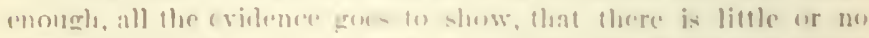

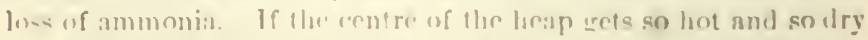

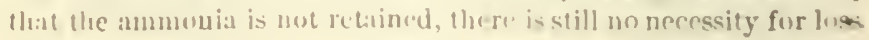


The silles of the hatap are ceol amel monint, ancl w ill retain the carbonate of atumersia, the an the mentumal alon coming into plays.

The ammonia is much more lihely we castane from the top of the heap than from the siles. 'l'he latat and steam form litte chim. neys, not when a fromsentine manure-heap in revered with snow, these little chimmey a are remlily secth. If you think the manner is fermenting tor rapilly, and that the ammomia in escapping, trample

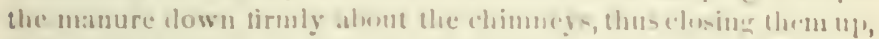
and if me! he, or if anvenicnt, throw more manure on topl, or throw on a few pailfuls of waser.

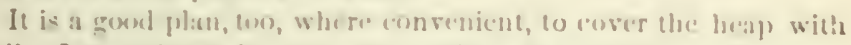
soil. I sometimes do this when filing monure in the field, not frum fear of losing amenonis, but in oreler to retain moisture in the hrap. With proper irenantions, I think we may safely dlamiss the idea of ang se rions luss of anmunin from formenti ing mante.

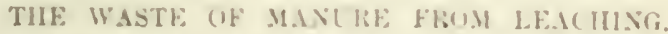

As we have endearored to show, these is litud danger of losing ammonia ly herping and formentine mature. Hut this is not the only questien fo be com-inlered. We have seen th.t in $10,0(x)$ lls.s.

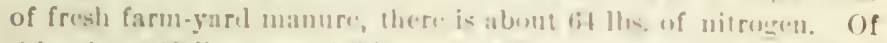
this, alust 15 llis. are suluble, wnd 49 lls. inculullu. of mineral matter, we hare in this yuantity of manure, nitl lls.s, of which list lbs. are soluble in water, and lo.j llh. inswluble. If we bacl a heap of five cuns of fermenting manure in a stable, the ( seape of laalf an ounce of carbonate of ammonia would make a tremcudeus smell, and we should at unee use mata- to check the weraje of this precious substance. But it will he senth that we have in this tive tons of fresh manure, nitrogenous matter, rapable of forming over 150 lls. of carlonate uf :mmonia. orer 42 11, of which is in a soluble condition. This may he leachud day afurdar, slowly and imperceptibly, with no lasat, or sucell, to attraret allention.

How often do we see minur lying under tle eares of an unspruted shed ur barn, where one of our heary shuwers will satu. rate it in a few minutes, and yot where it will lie for lıours, and days, and weeks, until it wnuld sfem that a larepe proportion of its soluble matter would be wa-licel nut of it! T.ur less is unquegtionahly very great, and would be grenter if it were not for the coarse nature of the material, which allows the water (o) pass through it rapidly and without eoming in direct contact with only the nutsicle portions of the particles of hay, straw, etce of which the manure is litegely complosel. If the manure was ground up very fone, as it would be when prepareal for analysis, the loss of 
soluble matter would be still aure scrobs. Or, if the mamure was first fermented, so that the partickes of matter would be more or less decomposed ant brok'n "1] time, the rain would wash ont a large amount of soluble matter, am prove much more injurions

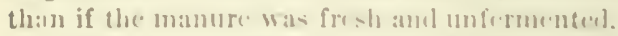

"That is an argument," saill the J) a(c)u, " ngaginst your plan of piling and formonting manure."

"Not at all," I repliedl; "it is as stronle reason for mot letting manure be under the eaves of an mo-punterl hulhling-ejerially gend manure, that is mate from rich fount. The letter the mantere, the more it will lose from hat manarement. I have never reeommented any wue fe pile their manure where it would receive from ten to twenty times as muih water as would fall on the sur face of the hreap."

"But you de recommenl puling manure and f fermenting it in the open air and kerpine the lop that, sn that it will catch nll the rain,

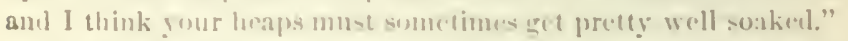

"Soaking the heape of mabure," I replied, "dres not wash out ang of its celuble mathr, premrided you carry the matter no further than the point of sturation. The water may, and doubless does, wash out the soluhle matter from some portions of the manure, hut if the water dowe not tile r thromeh the heap, but is all alsororled by the manure, the re is nu lose. It is when the water passes through the beap that it rums away with our suluble nitronenems and mincral matter, aud with any re"uly formel anmmonia it may find in the manure"

Iow to ke(b) cows tie l up in the harn, and at the same time save all the urine, is one of the mo-t dimienll problems I luve to deal witli in the manasement of monnes on my farm. The luest flan I have yet tried is, to throw luss -mannure, or shere-manure, batek of the eowe, where it will rece ive and alserb the urine. The plan worlss well, but it is a question of labur, and the answer will depeat on the arrangement of the bullingrs. If the luorses are kept near the cows, it will be little trumble to throw the horselitter, crery diar, umeler or liatek of the cows.

In my own rase, my cows are kept in a hasement, with a tight

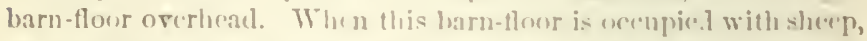

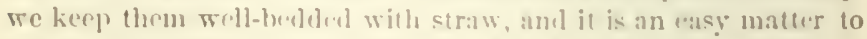
throw this sniled hediling down to the eow-tahle betow, where it is used to ahworl the urine of the cows, and is then whended out to the manure-heap, in the yaril.

At other tines, we use dry earth as an absurbent. 


\section{H A P'I E R I I I I.}

\section{MANUIBL, ON DAIIRY-WARMS.}

Farms devoted principilly wo dairyine ontht en lw richer aud more prosluetive tuan farmas larealy desented to the prosluetion of gruin.

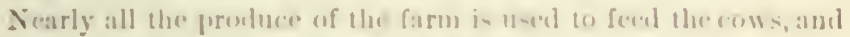

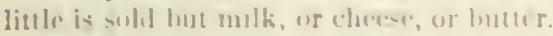

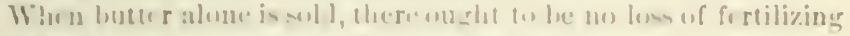

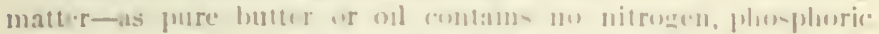

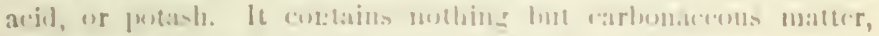
which and be rensosed from the farm without detriment.

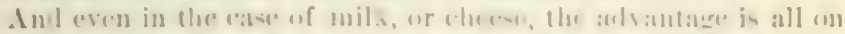

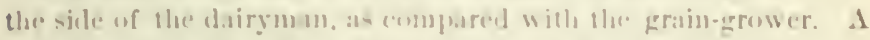

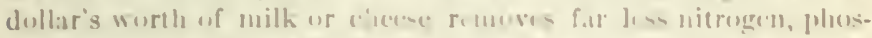

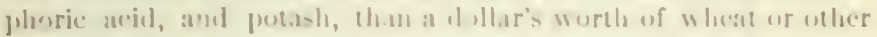

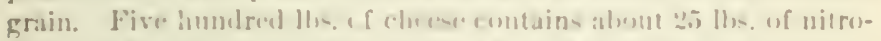
gen, and 21) ltes. of mincral matter. A con that wombl make this amount of chee-e woull cat not less than sic tons of haty, or itequisulent in gra-s or graiu, in a yar. And this amonot of food,

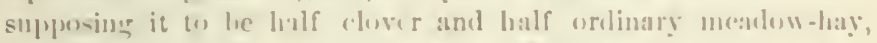

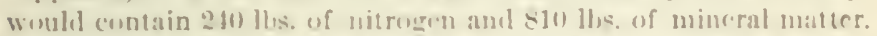

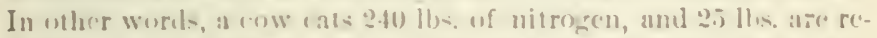

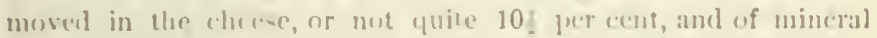
matter not quite 21 fure cent is remored. If it takes three ateres to produce this amount of foud, there will be st Hls. of nituren

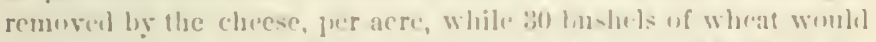

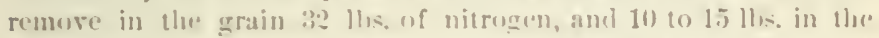
straw. So that a crop of wheat remores from five to six times as much nitrogen jer acre ato a crop of cherese : amel hle removal of

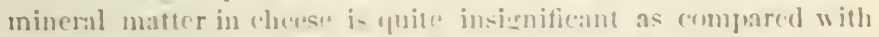
the amount remowed in a crop uf whell or corn. If our graingrowing farmers ean kerelu up the fertility of their land, as they undouhtedly esn, the daryuen ought to be making theirs richer and more prouluction esery year.

"All that is quite the," -ilid the Doetor, "and yet from what I hare seen and heard, lhe farms in the dairs di-tricts, do not, as a rule, slon any rapil improvement. In fact, we hear it often

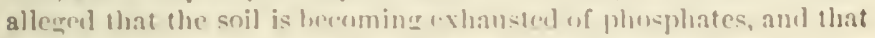
the quantity and quality of the gross is leteriorating." 
"There may be some truth in llis," satid I, "and yet I will hazaril the predietion that in no otlure hranch of atriculture shatl

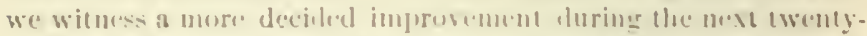

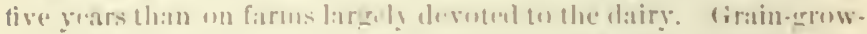

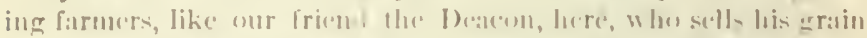
and never brings lomme a lond of manure, and rarely bugs even at

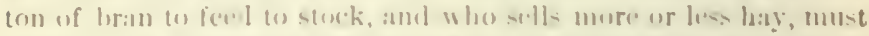
cretanly le imporeri-hine the ir soilo of phosphates much more

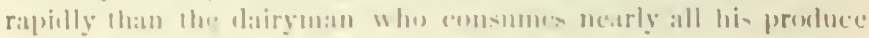
on the form, amb : Hls lit:le escept milli, butter, ehecse, young

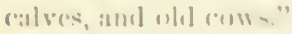

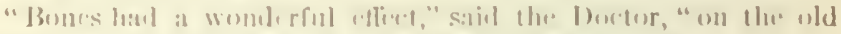

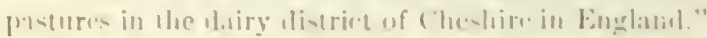

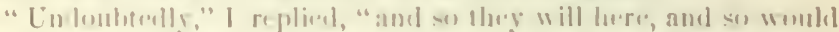
well-rulled mamme. There is nething in this falet to prove that

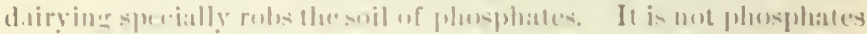
that the dairyman ments su much on ric her manure."

"What womll yom ahl to the mamure (1) make it richer?" as'ied (thiי D)iretur.

"Nitrogen, phusphurio :acis, smol potash," I ruplicci.

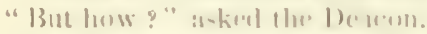

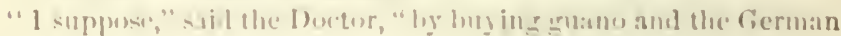
put:ash rilt

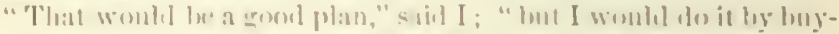

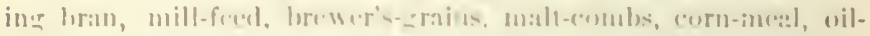

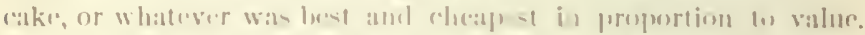

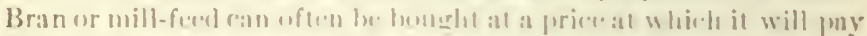

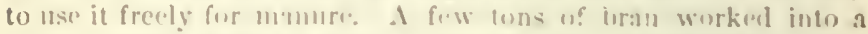

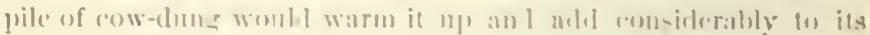

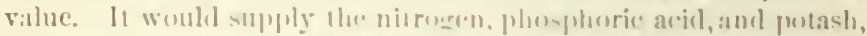
in which ordinary manure in d. ticient. In short, it would convert porer mamere into rich manıme."

"Well, wall," "xelatmed the Dearon, " I knew yon talkerl of mix-

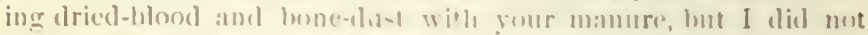

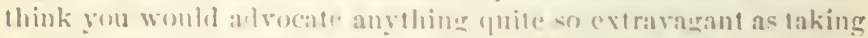
good, wholesome hran and spent ford and throwing it on to your manure-pile."

"Why, De:acon," said I, "wo do it erery day. I am putting

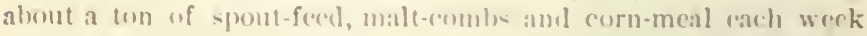
into my mantere-pile, and that is the reasm why it forments sn

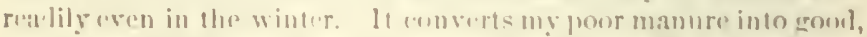

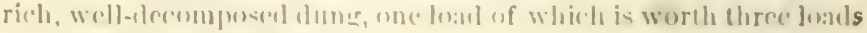
of your longr, strawy manure." 
"1) you mot wet it and lot it forment before putting it in the pili"?"

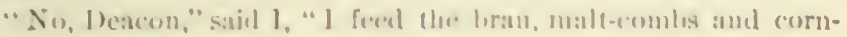

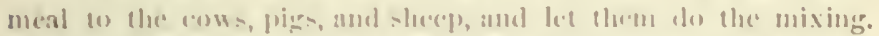
'They work it up tise, mointen it, Juenk up the particlus, take out

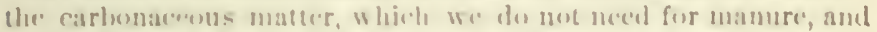
the rows and sheep and hores mix it mp thoromghly with the huy, seraw, and corm-athes, learing tue whole in just the right condition to pun into a pile to ferment or wo apply directy to the land."

"(1) ! I see," said the I) acen, "I diul not lhink you used bran for m:mure."

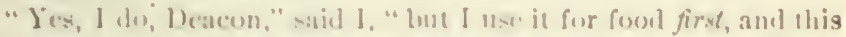

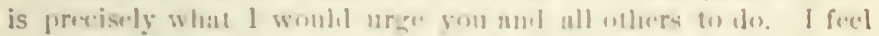
sure that onr dairymu ran well atloril to lom more mill-fecel, rorm-meal, wil-ratie, ate., anel mix is with their cow-elumg-or rather, let the cows de the miring."

\section{LFTTFI: FROM TIF, IIU, M.ARIIS I.FWIS.}

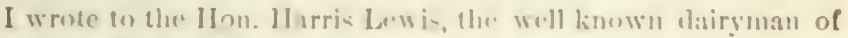

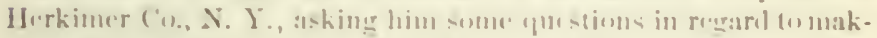

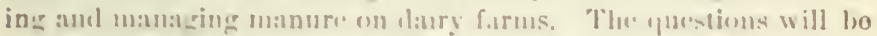
understomel from the ansore. H1. w ritea as follows:

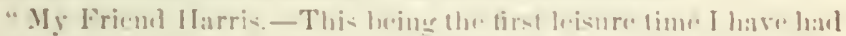
since the rexiph of your lase leter, 1 dervte it en answering your (pur:stiuns :

"1st. I lase nu manure cullar.

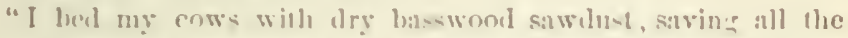

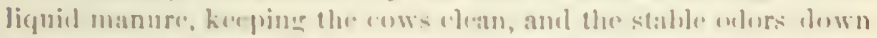

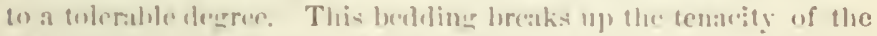

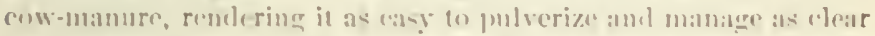

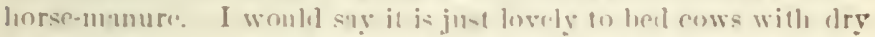

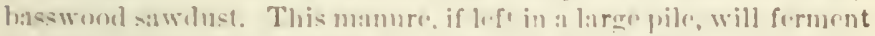
and burn like horse-mamure in alont 10 digs. Hunee 1 draw it nut as malu where I desire to use it, laving it in small heaps, ("envenient to spreat.

" My pigs and calres are bedded with straw, anul this is piled and rnited hefore using.

"I use most of my manure on grass lant], and mangrels, some on corm and potatoes: hut it pays me lese, when in proper condition, to apply all I do not neerl for mangels, on meadow and pasture.

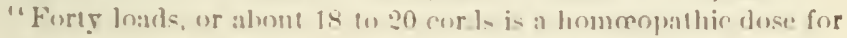
an aere, and this (puantily, or motec, ipplicel once in threc years to grass land, agrees with it first rate. 


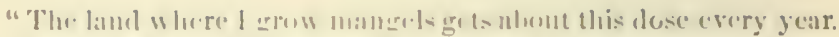

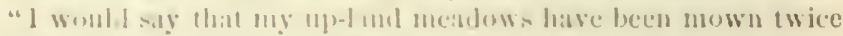
calch year for al inteil many y ars.

"I have been usine refuse salt from syrueuse, on my mangels,

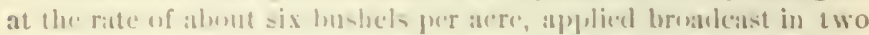
applieations. Iy lem manure is pulserized, and sifted through a

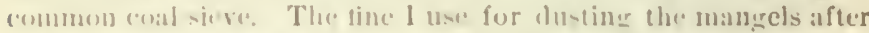

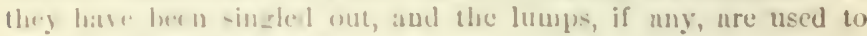
warm up the red gener.

"I have s)m timu - mix I Iny luen-mantre with dry muck, in the preportion of one lit-hel of he+11-munure 10 10 of muck, and recriseal a protit from it toubiz 1 tedl of, on corn, and on mangels.

"I latre sprinkled the refuse salt on my cow-stable floors sometimes, but where all the liqgide i-sased, I think we hatre salt enough for must iropis.

"I lave abimulomul the use of filaster on my pastures for the retson dhat milh produced on greeth-eluver is not so good ats that

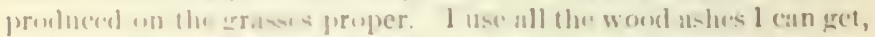

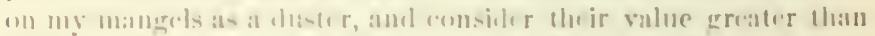

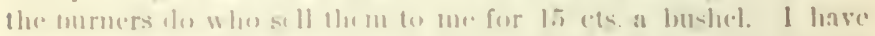

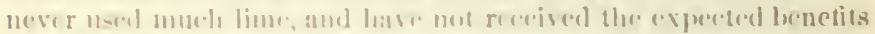

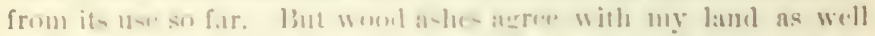

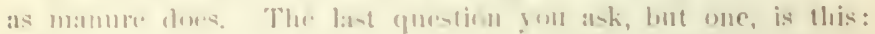

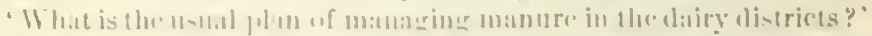

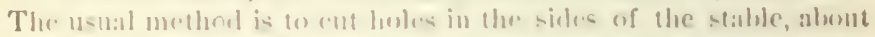

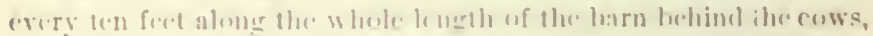

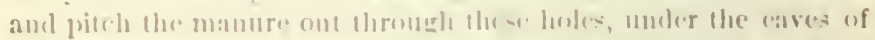
the harn, where it rematua mutil tou much in the way, when it is

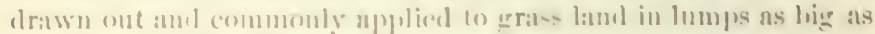
vour losal. This practioe is gettinge out uf fashion a litte now, lut nearly one half of all the o w-munture made in llerkimer Co. is losi, wanted.

"Yumr last quection, 'What improrement womld you sugrest,' I answer ly saving it i- of no lise (1) make any to these men, it

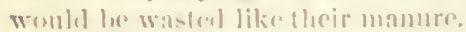

"Tle marliet valuw of manure in this county is 50 (ts. fer ligr load, or about one dollar pur cordl."

"That is a capital letter," sinitl the Dearon. "It is right to the puint, an 1 mo momsense ahout it."

"Ile munt make a goot d dail of mamure" said the Doctor,

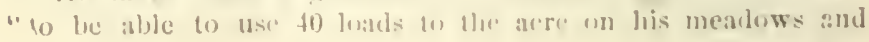


pastures once in thren ye.ur, and the same quantity every year ou his tichl of mangel-wnethl.

"That is prerively what I have been enontending for," I replied;

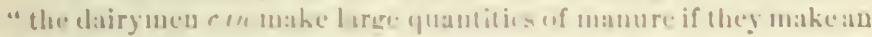
etrort to elo it, and the ir farms umght lo be con-tantly infureviag.

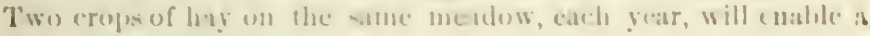

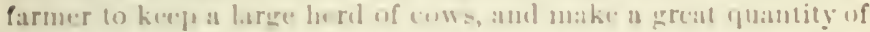

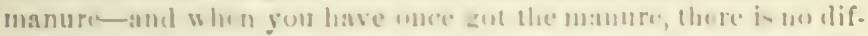
fievalty in kic ping up ant ine reasing the productiveness of the lantl."

\section{HOW TU MAKE MORE ANU BSTILR MANURE OX DAIRY F.IRMS.}

"Vou are right," stid the Boxetur, "in saying that there is no dif-

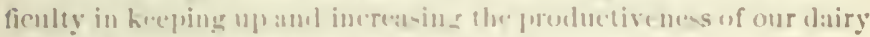
farms, when you lave ome got pleity of manure-lut the ditlienlty is to get a groul stupply of manure in start witlı,"

This is truw, and it is (m)

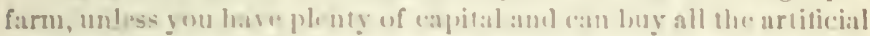
manure you want. By the free $18-x$ of artificial manures, you combld make a farme very pro luetive in ane or two years. IBut the slower

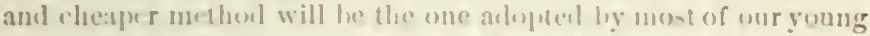
and intellizent dairymen. Fen uf us are horn witls silver spons

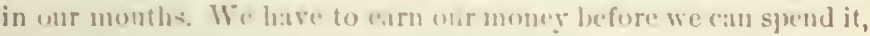
and we are mene the woras for the divejpline.

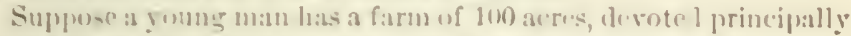
to darying. Some of the l:mul lins on a crok ker river, while other portions are lieglur and elrier. In the spring uf the year, a stream of water runs through a part of the farm from the adjoining hills down to the ereck or river. The farm now sppports ton heal of

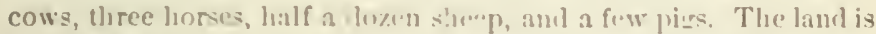
worth şin per a're, but elowe not pay the interest on half that sum. It is getticg wore inteat of hetler. Werels aremultiplyine, and the more valuable errasess are dyine out. What is to be done?

In the tirst pluee, liet it lw distinnlly umlerstoml that the lant is

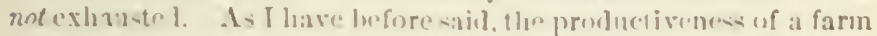

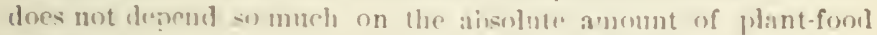
which the soil contains, as on the amount of plont-forml which is immediately arailahle for the use of the plants. An acre of land that produces lialf a ton of hay, mar enntain as much plant-fond as an acre that produces three tons of liay. In the one case the plant-font is lockel up in such a form that tipe crope cannot absorb it, while in the other it is in an avalahle comblition. I have no doubt there are ficlds on the farm I am alluding to, that contain 
3,000 lbs, of nitrogen, amel an equal amount of phosphoric acid, per acre, in the first six inches of the surface soil. This is as much nitrogen as is coutained in 100 tous of mealowhay, and more phosphuric acid than is contained in 350 tons of mealow-hay. Thes are the two ineredients on which the fertility of nur farms mainly trpend. Anl yet there are soils containing this quantity of plant-fond that do not produce more than half a ton of liay per acre.

In some ficlds, or parts of fockls, the land is wet and the plants cannot take up the foud, eren while an nhundance of it is within reach. The remedy in this rase is mulerellatining. On other

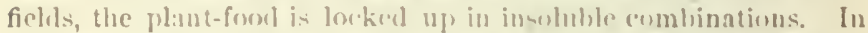
this rase we must plow up the suil, p: lverize it, and expose it to the oxygen of the atmusphere. We mut trat the soil as my mother used (1) tedf me to treat my cotlies, when 1 complatines that it was not swect enomeht. "I put plenty of sugar in," she said, "and if you will stir it ul, the cotfer will be swetter." The sugar lag undissulved at the brotom of the (-13) ; and st it is with mang" of our soils. There is plonty of flimtitonut in the m, hut it needs stirring up. They contain, it maty be, :3,14.1) lls.s. of nitrogern, and other plant-fond in still errater propurtion, and we aro only getting a crop that contains 14 ths. of nitronen a year, and of this probalbly the rain supplies of llie. L, I u- stir up the soil and sere if

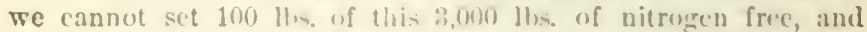
get three tons of hay p r acere insteiul of hulf a ton. There are men who own a lis re ammunt of valualule propurty in vacant city lcts, who do not get enough from them to pay eheir taxes. If they would sull half of them, and put huilliues on the other lialf, they

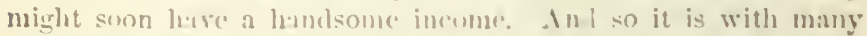
farmeres. They have the elemente of 100 tons of hay lying dorment in crery acere of their lamel, while they are enontent in reecue

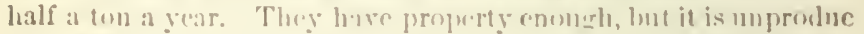
tive, whild they pay high tixes for the privileuge of lowlding it, and high walese for the pleasure of hoardung two or three hired men.

Wa have, sny, 3,000 the of nitrogen lockent up in each acre of our soil, anel we get s or 10 Hes. erepy year in rain and dew, and yet, practically, all that we want, to make our farms highly productive, is 100 liwe of nitrenen per are jer anuum. And furthermore, it should he romemhered, that to krepour farms rich, after we have one get them rich, it is not necessary (1) ilevelope this amount of nitrugen from the soil erery yeai. In the ease of clover-hay, the entire loss uf nitrogen in the animal and in the milk would not exceel 15 iner (ent, so that, when we feed out 
100 llos. of nitregren, we have s.j llos, left in the manure. We

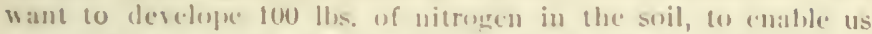

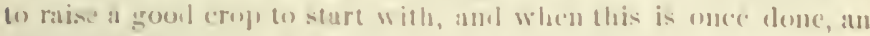
ammual develupment of 1.5 llw. per as re in aldition to the manure,

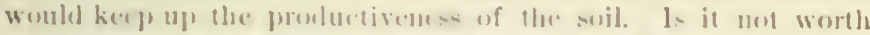

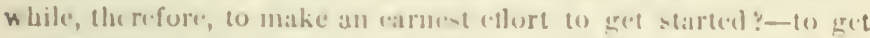

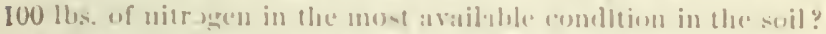

As 1 said before, this is practically all that is needed to give us

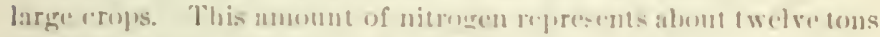

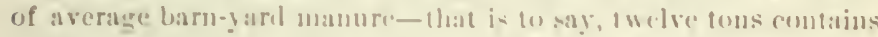
106) lls. of nitrusern. [But in point of fart it is not in an imunediately arabiable condition. It woubl probubly tisk at lenst two years before all the nitrogen it contain- would be givin up to the plants. We wat, therefore, in orler lo gire us a gooel start,

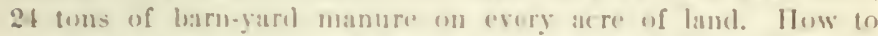
get this is the ereat problem which our young dairy farmuce has to solve. In the rain-erowint districts we gev it in part ly sumunerfallowing, and I beline the dairyman mienlat often do the same thing with alvantitge. A thorough smmurefallew would not

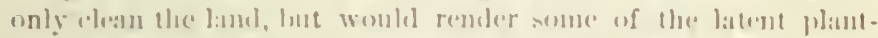
foul avalahle. This will lue urranizel in the nexlerop, and when the dairyman has onee got the plant-fond, he has derejelly the alvantage over the grain-growing farmer in his alility to retain it.

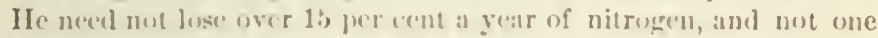

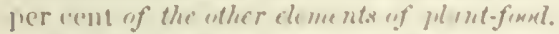

The land lying on the burders of the creek could be ereatly benetited by cuttinger surface ditches t, let otl the water; and later, probaluly it will be foumel that a few underilrains an be put in to alvantage. These alluvial soils on the borlers of creeks and rivers

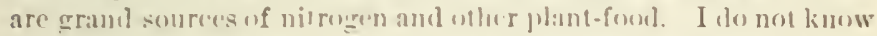
the fact, hut it is quite probabse that the meaclows which Harris Lewis mows twice a year, are on the banks of the river, and are perlaps thoted in the sprine. I3ut, he this as it may, there is a field on the farm I am alluding (1), lying on the creek, which now produces a bountiful growth of weels, rushes, and coarse grasses, which I am sure could easily he mate to produce great crops of haty. The ereek orerthows in the spriner, and the water lies on some of the lower parts of the fiedd until it is eraporated. A few ditches would allow all the water to pass olf, and this alowe would he a great improvement. If the field was flondel in May or June, and thorouglily cultirated and harrewel, the sod would he sufficiently rotted to plow again in Alugust. Then a thorough harrow ing, polling, and cultivating, would make it as mellow as a garden, 
and it ronld be secilul duw 11 with timuthy and wther goot grasses

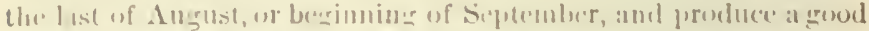
crop of hay the next year. Ur, if thenghtal better, it might b sown to rye and seceled down with it. In eiblure ease the land wonld te

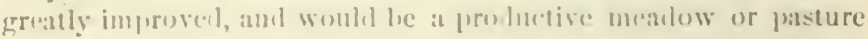

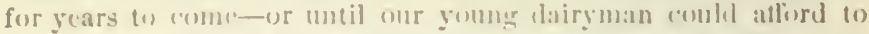

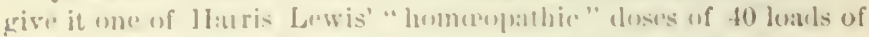

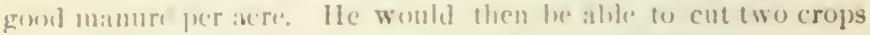
of hay a year-and such lay ! lout we are anticipatiug.

That steam which runs throngh the farm in the spring, and

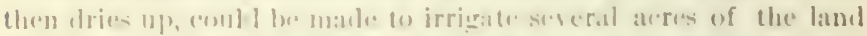

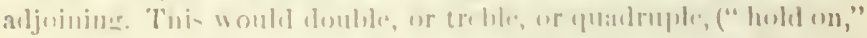

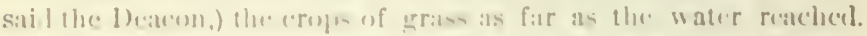
The Deateon dous not serm to rodit this statcment; but I have

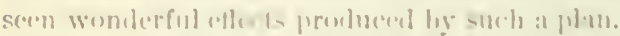

What I an comlensoring to show, is, lhat these and similar means

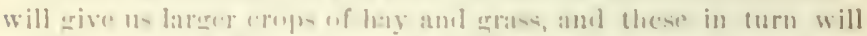

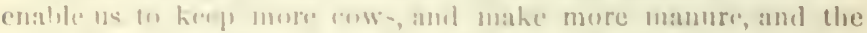

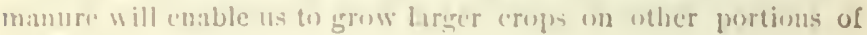
the. f:Irm.

I :mo a ware that many will ohject to plowing up old grase lant,

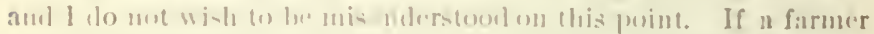

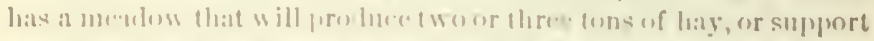

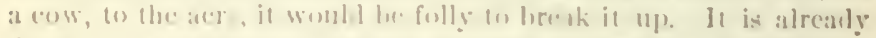

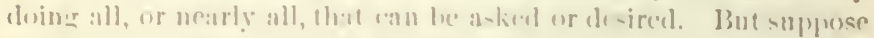

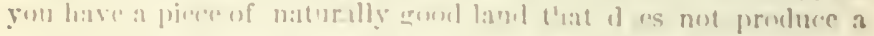

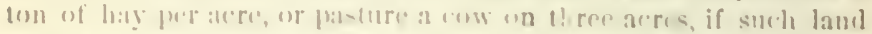

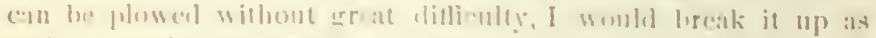

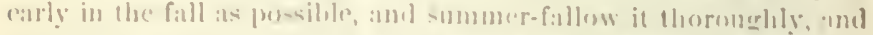

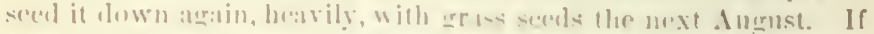

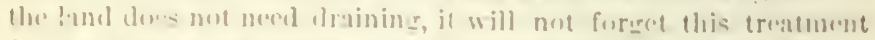

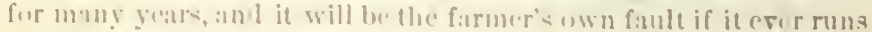
down :1:ain.

In this country, where wases are sn liegl, we must ruise large

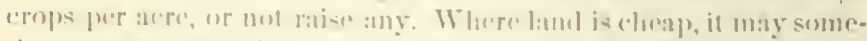
times pay (1) (a)mpel a cow to trasel orer there or four acres to gret

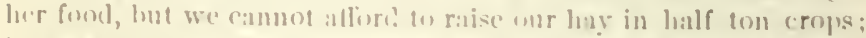

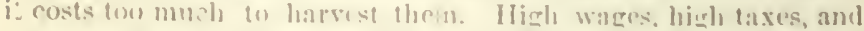

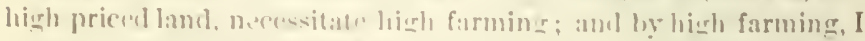
mean growing laren crops overy rear, am on exory portion of the

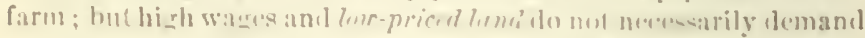

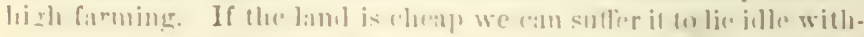
rut muth loss. But when we relist cropls, whether on high-priced 


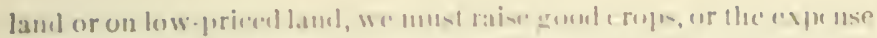

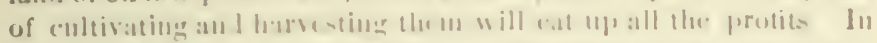
the dairy distrints, 1 heliese lusel, in propertion to its ytullity und

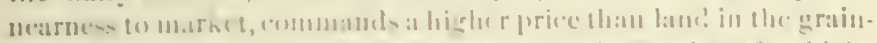
growing di-trirks. Hence it follow - that high farming sloweld be Lle aim of the . Duerit :t:1 dairy man.

l am toll that there ure farm- in the dairy datricts of this State

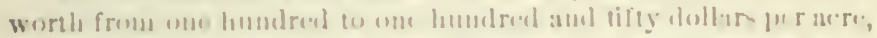

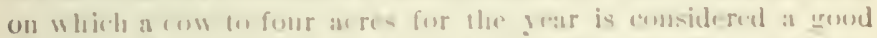

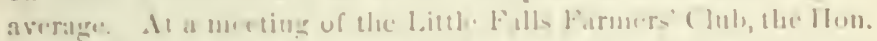

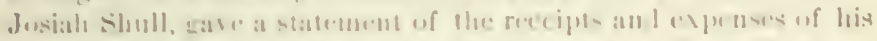

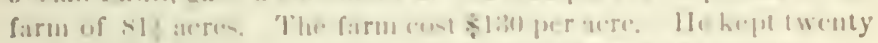

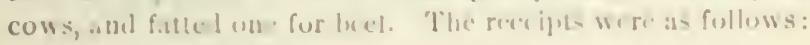

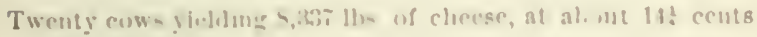

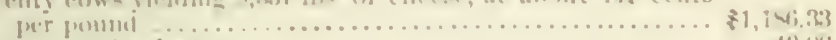

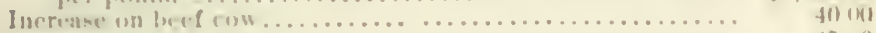

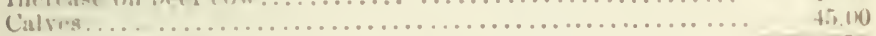

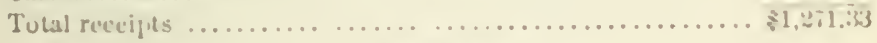

1.210-12

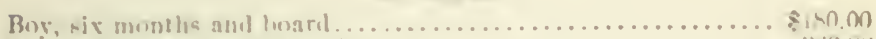

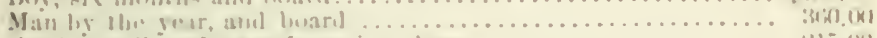

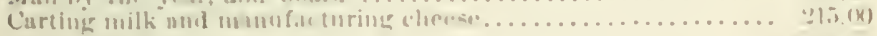

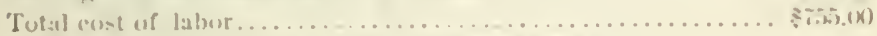

TII: (ITHस I: I:IIES-I- W I:I:I: :

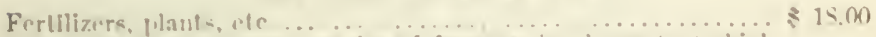

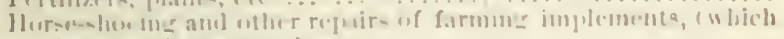

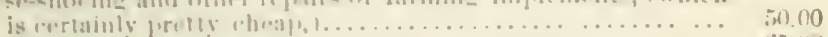

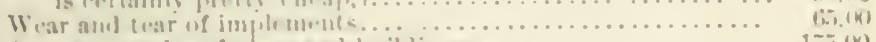

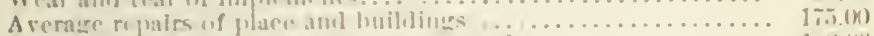

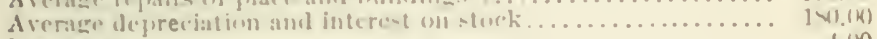

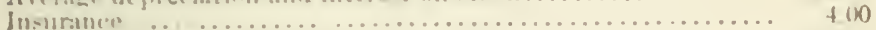

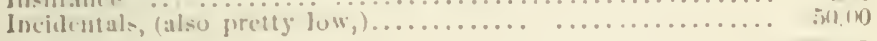

sิi:

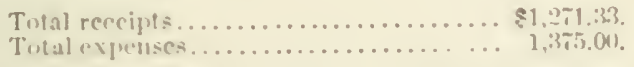

This stateme nt, it is sairl, the Cluh consile rest a very fair estimale.

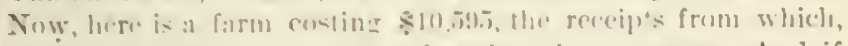

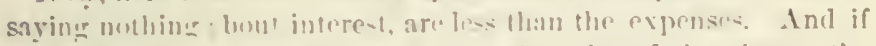

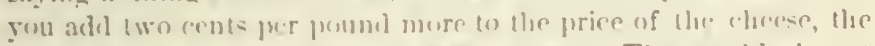

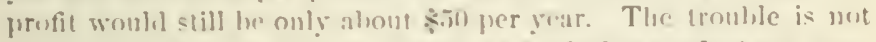

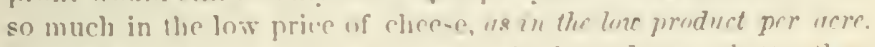
I know some grain-erowine farmers who have done no betler ban this for a few years jiast.

Mr. Shull plices llee ammual d preciation and interest on stock at \$180), c(zual to mearly one-serenth uf the tofal receipts of the farm. It would pay the wages and boarl of another matu for six months 


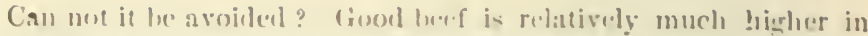

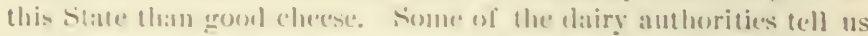

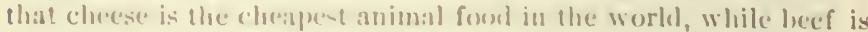
the deareas. Whe, then, should our dairymen contine their attention to the prouluetion of the chestexes of farm products, mul nearleet alumes entirely the prouluction of the dearest? If heef is high and chese low, why not rais. more lnef? On low-pricel land it

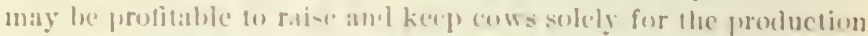

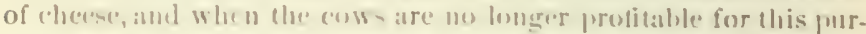
fose, (1) socriljer them-l1) throw them an-ide as we do a worn-ent marliur. Ant in similar rireumstames we may be able to keep sheep seldely for their wool, but on hierh prierel land we can not

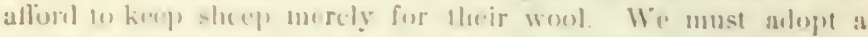
higher system of forming and fereling, and kexp slarep that will give us woul, lambs, amb muthon. In patts of south Amrien,

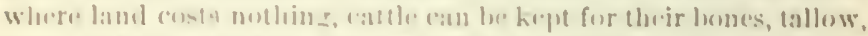
and hibles, luet where foul is eostly we must make lecter use of it. A cow is at mathene for comsertinz werelable foul into veal, hutter, elacent, and beef. The lirt rost of the machine, if a gumel

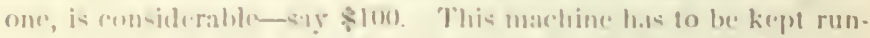
nine night mul day, smmmer mul winter, wek days mul sumlays. If we were running as stentu-flouring mill that could never be

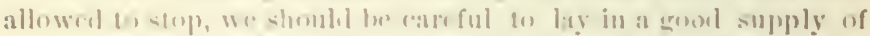
coal anel alos hase plenty of grain on hasd to grind, se that thr mill would never laswe on run emply. No sensible man would

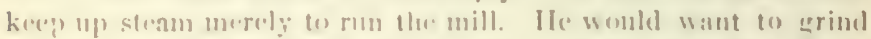

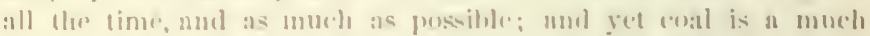

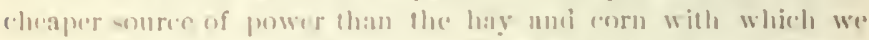
run our milk-produseing machime. Jluw often is dlue latler allowed

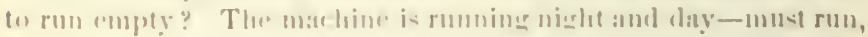
lum is it always running (1) alvamlage? Du we furnish furl

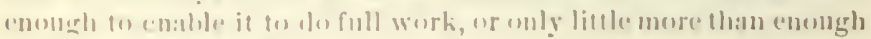
to run the markinery?

"What lase all thic fo do with makiner mamure on dairy farms?"

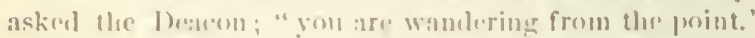

"I hope not: I am irying fo slow that grond feceling will pay

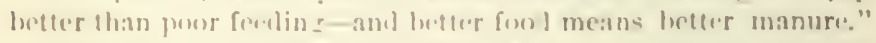

I estmate that it takes from 1.5 to ls llas of ordinary hay per day to run this ouw-mathine, whill we have hern talking ahout,

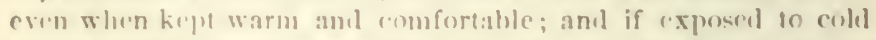

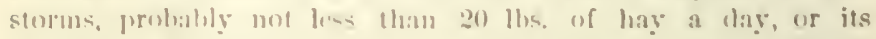
equiralent, and this merely to keep the mathine rumning, withent dong any work. It reguires this to keep the cow alire and to pre- 


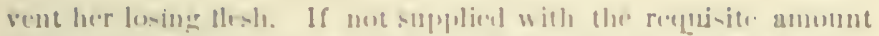

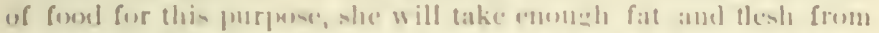

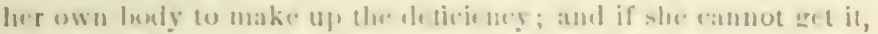
the mathine will stop-in weler work, the (⿻) will alic.

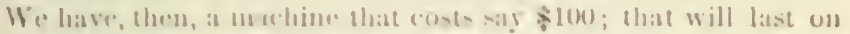

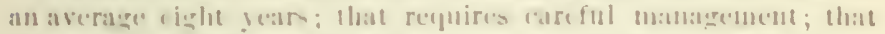
must hare com-tant watehing, or it will In liable tu got ant of

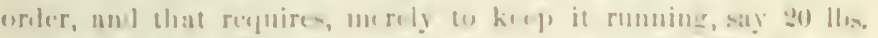
of lay juer day. Sow, what de we get in return: It we furmish

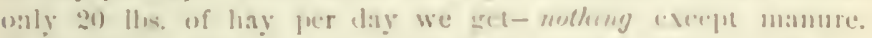

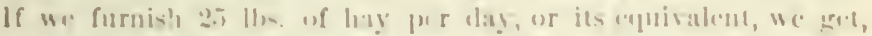

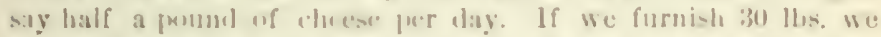

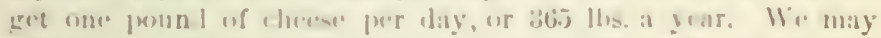

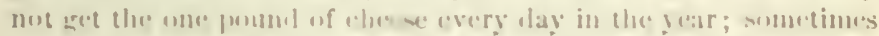

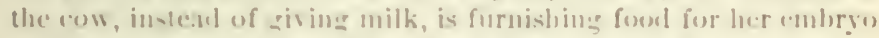

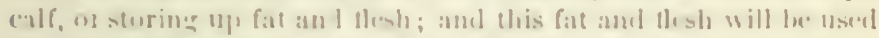

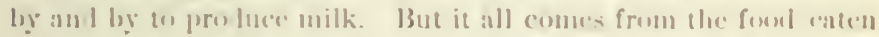

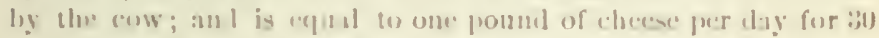
Ibs. of hay or its repuivalent (en)

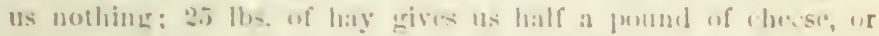

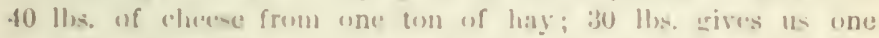

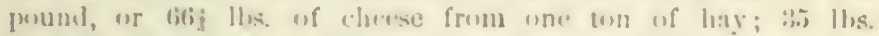

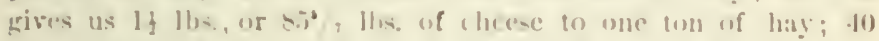

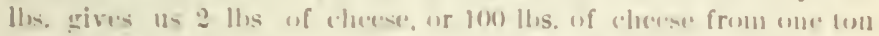

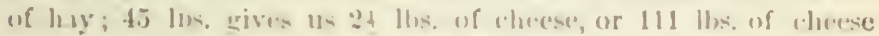

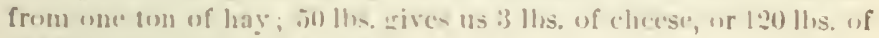
eluever from une (um uf laty.

On this basis, one ton of hay, in cecess of the umonut requirel to

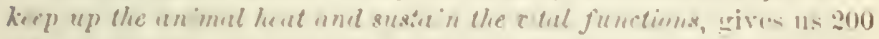

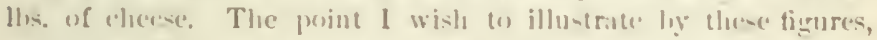

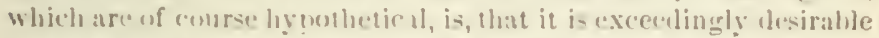

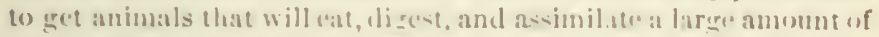
foml, over and ahove that repuired to kecp up the luat of the holy and sustain the vital functions. When a cow eats unly 2j lls. of hay a lay, it repuires one ton of hay wo proiluce 40 lbs. of cherse. But if we conli induce her to ant, digest, and

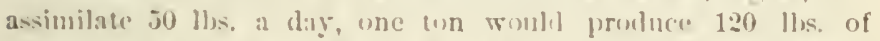
chcese. If a cow cats $3: 3$ llis. wf hay per dity, or its equiralent in grass, it will repuire four arres of land, with a protuctive caparify refual to $1 \frac{1}{t}$ tuns of liay feer acere, to keep her a yuar.

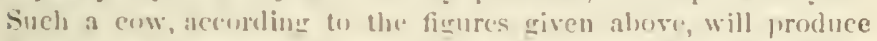

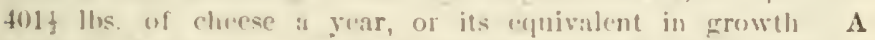
farm uf 80 acres, on this basis, would support 20 cow3, yiclding, 
say 8,000 lhs. of cheese. Increase the prorluctive power of the

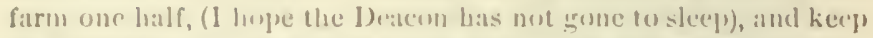
20 cows that will cat hatf as much a sallo forel, and we should then

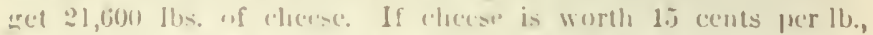

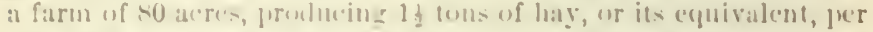

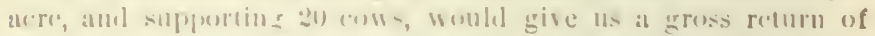

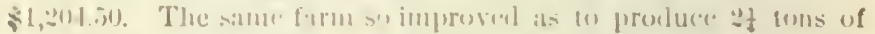

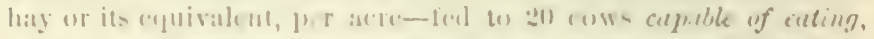

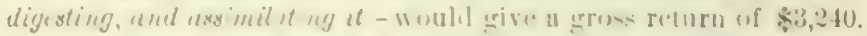

In presentine thene tientre-, I louge you will not think we a visionary. I do mot think it i- pow-ible to get a cos to produce

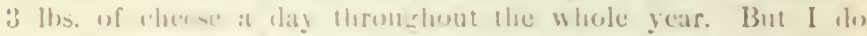

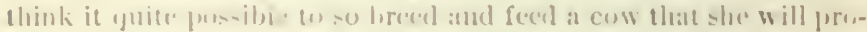

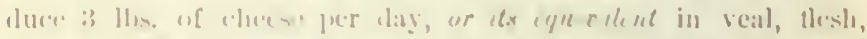
or fatt. We frepuntely lase couss that profuce 3 los. of

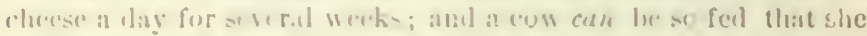
will produee : llo- of eluere a day without lesing weight.

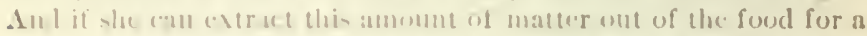

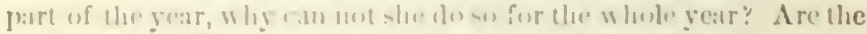
juwers of digention we ther in the t.all and winter than in spring

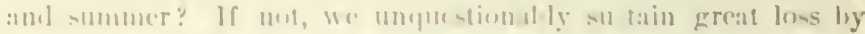
allowing this dig-live puwer tos run (1) ws-te. This digrstive

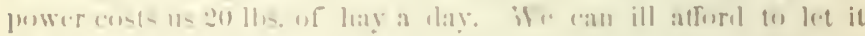

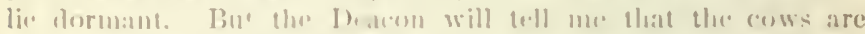

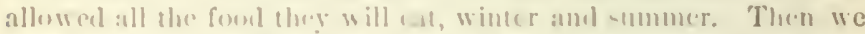

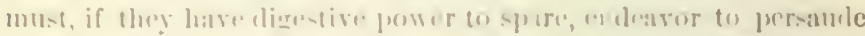

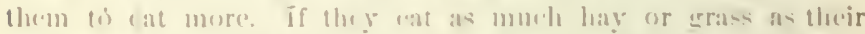

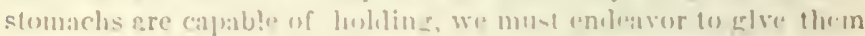

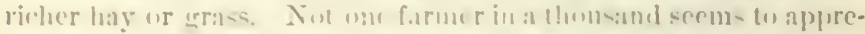

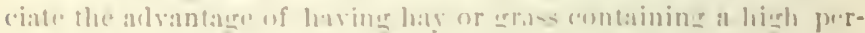
centage of nutrime nt. I lowe ondrabored to show that as cow enting six tons of hay, or it-cepuivalent, in al year, would produce 400 lhs of eberese, woth șibl). While a cow capalie of eating, digesting, and turning (1) erom: actentut, nime tons of hay, or ite

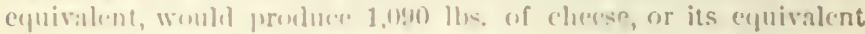
in ohere proulucts, worth sitio.

"I am corry 10 interrupl the gentluman," saill the Deacon with mock gravity.

"Then pray don"t," saill I ; I will uot detain you long, and the

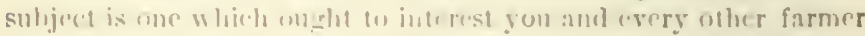
who kerps his corss on pour grates in smmmer, and corn-stalks and straw in winter."

I was going to sity, when the Deacon infrrtepted me, that the 


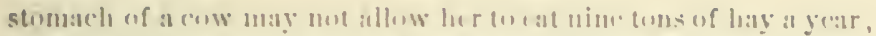
but it will alluw her to tat sis ton-; and if these six fous emation as much mutriment as the nime \{es s, 1 hate in the real dilli rence in

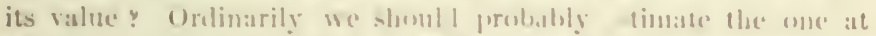

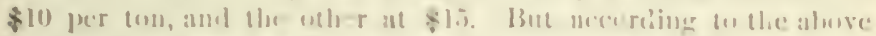

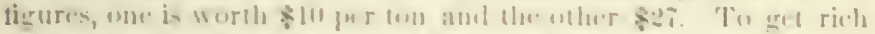

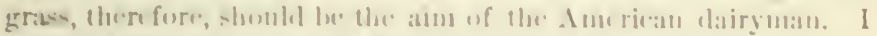

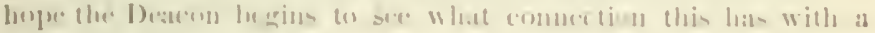
larege pile uf rielb manure.

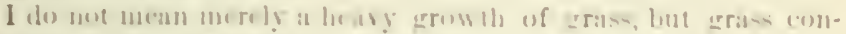

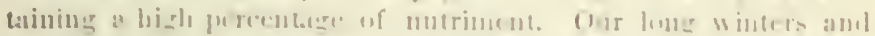

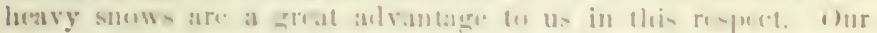

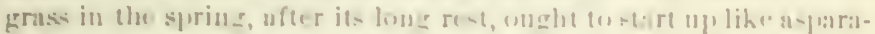

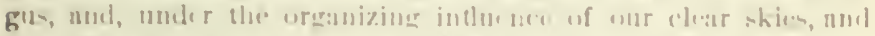

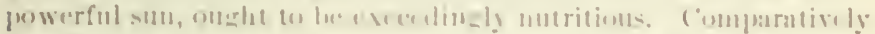

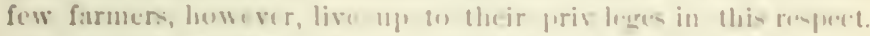
Our climate is better than un farming, the sum ricluer than our

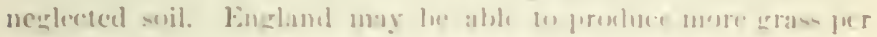
acre in a vear than w ("an, but we andhe to proluce richer arrass,

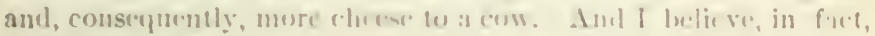

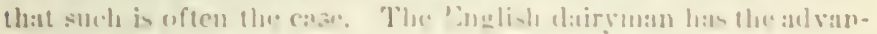

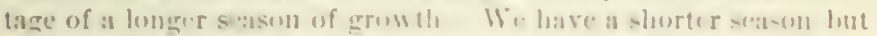

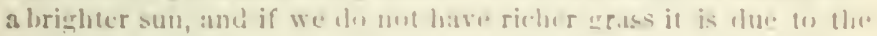

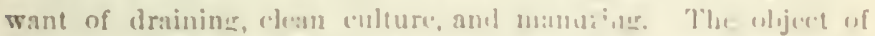

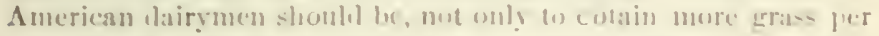

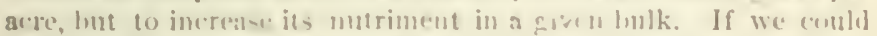

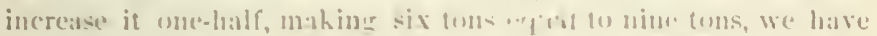

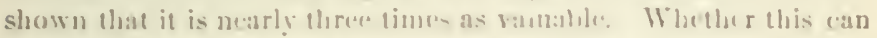

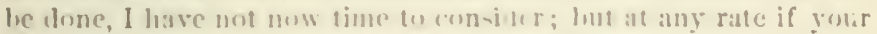

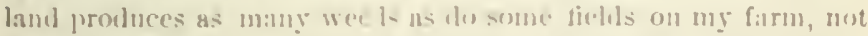

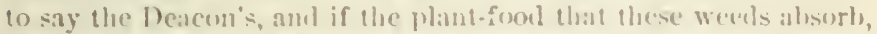
could bo oreanized ly nutritius grances, this alune would dle al

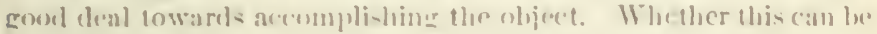
done or not, we want ('nws th:1 ("an eat and furn fo gruel aceonut as much fuol par annum as is cuntrined $\mathrm{ju}$ nir (e tons of ordiusry mealow-lıay ; and we want this nutriment in a bulk unt exreceling six tois of hay. If presilbe, we should get this amount of nutriment in arass or lasy. But if we tan not du this, we unust ferd enoujh concentruted find to liring it up to the desired stantarel.

"But will it pay?" askel the Heacon, "I have not much faith in huying feed. I farmer ought to raise wrerything he ferdis ort 
"As a rule, this may he true," I replienl, "lut there are many exceptions. I an trying 6 show that it will often paty a tairyman well (1) buy feed rich in nitrugen and pimsphates, so as to make rich manure, anıl give him al sart. Alter he grets his land rich, there is little diftieduly in kecpoing up its productoreness

"Now, I have sild-and the ligue's, if ayblhing, are loo low-that if a cow, eating six tous of hay, or its eifulvalent, at year, produces $400 \mathrm{llss}$ of cherese, a cow eaprahle of eating, thiresting, and turning (1) gromb aenunt nine tons of hay, ur its epuivalent, a year, would produce 1,090$)$ liss. of cheese, or its enjuivalent in otleer products."

I would like to sily much more on this subjeet, but I hope enough has been sainl to show that there is great alvantige in feeding rich food, even so far ats the prouluetion of milk or heef is concermed; and if this is the ease, then there is no difleculty in making rich manure on a dairy farm.

And 1 am delighted to know that many farmers in the dairy districts are purchasing mole and morelran and meal every gear. T:L'sing milk, and bexf, and mitmure all info the ancount, I feel sure that it will he foumb highly prolitable; but you must have geod cows-rows llatt catu turn their extra food to grool aceount.

This is not the plike to distu-s the merit- of the ditferent breeds of eows. All I wish to show is, lhat to make better manture, we

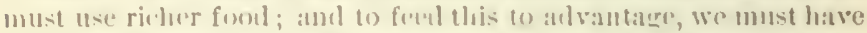
animals that can turn a larere amount of foul, over and atove the amonut requidel fo sustain the vital fumetions, into milk, llesh, ete.

"You do not think," said the Deacon, "that a well-bred cow makes any richere manure than a rommon cow" "

Of course nut; lut to make rich mamure, we must fred woll; and we can not afforl to feed well unless we have good animuls.

\section{HOW TO SAIE MND APPLY MANCRE ON A DAIRY-FARM.}

We can not go into detrils on this subject. The truth is, there s.re several goul methols of saving manure, and which is best depends (ntirely on circumstances. The real point is to sare the urine, and kenp the dew-stalble elean and swet. There are three prominent methods adoptetl:

1st. To lhow all the Jiçuid and solid exerements into a manurecoliar uuderneath the cow-stoble. In this cellar, dry swampmake, ary earth, or other aborbent material, is mixel with the manure in suflicient quantity to keep) down olfensive olurs. A little dry earth or muck is al-1) llsinl in the sable, scitlering it twier a day in the gutters and muler the hind lenes of the enwe. Wher: this is carried out, it has many and decilled anvantuges 
21. To where or throw out the solid parts of the mannre, and to have a drain for corrying the lippiel into as tank, whese it ran be pumper on to the heaje of manure in the yart. Where many horses or sheepl are kepte, aud only a few rows, this plitn can often be used to alvantage, at llee he':1p of matsure in the yard, comsist

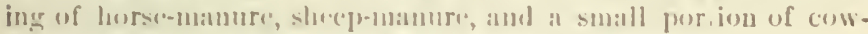
lung, will be able to aburl, all the urine of the cows.

3d To wse sulliciont ledeling (1) al worb all the urine in the st:1. hle. In my own canc, as I hase sabl lufore, we msnally rhatl all our straw and stalks. The orts are usel for hedeling, and we also use a little dry earth-or, to be mare exact, I use it when 1 attend to the matter myself, but hase alwalys found more or lase trouble in gratting the work dome propurly, mulen l give it peremal atten

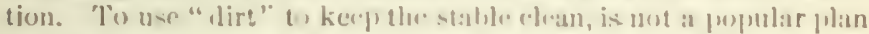

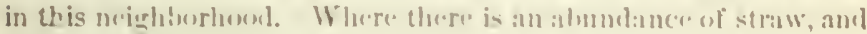

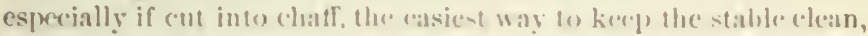

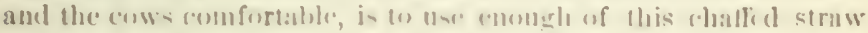

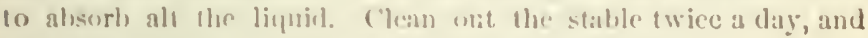
wheel the manure directly to the laeap, and spread it.

In regard to the application of manure on a dairy-farm, we hare secn what !Iarris Lewis does w ith his. 1 alson wrote 10 T. I. IIariscon, Esif., of St. Lawrener Co., X. Y. ; and knowing that he is nut conly a very intcliigent farmer and hreeder, but al on one of our best agrieultural writers, 1 asked him if he hat written anything on the sulject of manures.

"St. Lawrence Co.," silisl thr. De"icun, "produces capital eraes, oats, and burles, but is, 1 shomld think, ton far mortls for winter wheat; but wha: liu Mr Harions say?"-Here is his letter:

"I never wrote anything alout manure. Catch me at it! Nor do I know anything about the manatement of barn-yard manure worth telling. Mr own practire is dictated gluite as much by converience as hy cunsiderations of economy."

"Goul," said the Deacon; "lie writes like a s.ncible man."

" Iy rotation," he continues, "is such that the bulk of the mat nure made is applied to one crop; that is, to my luesed crops, corn. putatoes, and roots, in the sicolid year.

"The manure from the staliles is thrown or whecled out under the sheds aljoining, and as fast as it heromes so large a quantity as to be in the way, or whenever there is an ofmortunity, $\mathrm{ji}$ is hanleal wit to the field, where it is to be used, and put in large piles. It is turned once, if possihle, in the spring, and then spread 
"The quantity appliml, is, as near as may be, 25 loads per acre; but as we usc a great deal of straw, we haul ont 30 loails, and es. timate that in the spring it will be aluout 25 loads.

"If we have any more ( nel oxeasionally we have 100 loads orer), we pile it mear the barn, and tum it once or twice during the summor, ard use it as secme most protitable-somedimes to top-dress an wld grass-ticeld, that for sume reason we prefer not to break for another year. Sometimes it goces on a piece of fall wheat, and sometimes is kepterer for a barley tichl the following spring, and barrowerl in just before sowiug.

"I should spreat the manure as it crimes from the sheds, instead of piling it, but the great quantity of suow we usually have, las always seemed to be an insuprerable olistacle. It is an arlvantage to pile it, and to grive it one turning, lut, on the otlecr hand, the piles mate in cold weather frecze through, and they take a prorokingly long time to thaw out in the spring. I never found manure piled out of toons (o) get tou much water from rain.

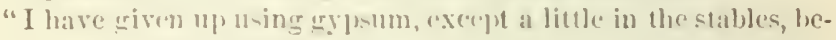
cause the elover grows t(x) + tron!r without it, and so long as this is the case, a do net need eypenum. But I sumetimes liave a piece of oits or barley that stands still, and jooks sick, and a dose of grpium lupes it very much."

"That is a fuct worth rememberiner," said the Deacon.

"I use some superphowphate," continues Mr. Harison, "and some erromil hones on my turnips. Wre also use smperplosphate

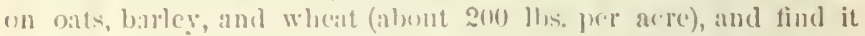
pays. Last year, our catimatr was, (on 10 areres of oats, comparing witls a strif in the millille, fefe for the purpuse, that the 200 llos. of superphesplate increacell the (rop) 15 bushels per acre, and gave a gain in quality. It was the ". Manhattan," which hats about three per

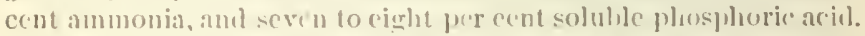

" Iy rotation, which I stick to ats (done as I cam, is : 1, oats; 2, corn, and potatoes, and ronts: :3, barley or spring wheat; 4,5 , and 6, arass (clover al timuthy, with a little mixture accusionally).

"I am trying to g(t t) 4 , f.ll wheat, but it is mighty risky."

"That is a rery sensible letter," sait the Deacon; "lut it is erident that he rases more grain than I supposed was generally the ease in the dairy districts; and the fact that his elover is so heavy that he dous not need plaster, indiente's that his lamd is rich."

It merely confirms what ! have silit all along, and that is, that the darymen, if they will foed their animals liberally, and culti 
vate their soll thoroughly, can som have probuctive farms. There are very few of us in this rection who (an make manure enough to grive all our corn, potatoce, and roots, 25 loacls of rotted manure per acre, and have sme to spare.

In the spring of 1sit, Mr. 11arison wrofe: "I have been hauling ont mamure all winter als fint as made, and putting it on the land.

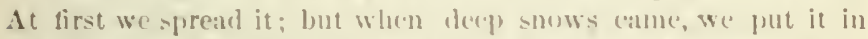
small heaps. The tidld looks ats if there had been a grain crope on it left unsut."

"That last remark," salid the Doctor, " inclieates lliat the manure

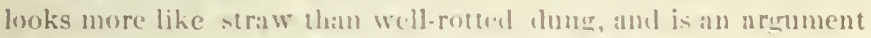
in favor of your plan of piliner the manure in the yard or fiedd, instead of sprealing it on the land, or putting it in small heaps."

\section{II A P T E X XIII.}

\section{MANAGEMEXT OF MANLRES ON GRAIN-FARMS.}

"I am surprised to finc," said the Deacon, "that Mr. Ilarison, living as lie does in the great errass and dairy district of this state, slionld raise so much grain. IIe has nearly as large a proportion of his land unler the plow as some of the beat wheat-growers of Western New York."

This remark of the Deacon is right to the point. The truth is, that some of our leset wheat-growers are plowing less land, and are raising more grass, and keeping more stock; and some of the dairymen, though not ke'p)ing less stock, are pluwing more land. The better farmers of hoth sections are approaching each other.

At all events, it is ecrtain that the wheat-growers will keep more stock. I itrote to the IIon. Fen. Gedeles, of Onondaga Co., X. Y., well known as a large wheat-grower, and as a life-long alvocate of keeping in the fertility of our farms ly growing clover. He replies as follows:

"I regret that I have not time to give rour letter the consideration it deserres. The sulject you hare undertaken is truly a difficult one. The circmmstances of a grain-raiser and a dairyman are so unlike, that their views in regard to the treatment of the manure prodneed on the farm would vary as greatly as the lines of farming they follow. 
"The grain-grower has straw in exeess; he tries hard to get it into such form that lec an draw it to lis tictlls, and get it at work, at the least cont in labor. So he coveres his harn-yards deep with straw, after each suow-storm, and gets lis cattle, sheep, and horses, to trample it meler fout; and he makes his pigs convert all he ean into such form that it will do to alply it to his pastures, ete., in winter ur early sprime.

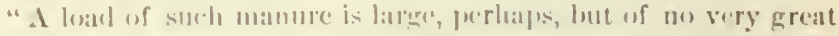
value, as contupared with well-rotted sable-manture frem grain-f(x) lorses ; lute it is as goorl as much that I hawe seen drawn from rity silables, and arried far, to restore the worn ent hay-tichls on the shores of the North liscr-in fare, pritre like it.

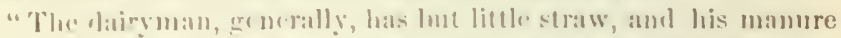
is mostly dime of cows, worth much more, per cord, than the straw-litter of the grain-growes.

"The grain-errower will want ne slects for keeping out the rain, but, rather, lo will dereire more water than will fall on an open yarl. The milkman will wiols to protece his colw-tlung from all rains, or rsen smows; so le is a great advocate of manure-slaeds. These two clasese of farme will adop, quite mulike methods of applying their mamme to (rops.

"I have (eited these (wo () lisures of farmers, simply to show the ditliculty of making aly miverall laws in reysard to the treatment andl use of hatru-1:ard mianure. * * *

"I llink you and I aro fully ngrend in rearal te llwe farm being

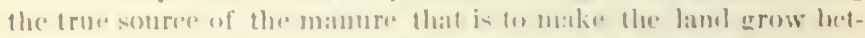
tor with nece, and still prouluee (rops-perhaps you will go with

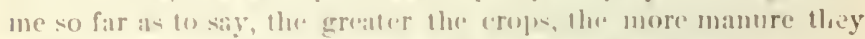
will make-and the more manure, the lareer the cropse.

" Now, I whjeet to any sperial farming, when applied io a whole great division of eomutry, such as merely raising grain, or devoted molirely to dairyiner.

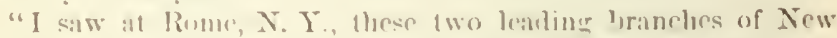
York farmine miteil on the Huntington tract of 1,300 acres. Three or four farms (I forerd which) hat separate and distinct management, condurted loy different families, hut eroch ham a dairy combinet with the raising of lirge crops of gram, such as wheat, corn, oats, ele. These grain-erops, with suitable areas of meadow and pasture, sustained the dairy, and the cows converted much of the erain, and all of the forager, into momore. Thus was ("om-

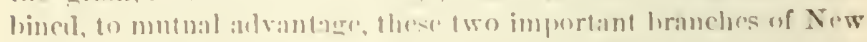
York farming. Whont and chene to soll, and eonstant improvemeat in ( $r(1)$ s. 


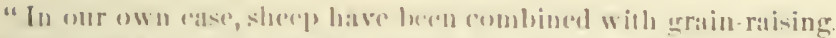
So we have suld wonl, wheit, and harley, and, in all my life., nest

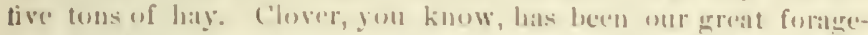

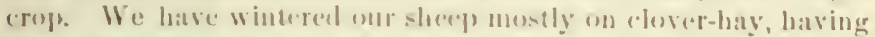

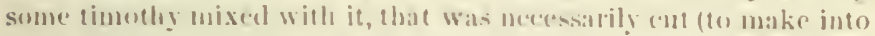
hay with the molium, or carly (luser, when it was but grass. We have feed such bay on cour cows and herses, anel have usually

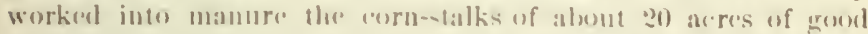
mrn, rach winter, and we have worked all the straw into shape te apply as manture lhat wo could, spreatine it thickly on patatures and such other tirlils as wrer. convenient. Some struw we have sold, mostly to pitper-misliers."

"That," said the Deacon, "is eroul, olet fashionerl farming. Plenty of straw for bedeline, and groul elever and timothy-hay for f(eel, with wool, wheat, amb harley to sell. Nu talk allont oilcake, maltrombs, amel mangrels; nothing about superphesphate, gu:no, or sw:mp-murli."

Mr. Geddes and Mr. Johnston are luth represcontative farmers;

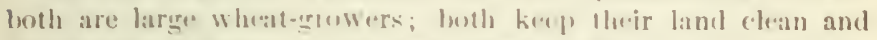
thoromghly coltivated; luth use gyjesum frecely; lonth raise large

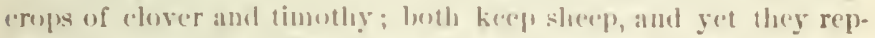
reent two contirely diflerent systems of farmintr. ()ne is the great alverate of elover; the other is the great alvorate of manure.

I once wrote to Mr. Cieldles, asking hic epinion at to the best time of plow under choser for whear. He replird as follows:

"Plow under the elover when it is at full growth. But your question ran much) hetter le answereal at the and of a lomer. free talk, whish can lese he haul hure. I harre many times asked you to come here, not to see fine farmine, for we have none to show, but to see land that has been lised to test the eflects of clover for nearly io years. On the ground, I could talk to a willing atuditor long, if not wisely. I am grutting liretl of being misunderstood, and of haring my statements doubted when I talk about clover as the great renovator of land. Fou preach agricultural truth, and the facts you would gather in this neighlorluond are worth your knowing, and wortl giving to the world. Su come here and gather some facts about relever. All that I shall try to prove to you is, that the fact that clover and plaster are by far the clieapest manures that can be had for our lands, has been demonstrated by many farmers beyond a duuht-so much cheaper than barn yard manure that the mere loading of and spreating costs more than 
the pluster and clover. Do not yutete me as siying this, but come and see the farms hereabouts, and lalk with our farmers."

Of course I ment, and had a capital time. Mr. Gedhes lons a magnitiecnt farm of about $f(x)$ atcres, some four miles from Syracuse. It is m high somlition, and is romtinually improviner,

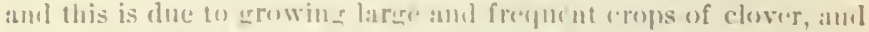

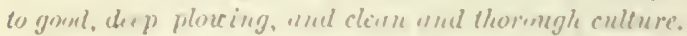

We drowe rouml amome the farmers. "Ilere is a man," said

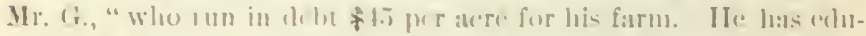

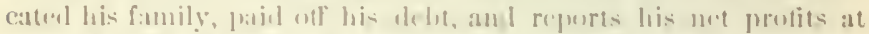
from so, lue to clover. Yon see lı is buildine a new barn, and that does not luok :k themeh his latnd was rubuing down umder the system." The mext farmer we ("ame (o wals alse) puttiue up) a new barn, and another farmer was enlareing au old one. "Now, these farmers have merer paid a dollatr for manure of any kind exerpt plaster, and their lamels certuinly do not de.terioratu."

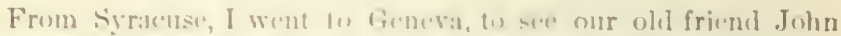

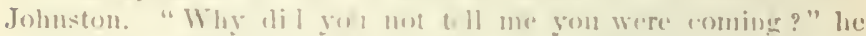

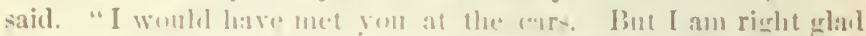

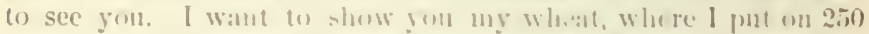
11)s. of gutatno pere atcre last fall. P'opple here don't know that I used it, and you munt mot mintion it. It is gramel."

I lo not know that I "ror saw al huer piece of wheat. Jt was the Diehl varicty, sown 1 thl september, at the rate of 1 th bushels per

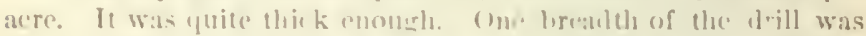
sown at the rate of two lm-hel juracre. This is marlier. "But," said Mr. J., "the other will have larerer healle, and will rield more." After cxamining the wheast, we wemt to lowk at the piles of muck and manure in the burn-vard, and from these to a splen-

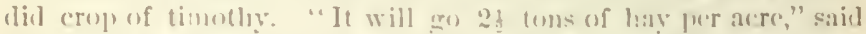
Mr. J., "an 1 now lewk at this anljuinine tirld. It is just as good land naturally, and there is merely a fence betwern, and yot the grase and elover are s) pour as liarilly to be wortl cutting."

"What makes lue differenee?" I askerl.

Mr. Jolustom, emplationally, "Yannre."

The poor fiald did not belone 10 loim!

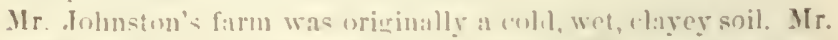
Gedles' lant di l not neesl draiuing, or very little. Of course, land that neesls draining, is richer after it is trainet, than land that is 


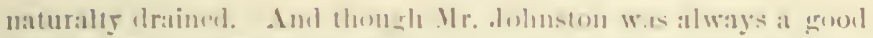

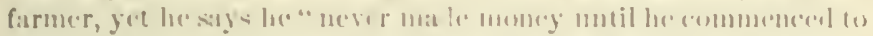

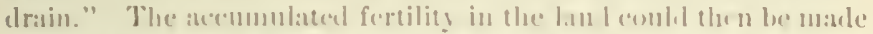
availahle by anend tillage, amel from that diag fo this, his lambl hats been grow ing richer und rie lo r. And, in fart, the same is erue of Mr. lieldes' farm. It is riclue r lamed torlay than when tirs plowed, while there is one ficld that for serenty years has has l on unanure

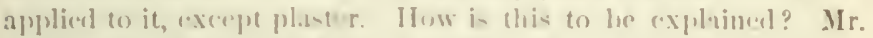

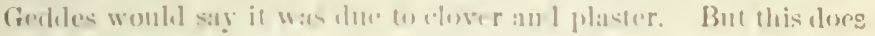
not fully sati-fy those w luo (laim, (amd truly), flatt "always taking

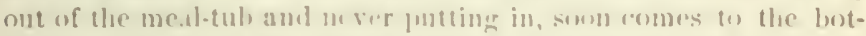

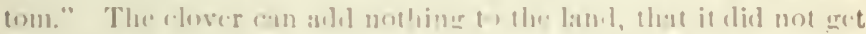

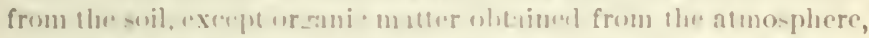

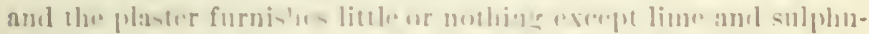

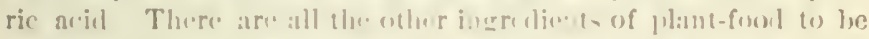

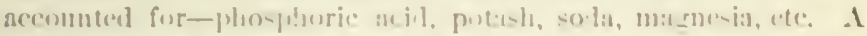

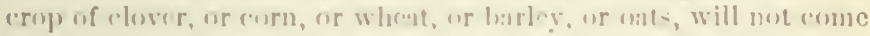
(1) perferetion und at arery onse of these trments is present in the

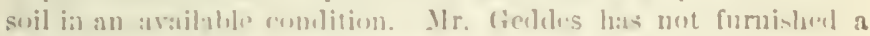
single oumer of any one of them.

"Where (a) thece (rome from ?"

I answer, fiom the wo l teelf. There i probalily cnoush of these elements in the suil fol last ten thuntanel years; and if we return to

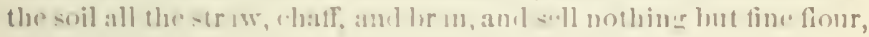
meat, lutter, ell.. ticere is prohnbly enonzh ts last at million years,

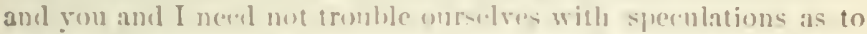
what will balpenen after that time. Nearly all umr soils are practically inexhautible. But of rour-e tloese tements are not in an

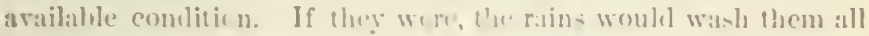

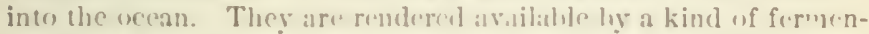

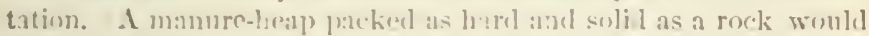
not decay, isut break it up, make it fune, tum it exceasionally so as to experse it to tia atmospluere, and with the proper degree of moisture and lieat it will ferment rapilly, aml all its elements will soon beenme avalialse foot for plants. Nothing has been created by the process. It was all there. We latre simply made it ereituble. So it is with the soil. Break it up, make it fine, tum it orcisionally, expose it to thr atmosphere, and the elements it eontains hecome arailalle.

I do not think that IIr. Gedles' lanel is any better, noturally, tlan gours or mine. We can all raise fair crops by eultivating the land thoroughly, and hy nerer allowing a weed to erow. On Mr. Lawes" experimental whent-field, the plot that has neerer re 
crivecl a particle of munure, proiluces cery yeur an average of about 15 lushels per acre. And the whole crop is removed-grain, straw, and ehatl. Nothing is returned. And that the land is not remarkably rich, is evident from the fact that some of the farms in the neighborlookl, produce, mulder the orelinary system of management, but little more wheat, once in four or five years than is raised cery year on this exprimental plot without any manure.

Why? Becense thene farmers de not half work their land, and the manure they make is little butter than rotien straw. Mr. Lawes' wheat-ficld is flowed twice rery year, and when I was there, the crop was hamb-hoed two or three times in the spring. Not a weerl is suffered to grow. And this is all there is to it.

Now, of course, instaul of risin r 1.5 buthels of whent every year, it is a goul denl fweture to raise a crop of 30 bushels every other year, and still heter to raise 45 inshels avery lhird year. And it is here that clurer (omes to our aill. It will enable us to do this very thing, and the land rums mo greater risk of exhaustion than Mr. Lawes' unmanmenl what (rop).

Mr. Gediles and I lo not ditter as much as you suppose. In fact, I do not believe that we liffer at all. He has for vears been an earnest alverate for growing clover as a ronorating erop. He thinks it hy far the rleapuest manure that ean be obtained in this section. I arree with him most fully in all these partieulars. He formed his opinion fom exprence and observation. I derived mine from the lothamsted experiments. And the more I see of practical farming, the more um I satisfied of their truth. Clover is, uncuestional,ly, the erreat renovatine crop of Ameriean agriculture. A repp of clover, whial to two toas of hay, when plowed under, will furnisla more ammonia to the soil than twenty tons of straw-mate manure, drawn out fresh and wet in the spring, or than twelve toms of unr ordinary barn-yart manure. No wonder Mr. Geddes and other intelligent farmers recommend plowing under clower as manure. I differ from them in no respect exeept this: that it is not absolutely essential to plow clover under in the green state in order to get its fertilizing effect; but, if made into hay, and this hay is fed to animals, and all the manure earefully savel, and returned to the land, there need he eomparatively little loss. The animals will seldom take out more than from fire to ten per eent of all the nitrouen furnishet in the forml-and less still of mineral malter. I sulvocate growing all the clover you possibly can-so does Mr. Gedles. IIe says, plow it under for manure. So say I-unless you can make more from freding out the elover-bay. 
that will pay yent for watimes al year, and for entting and curing the elover and ilrawing hatek the mitmore. If you plow it unter, you ate sure of it. There is no losis. In freding it ant, you may lose more or less from leadhing, and injurious fermanta-

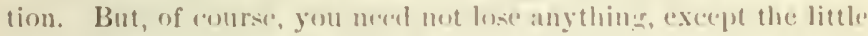
that is retrined in the tle-h, or wowl, or milk, of the antmals. As thing are on many farms, it is perhaps bese 20 plow under the clover for manure at suce. As things onglat to le, it is a most

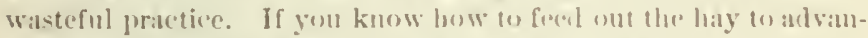
tage, and t.ke pains to save the manure (and to andel to its value hy feeding oil-eake, bratu, (te., with it), it is far bettre to mow your clover, once for hay, and once for seed, tham to plow it muler. Buy oil-eake and hron with the money grot from the secel, and growing clover-secd will mot injure the lind.

I am glad to hear that Mr. Cienlles occisionally sells straw. I nnee sold 1.j tons of straw to the perper-makers for \$1.j), they drawing it themselves, and some of my neighthors coliticised me severely for doinesso. It is not considered an ortserdex pratedice. I do not advorate selling straw as a lule; but, if you hatve more than you can use to alviutare, and it is bringing a soul price, sell part of the straw ancl buy hran, oil-rake, etre, with the money. To feed nothing but straw to stock is poor ecomomy ; and to rot it down for manure is no hetter. Straw it:-1f is not worth \$s:3.00 a ton for manure; and as one ton of straw. spreanl in an open yard to rot, will make, in sprian, alorut four tons of so-callexl manure, and if it costs jo eents a ton to draw out and spreal it, the straw, even at this comparatively ligh estimate of its value, nets you, when fed ont alone, or rotter clown, only \$1.00 a ton.

I had about 30 tons of straw. Fed ont alome or rotted down it would make 120 tons of manure. After cledueting the expense of lauling, and spreading, it nets me on the land. si30. Now s'll half the straw for \$150, and huy three tons of oil-cake to feed out with the nther half, and you would have abont serenty tons of manure. The manure from the fifteen tons of straw is worth, say $\$ 45$, and from the three tons of nil-ake, $\$ 60$, or $\$ 10.5$. It will cost \$3. to draw and spread it, and will thus net on the land, $\$ \pi 0$. So far as the manure question is roncerned, therefore, it is far better to sell half your strim, and buy oil-eake with the money, than to feed it out alone-and I think it is also far better for the stock. Of course, it would be hetter for the farm, not to sell any of the straw, and to buy six tons of oil-cake to feed out with it; 
but those of us who are short of eapit:l, must be content to bring II) wur land by slow degrees.

"I am at a loss to understand," wrote Mr. Geddes, "what you mean, when you say that a ton of straw will make, in the spring of the year, foll tons of so-ealled manure. If you hatd said that four tons of straw would make one ton of manure, I should have thought nothing of it. But how you can turn one ton of straw into four tous of anything that anyboly will call manure, I do not see. In a conversation l hat with Hon. Lewis F. Allen, of Black Rock, more than a yar aro, he tolul me that he haul enquired of the man who furnished hay for fuediner cattl: at the central Yirrels, in Butlinlo, at to the louts of manure he sold, and thongh I can not now say the exact qquantity $t(1)$ a ton of hay, I remember that it was very little-lar less than I lad before supposed. Please explain this straw-manure matter."

Boussingault, the great French chemist-farmer, repeatelly analyzed the manure from his barn-yard. "The animals which had produced this dung, were 20 horses, $: 0$ oxen, and from 10 to 20 pigs. The absulute quantity of meisture was ascertained, by first drying in the air a considerable weight of dung, and after pounding, eontinuing and eompleting, the drying of a given cuantity." No one can sloutht the accuracy of the results. The dung made in the

Winter of $183 \%$-S, contained 79.6 per eent of water.

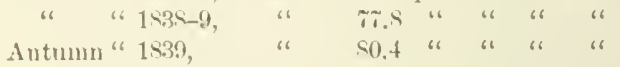

Fresh solid enw-dung contains, according to the same anthority, 90 per eent of water.

I have frequently seen manure drawn out in the spring, that had not heen decomposed at all, and with more or less snow among it, and with water dripping from the wagon, while it was beinglonded. It was, in fact, straw saturuted with water, and discolored hy the droppings of animals. Now, how much of such manure would a ton of dry straw make? If we should take 20 lhs. of straw, trample it down, and from time to time sprinkle it with water and snnw, until we lad got on 80 lbs., and then put on 20 lhs. more straw, and 80 llss. more water, and keep on until we hat used up a ton of straw, linw much "so-called manure," should we have to draw out?

20 lbse of straw, and so the. water $=100$ the, so-ealled manure.

2,000 lbs, of straw, and 8,000 lhs. waler $=10,000 \mathrm{lbs}$. so-ealled manure.

In other words, we get five tons of such mannre from one ton of 
straw. This is, perhaps, an extreme case, but there can be litte donbt, that in ton of straw, trampled down by cattes, and sheep, in an open barn-yard, exposed to snow and rain, would weigh four tons when drawn out wet in the spring.

Yes, it is quite an argumcut in faror of manure cellars. I have always had a prejuliee against them-probably, because the first one I saw was bally mantıred. There is, however, no necessity, even in an ordinary open barn-yard, with more or less sheds and stables, of having so much water in the manure when drawn out. The real point of my remarks, which so surprised Mr. Geddes, was this: We liave to draw out so much water with our manure, under any eireumstances, that we should try to have it as rich as possible. It is certainly true, that, if the manure from a ton of straw is worth $\$ 3$, that from a ton of clover-liay, is worth $\$ 10$. And it costs no more to draw out and spread the one than the other. I have never yet fomd a farmer who would believe that a ton of clover-hay, rotted down in the barn-yard, would make three or four tons of manure; but he would readily assent to the proposition, that it took four or fire tons of green clover to make a ton of liay; and that if these four or five tons of green-clover were rotted in the yard, it would make three or four tons of manure. And yet, the only difference between the green-clover and the hay, is, that the latter has lost some 60 or 70 per cent of water in curing. Add that amount of water to the hay, and it will wake as much manure as the green-clorer from which the lay was inade.

\section{GYPSEM AND CLOVER AS MANURE.}

A good farmer came in while we were talking. "Nothing like plaster and clorer," he said, "for keeping up a wheat-farim." And you will find this the generil opinion of nearly all American wheat-growers. It must be accepted as a fact. But the deductions dramn from the fact are as rarious as they are numerous.

Let us look first at the fact. And, if you like, we will take my own farm as an example. About 60 years ago, it was corered with the primeral forest. The trees, on the higher and drier land, were first cut down, and many of them burnt on the land. Wheat was sown among the stumps. The crop varied in different years, from 10 to 30 bushels per acre. When 30 bushels were grown, the fact was remembered. When 10 bushels only were grown, little was said about it in after years, until now there is a general impression that our wheat crops were formerly much larger per acre than now. I doubt it; but we will not discuss the point. One thing is 
certain, the land would produce good erops of chrer; and when this clover was plowed under for manure, we got better arops of wheat afterwarts. 'This was the rule. Later, we commenced to use gypsum as a top-dressing on clover. The effect was often wonderful. Farmers will tell you that they sowed 200 libs. of plaster per acre, on their young elover, in the spring, and it doubled the crop This statement expresses an agricultural, and not an arithmetical fact. We do not know that the crop on the plastered portion was twice as heavy as on the unplastered. We know that it was larger, and more luxuriant. There was a greater, and more rigorons errowth. And this extra growth was cause 1 by the small top-dressing of powdered gypsum rock. It was a great fact in agriculture. I will call it fact, No. 1.

Then, when the elover was turmed under, we usually got good wheat. This is finet, No. 2. On these two facts, liang many of our arrieultural theories. We may state these facts in many ways. Still, it all comes to this: Clover is good for wheat ; plaster is good for clover.

There is another fact, which is a matter of general observation and remark. You rarely finl a good farmer who does not paly special attention to his clover-crop. When I was ricling with Mtr. Gedues, among the farmers of Ooundaga Comnty, on passing a farm where everything looked thrifty-grood fences, good buildings, good garten, good stock, and the land dean and in good condition-I would ask who lived there, or some other question. No matter whit. The answer wals always the same. "Olı! he is another of our clover men." We will "all this fact, No. 3.

And when, a year afterwards, Mr. Geddes returned my visit, and I drove him aromnd among the farmers of ILonroe County, he found precisely the same state of facts. All our grood famers were clover men. Among tire good wheat-growers in Michigan, you will find the same state of things.

These are the facts. Let us not quarrel over them. 


\section{$\mathrm{C} I \mathrm{II} \mathrm{P} \mathrm{TR} \mathrm{X} \mathrm{I} I \mathrm{~V}$.}

\section{THE CIEAPEST MANLLRE A FARMER CAN LSE.}

1 do not know who first said, "The eheapest manure a farmer ean use is-clover-seed," but the saying has become part of our agrieultural literature, and deserves at pissing reniark.

I linve heard good farmers in Western New York say, that if they had a field sown with wheat that they were going to plow the spring after the (rop) was harvested, they would sow $10 \mathrm{ll}$ s. of clover-seed on the wheat in the spring. They thought that the growth of the clover in the fall, after the wheat was cut, and the grow th the next spring, before the land was plowed, would afford manme worth much more than the cost of the clorer-sced.

"I do not doubt it," salil the Deacon; "but would it not be better to lat the crop grow a few months longer, and then plow it under?"

"But that is not the point," I remarked; "we sometimes adopt a rotation when Indian-corn follows a crop of wheat. In such a case, good farmers sometimes plow the land in the fall, and again the next spring, and then plant corn. This is one method. But $I$ have known, as I said before, good famers to seet down the wheat with elover; and the following spring, say the third weck in May, plow under the young clover, and plant immediately on the furrow. If the land is warm, and in good condition, you will frequently get elover, by this time, a foot high, and will have two or three tons of succulent vegetation to turn under; and the farmer who first recommended the practice to me, said that the cut-worms were so fond of this green-clover that they did not molest the young com-plants. I onee tried the plan myself, and found it to work well; but since then, I hare kept so many pigs and sheep, that clover has been too useful to plow under. But we will not diseuss this point at present.

"What I wanted to say is this: Here we have a field in wheat. Half of it (A) we seed down with 12 lbs. of clover-sced per acre; the other half $(B)$ not. The clover-seed and sowing on $A$, cost, say, $\$ 2$ per acre. We plow $B$ in the fall; this will cost us about as much as the clorer-seed sown on $A$. In the spring, $A$ and $B$ are both plowed and planted to corn. Now, which half of the field will be in the cleanest and best condition, and which will produce the best corn, and the best barley, or oats, afterwards?" 
"I vote for $\Lambda$," silil the I)(eiceon.

"I vete for 1 ," sinil the boctor.

"I vote for $\Lambda$," siliel the sipuire.

"I shoull think," modrstly sueresetel Charley, "that it wouh depend somm wat on the soil," and cluarley is riglit. On a clean, moderately rich piece of lierlit, sandy soil, I should certainly ixpeet much lueter eorn, and better barley or vats, on $\Lambda$, where the clover was errown, than on I?. But if the tichl was a stromg loam,

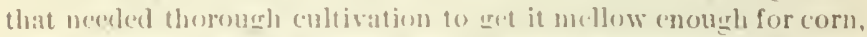
I am inclinerl (1) think that B would (ame out ahead. At any rate, I am sure that on my own fam, moleratry stift lame, if 1 wis groing to plant corn after wheat, I shomld mot seed it down with clover. I would plow the whent sulible immediately after harvest, and Jarmo and roltivate it to kill the weeds, and then, six weels or two months linter, I wumld plow it again. I would draw out mantore in the winter, pile it up ju the find to ferment, and the next sprimer sjureal it, and plow it under, nnd then-

"And then what ?" a-kerl the buron.-" Why the truth is," said 1, "then I would unt plant corm at all. I should fither sow the fictel to burley, or drill in mangel-wurzel or Swele-turnips.

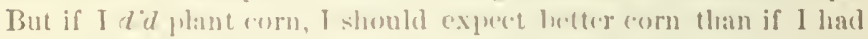
sown clover witl the whent; and thre lamel, if the corn was well

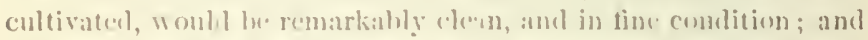
the next time the land was sereled down with clover, we enuld

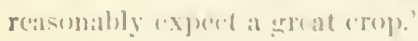

The truth is, that chrex-scen] is sometimes a very cheap manure, and farmers are in me danger of sowjus too much of it. I do not

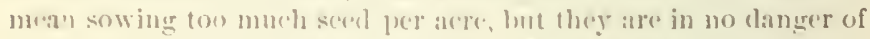
sowing ton many acres with elover. On this point, there is no dislerence of aprision. It is omly when we come te explain the action of enver-when we draw aledurtions frem the facts of the the case-that we enter a field bristling all over with controversy.

" Tou have just finished threshiner," saill the Deacon, "and for my part, I would ratler hear loww your wheat turned out, llau to listen to any of your chemical talk about nitrogen, phosjulıric acid, and fintash."

"The wheat," sild I, " turned ont full as well as I expected. Fourteen arepes of it was after wheat, and right areres of it after oats. Both these ficlkls were serelcel down with dover last year, but the elovel failel, and there was nothing to he lome lut to risk them arain with wheat. The remainder was after harley. In all, 


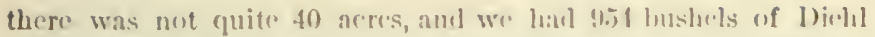
wheat. 'This is not b:ul in the cirrum-tances; hat I slatll not

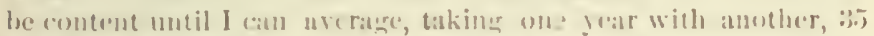

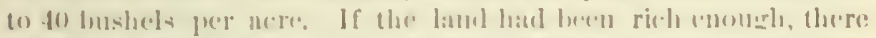
womld unquestionably hatre been fo buslects per acre this year.

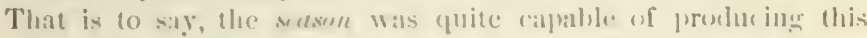

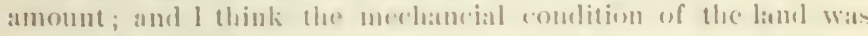
also expual to it; all that was mededed was sutlicit mt available plantforst in the soil."

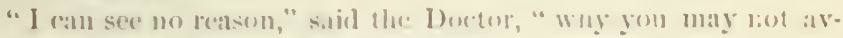

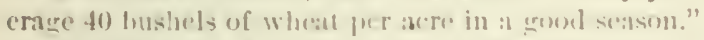

"The tichle of 14 aceres," sialel I, "where wheat follewwerl wheat,

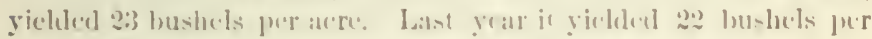
aere: and so we got in the two yatrs tio bushe - per acere."

This field has had no manure of any kitul for years. In fact,

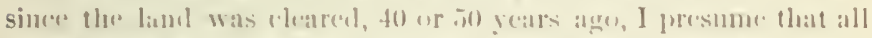

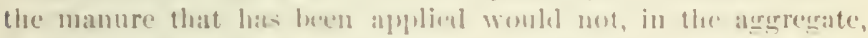

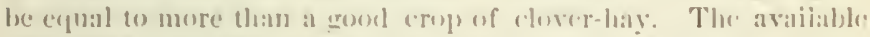

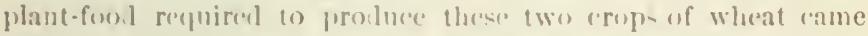
from the soil itself, and from the rain, dews, and atmospluere. The land is now seeded down with clover, and with the aid of a bushel or two of plater per acre, next sprine, it is mot improbalile that, if mown twied fur hay next year, it will yield in the two crups three tons of hay per acre.

Now, three tons of elower-hay contain alout 3is lis. of plos-

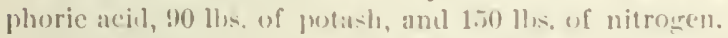

The last (rop) of wheat, of 222 bushels per acre, and say 1,500 lus. of straw, would contain:

1. the grain. In the stiner. In twial crop.

Phosplioric acisl ............. 11 iths.

Potash ...................

Nitrogen.........................

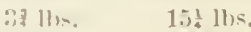

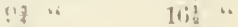

!!" " $3: 2 \%$

It secms very unkind in the what-plants not to give me more tham 22 bushels per acre, when the cluser-plants comiag after will find phosphoric aciu cnough for 40 bushels of wheat, and potash and nitrogen enough for nearly 100 bushcls of what per acre. And these are the thrce important constiments of plint-food.

Why, then, liel I get only :2 lmsliels of wheat per aere? I got 23 bushels on the same lind the rear prerims, and it is not improbable that if I loal sown the same land to wheat again this fall, I should get 12 or 15 hushels per acre again next year. But the clover will find plint-forol enough for to lusheds of whent.

"There is mot much douht," said the Deacon, "that you will 
get a grod crop of clover, if you will keep the slicep off of the land this fall. But I do not see what you mean by the clover-plants finding food enough for 40 bushels of wheat, while in point of fact, if you laad sown the field again to wheat this fall, you would not, as you say, probably get more than 12 or 15 bushels of wheat.

"IIc merns this," said the Doctor. "If he bad sown the land to wheat ihis fall, without manure, he would probably not ge over 15 bushels of wheat per acre, and yet you both agree that the land will, in all probability, produce next year, if mown twice, three toms of clover-hay per acre, without any manure.

"Now, if we admit that the clover gets no more nitrogen from the rain and dews, and from the atmosphere, than the wheat will gret, then it follows that this soil, which will only produce 15 bushcls of wheat per acre, cloes, in point of fact, contain plant-food enourh for 40 hushels of wheat, and the usual proportion of straw.

"The two cropss talke up from the soil as follows:

\section{Phosphoric acid. Potesh.} 15) hushels wheat and straw.........10! lbs.

3 tons tover-hay.

"These facts and figures," contimuer the Doctor, "are worth $11 \div 1 \mathrm{ths}$. 90 "

Nitrogen. looking at and thinking about. Why ean not the wheat get as nuch phosphoric acid ont of the soil as the clover?"

"Beculuse," said the Deacon, "the roots of the clover go down decper into the subsoil than the roots of wheat."

"That is a very good reason, so far as it goes," said I, "but does not include all the facts. I have no sort of doubt, that if I had sown this lind to wheat, ant put on 75 lbs. of nitrogen per acre, I should have got a wheat-crop containing, in grain and straw, 30 1hs. of phosphoric acil. And so the reason I got 15 lushicls of wheat per acre, instead of 40 bushels, is not because the roots of wheat co not go deep enough to find suflicient soluble phosphoric acid."

"Possibly," said the Doctor, "the nitrogen you apply may render the phosphoric acil in the soil more soluble."

"That is true," said I ; "and this was the answer Liebig gave to Mr. Lawes. Of which more at some future time. But this anstrer, like the Deacon's, does not cover all the facts of the case; for al supply of soluble phosphoric acid would not, in all prolability, give me a large crop of wheat. I will give you some facts presently bearing on this point.

"What we want to find out is, why the (dover ean get so much more phosphoric acid, potash, and nitrogen, than the wheat, from the same soil ?" 


\section{MORE ABOUT CLOVER.}

The Deacon scemel to think the Doctor was going to give a scientific answer to the question. "If the clover can gret more nitrogen, phosphoric acid, and potash, from the same soil than wheat," said he, "why not accept the fact, and act accordingly? You seientifie gentlemen want to explain everything, and sometimes make confusion worse confounded. We know that a sheep will grow fat in a pasture where a row would stare."

"True," said the Doetor, "and that is because the cow gathers food with her tongue, and must have the grass long enough for her to get hold of it; while a shecp picks up the grass with her tecth and gums, and, consequently, the sheep ean cat the grass down into the very ground."

"Very well," said the Deacou; "and how do you know but that the roots of the elover gather up their food sheep-fashion, while the wheat-roots eat like a cow?"

"That is not at very scirntific way of putting it," said the Doctor"; "but I aun inclined to think the Deacon has the right idea."

"Perhaps, then," said I, "we had better let it go at that until we get more light on the sulject. We must conclude that the wheat can not get food enough from the soil to yield a maximum crop, not because there is not food enough in the fied, bat the roots of the wheat are so constituted that they ean not gather it up; while clover-roots, furaging in the same soil, can find all they' want."

"Clover," said the Deacon, " is the scavenger of the farm; like a pig, it gathers up what would otherwise be wasted."

"Of course, these illustrations," saiıl the Doctor, "do not give us any clear idea of how the elover-plants take up food. We must recollect that the roots of plants take up their food in solution; and it has just occurred to me that, possibly, Mr. Lawes' experiments on the amount of water given off by plaats during their growth, may throw some light on the subject we are discussing."

"Mr. Lawes found," continued the Doctor, " that a rheat-plant, fiom Mareh 19 to June 28, or 101 days, evaporated inrough its leaves, etc., 45, 113 grains of water; while a clover-plan', standing alongside, and in precisely similar condition, evaporated 5.5,093 grains. The clover was cut June 28 , when in full bloom. The wheat-plant was allowed to grow until ripe, Sept. 7. From June 28 to Sept. 7 , or 72 days, the wheat-plant evaporated 67,814 grains."

"One moment," said the Deacon; "as I understand, the eloverplant evaporated more water than the wheat-plant, until the 28th of June, but that dnring the next 71 days, the wheat-plant evap. orated more water than it had during the previous 101 days." 
"Yes," said I, "and if these facts prove nothing else, they at least show that there is a great difficrence between wheat and clover. I was at Rothamsted when these experiments were macle. During the first nine days of the experiment, the cloverplant evaporatel 399.6 grains of water; while the wheat-plant, standine alongsi le, evaporated only 128.7 grains. In other words, the elover-plant evaporated thee times as much water as the wheat-plant. During the next 31 days, the wheat-plant evap. orated 1,267.8 gr:ins, and the clover-plant 1,643.0 grains; but dur ing the next $2 \pi$ days, from April 28 to May $2 \pi$, the wheat-plant evaporate.l 16?.t grains of water per day, while the dover-plant only evalporated 109.2 grains per lay. During the next 34 days, from $V_{\text {aty }}$.5 to June 28 , the wheat-plint evaporated 1,17\%.4 grains per day, and the elover-piant $1,473.5$ grains per day."

"In June," said the Deacon, "the rlover evalprates ten times as much water per day as it did in May. How much water would an acre of (clover evaporate?"

"Lect Charley figure it out," said the Doctor. "Suppose each

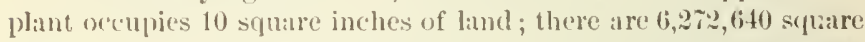
inches in an acre, and, conserpently, there would be 627,264 clover-plants on an acre. Each plant evaporated 1,473.5 graine per diy, and there are $\tau, 000$ grains in a pound."

Charley" mate the calculation, and found that an acre of clover, from Maty 25 to June 28 , evaporated 528,598 lbs. of water, or 15,54 lins. jer day.

A much more aceurate way of aseertaining low much water an acre of elover evilporates is afforded 10 by these experiments. After the plants were cut, they were weirhed and analyzed; and it being known exactly how much water each plant hat given of during its growth, we have all the facts necessary to tell us just how much a crop of a given weight would evaporate. In brief, it was found that for each pound of clry substance in the wheatplant, 24\%.t lbs. of water had heen evalporated; and for each pouncl in the clover-plant, $269.113 \mathrm{~s}$.

An acre of wheat of 1.j bushels per acre of grain, and an equal weight of straw, would exhale during the spring and summer $17 \%$ toms of water, or ealeulated on 172 days, the duration of the experiment, $2,05 \tilde{5}$ lbs. per day.

An acre of clover that would make two tons of hay, would pass off through its leaves, in 101 days, 430 tons of water, or 8,600 lbs. per day-more than four times as much as the wheat.

These figures show that, from an agricultural point of view; there is a great difference between wheat and clover; and yet I 
tinink the figures lo not show the whole of the difference. The elover was eut just at the time when the wheat-plant was entering on its periocl of most raphicl growtl and cxbalation, and, consequently, the figures given above probably exaggerate the amount of water given otf by the wheat during the early part of the seasons. It is, at any rate, quite clear, and this is all I want to show, that an acre of gool elorer exlisles a munch larger anount of water from spring to hay-larvest than an acre of wheal.

"And what," saicl the Deacon, who was evilently gretting tired of the figures, " loes all titis prore?"

The figures prove that clover can drink a much greater quantity of water during Mareh, April, May, and June, than wheat; and, conseynently, to get the sime amomint of food, it is not necessary that the clover should lave as much nitrogen, phosphoric acil, potasl, etc., in the water as the wheat-julant requires. I do not know that I make myself understood."

"You want to slow," saill the Deacorl, "that the wheat-plant requires rieher food than clover."

Yes, I want to show that, though clover lecpuires more foul per day thim wheat, yet the dover can drink such a large amomnt of water, that it is mot necessary to make the "sap of tha soil" so rich in nitrogen, phosphoric acil, and potash, for clover, as it is for wheat. I think this tells the whole story.

Clover is, or may he, the irrandest renovating and enriching crop commonly grown on our farms. It owes its great value, not to any power it may or may not possess of getting nitrogen from the atmosphere, or plosphoric acid and potash from the subsoil, but principally, if not entirely, to the faet that the roots can alrink up such a large amount of water, and live and thrive on very weak food.

\section{HOW TO M.AKE A FARM RICH BY GROWIXG CLOVER.}

Not by growing the clover, and selling it. Nothing would exhaust the land so rapidly as such a practice. We must either plow under the clover, let it rot on the surface, or pasture it, or use it for soiling, or make it into hay, fecd it out to stock, and return the manure to the lind. If clover got its nitrogen from the atmosp'rcre, we inight scll the clorer, and depend on the roots left in the groune, to enrich the soil for the next crop. But if, as I have endearored to show, clover gets its nitrogen from a weak solution in the soil, it is clear, that though for a year or two we might raise good crops from the plint-fool left in the clover-roots, yet we 
should soon find that growing a crop of clover, and leaving only the roots in the soil, is no way to permanently enrich land.

I do not say that such a practice will "exhaust" the laud. Fortunately, while it is an easy matter to impoverish land, we should have to call in the aid of the most advanced agricultural science, before we could "exhaust" land of its plant-food. The free use of Nitrate of Soda, or Sulphate of Ammonia, might enable us to do something in the way of exhausting our farms, but it, would reduce our balance at a bank, or send us to the poor-house, before we had fully robhed the land of its plant-food.

To exhaust land, by growing and selling clover, is an agricultural inpossibility, for the simple reason that, long before the soil is exhausted, the elover would produce such a poverty-stricken crop, that we should give up the attempt.

We can make our land poor, by growing elover, and selling it; or, we can make our laud rich, by growing clover, and feeding it out on the farm. Or, rather, we can make our land rich, by draining it where needed, cultivating it thoroughly, so as to develope the latent plant-food existing in the soil, and then by growing clover to take up and organize this plant-food. This is how to make land rich hy growing clover. It is not, in one sense, the clover that makes the land rich; it is the draining and cultivation, that furnishes the ford for the clover. The clover takes up this food and concentrates it. 'The clover does not create the plantfood; it merely sares it. It is the thorough cultivation that enriches the land, not the elover.

"I wish," writes a distinguished New York gentleman, who has a farm of harren sand, "you would tell us whether it is best to let clover ripen and rot on the surface, or plow it under when in blossom? I have heard that it gave more nitrogen to the land to let it ripen and rot on it, but as I am no chemist, I do not know."

If, instead of plowing under the clorer-say the last of June, it was left to grow a month longer, it is quite possible that the cloverroots and seed would contain more nitrogen than they did a month earlier. It was formerly thought that there was a loss of nitrogen during the ripening process, but the evilence is not altogether conclusive on the point. Still, if I had a piece of sandy land that I wished to enrich by clover, I do not think I should plow it under in June, on the one liand, or let it grow until maturity, and rot down, on the other. I should rather prefer to mow the erop just as it commenced to blossom, and let the clover lie, spread out on the land, as left by the machine. There would, I think, be no loss of fertilizing elements by evaporation, while the clover-hay would act 
as a mulch, and the second growth of clover would be encouraged by it. How this second crop again, about the first week in August. Then, unless it was desirable to eon tinue the process another year, the land might be plowed up in two or three weeks, turning under the two previous crops of clover that are on the surface, together with the green-clover still growing. I believe this would be better than to let the clover exhaust itsclf by running to seed.

\section{CHA P TER XXT.}

\section{DR. VELCKER'S EXPERINENTS ON CLOVER.}

In the Journal of the Royal Agricultural Society of England, for $1 \times 68$, Dr. Volcker, the able chemist of the Society, and formerly Professor of Agricultural Chemistry, at the Royal Agricultural College at Cirencester, England, has given us a paper "On the Causes of the Benefits of Clover, as a preparatory Crop for Wheat." The paper has been repeatedly and extensively quoted in this country, but has not been as critically studied as the importance of the subjert demands.

"Never mind all that," said the Deacnn, "tell us what Dr. Volcker says."

"Ilere is the paper," said I, "and Charley will read it to us." Charley read as follows:

"Agricultural chemists inform us, that in orler to maintain the productive powers of the land unimpaired, we must restore to it the phosphoric acid, potash, nitrogen, and other substances, which enter into the composition of our farm crops; the constant removal of organic and inorganic soil constituents, by the crops usually sold off the farm, leading, as is well known, to more or less rapid deterioration and gradual exhaustion of the land. Even the best wheat soils of this and other countries, become more and more imporerished, and sustain a loss of wheat-yicleling power, when corncrops are grown in too rapid succession without manure. Hence, the universal practice of manuring, and that also of consuming oilcake, corn, and similar purchase 1 food on land naturally poor, or partially exhausted by previous cropping.

"Whilst, however, it holds good as a general rule, that no soil can be cropped for any length of time, without gradually becoming 
more and more infertile, if no mannre be applied to it, or if the fertilizing elements removed by the crops grown thereon, be not by some means or other restored, it is, nevertheless, a fact, that after a heavy crop of clover earried off as hay, the land, far from being less fertile than before, is peculiarly well adapted, even without the addition of manure, to bear a good crop of wheat in the following year, provicled the season be favorable to its growth. This fact, indeed, is so well knowu, that many farmers justly regard the growth of clover as one of the best preparatory operations which the land can undergo, in order to its producing an abundant crop of wheat in the following year. It has further been noticed, that clover mown twice, leaves the land in a better condition, as regards its wheat-producing capabilities, than when mown once only for hay, and the second crop fed off on the land by sheep; for, notwithstanding that in the latter instance the fertilizing elements in the clover-crop are in part restored in the sheep exerements, yet, contrary to expectation, this partial restoration of the elements of fertility to the land has not the effect of producing more or better wheit in the following year, than is reaped on land from off which the whole clover-crop has been carried, and to which no manure whaterer has been applied.

"Again, in the opinion of sereral good, practical agriculturists, with whom I have conversed on the subject, land whereon elover has been growu for seed in the precerling year, yields a better crop of wheat than it does when the elover is mown twice for hay, or even only once, and afterwaris fed off by sheep."

"I do not think," said the Deaeon, "that this agrees with our experience here. A good erop of clocer-seed is profitable, but it is thought to be rather liard on land."

"Such," said I, " is the opinion of John Johnston. He thinks allowing clover to gro to seerl, impoverishes the soil."

Charley, contimued to read:

"Whatever may be the true explanation of the apparent anomalies conneeted with the growth and chemical history of the cloverllint, the facts just mentioned, laving been noticed, not once or twice only, or by a solitary observer, bint repeatedly, and by numhers of intelligent farmers, are ecrtainly entitled to eredit; and little wislom, as it strikes me, is displayed by calling them into question, because they happen to contradict the prevailing theory, according to which a soil is sail to become more or less impoverished, in proportion to the lirge or small amount of organic and mineral soil constituents carried off in the produce." 
"That is well said," I remarked, "and very truly; but I will not interrupt the reading."

"In the course of a long residence," continues Dr. Volcker, "in a purely agricultural district, I have often been struck with the remarkably healthy appearince and good yield of wheat, on land from which a heary crop of clover-hay was obtained in the preceding year. I have likewise had frequent opportunities of observing, that, as a rule, wheat grown on part of a ficld whereon elover has been twice mown for hay, is better than the produce of that on the part of the same field on which the elover has been mown only once for hay, and afterwards fed off hy sheep. These observations, extending over a number of years, led me to inquire into the reasons why clover is specially well fitted to prepare land for wheat; and in this praper, I shall endearor, as the result of my experiments on the subject, to give an intelligible explanation of the fact, that clover is so excellent a preparatory erop for wheat, as it is practically known to be.

"By those taking a superficial riew of the sulject, it may be sug. gested that any injury likely to be cansed by the removal of a certain amount of fertilizing matter, is altogether insignificant, and more than empensited for, by the henefit which results from the abundant growth of elover-roots, and the physical improvement in the soil, which takes place in their decomposition. Looking, howerer, more closely into the matter, it will be found that in a good crop of elover-hay, a very considerable amount of both mineral and organic substances is carried ott the land, and that, if the total amount of such constituents in a crop had to be regarded exclusirely as a measure for determining the relative legrees in which different farm crops exhaust the soil, clover would have to be described as about the most exhausting crop in the entire rotation.

"Clorer-luay, on an arerage, and in round numbers, contains in 100 parts :

Water.

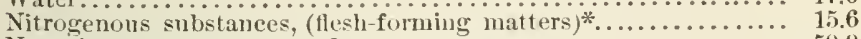

Non-nitrogenous compounds........................... 59.9

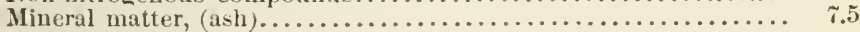

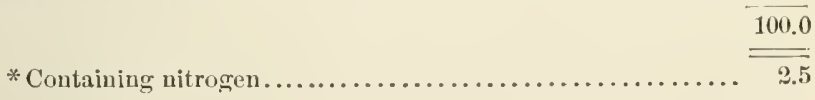

"The mineral portion, or ash, in 100 parts of clover-hay, consists of : 
Phosphoric acid................................ $\quad 7.5$

Sulphuric aeid........................................... 4.3

Carbonic acid........................................ 18.0

Silica .................................................. $\quad 3.0$

Lime................................................ 30.0

Magnesia............................................ 8.5

Potash.................................................. 20.0

Soda, chloride of sodium, oxide of iron, sand, loss, etc.......... 8.7

"Let us suppose the land to have yiclded fonr tons of clover-hay per acre. According to the preceding data, we find that such a crop includes 224 lbs. of nitrogen, chual to 272 lbs. of ammonia, and $672 \mathrm{lbs}$. of mineral matter or ash constituents.

In 672 llss, of clover-ash, we find:

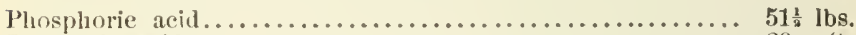

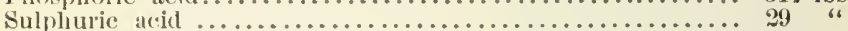

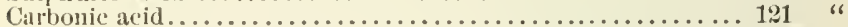

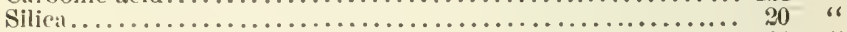

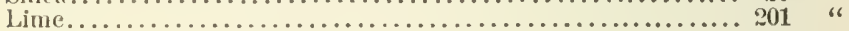

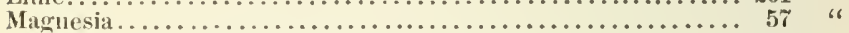

Potash ........................................... $134 \frac{1}{4}$ "

Soda, ehloride of sodium, oxide of iron, sand, ete.......... 58 "

$67 \overline{\mathrm{Ibs}}$.

"Four tons of clover-hay, the produce of one acre, thus contain a large amount of nitrogen, and remove from the soil an enormons quantity of mineral matters, abounding in lime and potash, and containing also a good deal of phosphoric acid.

"Leaving for a moment the question untonched, whether the nitrogen contained in the clover, is derived from the soil, or from the atmosphere, or partly from the one, and partly from the other, no question can arise as to the original sonrce from which the mineral matters in the clover produce are derived. In relation, therefore, to the ash-constituents, clover must be regarded as one of the most exhausting crops usually cultivated in this country. This appears strikingly to he the case, when we compare the prereding figures with the quantity of mineral matters which an average crop of wheat removes from an acre of land.

"The grain and straw of wheat contain, in round numbers, in 100 parts:

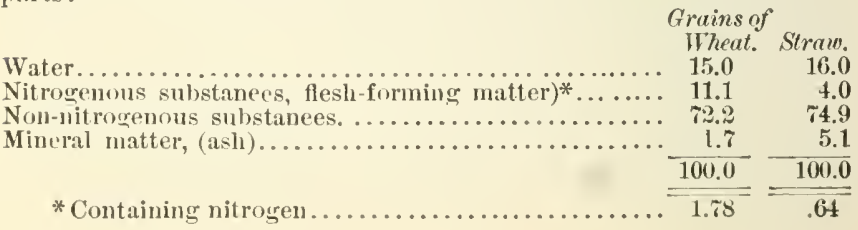


"The ash of wheat contains, in 100 parts :

\begin{tabular}{|c|c|c|}
\hline ic acid $\ldots \ldots \ldots \ldots \ldots \ldots \ldots \ldots \ldots \ldots \ldots \ldots \ldots \ldots \ldots \ldots \ldots$ & $\underset{50.0}{\text { Grain. }}$ & $\begin{array}{r}\text { Straw. } \\
5.0\end{array}$ \\
\hline 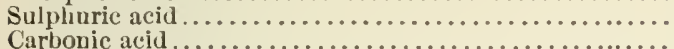 & 0.5 & 2.7 \\
\hline 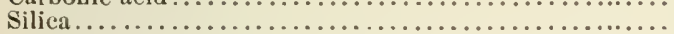 & 25 & 60 \\
\hline (n. & 3. & or. \\
\hline 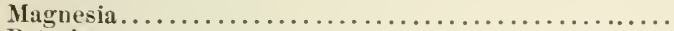 & 11.5 & 2.0 \\
\hline$\ldots \ldots \ldots \ldots \ldots \ldots \ldots \ldots \ldots \ldots \ldots$ & 30.0 & 13.11 \\
\hline ua, & 2.0 & \\
\hline & (1) & 100.0 \\
\hline
\end{tabular}

"The mean produce of wheat, ner acre, may be estimeted at 25 bushels, which, at $60 \mathrm{Jbs}$. per bushel, gires $1,000 \mathrm{lbs}$; and as the weight of the straw is generally twice that of the grain, its produce will be 3,000 lus. According, therefore, to the preceding data, there will be carried away from the soil:

In $1,500 \mathrm{lbs}$. of the grain. . $25 \mathrm{lbs}$. of mineral food, (in round numbers). In $3,000 \mathrm{lbs}$. of the straw.. $150 \mathrm{lbs}$ of mineral food, (in round numbers).

Total $175 \mathrm{lbs}$.

"On the average of the analyses, it will be found that the composition of these 175 lbs. is as follows:

Phosphoric acid

Sulphuric acid.

Carbonic acid

Silica.

Lime.

Macnesia.

Potash

Soda, chloride of sodium, oxide of irui, sand, etc.

"The total quantity of ash constituents carried off the land, in an average crop of wheat, thus amounts to only 1ii liss. per acre, whilst a good crop of clover removes as much as $672 \mathrm{lbs}$.

"Nearly two-thirds of the total amount of mineral in the grain and straw of one acre of wheat, consists of silica, of which there is an ample supply in almost erery soil. The restoration of siliea, therefore, need not trouble us in any way, especially as there is not a single instance on record, proving that silica, eren in a soluble condition, has ever been applied to land, with the slightest alvantage to corn, or grass-crops, which are rich in silica, and which, for this reason, may be assumed to be particularly grateful for it in a soluble state. Silica, indeed, if at all capable of producing a beneficial effect, ought to be useful to these crops, either by strengthening the straw, or stems of graminaceous plants, or otherwise beneiting them; but, after deducting the amount of silica from the 
total amount of mineral matters in the wheat produced from one acre, only a trifling quantity of other and more valuable fertilizing ash constituents of plants will be left. On comparing tine relative amounts of phosphorie acid, and potash, in an average crop of wheat, and a good crop of clover-hay, it will be seen that one acre of elover-hay contains as much phosphoric acid, as two and onehalf acres of wheat, and as much potash as the produce from five acres of the same crop. Clover thus unquestionably removes from the land very much more mineral matter than does wheat; wheat, notwithstanding, succeeds remarkably well after clover.

"Four tons of elover-hay, or the produce of an aere, contains, as already stated, 224 lbs. of nitrogen, or calculated as ammonia, $2 \% 2$ lbs.

"Assuming the grain of wheat to furnish 1.78 per cent of nitrogen, and wheat-straw, .64 per cent, and assuming also that 1,500 lbs. of corn, and 3,000 lbs. of straw, represent the average produce per acre, there will be in the grain of wheat, per acre, 26.7 lbs. of nitrogen, and in the straw, 19.2 lbs., or in both together, 46 lbs. of nitrogren; in round numbers, equal to about 55 lbs. of ammonia, which is only about one-fifth the quantity of nitrogen in the produee of an acre of clover. Wheat, it is well known, is specially benetited by the application of nitrogenous manures, and as clover carries off so large a quantity of nitrogen, it is natural to expect the yield of wheat, after clover, to fall sliort of what the land might be presumed to produce without manure, before a crop of clover was taken from it. Experience, however, has proved the fallacy of this presumption, for the result is exactly the opposite, inasmuch as a better and hearier crop of wheat is produced than without the intercalation of clover. What, it may be asked, is the explanation of this apprarent anomaly?

"In talking "1 this inquiry, I was led to pass in review the celebratel and highly important experiments, undertaken by Mr. Lawes and Dr. Gilhert, on the continued growth of wheat on the same soil, for a long succession of years, and to examine, likewise carefully, many points, to which attention is drawn, by the same anthors in their memoirs on the growth of rad clover by different manures, and on the Lois Teedon plan of growing wheat. Abundant and most envineing evidence is supplied by these indefatigable expreimenters, that the wheatproducing powers of a soil are not increased in any sensible degree by the liheral supply of all the mineral matters, which enter into the emmosition of the ash of wheat, and that the abstration of these mineral matters from the soil, in any mueh larger proportions than ean possibly take place 
under ordinary cultivation, in no wise affects the yiele of wheat, provided there be at the same time a liber.ul supply of available nitrogen within the soil itself. The amount of the latter, therefore, is regarded by Messis. Lawes and Gilbert, as the measure of the increased produce of grain which a soil furnishes.

"In conformity with these views, the farmer, when he wishes to increase the yield of his wheat, finds it to his advantage to have recourse to ammoniacal, or other nitrogenous manures, and depends more or less entirely upon the soil, for the supply of the neccessary mineral or ash-constituents of wheat, having found such a supply to be amply sufficient for his requirements. As far, thercfore, as the removal from the soil of a large amount of mineral soil-constituents, by the clover-crop, is concerned, the fact viewed in the light of the Rothamsted experimeuts, becomes at once intelligible ; for, notwithstanding the abstraction of over $600 \mathrm{lbs}$. of mineral matter by a crop of clover, the succeeding wheat-crop does not suffer. Inasmuch, however, as we have secn, that not only much mineral matter is carried off the land in a crop of clover, but also much nitrogen, we might, in the abscnce of direct evidence to the contrary, be led to suspect that wheat, after clover, would not be a good crop; whereas, the fact is exactly the reverse.

"It is worthy of notice, that nitrogenous manures, which have such a marked and bencficial effect upon wheat, do no good, but in certain combinations, in some seasons, do positive harm to clover. Thus, Messrs. Lawes and Gilbert, in a series of experiments on the growtl of red-clover, by different manures, obtained 14 tons of fresh green produce, equal to about three ant threefourths tons of clover hay, from the unmanured portion of the experimental field; and where sulphates of potash, soda, and magnesia, or sulphate of potash and superphosphate of lime were $\mathrm{cm}$ ployed, 18 to 18 tons, (ecpual to from ahout four and one-half to nearly five tons of hay), were obtained. When salts of ammonia were added to the mineral manures, the produce of clover-hay was, upon the whole, less than where the mineral manures were used alone. The wheat, grown after the clover, on the unmanured plot, gave, however, $29 \frac{1}{2}$ bushels of corn, whilst in the arljoining field, where wheat was grown after wheat, withont manure, only 1 is $\frac{1}{2}$ bushels of corn per acre were obtained. Messrs. Lawes and Gilbert notice especially, that in the clover-crop of the preceding year, very much larger quantities, both of mineral matters and of nitrogen, were taken from the land, than were removed in the unmanured wheat-crop in the same year, in the adjoining field. Notwithstanding this, the soil from which the clover had been 
taken, was in a condition to yicld 14 bushels more wheat, per acre, than that upon which wheat hat been previously grown; the yield of wleat, after clover, in these experiments, being fully equall to that in another fiedd, where large quantities of manure were used.

"Taking all these circumstances into accuunt, is there not presumptive evidenee, that, notwithstanding the removal of a large amount of nitrogen in the elover-hay, an abundant store of avilable nitrogen is left in the soil, and also that in its relations towards nitrogen in the soil, clover differs essentially from wheat? The results of our experience in the growth of the two crops, appear to indicate that, whereas the growth of the wheat rapidly exlausts the land of its a vailahle nitrogen, that of elover, on the contrary, tents somehow or other to acemulate nitrogen within the soil itself. If this ean lo shown to be the case, an intelligrible explanation of the fact that (eover is so useful as a preparatory crop for whe:1t, will be fomml in the circumstance, that, during the growth of elover, nitronenous fool, for which whent is particularly grrateful, is either stored up or rondered available in the soil.

"An explanation, howerer plansible, cam hardly be acepoled as correct, if based mainly on dita, which, although highly probahle, are not proved to lo based on fact. In chemicial incpuiries, especially, nothine must he taken for grauted, that has not been proved liy direde experiment. "The followinge fuestions naturally slererest themselves in reforence to this suloject: What is the amount of nitrogen in solils of dillerent rharacters? What is the

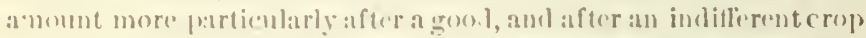
of elover? Why is the amount of nitrogen in soils, larger after cherer, than after wheat and oflece eropse? Is the nitrogen present in a comblition in which it is avalablie and useful to wheat? And lastly, are there any other riremustanees, apart from the suply of nitrogenous matter in the suil, which help to alecomt for the benetiveial efferes of cluser as al prepalratery crop for wheat?

"In order to throw some light on these upestions, and, if possible, to grive distinct answers to at least some of them, 1, years :uru, when resilling all (Cirencester, bewan a series of experiments; and more recently, I have heen fortmate enongh to ohtain the cooperations of Mr. Robert Valentine, of Leighton Buzzarl, who kindly mulertook to supply me with materials for my analysis.

" Jy first experiments were male on a thin, caleareous, clay soil, resting on oolitie limestonc, and proeluciner ereuerally a fair crop of red-elover. The clover-field formed the slope of a rather steep litlerek, and varied much in depth. At the top of the hill, the soil became very stony at a depth of four inches, so that it could only 
with difticulty be exeavated to a depth of six inches, when the bare limestune-rock matle it: alpunarance. At the bettom of the tiold the soil was mueh deeper, and tue cherer strumere than at the upper part. On the brow of the hill, where the clover alpereared to be stromg, a square yard was metasurel oat ; and at at litle distance ofl, where the clover was very hatl, a secombl seflatre yald wats mealsureel; in both phots, the soil leciner take'n up to a depth of six

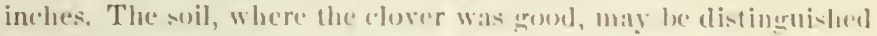
from the other, by being marked as No. 1, and hat where it wats bal, as No. :

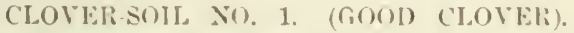

"The root- having tirst heen shatien out to free them as much as possible from the soil, were the'n washed one or twien with could distilled water, and, after liaving leen dried for a litte while in the sun, were weighed, when the syuare yard produced $1 \mathrm{lh} .101 \mathrm{gz}$. of ceanced cluser-ruts, in an air-liry stute; an acre of lamt, or 4,840 square yards, accordinerly yieleled, in a cepth of six inches, 3.44 tons, or $3 \frac{1}{2}$ tons in round numbers, of (lover-routs.

"Fully dried in a water-bath, the roots were found to (ontain altugether H4fi per cent of water, and wh hing hurut in a platinum capsule, yicleded (i.ts? of :1-h. I portion of the dried, fincly powdered and well mixed ronts, was hrmed with soda line, in a comlustion tule, and the nitrogen contained in the reotsotherwise determined in t'.e ustul way. Acourdingly, the following is the general compusition of the ronts from the stil No. 1 :

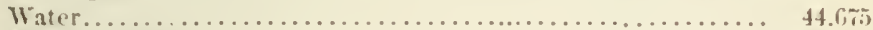

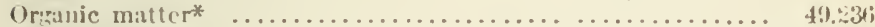

Mtineral inatter ................................. 6.099

-100.000
$=$

* Containing nitrogren.......................... 1.29i

Equal to ammonia............................... 1.575

"Assuming the whole ficlel to have produced $3 \frac{1}{2}$ tons of cloverroots, per acre, there will be $99.6: 36 \mathrm{lbs}$, or in round numbers, 100 lbs. of nitrogen in the clover-ponts from one ace; or, about twice as much nitrogen as is present in the average produce of an acre of whent."

"That is a remarkahle faet," said the Deacon, "as I understand nitrogen is the great thing needed by wheat, and yet the roots alone of the clover, contain twice as much nitrogen as an average crop of wheat. Go on Charley, it is quite interesting."

"The soil," continues Dr. Velcker, "which had been separated from the roots, was passed through a sicve to deprive it of any stones it might contain. It was then partially dried, and the nitro 
gen in it determined in the usual manner, hy combustion with sodalime, when it yielded .313 per cent of nitrogen, equal to .38 of ammonia, in one combustion; and .373 per cent of nitrogen, equal to .46 of ammonia, in a second determination.

"That the reader may have some idea of the character of this soil, it may be stated, that it was further submitted to a general analysis, according to which, it was found to have the following composition :

GENELAL COMPOSITION OF SOIL, NO. 1. (GOOD CLOVER). Moisture................................... 18.73

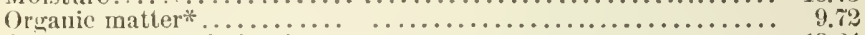

Oxide of irom and alumina................................... 13.24

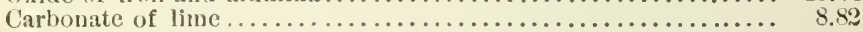

Magnesia, alkalies, etc................................. $1 ., 2$

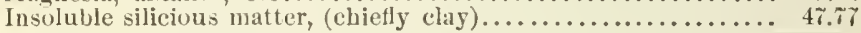

100.10

* Containing nitrogen .............................313

Equal to ammonia.................................... 380

"The second stuare yard from the brow of the hill, where the clover was bad, produced 13 ounces of a $\mathrm{r}$-dry, and partially clean roots, or 1.75 tons per aere. On analysis, they were found to have the following composition:

\section{CLOVER-ROOTS, NO. 2 (BAD CLOVER).}

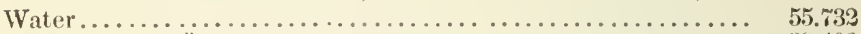

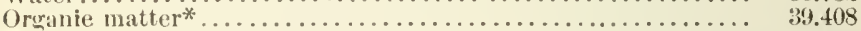

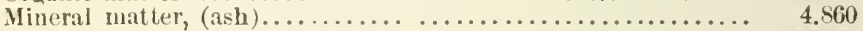

* Containing nitrogen.......................

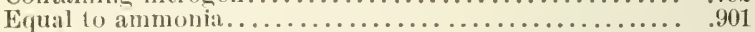

"The roots on the spot where the clower was very bal, yielded only 31 lbs. of nitrogen per acre, or scarcely one-third of the quantity which was obtained from the roots where the elover was good.

"The soil from the sccond stuare yard, on analysis, was found, when freed from stones by sifting, to contain in 100 parts:

COMPOSITION OF SOIL, NO. 2. (BAD CLOVER).

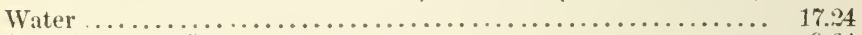

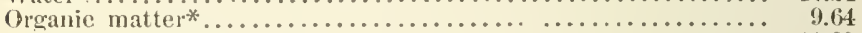

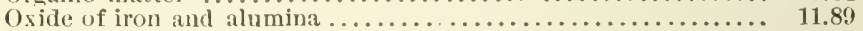

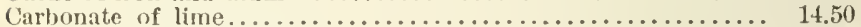

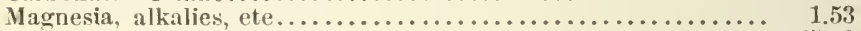

Insoluble silicious matter................................ 45.:0

100.00

2 deter-

Equal to ammonia.......................... 
"Both portions of the clover-soil thus contained about the same percentage of organic matter, and jielded nearly the same amount of nitrogeu.

"In addition, however, to the nitrogen in the clocer-roots, a good deal of nitrogen, in the shape of root-fibres, decayed leaves, and similar organic matters, was disseminated throughout the fine soil in which it oecurred, and from which it could not be separated; but unfortunately. I neglected to weigh the soil from a square yard, and am, therefore, unable to state how much nitrogen per acre was present in the shape of small root-fibres and other organic matters.

"Before mentioning the details of the experiments made in the next season, I will here give the composition of the ash of the partially cleaned clover-roots :

\section{COMPOSITION OF ASH OF CLOVER-ROOTS, (PARTLALLY CLEANED).}

Oxide of iron and alnmina......................... 11. i $_{3}$

Lime............................................. 18.49

Magnesia....................................... $\quad 3.03$

Potash .............................................. 6.88

Soda......................................... 1.93

Phosphoric acid................................... 3.61

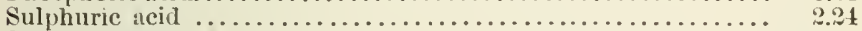

Soluble silica ..................................... 19.01

Insoluble silicious matter............................ 24.83

Carbonic acid, chlorinc, and loss.................... 8.25

"This ash was obtained from elover-roots, which yielded, when perfeetly dry, in round numbers, eight per cent of ash. Cloverroots, washed quite clean, and separated from all soil, yield about five per cent of ash; but it is extrencly difficult to clean a large quantity of fibrous roots from all dirt, and the preceding analysis distinctly shows, that the ash of the clorer-roots, analyzed by me, was mechanically mixed with a good deal of fine soil, for oxicle of iron, and alumina, and insolnble silicious matter in any quantity, are not normal constituents of plant-ashes. Making allowance for soil contamination, the ash of clover-routs, it will be noticed, contains much lime and potash, as well as an appreciable amount of pinsphoric and sulphuric acil. On the decay of the clover-roots, these and other mineral fertilizing matters are left in the surfacesoil in a readily available condition, and in considerable proportions, when the clover stands well. Although a crop of elover removes much mineral matter from the soil, it must be borne in mind, that its roots extract from the land, soluble mineral fertiliz- 
ing matters, which, on the decay of the roots, remain in the land in a prepared and more reatlily available form, than that in which they originally oceur. The benefits arising to wheat, from the growth of clover, may thus be due partly to this prepanaion and concentration of mineral food in the surface-soil.

"The clover on the hillside field, on the whole, turned out a very good crop; and, as the plant stood the winter well, and this field was left another season in clover, without being plowed up, I arailed myself of the opportunity of making, during the following season, a number of experiments similar to those of the preceling year. This time, howerer, I selecterl for examination, a square yard of soil, from a spot on the brow of the hill, where the clover was thin, ant the soil itself stony at a depth of four inches; and another plot of one scluare yard at the bottom of the hill, from a place where the cluver was stronger than that on the brow of the hill, and the soil at a depth of six inches contained no large stones.

SOIL NO. 1. (CLOVER THIN), ON TIIE BROW OF THE HILL.

"The roots in a square yard, six inches deep, when picked out by hand, and cleaned as much as possible, wcighed. in their natural state, 2 lhs. $11 \mathrm{oz}$; and when dried on the top of a water-bath, for the purpose of eretting them lrittle and fit for reduction into fine powder, $1 \mathrm{lb}, 12 \mathrm{oz} .31$ grains. In this state they were submitted as before to analysis, when they yiched in 100 parts :

COMPOSITION OF CLOVER-ROOTS, NO. 1, (FROM BROW OF HILL).

Moisture....................................... 4.34

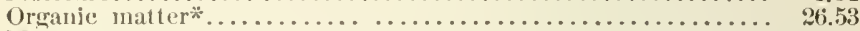

Mineral matter..................................... 69.13

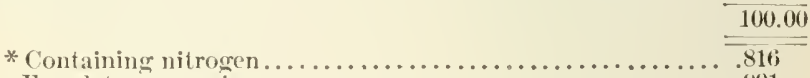

Equal to ammonia.........................................991

"According to these data, an acre of land will yield three tons $12 \mathrm{cwts}$ of nearly dry clover-roots, and in this quantity there will be about 66 lhs. of nitrogen. The whole of the soil from which the roots have been picked out, was passed through a half-inch sicre. The stones left in the sieve weighed $141 \mathrm{lbs}$; the soil which passerl through weighing 218 lhs.

"The soil was next dried by artificial heat, when the 218 lbs. beeame reduced to $185.487 \mathrm{lbs}$.

"In this partially dried state it contained: 
Moisture................................. 4.21

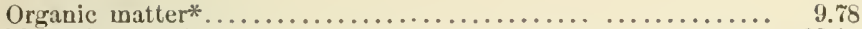

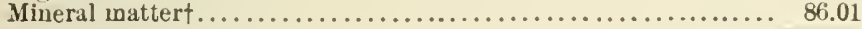

* Containing nitrogen ................................

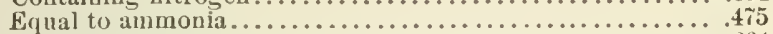

† Includiug phosphoric acid.........................

"I also determined the phosphorie acid in the ash of tìe cloverroots. Calculated for the roots in a nearly dry state, the phosphoric acid amounts to .287 per cent.

"An acre of soil, according to the data, furnished by the six inches on the spot where the elover was thin, produced the following quantity of nitrogen:

Ton. Cwts, Lbs.

In the fine soil

\begin{tabular}{rrr}
1 & 11 & 33 \\
0 & 0 & 66 \\
-1 & -11 & 93 \\
\hline
\end{tabular}

Total quantity of nitrogen per acre............ $1-11$

"The organic matter in an acre of this soil, which ean not be picked out by hand, it will be seen, contains an enormous quantity of nitrogen; and althougil, probably, the greater part of the roots and other remains from the clover-crop may not be decomposed so thoroughly as to yield nitrogenous food to the succeeding wheat-crop, it can scareely be doubted that a considerable quantity of nitrogen will become available by the time the wheat is sown, and that one of the chief reasons why clover benefits the succeeding wheat-crop, is to be found in the abundant supply of available nitrogenous food furnished by the decaying clover-roots and leaves.

\section{CLOVER-SOIL NO. 2, FROM THE BOTTOM OF THE HILL. (GOOD CLOVER.)}

"A square yard of the soil from the bottom of the hill, where the clover was stronger than on the brow of the hill, produced 2 Ibs. 8 oz. of fresh clover-roots; or $1 \mathrm{lb} .11 \mathrm{oz} .47$ grains of partially dried roots; 61 lbs. 9 oz. of limestones, and $239.96 \mathrm{lbs}$. of nearly dry soil.

"The partially dried roots contained:

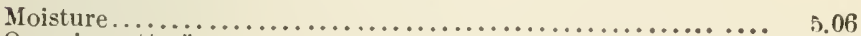

Organic matter*.......................................... 31.94

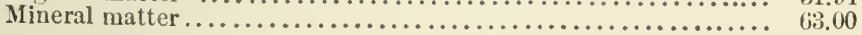

* Containing nitrogen $. \ldots \ldots \ldots \ldots \ldots \ldots \ldots \ldots \ldots \ldots \ldots . .804$

"An acre of this soil, six inches deep, produced 3 tons, $7 \mathrm{cwts}$. 65 lbs. of clover-roots, containing $61 \mathrm{lbs}$. of nitrogen; that is, there 
was very nearly the same quautity of roots and nitrogen in them, as that furnished in the soil from the brow of the hill.

'The roots, moreover, yielded 365 per cent of phosphoric acid; or, calculated per acre, $2 \tau$ lbs.

"In dle partially dried soil, I found:

Moisture..................................... $\quad 4.70$

Urganic natier*.................................... 10.87

'Lincral mattert..................................... 84.43

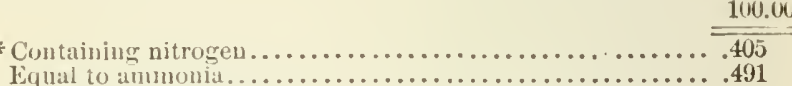

t Includiug phos phorie acid.......................... . 321

"According to these determinations, an acre of soil from the bottom of the hill, contains:

Toms. Curts. Lls.

Nitrogen in the ormanic matler of the soil.......... is : 0

Nitrogen in elover-roots of the soil ................ $0 \begin{array}{llll}0 & 0 & \text { (i1 }\end{array}$

Total amount of nitrogen peracre............

"Compared with the amount of nitrogen in the soil from the brow of the hill, about 11 ewt. more nitrogen was obtained in the soil and roots from the bottom of the lill, where the clover was more luxuriant.

"The increased amount of nitrogen occurred in fine root-filures and other oreanie matters of the suil, and not in the coarser bits of roots which were picked out by the hand. It may be assumed that the finer particles of organic matter are more readily decompose? thin the coarser roots; and as there was a larger amount of nitrogen in this than in the preceding soil, it may he expected that the land at the bottom of the liill, after removal of the clover, was in a better agricultural eondition for wheat, tlan that on the brow of the lill. 


\section{$\mathrm{C} I \Lambda \mathrm{P}$ ' E R X X V I.}

\section{EXPERIMENTS ON CLOYER-SOILS FROM BURCOTT LODGE FAISI, LEIGHTON BLZZARD.}

"The soils for the next experiments, were kindly supplied to me, in 1866, by liolert Valentine, of Burcott Lodge, who alson sent me some notes respecting the grow th and vicld of elover-bay and seed on this soil.

"Foreign seed, at the rate of $12 \mathrm{lhs}$. per acre, was sown with a crop of wheat, which yielded five quarters per acre the previous year.

"The first croly of clover was cut down on the 25th of June, 1866 , and carriel on June 30th. The weather was rery warm, from the time of cutting until the chever was carted, the thermometer standing at 80 Falur. every day. The clover was turned in the swath, on the second clay after it was ent; on the folisth day, it was turned orer and put into small heaps of about $10 \mathrm{llss}$. each; and on the fifth day, these were collected into larger cocks, and then stacked.

"The best part of an 11-acre field, produced nearly three tons of clover-hay, sum-lried, per acre; the whole ficld yichling on an average, $2 \frac{1}{2}$ tons per acre. This sesult was obtained by weighing the stack three months after the clover was carted. The second crop was cut on the 21st of $A$ uguot, and carried on the $2 \pi$ tl, the weight being nearly $30 \mathrm{cw}$. of hay per acre. Thus the two cuttings produced just about four tous of cliver-hay per acre.

"The 11 acres were diviled into two parts. Al,out one-half was mown for hay a second time, and the other part left for seed. The produce of the second half of the 11-acre field, was ent on the 8th of October, and carried on the 10th. It yielded in round numbers, $3 \mathrm{cwt}$ of clover-seed per acre, the season being very unfavorable for clover-seed. The second crop of clover, mown for lay, was rather too ripe, and just beginning to show seed.

"A square foot of snil, 18 inclies deep, was dug from the second portion of the land which produced the clover-hay and cloverseed.

SOIL FROM 'TART' OF 11-ACRE FIELD TWICE MOWN FOR HAY.

"The upper six inches of soil, one foot square, contained all the inain roots o? 18 strong plants; the next six inches, only small root fibres, anc? in the third section, a six-inch slice cut down at a 
deptls of 12 inches from the surface, no distince tibres could be found. The soil was almese rompletely saturated with rain when it was dug up on the 13th of seftember, 186t:

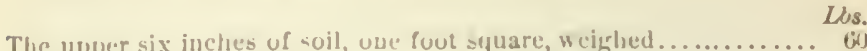
The sicund " The lhire " " "

"These throp purtions of une font of soil, is inclaes deep, were dried nearly munpletely, and wighlsed ng:in; when the tirst six

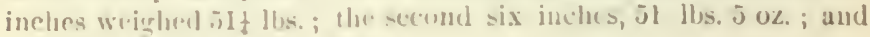

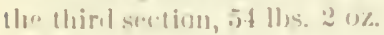

"The firs six inches rent him l 3 lbs. of silicinns stones, (llints),

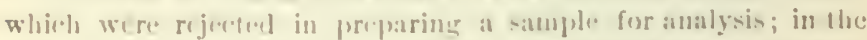
two rematinine seetion- there were an laree siond stumes. The suils were pennded down, and frese l throngh a wire sicve.

"The three layer of sil, dried amel refuced to peweler, wre

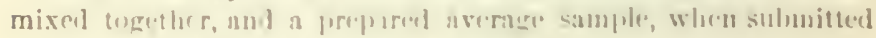

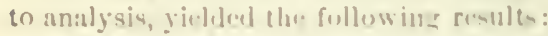

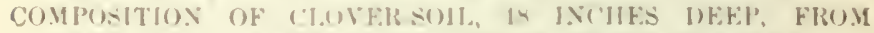
P.IRT OF 11.ACHE, FIEI.I), TWICE MUWN FUR HAY.

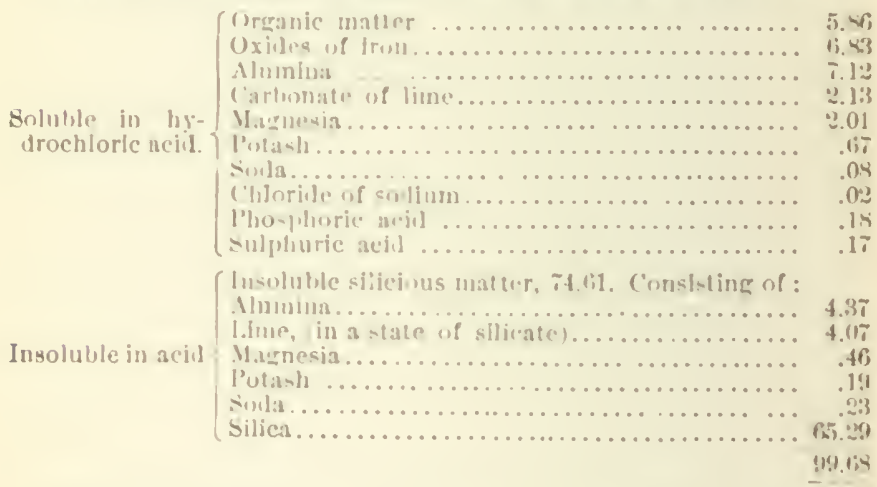

"This suil, it will he seen, cont:iner, in appreciable quantities, not only potash and phospherie acisl, but all the elemente of fortility which enter into the compustion of goosh arable land. It may he briefly described as a stiff elay soil, containing a sufficieney of

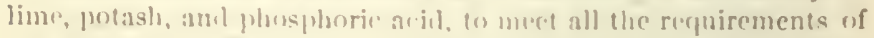
the cluverereps. Oriminally, rother unprodurtier, it has heen much improsed ly deep rulture; hy being smathed up into ronsh clouls, errly in autumn, and hy heing exposin) in this state (o) the crumbing effects of the air, it now yichls gooll corn and furnge crops. 
"In separate pertions of the three layers of soil, the propmertions of nitrogen and plisusphoric acid contained in each layer of six inches, were determined and found to the as foltows:

suil dried ut :21:2 eleg. Fizlor.

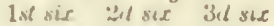
incluss, inclues, inclues.

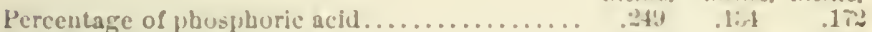

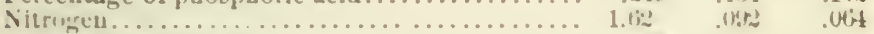

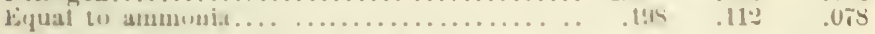

"In the "lyper six inclees, no will be secn, the perenentige of both phosphoric achel and nitrogen, was larger tinan in the $t$ mol following layers, while the propurtion of nitrogen in the six inches of surface soil, was much laserer than in the next six inclies; and in the

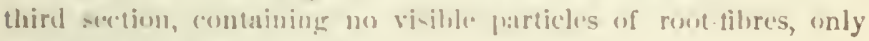
very litte nitrugen vecurred.

"In their natural state, the three layers of snil contained:

ineles. inches. incluss.

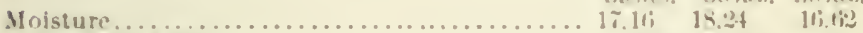

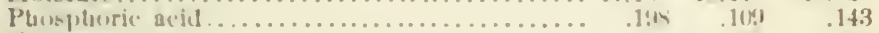

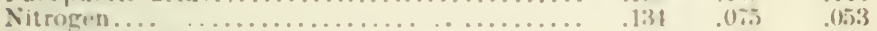

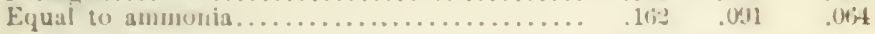

Weight of on. foot square of soil............. (id) lis of

"Calculated juer nere, the absulute weight of one acre of this land, six inclices cleep, wiglis:

Ihes.

Ist six inches............................... 2,613,610

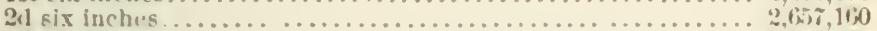

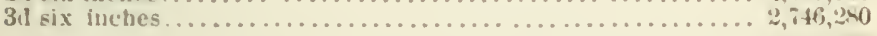

"No great erior, llirefore, will be madc, if we assume in the subsequent calculations, that six inches of this suil weiglıs wo and ode-lialf millions of pounils per acre.

"An acre of land, accurling to the preceling determinations, contains :

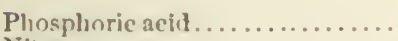

Nitrogen........................

1 st sir incles, 21 six inches, 3 d six inches, His. Lls. Libs.

4.9.50 2, $3,5 \%$

$3,350 \quad 1,8 \% 5 \quad 1,325$

Equal to ammionia........... $4,0,01 \quad$ - 2,275

"The proportion of phospluric acid in six inches of surface soil, it will he seen, amounted to about two-tenths per cent; a proportion of the whole soil, so small that it may appear insufficient for the production of a guod corn-crop. Ilwever, when caleulated th the acre, we find that six inclıes of surface soil in an acre of land, actually contain over two tons of plusploric acil. An average crop of wheat, assumed to he 25 busluels of grain, at $60 \mathrm{lbs}$. per 
bushel, and 3,000 11s. of striat, remores from the lind on which it is grown, 20 1ls. of phosphoric acid. The elover-soil anilyzed by me, consecpuently contatins an anount of pliosphoric acid in a depth of only six inches, which is cepual to that present in $247 \frac{1}{2}$ average crops of wheat; or supposing that, by groucl cultivation and in farorable suams, lue arerage yichl of wheat could be doubled, and 50 bushels of grain, all b0 1hs. a bushel, and 6,000 lbs. of straw could be raised, 124 if ste-h heary wheat-erops would contain no more phosphoric acid than accually oceured in six inches of this cluver-soil per acre.

"The mere presence of siach all amount of phosphoric acid in a soil, howerer, by no means proves its suflicichey for the production of so many (reples of wheat ; for, in the first place, it can not be shown that the whole of the pilus phoric acis found by analysis, occurs in the soll un a readily availathle combination; and, in the second plate, it is guit reptian that the rout filores of the wheatplant can not reach and pick np, so to speak, "rery particle of

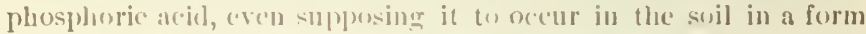
most conducire to 'realy assimilation hy lle plant.'

"The eabenlation is not given in pronf of a conclusion which would le manifestly alsurd, lut simply as an illu-tration of the enormous (fuantity in an a (Te of soil six inclues depe, of a constituent lorming the subiller propurtions of the whole weinlit of an acre of soil of that limiterl (le f)th. It slows the existence of a pracfically unlimitud amonut of tluc mot important mineral constitucuts of plants, and clarly puints out t!c propriety of remdering available to plants, the natural resources of the soil in plantfood ; to draw, in fact, up, the mincral wealth of the soil, by thorongly working the land, and not lavingr it unutilized as so much dead capital."

"Good," said the Dencon, "that is the riglit doetrine."

"The roots," continues Dr. Treldicr, "from one square foot of soil were cleined as much as possible, dried completely at $212^{\circ}$, and in that state weighed 240 gratins. An acre consequently contained $1,493+1$ lbs. of dried (elover-routs.

"Tlie elover-roots contained, dried at 212 Fahr.,

Organic matter*............................. 81.33

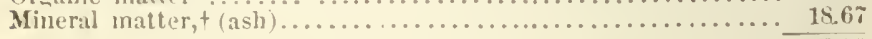

* Yichling nitrogen.......................... 1.6.5

Fr(nal ti) ammonia.................................... 1.9k

tIncluding insoluble silicions matter, (elay and Eand)....... $11.6 t$ 
"Accurdingly the clover-roots in an are of land furuished 241 lbs. of nil rogen. We have thus:

Lis. of nitrogen.

In the sir inches of surface foil .................... 3, ,iino

In large elover-roots.................................

In seeond six inches of soit ............................. 1,8it

Total amonut of nitrogen in sne acre of soil 12 inclues deep.... 5,249?

Equal to ammonia.............................. $6,3 \pi t !$

Or in round numbers, two tons six ewt. of nitrogen per aere; an enormous guantity, which must have a powerful influence in encouraging the luxuriant deselopment of the sneceeding wheaterop, althongh only a fraction of the total amount of nitrogen in the elover remains may become sufticiently decomposed in time to be avilable to the young wheat-plants.

CLOVER-SOIL FROM PART OF 11-ACRE FIELD OF BLRCOTT LODGE FARM, LEI(IITON BLZZARD, ONCF, MOWN FOR HAY, AND I.EFT AFTERWARDS FOR SEED.

"Produce $2 \frac{1}{2}$ tons of elover-laty, and $3 \mathrm{cwt}$. of seed per aere.

"This soil was obtained within a distance of tive yards from the part of the field where the wil was dug up after the two euttings of hay. After the seel there was some difficulty in finding a square foot containing the same number of large clover-roots, as that on the field twice mown; however, at last, in the beginning of November, a square foot containing exactly 18 strong roots, was found and dug up to a depth of 18 inches. The soil dug after the seed was much drier than that dug after the two cuttings of hay :

The upper six inches deep, one foot square, weighed......... 55 lbs. The next
The third "

The third " "

"After drying by exposure to hot air, the three layers of soil weighed:

The upper six inches, one foot square.............. $497 \mathrm{lbs}$.

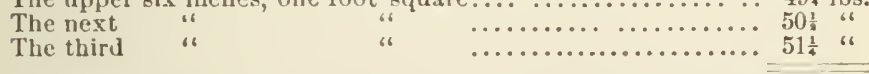

"Equal portions of the dried soil from each six-inch section were mixed together and reduced to a fine powder. An average sample thus prepared, on aualysis, was found to have the following composition: 
COMPOEITION OF (IOLER-AOL, (INCE, MOWX FOR HAY, AND AFTERWARIS LEFT FOIR SEEL. DRIEI) AT 212 FALR.

Soluble in liy-

Insolubli in acil
Organic matter................... 5.34

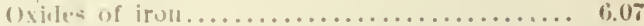

Alumina ........................ 4.51

Cirlunate of lime................... $\mathbf{6 1}$

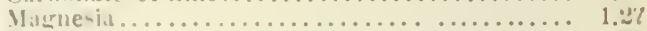

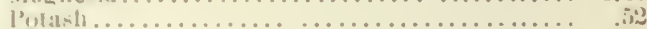

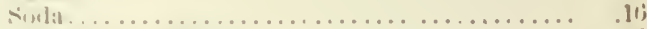

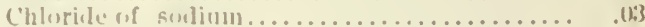

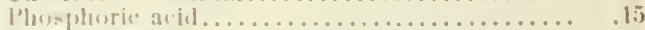

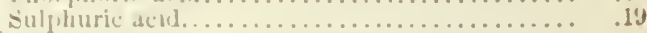

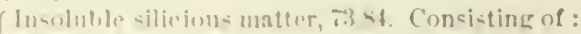

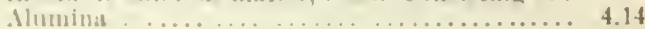

lime (in as state of silicite) . . . . . . . . . . .

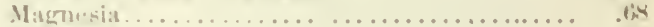

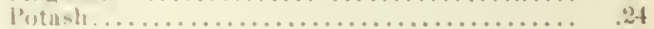

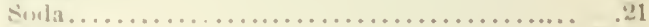

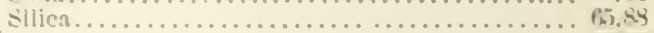

(19.59

"The soil, it will hr. scen, in ge nural cluaructer, resombles the pre-

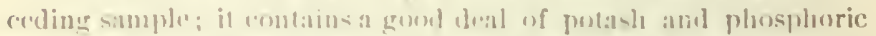

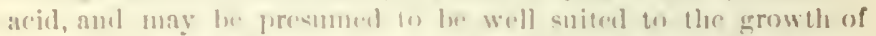

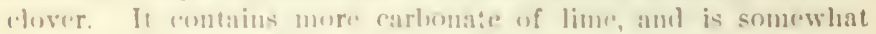
lighter than the sample from the purt of the ficlel twice mown for liay, and may lue termed luavy calcureums clay.

"In acre of this liuıl, 1sinches deep, wrighud, when very nearly dry :

$I$ I.S.

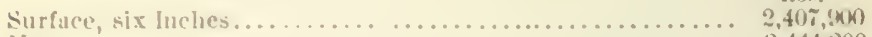

Next

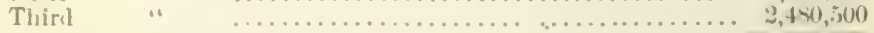

"Or in rounil numbers, crory six incles of soil wrimbed per acre $2 \frac{1}{2}$ millims of pumuls, which agrees lulerably well with the actual weight jur arre of the preeeding soil.

"The ammunt of plonsphoric acill and nitrogen in each six-inrl layer was determined separately as before, when the following results were ublaincel:

IN DRIEI) SOHL.

First Sirond Third sis inches. sis inches, six inches.

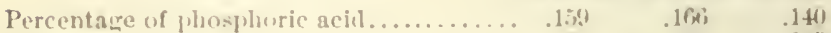

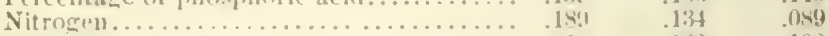

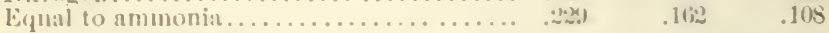

"In arro" aceorline to thes" dederminations, combins in the three separate sinctions: 


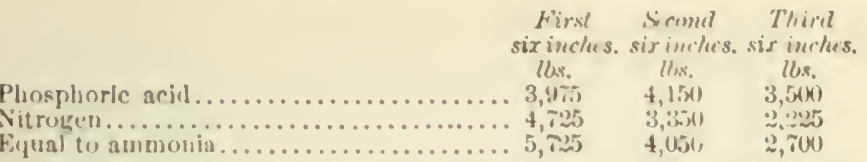

"Here, again, as Imight niturally be expected, the proportion of nitrogen is largest in the surfare, where all the derenying leaves Iroppesl during the growth of the elover for sceet ane found, and wherein roentefibes are more alumelant than in the fower strata. The tirst six inches of soil, it will be sech, contained in round numbers, 21 tons of nitrugen pere atere, that is, considerably more than was found in the sande sertion of the soil where the clover was mown twice for laty ; sluwing plainly, that during the ripening of the clover secel, the surface is untuch euriched by the nitrogenons matter in the dropping labes of the elever-plant.

"Clover-routs. - Thu" routs from one square font of this soil, freed as much as possible from athering soil, were tried at 212 , and when weighed and renteel to a fine puwler, gave, on analysis, the following results:

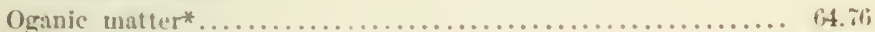

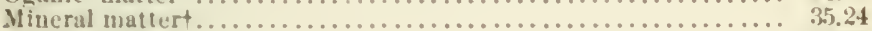

$100 .(M)$

* Containing nitrugen.............................. 1.ik2

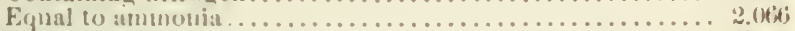

+ Including clay and sand (insuluble silicions matter)....... 20.04

"A square font of this soil produced 542 wrains of iried elowerroots, consequently an aere yielded $3,622 \mathrm{ll} s \mathrm{~s}$. of routs, or more than twice the weight of roots ohtained from the soil of the same field where the cluver was twice mown for hay.

"In round numbers, the 3, $62: 2 \mathrm{lbs}$. of clover-ronts from the land mown once, and afterwarls left for seed, contained 51 $1 \frac{1}{2}$ lls. of nitrogen.

"The roots from the soil after clorer-seed, it will be noticed, were not so clean as the preceding sample, nevertheless, they yielded more nitrogen. In 64.76 of organic matter, we have here 1.702 of nitrogen, whereas, in the case of the roots from the part of the field where the clover was twice mown for hay, we have in 81.33 parts, that is, much mre organic matter, and 1.635 , or rather less of nitrogen. It is evident, therefore, that the organic matter in the soil after clover-seed, occurs in a more advanced stage of decomposition, than found in the elover-roots from the part of the field twice mown. In the manure, in which the decay of such and similar organic remains procevels, much of the non-nitrogenous, or carboniceous matters, of which these remains chiefly; 


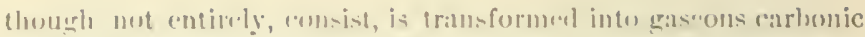

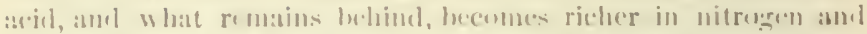

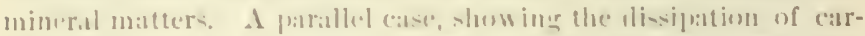

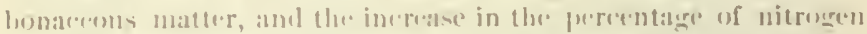
and mineral matter in whal is left beldind, is preseated to us in

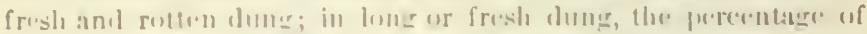

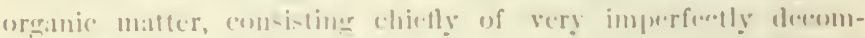

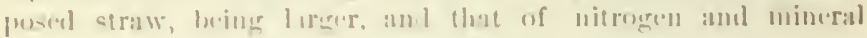
mollers smatller, tham in well-rollenl dumer.

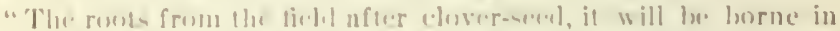

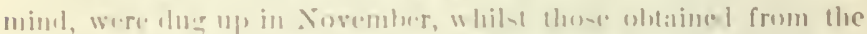

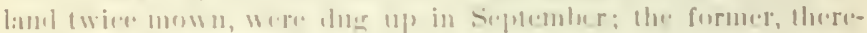

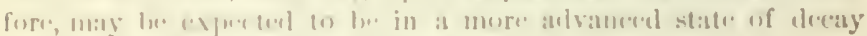

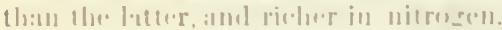

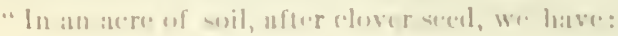

Vlis.

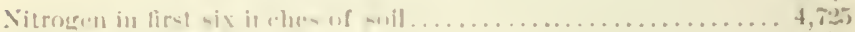

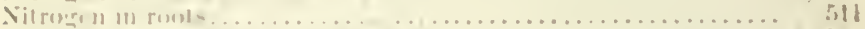

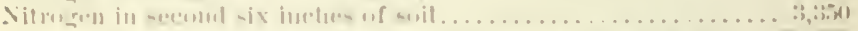

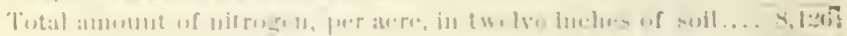

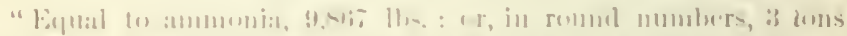

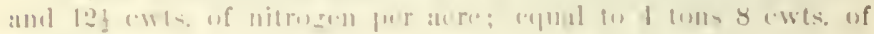
atmumumi:

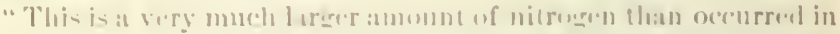

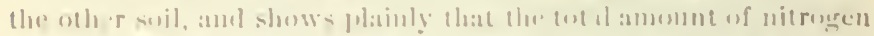

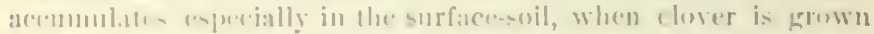

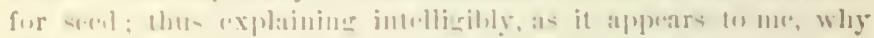

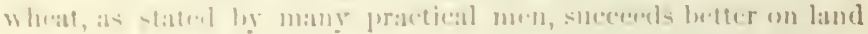

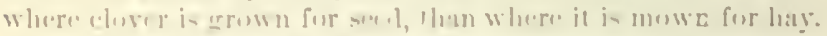

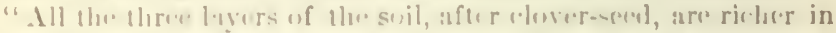
nitrenen than the same sections of the stil where the clover was

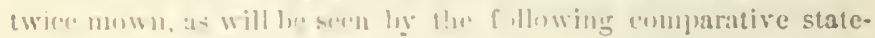
mint of resultis:

\begin{tabular}{|c|c|c|c|c|c|c|}
\hline & Chuve & 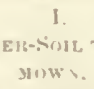 & TWUE & 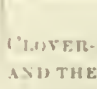 & $\begin{array}{c}\text { II. } \\
\text { SuL ON } \\
\text { S I.E.T F }\end{array}$ & 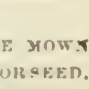 \\
\hline & 6i clens. & $\begin{array}{l}\text { Secoul } \\
\text { Giterlese }\end{array}$ & $\begin{array}{l}\text { Thiral } \\
\text { litinshes. }\end{array}$ & $\begin{array}{l}\text { Tplorer } \\
\text { ciiniliex. }\end{array}$ & $\begin{array}{l}\text { liert } \\
\text { binclies. }\end{array}$ & $\begin{array}{l}\text { Inwest } \\
\text { linclire. }\end{array}$ \\
\hline 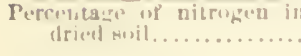 & .1 tis & . 10,12 &.$(n+1$ & $-1 \sim 9$ & .131 & $.0 \sim 9$ \\
\hline Ey & 192 & .112 & n? & $.2 * 1$ & .162 & .195 \\
\hline
\end{tabular}

"This ditrerene in the amomat of acemmulaterl nitrogen in cluver-land, appears still mure strikingly on comparing the tets! 


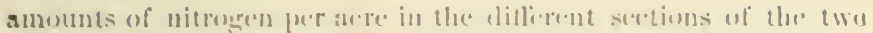
gurtions of the 11 -allere tield.

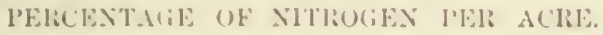

\begin{tabular}{|c|c|c|c|}
\hline In snil, clover twice mown* ......... & 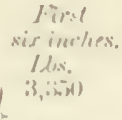 & 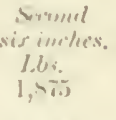 & $\begin{array}{l}\text { Third } \\
\text { sis inches. } \\
\text { ldss. } \\
\text { l,w2 }\end{array}$ \\
\hline alterwarilst..................... & $1.1 \div$ & $\therefore: \therefore 1$ & 2,2,201 \\
\hline 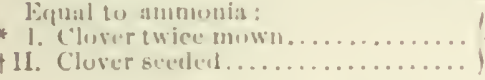 & $\begin{array}{l}4,11 ; 1 \\
5,025 ;\end{array}$ & $\begin{array}{l}2,27,1) \\
4,(1,4)\end{array}$ & $\begin{array}{l}1, t ;(x) \\
2,7100\end{array}$ \\
\hline
\end{tabular}

Sitrogen in ros.

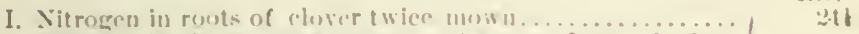

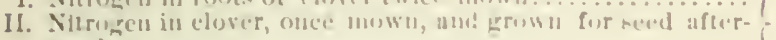
wards.....................................

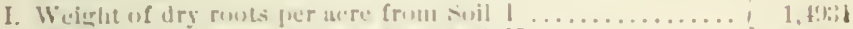

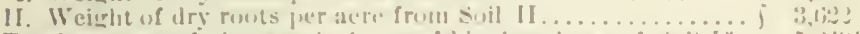

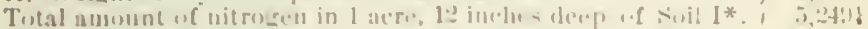

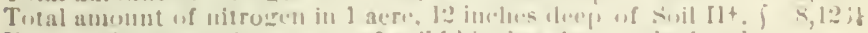

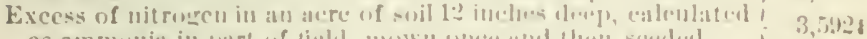

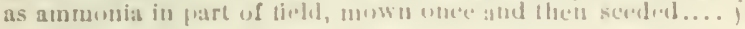

* Ey ual in ammunia........................ li,3itb

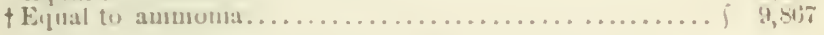

"It will be seen that not wuly was thu amount of lisge cluser-

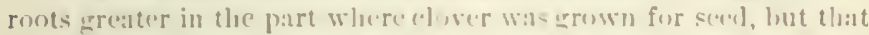
likewise the different layers of soil were in wery instance richer in nitrogen after churer.s at, t!am after clover mown twice for lay.

"Reasons are given in the lecginning of this paper which it is heneed will have convinced the realer, that the fertility of land is not so much measured ly the amomint of as! constiuments of plants which it contains, as hy the amount of nitrogen, which, tog ther with an excess of such ash comstituents, it contains in an available form. It has leen shown likewise, that the removal from the soil of a large amount of mineral matter in a crood riwer-crop, in conformity with many direct field experiments, is mot likely in any degree to affect the wheat-crop, and that the yield of wheat on soils under ordinary cultiration, aceording to the experience of many farmers, and the direet and numerous experiments of Messrs. Lawes and Gilbert, rises ur falls, other circumstanees being equal, with the supply of avilable nitrogenous fond which is given to the wheat. This being the case, we can not doubt that the henefits arising from the growth of clover to the succeeding wheat, are mainly due to the filet that an immense amount of nitrogenous food accumulates in the soil during the growth of clover. 
"This acemunutation of nitrogenons pliant-food, specially useful te cercal cropps, is, is shown in the preceding experiments, much greater when cluser in erown for seed, than when it is male into hay. This atfords an intellirible explanation of a fact long observal by goud practical men, although denied ly other: who deediae to aceept their experienee as resting upon trustworthy evidence, beeamse, as they say, land cannot berome more fertile when a cropl is grown upon it for seenl, which is arricel otf, than when

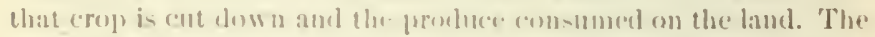
rlemieal points bromght forwarl in the conrese of this inquiry, show plainly that metre specolotion as 10 what ean take place in a soil, an! what mot, elu not math advante the true theory of cer-

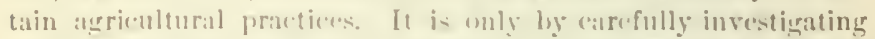
subjects like the one mulcr com-inleration, that pusitive proses are given, showing the correnenes of intellitent observers in the fields. ILany gears ago, I marle a great many experiments relative to the chemi-try of farm-yard manum, and then showed, amongst other proticulars, that manure, spreatl at ince on the land, need not tiere and then he plowed in, ina-much as neither a broiling sun, nor a sweppine and drying wind will canse the slightest loss of ammeni : and that, the refore, the old-fashioned farmer who earts hi- mainre on the land as som as he can, and spreads it at once, but whe plows it in at his convenience, acts i't perfert aceordance with correct rhemilal principles insolved in the management of farm-yard manure. 1) the present oecusion, my main olyeet has been to show, not merely log rea-oning on the subject, lut hy actual experiments, that the larere the amounts of nitrogen, potasis, sola, lime, phosploric acie., ete., which are remored from the land in a

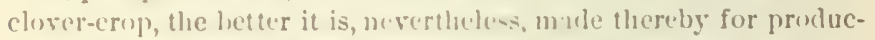
ing in the sucereding year an almudant crop of wheat, other circumstances locing fororable to its growth.

"Indecel, no kiu'l of manure can be complared in point of eflicacy for wheat, to the manuring which the land gets in a really good crop of clover. The farmer who wishes is derive the full benefit from his clover-lity, shoull plew it up for wheat as soon as possible in the autumn, and loave it in a rough state as long as is admissible, in order that the air may find free aceess into the land, and the organic remains left in so much abundance in a good crop of clorer be changerl into plant-ford ; more especially, in other words, in orter that the ermle nitrogenous oremie matter in the cluverronts and decaying leaves, may have time to become transformal into ammoniacil componnts, and these, in the comrse of time, into nitrates, which $I$ am stromgly inclined to think is the form in which 
nitrogen is assimilatted. par excellenee hy ecreal eropsimel in which, at all events, it is more eflications thatn in any other state of combinntion wherein it may be used ats a fertilizer.

"When the clover-lity is plowed ap carly, the deeny of the clover is sutliciently advanced by the time the young wheat-plant stants in need of realily avaibule nitromens ford, and this heing miformly dislributed through the whole of the cultivated soil, is rearly io benetit every single plint. This eyual and alumdant dastribution of food, peculiarly valuable to (rereals, in at great advan. tage, and speaks stronely in lisur of (hover ats a preparatory crop) for wheat.

"Nitrute of sodin, an excellent spring top-dresing for wheat and

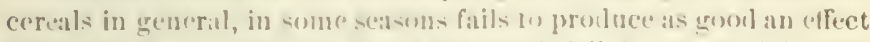
as incthers. In very ary -prins, the rainfall is not sutlicient to wash it properly into the soil and to distribute it equally, and in very wet seasons it is apt to he wathed (ither iuto the drains or into a stratum of the suil not acessibl. to the roots of the young wheat. As, therefore, the character of the approaching season can not usually be predicted, the application of nitrate of sodat to whet is always attende 1 with more or less uncertaiuty.

"The case is ditlierent, when a good crop of threr-hay has been ohtaine 1 from the land on which wheat is inten lel to be grown afterwarels. An enormons puintity of nitrogenous organic matter, as we lave seen, is left in the land after the removal of the elorercrop; and these remains eradually decay and furnish ammonia, which at first and during the coll ler montlis of the rear, is retained by the well known absorhing properties which all good wheatsoils possess. In spring, when warmer weather sets in, and the wheat begins to make a push, these ammonia compounds in the soil are by degrees oxidized into nitrites; and as this cliange into food peculiarly farorable to young cereal plant, proceeds slowly but stealily, we have in the soil itself, after ("lover, a source from which nitrates are contiumously produced; so that it does not much affect the final yield of wheat, whether heary rains remove some or all of the nitrate present in the soil. The chorer remains thus afford a more continuous source from which nitrates are produced, and greater certainty for a good crop of wheat than when recourse is had to nitrogenous top-dressings in the spring.

\section{SUMMART.}

"The following are some of the chief points of interest which I hare endeavored fully in derclope in the precerlin? pages:

"1. A good crop of clover removes from the soil more potash, 
pho-phoric acid, lime, and other mineral matters, which enter into the comprestion of the ashe's of our cultivated crops, than any other cropl usually grown in this comntry.

"2. There is fully thre times as much nitrogen in a crop of cluver as in the arerage produce of the grain and straw of wheat per ancere.

"3. Notwithstancling the lirge amount of nitrogenous matter and of an-constituents of plants, in the produce of an acre, clover is an excellent preparatory ('rop for whent.

“4. Doring the growth of clover, a large amount of nitrogenous matter ancoumulatu's in the soil.

"5. This acemunlation, which is greatest in the surface soil, is

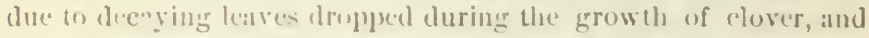
(1) an alumblane of roots, containing, when dry, from one and thre(e-fonthis te two per cent of nitrogen.

" $($. Tue clover-robts ar" stronger and more numerous, and more leavere fall on the erouml when chover is grown for seedl, than when it is mown for hays; in consequence, more nitrogen is left after chowerserel, tlan after hay, which accounts for wheat yiclel-

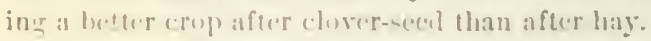

"7. The der lopment of rents lieine checked, when the produce,

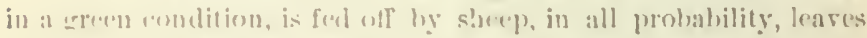
still les nitrercmon- matter in the suil than when chorer is allowed on geet rijur $r$ an 7 is mown for hay; thus, no doubt, aceounting ene the ols rvition male by practical men, that, untwithstanding the retum of the proluen in the slunp exerements, whent is

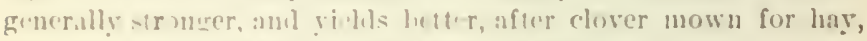

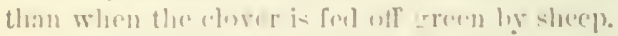

"s. The nitrue monte matters in the elower remains, on their gradual dee.ey, are finally transformed into nitrates, thus atfordiner

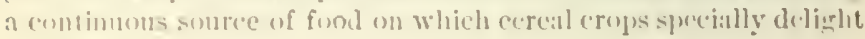
to : 2 (n)

"!. There is strong presmuptive cvilunce that the nitrogen which exists in the air, in shape of ammunia and nitric acisl, and descrukls, in these combinations, with the rain which falls on the ground, satisfies, muder ordinary circumstances, the requirements of the elowererop. This cropl causes a large accumulation of nitronenotis matters, which arr gralually changed in the soil into nitrates. The atmosibere thus furnis'es nitrugrnous fool to the succepline wheat indirectly, and, so in say, gratis.

"10. Clower not only provides abundanee of nitrogenous food, lut delivers this foud in a rea lily avalibhle form ('Is nitrates), more gratually ant continuously, aul, consequently, with more cer- 
tainty of a gond result, than such food can he applied to the land in the shape of nitrogenous spring top.dressings."

"Thank you Charley," siad the Ductor, "that is the most re. markable puper I ecer listened to. I do not suite know what to think of it. We shall have to examine it carefully."

"The tirst three propositions i: the summary," salicl ], "are unquestionably tiue. Proposition No, 4 , is c(puilly true, but we must be careful what meaning we attach to ble word 'ace'munlate.' The idea is, that clover gathers up the nitrogen in the soil. It does not increase the absolute anount of nitrogen. It accumulates it-brings it together."

"Proposition Yo. 5, will not he dieputed; and I think we may accept No, 6, also, thengh we ean mot he sure that allowing clower to go to seed, had anything to do with the increased quantity of clover-ronts."

"Propusition No. T, may or may not be true. We have no proof, only" a "probability'; 'ant the same may be said in regard to propusitions Nos. s, 9, and 10."

The I)acon semed uneasy. II d diul not like these remarks. IIe had got the impression, while C'harley was reading, that much more was proved thin Dr. Vuleker claims in lis summary.

"I thought," said he, "that on the part of the lickl wiere the clover was allowed to gro to seed, D). Fielcker found a great increase in the amrunt of nitrogen."

"That scems to be the gemeral impresion," sail the Durtor, "Int in point of fact, we hare no proof that the erowth of cluver, either for hay or for seed, hat anything to do with the quantity of nitrogen ant phosphoric achi found in the soil. The fucts given by Dr. Volcker, are exceelinely interesting. Let us look at them:"

"A field of 11 acres was sown to winter-wheat, and seeded down in the sprine, with 1: lbs, per ace of clorer. The wheat yielded 40 bushels per acre. The next year, on the 250 th of June, the clover was mown for hay. We are told that 'the best part of tie field yielded three fons (6, $200 \mathrm{Hhs}$ ) of clover hay per acre; the whole ficli areraging $2 \frac{1}{2}$ tons $(5,600$ l] s.) pur acre."

"We are not informed low much land there was of the "hest part,' hut assuming that it was half the field, the poores part nust have yielded only $4,480 \mathrm{hl}$ s. of hay per acre, or only twothirls as much as the other. This shows that there was considerable difference in the quality or condition of the lamel.

"After the fielel was mown for hay, it was dirided into two parts: one part was mown again for hay, $\Delta u_{y}$ ust 21 st, and yielded about 
$30 \mathrm{cwt}$ ( $(3,360 \mathrm{lbs}$.) of haly per acre; the other half was allowed to grow six or seven weeks longer, and was then (October 8th), cut for seed. The yicld was a little over $5 \frac{1}{2}$ bushels of seed per acre. Whether the elover allowed to grow for seed, was on the richer or poorer half of the ficld, we are not informed.

"Dr. Velcker then analyzed the soil. That from the part of the field mown twice for hay, contained per acre:

\begin{tabular}{|c|c|c|c|c|}
\hline Phosphoric ac & $\begin{array}{c}\text { First six } \\
\text { inclies. } \\
4,300 \\
3,3.50\end{array}$ & $\begin{array}{l}\text { Sremend six } \\
\text { inches. } \\
2,7,2 . ; \\
1, \times 75\end{array}$ & $\begin{array}{c}\text { Third sis } \\
\text { incles. } \\
3,575 \\
1,325\end{array}$ & $\begin{array}{c}\text { Total, } 18 . \\
\text { inches deep. } \\
11,250 \\
6,550\end{array}$ \\
\hline
\end{tabular}

"The soil from the purt moan once for hay, and then for seed, continined per acre:

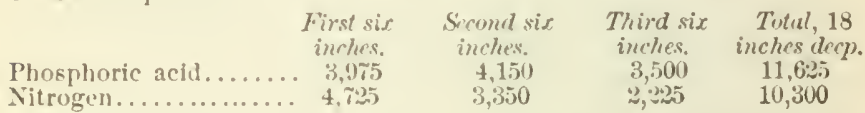

"Dr. Volcker also ascertained the amount and composition of the clover routs growing in the soil on the two parts of the field. On the part mown tacice for h'y, the roots contained per acre $24+1$ los. of nitrogen. On the purt moicn once for hay, and then for seed, the roots contained $51 \frac{1}{2} \mathrm{lbs}$. of nitrogen per acre."

"Now," saicl the Doctor, "these facts are very interesting, but there is no sort of exidenee tending to shone that the clover hus anything to do with increasing or decrensing the quantity of nitrogen or phosphorie acid found in the soil."

"There was more clorer-roots per acre, where the clover was allowed to go to seed. But that may be leeause the soil happened to be richer on this part of the field. There was, in the first six inches of the soil, 3,350 lhs. of nitrogen per acre, on one-half of the field, and 4.225 lhs. on the other half; and it is not at all surprising that on the latter half there should be a greater growth of clover and elover-roots. To smppose that during the six or seren weeks while the clover was matnring its seed, the elover-plants could accumulate $1,3 \pi 5$ lbs. of nitrogen, is absurd."

"But Dr. Veleker," said the Deacon, "states, and states truly, that "more leaves fall on the ground when clover is grown for seed, than when it is mown for hay; and, consequently, more nitrogen is left after clover-seed than after hay, which accounts for wheat yielding a hetter crop after clover-seed than after hay." "

"This is all true," said the Doctor, "but we can not accept Dr. Voelcker's analyses as proving it. To account in this way for the 1,375 lbs. of nitrogen, we slonld have to suppose that the cloverplants, in going to seml, slied one hundred tons of dry clover-leaves 
per acre! The truth of the matter seems to be, that the part of the field on which the clover was allowed to gro to seed, wils naturally much richer than the other part, and consequently produced a greater growtl of clover and clover-roots."

We cam not find anything in these experiments tending to show that we can make land rich by growing clover and selling the erop. The analyses of the soil show that in the first eighteen inches of the surface-solil, there was $6,550 \mathrm{lbs}$. of nitrogen per aere, on oue part of the field, and $10,300 \mathrm{lhs}$, on the other part. The elover did not create this nitrogen, or bring it from the atmosphere. The wheat with which the clover was seeded down, yielded 40 bushels per aere. If the field bad been sown to wheat again, it nrobably wonld not have yielded over 25 bushels per acre-and that for want of available nitrogen. And yet the closer got nitrogen enough for over four tons of clover-liay; or as much nitrogen as a crop of wheat of 125 bushels per acre, and $\tau_{\frac{1}{2}}$ tons of straw would remove from the land.

Now what does this prove? There was, in 18 inches of the soil on the poorest part of the field, 6,5;0 lbs. of nitrogen per acre. A crop of wheat of 50 bushels per acre, and twice that weight of straw, would require about $92 \mathrm{lbs}$. of nitrogen. But the wheat can not fet this amount from the soil, while the clover can get double the quantity. And the only explantion I can give, is, that the cloverroots can take up nitrogen from a weaker solution in the soil than wheat-roots can.

"These experiments of Dr. Tœleker," sa'd I, " give me great encouragement. IIere is a soil. 'originally rather unproductive, but much improved by deep culture; by being smashed up into rough clods early in autumn, and by being exposed in this state to the crumbling effects of the aur.' It now produces 40 bushels of wheat per acre, and part of the field yielded three tons of clover-hay, per acre, the first eutting. and $5 \frac{1}{2}$ bushels of clover-seed afterwards - and that in a rery unfarorable season for clover-seed."

You will find that the farmers in England do not expect to make their land rich, by growing clover and selling the produce. After they have got their land rich, by good cultivation, and the liberal use of animal and artificial manures, they may expect a good crop of wheat from the roots of the elover. But they take good care to feed out the clover itself on the farm, in connection with turnips and oil-cake, and thus make rich manure. 
And so it is in this conntry. IIuch as we hear about the value of clover for manure, eren those who extol it the highest do not depend upon it alone for hringiug up and maintaining the fertility of their farms. The men who raise the largest crops and make the most money by farming, do not sell clower-hay. They do not look to the roots of the clover for making a poor soil rich. They are, to at man, goul cultiviturs. They work their land thorouglily and kill the weeds. 'Tuey keep good stoxk, and feed liberally, and make good manure. They use lime, asles, and plaster, and are clad to draw manure from the cities and villates, and muck from the swamps, and not a few of them buy artificial munures. In the hands of such farmeri, clover is a grand renovating crop. It gathers up the fertility of the soil, and the roots alone of a large crop, often furnish food enourly for a goud erup of corm, potatoes, or wheit. But if gour l:tnel was not in good heart to start wilh, you wnuld not get llie large crop of clover; and if you depend on the elover-ronts alone, the time is nut far distant when your larfe crops of clover will he things of the past.

A.HOLNT OF l:OOTS LEFT IN THE SOLL BY DIFFERENT CROPS.

We have seen that Dr. Vinleker male four separate determinations of the amount of elover-roots left in the soil to the depth of six inches. It may be well to tabulate the figures obtained:

CLUVER IROTTS, IN SIX INCIIEG OF ROIL. TEK ACRE.

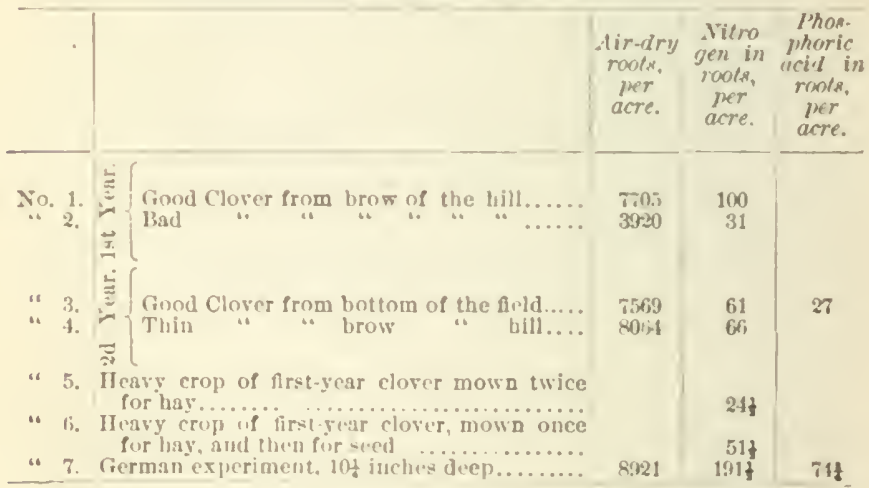

I lave not much enfiulenee in experiments of this kind. It is so easy to make a little mistake; and when you take only a squatre foot of land, as was the ease with Nos. 5 and 6, the mistake is multiplied hy 43,560. Still, I give the table for what it is worth. 
Nos. 1 and 2 are from a ene-Year-old crop of clover. The lield was a calcareous diy suil. It was sumewhat hilly; or, perlayps, what we lere, in Wistern Nis Yort, should call "rolling land." The ssil on the lirow of the hill, "was very stony all a depth of four inches, so that it could only with dittenley le exarated to six inches, when the bare linustone-rock made its appearance."

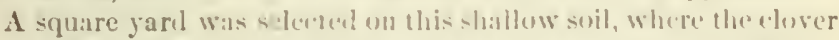

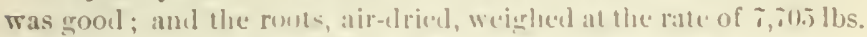

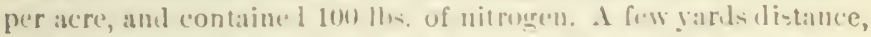
on the satue soil, where the eluver wais bitl, the acre of roots containced only 31 lls. of nitronen per anre.

Su far, so grome. We (an well mulerstand this renlt. Chemistry lats little to do with it. There wats a goosel stamel of elover on the one plot, and a puer one on the other. And the conselusion to lie drawn from it is, that it is well worth our white to try to sceule ab good catch of chiver.

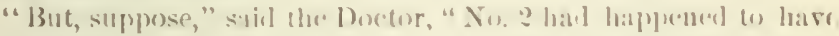

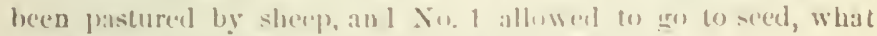
magi- there would have heen in the alwore fienres: "

Nos. 3 and 4 are from the same fiell, the secend year. No, 4 is from a spluare yard of thin cherer on the brow of the hill, and No. 3, from the rieher, deeper lanel tuwards lase bontom of the hill.

There is very little difference betwen them. The rootsof thin clover from the brow of the hill, cuntain five lhs. more nitrogen per acre, than the routs on the deeper soit.

If we cam depend on the figures, we may conclude that on our poor stony "knulls," the clover has larger and lonerer ronts than on the richer parti of the ficld. We know that jouts will run long distances and groat depths in search of food and water.

Nos. 5 and if are from a heary crop of one-yelr-isld elorer. No. 5 was mown twice for hay, prolucing, in the two cutliners, orer four tons of hay fer acre. No. fi was in the same ficld, the only ditference being that the clover, insteas of being cut the second time for hay, was allowed to stand a few wecks longer to ripen its seed. You will see that the latter has more roots than the former. There are $24 \frac{1}{2}$ lbs. of uitrogen per ace in the one ease, and $51 \frac{1}{2}$ lbs. in the other. How far this is due to difference in the condition of the land, or to the difticulties in the way of getting out all the roots from the square yard, is a matter of conjeeture.

Truth to tell, I have rery little confirlence in any of these figures. It will he observed that I hare put at the bottom of the table, the result of an examination marle in Germany. In this case, the nitrogen in the roots of an acre of clover, amounted to $191 \frac{1}{2}$ lbs. per 
acre. If we can depend on the figures, we must conclude that there were nearly eight times as much clover-roots per acre in the German field, as in the remarkably heavy erop of clover in the English field No. 5.

"Yes," said the Deacon, "but the one was $10 t$ inches deep, and the other only six inches deep; and besides, the German experiment includes the "stubble' with the roots."

The Deacon is right; and it will be well to gire the complete table, as published in the Americun Agriculturist:

TABLE SHOWISO THF AYOUNT OF BHOTS AND STIBHLE LEFT PEI ACRE BY DIFFERENT CROHB, AND THE AMOL'NT OF INGREDIEXTS WHICI THEY CONTAIS PER ACRE.

\begin{tabular}{|c|c|c|c|}
\hline & & & \\
\hline 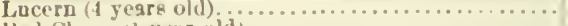 & $9,67 K .1$ & 136.4 & $1,201.6$ \\
\hline 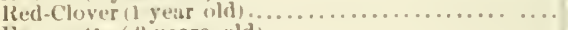 & $8,3 \geqslant 1.6$ & 191.6 & $1,\{11\} .9$ \\
\hline 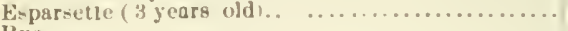 & $5,9: 30.9$ & 123.2 & $1,023.1$ \\
\hline 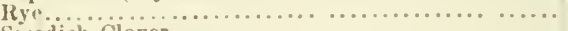 & $5,26\}, 6$ & 65.3 & $1,717,8$ \\
\hline 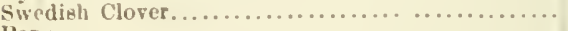 & 5.001 .3 & 102.3 & 471.6 \\
\hline 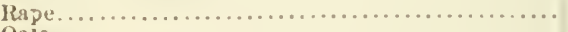 & $1,17 \pi$ & $5 f i .5$ & $1 ; 223$ \\
\hline 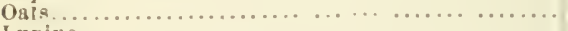 & 3,3319 & 26.6 & $1,414.7$ \\
\hline 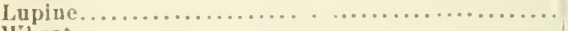 & $3,520.4$ & 62.2 & 550 \\
\hline 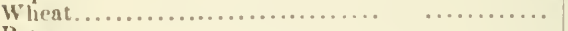 & 3.476 & 23.5 & $1,0 \times 3.8$ \\
\hline 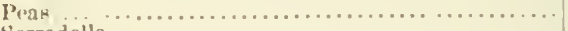 & 3.22 .2 .5 & 55.6 & 670.7 \\
\hline 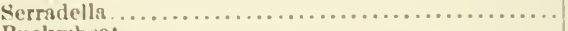 & 3.120 .1 & 64.8 & 515.6 \\
\hline 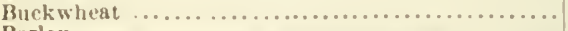 & $2,19 \div 6$ & 47.9 & 465.5 \\
\hline 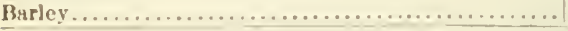 & 1.9114 & 22.8 & $3 ! 1.1$ \\
\hline
\end{tabular}

CONTEXTA OF THE ASIES, LN POLNDS, PEI ACRE.

\begin{tabular}{|c|c|c|c|c|c|c|}
\hline & $\underset{\mathbf{J}}{\stackrel{\Xi}{\Xi}}$ & 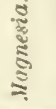 & 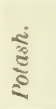 & हुँ & 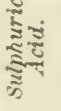 & 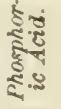 \\
\hline 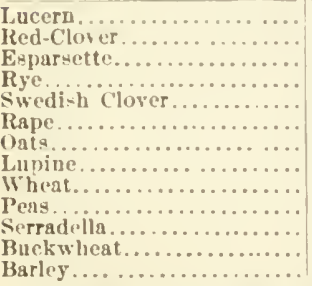 & $\begin{array}{r}19 . .7 \\
2+i 2.9 \\
132.8 \\
73.2 \\
13 t i .1 \\
163.9 \\
85.5 \\
81.5 \\
71.7 \\
71.7 \\
79.8 \\
80 . \\
42.2\end{array}$ & $\begin{array}{l}24.2 \\
4 \times .1 \\
24.7 \\
14.3 \\
17.6 \\
12.9 \\
11.2 \\
11.2 \\
10.1 \\
11 . \\
13.4 \\
7.2 \\
5.5\end{array}$ & $\begin{array}{l}36.7 \\
58.3 \\
42.6 \\
31.2 \\
25.11 \\
31.7 \\
21.8 \\
11 . .5 \\
28.4 \\
11.2 \\
8.8 \\
8.8 \\
9.5\end{array}$ & $\begin{array}{r}26.4 \\
200 \\
13.8 \\
43.3 \\
5.7 \\
20.9 \\
18 . \\
3.5 \\
11 . \\
7 . \\
4.8 \\
4.2 \\
3.5\end{array}$ & $\begin{array}{l}18.7 \\
26.1 \\
20.6 \\
11.8 \\
13.2 \\
30.8 \\
8.8 \\
7 . \\
7.4 \\
9.4 \\
3 . \\
6.6 \\
5.5\end{array}$ & $\begin{array}{l}38.5 \\
74.8 \\
29.7 \\
24.4 \\
24.2 \\
31.9 \\
29 . \\
13.8 \\
11.8 \\
14.3 \\
88.4 \\
11 . \\
11.2\end{array}$ \\
\hline
\end{tabular}

It may be presumed, that, while these figures are not absolutely, they are relatively, correct. In other worls, we may conclude, that red-clover leaves more nitrogen, phosphoric acid, and potash, in the roots and stubhle per acre, than any other of the crops named. 
The gross amount of dry substance in the roots, and the gross amount of ash per acre, are considerably exagrerated, owing to the eridently large quantity of dirt attached to the roots and stubble. For instance, the gross amount of ush in Lucern is given as 1,201.6 lus. per acre; while the tutal amount of lime, magnesia, potasl, soda, sulphuric and phosphoric acids, is only 342.2 lbs. per acre, leaviug $859.4 \mathrm{lbs}$ as sand, clay, iron, etc. Of the $1,919.9 \mathrm{lbs}$. of ash in the acre of clover-routs and stubble, there are $1,429.4 \mathrm{lbs}$. of s:Ind, clay, etc. But eren after deducting this amount of impurities from a gross total of dry matter per acre, we still have $7,492.2$ lus. of dry roots and stubule per acre, or nearly $3 \frac{1}{5}$ tons of $d r y$ roots per acre. This is a very large quantity. It is as much alry matter as is containel in 13 tous of ordinary farm-yard, or stable-manure. And these $3 \frac{f}{\text { tons of }}$ dry clover-roots contain $191 \frac{1}{2}$ lus. of nitrogen, which is as much as is contained in 19 tons of ordinary stable-manure. The clover roots also contain 74 los. of phosplioric acid per acre, or as much as is contained in from 500 to 600 lbs. of No. 1 rectified Peruvian guano.

"But the phosphoric acil," said the Doctor, "is not soluble in the roots." True, but it was soluble when the roots gathered it up out of the soil.

"These figures," said the Deacon, "hare a very pleasant look. Those of us who have nearly one-quarter of our land in clover every year, ought to be making our farms very rich."

"It would seem, at any rate," said I, "that those of us who have good, clean, well-drained, and well-worked land, that is now pro. ducing a gool growth of clover, may reasonably expect a fair crop of wheat, barley, oats, corn, or potatoes, when we break it up and plow under all the roots, which are equal to 13 or 19 tons of stablemanure per acre. Whether we can or can not depend on these figures, one thing is clearly proven, both by the chemist and the farmer, that a good clover-sod, on well-worked soil, is a good preparation for corn and potatoes."

\section{MANLRES FOR WHEAT.}

Probably nine-tenths of all the wheat grown in Western New York, or the "Genesee country," from the time the land was first cleared until $18 \% 0$, was raised without any manure being directly applied to the land for this crop. Tillage and clover were what the farmers depended on. There certainly lias been nosystematic manuring. The manure made during the winter, was drawn out in the spring, and plowed under for corn. Any manure made during the summer, in the yards, was, by the best farmers, scraped up and 
spreatel on portions of the lanel sown, or to be sown, with wheat. Even so goonl a farmer and whent-rrower as John Johnstun. rarely usel manture, (excejt lime, ant latterly, il litte gruano), directly for wheal. Clover and summer-fallowing were for many gears the dependence of the Western New lork wheat-growers.

"One of the ollest and nost experienced millers of Wwstern New York," remarked the Ductor, "mee told me that "ever smee our farmers began to munure their lend, the wheat-crop had deterioratel, not only in the yield per acere, luat in the quality and quantity of the thour whtained from it.' It secmed as strange remark to make; but when he explained that the farmers hat given up stmmerfallowing and plowing in clover, and now sow spring crops, to be followed by winter wheat with an oceasional dressing of poor manure, it is "asy to se how it maly be true."

"Yes," said 1, "it is not the minure that hurts the wheat, but the growth of spring crops and werds that roluthe soil of lar more plant-foed than the pror, strawy manure can supply. We do not now, rially, furnish the wheaterop as muth manure or plant-fond as we formerly did when litule or no manure was used, aml when we depended on summer-fallewing and plowing in clorer."

We must either give up the prattice of sowing a spring crop, hefore wheal, or we must make more and richer manure, or we must plow in more clover. The rotation, whind many ut us now adopt -corn, harly, whent-is protitable, brovided we can make onr lamd rich enough to produe in hushels of shelled eorn, 50 mushels of barley, ame inj bushels of wheal, per acre, in three years.

This ean lue done, but we shall either require a number of acres of rich luw land, or irrigated meadow, the produee of which will make manure for the upland, or we shatl hare to purchase ontcake, hran, malt-combs, or refuse losans, to feel ont with our straw and elover-hay, or we must purchase artificiat manures. Unless this is doup, we must summer-fallow more, on the heavier clay sorils, sow less bats and barley; or we must, on the lighter soils, raise and plow moler more cluser, or feed it out on the tarm, being careful to save and apply the manure.

"Better do hoth," silil the Doetor."

"How?" askeel the Deacun.

"Yon hal better make all the manure you can," continued the Doetor, "amel heny artificial manures be-illes."

"The l)w.tor is rieht," satil I, "and in point of fact, our best farmers are loing llis very thing. They are making more manure and buyine more manure than erer hefore; or, to state the matter correctly, fhey are huying artificial mamures; and these increase the 
crops, aud the extra quantity of straw, corn, and clover, so obtitined, enables them to make more manure. They get clieated sometimes in their purelalses; h:at, on the whole, the movement is a govol one, and will result in a liglucr and better systen of farming."

1 am amused at the interest und enthusiasm manifested by some of our farmers who lave used artiticial mantures for a year or two. They seem to regaril ne us a sad old fogy, lucasuse I am now depending almost entirely on the mammes mate on the farm. Years ago, I was latghed at because I u-ed guamu and $\mathrm{k}$ (t) was only yesterelay, that a young farmer, who is the local agent of this neighborhoul, for a manure manufacturer, remarked to me, " Jou hatrenerer used superphosphate. Wesowed it on our wheat last yeur, and could se to the very drill mark how far it went. I would like to tak" your order for at tom. I am sure it would pay."

" IV a are making manure cheaper than you can sell it to me, "I replied, " and besides, I do mot think superplasplote is a good manure for wheat." - "Oh," he exclaimel, " you would not say so if you had erer used it."-" Why, my dear sir," said I, "I made tons of superpliospliate, and used large quantities of guano before you were burn; aml if you will rome into the house, I will show you a silwer goblet I got for a prize essily on the use of superphosphate of lime, that I wrotemore than a quarter of a century ago. I sent to New York for two tons of guano, and published the result of its use on this farm, hefore rou were out of your cralle. And I lial a ton or more of superphospliate mate for me in 18.56 , and some hefore that. I hare also used on this farm, many tons of superphosphate and other artificial mantures from different manufacturers, and one year I used 15 tons of bone-dust."

If ill rearly tact, he turned the tables on me by saying: "Now I can understand wly your land is improving. It is because you have used superphosphate and bone-dist. Order a few tons."

By employing agents of this kind, the manufacturers have sue. cereled in selling the farmers of Western $N$ ("w Yurk thousands of tons of superphosphate. Sone farmers think it pays, aud some that it does not. We are more likely to hear of the suceesses than of failures. Still there can be no dombt that superphosphate has, in many instances, proved a valuable and profitalle manure for wheat in Western New York.

From 200 to 300 lls. are nsel per acre, and the rvidence seems to show that it is far lyetter to drill in the munure with the seed than to sow it broalcast.

My own opinion is, that these superphosphates are not the most 
economical artificial manures that (ondel be used for wheat. They contuin too little nitrogenn. Peruvian gruano containing uitrogen equal to 10 furrent of anmonia, would be, I think, a much more efferive and profitable manure. But before we discuss this question, it will he neessary to stuly tue results of actual experiments in the use of various fertilizers for wheat.

\section{II \& P T E R X I V I I .}

\section{LAWES AND GILBLIRT'S E.XPERIMENTS ON WIEAT.}

I hardly know how (1) commonce an alcount of the wonderful experiments mate at Rothamsted, Eingland, by John Bennett Lawes, Exyl., and I)r. Joseph I1. Gilhert. Mr. Lawes' first systematic expriment on wheat, commenced in the antumn of 1843. A tichl of 14 acres of rather heayy clay soil, reiting on chalk, was selected for the purpusi. Niucteren plots were aceurately incasured and staked off. The plots ran the loner way of the ficlil, and up a slight ascent. On each side of the tielil, alonesside the plots, there wats some land not ineluded, the firet year, in the experiment proper. This land wis either left without manure, or a mixture of the manures used in the experiments was sown on it.

I have heard it sald that Mr. Lawes, at this time, was a believer in what was ealled "Lielig's Mineral Manure 'Thuory." Liebig had saitl that "Thre crops on a fiell, diminish or increase in exact propurtion (1) the diminution or increase of the mineral sulutances convegerl to it in manure." Ansl enthusiantir gentlemen have been kuown to tell farmer: who were engaged in drawing out farm-yard manure to their lanil, that they were wasting their strength; all they neeled was the nineral ilements of the manure. "And yon might," they salil, "hurn your manure, and sow the ashes, and thus stre much lime an l labor. The ashe's will do just as much gool as the manure itself."

Whether Mr. Lawe disl, or lid not entertain such an opinion, I do not know. It looks as thourh the experiments the first year or two, were made with the expectation that mineral manures, or the ashes of plints, were what the wheat needel.

The following table gires the kind and quantities of manures used per acre, amd the yielel of whent per acre, as carfully reanud for market. Also the total wcight of grain per acre, and the weight of straw and chatl per acre. 


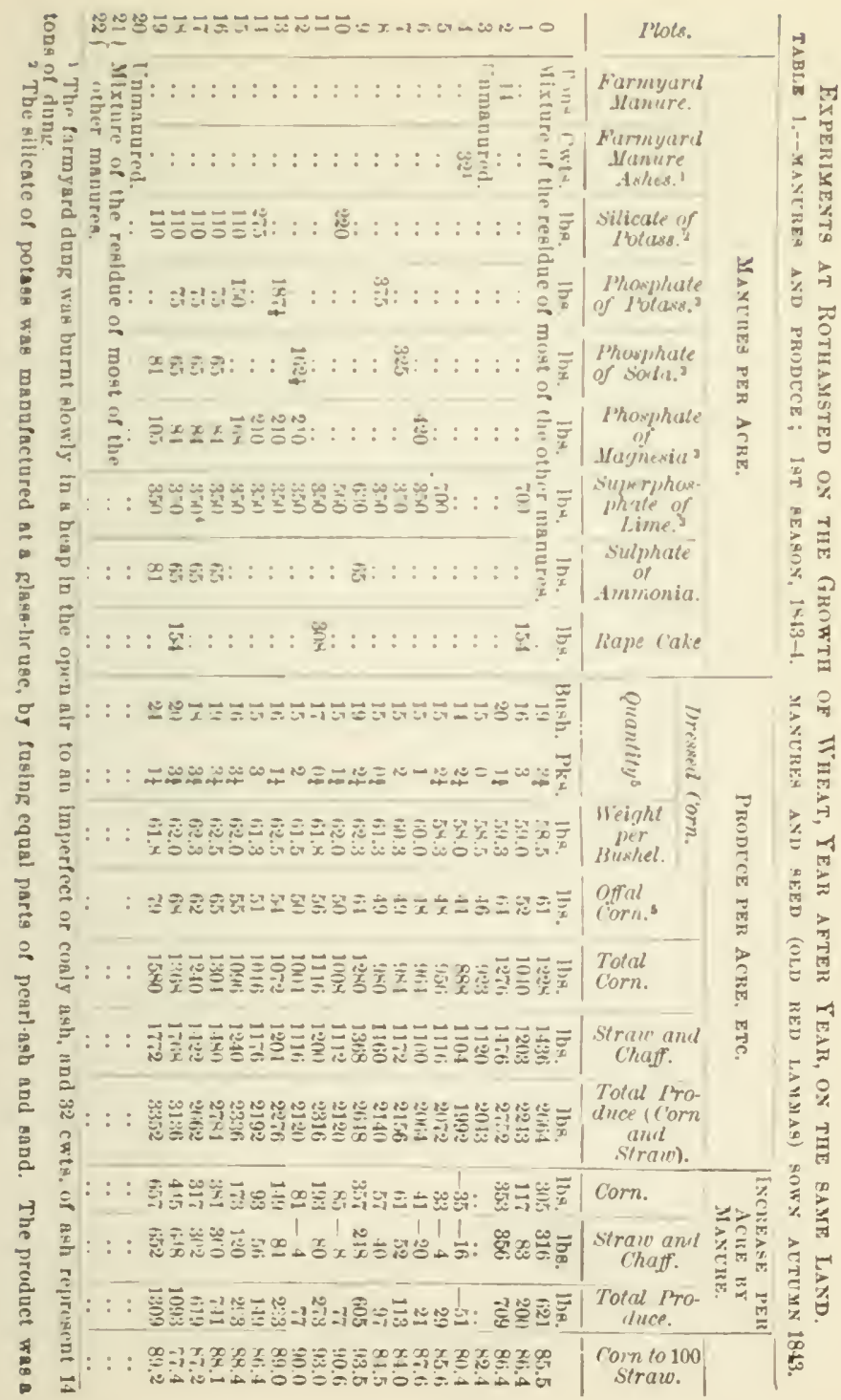


These wre the results of the harvest of 1844 . The first year of

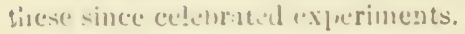

If Mr. Lawes axpectenl that the erops would be in proportion to the minerals supplied in the manure, he must have been greasly disalpointe.l. Tise ploi willosut unature of any kind, gave 15 pushels of wheat per ace ; 700 ibs. of steperphosphate of lime, male from burnt bones, produced only $\$ 33 \mathrm{lbs}$ or about half a bushel more grain per atere, and $\$$ lls. hexs strat than was obtained

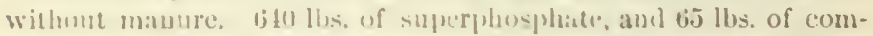

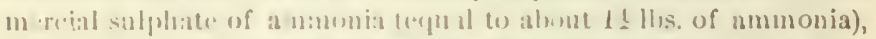

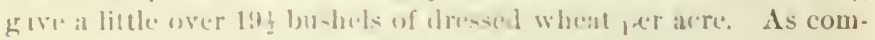

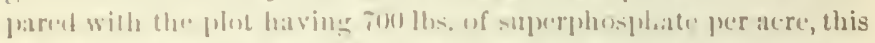

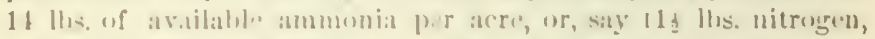

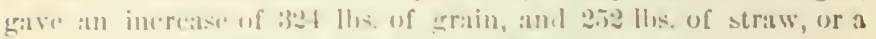
tultal increas of giti lls. of grain amel siraw.

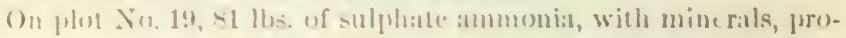
duen ? moni:r.

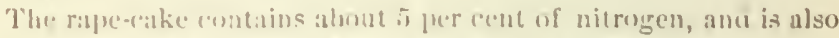
riels in miner.ts and e tronnceme muller. It gives an iuerease, but

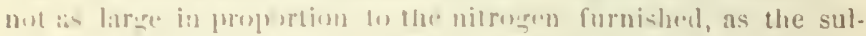
phote of ammonia. Amd the same remarks apply $t$ 's the 14 tons uf form-yarl manume.

Wie shmblil have expectind a greatur increase from such a liberal Aresing of barn yaml manure. I tlank the explanalion is this:

tranaparent plass, slighsly delique-cent in the air, which was ground to a pow-

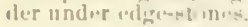

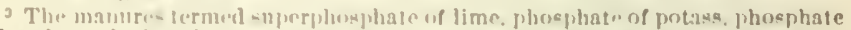

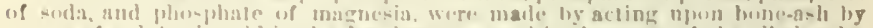

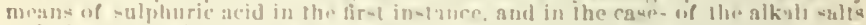

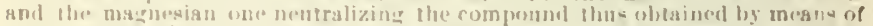

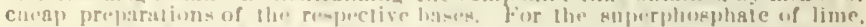
the propertions were i part- buse-ach. 3 parte water. and 3 parte sulphuric acid

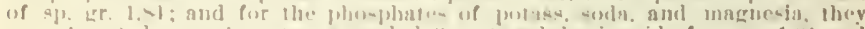

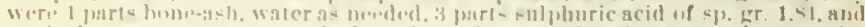

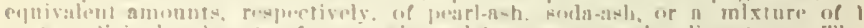

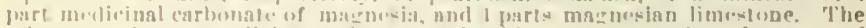

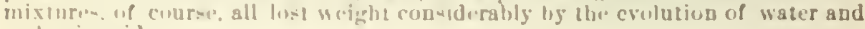
cirlwnic meid.

- Maull. wilh unlurnl bones.

5 In lhis first senson, neifluer the wiugh nor the measure of the offal rorn was

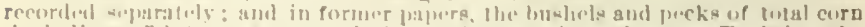

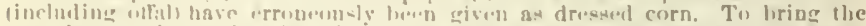

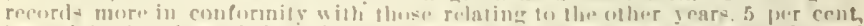

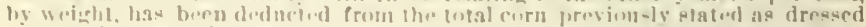

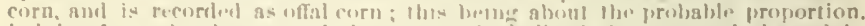

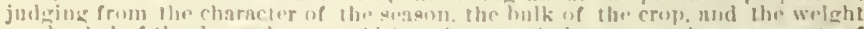

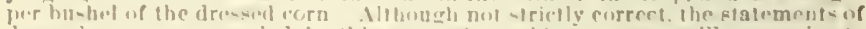

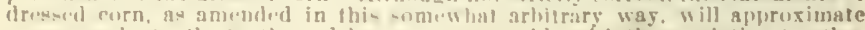
more nearly fo the irulh, and he nure comparable with those relating to other Beneuns, than those bitherto recorded. 
The manure hat not been piled. It was probably taken ont fresh from the gard (this, at atuy rate, was the eatec when I was att

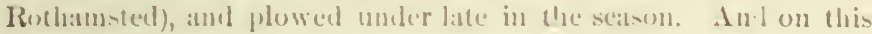
heavy land, manure will lie buried in the suil for months, ur, if $11 n$ disturbed, for years, withent decomperition. In other words, while this 14 tons of barn-yard manure, contanined at le:a-t 1,50 lbs. of nitrogen, and a latree quantity of mincrals and rarbonaceous matter, it did an probluce a bushel per acee more than a manne

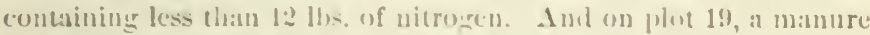
containing less than 1.j lhs of availathe nitreng ne proluced nearly 4 bushels per acre nore whe:at th on tite barn-yard mamure containing at leatst ke times als mueh nitrugend.

There eam lec but one explanation of this fact. The nitrogen in the manure lay dormate in this heary soil. Hat it heen at light s.mely soil, it would have decomposed urore rapidly and proluced at hetter effiect.

As we hare before stated, John Johnetun finds, on his clay-land, a far greater efferet from manure spreat on the surfice, where it decomposes raphilly, than when the mamme is plowed muder.

The Deacon was leokine at the tigures in the tahle, and not payine much aterntion to our talk. "Whlat (ould a man be thinking

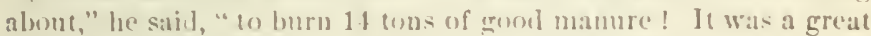
waste, and I am gliul the a thes diel no sort of ground."

After the whest was lanvested in 184 , the laul was immediatcly plowed, harrowed, ete. ; and in a few weeks was pluwed geain and sown to wheat, the different phots being kept separate, is hefore.

The following table shows the manures used this second year, and the yield per acre: 


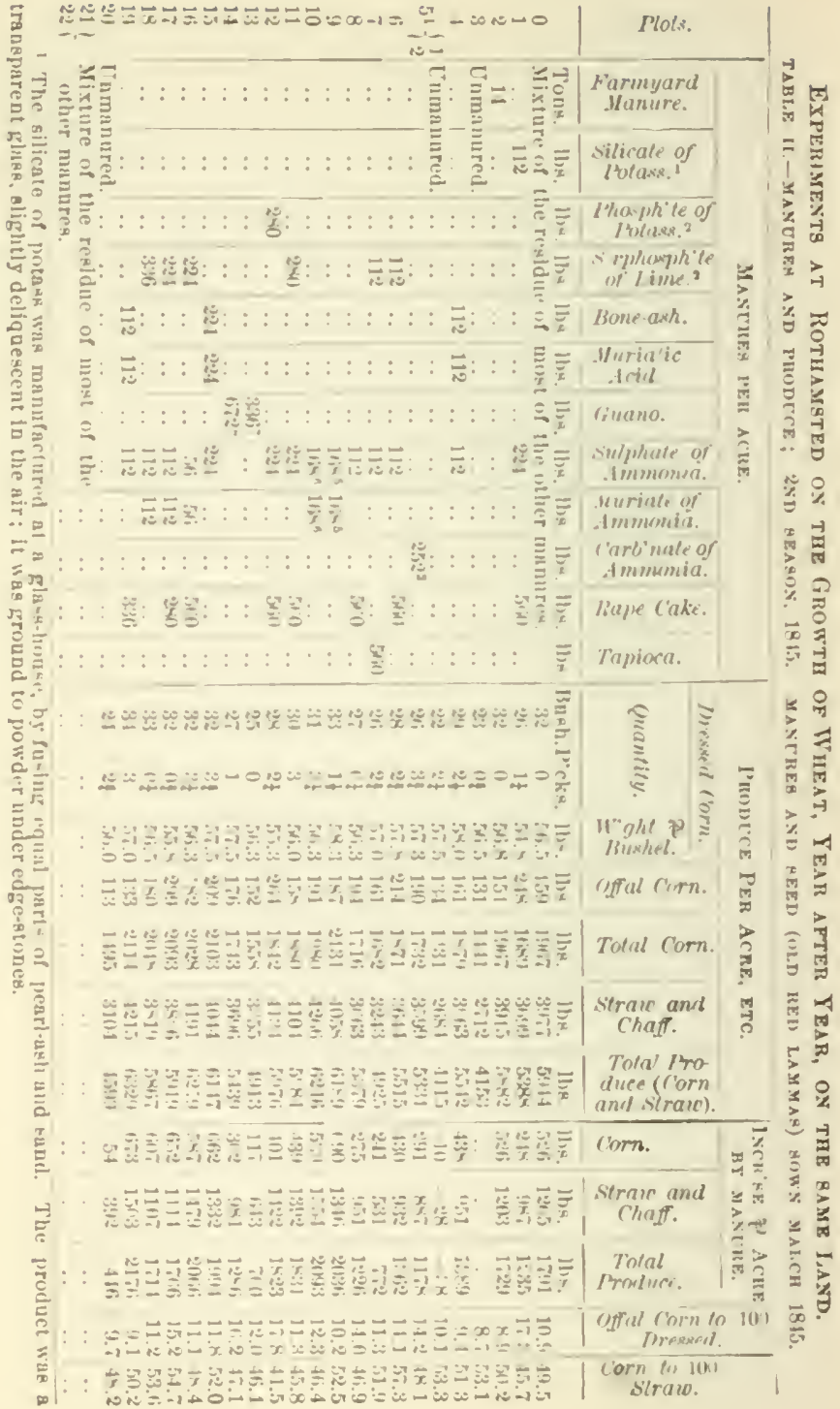


The season of 1845 was more favoralle for wheat, than that of 1844, and the crops on all the plusts were leetter. On plot No. 3, which hat no manure last year, or this, the yichl is 23 bushels per acre, arainst 15 luchels last year.

Last jear, the 14 tom of harn-yard manure gave an increase of only it bushels per acere. This jear it gives an increase of nearly 9 bustucls per acre.

"Do you meatn," sail the Deacon, "that this plot, No. 2. had 14 toms of manure in 1844 , and 14 tons of manure agrain in 1845 ?" "Preciscly that, 1)eacon," said 1, "and this same plot has received this amonnt of manurecrery year smee, up to the press'nt time - for these sime experiments are stili contimed from yeur to year at Rothamsted."

"It is poor farmiug," said the [Deacon, "and I should think the land would gret too rich to grow wheat."

"lt is uot so," said l, "and the fact is an interesting one, and teaches a most important les-om, of which, more hereafter."

Plot 5, last year, receivent 700 lls. of superphosplate puer acre. This year, this plot wats divided: one half was left without ma* nure, and the other Iressed with 2.22 los. of pure carbonate of ammonia per acre. The half without manure, (ive ), liul not produce quite as much grain and straw as the plot which hal receired no manure for two years in suceesion. I3ut the wheat was of hetter quality, weighing 1 lb. more per lushel buan the other. Still it is sufliciently cvicient that superphosphate of lime did no gond so far as increasing the growth was evencerned, either the first year it was applied, or the year following.

The carbonate of ammonia was dissulved in waterand sprinkled orer the growing wheat at three different times during the spring. You see this manure, which enntains no minerul matter at all, gives an increase of nearly 4 bushels of grain per aere, and an increase of 88 ilhs. of stram.

"Wait a moment," said the Deacon, "is not 88 i lbs. of straw to

2 The manures termed superphosphate of lime and phosphate of potasa, were made by acting upon bone-arh by means of sulphuric arid, and in the ca-c of the potass salt neatralizing the compound thus ohtained. by means of pearl-ash. For the sn'erphoshate of lime. the proportions wre. s parts bone-ash. 3 parts waler, and 3 parts sulphuric acid of ep. gr. 1. 4: and for the phosphate of potars, 4 parta hone ash. water as needed, 3 parta sulphuric acirl sf op. rr. 1.81 ; and an equivalent amount of pear]-anh. The mixlarns of collwe, lost weight considerably hy the pvolution of water and carhonic acid.

3 The medicinal carbonate of ammonia; it was discolred in water and top. dresand.

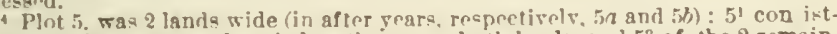
ing of 2 alternate one fourth lengths acrose both lands, and $5^{2}$ of the 2 remaining one-fonrth lenglba.

5 Top-dressed at once. - Top-dressed at 4 intervals. ' Peruvian. ' Ichaboe. 
4 bushels of grain an umusually large proportion of straw to grain? I have heard you say that 100 lbs. of straw to each bushel of wheat is about the average. And according to this experiment, the carbonate of immonia produced over $200 \mathrm{lbs}$. of straw to a bushel of grain. Ilow do you account for this."

"It is a general rule," said 1, "that the heavier the crop, the greater is the proportion of straw to grain. On the no-manure plot, we have, this year, 118 lbs. of straw to a buslicl of dressed grain. Taking this as the standarl, you will tind that the inerease from manures is proportionally greater in straw than in grain. Thus in the increase of harn-yarl manure, this year, we have about 133 lbs. of straw to a bushel of urain. I lo not beliere there is any manure that will give us a largecrop of grain without a still larger erop of straw. There is considerable difference, in this respect, between different varieties of wheat. Still, I like to see a gool growth of straw."

"It is curious," said the Ductor, "that $3 \mathrm{ewt}$. of ammonia-salts alone on plots 9 and 10 should produce as nuch wheat as was ohtined from plot 2, where 14 tons of harn-yard manure lad been applied two years in sucession. I notice that on one plot, the ammonia-salts were applied at nnce, in the spring, while on the other plot they were sown at four different times-and that the former gave the best results."

The only conclusion to be drawn from this, is, that it is desirable to apply the manure early in the spring-or better still, in the autumn.

"You are a great adrocate of Perurian guano," said the Deacon, "and yet 3 ew't of Pirurian guano on Plot 13, only produced an increase of two bushels and 613 lbs. of striw per aere. The griano at $\$$ fio per ton, would cost $\$ 9.00$ per arre. This will not pay."

This is an unusually small increase. The reason, problably, is to be found in the fact that the manure and seed were not sown until March, insteal of in the autumn. The silts of ammoniz are quite soluble and act quickly; while the Peruvian guano has to lecom. pose in the soil, and consequently needs to be applied earlier, especially on clay land.

"I lo not want you," said the Deacon, "to dodge the question why an application of 14 tons of farmyari-manure per acre, every year for over thirty yeirs, does not make the lant too rich for whe'it."

"Possibly," sair] I, "on light, sandy soil, such an annual dressing of manure would in the conrse of a few years make the land too 
rich for wheat. But on a clayey soil, such is evidently not the ease. And the fact is a very important one. When we apply manure, our object should be to make it as available as possitole. Naturo preserves or conserves the food of plants. The object of anriculture is to use the food of plants for our own anlvantage.

"Please be al little more definite," satid the Deatcon, "for I must confess I do not quite see the sirnifieance of your reuarks."

"What he me:ns," saicl the Doctur, "is this: If you put a quantity of soluble and arailable manure on land, amil to not suw any crop, the manure will not be wasted. The soil will retain it. It will change it from a soluble into a compraratively insuluble form. Ifarl a crop been sown the first year, the manure would do far more good than it will the next year, and yet it may be that mone of the manure is lost. It is merely locked up in the soil in such a form as will prevent it from ruming to waste. If it was not for this principle, our lands would lave been long ago exhausted of all their a vailable plant-ford."

"I thiuk I underst:ind," sairl the Deacon; "but if what you say is true, it upsets many of our ol! notions. We have thought it desirable to plow unler manure, in order to prevent the ammonia from escuping. Yon claim, I believe, that there is little danger of any loss from spreading manure on the surfare, and I supprose you would have us conclude that we make a mistake in plowing it under, as the soil renders it insoluble."

"It depends a good deall," sill I, "on the character of the soil. A light, sauly soil will not pres rve manure like a clay soil. But it is undoubtel!y truc that our aim in all cases should be to apply manure in such a form and to such a (rop) as will grive us the greatest immediute benefit. Plowin $⿺$ uncler fresh munure every year for wheat is evidently not the best way to get the greatest benefit from it. But this is not the place to discuss this matter. Iot us look at the result of Mr, Lawes' experiments on wheat the third year:" 
Experiyests at Rothassted on the Growtr of

TABLE III. - XANURES AND TRODLCE; 3HD BEASON, 1815-6.

\begin{tabular}{|c|c|c|c|c|c|c|c|c|c|c|c|c|c|c|}
\hline \multirow[b]{3}{*}{$\frac{\ddot{\sigma}}{3}$} & \multicolumn{14}{|c|}{ MaNUHES TER ACRE. } \\
\hline & \multirow{2}{*}{ 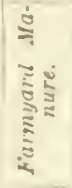 } & \multirow{2}{*}{\multicolumn{2}{|c|}{ 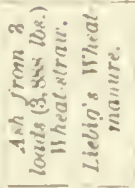 }} & \multirow{2}{*}{ 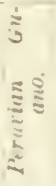 } & \multirow{2}{*}{ 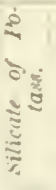 } & \multirow[b]{2}{*}{ 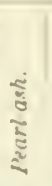 } & \multirow[b]{2}{*}{ 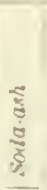 } & \multirow[b]{2}{*}{ 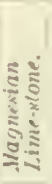 } & \multicolumn{3}{|c|}{$\begin{array}{l}\text { Suje rphowph ite } \\
\text { of leme. }\end{array}$} & \multirow{2}{*}{ 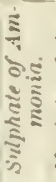 } & \multirow{2}{*}{ 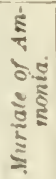 } & \multirow[b]{2}{*}{ 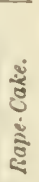 } \\
\hline & & & & & & & & & 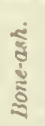 & : & 岂 & & & \\
\hline & Tons. & & Ibs. & Ihs. & $\mathrm{Jb}$. & lbes. & lbe. & lhe. & lha. & Ibs. & Ibs. & Ihs. & 104. & Ibes \\
\hline 0 & - & .. & .. & $333 i$ & & . & . & . & & .. & .. & .. & .. & .. \\
\hline 1 & 31 & . & .. & . & .. & .. & . & . & 224 & -. & . & .. & .. & 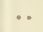 \\
\hline $\begin{array}{l}2 \\
3\end{array}$ & Loma & nured & $\cdots$ & . & .. & $\cdots$ & $\cdots$ & $\cdots$ & $\cdot \cdot$ & $\because$ & $\because$ & $\cdots$ & $\cdots$ & .. \\
\hline 4 & (19. & . & & .. & .. & .. & .. & & 221 & & & $2-31$ & $\cdots$ & . \\
\hline & & & & & & .. & .. & & .. & & .. & & .. & . \\
\hline $50 ;$ & $\cdots$ & Siraw & $\therefore$ & . & .. & $\therefore$ & $\because$ & $\therefore$ & .. & .. & .. & $22 i 1$ & $\because$ & 0 \\
\hline$b !$ & - & A*h. & .. & $\because$ & $\because$ & $\because$ & $\cdots$ & $\cdots$ & .. & $\cdots$ & .. & $20, j 1$ & -. & 4.12 \\
\hline $\mathrm{CMt}^{2}$ & 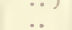 & .. & I19 & $\ddot{*}$ & $\because$ & $\because$ & $\ddot{0}$ & ․ &.. & $\therefore$ & $\because$. & 228 & .. & He \\
\hline in & .. & $\because$. & 414 & .. & $\therefore$ & $\therefore$ & $\therefore$ & $\because$ & $\because$ & $\because$ &.. & $1 i 2$ & $\ddot{112}$ & $\cdots$ \\
\hline$\pi$ & . & .. & H4 & .. & .. & .. & .. & .. & .. & .. & .. & & & 118 \\
\hline .6 & .. & .. & 119 & .. & .. & .. & .. & .. & .. & .. & .. & 112 & 112 & 448 \\
\hline \&a & .. & .. & .. & .. & .. & .. & .. & .. & 231 & .. & .. & & & 448 \\
\hline $8 B$ & .. & .. & .. & .. & .. & .. & .. & .. & 221 & .. & .. & 112 & 112 & \\
\hline $9 a$ & .. & . & .. & .. & .. & .. & .. & .. & .. & .. & .. & $\therefore$ & .. & 415 \\
\hline 10 & . & . & .. & . & . & .. & . & .. & .. & .. & .. & 221 & .. & 412 \\
\hline 108 & linms & nared. & $\because$ & $\because$ & $\because$ & 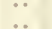 & $\because$ & $\because$ & $\because$ & $\because$ & $\because$ & 221 & $\because$ & $\because$ \\
\hline $11 a$ &.. & . & .. & $\ldots$ & .. & .. & .. & & $22\}$ & 224 & & & & 149 \\
\hline 116 & .. & .. & . & .. & .. & .. & & .. & 221 & 22.4 & .. & 112 & 112 & \\
\hline 1214 & .. & .. & .. & .. & .. & . & 1की & .. & 221 & 281 & .. & & & 4.18 \\
\hline 128 & .. & .. & .. & .. & .. & & का & .. & 231 & 221 & .. & 112 & 112 & \\
\hline $1: 3 a$ & .. & .. & .. & .. & .. & 20 & . & .. & 234 & $2 ! 1$ & .. & & & 449 \\
\hline 1.36 & .. & .. & .. & .. & .. & 20 & .. & & 2031 & 224 & .. & 112 & 112 & \\
\hline $14 a$ & .. & .. & .. & .. & .. & .. & . & 81 & 224 & 221 & . & & & 418 \\
\hline 118 & .. & .. & .. & .. & .. & .. & .. & 81 & 234 & 234 & .. & 112 & 112 & .. \\
\hline $5 / 2$ & .. & .. & .. & .. & & .. & .. & .. & $\approx 21$ & .. & 221 & 22.1 & . & 448 \\
\hline & $\cdots$ & .. & .. & . & 221 & .. & & .. & 224 & .. & 221 & 221 & $\cdots$ & 418 \\
\hline a & .. & $\ldots$ & .. & .. & .. & 67 & 60 & 4 & 221 & 221 & .. & & & 4.18 \\
\hline (ix) & & & .. & .. & .. & 67 & (10) & 81 & $2: 24$ & 231 & .. & $22 i$ & & 44 \\
\hline 1ia & .. & .. & .. & .. & .. & 67 & 10 & 44 & $2: 4$ & 221 & .. & 112 & 112 & 418 \\
\hline 170 & .. & .. & .. & .. & .. & 67 & co & 81 & 2024 & 221 & .. & 224 & & .. \\
\hline 183 & .. & .. & .. & .. & .. & iii & 60 & 81 & 2221 & 221 & .. & 112 & 112 & .. \\
\hline $1 \times b$ & .. & .. & .. & .. & .. & $6 i$ & 6i) & 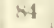 & 224 & 221 & .. & .. & .. & .. \\
\hline & .. & .. & .. & .. & .. & .. & .. & .. & 112 & .. & 112 & 112 & .. & 448 \\
\hline 1 & Mixtu & of $t$ & resi & due & of $\mathrm{m}$ & nat of & e the & othe & $m$ & a & & .. & .. & .. \\
\hline
\end{tabular}

I Top-dressed in the 8 pring. 
Wueat, Year after Yeak, oN the same Land.

MANCRES AND BEED (OLD HED LAMYAS), SOWY AUTCMN, 1815.

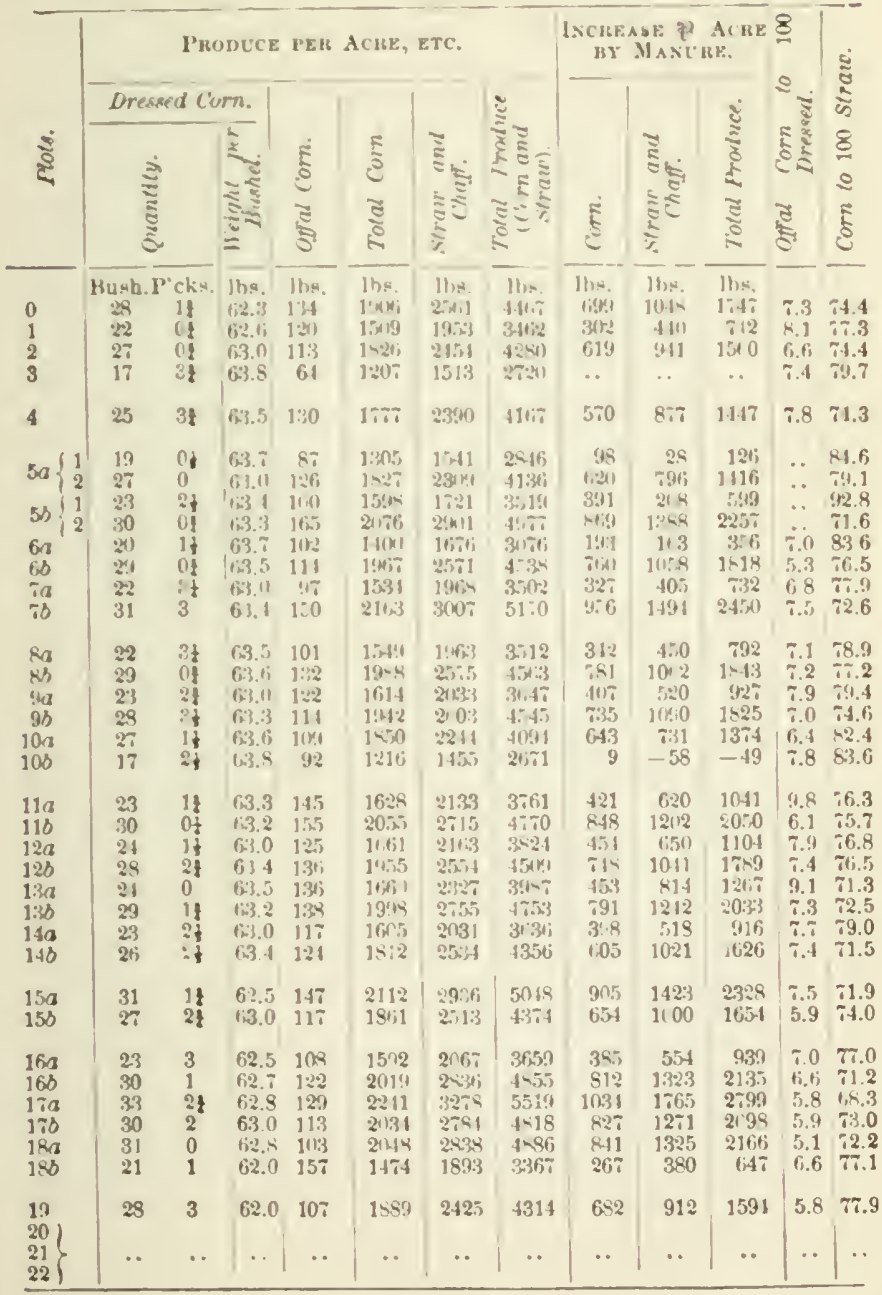


This year, the seed and manures were sown in the autumn. And I want the Deacon to louk at plut $0.3 \mathrm{cwt}$. of Peruvian guano here gives an increase of $10 \frac{1}{2}$ hushels of when:, and $1,048 \mathrm{lbs}$. of straw per acre. This will pay well, even on the wheat alone. But in adilition to this, we may expect, in our ordinary rotation of crops, a far better crop of clover where the guano was used.

In regard to some of the results this year, Messrs. Lawes and Gilbert have the following concise and interesting remarks:

"At this thirb experimental harvest, we have on the continuously unmanured plot, namely, No. 3, not quite 18 bushels of dressed corn, as the normal produce of the season; and by its side we have on plot $10 b$-comprising one-half of the plot 10 of the previnus years, and so highly manured by ammoniacal salts in 1845, but now unmanured-rather more than 17 bushels. The near approach, again, to ilentity of result, from the two unmanured plots, at once gires contidence in the accuracy of the experiments, and shows us how etfectually the preceding crop had, in a practical point of view, reluced the plots, previnusly so differently circumstaneed both as to manure and produce, to something like an uniform standard as regards their grain-producing qualiti s.

"Plot 2 has, as before, 14 tons of farm-yard manure, and the produce is $2 i t$ bushels, or between 9 and 10 bushels more than without manure of any kind.

"On plot 10a, which in the previous yenr gave l y ammoniacal salts alone, a produce equal to that of the farm-yard manure, we have again a similar result: for two $\mathrm{cw} t \mathrm{~s}$ of sulphate of ammonia has now given $1,8.50$ lis. of total corn, instead of $1,826 \mathrm{llhs}$., which is the produce on plot 2 . The straw of the latter, is, bowever, slightly heavier than that by the ammoniacal salt.

"Again, plut j) t, which was in the previous s'ason unmanured, was now subdiviled: on one-half of it (namely, $5 a^{7}$ ) we have the ashes of wheat-straw alone, by wheh there is an increase of rather more than one lust 2l per acre of iressed corn; on the other lialf (or $5 t^{2}$ ) we have, besilles the straw-ashes, two ewts. of sulphate of ammonia put on as a top-llressing : two cwts. of su.phate of ammonia have, in this case, only increased the produce beyond that of $5 a^{1}$ by 72 bushels of corn and 7621 bs. of straw, irstead of by $9^{3}$, bushels of corn ancl $r \times ! l$ lls. of straw, which was the increase obtained by the same amount of ammoniacal salt on 10at, as comparel with $10 b$.

"It will be observed, howerer, that in the former case the ammoniacal salts were top-dressed, but in the latter they were drilled 3.t the time of sowing the secd; and it will be remenbered that in 
1815 the result was better as to corn on plot 9 , where the salts were sown earlier, than on plot 10, where the top-dressing extended far into the spring. We have had sereral direct instanees of this kind in our experience, and we would give it as a s'lggestion, in most cases applicuble, that manures for wheat, and especially ammoniacal ones, should be applied before or at the time the seed is sown; for, although the apparent luxuriance of the crop is greater, and the produce of straw really heavier, by spring rather than autumn sowings of Peruvian gुtuno and other aumoniacal manures, yet we beliere that that of the corn will not be increased in an equiralent degree. Indeed, the success of the erop undoubtedly depends rery materially on the progress of the underground grow th during the winter months; and this again, other things being equal, upon the quantity of arailable nitrogenous constituents within the soil, without a liberal provision of which, the range of the fibrous feeders of the plant will not be such, as to take up the minerals which the soil is competent to stpply, and in such quantity as will be required during the after progress of the plant for its healthy and farorable growth."

These remarks are very suggestive and deserve special attention.

"The next result to be noticed," continue Messrs. Lawes and Gilbert, "is that obtained on plot 6, now also divided into two equal portions designated respectirely $6 a$ and $6 b$. Plot No. 6 bad for the crop of 1841, superphosphate of lime and the phosphate of magnesia manure, and for that of 1845 , superphosphate of lime, rape-cake, and ammoniacal salts. For this, the third season, it was deroted to the trial of the wheat-manure manufactured under the sanction of Professor Liebig, and patented in this country.

" Upon plots 6.1, four cwts. per acre of the patent wheat-manure were used, which gare $20 \frac{1}{5}$ bushels, or rather more than two bushels beyond the produce of the unmanured plot; but as the manure contained, besiles the minerals peculiar to it, some nitrogenous compounds, giving oft a rers perceptihle odor of ammonia, some, at least, of the increase would be due to that substance. On plot $6 b$. however, the further aldition of one ewt. each of sulphate and muriate of ammonia to this so-called 'Mineral Manure,' gives a produce of $29 \frac{1}{5}$ bushels. In other words, the addition of ammeniacal salt, to Liebig's mineral manure has increased the produce by very nearly 9 bushels per acre beyond that of the mineral manure alone, whilst the increase obtained nrer the unmanured plot, by 14 tons of farm-yard manure, was only $9 \$$ bushels !

The following table gires the recults of the experinents the fourth year, 1816-7. 
EXPERTMENT at Rothaysted ON tue Growti or TABLE IV.-YANURES AND PRODECE; 4TII 8EA8ON, 1816-7.

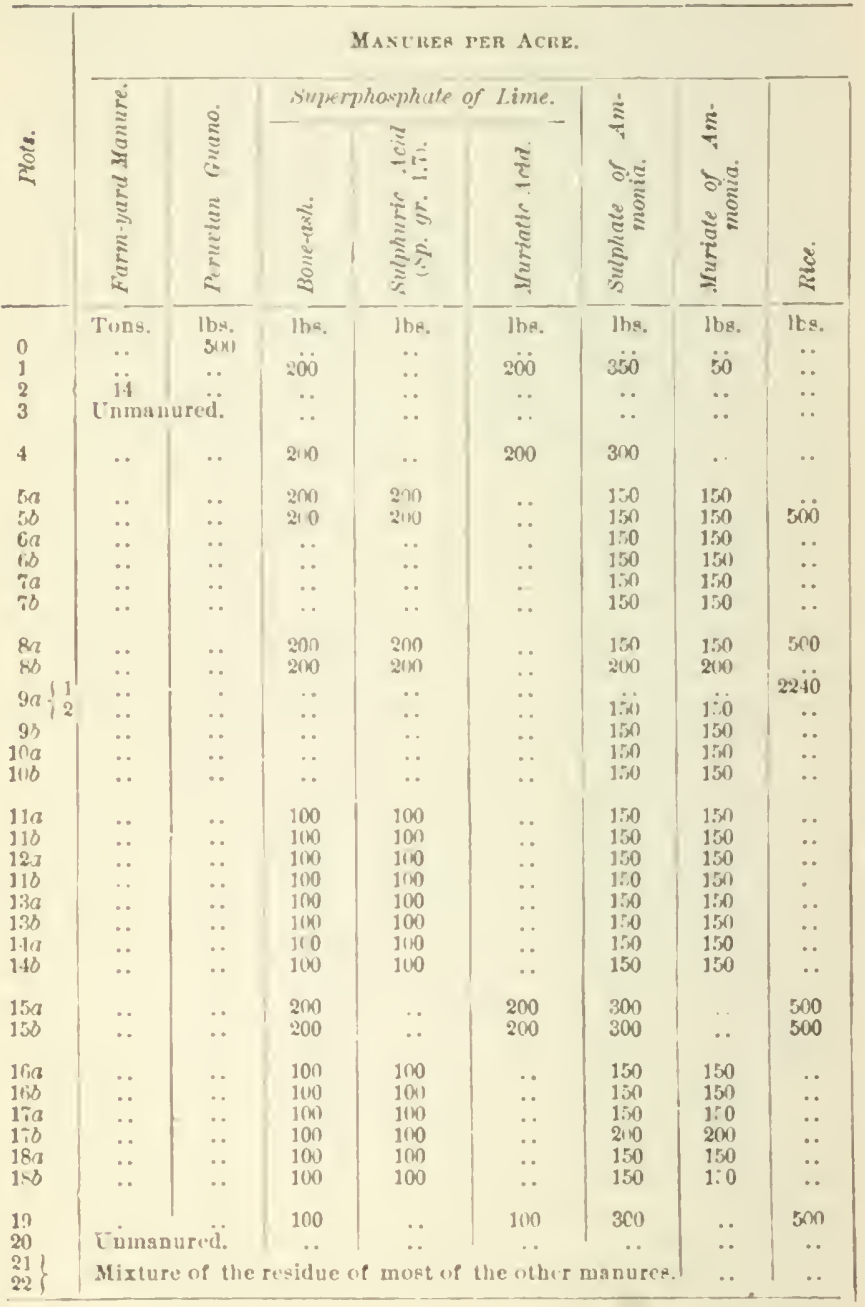


Wheat, Yeak afteh Iear, un tile same LaNd.

MANCRES AND BBED (OLD WED LAMYAS), SOWN END OF OCTOBER, 1816.

\begin{tabular}{|c|c|c|c|c|c|c|c|c|c|c|c|c|}
\hline \multirow{3}{*}{$\frac{\mathfrak{s}}{a}$} & \multicolumn{7}{|c|}{ PRODLCE FFR ACRE, \&C. } & \multicolumn{3}{|c|}{$\begin{array}{c}\text { INCREASR P ACRE } \\
\text { BY MIASTEE. }\end{array}$} & \multirow{3}{*}{ 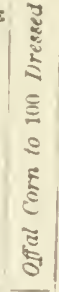 } & \multirow{3}{*}{ 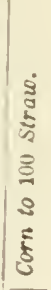 } \\
\hline & \multicolumn{3}{|c|}{ Dressed Corn. } & \multirow[b]{2}{*}{ 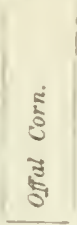 } & \multirow[b]{2}{*}{ 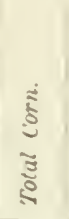 } & \multirow{2}{*}{ 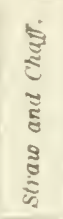 } & \multirow{2}{*}{ 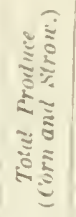 } & \multirow[b]{2}{*}{ ș } & \multirow{2}{*}{ 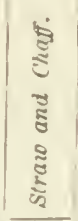 } & \multirow{2}{*}{ 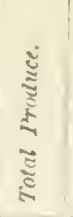 } & & \\
\hline & 这 & & 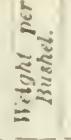 & & & & & & & & & \\
\hline $\begin{array}{l}0 \\
1 \\
2 \\
3\end{array}$ & $\begin{array}{c}\text { Bush. P } \\
33 \\
32 \\
23 \\
16\end{array}$ & $\begin{array}{l}\text { 'chs. } \\
2 \\
1 \\
3 \\
3 \\
3\end{array}$ & $\begin{array}{l}13 . \\
61.1 \\
61.2 \\
6,2.3 \\
610\end{array}$ & $\begin{array}{l}\text { lbs. } \\
116 \\
117 \\
117 \\
95\end{array}$ & $\begin{array}{l}\text { lbs } \\
2031 \\
2110 \\
1941 \\
1123\end{array}$ & $\begin{array}{l}11 \% 8 \\
327 \% \\
3: 35 \\
31 ; 28 \\
1: 02\end{array}$ & $\begin{array}{l}11) \\
5.313 \\
5-51 \\
50.1 \\
3025\end{array}$ & $\begin{array}{l}110.8 \\
318 \\
909 \\
8,8 \\
\ldots\end{array}$ & $\begin{array}{c}1 \mathrm{bs} . \\
1375 \\
1833 \\
172 \mathrm{i} \\
. .\end{array}$ & $\begin{array}{l}\text { lhs } \\
2 \times 3 \\
2809 \\
254 \\
\ldots\end{array}$ & $\begin{array}{l}8.2 \\
7.2 \\
6.2 \\
8.2\end{array}$ & $\begin{array}{l}61.9 \\
81.7 \\
51.6 \\
5 ! 1.0\end{array}$ \\
\hline 4 & 27 & $1 /$ & $61 . ?$ & 82 & 1780 & $\approx 218$ & 4728 & 65 & 1046 & 170.3 & 4.7 & $f, 0.3$ \\
\hline $\begin{array}{l}5 a \\
5 b \\
6 a \\
6 b \\
7 a \\
7 b\end{array}$ & $\begin{array}{l}2.7 \\
52 \\
21 \\
21 \\
27 \\
25\end{array}$ & $\begin{array}{l}0 \\
2 \\
3 \xi \\
1 \neq \\
3 t \\
1 \neq\end{array}$ & $\begin{array}{l}61.4 \\
61.1 \\
62.1 \\
61 . .4 \\
61.7 \\
61.5\end{array}$ & $\begin{array}{l}130 \\
1.73 \\
12: 2 \\
12 i \\
119 \\
125\end{array}$ & $\begin{array}{l}1.921 \\
2132 \\
11633 \\
1,332 \\
1811 \\
16,22\end{array}$ & $\begin{array}{l}3412 \\
3721 \\
2740 \\
2 * 03 \\
3151 \\
2453\end{array}$ & $\begin{array}{l}5333 \\
585 \times 3 \\
1113 \\
48: 5 \\
4 ! 15 \\
4635\end{array}$ & $\begin{array}{r}798 \\
11001 \\
540 \\
504 \\
711 \\
559\end{array}$ & $\begin{array}{r}1510 \\
1519 \\
8 \times 4 \\
\vdots \% 1 \\
1249 \\
1051\end{array}$ & $\begin{array}{l}2: 09 \\
2827 \\
1121 \\
1410 \\
1: 60 \\
11110\end{array}$ & $\begin{array}{l}7.1 \\
6.6 \\
7.4 \\
8.2 \\
6.9 \\
7 . .4\end{array}$ & $\begin{array}{l}55.3 \\
57.2 \\
53.6 \\
58.2 \\
58.2 \\
56.9\end{array}$ \\
\hline $\begin{array}{l}8 a \\
8 b \\
8 a\left\{\begin{array}{l}1 \\
2\end{array}\right. \\
n b \\
10 a \\
10 b\end{array}$ & $\begin{array}{l}32 \\
3 j \\
22 \\
29 \\
26 \\
25 \\
25\end{array}$ & $\begin{array}{l}11 \\
3 \\
3 \\
2 \\
0 \\
3 \\
2 t\end{array}$ & $\begin{array}{l}62.1 \\
61.7 \\
6.2 .5 \\
61.0 \\
61.3 \\
61.5 \\
61.2\end{array}$ & $\begin{array}{c}102 \\
123 \\
\cdots \\
123 \\
113 \\
1.23\end{array}$ & $\begin{array}{l}2115 \\
20: 20 \\
1177 \\
1755 \\
1717 \\
1702 \\
17: 15\end{array}$ & $\begin{array}{l}3 \% 83 \\
3 \% 20 \\
25116 \\
3052 \\
28 \div 8 \\
2831 \\
25 i 1\end{array}$ & $\begin{array}{l}5798 \\
5741 \\
3.183 \\
4217 \\
4575 \\
4513 \\
45: 9\end{array}$ & $\begin{array}{l}972 \\
837 \\
224 \\
632 \\
531 \\
5 \% 9 \\
582\end{array}$ & $\begin{array}{r}1791 \\
1818 \\
1,01 \\
1150 \\
956 \\
98: 1 \\
972\end{array}$ & $\begin{array}{c}2 \% 3 \\
2 \div 15 \\
\cdots \\
1550 \\
15104 \\
1554\end{array}$ & \begin{tabular}{|c|}
5.5 \\
6.3 \\
$\cdots$ \\
. \\
$\ddot{7.3}$ \\
8.2
\end{tabular} & $\begin{array}{l}57.4 \\
54.3 \\
53.9 \\
55.5 \\
60.1 \\
58.8 \\
59.3\end{array}$ \\
\hline $\begin{array}{l}11 a \\
11 b \\
123 \\
123 \\
13 a \\
13 b \\
14 a \\
14 b\end{array}$ & $\begin{array}{l}30 \\
29 \\
29 \\
27 \\
21 \\
27 \\
23 \\
26\end{array}$ & $\begin{array}{l}3 \\
1 \\
2 \\
0 \\
2 \\
1 \\
0 \\
3 \\
0\end{array}$ & $\begin{array}{l}61.6 \\
61.9 \\
62.0 \\
411.5 \\
4 i 2.5 \\
63.3 \\
32.8 \\
62.8\end{array}$ & $\begin{array}{r}112 \\
123 \\
121 \\
121 \\
1113 \\
96 \\
175 \\
166\end{array}$ & $\begin{array}{l}2011 \\
1911 \\
1 ! 15.3 \\
17.16 \\
195.4 \\
1001 \\
1.914 \\
1556\end{array}$ & $\begin{array}{l}3517 \\
3203 \\
3452 \\
3121 \\
3306 \\
3171 \\
3362 \\
3006\end{array}$ & $\begin{array}{l}55011 \\
5141 \\
5415 \\
43: 0 \\
32.5 \\
4372 \\
5306 \\
45622\end{array}$ & $\begin{array}{l}921 \\
813 \\
830 \\
673 \\
836 \\
678 \\
821 \\
733\end{array}$ & $\begin{array}{l}1615 \\
1301 \\
1550 \\
1222 \\
1404 \\
1264 \\
1460 \\
1104\end{array}$ & $\begin{array}{l}2536 \\
2119 \\
2: 340 \\
1895 \\
22111 \\
1317 \\
2281 \\
1837\end{array}$ & $\begin{array}{l}6.3 \\
1.7 \\
6.1 \\
7.1 \\
5.5 \\
5.3 \\
9.7 \\
9.8\end{array}$ & $\begin{array}{l}59.5 \\
60.6 \\
57.1 \\
574 \\
57.3 \\
56.7 \\
59.5 \\
61.7\end{array}$ \\
\hline $\begin{array}{l}15 x \\
158\end{array}$ & $\begin{array}{l}32 \\
32\end{array}$ & $\begin{array}{l}3 \\
0\end{array}$ & $\begin{array}{l}63.0 \\
62.15\end{array}$ & $\begin{array}{l}151 \\
137\end{array}$ & $\begin{array}{l}2214 \\
2140\end{array}$ & $\begin{array}{l}3876 \\
3 \bullet 17\end{array}$ & $\begin{array}{l}60: 30 \\
5 \div 5 i\end{array}$ & $\begin{array}{l}1091 \\
101 \%\end{array}$ & $\begin{array}{l}19 \pi 4 \\
1715\end{array}$ & $\begin{array}{l}30 f 5 \\
27.32\end{array}$ & $\begin{array}{l}7.2 \\
6.6\end{array}$ & $\begin{array}{l}57.1 \\
59.1\end{array}$ \\
\hline $\begin{array}{l}16 a \\
16 b \\
17 a \\
17 b \\
18 z \\
18 b\end{array}$ & $\begin{array}{l}29 \\
34 \\
33 \\
35 \\
32 \\
29\end{array}$ & $\begin{array}{l}1 t \\
2 t \\
3 \\
1 t \\
0 \\
1\end{array}$ & $\begin{array}{l}52.3 \\
122.6 \\
6,2.3 \\
62.0 \\
62.8 \\
629\end{array}$ & $\begin{array}{l}132 \\
119 \\
119 \\
117 \\
14.3 \\
181\end{array}$ & $\begin{array}{l}10,50 \\
2283 \\
2222 \\
2314 \\
2160 \\
2029\end{array}$ & $\begin{array}{l}3417 \\
4012 \\
4027 \\
4261 \\
3852 \\
4161\end{array}$ & $\begin{array}{l}5.376 \\
6: 2 ! 15 \\
62.19 \\
65.57 \\
6012 \\
6193\end{array}$ & $\begin{array}{r}836 \\
1160 \\
10199 \\
1191 \\
1037 \\
906\end{array}$ & $\begin{array}{l}1,515 \\
2110 \\
2125 \\
2: 359 \\
1370 \\
224 i 2\end{array}$ & $\begin{array}{l}2351 \\
3270 \\
3221 \\
3550 \\
2347 \\
3163\end{array}$ & $\begin{array}{l}6.9 \\
5.2 \\
5.6 \\
6.4 \\
69 \\
9.7\end{array}$ & $\begin{array}{r}57.3 \\
5 f .9 \\
55.1 \\
54.3 \\
56.0 \\
48.7\end{array}$ \\
\hline $\left.\begin{array}{l}19 \\
20 \\
21 \\
22\end{array}\right\}$ & $\begin{array}{l}32 \\
20 \\
\cdots\end{array}$ & $\begin{array}{l}3 \\
0 t \\
\cdots\end{array}$ & $\begin{array}{c}62.8 \\
62.5 \\
\cdots\end{array}$ & $\begin{array}{r}140 \\
70 \\
. .\end{array}$ & $\begin{array}{c}219 ; \\
13: ; 2 \\
\ldots\end{array}$ & $\begin{array}{c}4202 \\
2171 \\
\ldots\end{array}$ & $\begin{array}{c}6397 \\
3406 \\
.\end{array}$ & $\begin{array}{c}10 \div 2 \\
203 \\
\cdots\end{array}$ & $\begin{array}{c}2300 \\
172 \\
. \cdot\end{array}$ & $\begin{array}{c}3372 \\
381 \\
\ldots\end{array}$ & $\begin{array}{l}6.7 \\
4.9 \\
\cdots\end{array}$ & $\begin{array}{r}52.2 \\
64.2 \\
\quad \cdots .\end{array}$ \\
\hline
\end{tabular}


Here again, I want the Deacon (1) look at plot 0 , where 500 lbs. Peruvian gusno, sown in Oetuber, gives an increase of nearly 14 bushels of dressel wheat and 1,375 lbs. of straw per acre. On plot 2 , where 14 tons of barn yard manure have now been applied four years in suceession ( 56 tons in all), there is a little more straw, but not quite so mueh grain, as from the $500 \mathrm{lhs}$. of guano.

"But will the gratno," saitl the Deacon, "lue as lasting as the manure?"

" Jut for wheat," saiel I. "But if you seed the wheat duwn with clover, as would be the e.se in this section, we should get considerable be netit, probably, from the ertano. If wheat was sownafter the wheat, the grasun applied the previous seaton would do little geond on the second cropu of whrat. Anel yet it is a matter of lact that there would be a considerable propurtion of the gaano left in the soil. The wheat (annut talic it up). But thre elover ("in. And we alli know that if we can arow groud cropse of clover, plowing it under, or feceling it out on the lanel, or making it into hay and saving the manure obtained from it, we shall thus be enabled to raise good erops of whealt, harley, oats, potatnes, and com, and in this sense guano is a 'listing' manure."

"Barnvard-manure," sild the Ductur, "is altoecther ton "lasting.' II re we have hatd 56 tons of manure an an acre uf land in four years, and yet an acre dresied with jol) lbs. wf gutuo produces just as good a crup. The manure cont:in- far more plant-fond, of all kinds, than the gutmo, but it is sn 'lanting ' that it does not do half as much gool as its eompusition would leasl us to expect. Its 'lasting' properties are a decidled objection, rather than an aclvantage. If we could make it less l:stint-in other works, if we could make it act quicker, it woul 1 promluer a greatur reffeet, and possess it greater ralue. In jropurtion to its constituents, the harn-yard manure is far eheaper than the guano, but it has a less beneficial effoct, hecau-e these constituents are not more eompletely lecomposed and rendered arailable."

"That," saill I, "opens up a very importent question. Te have more real value in manure than most of us are as y't able to bring ont and turn to gnod account. The sandy-land farmer has an advantage orer the day-laml farmer in this respect. The latter has a naturally rieher soil, but it costs him more to work it, and mamure does not aet so rapilly. The clay-land farmer should use his best endearors to decompose his manure."

"Yes," said the Doctor, "and, like John Jolinston, he will probahly fiml it to his allvantage in use it larery as a top-tressing on the surface. Exposing manure to the atmesphere, spreat out on 
the land for several montlis, and harrowing it occasionally, will do much to render its (onstituents available. But let us return to Mr. Lawes' womberful experiments."

"On eight plots," said I, "300 lbs. of ammonia-silts were used without ang other manures, and the average yich on these cight plots was nearly 26 bushels per acre, or an average increase of 9 bushels per acre. The sime amount of ammonia-salts, with the aldition of superphosphate of lime, gave an increase of 13 bushels per acre. 400 lhs. ammonia salts, with superphosplate of lime, gave an increas. of bearly 16 bushels per acre, or three lushels per acre more than where 14 tons of barn-yard manure had been used four years in succession.

"I hope, after this, the Deacon will forgive me for (lwelling on the value of availuble nitrogen or ammonia as a manure for wheat."

"I see," said the Deacon, "that ground rice was used this year for manure; and in 18.5, tupioe $t$ was also tesed as a manure. The Connecticut Tobacco growers a f'w years since used corn-meal for manure, and you thought it a creat waste of good food."

I think so still. But we will not discus the matter now. Mr. Lawes wantel to ascertain whether cirbonuceo"s mattr $r$ was needed ho the growing wheat-plants, or whether thes could get ail they needed from the soil and the atmosphre. The enormous quantities of carbonaceous matter supplied by the barn-yard manure, it is quite evident, are of little ralue as a manure for wheat. And the rire seems to have done very little more gond than we should expect from the $22 \mathrm{lbs}$. of nitrogen which it contained. The large quantity of rarbonaceons matter evidently did little good. Avail able carbonacenus matter, such as starch, sugar, and oil, was intended as food for man and beast-not as food for wheat or tobacen.

The following table gires the results of the experiments the fifth sear, 184i-s. 


\section{Experimenty at Rothaysted on the Growtil of}

TABLE Y.-YANURES AND PRODLCE; 5TI SEASON, 184T-8.

\begin{tabular}{|c|c|c|c|c|c|c|c|c|c|c|c|}
\hline \multirow[b]{3}{*}{ 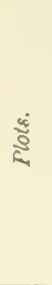 } & \multicolumn{11}{|c|}{ Masereg PER Acke. } \\
\hline & \multirow[b]{2}{*}{ 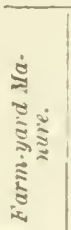 } & \multirow[b]{2}{*}{ 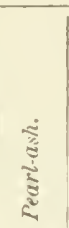 } & \multirow[b]{2}{*}{ 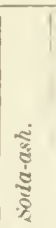 } & \multirow[b]{2}{*}{ 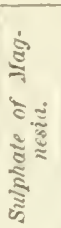 } & \multirow[b]{2}{*}{ 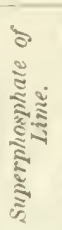 } & \multicolumn{3}{|c|}{$\begin{array}{c}\text { superphavyluate of } \\
\text { Lime. }\end{array}$} & \multirow[b]{2}{*}{ 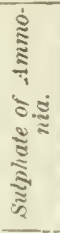 } & \multirow[b]{2}{*}{ 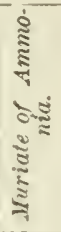 } & \multirow[b]{2}{*}{ 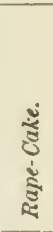 } \\
\hline & & & & & & 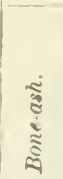 & 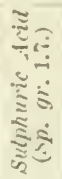 & 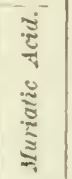 & & & \\
\hline 0 & Tonn. & $\begin{array}{l}\text { lhs. } \\
\text {... }\end{array}$ & $\begin{array}{c}\text { lbs. } \\
\text {.. }\end{array}$ & $\begin{array}{l}\text { lbs. } \\
\text {.. }\end{array}$ & $\begin{array}{l}\text { lhs. } \\
2211\end{array}$ & $\begin{array}{l}\text { Ibs. } \\
\text {.. }\end{array}$ & Ibs. & $\begin{array}{l}\text { Ihe. } \\
\text {.. }\end{array}$ & line. & lbe. & Ibs. \\
\hline 1 & $\cdots$ & .. & .. & $\because$ & .. & .. & .. & .. & .. & .. & .. \\
\hline$\frac{2}{3}$ & \multirow{2}{*}{\multicolumn{2}{|c|}{ Cnimanured. }} & $\cdots$ & .. & . & .. & •. & $\cdots$ & .. & $\ddot{*}$ & $\because$ \\
\hline & & & $\cdots$ & .. & $\cdots$ & $\cdots$ & 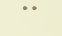 & $\cdots$ & -. & $\cdot$ & • \\
\hline 4 & .. & .. & .. & .. & .. & 200 & .. & 200 & 300 & .. & .. \\
\hline $5 a$ & .. & 300 & 200 & 1110 & .. & 200 & 150 & .. & 250 & 250 & \\
\hline 50 & $\cdots$ & 300 & 201 & $1(t)$ & . & 200 & $\begin{array}{l}1: 50 \\
3: 0\end{array}$ & . & $\begin{array}{r}200 \\
200\end{array}$ & $\begin{array}{l}200 \\
200\end{array}$ & 500 \\
\hline $\begin{array}{l}6 a \\
6 b\end{array}$ & $\because$ & $\because$ & $\ddot{0}$ & $\because$ & $\because$ & $\begin{array}{l}400 \\
200\end{array}$ & $\begin{array}{l}3.10 \\
150\end{array}$ & ․ & 200 & 200 & $\ddot{\therefore}$ \\
\hline $7 a$ & $\because$ & $\because$ & $\ddot{0}$ & 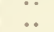 & $\therefore$ & 400 & 300 & $\ddot{0}$ & 150 & 150 & 500 \\
\hline 76 & .. & .. & .. & .. & . & 200 & 150 & .. & 150 & 150 & 500 \\
\hline $8 a$ & .. & 300 & $2(4)$ & $1 \mathrm{~m}$ & $\ldots$ & 200 & 150 & .. & .. & .. & .. \\
\hline $8 b$ & .. & 300 & $P(y)$ & 1100 & .. & 210 & 1.0 & .. & .. & .. & .. \\
\hline $9 a$ & .. & .. & .. & .. & .. & 200 & 1.00 & .. & $\ddot{1} \ddot{0}$ & $\ddot{1} \ddot{0}$ & .. \\
\hline $9 b$ & $\because$ &.. & & .. & .. & 200 & 1,50 & $\because$ & 1,0 & 150 & $\because$ \\
\hline 106 & $\ddot{*}$ & 300 & 200 & 100 & $\because$ & $2 \ddot{00}$ & $1 \ddot{0} 0$ & $\because$. & 150 & 150 & $\ddot{*}$ \\
\hline $11 a$ & .. & .. & .. & .. & .. & $2 n 0$ & $1: 0$ & .. & $1: 0$ & 150 & 500 \\
\hline 116 & $\because$ & & .. & $\therefore$ & .. & 200 & 1.20 & .. & 200 & 200 & . \\
\hline 120 & .. & sin & .. & .. & .. & 200 & 1.50 & .. & 150 & 150 & 500 \\
\hline 126 & .. & 3110 & .. & .. & .. & 200 & 150 & .. & 2110 & 200 & \\
\hline $13 a$ & .. & 300 & .. & $\ldots$ & .. & 200 & $1: 0$ & .. & 150 & 150 & 500 \\
\hline $13 b$ & .. & 300 & .. & .. & .. & 200 & $1: 0$ & .. & 20 & 200 & rin \\
\hline & .. & 300 & .. & .. & $\because$ & 210 & 150 & $\ddot{.}$ & $\begin{array}{l}1.50 \\
200\end{array}$ & $\begin{array}{l}150 \\
200\end{array}$ & 500 \\
\hline & & 300 & & & & & & & & & \\
\hline $15 a$ & .. & 300 & 200 & 100 & .. & 200 & .. & 200 & 300 & .. & .. \\
\hline $15 b$ & .. & 300 & 200 & 1110 & .. & 200 & .. & 200 & 300 & .. & .. \\
\hline $16 a$ & .. & 300 & 200 & 100 & .. & 200 & 150 & .. & 150 & 150 & 500 \\
\hline $11 i b$ & .. & 300 & 200 & 1100 & & 20 & $1: 0$ & .. & 150 & 1.0 & 500 \\
\hline $17 a$ & .. & 300 & 200 & 11:0 & $\because$ & 200 & 150 & .. & 200 & 200 & .. \\
\hline $1 ; 0$ & .. & 309 & 200 & 107 & .. & 210 & 157 & 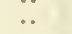 & 2110 & 2110 & .. \\
\hline 182 & $\therefore$ & 300 & 200 & 100 & .. & 200 & 150 & .. & 150 & 150 & .. \\
\hline $1<b$ & $\cdots$ & 300 & 200 & $1(10$ & $\ldots$ & 200 & $1: 0$ & . & 150 & 150 & .. \\
\hline 19 & & & $\therefore$ & 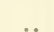 & .. & 200 & .. & 200 & 300 & .. & 500 \\
\hline 20 & Unmar & ured. & .. & $\ddot{0}$ & 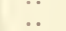 & . & $\ddot{0}$ & .. & .. & $\because$ & .. \\
\hline $\begin{array}{l}21 \\
22\end{array}$ & .. & .. & .. & .. & .. & .. & .. & .. & .. & .. & .. \\
\hline
\end{tabular}


WHEAT, Yeah AFTBK YEAR, ON THE SAME LAND.

MANUREG AND BEBD (OLD RED LAMYAY) SOWN AUTUMN, 1647.

\begin{tabular}{|c|c|c|c|c|c|c|c|c|c|c|c|c|}
\hline & & & RODEC & CE PE & ACRE & TC. & & Isch & : & $\begin{array}{l}\text { ACrR } \\
\text { 8K. }\end{array}$ & $\mathbf{x}^{\prime}$ & \\
\hline & Dress & d & & & & & & & & & & \\
\hline & گ્) & & $\begin{array}{l}\vdots \\
\vdots \\
\vdots \\
\vdots\end{array}$ & 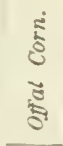 & 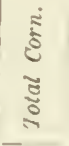 & 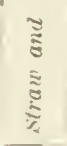 & 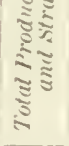 & है & $\begin{array}{l}\cong \\
\Xi \\
\Xi \\
\vdots \\
\vdots\end{array}$ & 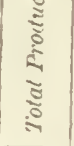 & $\begin{array}{l}\vdots \\
\vdots \\
\vdots \\
\vdots \\
\vdots \\
\vdots\end{array}$ & $\begin{array}{l}8 \\
8 \\
0 \\
5 \\
5 \\
3\end{array}$ \\
\hline $\begin{array}{l}0 \\
1 \\
2 \\
3\end{array}$ & $\begin{array}{c}\text { Bush. } \\
19 \\
16 \\
2.7 \\
14\end{array}$ & $\begin{array}{l}1 \text { 'ks. } \\
0 \% \\
0 ! \\
2 ! \\
3\end{array}$ & $\begin{array}{l}16.4 \\
55.4 \\
59.6 \\
5.9 .2 \\
57.3\end{array}$ & $\begin{array}{l}16.8 . \\
134 \\
160 \\
210 \\
106\end{array}$ & & $\begin{array}{l}1 \mathrm{bos}, \\
20 \pi 4 \\
10.25 \\
3011 \\
1712\end{array}$ & 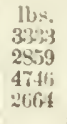 & $\begin{array}{l}1 \mathrm{bs} \\
307 \\
172 \\
7,233 \\
. .\end{array}$ & $\begin{array}{r}\text { lhs. } \\
312 \\
23 \\
13: 9 \\
\ldots\end{array}$ & $\begin{array}{c}\text { Ihy } \\
6 \div i \\
19.5 \\
2082 \\
. .\end{array}$ & $\begin{array}{l}13.4 \\
16.3 \\
13.8 \\
12.1\end{array}$ & $\begin{array}{l}60.7 \\
61.7 \\
56.0 \\
55.6\end{array}$ \\
\hline 4 & 21 & $0+$ & 58.5 & 172 & 1583 & $2: 13$ & 4296 & $6 ? 1$ & 1001 & 16.32 & 12.0 & 58.3 \\
\hline $\begin{array}{l}5 a \\
5 b \\
6 a \\
6 b \\
i a \\
i b\end{array}$ & $\begin{array}{l}29 \\
31 \\
21 \\
25 \\
30 \\
29\end{array}$ & $\begin{array}{l}3 \\
3 t \\
3 t \\
3 \\
3 t \\
3 t\end{array}$ & $\begin{array}{l}59.2 \\
59.1 \\
52.4 \\
56.9 \\
59.4 \\
59.6\end{array}$ & $\begin{array}{l}144 \\
107 \\
214 \\
216 \\
106 \\
187\end{array}$ & & $\begin{array}{l}3266 \\
35: 3 \\
2 ; 78 \\
29: 8 \\
30: 8 \\
3113\end{array}$ & $\begin{array}{l}517 \% \\
5165 \\
4550\end{array}$ & $\begin{array}{r}9.59 \\
980 \\
720 \\
75 \\
911 \\
1011\end{array}$ & & $\begin{array}{l}2513 \\
2501 \\
18: 6 \\
2041 \\
2360 \\
2 \div 12\end{array}$ & $\begin{array}{r}7.9 \\
5.8 \\
11.6 \\
14.0 \\
5.7 \\
10.3\end{array}$ & $\begin{array}{l}57.5 \\
58.0 \\
53.5 \\
62.6 \\
5.5\end{array}$ \\
\hline $\begin{array}{c}8 a \\
\varepsilon b \\
9 a \\
9 b\end{array}$ & $\begin{array}{l}19 \\
13 \\
18 \\
25 \\
19 \\
25\end{array}$ & $\begin{array}{l}3 \\
0 ! \\
21 \\
11 \\
1 \\
0 t\end{array}$ & $\begin{array}{l}56.2 \\
59.4 \\
56.7 \\
53.3 \\
53.1 \\
57.8\end{array}$ & & & $\begin{array}{l}2317 \\
2119 \\
1115 \\
2918 \\
2: 67 \\
2926\end{array}$ & $\begin{array}{l}3126 \\
4^{-}-5 \% \\
3701 \\
4530\end{array}$ & & $\begin{array}{r}605 \\
436 \\
2: ; 3 \\
1206 \\
65.5 \\
1211\end{array}$ & $\begin{array}{r}916 \\
751 \\
462 \\
19 \div 3 \\
10: 7 \\
1566\end{array}$ & $\begin{array}{l}13.6 \\
11.1 \\
11.6 \\
13.9 \\
19.0 \\
10.1 ;\end{array}$ & $\begin{array}{l}54.5 \\
58.8 \\
60.7 \\
57.1 \\
56.3 \\
51.8\end{array}$ \\
\hline & $\begin{array}{l}29 \\
21 \\
29 \\
26 \\
29 \\
25 \\
29 \\
25\end{array}$ & $\begin{array}{l}11 \\
3 \\
3 \\
0 \\
1 \\
3 \frac{1}{4} \\
0+ \\
2\end{array}$ & $\begin{array}{l}59.6 \\
57.9 \\
59.3 \\
59.2 \\
57.9 \\
53.4 \\
58.9 \\
58.5\end{array}$ & & & & $\begin{array}{l}52 \pi 8 \\
45 ; 19 \\
5 ; 29 \\
4597 \\
5 * 45 \\
4872 \\
5791 \\
4623\end{array}$ & $\begin{array}{r}10: 32 \\
659 \\
946 \\
765 \\
1003 \\
789 \\
882 \\
7.4\end{array}$ & & $\begin{array}{l}2591 \\
1875 \\
2664 \\
1 ! 935 \\
2-81 \\
2138 \\
2127 \\
1959\end{array}$ & $\begin{array}{r}13.1 \\
11.1 \\
9.7 \\
10.7 \\
14.7 \\
11.7 \\
11.1 \\
15.1\end{array}$ & $\begin{array}{l}60.6 \\
56.4 \\
57.2 \\
59.8 \\
5 ! 9.4 \\
56.3 \\
56.3 \\
59.5\end{array}$ \\
\hline & $\begin{array}{l}22 \\
24\end{array}$ & 21 & $\begin{array}{l}59.1 \\
56.9\end{array}$ & & & & & & & $\begin{array}{l}1814 \\
1959\end{array}$ & $\begin{array}{l}18.1 \\
14.1\end{array}$ & $\begin{array}{r}53.4 \\
53.2\end{array}$ \\
\hline & $\begin{array}{l}29 \\
30 \\
27 \\
28 \\
26 \\
26\end{array}$ & $\begin{array}{l}37 \\
17 \\
17 \\
21 \\
27 \\
3 \\
24\end{array}$ & $\begin{array}{l}67.0 \\
-38.4 \\
59.7 \\
59.1 \\
59.2 \\
59.6\end{array}$ & & & $\begin{array}{l}311.5 \\
3: 297 \\
3296 \\
3321 \\
2735 \\
305 \%\end{array}$ & $\begin{array}{l}5089 \\
53: 8 \\
5: 23 \\
5270 \\
41 i f 9 \\
4 \cup 60\end{array}$ & $\begin{array}{c}1021 \\
9: 6 \\
981 \\
991 \\
7 \times 2 \\
8.52\end{array}$ & & $\begin{array}{l}2424 \\
21 ; f 4 \\
25 f ; 5 \\
2 f i 06 \\
2005 \\
219 f ;\end{array}$ & $\begin{array}{r}10.2 \\
9.4 \\
17.0 \\
12.6 \\
9.2 \\
13.3\end{array}$ & $\begin{array}{l}63.3 \\
57.6 \\
58.6 \\
58.5 \\
59.0 \\
58.7\end{array}$ \\
\hline $\left.\begin{array}{l}19 \\
20 \\
21 \\
22\end{array}\right\}$ & $\begin{array}{l}29 \\
16 \\
\cdots\end{array}$ & $\begin{array}{l}17 \\
\text { ct } \\
.\end{array}$ & $\begin{array}{c}56.2 \\
58.3 \\
. .\end{array}$ & $\begin{array}{c}185 \\
111 \\
. .\end{array}$ & $\begin{array}{c}1938 \\
1050 \\
. .\end{array}$ & $\begin{array}{c}3205 \\
1721 \\
\cdots\end{array}$ & $\begin{array}{c}5133 \\
2771 \\
. .\end{array}$ & $\begin{array}{c}886 \\
48 \\
\cdots\end{array}$ & $\begin{array}{r}1583 \\
9 \\
.\end{array}$ & $\begin{array}{c}2469 \\
107 \\
\cdots\end{array}$ & $\begin{array}{c}10.4 \\
11.3 \\
\cdots\end{array}$ & $\begin{array}{r}55.7 \\
61.0 \\
\mid \cdots\end{array}$ \\
\hline
\end{tabular}


This season was considered unfarorable for wheat. The ron. tinuously unmanured filut produced 1 ti bushels, and the plot receiving 14 tons of barn yard manure, 2.5 bushels per acre nearly.

$300 \mathrm{lbs}$ of ammoni:-salts alone on plot 10a, frave 191 bushels per acre, whild the same quantity of ammonia, with superphosphate in arldition, grave, on plot 96,25 bushels per acre.

The adclition to the above manures of 300 lls. of potacli, 200 lbs. snia, andl 100 lbs. sllphate of magnesia, on plot 10h, gave pre(isely the same yie lil per are as the ammonia and the superplinsphate alone. The pothsh, sull, and mugnesi h, therefore, did no goorl.

400 lhs. of ammonia-silts, with superphosphate, putssh, cte., gave,

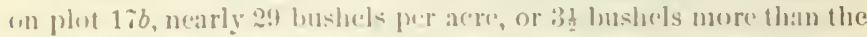
flot which has now receivel of toms of hatn-yard manure in five sucensive years.

"I scee that, on plut 1)," sairl the Deacon, "nne ton of superphosphate was usiel furer are, and it gave only half a hushel per acre more than 350 liss. on 9a."

"This proves," said I, "thit an exersire lose of superpliosphate will de ne harm. I am not sure that 100 llas. of a good superphusplate drilled in 2 th the sed, would not hate done as much greul as a ton per atre."

"You say," remarked the Deacon, "that the season was unfarorable for wheat. And yet the me-manure plot produced nearly 15) bushels of wheat peracre."

"That is all true," said I, "and yet the searon was undoubtedly an unfavorable one. This is shown not only in the less yiedd, but in the inferior ruality of the gratin. The "dresent corn' on the nomanure plot this year only weighed 5it lhs. per hushel, while last year it weigheel til lles. per lushel."

"Br the wiy," said the loctor, "what do Messrs. Lawes and Gilbert mean he "Iressed roorn" "

"I3y "corn,", said I, "they mean wheat ; and by " Iressed corn" fley unean wheat that has been run through a famning-mill until all the light and shrunken erain is blown or sieved out. In other worls, "dressed eorn' is wheal carefully cheinerl for market. The Fnglish farmers take more pains in cleaning their grain than we do. And this 'Aressed corn' was as elean as a good fanning-mill conld make it. You will ohserve that there was more "offil corn' this year than last. This also indicates an unfarorable season."

"It wolld hare heen rery interestine," said the 1)octor, "if Measers. Lawes and Gilhert had antilyed the wheat produeed by the dillerent manures, so that we might have known something in re- 
garil to the quality of the Hour as influenced by the use of different fertilizers."

"They did that very thine," said I, "anil not only that, but they male the wheat grown on diflerent plots, into tlour, and ascertained the yield of thour from a given weight of wheat, and the amount of bran, midclines, etc., etc. They obtained some very interesting and important results. I was there at the time. 13ut this is not the place to diseuss the question. I an often amused, however, at the remarks we often hear in regarl to the inferior quality of our wheat as compared to what it was when the country was new. Many' seem to think that "there is something lacking in the soil'-some say potash, and some phosphates, and some this, and some that. I beliere nothing of the kind. Depend upon it, the varicty of the wheat and the soil and suason have much wore to to with the qualite or streneth of the tlour, than the chemical composition of the manures applied to the land."

"At any rate," suid the D) x(ur, "we may be satisfied that anything that will produce a vignrous, healihy growth of wheat is favorable to quality. We may use manures in excess, and thus produce over-luxuriance and an unbealthy growth, and have poor, shrunken grain. In this case, it is not the use, but the abuse of the manure that does the mischicf. We must not manure higher than the season will bear. Is yet, this question rarely troubles us. Hitherto, as a rule, our seasons are hetter than our farming. It may not always be so. We may find the liberal use of manure so Inofitable that we shall oecasionally use it in excess. At present, however, the tendeney is all the other way. We hare more grain of inferior quality from lack of fertility than from an excess of flant-food."

"That may be true," said I, "but we hare more poor, inferior wheat from lack of draining and good culture, than from lack of plant-food. Red-root, thistles, cockle, and chess, hare done more to injure the reputation of 'Genesee Flour,' than any other one thing, and I should like to hear more said about thorough cultiration, and the destruetion of weeds, and less about snil exhaustion."

The following table shows the results of the experiments the sixth year, 1848-9. 
Experimexts at Rothamsted on the Growth of TABLE VI.-YANURES AND PRODUCE; 6TH 8EA8ON, 184S-9.

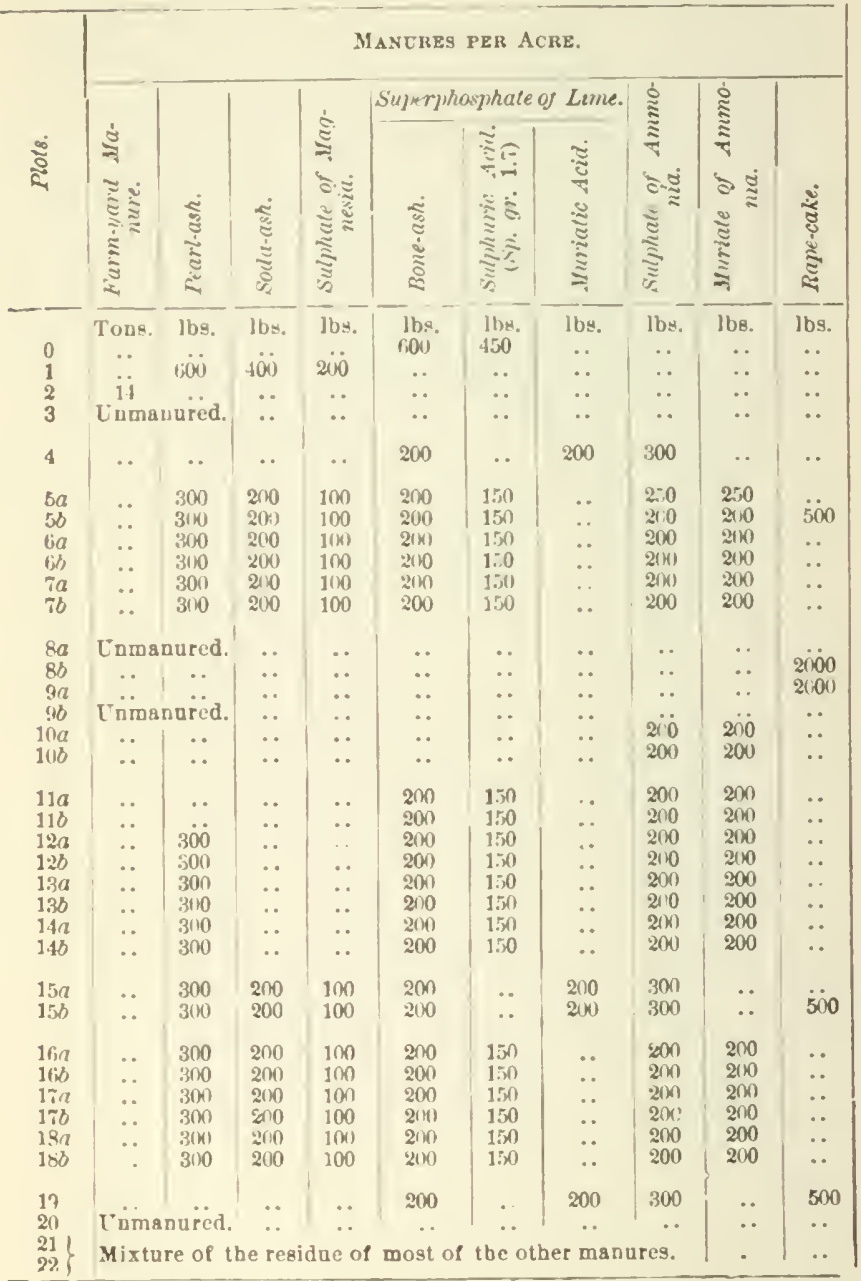


Wheat, Yeah after Year, oN tue same LaNd.

MANCREG AND BEED (RED CLUSTER), BOWN AUTUMX, 1818.

\begin{tabular}{|c|c|c|c|c|c|c|c|c|c|c|c|c|}
\hline \multirow{3}{*}{$\frac{z^{2}}{c^{2}}$} & \multicolumn{4}{|c|}{ Prodlce peF } & \multicolumn{2}{|c|}{ ACRE, ETC. } & \multirow{3}{*}{ 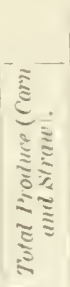 } & \multicolumn{3}{|c|}{$\begin{array}{l}\text { INUREASE P ACRE } \\
\text { BY MANERE. }\end{array}$} & \multirow{3}{*}{ 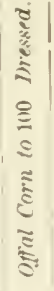 } & \multirow{3}{*}{ 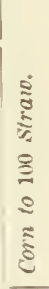 } \\
\hline & \multicolumn{3}{|c|}{ Dresied corn } & \multirow[b]{2}{*}{ 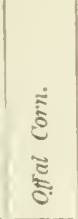 } & \multirow[b]{2}{*}{ 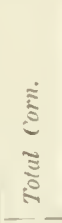 } & \multirow{2}{*}{ 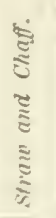 } & & & 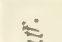 & & & \\
\hline & כ્) & & 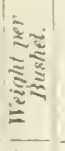 & & & & & 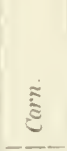 & 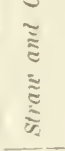 & 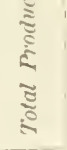 & & \\
\hline $\begin{array}{l}0 \\
1\end{array}$ & $\begin{array}{c}\text { Bush. } \\
. \\
.\end{array}$ & $\begin{array}{c}\text { Pks. } \\
\therefore \\
\therefore\end{array}$ & li) 8. & $\begin{array}{l}\text { lbs. } \\
\cdots\end{array}$ & $\begin{array}{l}11)=. \\
\cdots\end{array}$ & Jbs. & $\begin{array}{l}\text { lbs. } \\
\text {. }\end{array}$ & $\begin{array}{l}\text { lbs. } \\
\cdots\end{array}$ & $\begin{array}{l}\text { lihs. } \\
\text {.. }\end{array}$ & $\begin{array}{l}\text { Ibs. } \\
\cdots\end{array}$ & . & \\
\hline$\frac{1}{2}$ & $\begin{array}{l}3 i \\
19\end{array}$ & $\ddot{0}$ & 63.8 & 107 & 2üs & $3 \ddot{0} 21$ & $\operatorname{cosi}$ & 839 & 1115 & $225-4$ & 4.7 & 68.3 \\
\hline 3 & & & 61.4 & $4 i$ & 1229 & 1611 & 2813 & . & .. & *. & 3.9 & 76.1 \\
\hline 4 & 30 & 0 & 63.0 & 110 & $20 t i 3$ & 2645 & 4708 & $8: 34$ & 1031 & $184 ; 5$ & 5.6 & 78.0 \\
\hline $5 a$ & 37 & $1 \frac{1}{6}$ & 63.1 & \&9 & 2.146 & 3589 & 6035 & 1217 & 1575 & $31 ! 92$ & $3 . \tau$ & ti 8.1 \\
\hline $5 b$ & 39 & $3 t$ & 63.4 & 47 & $2 t i 51$ & $: \$ 21$ & $6 i 475$ & 1422 & 2210 & 36032 & 5.0 & 69.3 \\
\hline $6 a$ & 36 & $1+$ & (23).0 & 117 & 2410 & $3 \pi$ & 5482 & 1181 & 1458 & 26344 & 5.1 & 78.4 \\
\hline 63 & $3 i$ & $3 !$ & (63.) 0 & 34 & $215 !$ & 3516 & 600 & 125.5 & $1 !(1)$ & 3157 & 3.9 & 70.6 \\
\hline $7 a$ & $\begin{array}{l}38 \\
3 \pi\end{array}$ & 24 & $\begin{array}{l}631 \\
639\end{array}$ & 137 & $\begin{array}{l}25 i 6 \\
2531\end{array}$ & $\begin{array}{l}3: 81 \\
33 ! 16\end{array}$ & $\begin{array}{l}6110 \\
5427\end{array}$ & $\begin{array}{l}1 \% 47 \\
130 ;\end{array}$ & $\begin{array}{l}14 \% 0 \\
1 \div 82\end{array}$ & $\begin{array}{l}3317 \\
30 \times 1\end{array}$ & $\begin{array}{l}5.6 \\
5.9\end{array}$ & 7.9 \\
\hline & & & & & & & & & & & & \\
\hline $8 a$ & 22 & $\begin{array}{l}3 \\
27\end{array}$ & $\begin{array}{l}61.7 \\
63.0\end{array}$ & 76 & $\begin{array}{l}1451 \\
2 y-0\end{array}$ & $\begin{array}{l}1215 \\
316,60\end{array}$ & $\begin{array}{l}3296 \\
5246\end{array}$ & $\begin{array}{l}252 \\
851\end{array}$ & $\begin{array}{r}201 \\
15-2\end{array}$ & $\begin{array}{r}453 \\
2413\end{array}$ & $\begin{array}{l}5.3 \\
4.3\end{array}$ & $\begin{array}{l}81.6 \\
6 i 5.7\end{array}$ \\
\hline $8 b$ & 31 & 24 & $\begin{array}{l}63.0 \\
62.5\end{array}$ & $\begin{array}{r}85 \\
111\end{array}$ & $\begin{array}{l}21=0 \\
2135\end{array}$ & $\begin{array}{l}316,1) \\
2(n-3)\end{array}$ & $471 \%$ & 806 & JiM.9 & $18 \%$ & 5.8 & i5. \\
\hline $9 a$ & 30) & 2 & $\begin{array}{l}6 ? . S \\
62.3\end{array}$ & $\begin{array}{r}111 \\
80\end{array}$ & $11 \div 5$ & $1 \leqslant 10$ & 8265 & 24 & $1 ! 46$ & 432 & 5.7 & 81.5 \\
\hline 96 & 22 & 17 & $\begin{array}{l}62.3 \\
62.3\end{array}$ & $\begin{array}{r}80 \\
112\end{array}$ & 2141 & $2-51$ & $49 ! 12$ & $\$ 12$ & 1237 & $214^{\prime \prime}$ & 5.5 & 75.1 \\
\hline $\begin{array}{l}10, t \\
106\end{array}$ & $\begin{array}{l}32 \\
32\end{array}$ & $\begin{array}{l}2 \frac{1}{2} \\
1 \frac{1}{d}\end{array}$ & $\begin{array}{l}62.3 \\
63.3\end{array}$ & 110 & $215 i$ & 2360 & 5117 & 928 & 1346 & $22 \% 4$ & 5.3 & 72.9 \\
\hline $11 a$ & 35 & $0\}$ & 62.6 & 121 & 2317 & 2892 & 5209 & $10 \leqslant 8$ & $12: 8$ & 2366 & 5.6 & 80.1 \\
\hline 118 & 32 & $1 \frac{3}{6}$ & 63.0 & 112 & 2119 & $2(4+2$ & $50 \div 11$ & $\lfloor 20$ & $132 \mathrm{~K}$ & 2248 & 5.5 & 73.0 \\
\hline $12 a$ & 35 & $3 \frac{5}{5}$ & 64.3 & !3 & $2: 396$ & 3371 & $5.67 \%$ & 1167 & ז & 2924 & 4.1 & 71.1 \\
\hline $12 b$ & 34 & $1 \frac{1}{8}$ & 64.3 & i1 & 2277 & 3300 & 5.5. & 1048 & $168 \%$ & $2 \pi 355$ & 3.2 & 6 \\
\hline & 34 & $3 f$ & 64.1 & 101 & 2340 & 3236 & $55 \pi 6$ & 1111 & 1622 & 2733 & 4.5 & 72.3 \\
\hline $13 b$ & 34 & $2 \frac{1}{2}$ & 64.1 & 129 & $2346 j$ & 3216 & $55 !+2$ & 1117 & $16 i 32$ & 2749 & 5.8 & 72 \\
\hline 14 & 34 & $1 \frac{1}{13}$ & 64.3 & 56 & 2246 & $3: 11$ & 5177 & $103 \pi$ & $159 i$ & $2 t ; 31$ & 2.5 & 70.6 \\
\hline $14 b$ & 31 & $1 \frac{1}{6}$ & 64.3 & 11: & 2123 & 3218 & 5311 & 89.4 & 1604 & $24 ! 8$ & 5.5 & \\
\hline $15 a$ & 31 & $3 \frac{1}{2}$ & 64.2 & 65 & 2109 & 3038 & $514 \pi$ & $8<0$ & 1424 & 2301 & 3.2 & 694 \\
\hline $15 b$ & 30 & 04 & 64.1 & 68 & 2005 & $3: 2$ & 5267 & $\pi 6$ & 16,18 & 2421 & 3.5 & 61.5 \\
\hline 164 & 33 & 17 & 64.5 & 101 & 2254 & 334 & $5 f$ fis & 1025 & 1700 & 2795 & 4.7 & 66.6 \\
\hline & 33 & 3 & 64.6 & 75 & 22118 & 3559 & $5 \times 2 \pi$ & 1033 & 1945 & $29 ! 81$ & 3.4 & 633.7 \\
\hline 1 1ia & 34 & 1 & 64.3 & 111 & 2316 & 8.11 & $620 \pi$ & $108 \hat{\imath}$ & $22 \pi$ & $\begin{array}{l}336+4 \\
3 * 2-4\end{array}$ & $\begin{array}{l}5.1 \\
5.2\end{array}$ & $\begin{array}{l}59.4 \\
5.5\end{array}$ \\
\hline $17 b$ & 33 & $1 \frac{1}{3}$ & 61.4 & 112 & 2259 & 3454 & 6117 & $\begin{array}{r}1030 \\
934\end{array}$ & $\begin{array}{l}2241 \\
197 \mathrm{~S}\end{array}$ & 25112 & $\begin{array}{r}0.2 \\
4.5\end{array}$ & $\begin{array}{l}5.5 \\
60.2\end{array}$ \\
\hline $18 / 2$ & $\begin{array}{l}32 \\
33\end{array}$ & $\begin{array}{l}1 \frac{1}{2} \\
2 \frac{1}{6}\end{array}$ & $\begin{array}{l}64.0 \\
64.0\end{array}$ & $\begin{array}{l}93 \\
95\end{array}$ & $\begin{array}{l}2163 \\
2213\end{array}$ & $\begin{array}{l}35112 \\
3 \div \div 9\end{array}$ & $\begin{array}{l}57.55 \\
6022\end{array}$ & $\begin{array}{r}9.34 \\
1014\end{array}$ & 2165 & 3179 & 4.4 & 59.3 \\
\hline & & & & & & 270 & 5264 & 765 & 1656 & 2121 & 5.4 & 61.0 \\
\hline 19 & 29 & $2 \frac{1}{8}$ & 63.9 & $\begin{array}{c}102 \\
\ldots\end{array}$ & . & .. & .. & ond & 1000 & & 0. & .. \\
\hline 2011 & .. & $\ddot{.}$ & $\therefore$ & 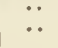 & .. & . & . & .. &. & .. & $\therefore$ & .. \\
\hline 22$\}$ & 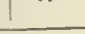 & & & & & & & & & & & \\
\hline
\end{tabular}


"This was my last year at IRothamsted," said I, "and I feel a peculiar interest in looking orer the results after such a lapse of time. When this crop was growing, my father, a good practical farmer, but with litte fath in chemical manures, paicl me a visit. We went to the experimental wheat-ficld. The first two plots, 0 and 1 , hat been dressed, the one with superphosplate, the other with potash, soda, and magnesit. My father did not secm much impressed with this kind of rhemical manuring. Stepring to the bext plot, where 14 tons of barn-yarl manure had been used, he remarkel, "this is gooul, what hive you here?"

"Nerer mind," said I, "we have ietter erops farther on."

The next plot, No, 3, was the une coatinumuly unmanured. "I ean heat this myself," satill he, and passed nn to the next. "Tluis is lietter," stisl he, "whit have you leere?"

"Superphosphate and sulp!ate of ammonia."

"Well, it is a enowl (rop), and thr straw is hright and stifr."-It turned out 30 bushele per acre, (633 lba. to the bushel.

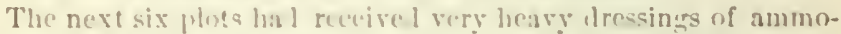
nia-salts, with suprophospliate, pota-h, suta, and magnesia. II cxamined then with the ereatest interest. "What have you here?" he asked, while he was examining ite, which aft rwards turued nut 3if husheli per acr:- " ["ut:a-h, sod:a, cpsom-salts, sulperphosphate, and ammonia-but it is the ammonis that dous the grmel."

He pass al to the next plo!, and was vere enthusiastiv over it. "What have you here?"- "IR pperake and ammonia," sairl I. "It is a grand crop," said he", and after "samining it wilh great interest, he gissed to the next, 6.r.-"What have you here?"-

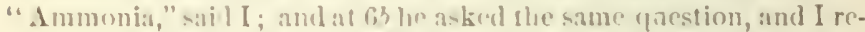
plie!? "ammunia." At î, llu. same question and t'.e same answer.

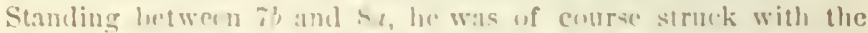
differenre in the erop: $k$, wals lift this year withont any manure, and thots ph it hal received a liheral supply of mincr.ll manures the year lefore, and minerals and ammonia-kilts, and rape-cake,

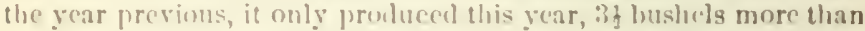
the plot contiunously unmanured. The eontrast between the wheat on this plot and the next one, mizht well interest a practical farmer. There was orer 1.5 linsliels per acre more wheat on the one plot than on the other, and 1,541 lhs. more straw.

Passing to the noxt plot, he exrlaimed "this is hetter, but not so gond as some that we lave passid." - "It has hat a heary dressing uf rape-eake." sitid I, "equal to aheme 100 llos of ammoniz per acre, and the next plot was monured this gear in the same way. The only difference being that one hail superphosphate and putash, 
soda, and magnesia, the year hefore, while the other hat supw.rphosphiate nlone." It turned ont, as you see from the table, that the potash, etce, only gare half a bushel more wheat pur acre the year it was used, and this year, with, 2, (0)0 lbs. of rilju'-eake on each flut, there is ouly a bushel per ace in faror of the putish, sola, and manesia.

The next flot, 9\%, was also unnatunurel and was passed by my father without comment. "Ah," sitil he, on cousing to the I wo next plots, 10 a and low, "Ibis is lucker, what have gou here?"-

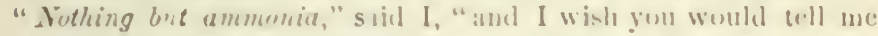
which is the best of the two? Lay grar lus bial a heary dressing of mincrals and suprpphosplate with ammonia, amel 10 i the sine quastity of ammonia alone, without superphospluate or other mineral manures. Aml this lear luth plets hatre hat a dressing of 400 lus. each of ammonil-silts. Now, which is the lest-the plot that loal superphosphate an I min rale l st year, or the one without:"-"Well," said he, "I can't see any ditlerence. Both are gund cropss."

You will se" from the table, that the pot which hat the superphosphate, potash, etc., the year luefore, grives a peck ks. w luat this yeur than the other plot which hat none. Practutally, the yield is the salu". There is an increasc of $1: 3$ bushels of wheth per arreand this incroase is cleorly the th the "mmonir-sults alone.

The next plot was also a splendid crop.

"What bave you here"?"

"Superpliospliate and ammonia."

This plot (11/t), turned nut üj lus-bels per aere. The next plot, with phosplates ant ummonia, was nearly as ceocl. The next plot, with potash, phosphates, and ammonia, wpually ge ol, but no better than 11a. There was lithle or no heusefit from the potish, except a little more struce. Thu next plot wis grool and I djed not wait for the question, lut sinuly silil, "ammonia," cond the next "ammonia," and the next "ammonia."-Standing still and looking at the wheat, my father askel, "Joe, whore can I get this ammonia?" He had previously been a little skeptical as to the ralue of chemistry, and hat not a ijeh npinion of "book farmers," lut that wheat-crop compelyed him to admit "that perhaps, after all, there mirht be some good in it." At any rate, he wanted to know where be could get ammonia. And, now, as then, every gond farmer asks the same question: "Where can I get ammonia?" Before we attempt to answer the question, let us lork at the next year's experiments. - The following is the results of the experiments the secenth year, 1849--50. 
Experimexts at Rothamsted on the Growth of

TABLE VIT-XaNURES AND PRODUCE; TTH 9EAson, 1849-50. AFter thr 2 TO 3 FEET DEEP. MANORES AND BEED

\begin{tabular}{|c|c|c|c|c|c|c|c|c|c|c|}
\hline \multirow[b]{3}{*}{$\frac{\infty}{2}$} & \multicolumn{10}{|c|}{ Manurea per Acre. } \\
\hline & \multirow[b]{2}{*}{ 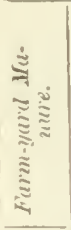 } & \multirow[b]{2}{*}{ 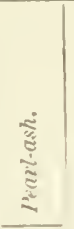 } & \multirow[b]{2}{*}{ 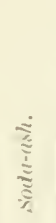 } & \multirow[b]{2}{*}{ 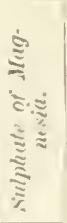 } & \multicolumn{3}{|c|}{ Superphasphale of Lime } & \multirow[b]{2}{*}{ 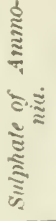 } & \multirow[b]{2}{*}{ 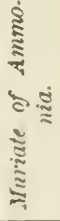 } & \multirow[b]{2}{*}{ 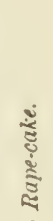 } \\
\hline & & & & & 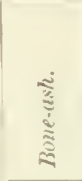 & 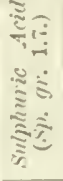 & 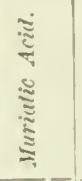 & & & \\
\hline 0 & $\begin{array}{c}\text { Tuns. } \\
\quad .\end{array}$ & Ibs. & lb: & lbs. & $\begin{array}{l}\text { lass. } \\
\text { eive }\end{array}$ & $\begin{array}{l}17 \times s . \\
450\end{array}$ & $\begin{array}{l}\text { lbs. } \\
\text {.. }\end{array}$ & $\begin{array}{c}\text { Ibs. } \\
. .\end{array}$ & $\begin{array}{l}168 . \\
. .\end{array}$ & lbs. \\
\hline 1 & . & 600 & 400 & $2(x)$ & .. & *. & . & .. & .. & .. \\
\hline 2 & 11 & $\ldots$ & $\cdots$ & .. & *. & $\cdots$ & -. & - & -. & .. \\
\hline 3 & \multicolumn{2}{|c|}{ Unmanured. } & $\cdots$ & *. & $\cdots$ & $\cdots$ & - & $\cdot \cdot$ & • & $\cdots$ \\
\hline 4 & .. & . & .. & $\cdots$ & 201 & .. & 200 & $\$ 00$ & -. & .. \\
\hline $5 \pi$ & $\cdots$ & 300 & 200 & $1 \mathrm{mo}$ & 200 & 150 & - & 250 & 250 & .. \\
\hline 5 & $\cdots$ & $3 \times 0$ & $2(11)$ & 10.1 & $2 n 0$ & 150 & . & 2.50 & 250 & .. \\
\hline 62 & - & 350 & 200 & $1 \div 0$ & 240 & 150 & $\because$ & 2100 & $\begin{array}{l}200 \\
200\end{array}$ & 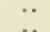 \\
\hline (i) & $\because$ & $\begin{aligned} 10 \\
31 \times 1\end{aligned}$ & 20 & $\begin{array}{l}110 \\
100\end{array}$ & $\begin{array}{l}20.1 \\
200\end{array}$ & $\begin{array}{l}151) \\
150\end{array}$ & $\because$. & 200 & 300 & $5 \ddot{0}$ \\
\hline$i 2$ & $\ddot{*}$ & 300 & $2(x)$ & 100 & 210 & 150 &.. & $2(10$ & 200 & 500 \\
\hline 812 & .. & $\cdots$ & . & . & . & .. & .. & 200 & 200 & .. \\
\hline $8 b$ & .. & .. & .. & .. & .. & .. & . & 200 & 200 & .. \\
\hline $9 / t$ & $\cdots$ & .. & .. & . & . & $\cdots$ & .. & 200 & 200 & $\because$ \\
\hline $\begin{array}{r}93 \\
10 a\end{array}$ & $\because$. & . & .. & $\cdot \cdot$ & $\cdots$ & $\cdots$ & $\because$. & $\begin{array}{l}200 \\
200\end{array}$ & $\begin{array}{l}200 \\
200\end{array}$ & $\because$ \\
\hline $10 h$ & 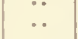 & 300 & 2011 & 100 & 200 & $10 \ddot{0}$ & .. & .. & . & .. \\
\hline $11 \pi$ & .. & .. & .. & .. & 2011 & $150)$ & .. & 200 & 200 & .. \\
\hline 1111 & .. & & .. & .. & 201 & 150 & .. & $2(1 \times)$ & 200 & .. \\
\hline 12,2 & .. & 3110 & .. & .. & 240 & 1511 & . & 200 & 200 & .. \\
\hline 123 & .. & 300 & .. & .. & 2061 & 150 & .. & 2007 & 200 & .. \\
\hline $1: 3 a$ & .. & 300 & .. & .. & 204 & 150 & .. & 200 & 2110 & . \\
\hline $1: 3 b$ & .. & 3100 & .. & .. & 201 & 1,00 & .. & 2017 & 2100 & . \\
\hline $14 a$ & $\ddot{.}$ & $\begin{array}{l}300 \\
300\end{array}$ & $\because$ & $\because$ & 201 & 150 & .. & 200 & 20100 & *. \\
\hline 117 & $\cdots$ & 300 & * & $\cdots$ & 200 & 1.50 & •. & 200 & & $\cdot$ \\
\hline $\begin{array}{l}15 n \\
153,\end{array}$ & $\ddot{0}$ & $\begin{array}{l}3100 \\
310\end{array}$ & $\begin{array}{l}310 \\
200\end{array}$ & 100 & 200 & .. & 200 & 300 & $\because$ & 500 \\
\hline & $\cdots$ & उसम & 200 & 100 & 210 & .. & 200 & 300 & •. & 200 \\
\hline $\begin{array}{l}11, l t \\
16 i k h\end{array}$ & .. & 390 & 200 & 100 & 200 & 150 & .. & 200 & 200 & .. \\
\hline $17 \pi$ & $\ddot{*}$ & $\begin{array}{l}3 !(k) \\
3 ! 10\end{array}$ & 210 & 100 & 200 & $15 n$ & .. & 200 & $\begin{array}{l}200 \\
200\end{array}$ & 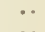 \\
\hline $17 h$ & $\ddot{0}$ & $\begin{array}{l}3: 100 \\
300\end{array}$ & $\begin{array}{l}22(4) \\
200\end{array}$ & $\begin{array}{l}\text { 101 } \\
100\end{array}$ & $\begin{array}{l}2(n) \\
2^{n} 0\end{array}$ & $\begin{array}{l}150) \\
1: 0\end{array}$ & .. & $\begin{array}{l}200 \\
200\end{array}$ & 200 & $\because$ \\
\hline $18 \pi$ & .. & 300 & 200 & 110 & 200 & 1.0 & 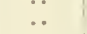 & 200 & 200 & . \\
\hline $18 b$ & .. & 300 & 210 & 100 & 200 & 150 & . & 200 & 200 & .. \\
\hline 19 & $\cdots$ & & .. & .. & 200 & .. & 200 & 300 & . & 500 \\
\hline $\begin{array}{l}20 \\
21\end{array}$ & ['uma & nured.' & .. & . & . & . & & • & $\cdots$ & - \\
\hline 22$\}$ & \multicolumn{8}{|c|}{ Mixture of the reaidne of moat of the other manures. } & *. & $\cdots$ \\
\hline
\end{tabular}


WheAt, YeAr after Year, oN tue same LAND.

EARTEGT OF 1849 THE FIELD WAS TILE.DIAINED IN EVERT ALTERNATE FURROW, (RED CLUSTER), DOWN IN AUTUMN, 1819.

\begin{tabular}{|c|c|c|c|c|c|c|c|c|c|c|c|c|}
\hline \multirow{3}{*}{ ญั } & \multicolumn{7}{|c|}{ l'RODUCE PEI ACIE, ETC. } & \multicolumn{3}{|c|}{$\begin{array}{c}\text { INCREAEE P ACRE } \\
\text { BY MANEUE. }\end{array}$} & \multirow{3}{*}{ 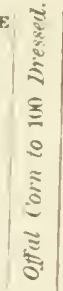 } & \multirow{3}{*}{ 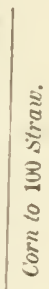 } \\
\hline & \multicolumn{3}{|c|}{ Dressed lorn. } & \multirow[b]{2}{*}{ 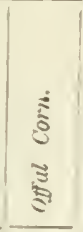 } & \multirow[b]{2}{*}{$\begin{array}{l}5 \\
\vdots \\
3 \\
3 \\
3 \\
3 \\
7\end{array}$} & \multirow{2}{*}{ 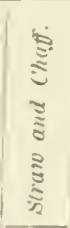 } & \multirow{2}{*}{ 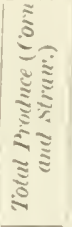 } & & & & & \\
\hline & 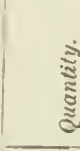 & & $\begin{array}{l}2 \\
z \\
\vdots \\
\vdots \\
\vdots \\
\vdots\end{array}$ & & & & & $\stackrel{3}{3}$ & $\begin{array}{l}\beth \\
\vdots \\
\vdots \\
\vdots\end{array}$ & 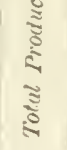 & & \\
\hline $\begin{array}{l}0 \\
1\end{array}$ & $\begin{array}{c}\text { Bush. } \\
19\end{array}$ & $\begin{array}{l}\text { l'ks. } \\
1 \mathrm{t}\end{array}$ & $\operatorname{lin}_{60.8}$ & $\begin{array}{l}1 \mathrm{his} . \\
42\end{array}$ & $\begin{array}{l}11) \div 0 \\
12: 20\end{array}$ & $\frac{11) \times 4}{21 \times 37}$ & $\begin{array}{l}1 \mathrm{bs}: \\
325 \%\end{array}$ & $\begin{array}{l}16 \mathrm{~s} \\
21 \mathrm{~s}\end{array}$ & $\begin{array}{l}\text { lbes. } \\
315\end{array}$ & $\begin{array}{l}1 \mathrm{~b}: \mathrm{s} \\
536\end{array}$ & 3.5 & $5 ! 1$ \\
\hline 3 & $\begin{array}{l}2 \dot{8} \\
15\end{array}$ & $\begin{array}{l}\ddot{2} \\
3 t\end{array}$ & 6ii.9 & $\begin{array}{l}\ddot{93} \\
+1\end{array}$ & $\begin{array}{l}\text { Iखibil } \\
10(1) 2\end{array}$ & $\begin{array}{l}304.5 \\
1 \% 19\end{array}$ & $\begin{array}{l}51 \% k j \\
2721\end{array}$ & $\begin{array}{l}8 \dot{5} 9 \\
\cdots\end{array}$ & $15: i$ & 23 i5 & $\begin{array}{l}5.4 \\
4.5\end{array}$ & $5 \%$ \\
\hline 4 & 27 & 3 & 61.2 & $8 \pi$ & $178 j$ & 3312 & $504 \pi$ & 783 & $159: 3$ & $23 \pi 6$ & 5.1 & 53. \\
\hline $\begin{array}{l}5 a \\
5 b \\
6 a \\
6 b \\
7 a \\
7 b\end{array}$ & $\begin{array}{l}29 \\
30 \\
30 \\
29 \\
32 \\
32\end{array}$ & $\begin{array}{l}3 t \\
3 \\
r t \\
3 t \\
1 \\
0 t\end{array}$ & $\begin{array}{l}60.4 \\
610.4 \\
61.1 \\
61.3 \\
61.0 \\
61.2\end{array}$ & $\begin{array}{l}171 \\
160 \\
11 ! \\
118 \\
1197 \\
150\end{array}$ & & & 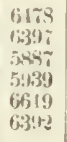 & $\begin{array}{r}9 \pi 2 \\
1011 ; \\
\vdots 1 \% \\
9 i \alpha \\
1132 \\
1110\end{array}$ & $\begin{array}{l}2755 \\
26 i^{2} 10 \\
2210 \\
2210 \\
27,11 \\
2561\end{array}$ & $\begin{array}{l}375 \pi \\
31566 \\
316,6 \\
3218 \\
3294 \\
3671\end{array}$ & $\begin{array}{l}9.5 \\
\times .6 \\
6.3 \\
-.0 \\
2.4 \\
7.6\end{array}$ & $\begin{array}{l}13.8 \\
86 . \\
49.9 \\
50.0 \\
17 . \\
49.4\end{array}$ \\
\hline $\begin{array}{c}8 a \\
8 b \\
9 a \\
3 b \\
10 a \\
10 b\end{array}$ & & $\begin{array}{l}3 \\
1 \\
1 \\
2 y \\
3 ! \\
3 !\end{array}$ & $\begin{array}{l}61.1 \\
61.0 \\
50.4 \\
60.8 \\
60.2 \\
51.1\end{array}$ & $\begin{array}{r}101 \\
1113 \\
118 \\
80 \\
100 \\
66\end{array}$ & & & & $\begin{array}{l}851 \\
\vdots 115 \\
914 \\
71511 \\
719 \\
169\end{array}$ & $\begin{array}{r}1649 \\
18 \% 2 \\
1831 \\
1416 \\
1370 \\
2: 30\end{array}$ & $\begin{array}{r}2512 \\
211 k \\
2701 \\
2206 \\
2069 \\
399\end{array}$ & $\begin{array}{l}5.5 \\
5.6 \\
6.3 \\
4.7 \\
6.1 \\
6.8\end{array}$ & $\begin{array}{l}51.5 \\
51.2 \\
550 \\
55.7 \\
55.7 \\
60.1\end{array}$ \\
\hline & & $\begin{array}{l}31 \\
11 \\
31 \\
3 y \\
31 \\
1 \\
18\end{array}$ & $\begin{array}{l}61.0 \\
61.1 \\
61.5 \\
61.4 \\
60.2 \\
61.0 \\
61.1 \\
61.5\end{array}$ & $\begin{array}{r}121 \\
145 \\
91 \\
115 \\
10.5 \\
111 \\
102 \\
6.5\end{array}$ & & & & $\begin{array}{r}999 \\
9: 39 \\
6133 \\
1011 \\
102.5 \\
962 \\
1121 \\
9 ! 33\end{array}$ & & $\begin{array}{l}3086 \\
29630 \\
313.5 \\
3197 \\
333: 32 \\
32.31 \\
3354 \\
3289\end{array}$ & $\begin{array}{l}6.4 \\
8.0 \\
5.1 \\
5.9 \\
5.4 \\
6.0 \\
5.3 \\
3.2\end{array}$ & $\begin{array}{l}52.6 \\
51.9 \\
49.4 \\
51.5 \\
50.3 \\
49.0 \\
4 ! .9 \\
49.7\end{array}$ \\
\hline $15 \alpha$ & $\begin{array}{l}26 \\
30\end{array}$ & $\frac{17}{21}$ & & $\begin{array}{l}90 \\
59\end{array}$ & & $\begin{array}{l}3.321 \\
3.26\end{array}$ & & $\begin{array}{l}691 \\
910\end{array}$ & & $\begin{array}{l}2293 \\
314 i\end{array}$ & $\begin{array}{l}5.7 \\
3.0\end{array}$ & $\begin{array}{l}51.0 \\
49.5\end{array}$ \\
\hline $\begin{array}{l}16 b \\
17 a \\
17 b \\
18 a \\
18 b\end{array}$ & $\begin{array}{l}33 \\
33 \\
31 \\
29 \\
29 \\
29\end{array}$ & $\begin{array}{l}2 \frac{1}{3} \\
3 \\
1 \\
2 \frac{1}{2} \\
3 \frac{1}{2} \\
2 \frac{1}{4}\end{array}$ & $\begin{array}{l}60.3 \\
60.4 \\
61.2 \\
61.5 \\
61.2 \\
60.9\end{array}$ & $\begin{array}{r}108 \\
122 \\
73 \\
139 \\
110 \\
103\end{array}$ & $\begin{array}{l}2134 \\
2159 \\
1945 \\
1951 \\
1931 \\
1 \times 45\end{array}$ & $\begin{array}{l}5103 \\
461 \% \\
4126 \\
41131 \\
3927 \\
3441\end{array}$ & $\begin{array}{l}7237 \\
6771 \\
6111 \\
5945 \\
5961 \\
5689\end{array}$ & $\begin{array}{r}1132 \\
115 \% \\
983 \\
459 \\
9332 \\
813\end{array}$ & $\begin{array}{l}33.341 \\
25 ! 115 \\
2407 \\
2315 \\
2209 \\
2125\end{array}$ & $\begin{array}{l}4516 \\
4053 \\
3390 \\
3274 \\
8140 \\
2968\end{array}$ & $\begin{array}{l}5.3 \\
6.0 \\
3.8 \\
7.7 \\
6.1 \\
5.7\end{array}$ & $\begin{array}{l}41.8 \\
46.8 \\
48.1 \\
48.6 \\
49.3 \\
48.0\end{array}$ \\
\hline $\left.\begin{array}{l}19 \\
20 \\
21 \\
22\end{array}\right\}$ & $\begin{array}{l}29 \\
14 \\
\ldots\end{array}$ & $\begin{array}{l}0 \\
0 \\
\cdots\end{array}$ & $\begin{array}{c}60.8 \\
59.1 \\
|\ldots|\end{array}$ & $\begin{array}{l}88 \\
40 \\
\cdots\end{array}$ & $\begin{array}{c}1850 \\
865 \\
. \cdot\end{array}$ & $\begin{array}{c}3527 \\
1639 \\
.\end{array}$ & $\begin{array}{c}53377 \\
2507 \\
\cdots\end{array}$ & $\begin{array}{r}818 \\
-131 \\
\ldots\end{array}$ & $\begin{array}{c}1808 \\
-80 \\
.\end{array}$ & $\begin{array}{c}2656 \\
-214 \\
. .\end{array}$ & $\begin{array}{l}4.9 \\
4.5 \\
. .\end{array}$ & $\begin{array}{c}52.4 \\
53.0 \\
\quad . .\end{array}$ \\
\hline
\end{tabular}


The summer of 1850 was unusually conl and unfarorable for wheat. It will be scen that on all the plots the yicld of grain is considerably iower than last year, with a greater growth of straw.

You will notice that $10 b$, which last year gave, with ammonia salts alone, $: 32 \frac{1}{6}$ bushels, this year, with superphosphate, potash, soda, an? sulphatc of magnesia, gives less than 15 bushels, while the adjo:ain plot, dressed with ammonia, erires nearly 27 bushels. In other worls, the ammonia alone gire's bushels per ace more than this large dressing of superphosphate, potash, etc.

On the three plots, $8 a, 8 b$ and $!)$, a dressing of ammonia-sults alone gives in euch case, a larecr yield, both of grain and straw, than the 11 tons of barn-yard manure on plot 2. And recollect that this plot has now receired 98 tons of manure in seren gears.

"That," said the boctur, "is certainly a very remarkable fact."

"It is su," sitil the loracon.

"But what of it " askenl the Syuire, " even the Professor, here, does not alvise the use of ammonia-silts for wheat."

"That is so," saitl 1, "hut perhaps I am mistaken. Such facts as those just griven, thengh I lave been acepuanited with them for many years, sometimes incline me to doub the sommlness of my conclnsions. Still, on the whole, I think I am riwht."

"We all knuw," saicl the Dcacun, "that you have great respect for your own "pinions."

"Never mind all that," said thr. Doctor, "but tell us just what ron think on this subject."

"In bricf," said 1, "my upinion is this. We need ammonia for wheat. But thum ammonia-salto and nitrate of stula can often he used witl deriderd profit, yit I fiel sure that we can fet ammonia or nitrogen at a less inst per lb. hy buying bran, malt routs, cotton-seet cake, and other fonds, and usine them for the double purpose of fectling stock and making mamure."

"I almit that such is the ease." said the Doctor, "but here is a flot of lanil that has now had 14 ins of manure every year for seven sears, and ret there is a plot along sille, dressed with ammonia-salts furnishing less than half the ammonia entained in the 14 tons of manure, that produces a better yicld of wheat."

"That," saicl I, "is simply because the nitrogen in the manure is not in an arailable condition. And the praclical question is, how to make the nitrowen in our manme more immerliately arailable. It is one of the most important cunestions which agrieultural science is called upon to nuswer. Until we get more light, I fed 
sure in saying that one of the hest methots is, fo feed our mumals (1) richer and usore casily digrated forml."

The following table gires the results of the cighth senson of $1850-51$. 


\section{Experiments at Rothangted on the Growtr of}

TABLE VIIL-MANURES AND PRODECE; 8TH SEASON. 1850-51.

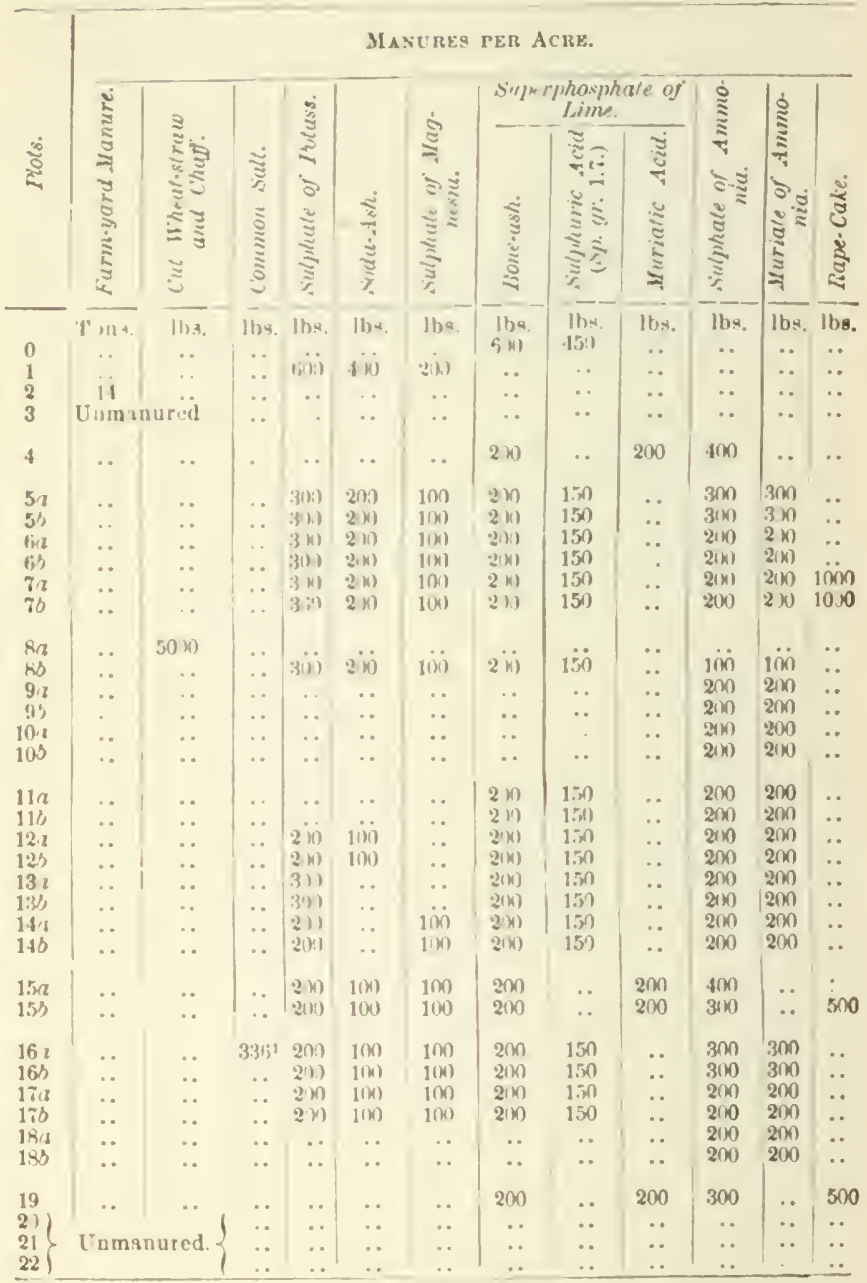

I Top-dressed in March, 1851. 
WuEat, Year afték Ýrar, oN tue same Laxd.

MANUREY AND BEED (KED CLCBTEK), SOWX AUTUMN, 1850.

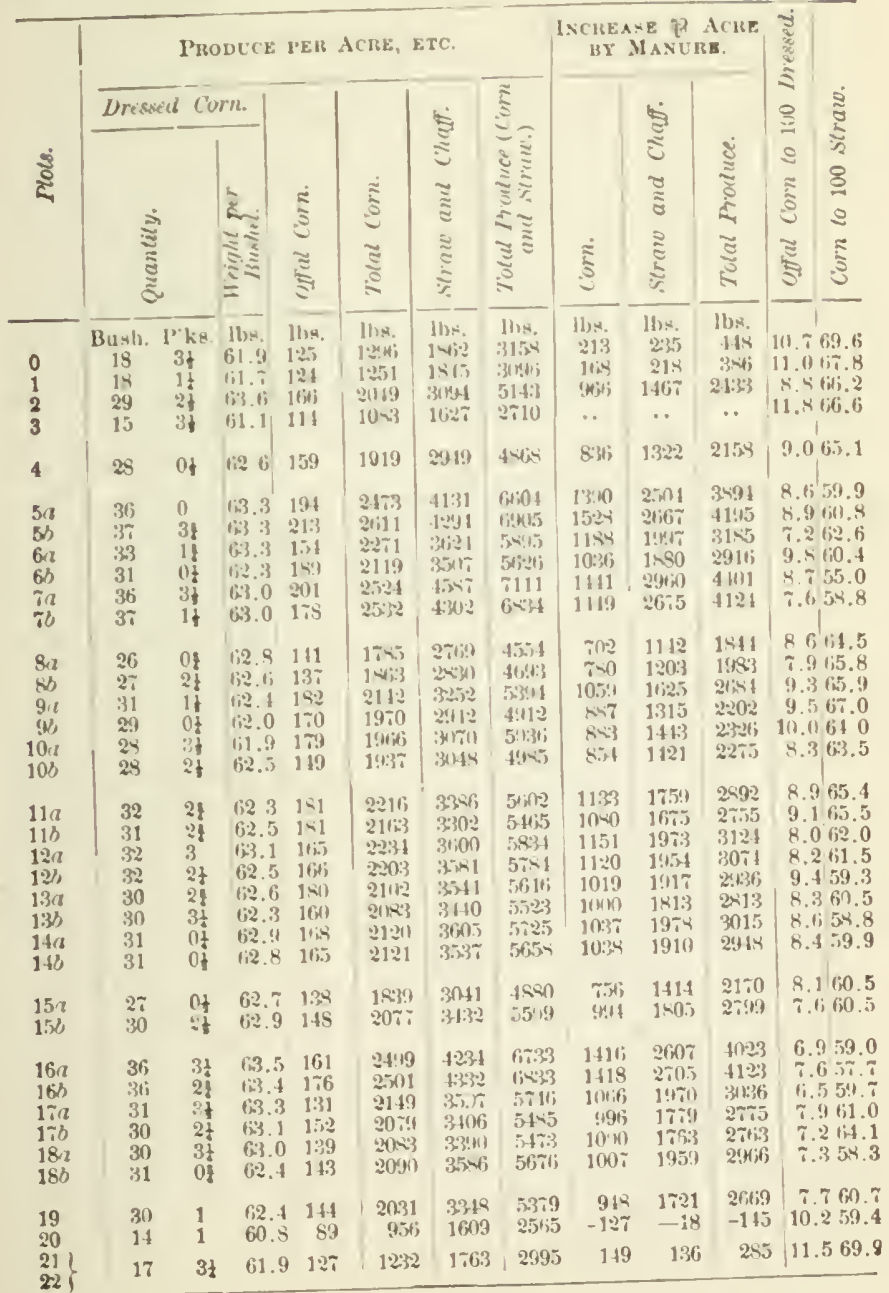


The plot continuously unuanuret, gives about 16 busbels of wheat per acre.

The plot with barn-yard manure, nearly $\ddot{0} 0$ bushels per acre.

400 lbs. of ammoniat-silts a'one, on plot 9il, $31+$ bushels ; nn $9 b$, 29 buslıels; on 10 and 106 , nearly 20 bushels caclı. 'This is remarkable uniformity.

400 llıs. ammonia-salts and a liırge çuantily of mineral manures in addition, on tuele dillerent flots, averigere nest quite 32 buslicls per acre.

"The superphospluate ant minerals," saitl the Deacen, "do not secm to do much groud, that is a fact."

Yoll will motice that $3: 96$ lls. of common salt was sown on plot 16a. It dloes not eerm to have done the slighliest groot. Where the

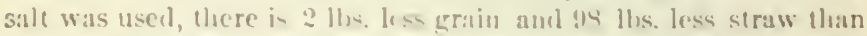
on the adjoining flot 16\%, where no silt was used, but obluerwise manurel alike. It would seem, luw rer, that the quality of the grain was slyghty improvel by the sait. The salt was sown in Marrh as a tope-dres-ing.

"It would have hern hetter," said the Dearon. "to hase suwn it in autumu with the other manures",

"The Dracon is right," sabil I, "hut it so happens that the next fear and the year after, the silt or 1.8 applied at the same time as the other manures. It gave an incruace of 91 hhs. of grain and 61 11s. of straw in 1s.i1, hut the following year the same quantity of salt used on the same plet id more harm that geod."

Before we lave qhe results of this year, it shombl he olserred ihat on $8,5,000$ lha. of ront siraw and chatf were nsed per arere. I do not recollect scein s anything in remard (1) it. And yet the result was rery remarkialile-so mueh so indecel, that it is a matter of regret that the erperiment was not repeatiul.

This 5,000 llss of straw aul thaff gave an inerease of more than 10 lusliels per acre ower the continumely unmanured plot.

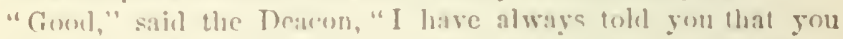
under-estimated the value of straw, especially in regart to its merhunioul action."

I did not reply to thic remark of the gond Deaenn. I hare nerer doubed the grond reftects of anything that lirhtens up a clay soil and renders it wormer anel mure porums. I supjuse the great bencfit derived from this application of straw must be attributel to its amelinating action on the snil. The 5,000 lhs. of straw and chatf producel a crop within nearly 3 bushels per acre of the plut matnured every year wilh 1 th lons of birn-yaril manure.

"I am surprised," sibil the Doctor, "that salt did no goot. I 
lave seen many instances in which it has had a wonderful eflect un wheat."

"Yes," sitil I, "abd our experiesecel friend, John Johnston, is very deciledly of the opiugion that its use is highly protitable. He sows a harrel of salt per acre hroadeast on the laml at the time he sows his wheat, and I have mysedf secu it prounce a deciled improvement in the erop)."

We have now given the results of the lirst eight years of the experiments. From this time forward, the s tme mentures were used yor after year on the some plut.

The results are given in the aceompanying tables for the follow.

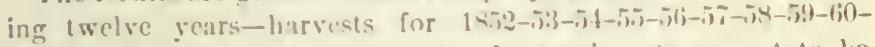
b1-62 and 18fi3. Such anodureret of experiments are not (o) be fouml in the world, and they de-erve and will reecive the eareful study of every intelligent $1 \mathrm{~m}$ riean farmer

"I am with you there," said llae Deacun. "You serm to think that I do not appreciate the lahors of seicntific men. I do. Sueh cxperiments as thes " we are axminine command the respect of every intelligent farmer. I may not fully molerstamd them. but I san sec clearly cnough that they are uf greas value." 
Experimests at Rothamsted on the Girowtu of Wueat, Yank APTER YEAK, ON TIE SAMB LAND.

Table IX.-Manures per Acle per Amum (with the exception explained in the Notes on p. 203), for 12 Years in succession-namely, for the 9 th, $101 \mathrm{~h}$, $11 \mathrm{th}, 12 \mathrm{th}, 13 \mathrm{th}, 14 \mathrm{~h}, 15 \mathrm{th}, 16 \mathrm{~h}, 17 \mathrm{t} . ., 18 \mathrm{th}, 19 \mathrm{th}$, and $20 \mathrm{th}$ Seasons: that is.

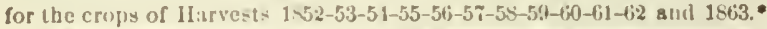

\begin{tabular}{|c|c|c|c|c|c|c|c|c|c|c|c|c|}
\hline \multirow{3}{*}{ ฐ্ } & \multicolumn{12}{|c|}{$\begin{array}{c}3 \text { anures per scre jer Annmm for } 12 \text { Jears, } 1.51-2 \text { to } 1862-3 \text { inclusioe, } \\
\text { except in the cases expluined in the Notes on } p .203 .\end{array}$} \\
\hline & \multirow{2}{*}{ 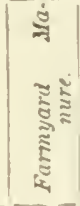 } & \multirow[b]{2}{*}{ 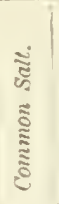 } & \multirow[b]{2}{*}{$\frac{a-}{3}$} & \multirow{2}{*}{ 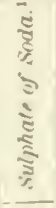 } & \multirow{2}{*}{$\begin{array}{l}\Xi \\
\Xi \\
\vdots \\
\vdots \\
\vdots \\
\vdots \\
\vdots \\
\vdots\end{array}$} & \multicolumn{3}{|c|}{$\begin{array}{l}\text { Superphasphate of } \\
\text { Lime. }\end{array}$} & \multirow{2}{*}{ 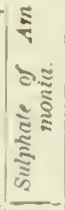 } & \multirow{2}{*}{ 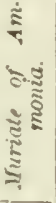 } & \multirow{2}{*}{ 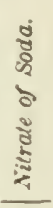 } & \multirow[b]{2}{*}{ 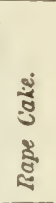 } \\
\hline & & & & & & 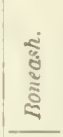 & 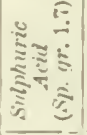 & 产: & & & & \\
\hline & Tous. & 16s. & Ibs. & lhs. & $11 \mathrm{se}$. & & 11), s. & 11)s. & Ibs. & los. & Ibes. & lbs. \\
\hline $\begin{array}{l}0 \\
1\end{array}$ & . & .. & $f_{1}(x)$ & $\sin$ & 200 & $f(x)$ & 450 & .. & .. & .. & .. & .. \\
\hline 2 & ii & & 年 & .. & 210 & .. & . & .. & .. & .. & •. & 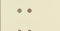 \\
\hline 3 & L'nmon & inred & .. & .. & .. & . & $\because$. & .. & $\because$ & $\begin{array}{l}. . \\
. .\end{array}$ & $\ddot{. .}$ & $\ddot{.}$ \\
\hline $\begin{array}{l}4 \\
5 a\end{array}$ & Int & & 300 & $2(1)$ & 100 & 200 & ifx & . & .. & .. & . & .. \\
\hline $5 a$ & $\because$ & .. & & & 100 & & $\begin{array}{l}1 \times 1 \times 1 \\
1: 50\end{array}$ & .. & .. & . & .. & $\ddot{.}$ \\
\hline $6 a$ & .. & . & & & & & & .. & 100 & 100 & . & .. \\
\hline fit & .. & .. & & & & & & .. & & & & .. \\
\hline it & .. & .. & & & & & & .. & & & & .. \\
\hline & .. & .. & & & & & & & & & & .. \\
\hline 8 & .. & .. & & & 11 & & & .. & & & .. & .. \\
\hline 8 & .. & .. & & 211 & 118 & 210 & 15 & .. & 30101 & 300 & & .. \\
\hline $\begin{array}{l}4 \\
4\end{array}$ & .. & .. & $3(x)$ & 200 & 100 & 200 & 150 & .. & .. & .. & & .. \\
\hline $\begin{array}{r}4 \\
10\end{array}$ & .. & $\because$ & .. &.. & .. & .. & .. & .. & 20 & 200 & 54 & 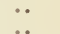 \\
\hline & .. & . & . & . & . & & & & & & & \\
\hline 11 & .. & .. & .. & . & . & 200 & 150 & & & & & .. \\
\hline & .. & .. & .. & & . & & & .. & & & & .. \\
\hline 12 & .. & . & . & 50 & . & & & & & & .. & . \\
\hline & .. & .. & & 550 & .. & & & & & & & \\
\hline $1 ?$ & .. & .. & 300 & .. & .. & & & .. & & & . & .. \\
\hline & .. & .. & 310 & .. & & & & & & & & \\
\hline 14 & .. & . & .. & . & 420 & & & .. & & & & .. \\
\hline 1. & .. & .. & & & 42 & & 150 & & & 200 & & \\
\hline & .. & .. & 300 & 200 & 11 & & & 20 & & .. & & \\
\hline & & & 311 & $2 n$ & 10 & 2100 & & 200 & & & & 300 \\
\hline & .. & $336^{4}$ & 300 & 210 & 10 & $21 x$ & 150 & .. & & & & .. \\
\hline & .. & .. & 300 & 200 & 100 & 200 & 150 & .. & & & & \\
\hline - $\begin{cases}17 a \\
17 b\end{cases}$ & .. & . & .. & .. & .. & . & .. & . & & & .. & $\cdots$ \\
\hline$\left\{\begin{array}{l}17 \\
18\end{array}\right.$ & . & .. & 300 & 200 & 100 & 200 & 150 & & 20 & & & $\ddot{0}$ \\
\hline o $\left\{\begin{array}{l}1 \times \infty \\
0\end{array}\right.$ & . & .. & 300 & $2(x)$ & 100 & $2 x$ & 150 & & 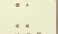 & $\ddot{.}$ & 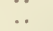 & ・• \\
\hline 19 & & & 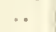 & .. & . & 200 & . & 200 & 300 & .. & . & 500 \\
\hline $\begin{array}{l}20 \\
21\end{array}$ & Cums & ured & 300 & 200 & 100 & . & . & . & & 100 & & .. \\
\hline 22 & & & 300 & 200 & 100 & & .. & & 100 & & . & 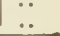 \\
\hline
\end{tabular}

- For the particulars of the produce of ench scjarate seasou, Eee Tablue X.-XXI. inclusive. 
NOTES TO TABLE IX. (p. 202.)

' For the 16th and sucecding sousons-the sulpliate of potass was reluced from 600 to 400 lbs. per acre per annum on Plot 1 , and from 300 to $200 \mathrm{ll}$ s. on all the uther Plots where it was used; the sulphate of soda from 400 to $200 \mathrm{lbs}$. on l'lot 1, to $100 \mathrm{lbs}$. on all the Plots on which $200 \mathrm{lbs}$. had previously been applied, and from 550 to $336 t$ lbs. (two-thirds the amount) on Plots $12, l$ and $12 b$; and the sulphate of magnesia from 420 to $280 \mathrm{lbs}$. (two-thirds the amount) on Plots $14 a$ and $14 b$.

- Plot $9 a$-the sulphates of potass, soda, and magnesia, and the superphosphate of linse, were applied in the 12 th and succeeding seasons, but not in the 9th, 10th, and $11 \mathrm{th}$; and the amount of nitrate of soda was for the 9th scason only 475 lhs. uer acre, and for the 10 th and 11 th seasons only $2 \pi$ lits.

- Plut $9 b$-in the 9 th season only 475 lbs. of nitrate of soda were applied.

- Common salt-not applicd after the 10 th season.

- Plots $17 a$ and 17b, and $18 a$ nnd $18 b$-the manures on these plots alternate: that is, Plots 17 were manured with ammonia-salts in the 9th season; with the sulphates of potass, soda, and magne. sia, and superphosphate of lime, in the $10 \mathrm{th}$; ammonia-salts again in the 11th; the sulphates of potass, soda, and magnesia, and superphosplate of lime, again in the 12th, and so on. Plots 18, on the other hand, had the sulphates of potass, soda, and magnesia, and superplospluate of lime, in the 9 th season; ammonia-salts in the $10 \mathrm{th}$, and so on, alternately. 
Experiments at Rothumsted ox the Ghowta of Wheat, Year AFTER YeAl, ON TIE SLME LAND.

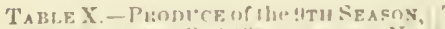

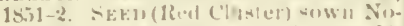
vimber i, 1401 ; (ropl) cul Aurul 28 . 1 siz.

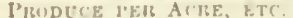

\begin{tabular}{|c|c|c|c|c|c|}
\hline \multirow{2}{*}{ ذँّ } & $\mathrm{Nr}$ & isseel ( & D.71. & & \\
\hline & & בָ & $\begin{array}{l}2 \\
\vdots \\
\vdots \\
\vdots \\
= \\
=\end{array}$ & 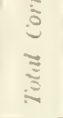 & \\
\hline $\begin{array}{l}0 \\
1 \\
2 \\
3 \\
4\end{array}$ & $\begin{array}{c}1312+11 . \\
15 \\
13 \\
27 \\
13 \\
13\end{array}$ & $\begin{array}{l}\text { liku } \\
0135 \\
1 \\
21 \\
31 \\
13 \\
13\end{array}$ & 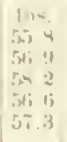 & 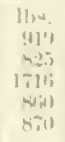 & $\begin{array}{l}11,4 \\
24025 \\
2: 122 \\
5173 \\
2117 \\
2111\end{array}$ \\
\hline $\begin{array}{l}5 a \\
5 x) \\
6 i a \\
6 b \\
5 a \\
7 b \\
8 a \\
8 b\end{array}$ & $\begin{array}{l}16 \\
17 \\
20 \\
211 \\
216 \\
216 \\
27 \\
27\end{array}$ & $\begin{array}{l}3 \\
01 \\
33 \\
31 / 2 \\
213 \\
339 \\
313 \\
01 \frac{1}{2}\end{array}$ & 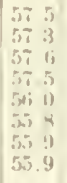 & 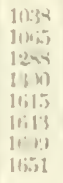 & 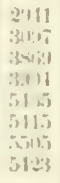 \\
\hline $\int_{115}^{9 I}$ & 25 & iss & $\begin{array}{l}556 \\
25,3 \\
25.3\end{array}$ & $\begin{array}{l}1.311 \\
1 \text { art. }\end{array}$ & $\begin{array}{l}5,305 \\
1-2\}\end{array}$ \\
\hline $\begin{array}{l}10 a \\
112 b \\
11 a \\
11 b \\
1212 \\
1: 2 b \\
1: a \\
1: 3 b \\
11 a \\
111 b\end{array}$ & $\begin{array}{l}21 \\
22 \\
21 \\
22 \\
21 \\
21 \\
21 \\
21 \\
21 \\
25\end{array}$ & 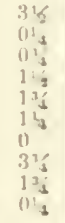 & 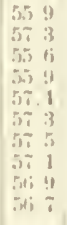 & $\begin{array}{l}1: 321 \\
1: 31: 3 \\
111: 2 \\
1: 347 \\
1.5113 \\
11.12 \\
11 \times 1 \\
11: 10 \\
1.517 \\
1.230\end{array}$ & 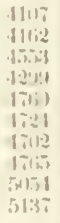 \\
\hline $\begin{array}{l}15 a \\
15 b\end{array}$ & $\begin{array}{l}2.3 \\
25\end{array}$ & ${ }_{06}^{12}$ & $\begin{array}{ll}\text { si } 1 \\
\text { stis }\end{array}$ & $\begin{array}{l}11.51 \\
1.120\end{array}$ & $\begin{array}{l}\text { finis } \\
4 ! 111\end{array}$ \\
\hline $\begin{array}{l}16 \Omega \\
1(i)\end{array}$ & $\begin{array}{l}28 \\
2.3\end{array}$ & $\begin{array}{l}36 / 2 \\
0\end{array}$ & $\begin{array}{ll}\therefore & 0 \\
51 & 0\end{array}$ & $\begin{array}{l}17+14 \\
17(k)\end{array}$ & $\begin{array}{l}\text { Citi1 } \\
\text { tizs1ij }\end{array}$ \\
\hline $\begin{array}{l}17 a \\
17 b \\
18 a \\
18 b\end{array}$ & $\begin{array}{l}25 \\
21 \\
1: 1 \\
11\end{array}$ & $\begin{array}{l}2 \\
12 y \\
3 \\
335\end{array}$ & $\begin{array}{ll}5 x & 5 \\
511 & \vdots \\
\therefore i & 11 \\
511 & 5\end{array}$ & $\begin{array}{l}1 \% 7 \\
1 \div 31 \\
4 \div ! 1 \\
1 ; 21\end{array}$ & $\begin{array}{l}5311 \\
11401 \\
25,11 \\
2145,3\end{array}$ \\
\hline 19 & 21 & 33 & 561 & 1.252 & 1979 \\
\hline $\begin{array}{l}20 \\
21 \\
22\end{array}$ & $\begin{array}{l}11 \\
19 \\
19\end{array}$ & $\begin{array}{l}0 \% \\
13 \\
213 \\
21 / 4\end{array}$ & $\begin{array}{r}5,6.6 \\
5 x .0 \\
50.9\end{array}$ & $\begin{array}{l}875 \\
117 \% \\
1176\end{array}$ & $\begin{array}{l}2152 \\
3525 \\
32505\end{array}$ \\
\hline
\end{tabular}

TABI.E XI.-P'RODTCE Of the 10TII SEA.

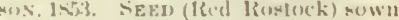

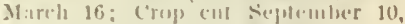
and carled siphember 20, 15is.

I'IUDICCE PEU ACRE, ETC.

(For the Manures see Jp. 202 and $2(13)$.
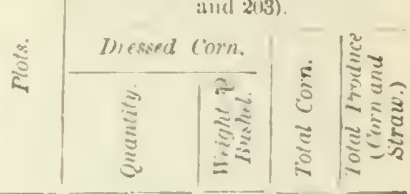

Bunth lilis.

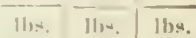

0

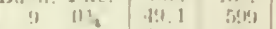

(i) $1 \%$ 16.1 114 21136

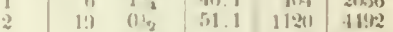

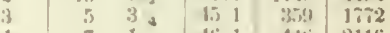

$\begin{array}{llllll}i & i & 1 & 16.1 & 414 & 2116\end{array}$

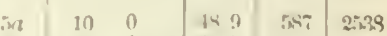

5x) 111 1 iि 11 till 27.11

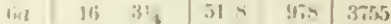

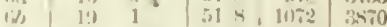

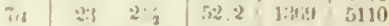

is 211 21 51 1 13\%

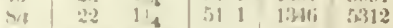

\begin{tabular}{lll|lll}
21 & 21 & 51.1 & 1125 & 5352
\end{tabular}

$\begin{array}{lllllll}91 & 11 & 1 & \text { โ. } & \mathbf{1} & 691 & 3000\end{array}$

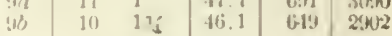

\begin{tabular}{lll|l|l|l}
108 & 9 & 333 & 189 & 612 & 26,11
\end{tabular}

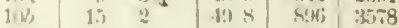

$\begin{array}{llllll}11 / 1 & 17 & 5 & 1 & 1015 & 3539\end{array}$

\begin{tabular}{lll|l|l|l}
$116)$ & 14 & 29 & 51.1 & $10 \% 3$ & 3780
\end{tabular}

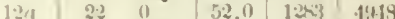

\begin{tabular}{lll|l|l|l}
$1: 2$, & 23 & 32 & 52 & 1375 & 5073
\end{tabular}

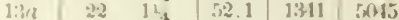

1:3, 2is 2: 51.1 13!4j 3308

\begin{tabular}{llll|l|l|l}
114 & 21 & 2 & 51.2 & 19322 & $4 \pi ! 13$
\end{tabular}

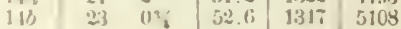

\begin{tabular}{l|ll|lll|l} 
& 1.2 & 0 & 51.1 & 1113 & 1508
\end{tabular}

\begin{tabular}{lll|ll|l}
1.25 & 23 & 26 & 51.1 & 1351 & 5107
\end{tabular}

$\begin{array}{lllllll}16 \mathrm{i} \pi & 21 & 1 \mathrm{~K} & 5.5 & 5.5 & 1496 & 6400\end{array}$

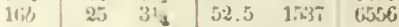

$\begin{array}{lllllll}172 & 8 & 13, & 49.8 & 520 & 2516\end{array}$

$\begin{array}{llllll}1 \% 8 & 8 & 33^{3} & 14.9 & 539 & 251\end{array}$

\begin{tabular}{lll|lll|l}
148 & 17 & 314 & 52.4 & 1111 & 4.49
\end{tabular}

$\begin{array}{llllll}1 \times 2 & 20 & 3 & 52.1 & 1256 & 5052\end{array}$

\begin{tabular}{l|ll|ll|l}
19 & 19 & 114 & 52.6 & 1160 & 4373
\end{tabular}

\begin{tabular}{l|ll|ll|l}
20 & 5 & $3 \%$ & 47.8 & $42 \%$ & $2 \mathrm{Re}$
\end{tabular}

\begin{tabular}{l|ll|lll}
21 & 12 & $3 \%$ & 50.4 & 75.3 & 2024
\end{tabular}

\begin{tabular}{l|ll|ll|l}
2.2 & 10 & 1 & 49.4 & 592 & 2.452
\end{tabular} 


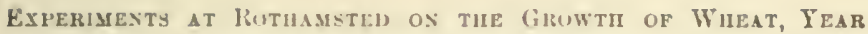
AFIEK УEAK, ON THE SAME LAND.

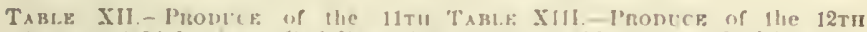

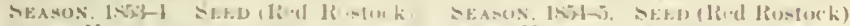

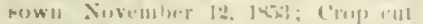
Auruv1 21, and cattul $1 u_{;}:-131,1<; 1$.

\begin{tabular}{|c|c|c|c|c|c|c|c|c|c|c|c|}
\hline \multirow{3}{*}{$\frac{1}{3}$} & \multicolumn{5}{|c|}{ 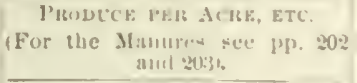 } & \multirow{3}{*}{$\stackrel{\dot{\Xi}}{\check{\Sigma}}$} & \multicolumn{5}{|c|}{ 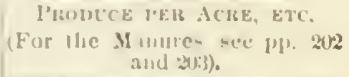 } \\
\hline & \multicolumn{3}{|c|}{ Dreased corn. } & \multirow[b]{2}{*}{\begin{tabular}{l}
$\vdots$ \\
$\vdots$ \\
\multirow{3}{5}{} \\
$\vdots$
\end{tabular}} & \multirow[b]{2}{*}{ 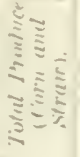 } & & \multicolumn{3}{|c|}{ Jresweel Corll. } & \multirow[b]{2}{*}{$\begin{array}{l}5 \\
\frac{5}{3} \\
3 \\
3 \\
3\end{array}$} & \multirow{2}{*}{ 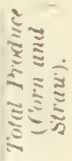 } \\
\hline & & 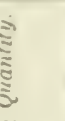 & $\begin{array}{l}2 \\
=3 \\
=3\end{array}$ & & & & & & $\begin{array}{l}\approx \\
\approx \\
\vdots \\
\approx\end{array}$ & & \\
\hline $\begin{array}{l}0 \\
1 \\
2 \\
3 \\
4\end{array}$ & $\begin{array}{c}\text { Busil. } \\
24 ; \\
24 \\
41 \\
21 \\
23\end{array}$ & $\begin{array}{l}13 \mathrm{~km} \\
135 \\
162 \\
115 \\
013 \\
3,62\end{array}$ & 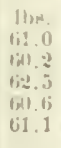 & 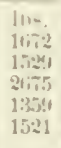 & $\begin{array}{l}1125 i \\
3 i v i \\
41 \times i 1 \\
i 12 j \\
31 ! n i \\
325 j\end{array}$ & $\begin{array}{l}0 \\
1 \\
2 \\
3 \\
4\end{array}$ & $\begin{array}{c}13110 . \\
17 \\
14 \\
31 \\
17 \\
15\end{array}$ & $\begin{array}{l}13 k s . \\
10 \\
2 \\
26 \\
10 \\
24\end{array}$ & 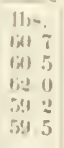 & 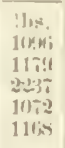 & 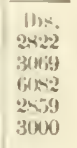 \\
\hline $\begin{array}{l}5 a \\
5 b \\
\text { tir } \\
i b \\
5 a \\
7 b \\
80 \\
8 b\end{array}$ & $\begin{array}{l}21 \\
21 \\
33 \\
31 \\
15 \\
45 \\
47 \\
49\end{array}$ & $\begin{array}{l}14 \\
0 \\
23 \\
23 \\
34 \\
25 \\
15 \\
13 \\
2\end{array}$ & $\begin{array}{l}\text { lil. } 0 \\
\text { fil. } \\
\text { lil } \\
\text { li1. } \\
\text { bil } ! \\
\text { lil } \\
\text { li1 } \\
\text { bil.s }\end{array}$ & 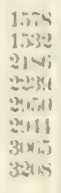 & 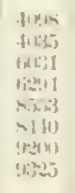 & 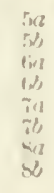 & $\begin{array}{l}19 \\
14 \\
37 \\
24 \\
32 \\
33 \\
341 \\
33\end{array}$ & $\begin{array}{l}2 \\
(1)^{3} \\
3 \\
1 \\
23^{3} \\
14^{4} \\
3 \\
\left(13_{4}\right.\end{array}$ & $\begin{array}{ll}50 & 4 \\
\text { (ii) } & 1 \\
\text { (iil } & 3 \\
\text { bill } & \vdots 1 \\
5 ! 1 & 1 \\
3 ! 1 & 5 \\
54 & 4 \\
\text { is. } & 1\end{array}$ & $\begin{array}{l}115 \pi \\
11 . k 3 \\
11, i 3 \\
1411 \\
21 k+1 \\
21: 24 \\
11 k k 1 \\
2153\end{array}$ & 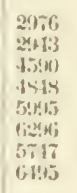 \\
\hline $\begin{array}{l}9 x \\
90\end{array}$ & $\begin{array}{l}34 \\
34\end{array}$ & $\begin{array}{l}3 \\
3 \div\end{array}$ & w. & $\begin{array}{l}\text { Q. I. } x \text {; } \\
2|x|\end{array}$ & $\begin{array}{l}1 \ldots 1 \\
6.23\end{array}$ & $\begin{array}{l}3 a \\
36\end{array}$ & $\begin{array}{l}2 ! 1 \\
25\end{array}$ & $\begin{array}{l}2 ! z \\
1 \%\end{array}$ & $\begin{array}{l}54.3 \\
5 \% .3\end{array}$ & $\begin{array}{l}12: 32 \\
1(x) 5\end{array}$ & $\begin{array}{l}5.78 \\
481 \%\end{array}$ \\
\hline $\begin{array}{l}10 a \\
10 b \\
11 a \\
11 b \\
12 a \\
12 b \\
13 / 1 \\
13 b \\
11 a \\
11 b\end{array}$ & $\begin{array}{l}31 \\
33 \\
41 \\
43 \\
4.5 \\
4.5 \\
4.5 \\
43 \\
4.5 \\
41\end{array}$ & 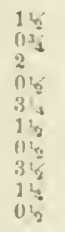 & 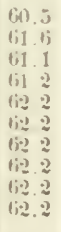 & 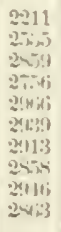 & 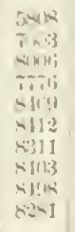 & $\begin{array}{l}10 a \\
11 b \\
11 a \\
11 b \\
12 a \\
12 h \\
13 a \\
13 y \\
11 a \\
11 b\end{array}$ & $\begin{array}{l}19 \\
24 \\
14 \\
21 \\
311 \\
33 \\
2 ! 4 \\
32 \\
214 \\
33\end{array}$ & $\begin{array}{l}3^{3} 1 \\
013 \\
3 \\
23 \\
0^{1}-2 \\
2 \\
0 \\
2 \\
3 \\
135\end{array}$ & 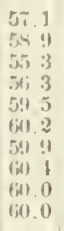 & 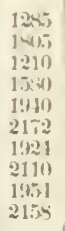 & $\begin{array}{l}37,5 \\
5073 \\
34,94 \\
47,33 \\
5178 \\
61152 \\
5127 \\
51180 \\
5531 \\
5161\end{array}$ \\
\hline $\begin{array}{l}15 a \\
1.56\end{array}$ & $\begin{array}{l}4.3 \\
4: 3\end{array}$ & 1 's & $\begin{array}{ll}62 & 1 \\
4 i-1 & 1\end{array}$ & $\begin{array}{l}2 x+1 \\
2 x] 0\end{array}$ & 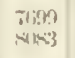 & $\begin{array}{l}1,5 a \\
1,86\end{array}$ & $\begin{array}{l}31 \\
33\end{array}$ & $3^{3^{1}}$ & $\begin{array}{l}60.0 \\
\text { (i). } 6\end{array}$ & $\begin{array}{l}2 \cap 30 \\
21 ! 1: 3\end{array}$ & $\begin{array}{l}5855 \\
6115\end{array}$ \\
\hline $\begin{array}{l}1 \text { if } a \\
11 ; 0\end{array}$ & $\begin{array}{l}49 \\
50\end{array}$ & ${ }_{03}^{23}$ & $\begin{array}{l}\text { ij }: \% \\
\text { (i) } \div\end{array}$ & $\begin{array}{l}32: 30 \\
322113\end{array}$ & 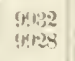 & $\begin{array}{l}16 \text { in } \\
11 ; b\end{array}$ & $\begin{array}{l}33 \\
: 32\end{array}$ & $2^{11}$ & $\begin{array}{l}5.2 .2 \\
54.2\end{array}$ & $\begin{array}{l}21 \mathrm{~m} \\
211.5\end{array}$ & $\begin{array}{l}61 ; 31 \\
7106\end{array}$ \\
\hline $\begin{array}{l}1 \div a \\
1 \div h \\
1 \div a \\
1.0\end{array}$ & $\begin{array}{l}45 \\
42 \\
21 \\
23\end{array}$ & $\begin{array}{l}3 \\
21 / 5 \\
0 \\
2^{3} ;\end{array}$ & $\begin{array}{l}62.1 \\
6.3 .2 \\
61.2 \\
61.0\end{array}$ & $\begin{array}{l}2,19 \\
27: 52 \\
15246 \\
1511\end{array}$ & $\begin{array}{l}\text { sing } \\
\text { iti2!! } \\
3 ! 14 \\
3 \operatorname{lin} 2\end{array}$ & $\begin{array}{l}1: a \\
1 \div 0 \\
1 \times a \\
1 \leqslant b\end{array}$ & $\begin{array}{l}19 \\
17 \\
32 \\
33\end{array}$ & $\begin{array}{l}3 \% 3 \\
0 \frac{3}{3} \\
3 \% 3 \\
13\end{array}$ & $\begin{array}{l}\operatorname{lin} .8 \\
\operatorname{lin} 3 \\
609 \\
\operatorname{lig} 0.8\end{array}$ & $\begin{array}{l}1227 \\
1110 \\
2127 \\
2170\end{array}$ & $\begin{array}{l}3203 \\
24114 \\
6141 \\
6385\end{array}$ \\
\hline 19 & 41 & 036 & 61.7 & 26 (fif & 7343 & 19 & 30 & 0,2 & 587 & $1967 \%$ & 5818 \\
\hline $\begin{array}{l}20 \\
21 \\
22\end{array}$ & $\begin{array}{l}22 \\
32 \\
31\end{array}$ & $\begin{array}{l}3 \\
01, \\
3\end{array}$ & $\begin{array}{l}608 \\
61.2 \\
61.0\end{array}$ & $\begin{array}{l}1115 \\
20 ; 30 \\
1934\end{array}$ & $\begin{array}{l}340 ; 2 \\
5470 \\
5: 334\end{array}$ & $\begin{array}{l}20 \\
21 \\
22\end{array}$ & $\begin{array}{l}17 \\
21 \\
21\end{array}$ & $\begin{array}{l}2 / 2 \\
13 / 1 \\
21 / 2\end{array}$ & $\begin{array}{l}61.1 \\
60.8 \\
60.1\end{array}$ & $\begin{array}{l}1155 \\
1533 \\
1553\end{array}$ & $\begin{array}{l}2986 \\
3952 \\
4010\end{array}$ \\
\hline
\end{tabular}

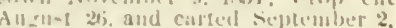
I'IOICE I'ER ACKE, ETC. and 2u:3). 
Experimexts at Rothassted os the Growtu of Wueat, Year AFTER YEAR, ON TUE SAMB LAND.

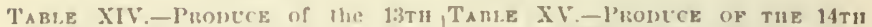

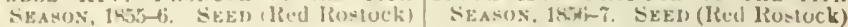

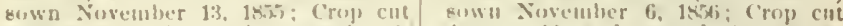
Amruat 2tj, and carted seplember 3. 1א:?

Angust 13, and carled Angust 22, $1507 \%$

\begin{tabular}{|c|c|c|c|c|c|c|c|c|c|c|c|}
\hline \multirow{3}{*}{ ֻँ } & \multicolumn{5}{|c|}{$\begin{array}{l}\text { Prodece PER Ache, ETC. } \\
\text { (For the Manuring see PH. } 202 \\
\text { and :0:3.) }\end{array}$} & \multirow{3}{*}{$\stackrel{\Sigma}{\Sigma}$} & \multicolumn{5}{|c|}{ 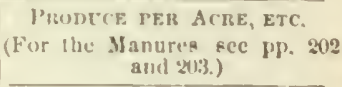 } \\
\hline & \multicolumn{3}{|c|}{ Dressed ciorn } & \multirow[b]{2}{*}{ 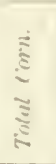 } & \multirow[b]{2}{*}{ 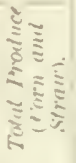 } & & Ihe: & sedel $C$ & & & \\
\hline & & 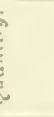 & $\begin{array}{ll}2 \\
=\end{array}$ & & & & 3 & & है & है & है \\
\hline $\begin{array}{l}0 \\
1 \\
2 \\
3 \\
4\end{array}$ & $\begin{array}{c}\text { Bu-h. } \\
14 \\
17 \\
36 \\
11 \\
11 ;\end{array}$ & $\begin{array}{l}11 k a . \\
1 \frac{14}{2} \\
013 \\
114 \\
2 \\
114\end{array}$ & 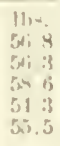 & 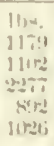 & 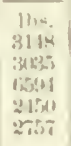 & $\begin{array}{l}0 \\
1 \\
2 \\
3 \\
4\end{array}$ & $\begin{array}{c}14+11 . \\
1 \% \\
17 \\
41 \\
14 \\
22\end{array}$ & $\begin{array}{l}\text { lhy. } \\
213 \\
213 \\
(13 \\
33 \\
13\end{array}$ & 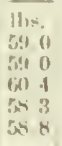 & 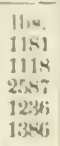 & 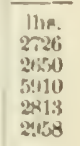 \\
\hline $\begin{array}{l}5,1 \\
5 b \\
\text { ind } \\
6 b \\
7 a \\
7 h \\
8 a \\
8 d\end{array}$ & $\begin{array}{l}14 \\
211 \\
27 \\
24 \\
37 \\
317 \\
111 \\
37\end{array}$ & $\begin{array}{l}31 \\
114 \\
114 \\
(11 / 4 \\
1 \\
214 \\
114 \\
31\end{array}$ & 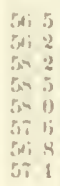 & $\begin{array}{l}1167 \\
1217 \\
1717 \\
17105 \\
2112 \\
2311 \\
2 \times 17 \\
23100\end{array}$ & 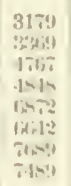 & 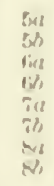 & $\begin{array}{l}22 \\
21 \\
32 \\
35 \\
13 \\
117 \\
17 \\
11\end{array}$ & $\begin{array}{l}33 \\
21 \\
11_{4} \\
11_{3} \\
11_{3} \\
14 \\
3 \\
314\end{array}$ & 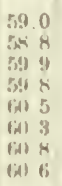 & 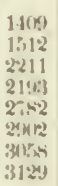 & 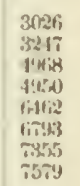 \\
\hline 94 & $\begin{array}{l}352 \\
24 i\end{array}$ & $0^{15}$ & $\begin{array}{ll}57 & 2 \\
5 & 3\end{array}$ & & & 10 & $\begin{array}{l}133 \\
336\end{array}$ & $\begin{array}{l}3 \\
0^{3} 4\end{array}$ & $\begin{array}{l}\operatorname{lin}_{1} 1 \\
\text { int. } 11\end{array}$ & $\begin{array}{l}2 \pi f_{1} \\
2420\end{array}$ & $\begin{array}{l}\text { Hit } \\
5: 213\end{array}$ \\
\hline $\begin{array}{l}10 a \\
112 \\
11 a \\
116 \\
12 a \\
123 \\
13 a \\
1: 31 \\
114 a \\
1.12\end{array}$ & $\begin{array}{l}21 \\
27 \\
31 \\
311 \\
331 \\
332 \\
32 \\
311 \\
30 \\
31\end{array}$ & 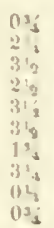 & 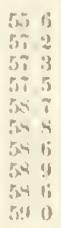 & 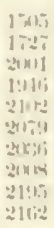 & 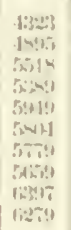 & $\begin{array}{l}10 a \\
114 b \\
11 a \\
116 \\
12 a \\
1: 2 \\
1: 3 a \\
1: 2 \\
11 a \\
112\end{array}$ & $\begin{array}{l}31 \\
31 \\
331 \\
351 \\
1: 3 \\
4: 3 \\
4: 2 \\
4: 3 \\
4: 3 \\
1: 2\end{array}$ & $\begin{array}{l}04 / 3 \\
2 \\
0 \\
(13 \\
33 \\
2 \\
3 \\
2 \\
3 \\
31,\end{array}$ & 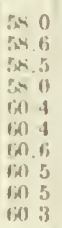 & 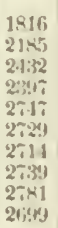 & 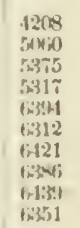 \\
\hline $\begin{array}{l}15 / 2 \\
15 \%\end{array}$ & $\begin{array}{l}30 \\
3: 2\end{array}$ & $\begin{array}{l}0 \% \\
0\end{array}$ & $\begin{array}{ll}591 \\
501\end{array}$ & $\begin{array}{l}1(r 2)\} \\
21145)\end{array}$ & & $\begin{array}{l}1: \mathrm{ml} \\
1: b\end{array}$ & $\begin{array}{l}42 \\
41\end{array}$ & $\begin{array}{l}113 \\
13\end{array}$ & $\begin{array}{l}\operatorname{lin} 1 \\
60.0\end{array}$ & $\begin{array}{l}21,81 \\
2765\end{array}$ & $\begin{array}{l}6348 \\
6513\end{array}$ \\
\hline $\begin{array}{l}\text { lfin } \\
\text { livis }\end{array}$ & $\begin{array}{l}34 \\
35\end{array}$ & $\begin{array}{l}01 / 2 \\
3\end{array}$ & 54 & 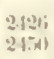 & זัก & $\begin{array}{l}\text { 1fia } \\
\text { Jide }\end{array}$ & IR & $3^{31}$ & $\begin{array}{ll}6 & 5 \\
6 & 5 \\
6\end{array}$ & $\begin{array}{l}3131 \\
319.1\end{array}$ & $\begin{array}{l}7811 \\
7 x^{2} 7\end{array}$ \\
\hline $\begin{array}{l}\operatorname{lin}_{1 \rightarrow 0} \\
1 \leqslant 0 \\
1 \leqslant 0\end{array}$ & $\begin{array}{l}31 \\
301 \\
1 \% \\
18\end{array}$ & $\begin{array}{l}22 / 2 \\
152 \\
34 \\
0\end{array}$ & $\begin{array}{l}59.0 \\
55.1 \\
57.2 \\
5 \% .7\end{array}$ & $\begin{array}{l}1 ! 143 \\
1: 1: 35 \\
11: 10 \\
11: 31\end{array}$ & 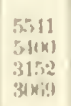 & 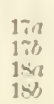 & $\begin{array}{l}21 ; \\
2 i \\
41 \\
40\end{array}$ & $\begin{array}{l}2^{3} 4 \\
33^{3} \\
0^{2}+4 \\
014\end{array}$ & $\begin{array}{ll}54 & 1 \\
54 & 8 \\
51 & 5 \\
5 ! 1 & 8\end{array}$ & 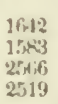 & $\begin{array}{l}3 \pi 00 \\
35223 \\
60009 \\
5481\end{array}$ \\
\hline 19 & 32 & 1 & 58.9 & 2059 & 51221 & $1 !$ & 11 & $2 \sqrt{8}$ & 5.5 & 28,00 & 5793 \\
\hline $\begin{array}{l}20 \\
21 \\
22\end{array}$ & $\begin{array}{l}1 \pi \\
22 \\
21\end{array}$ & $\begin{array}{l}0 Y \\
13 \\
13\end{array}$ & $\begin{array}{l}57.7 \\
54.0 \\
5 i .8\end{array}$ & $\begin{array}{l}10 \% 5 \\
1: 4 \%, 4 \\
1351\end{array}$ & $\begin{array}{l}24113 \\
34127 \\
3+19\end{array}$ & $\begin{array}{l}20 \\
21 \\
22\end{array}$ & $\begin{array}{l}19 \\
21 \\
23\end{array}$ & $\begin{array}{l}23 \\
0 \\
0 y\end{array}$ & $\begin{array}{l}5.84 \\
\text { in } 15 \\
60.6\end{array}$ & $\begin{array}{l}121.3 \\
1 ! 328 \\
11 ! 11\end{array}$ & $\begin{array}{l}2 \% 11 \\
3253 \\
3249\end{array}$ \\
\hline
\end{tabular}


EXPEMMENT at ROTHAMSTED ON THE GROWTH OF WUEAT, Yean AFTER YEAlל, ON TUE SAME LAND.

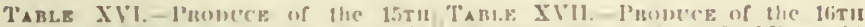

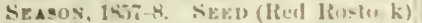
awn Novemoler 3 antal $11,1<37$; ('ru) cilr Allgust 9, aud carted Alghst 20, $1 \mathrm{sin}$.

\begin{tabular}{|c|c|c|c|c|c|c|c|c|c|c|c|}
\hline \multirow{3}{*}{ 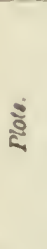 } & \multicolumn{5}{|c|}{ 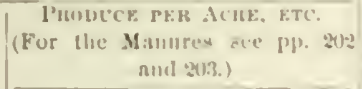 } & \multirow{3}{*}{$\stackrel{\vdots}{\vdots}$} & \multicolumn{5}{|c|}{ 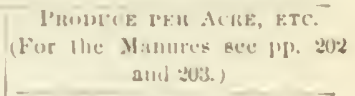 } \\
\hline & \multicolumn{3}{|c|}{ Drescell Corn. } & \multirow[b]{2}{*}{$\begin{array}{l}\sqrt[3]{3} \\
3 \\
3 \\
3 \\
3\end{array}$} & \multirow[b]{2}{*}{ 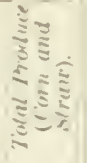 } & & \multicolumn{3}{|c|}{ In esseid Curn. } & \multirow[b]{2}{*}{ 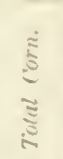 } & \multirow[b]{2}{*}{ 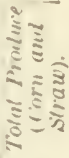 } \\
\hline & & 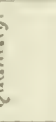 & $=$ & & & & $\vdots$ & $\therefore$ & $\stackrel{i}{\vdots}$ & & \\
\hline $\begin{array}{l}0 \\
1 \\
2 \\
3 \\
4\end{array}$ & $\begin{array}{c}\text { Buwli. } \\
20 \\
110 \\
30 \\
18 \\
19\end{array}$ & $\begin{array}{l}\text { Plow. } \\
3 \\
114 \\
314 \\
0 \\
114\end{array}$ & 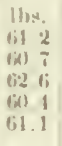 & 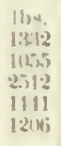 & 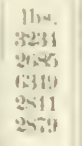 & $\begin{array}{l}0 \\
1 \\
2 \\
3 \\
1\end{array}$ & $\begin{array}{c}1311-11 . \\
21 \\
1 ! 1 \\
31 j \\
14 \\
19\end{array}$ & 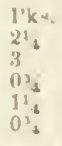 & 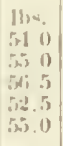 & 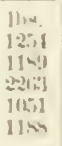 & 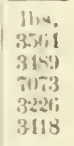 \\
\hline $\begin{array}{l}5 a \\
5 b \\
6 d \\
i b \\
i a \\
i b \\
8 b \\
8 b\end{array}$ & $\begin{array}{l}18 \\
111 \\
228 \\
291 \\
39 \\
291 \\
41 \\
41\end{array}$ & 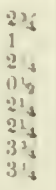 & 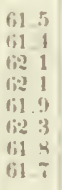 & 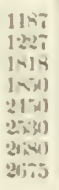 & 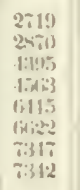 & 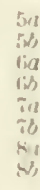 & $\begin{array}{l}20 \\
311 \\
3 ! 1 \\
343 \\
31 \\
31 \\
31 \\
31\end{array}$ & 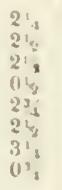 & 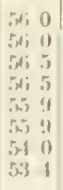 & 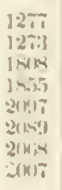 & $\begin{array}{l}0,12 \\
i 121 \\
i 501\end{array}$ \\
\hline $\begin{array}{l}9 a \\
9 b\end{array}$ & $\begin{array}{l}37 \\
23\end{array}$ & $\begin{array}{l}2 \zeta \\
2\end{array}$ & $\begin{array}{l}6009 \\
\text { ats } 5\end{array}$ & $\begin{array}{l}23-1 \\
1170\end{array}$ & & 92 & $\begin{array}{l}30 \\
21\end{array}$ & $\begin{array}{l}0 \\
213\end{array}$ & $\begin{array}{ll}51 & 5 \\
50 & 5\end{array}$ & $\begin{array}{l}14165 \\
1112\end{array}$ & \\
\hline $\begin{array}{l}10 a \\
10 b \\
11 a \\
11 b \\
12 a \\
12 b \\
13 a \\
13 b \\
14 a \\
11 b\end{array}$ & $\begin{array}{l}22 \\
27 \\
30 \\
33 \\
37 \\
37 \\
37 \\
37 \\
37 \\
33\end{array}$ & 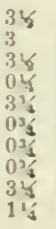 & 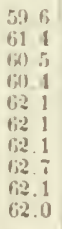 & 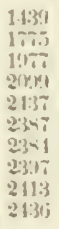 & & $\begin{array}{l}140 \\
143\end{array}$ & $\begin{array}{l}14 \\
27 \\
27 \\
27 \\
31 \\
31 \\
31 \\
31 \\
31 \\
31\end{array}$ & 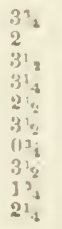 & & & \\
\hline $\begin{array}{l}15 a \\
15 b\end{array}$ & $\begin{array}{l}35 \\
37\end{array}$ & ${ }_{2}^{1 / 2}$ & $\begin{array}{l}62.6 \\
62.8\end{array}$ & $\begin{array}{l}2245 \\
21: 363\end{array}$ & $\begin{array}{l}5400 \\
611: 31\end{array}$ & $\begin{array}{l}15 \\
15\end{array}$ & $\begin{array}{l}34 \\
35\end{array}$ & $\begin{array}{l}0 y \\
0 y\end{array}$ & $\begin{array}{l}550 \\
550\end{array}$ & $\begin{array}{l}20: 3 \\
20,45\end{array}$ & \\
\hline $\begin{array}{l}16 n \\
16 b\end{array}$ & $\begin{array}{l}41 \\
42\end{array}$ & $\begin{array}{l}3 \\
0: 4\end{array}$ & $\begin{array}{l}62.1 \\
62.1\end{array}$ & $\begin{array}{l}27 \% ? \\
2 \pi 1 \%\end{array}$ & $\frac{7190}{7 \times 330}$ & $\begin{array}{l}160 \\
162\end{array}$ & $\begin{array}{l}31 \\
31\end{array}$ & $\begin{array}{l}396 \\
326\end{array}$ & $\begin{array}{l}526 \\
52.6\end{array}$ & $\begin{array}{l}2020 \\
2(x) 5\end{array}$ & $\begin{array}{l}79: 3 \\
7798\end{array}$ \\
\hline $\begin{array}{l}1 \pi a \\
17 b \\
18 a \\
18 b\end{array}$ & $\begin{array}{l}33 \\
33 \\
22 \\
20\end{array}$ & $\begin{array}{l}116 \\
314 \\
31 / 4 \\
236\end{array}$ & $\begin{array}{l}62.5 \\
625 \\
62.3 \\
62.4\end{array}$ & $\begin{array}{l}21.50 \\
21.51 \\
1.472 \\
1.33\end{array}$ & $\begin{array}{l}5.353 \\
5155 \\
3180 \\
3305\end{array}$ & $\begin{array}{l}1 i n \\
1 i b \\
1 \leqslant i \\
1 \leqslant b\end{array}$ & $\begin{array}{l}21 \\
13 \\
32 \\
32\end{array}$ & $\begin{array}{l}11^{2} \\
3 \\
32 y \\
2\end{array}$ & $\begin{array}{l}55.0 \\
54.5 \\
55.5 \\
5 t i .0\end{array}$ & $\begin{array}{l}12.17 \\
1168 \\
1 ! 173 \\
1 ! 180\end{array}$ & $\begin{array}{l}6.506 \\
66,30\end{array}$ \\
\hline 19 & 33 & $11 / 3$ & 62.5 & 217 & 5362 & 19 & 30 & 2 & 55.5 & 1903 & 5926 \\
\hline $\begin{array}{l}20 \\
21 \\
22\end{array}$ & $\begin{array}{l}17 \\
24 \\
22\end{array}$ & $\begin{array}{l}0 \\
1 \% \\
0\end{array}$ & $\begin{array}{l}60.3 \\
61.5 \\
61.5\end{array}$ & $\begin{array}{l}1089 \\
1574 \\
1412\end{array}$ & $\begin{array}{l}2819 \\
35117 \\
3542\end{array}$ & $\begin{array}{l}20 \\
21 \\
22\end{array}$ & $\begin{array}{l}17 \\
26 \\
24\end{array}$ & $\begin{array}{l}31 / 4 \\
11 / 3 \\
03 / 4\end{array}$ & $\begin{array}{l}52.5 \\
54.0 \\
55.0\end{array}$ & $\begin{array}{l}1039 \\
1529 \\
1460\end{array}$ & $\begin{array}{l}4723 \\
4.140\end{array}$ \\
\hline
\end{tabular}

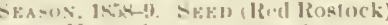

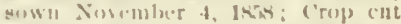

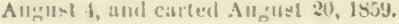

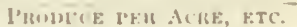
s. 


\section{Experments at Rothamsted on the Growtil of Wheat, Year}

\section{AFTER YEAR, ON THE SAME LAND.}

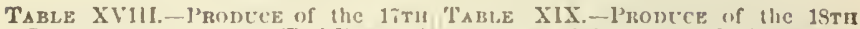

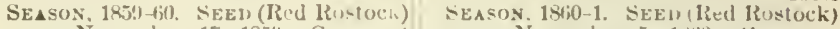
gowil November 17, 185\%); Crop cui September 17 and $1 !$, and carted October 5,1560 .

\begin{tabular}{|c|c|c|c|c|c|c|c|c|c|c|c|}
\hline \multirow{3}{*}{ ईँ } & \multicolumn{5}{|c|}{$\begin{array}{c}\text { Prodver PEI ACnE, ETC. } \\
\text { (For the Manures see pp. } 222 \\
\text { and } 203 .)\end{array}$} & \multirow{3}{*}{$\frac{\tilde{s}}{\tilde{L}}$} & \multicolumn{5}{|c|}{$\begin{array}{c}\text { 1'lionUCE P'k ACl:E, ETC. } \\
\text { (For the Manures see pp. } 202 \\
\text { and 203.) }\end{array}$} \\
\hline & \multicolumn{3}{|c|}{ Dressed Corn. } & \multirow[b]{2}{*}{ 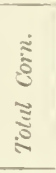 } & \multirow{2}{*}{ 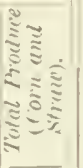 } & & \multicolumn{3}{|c|}{ Dressed Corn. } & \multirow[b]{2}{*}{$\begin{array}{l}\tilde{E} \\
\tilde{E} \\
\tilde{\Xi} \\
\dot{E}\end{array}$} & \multirow{2}{*}{ 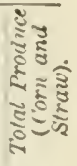 } \\
\hline & & 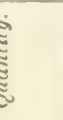 & 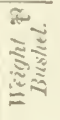 & & & & $\frac{1}{3}$ & & 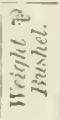 & & \\
\hline $\begin{array}{l}0 \\
1 \\
2 \\
3 \\
4\end{array}$ & $\begin{array}{c}\text { Bush. } \\
11 \\
12 \\
32 \\
12 \\
11\end{array}$ & 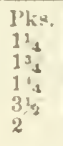 & $\begin{array}{l}11.5 \\
53.5 \\
52.8 \\
5.5 .5 \\
5.6 \\
53.0\end{array}$ & $\begin{array}{l}13= \\
826 \\
717 \\
141 ; 1 \\
734 \\
832\end{array}$ & $\begin{array}{l}11) 9 \\
2271 \\
20517 \\
53311 \\
2198 \\
2352\end{array}$ & $\begin{array}{l}0 \\
1 \\
2 \\
3 \\
4\end{array}$ & $\begin{array}{c}\text { Bush. } \\
15 \\
12 \\
31 \\
11 \\
11\end{array}$ & $\begin{array}{l}\text { Pks. } \\
112 \\
33 y \\
31 \\
1 y^{2} \\
3,2 \\
3,2\end{array}$ & $\begin{array}{l}13.4 \\
51.6 \\
57.6 \\
60.5 \\
57.4 \\
58.0\end{array}$ & 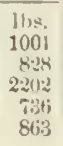 & $\begin{array}{l}11 \mathrm{~g} . \\
2763 \\
2215 \\
5303 \\
1990 \\
2193\end{array}$ \\
\hline $\begin{array}{l}5 a \\
5 b \\
6 a \\
6 b \\
5 a \\
7 b \\
8 a \\
8 b\end{array}$ & $\begin{array}{l}15 \\
16 \\
21 \\
22 \\
27 \\
27 \\
30 \\
31\end{array}$ & 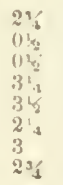 & $\begin{array}{ll}51 & 0 \\
53.1 & 1 \\
53 & 7 \\
54 & 2 \\
51 & 3 \\
51.3 \\
52.8 \\
52 & 3\end{array}$ & 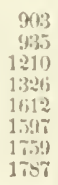 & 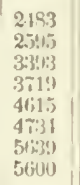 & $\begin{array}{l}5 a \\
5 b \\
6 a \\
6 i b \\
7 a \\
i b \\
8 a \\
8 b\end{array}$ & $\begin{array}{l}15 \\
15 \\
27 \\
27 \\
35 \\
31 \\
31 \\
31\end{array}$ & $\begin{array}{ll}13 \\
1 \\
1 \\
3 \\
2 \\
21 \\
11 \\
0 \\
0 \\
0 \\
0\end{array}$ & $\begin{array}{l}59.1 \\
59.0 \\
59.5 \\
59.4 \\
59.0 \\
59.0 \\
54.3 \\
58.5\end{array}$ & 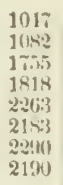 & $\begin{array}{l}2510 \\
25192 \\
4328 \\
4501 \\
5761 \\
5738 \\
6203 \\
51085\end{array}$ \\
\hline $\begin{array}{l}9 a \\
9 b\end{array}$ & $\begin{array}{l}32 \\
19\end{array}$ & $\begin{array}{l}2 / 2 \\
2: 4\end{array}$ & $\begin{array}{ll}51 & 5 \\
18.5\end{array}$ & $\begin{array}{l}18: 98 \\
1155\end{array}$ & $\begin{array}{l}605,5 \\
4: 255\end{array}$ & $\begin{array}{l}9 a \\
9 b\end{array}$ & $\begin{array}{l}33 \\
13\end{array}$ & $\begin{array}{l}3 \\
3\end{array}$ & $\begin{array}{l}56.8 \\
53.9\end{array}$ & $\begin{array}{c}216,2 \\
\left.! 0^{\prime}\right)\end{array}$ & $\begin{array}{l}6,07 \\
3079\end{array}$ \\
\hline $\begin{array}{l}10 a \\
10 b \\
11 a \\
11 b \\
12 a \\
12 b \\
13 a \\
13 b \\
11 a \\
1.1 b\end{array}$ & $\begin{array}{l}15 \\
18 \\
22 \\
22 \\
24 \\
24 j \\
26 \\
27 \\
27 \\
27\end{array}$ & 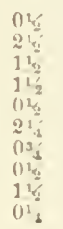 & $\begin{array}{l}49.5 \\
51.0 \\
51.0 \\
51.2 \\
53.1 \\
53.5 \\
51.3 \\
53.3 \\
53.7 \\
53.2\end{array}$ & 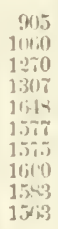 & 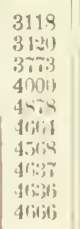 & $\begin{array}{l}110 \\
1: 2 a \\
128, \\
1: 3 t \\
1: 32, \\
11 a \\
1.1 b\end{array}$ & $\begin{array}{l}12 \\
15 \\
23 \\
25 \\
33 \\
33 \\
33 \\
35 \\
3: 3 \\
33\end{array}$ & 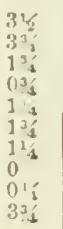 & $\begin{array}{l}5.0 \\
55.5 \\
55.3 \\
55.8 \\
5.8 .1 \\
58.7 \\
59.9 \\
60.0 \\
59.1 \\
59.3\end{array}$ & $\begin{array}{r}8.4 \\
1(133 \\
115.5 \\
1578 \\
2(4) 4 \\
2141 \\
2114 \\
2301 \\
212.4 \\
21 \% 3\end{array}$ & $\begin{array}{l}2781 \\
3196 \\
4032 \\
4223 \\
5201 \\
5481 \\
5186 \\
5791 \\
5502 \\
5176\end{array}$ \\
\hline $\begin{array}{l}15 a \\
15 b\end{array}$ & $\begin{array}{l}25 \\
29\end{array}$ & 1,6 & $\begin{array}{l}538 \\
51.0\end{array}$ & & $\begin{array}{l}1: 20 \% \\
1 \% 01\end{array}$ & & $\begin{array}{l}31 \\
31\end{array}$ & $3^{12 / 4}$ & $\begin{array}{ll}60 & 0 \\
60 & 2\end{array}$ & $\begin{array}{l}218 \mathrm{R} \\
22119\end{array}$ & $\begin{array}{l}5.506 \\
5.27\end{array}$ \\
\hline $\begin{array}{l}16 a \\
16 b\end{array}$ & $\begin{array}{l}32 \\
32\end{array}$ & $\begin{array}{l}2 \\
3\end{array}$ & $\begin{array}{l}520 \\
51.7\end{array}$ & $\begin{array}{l}1 S 56 \\
1 \times 30\end{array}$ & $\begin{array}{l}5 ! \pi+3 \\
60 ! 46\end{array}$ & $\begin{array}{l}16 a \\
11 ; b\end{array}$ & $\begin{array}{l}36 \\
3 i\end{array}$ & $2^{13 \prime}$ & $\begin{array}{l}58.0 \\
58.6\end{array}$ & $\begin{array}{l}2339 \\
2132\end{array}$ & $\begin{array}{l}6 \approx 61 \\
6 \div 65\end{array}$ \\
\hline $\begin{array}{l}1 \% a \\
17 b \\
18 a \\
18 b\end{array}$ & $\begin{array}{l}21 \\
26 \\
15 \\
16\end{array}$ & $\begin{array}{l}01 / 4 \\
11 / 2 \\
1 \\
114 \\
1: 4\end{array}$ & $\begin{array}{l}51.1 \\
51.3 \\
51.5 \\
51.15\end{array}$ & $\begin{array}{r}1109 \\
1519 \\
929 \\
? 1033\end{array}$ & $\begin{array}{l}4109 \\
1.519 \\
2619 \\
2 \pi 160\end{array}$ & $\begin{array}{l}1 \pi a \\
1 \% b \\
19 a \\
18 b\end{array}$ & $\begin{array}{l}19 \\
18 \\
32 \\
33\end{array}$ & $\begin{array}{l}1 \\
03 \frac{1}{4} \\
112 \\
11 \frac{2}{2}\end{array}$ & $\begin{array}{l}596 \\
59.5\end{array}$ & $\begin{array}{l}12: 29 \\
116 i 6 \\
20,201 \\
2122\end{array}$ & $\begin{array}{l}2982 \\
2829 \\
5141 \\
5416\end{array}$ \\
\hline 19 & 21 & $0 ! 3$ & 53.0 & 1135 & 117.8 & 19 & 32 & 2 & 58.8 & 2107 & $5: 345$ \\
\hline $\begin{array}{l}20 \\
21 \\
22\end{array}$ & $\begin{array}{l}12 \\
15 \\
13\end{array}$ & $\begin{array}{l}046 \\
2 \\
314\end{array}$ & $\begin{array}{l}51.5 \\
52.5 \\
53.8\end{array}$ & $\begin{array}{l}722 \\
81: 3 \\
817\end{array}$ & $\begin{array}{l}21 \% \pi \\
21 ; 3 ! 1 \\
211 !\end{array}$ & $\begin{array}{l}20 \\
21 \\
22\end{array}$ & $\begin{array}{l}13 \\
16 \\
19\end{array}$ & $\begin{array}{l}01 / 2 \\
13 \\
23 / 4\end{array}$ & $\begin{array}{ll}51 & 9 \\
58.2 \\
58.5\end{array}$ & $\begin{array}{r}872 \\
11116 \\
1306\end{array}$ & $\begin{array}{l}2310 \\
2 \div 19 \\
3263\end{array}$ \\
\hline
\end{tabular}


Experimexts at Rothaysted oy the Girowti of Wheat, Yealk AFTEK YEAR, OX TIE SAME LAND,

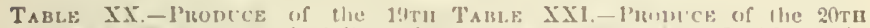

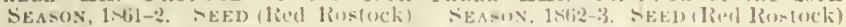
rown Oeluber 25, 1stil; C'inple cill Aupust :24, and carlet siplentiber 12. $18+i 2$.

\begin{tabular}{|c|c|c|c|c|c|c|c|c|c|c|c|}
\hline \multirow{3}{*}{$\frac{a}{\square}$} & \multicolumn{5}{|c|}{ 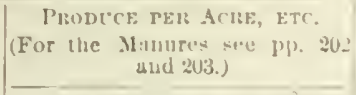 } & \multirow{3}{*}{$\stackrel{\infty}{2}$} & \multicolumn{5}{|c|}{ 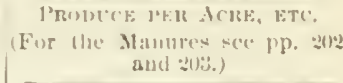 } \\
\hline & & esiscal & ועוז. & & & & Dres & Snetrl & $y$ & & \\
\hline & 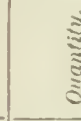 & $\stackrel{\Sigma}{\Sigma}$ & 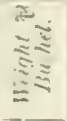 & 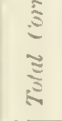 & 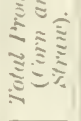 & & ह & & 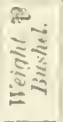 & $\begin{array}{l}\hat{\delta} \\
\tilde{z} \\
\frac{5}{0}\end{array}$ & $\begin{array}{l}\delta \approx \delta \\
j \approx \approx \\
\approx \delta 5 \\
\approx=2\end{array}$ \\
\hline $\begin{array}{l}0 \\
1 \\
2 \\
3 \\
4\end{array}$ & $\begin{array}{c}\text { Bush. } \\
1 ? \\
11 ; \\
34 \\
16 \\
16\end{array}$ & 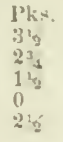 & $\begin{array}{l}11,8 . \\
545 \\
54.0 \\
6110 \\
57.5 \\
5 \times .5\end{array}$ & 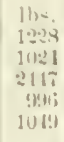 & 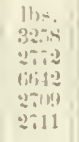 & $\begin{array}{l}0 \\
1 \\
2 \\
3 \\
1\end{array}$ & $\begin{array}{c}\text { Iinsh. } \\
22 \\
20 \\
41 \\
17 \\
20\end{array}$ & $\begin{array}{l}\text { I'lis. } \\
01 ; \\
3 \\
0 \\
1 \\
1\end{array}$ & 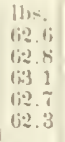 & $\begin{array}{l}11= \\
1124 ! \\
13331 \\
24461 \\
112 \% \\
1303\end{array}$ & 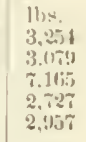 \\
\hline $\begin{array}{l}5 a \\
5 b \\
6 a \\
6 b \\
7 a \\
7 b \\
8 a \\
8 b\end{array}$ & $\begin{array}{l}17 \\
17 \\
27 \\
25 \\
35 \\
36 \\
34 \\
39\end{array}$ & $\begin{array}{l}331 \\
21^{3} \\
2 \\
3 \cdot 1 \\
2 ! \\
61^{4} ! \\
3 \\
0 !\end{array}$ & $\begin{array}{ll}59 & 0 \\
59 & 19 \\
5 ! 1 & 5 \\
5 ! 1 & 8 \\
5 ! & 3 \\
5 ! 1 & 5 \\
5 ! 1 & 2 \\
59.0\end{array}$ & $\begin{array}{l}111 ! 1 \\
1101 \\
1 \div 15 \\
1 \div 15 \\
23(h) \\
23145 \\
21 \div 7 \\
2152\end{array}$ & 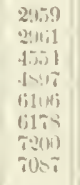 & 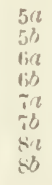 & $\begin{array}{l}19 \\
1 ! \\
3 ! 1 \\
3 ! ! \\
5 ! \\
5 ! \\
51 ; \\
5 !\end{array}$ & $\begin{array}{l}212 \\
3 \\
11 / 2 \\
3 \\
11_{2} \\
0 \\
24 \\
31\end{array}$ & 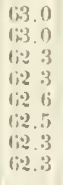 & 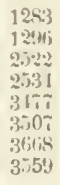 & 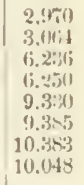 \\
\hline $\begin{array}{l}9 a \\
9 b\end{array}$ & $\begin{array}{l}43 \\
25\end{array}$ & $\begin{array}{l}13 / 4 \\
3 ! 2\end{array}$ & $\begin{array}{l}59.5 \\
56.3\end{array}$ & $\begin{array}{l}2658 \\
16,11\end{array}$ & $\begin{array}{l}8 \pi, \pi 9 \\
4 \div 5\end{array}$ & $\begin{array}{l}9 a \\
9 b\end{array}$ & $\begin{array}{l}55 \\
41\end{array}$ & $\begin{array}{l}2^{1} \cdot 1 \\
13 \\
3\end{array}$ & $\begin{array}{l}6: 2.1 \\
6 i 2.5\end{array}$ & $\begin{array}{l}3 \% 6 \\
2 \approx 23\end{array}$ & $\begin{array}{l}9,8 \div 8 \\
6,9 \div 20\end{array}$ \\
\hline $\begin{array}{l}10 a \\
10 b \\
11 a \\
11 b \\
12 a \\
12 b \\
13 a \\
13 b \\
14 a \\
11 b\end{array}$ & $\begin{array}{l}23 \\
21 \\
24 \\
27 \\
31 \\
33 \\
31 \\
32 \\
30 \\
32\end{array}$ & 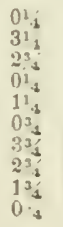 & $\begin{array}{l}50.5 \\
57.5 \\
58.0 \\
58.0 \\
58.0 \\
58.0 \\
58.0 \\
58.0 \\
58.0 \\
55.1\end{array}$ & 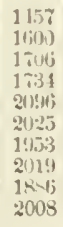 & 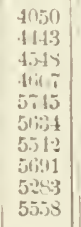 & $\begin{array}{l}10 a \\
11 b \\
11 a \\
11 b \\
12 a \\
12 z \\
13, a \\
13 b \\
11 a \\
11 b\end{array}$ & $\begin{array}{l}39 \\
43 \\
4.5 \\
463 \\
51 \\
53 \\
53 \\
53 \\
51 \\
5: 3\end{array}$ & $\begin{array}{l}01 / 2 \\
21^{1} \\
0 \\
2 \\
2 \\
2^{3} \\
1 \\
1 \\
11^{1} \\
1^{3} \\
13^{3}\end{array}$ & $\begin{array}{l}62.6 \\
6: 2.8 \\
62.5 \\
6: 2.1 \\
6: 2.1 \\
6: 2.2 \\
6: 2.6 \\
6: 5 \\
6: 2.5 \\
62.5\end{array}$ & $\begin{array}{l}2587 \\
28.58 \\
2479 \\
3060 \\
3533 \\
3.154 \\
3453 \\
3434 \\
3.527 \\
3450\end{array}$ & 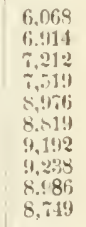 \\
\hline $\begin{array}{l}15 a \\
15 b\end{array}$ & $\begin{array}{l}30 \\
32\end{array}$ & $\begin{array}{l}13 \\
23 \\
23 \\
3\end{array}$ & $\begin{array}{l}58.3 \\
38.3\end{array}$ & $\begin{array}{l}19 \% 2 \\
202 ! 1\end{array}$ & $\begin{array}{l}5-268 \\
5 \div 57\end{array}$ & $\begin{array}{l}15 a \\
15 b\end{array}$ & $\begin{array}{l}4.5 \\
45\end{array}$ & $0^{1{ }^{-3}}$ & $\begin{array}{l}62.5 \\
62.9\end{array}$ & $\begin{array}{l}3114 \\
312 \tau\end{array}$ & $\begin{array}{l}8.2 \% 6 \\
8.210\end{array}$ \\
\hline $\begin{array}{l}16 a \\
160\end{array}$ & $\begin{array}{l}36 \\
36\end{array}$ & $\begin{array}{l}11 \\
0 \\
0\end{array}$ & $\begin{array}{l}58.0 \\
5 \pi .5\end{array}$ & $\begin{array}{l}2225 \\
2: 233\end{array}$ & $\begin{array}{l}6 \div 52 \\
6 \div 30\end{array}$ & $\begin{array}{l}16 a \\
16 b\end{array}$ & $\begin{array}{l}56 \\
55\end{array}$ & $\begin{array}{l}2^{3}{ }_{3}^{\prime} \\
0^{1}{ }_{-1}\end{array}$ & $\begin{array}{l}62.4 \\
62.3\end{array}$ & $\begin{array}{l}3710 \\
360 \%\end{array}$ & $\begin{array}{l}10.717 \\
10,332\end{array}$ \\
\hline $\begin{array}{l}1 \div a \\
1 \div b \\
1 \div a \\
1 S b\end{array}$ & $\begin{array}{l}27 \\
27 \\
15 \\
18\end{array}$ & $\begin{array}{l}34 / 2 \\
21 \\
13 \\
2 \%\end{array}$ & $\begin{array}{l}58.1 \\
58.1 \\
58.5 \\
585\end{array}$ & $\begin{array}{l}1717 \\
1655 \\
1168 \\
1195\end{array}$ & $\begin{array}{l}4527 \\
4762 \\
3161 \\
3397\end{array}$ & $\begin{array}{l}17 a \\
1 \div b \\
1: a \\
1 \div b\end{array}$ & $\begin{array}{l}21 \\
21 \\
46 \\
46\end{array}$ & $\begin{array}{l}01 \frac{1}{2} \\
1 \frac{1}{2} \\
1 \frac{1}{2} \\
03\end{array}$ & $\begin{array}{l}62.8 \\
62.8 \\
62.6 \\
62.8\end{array}$ & $\begin{array}{l}1370 \\
1389 ! \\
3006 j \\
3004\end{array}$ & $\begin{array}{l}3.288 \\
3,242 \\
7,889 \\
7,737\end{array}$ \\
\hline 19 & 23 & $1 / 6$ & 57.2 & 1179 & 4132 & 19 & 46 & 234 & 62.9 & 3051 & 7,577 \\
\hline $\begin{array}{l}20 \\
21 \\
22\end{array}$ & $\begin{array}{l}12 \\
20 \\
20\end{array}$ & $\begin{array}{l}1 \frac{1}{2} \\
11 / 2 \\
014\end{array}$ & $\begin{array}{l}57.3 \\
58.1 \\
58.0\end{array}$ & $\begin{array}{r}818 \\
1273 \\
1250\end{array}$ & $\begin{array}{l}2395 \\
34(055 \\
3430\end{array}$ & $\begin{array}{l}20 \\
21 \\
222\end{array}$ & $\begin{array}{l}17 \\
27 \\
23\end{array}$ & $\begin{array}{l}23 / 4 \\
2^{1 / 2} \\
3^{2}\end{array}$ & $\begin{array}{l}62.5 \\
1325 \\
62.4\end{array}$ & $\begin{array}{l}1137 \\
1796 \\
1306\end{array}$ & $\begin{array}{l}2.609 \\
4.279 \\
4,599\end{array}$ \\
\hline
\end{tabular}


The ninth season (18.51-2), was unusually cold in June and wet in August. It will be seen that the wheat, both in quantity and quality, is the poorest since the commeneement of the experiments. The unuanured plot gave less than 14 busbels of aressed grain per acre; the plot with harn-yard mamure, less than 28 buslets, and the best yivld in the whole serics was not quite $\mathbf{2 9}$ bushels per acre, and only weiphed 5i llos. per bushel. On the same plot, the year before, with preciscly the same manure, the rield was nearly 37 bushels p'rnere, and the weight per bushel, 63 lbs. So much for a favorable and an unfarorable season.

The tenth spason (18,is-i3), w:la still more unfavorable. The autumn of 1852 was so wet that it was impossible to work the land and sow the wheat untel the 16ith of March 18.5.3.

You will sne t'at thn proluee on the unmanured plot was less than 6 bushels per alere. With barn yard manure, 19 hushels, and with a heary lressing of ammonia-salts and minerals, not quite 26 bushels per acre. With a heary iressing of superphospluate, not quite $9 t$ bushels prer acre, and witl a full dressing of inised muneral manures an I saperphosphate, 10 bushels pur acre.

The werght per bushel on the mumanure l plot was 45 lbs.; with mixed mineral manures, 48 fhs. ; with ammunial salts nlone, $48 \frac{1}{2}$ lls.s. with harn-yaril mamure, 51 lbs.; and with ammonta-salts nnd mixed mineral manures, $52+$ lhs.

Firmers are greatly depemelent on the season, but the good farmer, who keeps up the feruluty of his dand stands a hetter chance of making money (or ut losing less), than the farmer who depends on the unaided products of the sout. The one gects 6 bushels per acre, and 1,413 lus. of straw of very inferior quality; tho other gets 20 to 26 bus?els per acre, and 5,000 lbs. of straw. And you inust recollect that in an unfarorable season we are pretly certan to get high prices.

The elevent' seitson (1853-4,) gires 19 much more attractivelooking figures! We have orer 21 bustiels per acre on the plot which has grown eleven crops of wheat in eleven years without any manure.

With barn-yard manure, orer 41 bushels per acre. With am. monia-salts alone $(1 \%(l), 45$ hushels. With ammonia-salts and mixed minerals, $(163)$, orer 50 lushels per acre, and 6,635 lus. of straw. A total produce of nearly $5 \frac{1}{2}$ tons per aere.

The trelfth season (18it-i), crives us 17 bushels of whent per acre on the contimuously unmunured plot. Orer $34 \frac{1}{2}$ bushels on the plot manured with barn-yarl manure. And I think, for the first tume since the commeneement of the experiments, this plot pro- 
duces the largest yield of any plot in the tield. And well it may, for it has now ha l, in twelwe years, 169 tons of barn-yard manure per acre!

Siveral of the plots with ammonia-salts and mixed minerals, are nearly up, to it in grain, and aheal of it in straw.

The thirtenth season (1si5-6i), gives 11 t bu-hels on the unmanured plot; orer 3tif lushe ls on the plut manured with barn-yard manure; and over 40 bushels on 84 , dressed with 600 lhs. ammonia. salts and mixel mincral manures. It will he noticed that 800 liss. ammonia-salts does not give quite as latrose a yichl this year as 600 lbs. I suppose 40 bushels per are was all that the se son was capable of produring, and an extri tguantity of ammonia did no gond. $400 \mathrm{lbs}$ of ammonia-salta, un ia, preduced $3 i t$ bushels per acre, and $800 \mathrm{lbs}$. on $16 \%$, only $3 i \frac{9}{6}$ bushels. That extra half bushel of wheat was producel at consile rable cost.

The fourteenth seasin (1siti-i), gire's ? bushels per acre on the unmanured plot, and 41 hushels on the plot with barn-yard manure. Mixed mincral manures aloue on ju gives nearly 23 bushels per acre. Mixel mineral manures and 200 lbs. ummonia-

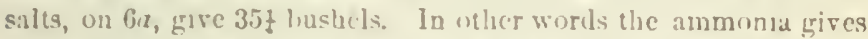
us over 12 extra busliels of wheat, and $1,110 \mathrm{lbs}$. of straw. Mineral manures and th0 $\mathrm{lhs}$. ammonia-salts, on $i b$, give $46 t$ busheis per acre. Mlineril manures and $600 \mathrm{lbs}$ ammonia-salts, on $8 b$, give nearly 49 busheli per acre. Yineral manures and 800 lbs. of ammonia-salts, on 163, gire 50 bushels per acre, and 4, 703 lbs. of straw.

"This excedingly heary manuring," said the Deacon, "dnes not pay. For instance,

"200 lbs. ammonia-salts give an increase of 196 bushels per acre.

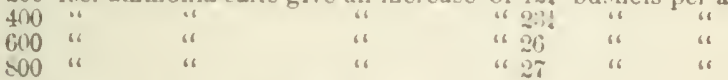

The Deacon is right, and Mr. Lawes and Dr. Gilhert call especial attention to this point. The 200 lbs. of ammonia-salts contain about 50 lus, of ammoniil, and the 400 Jbs., 100 Jbs. of ammonia. And as I have said, 100 lbs. of ammonia per acre is an unusually heary dressing. It is as much ammonia as is contained in 1,000 lbs. of average l'eruvian gruano. We will recur to this subject.

The fitleenth season (15\%i-8, glves a vicld of 18 hushels of wheat per acre on the continuously unmanured plot, and nearly 39 bushels on the plot continuously manured with 14 tons of harnfard manure. Mixed mineral manures on $5 a$ and $5 b$, give a mean yield of less than 19 bushels per acre. 
Mixed mincral manures and 100 lbs. ammonia-salts, on plots 21 and 22 , give 231 bushels per acre. In otler words:

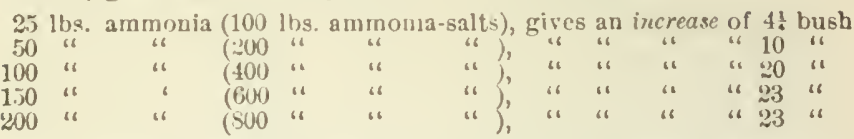

"It takes," sald the Deacon, "ahout 5 ths. of ammonia to produce a bushel of wheit. And accorlngry to this, 500 Ibs, of Peru vian guano, guaranted to contiin 10 per cent of ammonia, would give an increase of 10 bushels of whent."

"Thus is a very interestmy mattcr," said I, "but we will not discuss it at present. Let us continue the eximination of the subject. I do not propose to make many remarks on the tables. You must study them for yourself. I have spent hours and days and weeks making and pondering over these tables. The more you study them the incre interestung and instructure they beeome."

The sixtecnth seison (15ij)-9), frives us a little over $18 \$$ bushels on the unmanured plot. On the plot manured with 14 tons farmyard manure, $36 \frac{1}{6}$ hushels; and this is the lnghest yield this scason in the wheat-ficld. Mixed mineral manures alone, (mean of plot $5 a$ and 53 ), give $20 \frac{1}{2}$ hushels.

25 Jbs. ammoni.l (100 lbs. ammonı-salts), and muxed minerals, give $25+$ bushels, or an increase over minerals alone of 4 bushels.

\begin{tabular}{|c|c|c|c|c|c|c|c|}
\hline 100 & 6 & ") & 6 & $\because$ & " & 14 & 16 \\
\hline 150 & "6 & " & 16 & $" 4$ & " & 14 & " \\
\hline 200 & "1 & "6 & 4 & " & "6 & 14 & "6 \\
\hline
\end{tabular}

The scason was an unfarorable one for excessive manuring. It was too wet and the crops of wheat when highly manured were much laid. The quality of the grain was anferior, as will be seen from the light weight per busliel.

The serenteenth se:ason $(14,59 \cdot-60$,$) gives less than 13$ bushels per acre on the unmanured plot; and 321 hushels on the plot maJured with 14 tons farm-yarl manure. This season (1860), was a mecrable year for wheat in Englancl. It was both eold and wet. Mixed mineral manures, on plots $5 \cdot 2$ and 5 , gave nearly 16 bushels per acre. 25 lis. ammonia, in addition to the abore, gave less than 15 bushels. In other words it gare no increase at all.

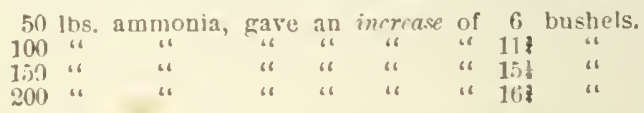

It was a poor year for the wheat-grower, and that, whether he manure? cxessively, hiberally, molerately, or not at all. 
"I do not quite sec that," satid the Deacon, "the farm-yard manure gave an increase of nearly 20 bushels per ace. And the quality of the grain must have beeis much better, as it wcighed $3 \frac{1}{3}$ lus. per busbel more than the plot unmanured. If the wheat doubled in price, as it ought to do in surbh a poor year, I to not see but that the grood farmer who had in previons years made his land riels, would come out alsea l."

"Gool for the I)eicon," said I. ". Is Situl also amongr the prophete?" If the Deacou continues fo stuty these experiments much longer, we shall have 'fim advocatiner cliemical andunres and Ligh farming!

The cightenth season (1\&60--1, gave less than $11 \frac{1}{2}$ bushels per acre on the unmanured plot; and nearly 35 bushels on the manured plot.

The mised mineral manures, gave nearly..........15: buslıels.

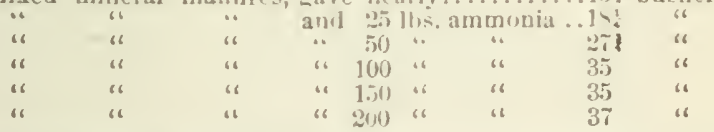

The nincleenth season (1861-2,) gave 16 busluels per acre on the unmanured plot, and over $3 \$ \frac{1}{6}$ bushels on the plot manured with farm-yard manure.

Mixed mineral manures, gare nearly........... 1s bushels per acre.

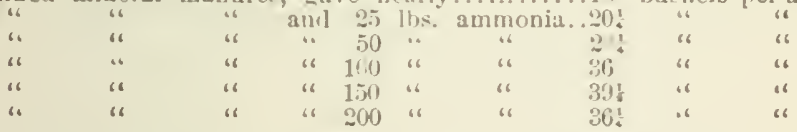

The ticenticth season (186:-3), gare 1 it bushels on the unmanured plot, and 44 bushels per acre on the manured plot.

Nixed mineral manures alone gave............10z bushels per acre.

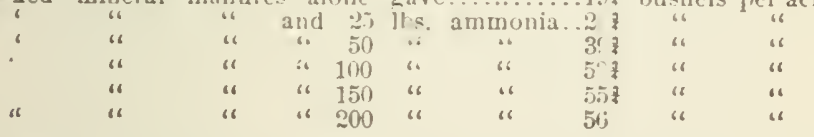

When we consider that this is the twentieth wheat-cron in succession on the same land, these figures are certainly remarkable.

"They are so," said the Deacun, "and what to me iss the most surprising thing about the whole matter is, that the plot which has had no manure of any kind for 2.5 years, and has grown 20 wheat-erops in 20 successire years, should still produce a crop of wheat of 171 bueliele per aere. Many of our farmers do not arerage 10 bushels per acre. Mr. Lawes must either bave very good land, or else the 
elinate of England is better alapted for wheat-growing than West. cru New Iork."

"I do not think," saiel I, "that Mr. Lawe's' land is any better than yours or mine: and I de not think the climate of England is any more farorable for gruwiug wheat withut manure than our climate. If there is any diflerence it is in our faver."

"Why, thrn," askedel the locetor, "do we nut grow as much wheat per acre as 11 r. Liw gets from bis continuously unmanured [1) lot?"

This is a question net dillicult on answer.

1st. We grene tim meny verdix. Mr. Lawes plowed the land twice cvery year; and llac cropl was hed ovece or twiec in the spring to kill the wicts.

21. We de not laalf work wur lieavy land. We do not plow it enough-ilo not cultivate, larrow, and rell chough. I have put whrat in on my ww farm, and lasse see nothers do the same lling.

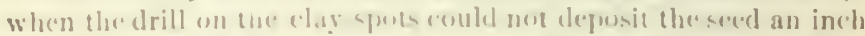
drep. There is "plintefoul" enon!h in these "chay-spots" to give 17 husieds of what per ace-or jerlaps 40 busluels-but we shall not get ten lumbls. Thie wheat will not come up until late in the antumn-the flants will lo weak and thin on the ground; and if they escape tlae winter thy will not get a fair hoid of the eromel until April or May. You know tl.e result. The straw is full of sıp, and is almo-l sure on rust; the grain shrinks up, and we harvest the cropl, not he ause it is worth the lahor, but hecause we can of eut the wheat rith a machine on the better parts of the fiell withont rutting thess puor spots also. An acre or two of poor spote pull down the arerame yild of the fielil lichuw the avera re of Mr. I'awe' well-worked but un manured lind.

3d. Yuch of our wheat is selionsly injured by stagnant water in the snil, and strmling water on the surface, I think we mas safely

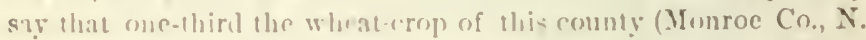
Y.), is lost for want of hettre tillage and hettre draining-and yet we think we have as cootl wheat-land and are as good farmers as can he fount in t! is country or any other!

Enless we drain lanł, where lrainage is needed, and unless we work land therourhly that necds working. and unless we kill the wemls or check their exeessive growth, it is poor economy to sow expensire manureg on our wheat-crops.

But I do not llink there is much danger of our falling into this error. The farmers who try artifieial manures are the men who ustally talie the greatest pains to malie the brst and most manure 
from the auimals kept on the farm. 'They houw what manures cost and what they are worth. As a rule, twe, such men are gooul farmers, an l endearor to work their land thoroughly and herp it clean. When this is the case, there can lu litule doubt that we can often use artificial manurcs to great advantage.

"You say," said the Deatom, who haul hern looking over the tables while I was talkiug, "lhat mixed mineral manures

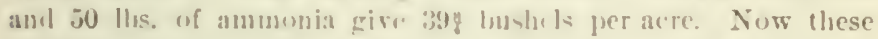
mixed mineral manures conlain furta-h, soda, ma@ne sia, and superphosphate. And I see whe re superphuephate was used without any potash, soda, and ma nesia, hut with the same amount of ammonia, the yiehl is nearly 10 lushels prere. This cones not say much in faror of potash, soila, and malgnesi:t, as manures, for wheat. A gain,

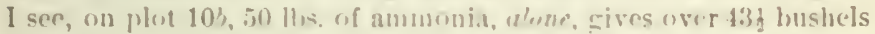
per acre. () n plot 11 \%, jo lls, aumonis and superphosphatte, give

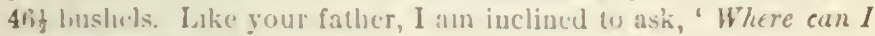
get this ammonit?" "

\section{(: II A I'T E R X I I I I I.}

\section{LIME AS A MANULE.}

These careful, systematic, and long-continurd experiments of Lawes and Gilferi seem to prove that it you have a piece of land well preparcel for wheut, which will produce, without manure, say 1.j bushele per acre, there is no way of making that land produce 30 bushels of wheat per aere, withou: dircelly or inclirectly furnishing the soil with a litseral supply of available nitrogen or ammonia.

"What do you mean by directly or indirectly?" asked the Deacun.

"What I had in my mind," said I, "was the fact that I lare seen a gond dressing of lime double the yichl of wheat. In such a case I suppose the lime decomposes the organic matter in the soil, or in some other way sets free the nitrogen or ammonia already in the snil; or the lime forms eompounds in the soil which attract ammonia from the atmosphere. $B e$ this as it may, the facts brought out hy Mr. Lawes' experiments warrant us in concluding that the increased growth of wheat wasemnected in some way with an increased supply of arailable nitrogen or ammonia. 
My father thed great quantities of lime as manure. Ho drew it a distance of 13 miles, and ustably applied it on land intended for whe:al, spreading it bro:ul-e ist, after the land hat receivenl its last plowing, and hatrowing it in, a few days or werks before sow-

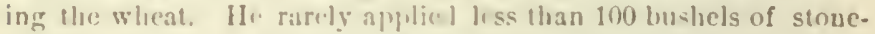
lime (1) the are-generally ligo hushls. II used to say that a small duse of line did little or no eroud. He wanted to use enongh to chunge the general tharacter of the land-eomake the light land former and the hestry lanil lighere

While I was will Mr. Jawe's and I)r. Gillort at Rothamsted, I went home on a vinit. My fuller lial a four-lurse tuam drawing lime coery day, and puthing it in larse hespes in the ticld to slake, lofore spreating it on the lamel for wh leate

"I do nut beliese it pass sou (1) dr.aw so much lime," saisl I, wilh

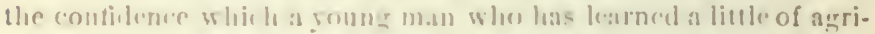

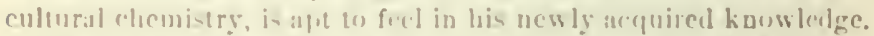

"Perhages not," saial my father, "hut we hare got (o) do sumething for the land, or the crups will he puor, and puor erops do not

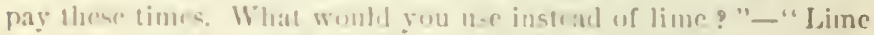

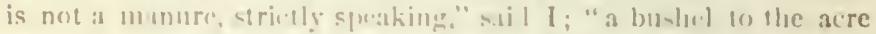
would furnich all the lime the rops repuire, even if there was not an almulant supply alraty in the soil. If you mix lime with guann, it wh free the amentulis ; and when you mix lime with the

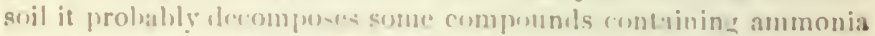

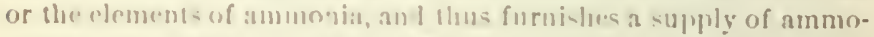
nia for the plants. I think it whlil be cheiper to buy ummonia in the shape of Peruxian Enano,"

After dinner, my fatler asterl me to take a walk over the farm. Whe camre to a tioll of harleg. Sinmline at one encl of the field,

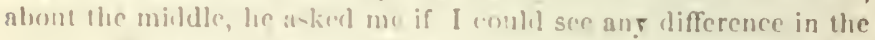
crop. "Oh, yes," I repliced, "the harley on the rimht-hand is far hetler than on the left hamel. The slraw is stiffer and hrieliter, and the heade lareer ambl heavier. I should think the right hall of the field will he ten hushels jur acre hetter than the other."

"Son 1 think," he sail, "ant now ean rou tall me why? ""Probahly you monure l me lailf the ficlat for turnips, ambl not the oilier half."-" No." - You may law drawn off the turnips from

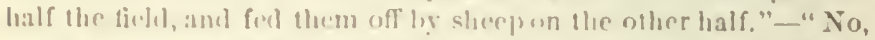

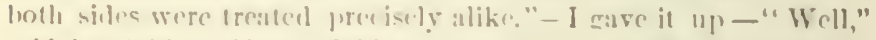
said he, "this half the fi.ld on the ri_ht-hand was limed, thirty years age, and that is the only reason I know for the difference. And now you need not tell une that lime does not pay."

I can well understand how this might happen. The ssstem of 


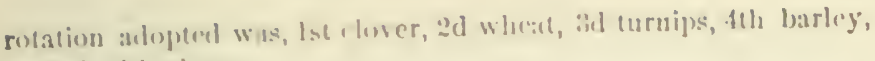
sceled with ifwer.

Now, yout put un, say ling bushels of lime for wheat. After the wheat the land is manured and sown with turnips. The lurnigs are eaten ofl on the land hy sheepr; and it is reamable to suppose that on the half of the tield dressed with lime there would he a much leavice crop of turnigh. These turnips lueing eaten ofl hy che sheep woull furmish more manne for this hale than the other talf. Then again, when the lamel was in grass or clover, the limed half would aflord more and swe ter teriss and elover than the other half, and the sheep would remain on it louger. They would eat it clone into the eromml, geing only on to the other half

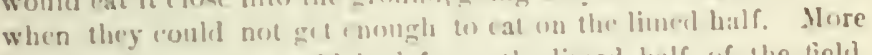
of their droppines would be left on the lined half of the lickt. The lime, for, would emtinue lo an l for severil years; hut even after all direet henefit frum the lime hasl ceased. it is easy to understand why the crops mighth he better for a longe perioul of time. "Do you think lime would do any ginod," asked the Deacon, "on our linestour land?" - I certainly do. Su far ac I liave secen, it does just as much gomel here in Western New York, as it diel on my fa:lier's farm. I shombl use it rery frecly if we comble get it cheap enough-hut we are charend from 2.510 s0 ce. a hushol for it, aml I du not think at llose rates it will puy to use it. Fren gold nay be bouryt to dear.

"You should hurn your own lime," said the Dearon, "you have plenty of limestone on the farm, and roulil use up gour down wood."-l heliere it would pay me to do sn, lut one man cannot do everything. I think if farmers woulh use more lime for manure we should get it cheaper. The demant wnuld increase will competition, and we shoult soon ect it at its real value. At 10 to 15 cents a hushel, I feel sure that we could use line as a manure with very great henefit.

"I was much interested some rears aqo," said the Doctor, "in the results of Prof. Way's inrestigations in regard to the absorptive powers of suils."

His experiments, sinee repeated and enfirmed he other chemisly, formed a new epocls in arricultural chemistry. They afforded some new suggestions in regara in how lime may benefil land.

Prof. Way found that ordinary soils possrssed the power of separating, from solution in water, the different carthy and alkaline substanees presented in them in manise: thus, when solutions of salts of ammonia, of potash, magnesi:t, ctc., were made to filter 
slowly through a hed of dry soil, five or six inches decp, arranged in a flower-pot, or other suitalle vessel, it was oliserved that the liquid which ran through, no longer contained any of the ammonia or other salt employel. The soil had, in sume form or other, retained the alkaline sulstance, while the water in which it was pre viously dissolfed passed through.

Further, this power of the soil was found not to extend to the whole salt of ammonia or potash, but only to the alkali itsclf. If, for instance, sulplate of ammonit were the compound uscel in the cxperiments, the ammonia would he remored from solution, hut the filtered liquid would contain sulphurie acid in abundancenot in the free or uncombined form, lut united to lime; insteat of sulphate of ammonia we shoulit fiml sulphate of lime in the solution; and this result was obtained, whatever the acid of the salt experimented upen might he.

It was found, moreorer, that the proeess of filtration was by no means necesary; ly the mere mixing of an akaline solution with a proper quantity of suil, as ly shaking them ingrther in a bottle, and allowing the soil $t u$ suberde, the same result was obtaincel. The action, therefore, was in no way referalile to amy physical law brought into operation hy the process of tiltration.

It was also founcl that the combination betwern the soil and the alkaline sulstanee was rapiul, if not instantumenus, partaking of the nature of the orlinary union hetween an acil and an alkali.

In the course of these experiments, scveral diflerent soils were operated upon, and it was found that all soils capalile of profitable cultiration possessed this property in a gleatcr or less degeec.

Pure sand, it was found, diel not possens this property. The organic matter of the snil, it was provel, had nothing to do with i: The addition of carhonate of lime to a soril clid not increase its absurptire power, and indeed it wiss found that a soil in which carbonate of lime did mot exist, possessed in a high degree the power of removing ammonia or potasla from solution.

To what, then, is the power of soils to arrest ammonia, potash, mannesia, phosploric acid, ctc., owing? The abore experiments lead to the ennelurion that it is due tuthe clory which they contain. In the language of Prof. Way, however,

"It still remained to he ennsidered, whether the whole clay took any actire part in these changes, or whether there existed in clay some chemical compound in small quantity to which the action was due. This guestion was to be decided by the extent to which clay was alıle to unite with ammonia, or other alkaline bases; and it soon hecame crident that the illea of the elay as a 
whole, theing the callse of the absorptive property, wis ineousise tent with all the asertaiuml laws of (hemical combination."

After a scries of experiments, l'rof. Wiy came to the conclusion that there is in (Itys a peruliar class of double silicites to which the absorptive properties of soil are lue. He found that the double silicate of alumin' and lime, or soda, whether found naturally in soils or produced artiticially, would be decomposed when a salt of anmonia, or potasl, rete, was mixed with it, the smmonia, or potash, taking the place of the lime or sola.

Prof. Way's discovery, then, is not that soils have "absorntire properties"-that has heen long known-but that they absorb ammonia, potasl, phusphuric actil, etc., by virtue of the double silicate of alumina and solia, or lime, ete., which they contain.

Soils are also found to lave the puwer of absorbing ammonia, or rather curbonute of ammonia, from the air.

"It has long been known," says Prof. Way, "that soils aecpuire fertility by exposure to the infuence of the atmosphere-lience one of the uses of fallows. * * I fiud that ( lay is so greedy of ammonia, that if air, charged with (arbo:ate of ammoni:t, so as to be higbly pungent, is passed through it tube filled with small fragments of dry clay, every purt cle of th: g is is urrested."

This power of the soil to aliarb ammonia, is also due to the double silicates. But there is this remarkable difference, that while either the lime, sola, or potas's silicate is capable of removing the ammonia from solution, the lime silicate alone luss the poicer of $a b$ sorbing it from the air.

This is an important fact. Lime mar act beneficially on many or most soils by converting the sola silicate into a lime silicate, or, in other words, converting a salt that will not absorb carbonate of ammonia from the air, into a salt that has this important property.

There is no manure that his been so extensively used, and with such general success as lime, and yet, "who among us," remarks Prof. Way, "can say that he perfectly understands the mode in which lime acts?" We are told that lime sweetens the soil, br neutralizing any acid character that it may possess; that it assists t'iz decomposition of inert organic matters, and therefore increases the supply of regetable food to plants: that it decomposes the remains of ancient rocks containing potash, socla, maşnesia, ete., occurring in most soils, and that at the same time it liberates silica from these rocks; and lastly, that lime is one of the substances found uniformly and in consilerable quantity in the ashes of plants, that therefore its applieation may be beneficial simply as furnıbing a material indispensable to the substance of a plant. 
These explamatiome are no double gool as far as they en, but experience furnishes many farts whith camnot be explained liy any one, or all, of these suppu-itions. Lime, we all kunw, does much good on soils abounding in orrini matter, and so it frequently does nn soils almost denitute of it. It maty liberate potisis, socla, silica, rte., from elity sorils, but the applieation of potash, soula, and silica has litte heneficial ellinet on the snil, and therefore we cannot aceonat for the actum of lime on the supposition that it renders the pota-ls, solla, ets., of the wil availahle to platats. Further-

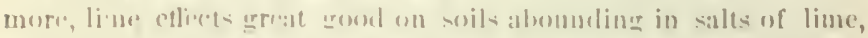

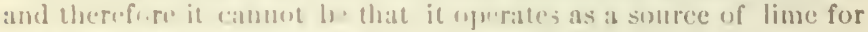
the struature of tle plant.

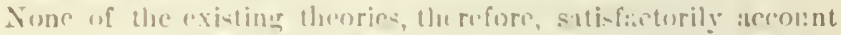
for the action of lime. Pruf. Way's views are most con-istent with

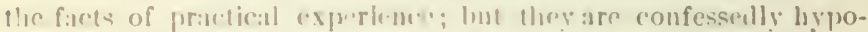
th lical ; and his more recent inve- ligutions d, not contirm the

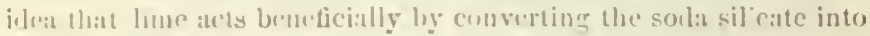
the lime silinate.

Thus, six soils were treatel with lime water until they houl ah-

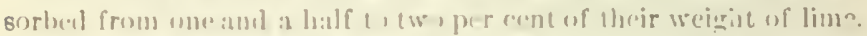

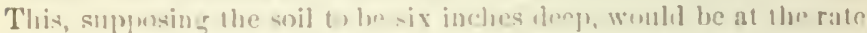
of about 300 busleclis of lime p r alere. Tue amount of ammonia in the soil wis determingl before liming, after liming and then after

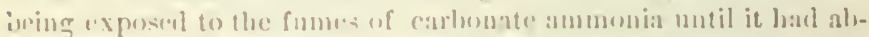
sorlxed as much as it wonhd. The following table exhlihits the results:

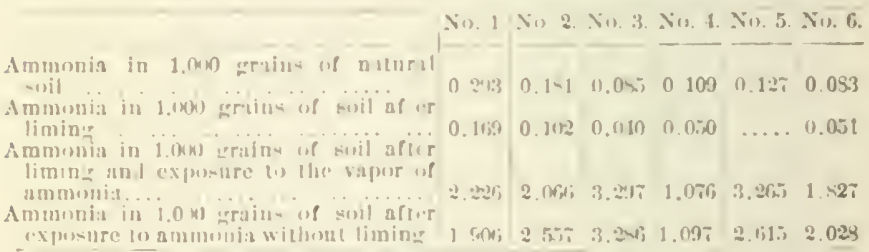

No. 1. Surface seril of l, n rom elay

Vii. 2. Sature seril frum it 1, 2 fecel befow the eurface.

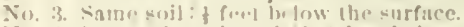

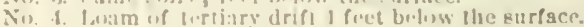

No. 5. rian? clas-4arficm-oil.

No. 6. listle clay i fect to low the surface.

It is eritent that limo neither as-jetel nor interiered with the alsorptiom of ammenia, and huner the lometicial refret of liming (1:) simh mils must he accommled for on some other supposition. This mentive result, however, lo s not disprove the truth of Prof.

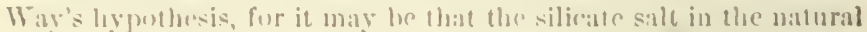
soils was that of lime and not that uf solit. Indecd, the extont to 


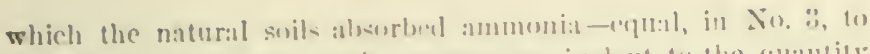

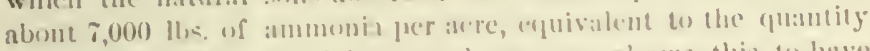
contaned in 700 tons of barm-yard manure- hows this to have been the case.

The lime liberated ons-lhalf the a mmonit omutained in the soil.

"This resu t," says Prof. Way, "is so menrly the same in all cases, that we are justifiel in helieving it to tredue lo some sperial

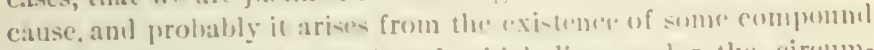
siliestes ("untaining ammonia, of which lime ander the cirrmmstanees can replace one-dalf-formine, for instance, a double silicotc of alumina, with half lims and half ammomin-such rompounds are not unusual or new to the che mi-t."

This lose of ammonia from a herey dresing of lime is very

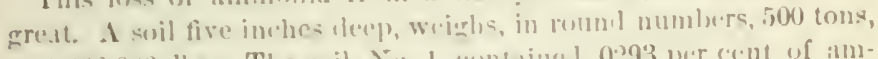

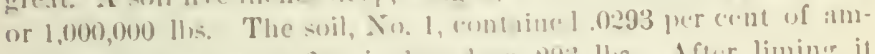

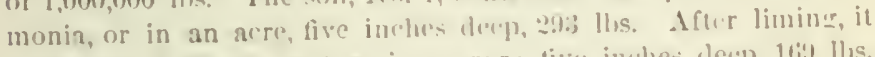
contalined .016! per cent, or in an acre, tive inches eleep, 16:1 lls. The loss by liming is 12 t llos of ammonits perace. This is equal to the quantigy contabined in 1:00) lli. of gemel Perusian guamo, or 12t tons of harn yarl mannre.

In commentine on this great lowe of ammonia from limine, Prof. Way ulserves:

"Is it not prisible, thut for the prolitable agrienltural use, the ammonia uf the soil is two tishtly lowkinl up in it? Can we suppose that the sery puwers of the soil to unito with and preserve the elements of manure are, howerer excellent a firuvision of nature, yet in some desree upposel to the growth of the abnormal crops which it is the business of the farmer (1) (nltivate? There is no absolute reason why such shoull not be thaceks. A provision of nature must relate 10 nutural circumstunces; fur instance, con: pouncls of ammonia m.y be foum in the soil, capable of giving ont to the a zencies of water and air quite enough of ammonia for the growth of ordinary plants and the preservation of their specirs; but this supply may be tutally inaldequate to the necessities of man. * * * Now it is not impossible that the laws which preserre the supply of reqetable nutrition in the soil, are tur stringent for the requirements of an unusual and excessive vegetation, such as the cultivator must promote.

"In the ease of ammonie lockel up in the soil, lime mar be the remely at the command of the farmer-his means of rendering immeliately arailable stores of wealth, wich can otherwise only slowly be brought into use.

"In this view, lime would well deserve the somewhat vague 
nume that lats heen eriven it, namely, that of a 'stimulant'; for its appriecations womld he in sosur sort an application of ammonia, whil its exersive almolication, ly driving off ammonia, would 1 anl (1) all thr distotrous (fliets which are su justly attributed to it.

"I do not wish to push this asimmption too far," salys Prof. Way, in "onclusom, "but if there he any truth in it, it points out llae impurtumer of cmpluyi gr lime in small yuantities at slort interrals, rather than in large dow's once in many years."

"The Siguire, l set year," saill the. Demeron, "Irew several hundred Imslects of refuse lime from lhe kiln, an I mixed it with his ma-

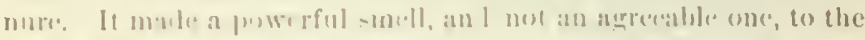

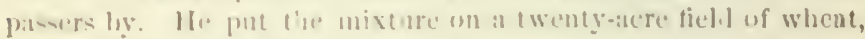

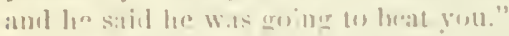

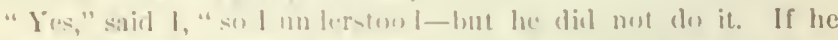
hat 1 applield the lime and the manure separately, la would have

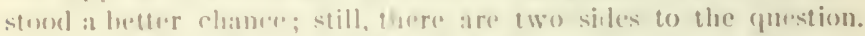
l should mot think of misine linse with eroul, rich farm-yard mamure; but will lone, courso, ctrawy munure, there would lee less injury, ant powilyly some atvantiare."

"Tine S frim," stid the Ditcon, "ent one advantage. He had nen much trouble in draw ing tie manure ahout the lanil. There was nut um th of it left."

Lime deses mot alwatys derompuse or ranie matter. In eertain

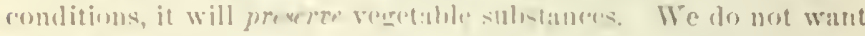
to mix lime with manme in meder lo prearese it ; and if omr ohject is to increase ferment:aliun, we must he careful to mix sufticient soil with the manure to kerp it moist (nough to retain the liberated ammonis.

Many farmers who use lime for the first time on wheat, are apt to fect a little discouraged in the spring. I hare frequently seen liment wheat in the spring lewk worse thas where no lime was used. But wat a litte, and you will see a change for the betler, and at harvest, the lime will enenerally give a gond account of itself.

There $i$ one thing about lime which, if erenerally true, is an important matter to our wheat-erowers. Jime is heliesed to liasten the maturity of the erop. "It is true of noarly all our cultivated crops," says the late Prufessur Johmston, "Iut especially of those of wheat, that their full growth is attaincil more speedily when the land is limed, and that lluy are ready for the harvest from ten to fourteen days earlier. This is the ease eren with buck- 
Whest, which becomes somer rije, elough it vivlils no larger a return when lime is applie ! tu the land on which it is grown.

In districts where the midge atiects the wheat, it is exceenlingly important to get a varicty of whe at that ripens early; and if lime will faror carly maturity, without checking the growth, it will be of great value:

A correspond me in Delaware writes: "I hare used lime as : manure in rarious ways. Fur low land, the best waty is, to sow it urossleast while the vigetation is in a gren stat , at the rate of 10 or 50 buslieh to the use; but if I e:m nut use it hefore the frost kills the venetation, I watit until the lanel is plowed in the spring, when I spread it on the plowel - roumel in aheut the some quantity as before. Last year, I triel it luth wass, amd llie resilt was, my cr(p) was increased at least fuuthll in atch iastance, bitt that used wh the veretation was he-t. The ruil is a low, black sand."

A farmer write from Liew Jirsy, that he has uscd over 6,1100 bushels of lime on hi. farm, and also consielerahlo guaroo and phespluates, hut consilers t at the lime lat pail the best. IJis farm las more thau doubled in real valuc, and he attributes this principally to th: use of lime.

"Wr lime," he silys, "whenerer it is conreaient, but prefer to put it on at least one year before ploring the land. We spreat from 25 in 41 luslucle of lime on the sol in the fall: flant with corn the following summer: next spring, sow with oats and clover: and the nest summer, plow under the clorer, ambl sow with wheat and timothy. We hare a rariety of soik, from a sandy loam in a stiff clay, and are certin that line will pay on all or any of them. Some of the best farmers in our County com-

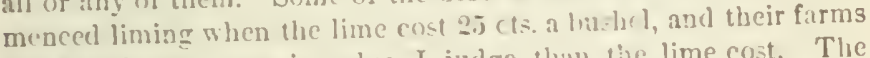
are aheal yet, more in value, I judge, thin the lime cost. The man who first commences using lime, will get so far alıead, while his neiglubors are looking on, that they will nerer catch up."

Another correspondent in IIuntercion Co., 5 . J., writes: "Experience bas taugbt me that the be-t and must profitale morle of applying lime is on grass lanel. If the grass seed is sown in the fall with the wheat or ry (", which is the common prictice with us in New Jersey, as sonn as the liarrest comes off the next year, we apply the lime with the least delaz, and while fresh slacked and in a dry and mealy state. It can be spread more evenly on the ground, and is in a state to be more readily taden up hy the fine roots of the plante, than if allowed to get wet and climms. It is found most beneficial to keep it as near the surfice of the ground 
as practicalsle, as the specific gravity or weight of this mineral manure is so great, that we soon find it too dcep in the ground for the tibrous ruots of plints to derive the greatest possible benetit from its use. With this method of application are connected several adrantages. The line can be hauled in the fall, after the busy season if over, and when spread on the sod in this way, comes in more inmediate contact with the grass snd grass-roots than when the land is first plowe.l. In fields that have been lined in part in this manner, and then plowed, and lime applied to the remainder at the time of planting with corn, I always observe a great ditlesence in the corn-crop; and in plowing up the stubble the nest se:tson, the part limed on the sud is much mellower than tlat limed after the sull was broken, presenting a ricb vegctable mould not ohecreed in the other part of the field."

A furuer in ('hestur Co., Pil, allso prefers to apply lime to newly. seetul erass or clover. He juts nu 100 busliels of slaked line per acre, either in the fall or in the spring, as most convenient. Ile limes oue fichl every year, and as the farm is laid off into eleven ticlds, all the land receives a dressing of lime once in eleven years.

In some sections of the country, where lime has been used for many years, it is possible that part of the money might better be used in the purrliase of guano, plunspluates, tish-manure, ete.; while in this sertion, where we scllom use lime, we might find it greatly to orir interest to give our land an orcasional dressing of lime.

The ralue of "f ick-line as a manure is not mercly in supplying an actual constifuent of the plint. If it was, a f('w pounds per acre would he sufticient. Its value consists in changing the chemical an! physical character of the soil-in cleveloping the latent mineral p)].nt-for:?, and in decompusing and remering arailable viguie matter, ant in forming compourds whicl attract ammonia from the atmoppliere. It may he that we can purchase this ammonia and oflere plant-food clieaper than we can grt it by using lime. It depends a gont deal on the nature and composition of the soil. At present, this question can not be definitcly settled, exrent by actual (rial on the farm. In Englint, where lime was formerly used in large quantities, the tendeney for some time has been towards a more lilserul and direct use of anmonia and phosphiates in minures, rather than to derelop them ont of the soil by the use of lime. A jullicions combination of the two systems will probably be found the most protitable.

Mn king composts with old sods, lime, and barn-yard manure, is 
a time-honored practice in Europe. I have seen excellent results from the appulication of such a compost on monduw-land. The usu.il pl:an is, to select an oly hedige-row or headlind, which has lain waste for nany years. F'low it up, and eart the soil, sods, ete., into a long, varrow heap. Mix lime with it, and let it lie six montlis or a sear. 'Then turn it, and as somn as it is fine and mellow, draw it on to the land. I have assisted at making many a hespe of this lind, but des not recollert the propertion of line used; in fact, I question if we hat any definite rule. If we wanted to use lime on the land, we put more in the hats); if nol, less. The manure wits usually put in when the heap was turued.

Dr. Velcker analyzed the dry earth used in the clusets nt the prison in Wakefield, Fugland. IIe found that:

yru. ir livid.

10 tous of dry earth before using mutained ........ 6. llis, st lls. 10 tous of iry earth after heing usied chec (ontained... it " in "

10 tons of dry curth after heine used twice containcel. st " is "

10 tons of ary earth after being used thrice contained.10:3 " $10:$ "

After lowking at the above figures, the I)eacon remarked: "Yom say 10 tous of Jry earth before lreing used in the closet contain w $62 \mathrm{lbs}$. of nitrogen. How much nitrogeu lows 10 tons of barnyand manure contain?"

"That depends a good deal on what fool the animals eat. Ten tons of average fresh manure would contain aluut 80 llis. of nitrugen."

"Great are the mysteries of chenistry!" exclaimed the Deacon. "Ten tous of dry earth contain almost as much nitrogen as 10 tons of barn-yard manure, and yet you think that nitrogen is the most valuable thing in manure. What shall we he toll next?"

"You will be told, Deacon, that the nitrogen in the soil is in such a form that the plants can take up only a small prortion of it. But if you will plow such land in the fall, and cxpose it to the disintegrating effects of the frost, and plow it again in the spring, and let the sun and air act upon it, more or less of the ormanic matter in the soil will be decomposed, and the nitrogen rendered solulile. And then if you sow this land to wheat after a good summer-fallow, you will stand a chance of haring a great crop."

This (lry earth which I)r. Velcker analyzel alppearel, he says, "to be ordinary garden silil, containing a con-iderable portion of clay." After it had been passed nnce througly the clnset, une ton of it was spread on an aere of grass-land, which produced 2 tons $8 \mathrm{cwt}$. of hay. In a second experiment, one ton, once passed through the closet, prodnced 2 tons $\mathrm{i} \mathrm{cmt}$ of hay per acre. We are not told how much hay the land produced without any dress- 
ing at all. Still we may infer that this top-dressing did considerable good. Of one thing, however, there can be no donbt. This one ton of earth manure containcd $m$ uly $1+1 \mathrm{lb}$. more nitrogen and $1 \frac{1}{2} \mathrm{~b}$. more phosphoric acid than a ton of the dry earth itself. Why then dicl it prove so raluable as a top-dressing for grass? I will not say that it was due sulely to the decomposition of the nitrogroous matter and other plant-food in the earth, caused ly the working over and sifting and exposure to the air, and to the action of the night-soil. Still it woull seem that, so far as the heneticial (eflect wis due to the supuly of plant-fool, we must aturibute it to the earth itself rather than to the small amount of night-soil which it containerl.

It is a very common thing in England, as I lawe said brfore, for faruers 10 make a comprist of the sorls and earth from an old hedere-row, ditch, or fence, and mix with it some lime or barnyard manure. Then, after turning it mee or twice, and allowing it to renain in the lesty) for a few months, to spread it on meatow-land. I luave seens great benctit apparintly derived from such a top-elressing. The young griss in the spring assumed a rich, dark green color. I have oloserved the same effect where coul-ashe's were spreart on grass-lanil; and I have thought that the apparemt lenefit was due largely to the material actine as a kind of muleb, rather" than to :ts smpplying plant-food to the grass.

I doubl very much whetlee we ean afford to make such a eompost of arth with lime, aslues, or manure in this country. But I icel sure that those of us having rich clay land eontaining, in an inert form, as much nitrogen and phosplorie acil as Dr. Voleker found in the soil in he necel in the earth-closet at Wakeficld, can well atford to stir it freely, and expose it to the disintegrating and deromposing action of the atmolubere.

An acre of try soil six inches derp weiglss ahont 1,000 tons; and consecpuenty an are of such soil as we are talking abont would contain 6,200 ltse of nitrogen, and 3.600 lhs. of phosphoric arid. In other words, it contains to the depth of only six inches as muely nitrogen as would he furni-bed by $\pi$.5 inns of common barn-yard manure, and a much phosphoric acis as 900 tons of manure. With such facts as these before us, am I to blame for urging farmers to cultivate their l:mol more thoroughly? I do not know that my lant or the Deacon's is as rich as this English soil; but, at any rate, I see no reason why such sluould not be the case. 


\section{CH A P'E E II I I I.}

\section{MANURES FOR BARLEY.}

Messrs. Lawes and Gilbert have published the results of experiments with different manures on barley grown anmually on the same land for twenty years in succession. The experiments commenced in 18.5\%.

The soil is of the same eneneral character as that in the field on the same farm where wheat wats grown annually for so many years, and of which we have given such a full account. It is what we should call a calcareous clay loan. On my farm, we have what the mon used to call "elay spots." Tlese spots vary in size from two acres down to the tenth of an acre. They rarely produced even a fair crop of corn or putatoes, and the barley was seldon worth harrestin:r. Since I have drained the land and taken special pains to bestow extral calle in plowing and working these hard and intractible purtions of the fielde, the " clay spots" have disappeared, and are now nothing more than good, rather stiff, clay loam, admirably adapted for wheat, barley, and oats, and capable of producing gend crops of corn, potatoc's, and manerel-wurzels.

The land on which Mr. Latwes" wheat and barley experiments were made is not dissimilar in groneral character from these "clay spots." If the land was only half-worked, we should eall it claty; but being thoroughly cultivated, it is a goou clay loan. Mr. Lawes deseribes it as "a somewhat heary Inam, with a subsoil of raw, yellowish red (lity, but resting in its turn upon chalk, which provides good natural drainage."

The part of the ficld deroted to the experiments was divided into 24 plots, about the fifth of an acre each.

Two plots were left without manure of any kind.

One plot was maunrel every year with 14 tons per acre of farmyarl manure, and the other plots "with manures," to quote Dr. Gilbert, "which respectively supplied certain constituents of farmyard manure, separately or in combination."

In England, the best barley soils are usually lighter than the best wheat soils. This is probably due to the fuct that barley usually follows a crop of turnips-more or less of which are caten off on the land by slieep. The trampling of the sheep compresses the soil, and makes even a light, sandy one tirmer in texture.

In this country, our best wheat land is also our best barley land, provided it is in good heart, and is very thoroughly worked. 
It is no use sowing barley on heary land half worked. It will do better on light soils; but if the clayey soils are made fine and mellow, they produce with us the best barley.

In chemical conıposition, harley is quite similar fo wheat. Mr. Lawes and Dr. Filbert give the composition of a wheat-crop of 30 lushels per acre, 1,800 lbs. of grain, and 3,000 llis. of straw; and of a crop of barley, 40 bushels per acre, 2,050 lbs. grain, and 2,500 lbs. of straw, as follows:

\begin{tabular}{|c|c|c|c|c|c|c|}
\hline & \multicolumn{2}{|c|}{ In Grain. } & \multicolumn{2}{|c|}{ In straw. } & \multicolumn{2}{|c|}{ In Tutal Iroduce. } \\
\hline & Whel. & Latrly. & Whal. & biarlay. & Whoral. & Barley. \\
\hline 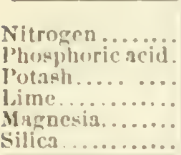 & $\begin{array}{l}\text { lbs. } \\
32 . \\
16 . \\
9.5 \\
1.5 \\
3.5 \\
0.5\end{array}$ & $\begin{array}{l}\text { lhs. } \\
: 33 \\
17 . \\
11.5 \\
1.5 \\
1 . \\
12 .\end{array}$ & 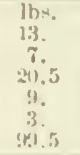 & $\begin{array}{c}\text { lbs. } \\
12 . \\
5 . \\
14.5 \\
1115 \\
2.5 \\
\text { fis. }\end{array}$ & $\begin{array}{l}\text { lbs. } \\
45 . \\
23 . \\
31) . \\
11) . \\
(i) .5 \\
1(x) .\end{array}$ & $\begin{array}{l}1 \mathrm{bs} . \\
45 . \\
22 . \\
30 . \\
12 . \\
6.5 \\
7.5 .\end{array}$ \\
\hline
\end{tabular}

A few years ago, when the midge destroyed our wheat, many farmers in Western New York raised "winter barley," insteal of "winter wheat," and I have secn remarkably heavy crops of this winter barley. It is not now grown with us. The maltsters would not pay as much for it as for spring barley, and as the midge troubles us less, our farmers are raising winter wheat again.

Where, as with us, we raise winter whent and spring barley, the ditlerence between the two (rops, taking the above estimate of yicld and proportion of errain to straw, would be:

1st. Almost identical composition in regard to nitrogen, phosphorie acid, potaslı, lime, and magnesia; but as it has more straw, the wheat-crop removes a larger amount of silien than barley.

2l. The greatest difference is in the lenith of time the two crops are in the ground. We sow our winter whent the last of August, or the first and second week in September. Before winter sets in, the wheat-plant often throws out a lunch of roots a foot in length. During the winter, though the thermometer groes down frequently to zero, and sometines 10 to 15 below zero, yet if the land is well covered with snow, it is not improbable that the roots continue to absorh more or less food from the ground, and store it up for future use. In the spring, the wheat commences to grow before we can get the barley into the grounil, though not to any considerable extent. I have several times sown larley as soon as the surface-soil was thawed out fire or six inches deep, but with a bed of solid frozen earth benenth.

30. Two-rowed barley does not ripen as early as winter wheat, but our ordinary six-rowed barley is ready to harrest the same time as our winter wheat. 
4th. We sow onr bar?ey usually in May, and harrest it in July The harley, therefore, has to take up its food rapidly. If we ex. pect a good grow $(1$, we must provide a grood supply of food, and have it in the proper eondition for the roots to reach it and absorb it; in other words, the land must be not only rich, but it must he so well worked that the roots ran spreal out easily and rapidly in search of food and water. In this comnery, you will tind ten good wheat-growers to one gom lo:arleg grower.

"That is so," said the Deacenn; "but t(ll us ahout Mr. Lawes" experiments. I have more confidence in them than in your spece ulations. And tirst of all what kind of land was the barley grown on?"

"It is," said I, "rather heary lan l-as heavy as what the men call '('lay-spots,' on my farm."

"And on these clay-spets," sail the Deatenn, "yol either get rery gool barley, ur a crop nut worth harwestine."

"You hare hit it eviletly, 1) acon," saitl I. "The bret harley I have this year (18-5) is on these clay-epots. And the reasun is, that we gare them an extral pluwing last fall with a lhere-herse plow. Tha cxira plowing has probably given me an extra 30 bushels of barley per ace. 'The barley on some of the lighter purtions of the field will not yide over $2 j$ lutshels per atere. On tie clay-spots, it lonks now (Jume 13) as thuligh there would lur over 50 bushels per aere. It is all heaclet out landsomely on the elayspots, and has a stron s, t!ark, luxuriant appearance, while on the sand, the crop is later and has a rellow, sickly look."

"Fon ought," said the Doctor, "tu have top-itressed these pour, sandy parts of the teld with a little superphosphate and nitrate of soda."

"It would have paisl wonderfully well," said I, "or, perhaps, more correctly speaking, the loss would have ben ennsiderably less. We have recently been alvised by a distinguished writu, to npply manure t.) our best land, and let the poor land take care of itself. But where the poor land is i the same fielil with the good, we are obliged to plow, harrow, cultirate, sow, and harrest the poor spots, and the question is, whether we shall make them eapable of producing a good crop by the application of manure, or the at all the labor and expense of putting in and harresting a crop of chicken-feed and weels. Artificial manures give us a grand chance to make our crops nore uniform."

"You are cerlainly right there," saill the Doctor, "but let us examine the Rothamsted experiments on barley."

Jou will find the results in the following tables. The manures 
used, are in many respects the same as were arlopted in the wheat experiments alrealy given. The mineral or ash constituents were supplied as follows:

Potish-as sulphate of potash.

Sodil-as sulphate of soda.

Magnesin-as sulphate of magnesia.

time-as sulphate, yhosphate, and superphosphate.

Phosphoric acid-ats boue-ash, mixed with suflicient sulphuric acid to convert most of the insolulile eartly phosphate of lime into sulphate and soluble superphosphate of lime.

Sulphuric ariel-in the phosphatic mixture just mentioned; in sulphates of potish, sodil, and maguesia; iu sulphate of ammonis, cte.

Chlorine-in muriate of ammonia.

Silicu-as artificial silicate of suda.

Other constituents were suppliewl as under:

Vitrugen-as sulphate an l muriate of ammonia; as nitrate of sola: in farm-yard manure; ju rapu-ecake.

Son-nitrogenms org.nic m ather, y eld ng by deromposition, curbonic acid, and other premlucts-in yard mamure, in rape-calic.

The artificial manure or mixture for cach plot was ground up, or otherwise mixed, with a suflicicut quantity of soil and turf-ashes to make it "1] to a conrenient meisure for equal distribution over the land. T'he mixtures so prepared were, with proper precantions, sown broalcast by hand; as it lias been found that the application of an exact amount of manure, to a lianited area of land, can be best accomplished in that way.

The same manures were used on the same plot each year. Any exceptions to this rule are mentioned in foot-notes. 


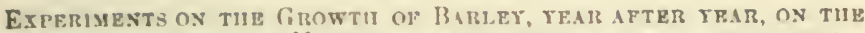

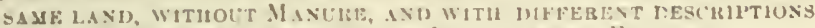

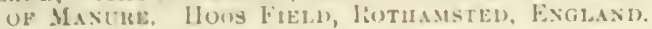

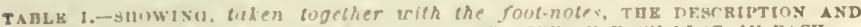

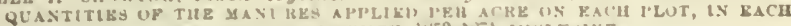

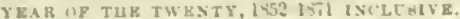

[X. B. This table has reference to all the succecting Tableg].

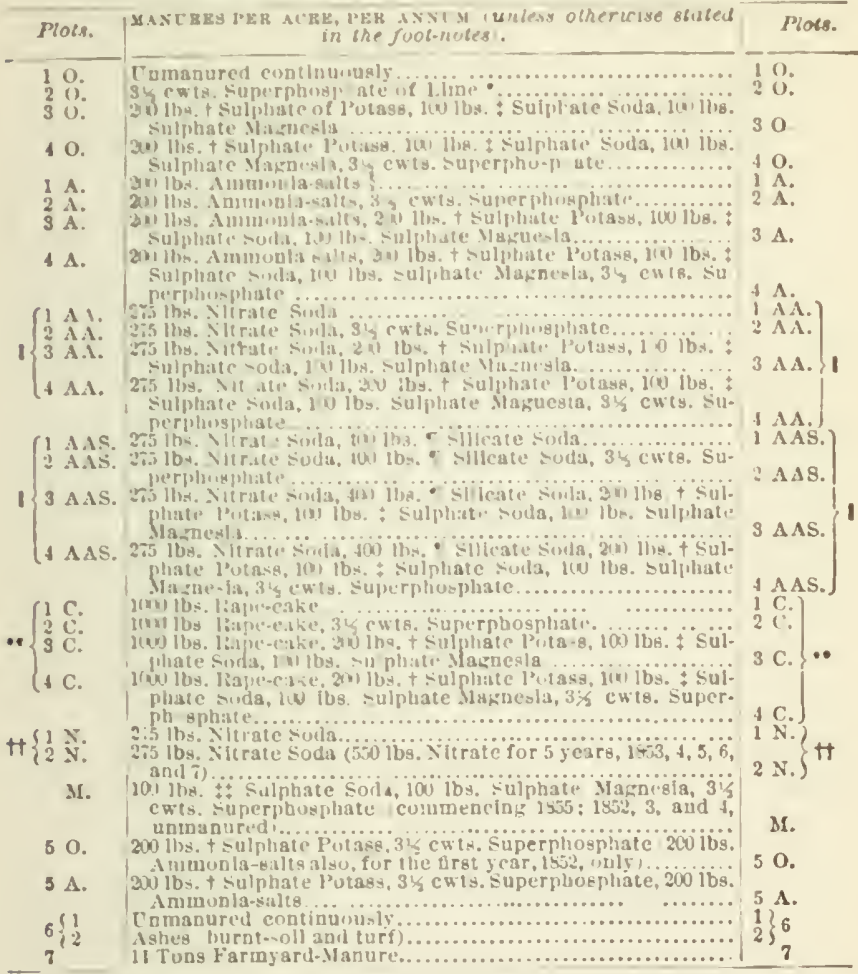

Notis TO TABLY t.

- "3y ewts. Superphnephate of Lime'-in all cases, made from 200 lbs. Boze asb. 1511 lhs. Sulphurlc acillop. er. 1.t and watr.r.

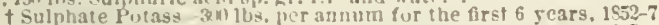

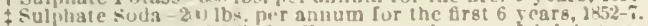

\$ The" Amuonla-salts "-Inall cases cqual parts of sulphate and Murlate of Am. monia of Cotmunerce.

1 llots "A " aud "A $\Lambda S "$ - first 6 years, 1852-7, instead of Nitrate of Soda, 400 lbs. Ammonia-salts per annum; nixt 10 years, 1855-6\%, 200 lbs. Ammnnla-8alta per anrum; 1sry, and since, 26 lbs, Yltrate of Soda per annum. 265 bs. Nitrate of Soda Is reckuned io e intain the same anount uf Nitrogen as 200 lbs. "Ammonla-galts."

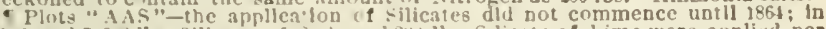

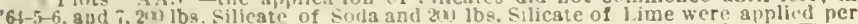
acre, but in jubs, and since, fro ibs. Slicate of Fora, and no Sllicate of Linie. These plots comnrlse, respectirely, one half of the urleinal "A $A$ "plots, and, cxcenting the addition of the silicater, have been, and are, In other respects, manured in the same way as the "A A "plots.

- 2ux 1 bs. liape-cake per annum for the first 6 years, and 10001 ba. only, each year

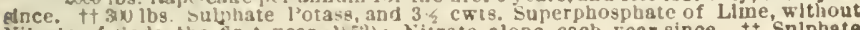
Nitrate 1 soda, the tir $-t$ sear $\left.255^{2}\right)$; Nitrate alone each sear since, $\$$ Sulphate Soda-200 1bs. per annum 1555,6 , and $:$ 
Experimtists on the firowtil of Barlet, Ygar after Year, on TIONY OF MANURE, HOOS

TABLE II. - DIEESED

[N.B. The double rertical lines show that there was a change in the descripTable $I_{\text {. }}$, and foot-notes

\begin{tabular}{|c|c|c|c|c|c|c|c|c|c|c|c|c|}
\hline \multirow{2}{*}{ ล } & \multicolumn{12}{|c|}{ HARTE8TS. } \\
\hline & 1852 & 1853 & 1851 & $1555^{5}$ & 1856 & 1557 & 1558 & 1859 & 1860 & 1861 & 1862 & 1863 \\
\hline $\begin{array}{ll}1 & 0 . \\
2 & 0 . \\
3 & 0 . \\
4 & 0 .\end{array}$ & $\begin{array}{c}\text { bushels. } \\
27 \\
273 \\
248 \\
3213 \\
3213\end{array}$ & $\begin{array}{c}\text { bush. } \\
2535 \\
33 y_{3} \\
275_{8} \\
3 ; 5\end{array}$ & $\begin{array}{l}\text { busb. } \\
3.7 \\
10 \% \\
346 \% \\
12\end{array}$ & $\begin{array}{l}\text { bus } \\
31 \\
364 \\
34 \\
37 \\
37\end{array}$ & $\begin{array}{l}\text { bus } \\
13^{7} \\
17^{3} \\
16^{4} \\
193\end{array}$ & $\begin{array}{l}\text { buwb. } \\
26 ! 8 \\
3: 3: 4 \\
3: 2 \\
3: 13\end{array}$ & $\begin{array}{l}\text { bush. } \\
212 \text {. } \\
241 \\
211 \\
211 \\
303\end{array}$ & $\begin{array}{l}\text { bus } \\
132 / 8 \\
1 ! s_{8} \\
15^{7} \\
193\end{array}$ & $\begin{array}{l}\text { bus } \\
133^{1} \\
155^{3} \\
151 \\
181 \\
184\end{array}$ & $\begin{array}{l}\text { hus } \\
166^{2} ; \\
25 \\
187 \\
23^{3}\end{array}$ & $\begin{array}{l}\text { bug } \\
111^{2} \\
213 \\
1 ! 13 \\
25 ! 8 \\
258\end{array}$ & 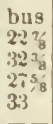 \\
\hline Means & $2 i^{3} \xi^{\prime}$ & $30 \% 8$ & $3 \times 16$ & $34^{3} 3$ & 17 & 323 & $26^{2} \mathrm{~s}$ & $171 / 4$ & $15 \%$ & 2238 & 2036 & 287.8 \\
\hline $\begin{array}{ll}1 & \text { A. } \\
2 & \text { A. } \\
3 & \text { A. } \\
4 & \text { A. }\end{array}$ & 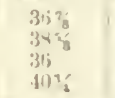 & $\begin{array}{ll}34: 8 \\
111 & 8 \\
35 & 8 \\
3 & 2\end{array}$ & $\begin{array}{l}17^{9} 3 \\
160 \\
50 \\
60.8\end{array}$ & 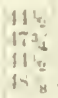 & $\begin{array}{l}25 \\
2 ! 116 \\
281 \\
31 \%\end{array}$ & $\begin{array}{l}3278 \\
5412 \\
428 \\
5738\end{array}$ & $\begin{array}{l}316 \\
51 \% \\
31 / 4 \\
51 \frac{6}{2}\end{array}$ & $\begin{array}{l}1598 \\
31 \mathrm{z}_{2} \\
167^{3} \\
34^{5}\end{array}$ & $\begin{array}{l}213 \% \\
13^{3} 8 \\
29 \\
13 \%\end{array}$ & $\begin{array}{l}304 \\
55 \\
321 / 1 \\
511_{18}^{13}\end{array}$ & $\begin{array}{l}313 \\
1.5 \\
355^{3} \\
-175^{3}\end{array}$ & $\begin{array}{l}1258 \\
613^{8} \\
1,48 \\
55 \%\end{array}$ \\
\hline Meano & $331_{8}$ & 3ís & 517 & $10 ; i_{3}$ & $28 \sqrt{2}$ & $48^{2} 4$ & 1218 & $25 \%$ & $35 \%$ & 134 & $10^{3 / 4}$ & $52 \%$ \\
\hline $\begin{array}{ll}1 & \text { A. } \\
2 & A . \\
3 & A . . \\
4 & \text { A.. }\end{array}$ & $\begin{array}{l}111 y_{2} \\
13 \% \\
111 \\
15 \\
15\end{array}$ & $\begin{array}{l}10^{3} \\
12^{7} \\
41 \\
416^{4}\end{array}$ & 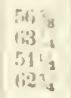 & $\begin{array}{l}12 \\
50 \% \\
171 \\
19.8\end{array}$ & $\begin{array}{l}3 r, 1 \\
31.4 \\
2 \% 3 \\
378\end{array}$ & 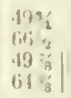 & $\mid \begin{array}{l}3: 25 \\
54 i^{2} \\
40 \% \\
56: \\
56:\end{array}$ & $\begin{array}{l}21 \mathrm{k} \\
3,53 \\
20 \\
355^{3} \\
5\end{array}$ & $\begin{array}{l}25^{3} 8 \\
433^{2} \\
3\left(1^{3}\right. \\
166^{4}\end{array}$ & $\begin{array}{l}35 \\
55^{3} ; \\
366^{2} \\
55 ? 8\end{array}$ & $\left\{\begin{array}{l}31 \% \\
51 \\
311^{1}-8 \\
483\end{array}\right.$ & $\begin{array}{l}49 \\
10 \% \\
54 \\
59 \%\end{array}$ \\
\hline Mteans & 133 & $421_{8}$ & 584 & $\mid K T_{i 8}$ & $32 \%$ & $5 \% 3$ & fil's & $293 x$ & 367 & $45 ?$ & $417^{\circ}$ & $55 \%$ \\
\hline $\begin{array}{l}1 \text { ANS. } \\
2 \text { ANS. } \\
3 \text { AAS. } \\
4 \text { AAS }\end{array}$ & & & & & & & & & & & & \\
\hline \multicolumn{13}{|l|}{ Means } \\
\hline $\begin{array}{ll}1 & c \\
2 & c \\
3 & c \\
4 & c \\
4 & c .\end{array}$ & $\begin{array}{l}31.18 \\
3115 \\
33 \frac{1}{2} \\
3 x\end{array}$ & $\begin{array}{l}3: 78 \\
31518 \\
355 \\
1018\end{array}$ & $\begin{array}{l}60 \% \\
\text { (i) } 18 \\
56 \% \\
601 \\
6\end{array}$ & $\begin{array}{l}121 \% \\
533^{\circ} \\
187^{\circ} \\
51 \%\end{array}$ & $\begin{array}{l}369 \\
371 \\
328 \\
35.8\end{array}$ & 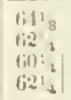 & $\mid \begin{array}{l}53^{3} i \\
573^{3} \\
52 \\
57^{2}\end{array}$ & $\begin{array}{l}38{ }^{3} \\
11 \\
311^{2} \\
35\end{array}$ & $\begin{array}{l}31^{3} \\
343^{3} \\
355^{1} \\
40^{3}\end{array}$ & $\begin{array}{l}564_{81} \\
567_{8} \\
511^{2} \\
533_{8}\end{array}$ & $\begin{array}{l}41 \\
45 \\
36 \\
45 \%\end{array}$ & $\begin{array}{l}513 \\
55 \\
531 \% \\
514\end{array}$ \\
\hline Means & $36 \div$ & $37>8$ & $5.91 / 2$ & $50{ }^{5} 8$ & 35, & $62: 4$ & 55 & $3 \pi^{\prime} j$ & $36,{ }^{2} 8$ & $5+11$, & 41 ?' & $533^{5}$ \\
\hline $1 \mathrm{~N}$. & \}$\left.\left(257_{8}^{\prime}\right)\right\}$ & $\begin{array}{l}317 \% \\
37{ }^{1}\end{array}$ & $\begin{array}{l}19 ? \mathrm{Y} \\
5: 1,4\end{array}$ & $\begin{array}{l}50 \\
493_{8}\end{array}$ & $2 \nmid L_{i j}$ & $47^{7} 8$ & $\begin{array}{l}37^{3} \\
437^{4}\end{array}$ & $\begin{array}{l}217_{8} \\
21 ; \varepsilon_{2}\end{array}$ & $\begin{array}{l}27{ }^{3} 8 \\
293_{j}^{8}\end{array}$ & $\begin{array}{l}392_{4} \\
415_{8}\end{array}$ & $\begin{array}{l}35,6 \\
3 r^{3}\end{array}$ & $51 \%$ \\
\hline $\begin{array}{ll} & \text { M. } \\
5 & 0 \\
5 & \text { A. }\end{array}$ & $\begin{array}{l}(361,2) \mid \\
3 i 5 \frac{2}{2}\end{array}$ & $\begin{array}{l}274 \\
1(1)\end{array}$ & $\begin{array}{l}30{ }^{1} \\
51{ }^{7} \\
7_{8}\end{array}$ & $\begin{array}{l}32{ }^{3}{ }_{3} \\
3: 2: 1{ }^{8} \\
17\end{array}$ & $\begin{array}{l}19{ }_{1} \\
19 ! \\
33^{\prime}{ }_{8}\end{array}$ & $\begin{array}{l}211 / 2 \\
311^{1} \\
5178\end{array}$ & 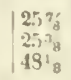 & $\begin{array}{l}194 \\
115 \\
33 .\end{array}$ & $\begin{array}{l}10^{5} \\
10^{2} \\
39\end{array}$ & $\begin{array}{l}2758 \\
2438 \\
193\end{array}$ & $\begin{array}{l}233^{3} \\
173^{3} \\
16 s^{5}\end{array}$ & $\begin{array}{l}2928 \\
214 \\
5116\end{array}$ \\
\hline $6\left\{\begin{array}{l}1 \\
2\end{array}\right.$ & $\begin{array}{l}29 \\
2.5^{1}\end{array}$ & $\begin{array}{l}263^{3} \\
27 \\
87\end{array}$ & $\begin{array}{l}351^{1} \\
3: 32^{8}\end{array}$ & $\begin{array}{l}374 \\
3+11^{4}\end{array}$ & $\begin{array}{l}152^{8} \\
157_{8}\end{array}$ & $\begin{array}{l}317 \% \\
311_{8}\end{array}$ & $\begin{array}{l}2 f_{1} y^{\prime} \\
25 y^{2}\end{array}$ & $\begin{array}{l}17{ }^{1} \\
113^{3}\end{array}$ & $\begin{array}{l}122^{4} \\
1218\end{array}$ & $\begin{array}{l}16 \% 58 \\
17 \% 8\end{array}$ & 18,2 & $\begin{array}{l}2715 \\
283^{3}\end{array}$ \\
\hline 7 & 33 & $36^{2}{ }_{8}$ & $56 i^{3}{ }^{8}$ & $50^{1} \mathrm{~g}$ & $321 ;$ & $51^{1 / 4}$ & 55 & 40 & $113_{8}$ & $5,5 \%$ & $49^{3}$ & 596 \\
\hline
\end{tabular}

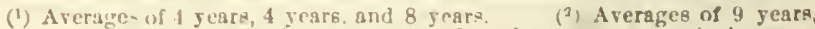
last 111 jenrs, aud fotal 17 jesrs.

(1) Averages 


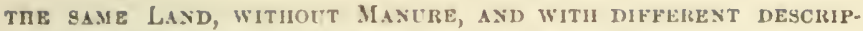
Field, Rothasisted, Englasid.

CORs PEU ACIE-bushels.

tion, or quantity, of Mauure, at the period indicated, for particulars of which ece thereto, p. 2:31.]

\section{HARYESTS.}

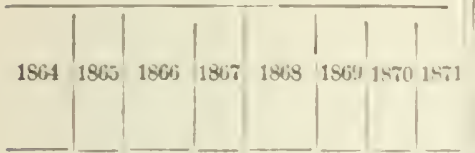

bugh. bus bu-h. bus bush. Duस bus bux

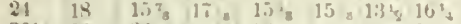

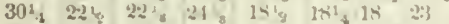

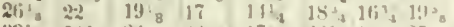

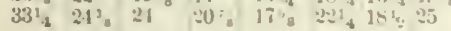

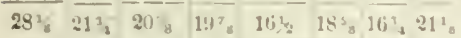

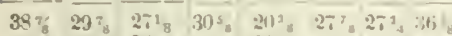

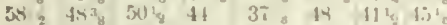

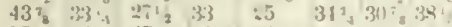

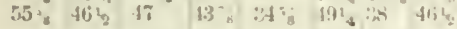

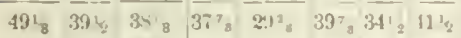

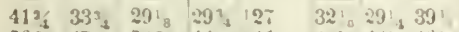

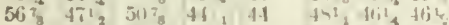

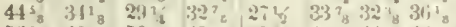

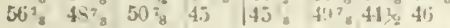

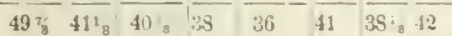

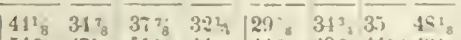

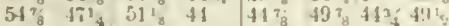

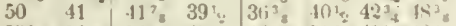

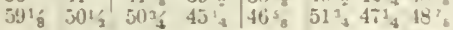

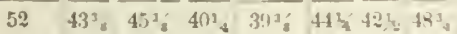

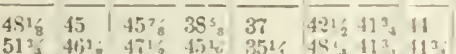

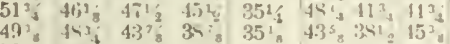

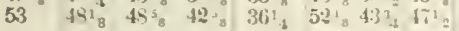

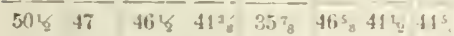

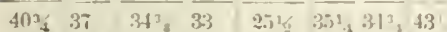

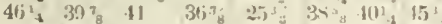

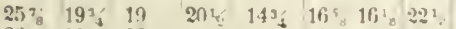

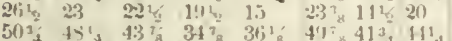

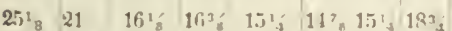

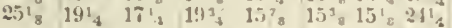

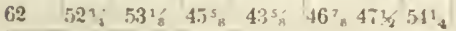

(1853- 61$)$, last 10 yearo, and total 19 yeara. of 9 years $(18-3-(1), 0$ to 10 (ors,
Average Anvual.

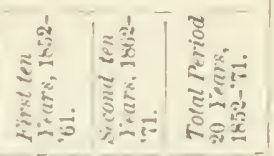

bushels. bugh. buthels. \begin{tabular}{ll|l|ll}
$2 \cdot 1$ & $1 \% 4$ & 20 & 1 & 0
\end{tabular} $27^{7}+33^{2}+25 \%$

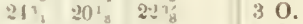
$301=24^{3}-271_{2} \quad 40$.

Means

$1 \mathrm{~A}$.

$2 \Lambda$.

$3 \mathrm{~A}$.

$4 \Delta$.

Meang

1 A A.

2 A.

3 A A.

4 A.

Means

1 A AS.

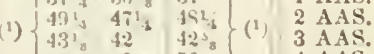

$4 \mathrm{AAS}$.

Мeans

$1 \mathrm{C}$.

$2 \mathrm{C}$.

3 C.

$4 \mathrm{C}$.

\section{Meang}

8) $137^{5}-37^{1} \quad 87^{3} / z^{2}, 1 \mathrm{~N}$.

$2 \mathrm{~N}$.

$\left(3 \quad\left(32^{5} / 215 \times 2\right)^{5}\right)\left({ }^{3}\right) \quad \mathbf{M}$.

4) $\left(21,211^{3} \quad 223_{4}\right)\left({ }^{4}\right), 50$.

$43: 410^{3} 41_{8}^{1}$

$\left.\begin{array}{l|l|l|l}25 & 127 & 22 & 1 \\ 237 & 20 & 27^{7} 8 & 2\end{array}\right\}$

$45 \quad 51 \% \quad 4 \times 1 ;$

(3) Arerages op ? Jears (1855-'61), jears. 
EXIEKIMENTA ON THE GIZUW TU OF BABLEY, YEAL AFTER YEAR, OX THB MANUKe. HoOs TABLE III.-WEIGIT PER N.B. The doubic verlical lines sbow that there was a change lo the description, Tilde 1. , and foot notes,

\begin{tabular}{|c|c|c|c|c|c|c|c|c|c|c|c|c|}
\hline \multirow{2}{*}{ ठे } & \multicolumn{11}{|c|}{ HAIVVETS. } & \multirow[b]{2}{*}{$18 \times 3$} \\
\hline & $1<52$ & $15 \mathrm{~s} 3$ & $15 i 1$ & 15 & Ixin & $1 \leq 57$ & $1 \leq 8$ & $1-50$ & 1800 & 186,1 & $15 \times 2$ & \\
\hline $\begin{array}{ll}1 & 0 \\
2 & 11 \\
3 & 0 . \\
4 & 0 .\end{array}$ & $\begin{array}{l}\lim \\
\because ! 1 \\
216 \\
\vdots 25 \\
\vdots 15\end{array}$ & $\begin{array}{l}134 \\
111 \\
311 \\
21 \\
21\end{array}$ & $\begin{array}{ll}1 & =1 \\
\vdots & 11 \\
5 & 0 \\
5 & 5 \\
51\end{array}$ & 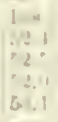 & $\begin{array}{l}11= \\
31.1 \\
115 \\
105 \\
151\end{array}$ & $\begin{array}{l}11: \\
\vdots=0 \\
\vdots \\
\vdots \geq 5 \\
5=5\end{array}$ & 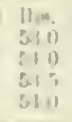 & $\begin{array}{l}1168 \\
11011 \\
5 \geq 0 \\
115 \\
51.5\end{array}$ & 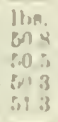 & 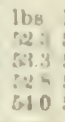 & $\begin{array}{l}168 \\
50.3 \\
52.0 \\
31.8 \\
320\end{array}$ & $\begin{array}{l}\text { Ihs } \\
\text { :3.6 } \\
\text { s. } 2 \\
\text { in. } \\
\text { H.S }\end{array}$ \\
\hline Mosuh & $: 22$ & 520 & $: 3=$ & $\because 7$ & I. 4 & 324 & $:: 11$ & $5 \times$ & 3. & $: 3.1:$ & 51.5 & 61.3 \\
\hline $\begin{array}{ll}1 & 1 . \\
2 & 1 \\
3 & 1 \\
1 & 1\end{array}$ & $\begin{array}{ll}11 & 7 \\
01 & 1 \\
31.1 & 1\end{array}$ & $\begin{array}{l}521 \\
21 \\
213 \\
21\end{array}$ & 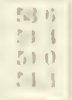 & $\begin{array}{l}31.2 \\
\because \vdots 11 \\
311\end{array}$ & $\begin{array}{ll}1+ & 5 \\
1 & 3 \\
11 & 1 \\
1 & 4\end{array}$ & $\begin{array}{ll}31 & 1 \\
\vdots 1 & 1 \\
\vdots & 1 \\
1 & 4\end{array}$ & 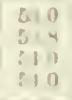 & $\begin{array}{l}4: 5 \\
30 \\
4: i \\
111\end{array}$ & $\begin{array}{lll}5 & 0 & 8 \\
3 & 1 & 11 \\
\vdots & 1 & 4 \\
31 & 1\end{array}$ & $\begin{array}{l}31 \\
31 .: \\
\vdots 1 \\
5111\end{array}$ & $\begin{array}{l}44.1 \\
: 3.5 \\
31 . ? \\
81.0\end{array}$ & 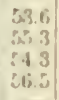 \\
\hline Mign* & $: 24$ & $1: i$ & 511 & $\$ 1$ & $B 1$ & 513 & iLt & 19.3 & $\therefore 0 \%$ & 526 & 519 & $51: 1$ \\
\hline $\begin{array}{lll}1 & 1 & 1 \\
2 & 1 & 1 \\
3 & 1 & 1 . \\
1 & 1 & 1 .\end{array}$ & $\begin{array}{l}411 \\
115 \\
i x) 6 \\
\vdots \cdots 16\end{array}$ & $\begin{array}{l}513 \\
511 \\
31 \\
: 11\end{array}$ & $\begin{array}{l}+15 \\
21 \\
231 \\
31\end{array}$ & $\begin{array}{l}31 \\
211 \\
=1 \\
1-5\end{array}$ & $\begin{array}{l}1=1 \\
1 \\
4 \\
6\end{array}$ & 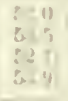 & 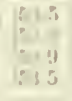 & 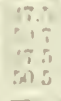 & $\begin{array}{l}501 \\
51.8 \\
501 \\
510\end{array}$ & $\begin{array}{l}51: \text { : } \\
51: 1 \\
51: 0 \\
51:\end{array}$ & $\begin{array}{l}50.0 \\
311 \\
51.5 \\
580\end{array}$ & $\begin{array}{l}53.4 \\
5.7 \\
515 \\
50.4\end{array}$ \\
\hline $\begin{array}{l}\text { Mrana } \\
1.114 \\
2.1 .14 \\
3.11= \\
4.14\end{array}$ & $: 10$ & $1+13$ & 2213 & $\operatorname{lin}$ & $11 I_{i}=$ & $: 24$ & sL, & $\begin{array}{l}\because 1 \\
--1\end{array}$ & 514 & 231 : & {$[2.5$} & 25.1 \\
\hline Meanu & & & & & & & & & & & & \\
\hline $\begin{array}{ll}1 & C \\
2 & 8 \\
3 & C \\
1 & C\end{array}$ & $\begin{array}{l}51 \% \\
51 \& \\
31.3 \\
51.1\end{array}$ & $\begin{array}{l}+13 \\
+113 \\
113 \\
511\end{array}$ & $\begin{array}{l}5: 1 \\
\vdots 3 \\
\vdots 11 \\
-4\end{array}$ & $\begin{array}{l}115 \\
101 \\
501 \\
11\end{array}$ & $\begin{array}{l}41,1 \\
1 i \text { is } \\
1+15 \\
11,3\end{array}$ & $\begin{array}{l}3: 3: 2 \\
5: 14 \\
511 \\
511\end{array}$ & $\begin{array}{l}x=5 \\
5 ! 4 \\
53.5 \\
i=1\end{array}$ & $\begin{array}{l}5.11 \\
51.5 \\
51 \text { i } \\
510\end{array}$ & $\begin{array}{l}520 \\
515 \\
51.4 \\
51.1 \\
-\end{array}$ & 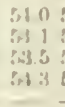 & $\begin{array}{l}515 \\
515,3 \\
63.5 \\
610 \\
-10\end{array}$ & 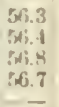 \\
\hline Mrana & $511 \mathrm{i}$ & :11:2 & $\because 4$ & $60:$ & $16 i$ & 5.34 & 5.3.2 & $51.1 \mathrm{i}$ & sili & $: 40:$ & 51.3 & 96.6 \\
\hline $1 \mathrm{Y}$. & $\{(i 1.7)\{$ & $\begin{array}{r}-13 \\
415\end{array}$ & $\begin{array}{l}: 33 \\
33.1\end{array}$ & $\begin{array}{l}\because 2.0 \\
=01\end{array}$ & $\begin{array}{l}\text { id) } 0 \\
\text { in } 1\end{array}$ & $\begin{array}{l}524 \\
5.11\end{array}$ & $\begin{array}{l}53.5 \\
510\end{array}$ & $\begin{array}{l}180 \\
145\end{array}$ & $\begin{array}{ll}511 & 11 \\
51.1\end{array}$ & 520 & $\begin{array}{l}51: 3 \\
51.3\end{array}$ & $\begin{array}{l}53.1 \\
53.9\end{array}$ \\
\hline $\begin{array}{ll} & \mathbf{M} . \\
5 & \mathbf{U} . \\
5 & \Lambda .\end{array}$ & $\mid \begin{array}{ll}51 & 01 \\
51 & 1\end{array}$ & $\begin{array}{l}118 \\
313\end{array}$ & $\begin{array}{l}1 \\
531\end{array}$ & $\begin{array}{l}526 \\
526 \\
51.7\end{array}$ & $\begin{array}{l}11 \\
17 \\
41\end{array}$ & $\begin{array}{l}256 \\
531 \\
5+5\end{array}$ & $\begin{array}{l}5.36 \\
50 \\
51.0\end{array}$ & $\begin{array}{l}1.5 \\
5111 \\
51.0\end{array}$ & $\begin{array}{ll}51 & 0 \\
31 & 0 \\
51 & 2\end{array}$ & $\begin{array}{l}5.8 \\
\operatorname{ra} 3.3 \\
53.0\end{array}$ & $\begin{array}{l}528 \\
515 \\
52.11\end{array}$ & $\begin{array}{l}5.9 \\
\text { til. } 1 \\
\text { si. } 6\end{array}$ \\
\hline ii $\left\{\begin{array}{l}1 \\
2\end{array}\right.$ & $\begin{array}{l}: 2.0 \\
: 30\end{array}$ & $\begin{array}{l}0.3 \\
: 0.11\end{array}$ & $\begin{array}{l}324 \\
53.6\end{array}$ & $\begin{array}{l}5: \div \\
5: 11\end{array}$ & $=0.1$ & $\because 33$ & $\begin{array}{l}53.1 \\
53.1\end{array}$ & $\begin{array}{l}48.5 \\
47.5\end{array}$ & $\begin{array}{l}51.3 \\
510\end{array}$ & $\begin{array}{l}520 \\
520\end{array}$ & $\begin{array}{l}51.8 \\
5 \% .0\end{array}$ & $\begin{array}{l}5.0 \\
541\end{array}$ \\
\hline 7 & $\div 3.8$ & $\therefore 16$ & :2. 9 & $: 29$ & 17.1 & $\therefore 12$ & 51.5 & 52.5 & 521 & $54 \&$ & 148 & 5,2 \\
\hline
\end{tabular}




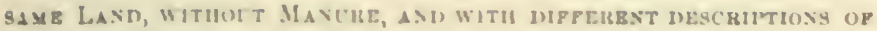

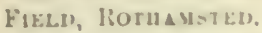

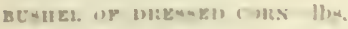

or quanuty, of Manure, at the period ladicated, for particalare of wbicb seo thereto, p. 211.]

\begin{tabular}{|c|c|c|c|c|c|c|c|c|c|c|c|}
\hline & & & & HaTVES & TS & & & AVERAC & $08 \mathrm{~A}:$ & NAUAL & \\
\hline 1501 & 13 is & ISW & $i^{15 x j i}$ & $1 \times 3$ & 1509 & $15 \div 0$ & $1 \leq 61$ & $\begin{array}{l}E= \\
= \pm 1 \\
5=2\end{array}$ & 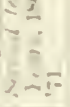 & 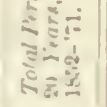 & 3 \\
\hline $\begin{array}{l}\text { Ibs. } \\
5.7 \\
51.8 \\
53.4 \\
5.3\end{array}$ & $\begin{array}{l}\text { Ihe. } \\
\text { 5il } \\
\text { i1 } \\
\text { sis } \\
\text { il } 11\end{array}$ & 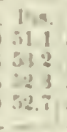 & $\begin{array}{l}13=1 \\
514 \\
313 \\
52 \\
536 \\
2\end{array}$ & $\begin{array}{r}1104 \\
11 \\
38 \\
5 i \\
23 \\
\end{array}$ & $\begin{array}{l}114 \\
\vdots 21 \\
i 11 \\
11 \\
516\end{array}$ & 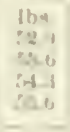 & $\begin{array}{l}\text { Ihs } \\
\because \because 0 \\
2 ; 0 \\
\therefore \quad 1 \\
=6\end{array}$ & $\begin{array}{l}1 \mathrm{bat} \\
\geq 1.1 \\
\vdots 20 \\
\vdots 11 \\
\vdots 2.3\end{array}$ & 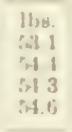 & $\begin{array}{l}168 . \\
223 \\
: 23.3 \\
: 310 \\
\text { ins.1 }\end{array}$ & $\begin{array}{ll}10 . \\
20 . \\
30 . \\
40 .\end{array}$ \\
\hline 56.7 & $\$ 11$ & 233 & 231 & $\begin{array}{l}5,1 \\
-\end{array}$ & 10 & 519 & $\Leftrightarrow ;$ & $\because \geq 0$ & 41 & $\therefore 3.0$ & Meabe \\
\hline $\begin{array}{l}5 i 1 \\
500 \\
51 \\
5 i 1\end{array}$ & $\begin{array}{l}519 \\
28 \\
31: \\
315\end{array}$ & $\begin{array}{ll}n+1 & 1 \\
51 & 1 \\
53 & 1 \\
31.7 & 1\end{array}$ & $\begin{array}{ll}31 & 3 \\
51 & 1 \\
51 & 1.3 \\
51 & 1\end{array}$ & $\begin{array}{l}21.3 \\
518 \\
115 \\
\therefore 56 \\
\end{array}$ & $\begin{array}{ll}3 & 1 \\
31 & 1 \\
11 & 11\end{array}$ & $\begin{array}{l}315 \\
3: 2 \\
31 \\
31\end{array}$ & $\begin{array}{ll}M & 6 \\
: i & 0 \\
: A i & 1 \\
x & 5\end{array}$ & $\begin{array}{l}11: 2 \\
11 \\
11 \\
1: 2\end{array}$ & $\begin{array}{l}30 \\
21 \\
11 \\
25.7\end{array}$ & 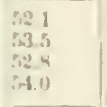 & $\begin{array}{ll}1 & A . \\
2 & A . \\
3 & A . \\
1 & A\end{array}$ \\
\hline 56.15 & 33.7 & is 0 & 52.3 & 511 & Rij 1 & in, 1 & 35,5 & 111, & 1.1: & :il. 1 & Means \\
\hline $\begin{array}{l}\text { in. } 5 \\
5 i 2 \\
51.5 \\
3 \div 6\end{array}$ & $\begin{array}{l}51.5 \\
51.3 \\
318 \\
51.1 \\
\end{array}$ & $\begin{array}{ll}5 & 1 \\
5 i & 1 \\
5 ! & 1 \\
53.1 & 1 \\
-\end{array}$ & $\begin{array}{lll}3 & 1 & 1 \\
3 & 1 & 1 \\
11 & 11 \\
3 & 8 & 6 \\
-2 & -1\end{array}$ & $\begin{array}{l}\because 3.1 \\
i 1.6 \\
i 1.1 \\
-i 1.1 \\
\end{array}$ & $\begin{array}{l}331 \\
312 \\
31 \\
31\end{array}$ & $\begin{array}{l}3+15 \\
3=3 \\
316 \\
311 \\
\end{array}$ & 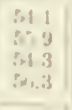 & 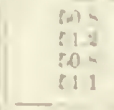 & $\begin{array}{l}13.2 \\
5: 4 \\
\text { in. } \\
? .5\end{array}$ & $\begin{array}{l}520 \\
513 \\
523 \\
331\end{array}$ & $\begin{array}{l}\text { I } A .1 . \\
3 A \AA . \\
3 A \Lambda . \\
4 A A .\end{array}$ \\
\hline 56.7 & $: 23.5$ & . 32 & 333 & 3.1 & a.j. & - & Ris 2 & 6.10 & arf.fis & 52.4 & Meang \\
\hline $\begin{array}{l}56.1 \\
5: 2 \\
5 \% .2 \\
51.0 \\
\end{array}$ & $\begin{array}{l}312 \\
5 ? 1 \\
514 \\
51.1 \\
-1\end{array}$ & $\begin{array}{l}315 \\
536 \\
52.5 \\
5.3\end{array}$ & $\begin{array}{l}33.5 \\
251 \\
230 \\
31.1\end{array}$ & $\begin{array}{l}312 \\
i 12 \\
\therefore 1.5 \\
-62 \\
\end{array}$ & 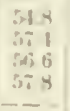 & $\begin{array}{l}2 \times 10 \\
5 i 1 \\
2 \pi 1 \\
5 i 2\end{array}$ & 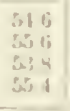 & (1) $\left\{\begin{array}{lll}? & 3 \\
? & 3 & 1 \\
3 & 1 & 1 \\
3 & 1 & 1\end{array}\right.$ & 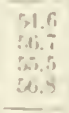 & $\left.\begin{array}{l}583 \\
599 \\
\sin .0 \\
5.2\end{array}\right\}(1)$ & $\begin{array}{l}1 \text { AAS. } \\
2 \text { AAS. } \\
3 \text { AAS. } \\
4 \text { AAS. }\end{array}$ \\
\hline $5 ; 3$ & 316 & 51,4 & $\begin{array}{l}539 \\
-\end{array}$ & $5 ; 5$ & Sili. & idj & 514 & 546 & is. 9 & 35.2 & Mend \\
\hline $\begin{array}{l}5 \% .1 \\
5 \% 0 \\
5 \% .3 \\
5 i .2 \\
\end{array}$ & $\begin{array}{l}5.34 \\
51.3 \\
i 33 \\
5.3 .7\end{array}$ & $\begin{array}{l}35.1 \\
37.8 \\
35.3 \\
5 i .1\end{array}$ & $\begin{array}{l}\text { if. } \\
\text { ixio } \\
\text { i1 } \\
51.4 \\
-1\end{array}$ & 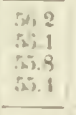 & $\begin{array}{l}m 7 \\
361 \\
31 \\
31\end{array}$ & $\begin{array}{l}35 \\
3 i 5 \\
576 \\
i n 0 \\
-\quad-\end{array}$ & $\begin{array}{l}\text { pis } 3 \\
\text { mi. } 1 \\
\text { it: } 1 \\
\text { sxi. } 1 \\
\end{array}$ & $\begin{array}{l}51 \% \\
517 \\
51.7 \\
51.4\end{array}$ & $\begin{array}{l}525.4 \\
510.11 \\
505 \\
5.5 .9\end{array}$ & $\begin{array}{l}.238 \\
23.9 \\
53.7 \\
53.6 \\
53.6\end{array}$ & $\begin{array}{l}1 \text { C. } \\
2 \text { C. } \\
3 \text { C. } \\
4 \text { C. }\end{array}$ \\
\hline $5: 1$ & $\overline{31.5}$ & $5 i 1$ & 517 & 5.9 & 5.1 & $5 \pi .7$ & $5.1 .+1$ & 51.6 & s; 9 &.$\overline{23.8}$ & Mesns \\
\hline $\begin{array}{l}140 \\
50.5\end{array}$ & $\begin{array}{l}51.1 \\
51.5\end{array}$ & $\begin{array}{l}521 \\
529\end{array}$ & $\begin{array}{l}229 \\
52.7\end{array}$ & $\begin{array}{l}324 \\
355\end{array}$ & $\begin{array}{l}51.3 \\
51.4\end{array}$ & $\begin{array}{l}\text { xi. } 6 \\
55.5\end{array}$ & $\begin{array}{l}\text { ipl.1i } \\
5.11\end{array}$ & (*) $\left\{\begin{array}{l}: 1.6 \\
151.1\end{array}\right.$ & $\begin{array}{l}53.7 \\
51.2\end{array}$ & $\left.\begin{array}{l}52.7 \\
32.7\end{array}\right\}(8)$ & $\begin{array}{l}1 \\
2 \\
2\end{array}$ \\
\hline $\begin{array}{l}5.3 \\
5 i .6 \\
5 i .5\end{array}$ & $\begin{array}{l}51.1 \\
51.5 \\
51.1\end{array}$ & $\begin{array}{l}52.9 \\
41.1 \\
31.9\end{array}$ & $\begin{array}{l}53.9 \\
510 \\
5.5 .2\end{array}$ & $\begin{array}{l}51.0 \\
5 i 4 \\
515\end{array}$ & $\begin{array}{l}=4.0 \\
5.6 \\
57.5\end{array}$ & $\begin{array}{l}5 i .3 \\
5 i .9 \\
5 i .3\end{array}$ & $\begin{array}{l}55.0 \\
55.1 \\
55.5\end{array}$ & $\begin{array}{ll}(3) & (i 1.8 \\
(4) & (.120 \\
51.9\end{array}$ & $\begin{array}{l}51.2 \\
54.4 \\
55.7\end{array}$ & $\begin{array}{l}.3 .2) \text { (9) } \\
3.1 .1 \text { (4) } \\
53.8\end{array}$ & $\begin{array}{ll} & \text { M. } \\
5 & 0 . \\
5 & \text { A. }\end{array}$ \\
\hline $\begin{array}{l}56.0 \\
50.9\end{array}$ & $\begin{array}{l}5.3 .7 \\
5.3 .9\end{array}$ & $\begin{array}{l}31.3 \\
31.3\end{array}$ & $\begin{array}{l}20 \\
i 25\end{array}$ & $\begin{array}{l}5.3 .5 \\
i 35\end{array}$ & $\begin{array}{l}5.2 .9 \\
52.9\end{array}$ & $\begin{array}{l}\text { in } \\
54.6\end{array}$ & $\begin{array}{l}5.7 .4 \\
5.3\end{array}$ & $\begin{array}{l}51.5 \\
51.6\end{array}$ & $\begin{array}{l}53.5 \\
53.6\end{array}$ & $\begin{array}{l}52.5 \\
52.6\end{array}$ & $\left.\begin{array}{l}1 \\
2\end{array}\right\} 6$ \\
\hline $52.4:$ & 51.4 & 31.9 & i4. 8 & 57.1 & $5 * i$ & 57.1 & 56.6 & 52.6 & 56.0 & 54.3 & 7 \\
\hline
\end{tabular}

(19:3-61). last 10 5eara, and trtal 13 reara.

of 9 jeara (15i3-6i). last 10 jears, and total 19 jears. 


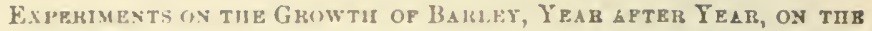
MaxtBe. HoOS

TABLE IV. -OFFAL

[N.13. The double vertical lines etow tha! there was a change in the description, Table 1 ., and foot-notes

\begin{tabular}{|c|c|c|c|c|c|c|c|c|c|c|c|c|}
\hline & & & & & HAE & ESTS & & & & & & \\
\hline 4 & $1 \times i 2$ & 15.3 & $1<5$ & 1 (2) & $18: 1 ;$ & $15: 7$ & $15: 3$ & 1450 & $1<601$ & 1861 & 18,2 & 1863 \\
\hline $\begin{array}{ll}1 . & 0 . \\
2 & 0 \\
3 & 0 \\
4 & 0\end{array}$ & 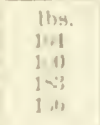 & $\begin{array}{l}11,8 . \\
2227 \\
1111 \\
1.51 \\
16.1\end{array}$ & $\begin{array}{c}110 . \\
\text { in } \\
101 \\
111 \\
1115\end{array}$ & $\begin{array}{l}\operatorname{lbm} \\
181 \\
10 \\
i f \\
91\end{array}$ & 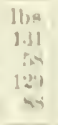 & $\begin{array}{c}31,4 . \\
10,3 \\
110, \\
1,1 \\
i, 3\end{array}$ & 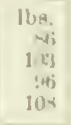 & $\begin{array}{l}1 \mathrm{~b} 4 \\
110 \\
100 \\
210 \\
1100\end{array}$ & $\begin{array}{c}169 \\
74 \\
4 \\
75 \\
7.4\end{array}$ & 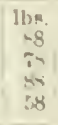 & $\begin{array}{r}118 . \\
61 \\
114 \\
7: 1 \\
117\end{array}$ & $\begin{array}{r}168 . \\
49 \\
54 \\
51 \\
57\end{array}$ \\
\hline Means & $11 \%$ & 153 & St & !Hi & I) 2 & 78 & $9 x$ & $1: 29$ & 78 & is & 9:2 & 5ii \\
\hline $\begin{array}{ll}1.1 \\
1 \\
1 & 1 \\
1 & 1\end{array}$ & 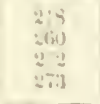 & $\begin{array}{l}243 \\
211 \\
3136 \\
\because 71\end{array}$ & $\begin{array}{l}: 119 \\
1: 0 \\
117 \\
1134\end{array}$ & $\begin{array}{l}135 \\
1=1 \\
1112\end{array}$ & $\begin{array}{l}: 111 \\
1 \geq 1 \\
151 \\
125\end{array}$ & $\begin{array}{l}113 \\
24 \\
51 \\
711\end{array}$ & $\begin{array}{l}04 \\
111 \\
118 \\
118\end{array}$ & $\begin{array}{l}1<1 \\
37.1 \\
175 \\
25.3\end{array}$ & $\begin{array}{l}1: 0 \\
15.1 \\
115 \\
150\end{array}$ & $\begin{array}{l}170 \\
1: 311 \\
109 \\
110\end{array}$ & $\begin{array}{l}219 \\
191 \\
46.1 \\
150\end{array}$ & $\begin{array}{r}11 f_{i} \\
(y ! 1 \\
108 \\
81\end{array}$ \\
\hline Mrana & $2 \div 1$ & 277 & $1: 2$ & 160 & 161 & 41 & $11 x_{j}$ & 222 & 1.13 & $1: 30$ & $1=20$ & 101 \\
\hline $\begin{array}{l}\text { 1. } 11 \\
\text { 2. } 11 . \\
\text { 3. } 11 . \\
\text { 4. } 1.1 .\end{array}$ & $\begin{array}{l}219 \\
315 \\
115 \\
216\end{array}$ & $\begin{array}{l}313 \\
271 \\
2315 \\
01\end{array}$ & $\begin{array}{l}x=6 \\
2 y \\
21 \\
2-3\end{array}$ & $\begin{array}{l}201 \\
14 i \\
21.2 \\
i .1\end{array}$ & $\begin{array}{r}310 \\
2-3 \\
\vdots 0 \\
10+5\end{array}$ & $\begin{array}{l}1: 3 i \\
1,3 \\
i=1 \\
i=1\end{array}$ & $\begin{array}{l}\text { 8iv } \\
131 \\
112 \\
113\end{array}$ & $\begin{array}{l}215 \\
3211 \\
25 \\
250\end{array}$ & $\begin{array}{l}\ln _{112} \\
112 \\
1: 21 \\
1.11\end{array}$ & $\begin{array}{l}17.3 \\
131 \\
1: 34 \\
1: 9\end{array}$ & $\begin{array}{l}9,4 i \\
121 \\
201 \\
191\end{array}$ & $\begin{array}{r}110 \\
1.11 \\
95 \\
6 \%\end{array}$ \\
\hline Mentlu & 201 & $: 73$ & 336 & $14 \pi$ & 252 & 1111 & 121 & $2 \div 1$ & 123 & 170 & 216 & 103 \\
\hline 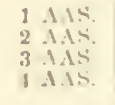 & & & & & & & & & & & & \\
\hline M) & & & & & & & & & & & & \\
\hline $\begin{array}{ll}1 & 5 \\
2 & 1 \\
3 & 1 \\
4 & 1 \\
2\end{array}$ & $\begin{array}{l}1711 \\
1+11 \\
140 \\
1.11\end{array}$ & 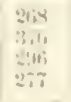 & $\begin{array}{l}17 x \\
2 x \\
28 x \\
227\end{array}$ & $\begin{array}{l}219 \\
195 \\
1-1 \\
2: 2\end{array}$ & $\begin{array}{l}171 \\
11,1 \\
10 ! 1 \\
2 \vdots 1\end{array}$ & $\begin{array}{ll}1 & 5 \\
1 & 1 \\
1-1 & 1 \\
11, i & 1\end{array}$ & $\begin{array}{l}1015 \\
115 \\
105 \\
125\end{array}$ & $\begin{array}{l}207 \\
171 \\
2: 17 \\
370\end{array}$ & $\begin{array}{l}1: 0 \\
154 j \\
11: 5 \\
1: 23\end{array}$ & $\begin{array}{l}151 \\
15,1 \\
2(+1 \\
201\end{array}$ & $\left|\begin{array}{l}1 ! r 1 \\
122 \\
1 ! n) \\
174\end{array}\right|$ & $\begin{array}{c}n j \\
i n j \\
i 1 \\
i k j\end{array}$ \\
\hline$M+a D=4$ & $31, \pi$ & 301 & $22:$ & $\because 0.5$ & $14 ?$ & $17 \pi$ & $1: 11$ & 216 & $1: 3 ;$ & 172 & $11 i 1$ & -3 \\
\hline${ }_{2} \mathrm{~N}$. & $\begin{array}{l}1 \\
i\end{array}$ & 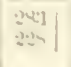 & $\begin{array}{l}1 \cdot 19 \\
246\end{array}$ & $\begin{array}{l}1: 2 \\
\because \because 11\end{array}$ & $\begin{array}{l}215 \\
113\end{array}$ & $\begin{array}{c}m t \\
1.51\end{array}$ & $\begin{array}{l}119 \\
110\end{array}$ & $\begin{array}{l}205 \\
25 i\end{array}$ & $\begin{array}{l}111 i \\
17 !\end{array}$ & $1 ! 0$ & $\begin{array}{l}245 \\
211 i\end{array}$ & $1: 0$ \\
\hline $\begin{array}{ll} & 11 . \\
5 & 11 . \\
5 & 1 .\end{array}$ & $\begin{array}{l}(1-3) \\
1 \% 3\end{array}$ & $\begin{array}{r}62 \\
210\end{array}$ & $\begin{array}{l}11: 1 \\
1 ; 11\end{array}$ & $\begin{array}{c}3 ; \\
\because 0 \\
12 i\end{array}$ & $\begin{array}{c}91 \\
\vdots \\
151 \\
1.1\end{array}$ & $\begin{array}{c}10 n \\
10 ! \\
b i n\end{array}$ & $\begin{array}{r}41 \\
71 \\
151\end{array}$ & $\begin{array}{l}5 \% \\
191 \\
165\end{array}$ & $\begin{array}{c}7 . \\
73 \\
19 ! 3\end{array}$ & $\begin{array}{r}i k \\
158 \\
158\end{array}$ & $\begin{array}{l}1518 \\
19: 3 \\
210\end{array}$ & $\begin{array}{l}46 \\
11 \\
81\end{array}$ \\
\hline $60 \begin{array}{l}1 \\
12\end{array}$ & 1:20 & $\because 00$ & $\begin{array}{l}111 \\
11: 1\end{array}$ & $\begin{array}{l}111 ; \\
7: 1\end{array}$ & $\begin{array}{l}1: 22 \\
1: 5\end{array}$ & 10 & $\begin{array}{l}4 \\
81\end{array}$ & $\begin{array}{l}121 \\
1.7\end{array}$ & $\begin{array}{l}6 Q \\
95\end{array}$ & i3 & 7.5 & 51 \\
\hline 7 & 101 & $2(3)$ & -6 & 107 & 111 & 1.31 & 121 & $36 n$ & 117 & 13 & 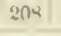 & $f, f_{i}$ \\
\hline
\end{tabular}




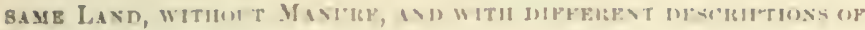
Firi.t), KutuastLo.

COHS TER ACHE- Ib?,

or yuantity, of Vauure, at the perind indicated, for particulars of whlch, aee thereto, p. 2:31.]

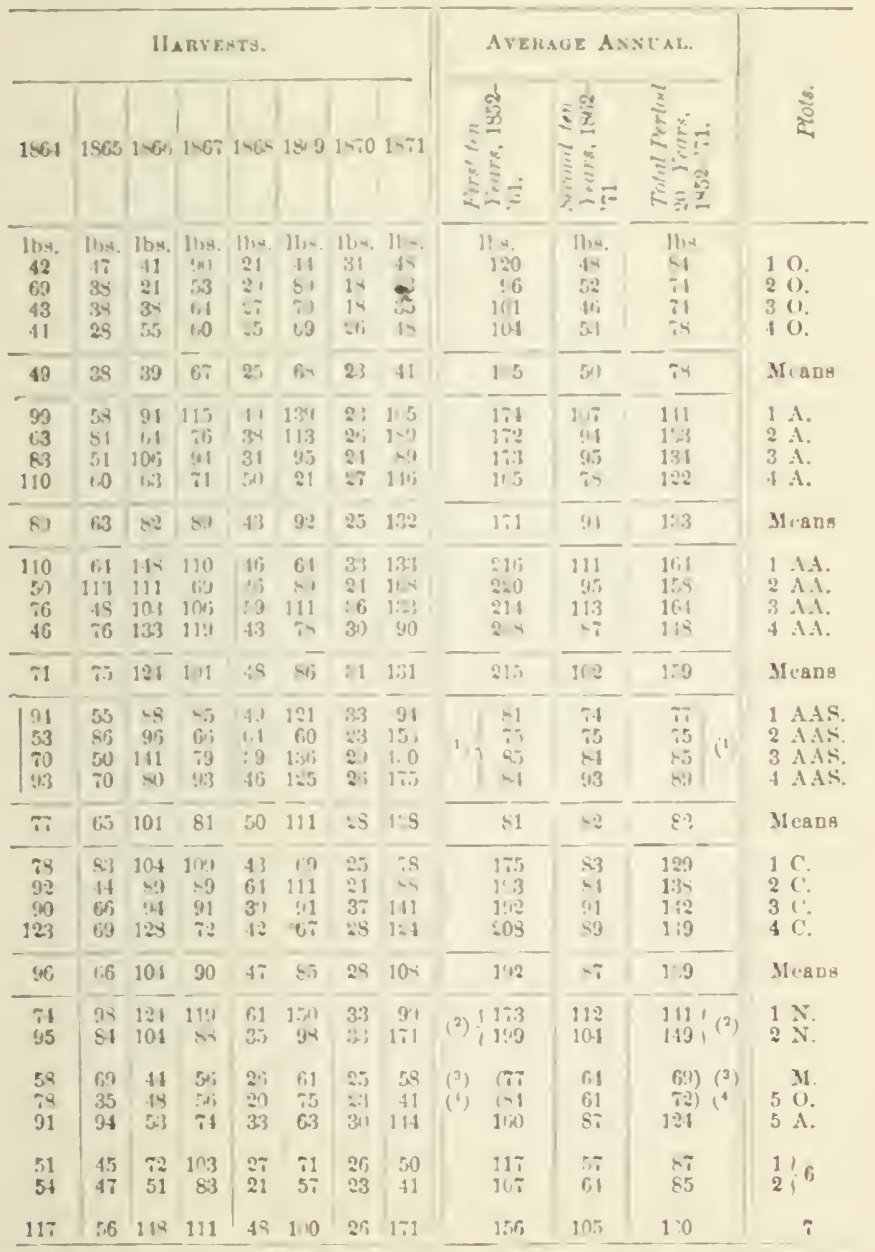

(1053-61), Iast in yrars, and tolal 19 pegra. ( $\left.{ }^{3}\right)$ Averages of 7 yearg (185i-"1,i), of y years (1+53-iil), last 10 ycars, and tutal 19 years. 
EXPEHMENTS ON TIE GROWTI OF BARLEY, YEAR AFTER YEAR, ON TIIS Maxure. Hoos

TABLE T.-BTRAW

N.B. The donble vertical lines ahow that there was a change in the descripTuble 1 , and foot notes

\begin{tabular}{|c|c|c|c|c|c|c|c|c|c|c|c|c|}
\hline & \multicolumn{12}{|c|}{ MARTESTS. } \\
\hline द & 1.952 & 155.3 & $15 ; 1$ & 165 & 1.256 & $1.5 \%$ & 1658 & $18: 9$ & $1: 60$ & 1861 & 1 18:2 & 1863 \\
\hline $\begin{array}{ll}10 \\
20 . \\
30 . \\
40 .\end{array}$ & 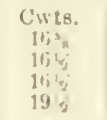 & $\begin{array}{l}\text { CWIs. } \\
14 \\
171 \\
17 \\
20 \\
20\end{array}$ & 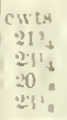 & $\begin{array}{l}\text { cwt } \\
17 \\
175 \\
17 \% \\
115\end{array}$ & $\begin{array}{c}c w t \\
6+1 \\
4 ? \\
9 \\
9\end{array}$ & 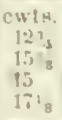 & 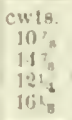 & 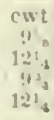 & 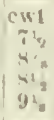 & $\begin{array}{l}\text { cwt } \\
11 \\
1: 3 y \\
114 \\
1.1 / 2\end{array}$ & $\begin{array}{l}c \times t \\
y^{2} \\
127 \\
10^{2}= \\
131:\end{array}$ & $\begin{array}{l}\text { cwt } \\
113 \\
15 \% \\
133^{3} \\
15 \%\end{array}$ \\
\hline Means & 1714 & $1+4$ & 221 & $17 \%$ & 9 & $1: 2$ & $1: 31$, & $10 \mathrm{~s}$ & Rs: & $123 / 6$ & 114 & $13^{7}$ \\
\hline $\begin{array}{ll}1 & \text { A. } \\
2 & \text { A. } \\
3 & \text { A. } \\
4 & \text { A. }\end{array}$ & $\begin{array}{l}227 \\
26 \\
233 \\
273_{3} \\
278\end{array}$ & $\begin{array}{l}213 \\
273 \\
27 \\
2+i 3\end{array}$ & 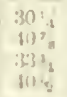 & $\begin{array}{l}31 \\
39 \\
21 \\
31\end{array}$ & $\begin{array}{l}17 \\
21 \\
17 \\
21\end{array}$ & $\begin{array}{l}173 \\
21 \% \\
21 \% \\
27\end{array}$ & $\begin{array}{l}1512 \\
253 \\
17 \\
219\end{array}$ & $\begin{array}{l}114 \\
217 \\
1: 34 \\
27 \\
27\end{array}$ & $\begin{array}{l}117 \\
274 \\
164 \\
363\end{array}$ & $\begin{array}{l}19{ }^{3} \\
243^{3} \\
213^{4} \\
301\end{array}$ & $\begin{array}{l}213^{3} \\
322^{2} \\
23 \\
231^{3} \\
31^{3}\end{array}$ & $\begin{array}{l}21 \% \\
31 \\
264 \\
32\end{array}$ \\
\hline Means & $25 \%$ & $25 ! 4$ & $2 i i^{3}$ & $2 \gamma$ & 19 's & 216 & $221=$ & $19 !_{4}$ & 203 & 25 & $26^{3}$ & $2 x^{\prime \prime}$ \\
\hline $\begin{array}{l}1 \mathrm{AA} . \\
2 \mathrm{AA} \\
3 \mathrm{AA} . \\
4 \mathrm{AA}\end{array}$ & $\begin{array}{l}27_{7} \\
24 \\
26: \\
24:\end{array}$ & $\begin{array}{l}21 i^{1} \\
24 \\
2 i 1 \\
31 \%\end{array}$ & $\begin{array}{l}37^{\circ} \\
11 \% \\
37^{\circ} \\
11\end{array}$ & $\begin{array}{l}32 \% \\
32+1 \\
31 \\
319\end{array}$ & $\begin{array}{l}21 \mathrm{y} \\
31 \mathrm{~s} \\
21 ; 1 \\
311\end{array}$ & 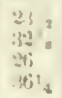 & $\begin{array}{l}\because 4 \\
\because 25 \\
\because 2 \\
33^{3}\end{array}$ & $\begin{array}{l}114 \mathrm{~L} \\
: 45: \\
11 ; 1: \\
30\end{array}$ & $\begin{array}{l}131 \% \\
2114 \\
14 \\
29\end{array}$ & $\begin{array}{l}22 \\
315 \\
211 \\
3: 35\end{array}$ & $\begin{array}{l}211 \\
311 \\
211^{2} \\
3211\end{array}$ & $\begin{array}{l}25^{1} 6 \\
3219 \\
27^{7} \\
319\end{array}$ \\
\hline Means & 275 & 24 & 121 & $36 \mathrm{~V}$ & $2+3$ & 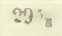 & 274 & $21 \%$ & 212 & $27^{7}$ & $27 \%$ & 30 \\
\hline $\begin{array}{l}1 \text { A AS. } \\
2 \text { AAS. } \\
3 \text { AAS. } \\
4 \text { A AS. }\end{array}$ & & & & & & & & & & & & \\
\hline Means & & & & & & & & & & & & \\
\hline $\begin{array}{ll}1 & C \\
2 & C \\
3 & C \\
4 & C .\end{array}$ & $\begin{array}{l}21 \% \\
235 \\
21 \% \\
215\end{array}$ & $\begin{array}{l}26^{2} \\
25= \\
\vdots 71 \\
27 \div\end{array}$ & $\begin{array}{l}1: 314 \\
1118 \\
111^{4} \\
1: 28\end{array}$ & $\begin{array}{l}3 i^{1} \\
3 i \\
3 \\
3 i\end{array}$ & $\begin{array}{l}36 \\
314 \\
36 \\
30\end{array}$ & $\begin{array}{l}30118 \\
3: 3 \\
: 00 \\
3 \div ; 3\end{array}$ & 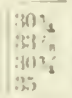 & 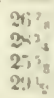 & 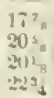 & $\begin{array}{l}27^{7} \\
03 \\
303 \\
31\end{array}$ & $\begin{array}{l}36 \\
2 \pi+1 \\
2 ; ?= \\
2 x ?\end{array}$ & $\begin{array}{l}285 \\
301 \\
2,17 \\
30 \%\end{array}$ \\
\hline Means & $231 ;$ & $2 i i_{4}$ & $1 \geq 3$ & $3 \%:$ & $24 \div 8$ & $325 \mathrm{~s}$ & 3325 & $27_{4}^{3}$ & 203 & 30 & $2 f ; y$ & $2 ! 1 \%$ \\
\hline $\begin{array}{l}1 \\
2\end{array}$ & $i\left(155_{4}\right) i$ & $\begin{array}{l}23 \cdot n \\
233^{3}\end{array}$ & 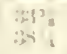 & $\begin{array}{l}27 \\
32314\end{array}$ & 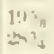 & $\begin{array}{l}23 \% 8 \\
328\end{array}$ & 201 " & $\begin{array}{l}183 \\
211_{4}\end{array}$ & $\begin{array}{l}1 \mathrm{fis}_{\mathrm{s}} \\
1 \mathrm{~s} \mathrm{~s}_{\mathrm{a}}\end{array}$ & 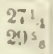 & $\begin{array}{l}213 \\
213\end{array}$ & $\begin{array}{l}30 \mathrm{~h} \\
29 \%\end{array}$ \\
\hline $\begin{array}{ll} & \text { II. } \\
5 & 0 . \\
5 & \text { A. }\end{array}$ & $\begin{array}{l}(25 t, 8) 1 \\
25: 8\end{array}$ & $\begin{array}{l}17^{3} \\
21^{4}\end{array}$ & 271 & $\begin{array}{l}1514 \\
11 \\
31\end{array}$ & $\begin{array}{l}10^{3}=8 \\
10^{2} \\
9: 23^{2}\end{array}$ & 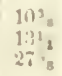 & $\mid \begin{array}{l}123{ }^{3} \\
12 y^{2} \\
2 \times 3\end{array}$ & 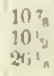 & $\begin{array}{r}71 \\
67 \\
25\end{array}$ & $\begin{array}{l}1516 \\
171 / 2 \\
317\end{array}$ & $\begin{array}{l}141 \% \\
10 \% \\
31=8\end{array}$ & $\begin{array}{l}19 \% \\
154 \\
81\end{array}$ \\
\hline $6 ! \begin{array}{l}1 \\
3\end{array}$ & $\begin{array}{l}17^{1} \\
14^{1}\end{array}$ & $\begin{array}{l}16 \% \\
15 \%\end{array}$ & $\begin{array}{l}224 \\
\because 02\end{array}$ & $\begin{array}{l}121, \\
163 "\end{array}$ & $\begin{array}{l}914 \\
9 \\
4\end{array}$ & $\begin{array}{l}1618 \\
113_{8}\end{array}$ & 12 & $10^{11}$ & $\begin{array}{c}i \frac{1}{2} \\
7 y\end{array}$ & ${ }_{10}^{97}$ & $\begin{array}{l}10^{3}= \\
11 s^{3}\end{array}$ & $\begin{array}{l}131 / 2 \\
141 \%\end{array}$ \\
\hline 7 & $18 \mathrm{~K}_{\mathrm{j}}$ & 223 & ${ }^{3} \pi_{4}$ & $2 \pi 4$ & $19 ?_{4}$ & 235 & 31 ' & $2 x y$ & $253^{3}$ & 31 s, & 314 & 3346 \\
\hline
\end{tabular}

(') Arerages of 4 years, 4 years. and 8 years. (2) Averages of 9 sears last 10 yeare, and total 16 years. (") Averages 


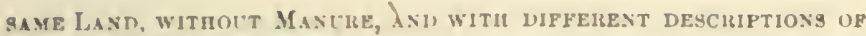
Fiel, 1 , Rutuaystel.

(AND CHAFT) PER ACRE CWT.

tion, or quantity, of Manurc, at the period indicated, for particulara of which aco thereto, p. 2:31.]

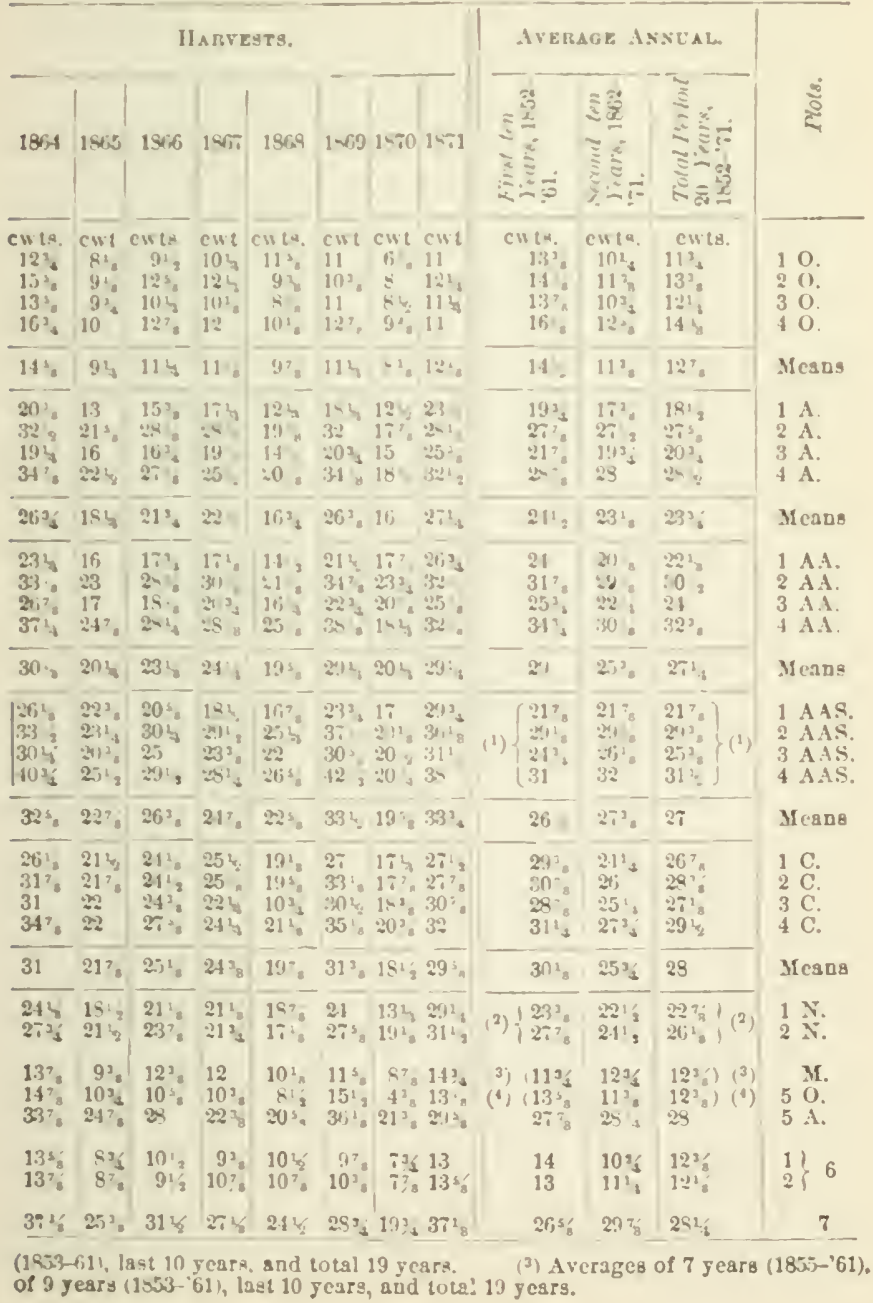


The produce of barley the first season (1852), was, per acre:

On the unmanured plot .................... $2 \tau_{t}$ bushels

With superphosphate of lime. . . . . . . . . . . . . . .

" potush, soda, and mmenesia................. "6? "

" ". " " and superphosphate...... "3\% "

" 14 tons barn-yard mamure ......................33 "

“200 lbs. ammonia-salts alone................. "

" " " $"$ and superplosphate.......... "3s

" " " and potash, suda, and magnesia 36 "

" " " und superphosphate, potash, soila, and magnesia......... 40 "

" 400 lbs, ammonia-salts alone.................. 4 . "

The 200 lbs. of ammonia-salts contain 50 lus. of ammonia $=41$ lbs. nitrogen.

It will be seen that this 50 lbs. of ammonia alone, on plot $1 a$, gires an increase of dearly 10 bushels per acre, or to be more accurite, it gives an increaso orer the unmanured plot of $503 \mathrm{lhs}$, of grain, and 32:) llis. of straw, while donble the quantity of ammonis

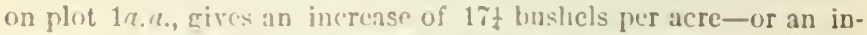
crease of $901 \mathrm{lbs}$. of grain, and 1,14t llis. of straw.

"Put that fact in separate liues, side ly side," said the Deacon, "so that we can see 1t."

Total

Grain Straw Broduce.

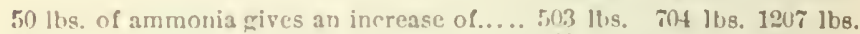

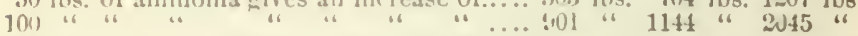

The first $50 \mathrm{lbs}$. of ammonia gives an in-

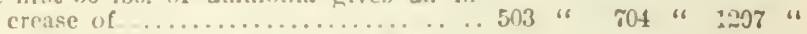

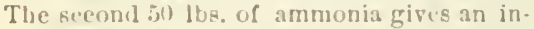

crease of...................... " 5930 " 738 "

"That slows," saicl the Deacon, "t'lat a dressing of 50 lbs. per nere pays better than a dressing of 100 lus. per acre. I wish Mr. Lawes had sown fij llos. on one plot."

I wish so, ton, but it is quite probille that in our climate. 50 lbs. of available ammonia per acre is all that it will usnally be profitable to aplly per acre to the barley crop). It is equal to a lressing of 500 lbs. guaranteed Perurian guano, or 275 lbs, nitrate of soda.- "Or to how much manure ?" asked the Deacon.

To about i tons of average stah]e-mauture, or say three tons of good, well-rofted manure from crain-fed animals.

"And yet," said the Deacon, "Mr. Lawes put on 14 tons of yard manure per acre, and the yiell of harley was unt as much as from the 50 llis. of anmonia alone. IIow do you account for that?"

Simply hecause the ammonia in the manure is not ammonia. It is what the chemists used to call "potential ammonia." $\mathbf{A}$ good deal of it is in the form of undigested straw and hay. The nitrogenous matter of the food which has been digested by the animal 
and thrown off in the liquid exerements, is in such a form that it will readily ferment and produce anmonit, while the nitrogenous matter in the undigested food and in the stritw used for hedling, deconuposes slowly cven muder the most farorable eonditions; and if buried while fresh in a clity soil, it probably would not all lecompose in many years. But we will not discuss this at present.

"The superpliosphate does not seem to have done much good," said the l)eacon; "3t cwt. per acre erves an increase of less than two bushels per acre. And 1 suppuse it was good superphosphate."

There need he no doubt on that point. Better superphosphate of lime cammot be made. But you must recullect that this is puro superphosphate male from hurnt lowes. It eontains no ammonia or organic matter. Commercial superphospluat 's contain more or less ammonia, and had they heen used in these experiments, they would have slown a better result than the pure article. They would have done gool in propurtion to the available nitroten they contained. If these experiments prove anything, they clearly indicate that superphosphate alone is a very poor manure for cither wheat or hatley.

The second year, the unmanured plot gave 2.5 fuslsels per acre. Potash, sola, and maguesil, (or what the Deacon calls "ashes,") 27 soushels; superphosphate $3 \ddot{8} 4$, and "ashes" and superphosphate, nearly 36 bushels p'r acre.

$50 \mathrm{lbs}$ of ammonia, alone, qives nealy 39 buslicls, and ammonia and superphospluate together, 40 bushels.

The superphospluate and "aslues" give a better acrount of themselres this year; but it is remarkable that tbe ammonia alone, grives almost as good a crop as the ammonia and supurphosphate, and a better crop than the ammonia and "ashes," or the ammonia, superphosphate, and asbes, torether.

The 14 tons farm-yard inanure gives over 36 bushels per acre. This plot las now hat 28 tons of manure per acre, yet the 50 lbs. of ammonia alone, still gives a better yield than this heary dress. ing of manure.

The third season (1951), was quite farorable for the ripening of wheat and barley. The seed on the experimental barley-field, was sown Feb. 24, and the harrest was late; so that the crop had an unusually lone seasm for growth. It was one of the years when even poor lanu, if clean, gives a good crop. The unmanured plot, it will be seen, yielded over 3.5 bushels per acre of dressed grain, weighing over $53 \frac{1}{2} \mathrm{lbs}$. per bushel. The total weight of grain, was 1,963 lbs. This is over 40 bushels per acre, of 48 lbs. per bushel, which is the standard with us. 
The 14 tons of farm-yard manure producc nearly $56 \frac{1}{2}$ bushels per acre.

50) lbs. of ammonia, on plot $1 a \ldots \ldots \ldots \ldots$. $i$ bushels per acre.

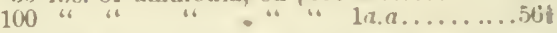

You will see, that though the plot which has received 42 tons of manure per acre, produceil a splendid crop; the plot having nothing execpt $100 \mathrm{lbs}$ of ammonia per acre, proluced a crop equally good. "Ilow much incruase do you get from 50 lbs. of ammonia," asked the Deacon, "aud how much from 100 lbs.?"

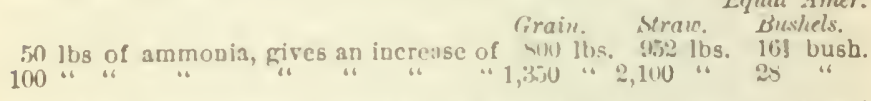

If you buy nitrate of soda at 3 gु ecnts a lh., the ammonia will cost 20 cents a lb. In the above experiment, 50 lbs. of ammonia, costing $\$ 10$, gives an increase of $16 \%$ bushcls of barley, and nearly lialf a ton of straw. If the straw is worth \$ $\$ .00$ per ton, the barley will cost 45 cuts a bushel.

Double the quantity of manure, costing $\$ 20$, gires an increase of 28 busluels of barley, and orer one ton of straw. In this case the extra barley costs ifi cents a busbel.

On plot $2 \imath$, 50 lbs. of ammouia and $32 \mathrm{cwt}$. of superphosplate, give 3,437 lbs. of erain, e(pual ti ilt of our bushels per aere.

On plot 2i.4. 100 lhe of ammonia and $34 \mathrm{cw}$. of superphos hate, gire $3,613 \mathrm{lbs}$ of errain, which laks only 5 lbs. of 76 bushels per acre, and nearly $2+$ tons of straw.

"That will ifo," sild the Dea nn, "but I see that in 185i, this same plot, with the same nuanure, proulueed 66! bushels of dressed grain per arere, weirhing $5: 3 \$$ lbs. In the bul-hel, or a total weight of 3,696 llos, equal to just of of our bushels per acre."

"Anel ret," saicl the Doctor, "this same year, the plot which had 84 tons of farm-yard manure per acre, produced only 2,915 lbs. of grain ur lesg than 61 of our bushels of barley per acre."

The Squire happened in at this time, and heard the last remark. "What are you silying," he remarkel, "about only 61 bushels of barley per acre. I should like to see such a crop. I ast year, in this neirhlorhond, there were hunireds of acres of barley that did not yield 20 bushels per acre, and rery little of it would weigh 44 lbs. to the bushel."

This is true. And the maltsters find it almost impossible to get six-rowed barley weighing 48 liss. per bushel. They told me, that they wouli pay \$1.10 per bushel for good bright barley weighing 48 ibs. per bushel, and for eareh pound it weighed less than this, they delueted 10 cents a bushel from the price. In other words, 
they would pay $\$ 1.00$ a lushel for barley weinhing 47 llos. to the bushel; 90 cents for barley weighingr $4191 \mathrm{bs}$; su cents for barley weighing 4 . 1 hs., and 70 conts for harley weighing $\$ 1$ lbs. -and at these figures they much preferrel the bu aviest barly.

It is certainly well worth our whiln, if we ruise barley at all, to eee if we cannot manage nut only to raise lareere crope per acere, but to produce barley of better quality. And these wonderful experiments of Mr. Lawes are well worth cireful examination and study.

The Squire put on his spectackes and lnoked at the tables of figures.

"Like ereryboly else," stid he, "you pick out the big figures, and to hear you talk, wne would think you scientific anentlemen never hate any puor crops, and yet I ste that in 1 s6o, there are three different crups of only $12 ! .12 f$, and $1: 3 t$ bushels per ucre."

"Those," suitl I, "are the threc glots which have grown barley every year without any munure, and you have silected the worst year of the whole twenty."

"Perlaps so," sald the Squire, "but we latre got to take the bal with the cond, and I have often hearl you say that a good farmer who has his land rich and clian makes more money in an unfaroralile than in a faroralile season. Now, this rear 1860 , seens th have ben an unfavorable one, and ret your pet manure, superphosplate, only gives an increase of $148 \mathrm{lbs}$ of barley-nr lliree lushels and 4 lus. Jet this plot has had a tremendous dressing of $3 \frac{1}{2}$ cwt of s'iperphosphate yearly since 1852 . I always told fou you lost money in huying superphosphate."

"That depends on what you do with it. I use it for turnips, and tomatoes, cahbages, lettuce, melons, cucumbers, etc., and would not like to be withunt it; but I have never recommeniled any one to use it on wheat, harles, oats, Indian corn, or potatoes, execpt as an experiment. What I have recommended you to get for barley is, nitrate of soula, and superphosphato, or I'eruvian guano. And you will see that even in this lecidedly unfarorable seasun, the plot 2a.n.. elres.el with superphosphate and 275 lbs. Of nitrate of sola, produced 2,338 lbs. of barler, or 489 bushels per acre. This is an increase over the unmanured plots of 331 busluels per acre, and $\mathrm{an}$ increase of $1,8,2 \mathrm{lbs}$. of straw. And the plot dressed with superphosphate and 200 lbs. of salts of ammonia, gare equally as good results."

And this, mark you, is the year which the Squire selected as the one most likely to show that artificial manures did not pay.

"I neverknew a man except you," said the Squire," who wanted unfavorable scasons." 
I have never said I wanted unfavorable seasons. I should not dare to say so, or even to eluerish the wish for one moment. But I do say, that when we have a season so firvorible that even pourly worked land will produce a fair crop, we are almost certain to have prices below the average cust of production. But when we have an unfavorable season, such crops as barley, potatoes, and beaus, of ten advance to extravag.ntly high prices, and the farmer who has gnod crops in such a s'asun, gets somcthing like adequate pay for his patient wailing, and for his efforts to improve his land.

"That soun ds all very well," said the Squire," but will it pay to use these artificial manures?"

I do not wish to wander ton much from the print, but would like to remark hefore I answer that question, that I an not a special advocate of artificial manures. I think we can often make manures on our farms far ch aper than we can buy them. But as the Sqquire has askell the question, an 1 as he has selected from Mr. Lawes' resulti, the year $181 ; 0$, I will meet him on his own ground. He has selected a season specially unfarorable for the growth of barley. Now, in such an unfavorable year in this country, barley would be likely to hring, at least, s1.25 per hushel, and in a favorulule scason not over 75 c'ents a bushcl.

Mr. Lawes keeps his land clean, which is more than can be said of mun barley-erowers. Aul in this unfarorable season of 1860 , he getson his three unmanureu plots an average of 730 lhs. of barey, cqual to lis bustels per acre, and not quite 800 lhs. of straw.

Many of our farmers frequently do no better than this. And you must recollect that in such careful experiments as those of Mr. Lawes anl 1)r. (iilhert, great pains wouhl he taken to get all the barley that grew on the lanl. With us, barley is eut with a reaper, am] almirable as our machincs are, it is not an easy matter to elu a light, spindling cropy of barley perfectly clean. Then, in pithing the er p aml drawing it in, more or less barley is senttered, and even afur we have bern orer the fir li] two or three times with a steceltoot rake, there is still ronsiderable barley left on the ground. I think we may safoly ascume thut at lenst as much barley is loft on the ground as we usually sow-say two bushels per acre. Anil so, insteal of having $15, \frac{1}{3}$ mishels per acre, as Mr. Lawes bad, we should only harrest 13 ! bushels.

Of all our orlinary farm crops, harley is attended with the least lahor and expense. We usually sow it aftercorn or potatnes. On s.rh stroner land as that of Mr. Lawe's, we ought to plow the land 
in the autumn and again in the spring, wr at least stir up the land thoroughly with a two or turece-horse cultisator or gange-plow.

Let us say that the cost of flowing, harrowing, drilling, and rolling, is \$ij.00 jer uere. Seed, \$2.00. Harvesting, \$2.00. Threshing, 6 cents a bustrel.

Receipts :

13! busleels barley (t $1.25 \ldots \ldots \ldots \ldots \ldots+16.57$

sou lus. uf straw (1) \&4. per tou........ 1.60

Putting in and harvesting the erop ș!.10

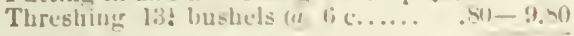

lient and protit fint acre.......... s.:if

"That is a hetter showing than I expected," said the Sruire, "and as barles oceupie's the land only a few months, and as we sow wheat after it, we cannot expect larepe profits."

"Very well," said I, "Now let us take the crop, this same unfavorable year, on plot 2a.r., dressed with superphosphate and nitrate of solla.

The expense of plowing, harrowing, drilling, rolling, seed, and harresting, would be about the same, or we will say \$2.00 an acre more for extra labor in larvesting. And we will allow two bushels per acre for scitterings-though there is nothing like as much barles left on the ground when we lave a good crop, as when we have a poor erop. But I want to be liberal.

The yield on plot $2 a . a$., was $19 \frac{\pi}{6}$ bushels per acre, and $2,715 \mathrm{lbs}$. of straw.

Receipts :

4 tot bushels $(a+1.25 \ldots \ldots \ldots \ldots \ldots \ldots \ldots \ldots .5 .43$

2,715 lbs. straw (it s4. per ton........... 5.43

Putting in the erop and harvesting... $\$ 11.00$

513.06

Threshiner 4 it busliels $(i t$ ti c........ 2. 40

$2 \%$ lbs. nitrate of soda $(u+c \ldots \ldots \ldots .11 .00$

392 lbs. superphosphate $(a 2 \mathrm{c} \ldots \ldots \ldots$. 7.4

Rent and profit . . . . . .

In ordinary farm practice, I feel sure we can do better than this. Growing barles rear after year on the same land, is not the most economical way of getting the full value of the manure. There is mueh nitroen and phosphorie acjel left in the land, which barley or even wheat does not seem capahle of taking up, but which would probably be of great benefit to the elover. 


\section{MANURE AND ROTATION OF CROPS.}

The old notion that there is any real chemieal necessity for a rotation of erops is unfounded. Wheat can be grown after wheat, and barley after barley, and corm after eorn, provided we use the necessary manures and get the soil clean and in the right mechanical condition.

"What, then, do we gritin by a rotation?" asked the Deaeon.

Mucls every wity. I good rotation cnables us to clean the land. Wie can put in different (rojes at diflierent seasons.

"So we could," broke in the Ilacon, "if we sowed wheat after wheat, barley after barlıy, anu corn after corn."

True, but if we sowed winter-wheat after winter-wheat, there would unt be time conougle to clean the land.

"Just as much as when we sow wheat after oats, or peas, or barley."

"True again, Dearon," I replicd, "but we are supposed to have cleaned the lan ? while it was in corn the previous year. I say supfosed, because in point of fact, many of our farmers do not half clean their land while it is in corn. It is the weak spot in our agriculture. If our land was as clean as it slonld be to start with, there is no rotition so convenient in th:is section, as corn the first year, barley, peas, or oats the second year, followed by winterwheat secicil down. But to carry out this rotation to the best advantage we need artificial manures."

"But will they pay?" ask the Deacon.

"They will pay' well, provided we can get them at a fair price and get fair prices for our produce. If we could get a good superphosplate made from Charleston phosphates for $1 \frac{1}{2}$ eent per lb., and nitrate of soda for at or 4 ecnts per lb., and the German potash-salts for a cent per lh., and conld get on the arerage $\$ 1.25$ per bushel for barler, and $\$ 1.75$ for good white wheat, we could nse these manures to great advantage."

"Nolhing like harn-yard manure," sayss the Deacon.

No doulit on that point, provilled it is good manure. Barn-yard manure, whether ricls or poor, contains all the elements of plantfood, but there is a great difference between rich and foor manure. The rich manure contains twice or three times as much nitrogen and phospluoric acil as ordinary or poor manure. And this is the reason why artificial manures are valualile in proportion to the nitrogen and phosphoric acid that thes contain in an arailable condition. When we use two or three humeled pounds per acre of a good artificial manure we in effect, directly or indirectly, convert 
poor manure into rich maunre. There is manure in our soil, but it is poor. 'lleere is manure in our barn-yartl, but it is poor also. Nitrogen and phosphoric acid will make these manures rich. This is the reason why a few pounds of a good artificial manure will produce as great an effect as tons of common manure. Depend upon it, the coming farmer will arail himself of the discoreries of science, and will use more artificial fertilizers.

But whether we use artiticial fertilizers or farm-yard manure, we shall not get the full effect of the wanures ualess we alopt a judicious rotation of crops.

When we sow wheat after wheat, or barley after barley, or nats after oats, we certainly do $n$ nt at the full effect of the manures used. Mr. Lawes' expriments afford conclusive evidenee un this point. You will recollect tint in 1816 , one of the plots of wlieat $(10 b)$, which had received a liberal dressing of salts of ammonia the year previous, was left without manure, and the vielel of wheat on this plot was no greater than on the plot which was continuously unmanured. In other worts, the ammonit which aras left in the soil from the prexinus year, lual no effect on the whent.

The following table shows the amount of ni:rogen furnished by the manure, and the amount recovered in the crop, when wheat is grown after wheat for a series of years, and also when barley is grown after barley, and oats after oats. 


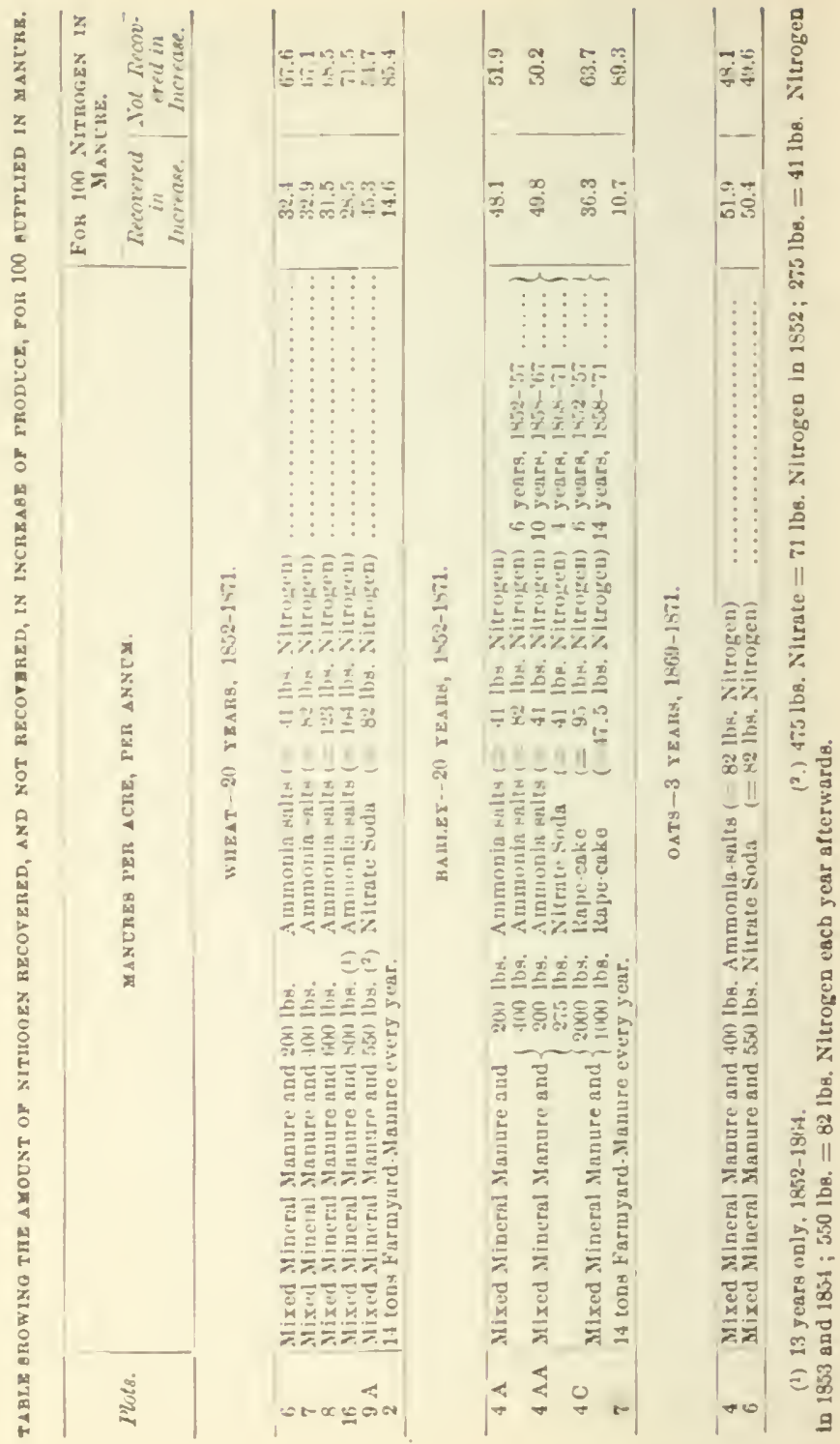


It is not necessary to make any comments on this tahle. It speaks for itself; but it does not tell half the stury. Fur instance, un the cite of wheat and harley, it gives the arerage result for 20 years. It shows that when 100 lhis, of nitrugen in al suluple and arialable form, are applied to wheat, about $6 \times 1$ s. are left in the art. But you must recollect that 100 lts. was applied again the next year, and no aceount is taken of the $6 \mathrm{~s}$ ltss. left in the soilnnd so on for 20 years. In other worils, on plot 8 , for instance, 2,460 lbs. of nitrogen have heen applied, and only ion lbs. have been recovered in ihe cutin produce of grain, straw, and clatf, and 1,685 lis. Jave been left in the suil.

Mr. Lawes estimates, from streral analyses, that lis farm-yard manure contains $0.63 i$ per ent of nitrogen, 2.76 pereent of mineral matter, and 2i.24 per cent of organic matter, and 70 percent of water.

Accorling to this, the plot dresecel with 14 tons of manure erery

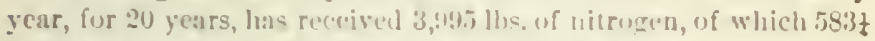
It)s. were tecurered in the prodice, and 3,411 lbs. wore left in the soil.

In the case of hitrles, $3,99.5$ llos, of nitrogen was applied during the 20 years to the plot dressinl with farm-yarl manure, of which $42 \mathrm{it}$ Jbs. were recorcred in the crop, and $3,56 \mathrm{tg}$ los. left in the suil.

"I see," sail the Deacon, "that barley gets less of the goodness out of farm-yard manure than wheat, but that it gets more out of the salts of anmonia and nitrate of soda. How do you account for that?"

"I su' pose, because the manure for wheat was applicd in the autumn, and the rains of winter ard spring dissolvel more of the plant-food than would be the case if the manure was appliced in the spring. If the maure lad heen applied on the surface, insteal of plowing it under, I liclicve the effect would have been still more in faror of the autumn-manuring."

When the nitrogen is in an arailable condition, spring barley can take up and utilize a larger proportion of the nitrogen than winter wheat. Neither the wheat nor the barley can get at and take up half what is applied, a ul this, notwithstanding the fuct that a beary dew or a slight rain furuishes water enough on an acre to dissolve a liberal elressing of nitrate of soda or sulphate and muriate of ammonia. The truth is, the soil is very conscrvative. It does not, fortunatcly for us, yield up all its plant-food in \& year

We have seen that when wheat or barley is dressed with sol- 
uble ammonil-salss or nitrate of solit, a consiclerable amount of the nitrugen is left in the seril-an l yet this nitrogen is of comparatively litale b-urtit to the suceeding crops of whe.t or horley, while a fresh dressing of ammonial-salts or nitrate of soda is of great benefit to the crop.

In other words, when whe:It is sown after wheat, or barley after harley, we do not get half the beuetit from the manure which it is theoretically cilpable of producing.

Now, the question is, whether ly a judicious rotation of crops, we ean aroi this areat low of manure?

Thre was a time when it was thonght that the growth of tur-

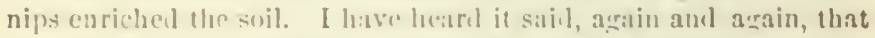

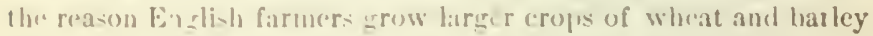

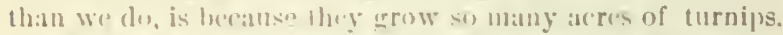

"Su I lise often lucaril," satil the De"acun, "and I supposed the broal 1 eurnip) leares alsourbed nitrogen from lhe atumusphere."

Thre is no evilence that lonese have any such power; while there are many facts which puint in an oplusite direction. The following experimente of Latwes and filthert secm to show that the mere growth of turnips dews nut andich lind for grain erops.

Turnipi were erown on the same liml, year after year, for ten years. The lut l was then plowed and sown to barley for three years. The following tahlo grives the results:

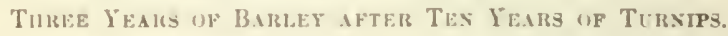

\begin{tabular}{|c|c|c|c|c|}
\hline \multirow[b]{2}{*}{ PAITICILARS OT MANIIEE, RTC. } & \multicolumn{4}{|c|}{ Prombice of Barley jor Acre. } \\
\hline & 落 & 胥 & 3 & 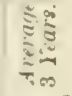 \\
\hline 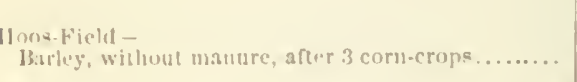 & $\begin{array}{l}\text { ใน:11. } \\
26 ;\end{array}$ & $\begin{array}{l}\text { lush. } \\
3 \% 18\end{array}$ & 3118 & $\begin{array}{l}\text { bush } \\
31 \text { s. }\end{array}$ \\
\hline 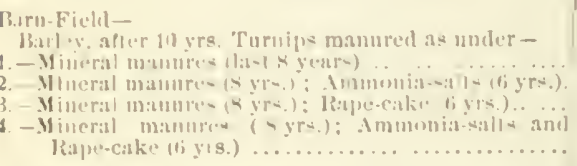 & $\begin{array}{l}201 ; \\
2318 \\
2278 \\
2918\end{array}$ & $\begin{array}{l}191 / 2 \\
2114 \\
215_{3}^{3} \\
233.4\end{array}$ & $\begin{array}{l}20 \\
213 \\
2313 \\
2318\end{array}$ & 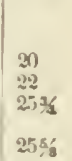 \\
\hline 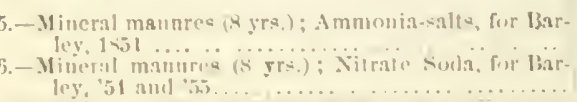 & 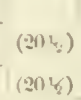 & $\begin{array}{l}523 \dot{8} \\
5177_{\mathrm{B}}\end{array}$ & $2 i j 5$ & $39 y_{3}$ \\
\hline
\end{tabular}

The yichl of barley after turnips is less than it is after grain crops, and it is crident that this is due to a lack of availatile nitro- 
gen in the suil In other worts, the enrujpe leave lesx avabible nitrogen in the soil thath grain ('re)ps.

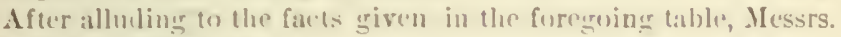
Lawe's and Gilbert say :

"There is eviluner of another kinl that may be citcel as showing that it was of avalable nitrugen that the turnips bat rembred the soil so defieient for the aftererom th uf larley. It may be as

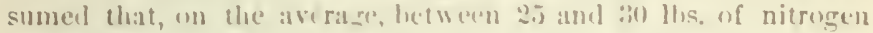
would be ammually removel from the Rothamsetel soil by whent or barley grown year after year withunt nitrumanums manure. But it is estimatol that from the mimeral-mamured turnip-plots there

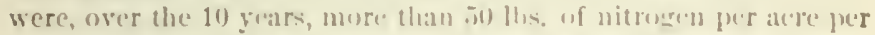
annum removed. As, lowever, (1) smu uf the plots, small qusm-

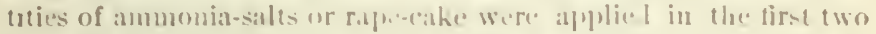
years of the ten of turnips, it is, perhspes, mere (u the purpuse to

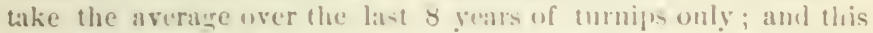

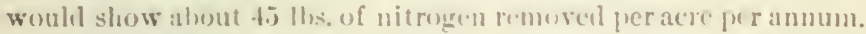
An immaterial proportion of this mirht lo due to the smitl

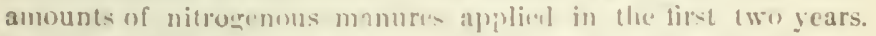
Still, it may be assmmed tlat alumt 1 th time as man nitrugum was remorul from the land for 8 , if not for 10 years in succession, as would lave been taken in an equal number of crups of wheat or barley grown without nitrogemus mammre. Su wonder, then, that consilerably less barley has ben gruwn in 3 gears after a series of mineral-maumrel turnip-crops, than was ubtained in another ficli after a less number of enrn-crops.

"The results olitained in Basn-field afforil a striking illustration of the dependenee of the turnip-plant on a supply of arailable nitrogen within the snil, and of its comparatively ereat power of exhausting it. They are also perfortly consistent with those in Hons-ficlel, in showing that mineral manures will not yicld fair erops of barles, unless there be, within the snil, a liberal supply of arailable nitrogen. The results ohtained under suell very dilferent conditinns in the two fields are, in fact, strikingly mutually con. firmatory." 


\section{II A P'T E R I X X.}

\section{MANURES FOR OATS.}

"What is the use of talking about manure for oats," said the Deacon, "if land is not rich enought to produce onts without manure, it certainly will not pay to munre tlicm. We can use our manure on some crop thitt will pay better."

"That is precisely what we want to know," said I. "Very likely you are right, but have you any evidenee?"

"Evidence of what?"

"Ilave you any facts that slow, for instance, that it will pay better to use manure for wheat or harley than for oats?"

"Can't saly that I have, but I think manure will pay" hetter on wheat than on oats."

Mr. Lawes is making a series of experiments on oats. Let us take a hasty glance at the results of the first two seasons:

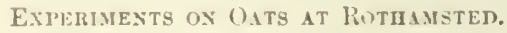

\begin{tabular}{|c|c|c|c|c|c|c|}
\hline \multirow[t]{2}{*}{ MANUI:E PER ACRE. } & \multicolumn{2}{|c|}{$\begin{array}{l}\text { Gruin, in } \\
\text { Gushels. }\end{array}$} & \multicolumn{2}{|c|}{ Strate, ciots. } & \multicolumn{2}{|c|}{$\begin{array}{l}\text { Weiglut per } \\
\text { bushel, los. }\end{array}$} \\
\hline & MHis. & $1 \kappa 70$. & $186 \% !$ & 1870. & $1,469$. & 1870. \\
\hline 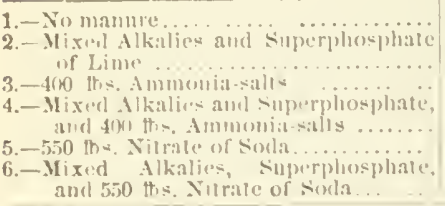 & 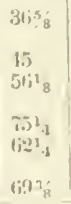 & $\begin{array}{l}511.58 \\
361 \% 2 \\
50\end{array}$ & $\begin{array}{l}2116 \\
3678 \\
51 \\
4296\end{array}$ & $\begin{array}{r}158 \\
17.4 \\
2458 \\
23\end{array}$ & $\begin{array}{l}381 / 2 \\
37 \% \\
391 \% \\
38 \% \\
351 \%\end{array}$ & $\begin{array}{l}35 \\
35,16 \\
31^{1} 4\end{array}$ \\
\hline
\end{tabular}

It seems clear that, for oats, as for barley and wheat, what we most need in manure, is available nitrogen.

The first year, the no-manure plot produced 36 bushels of oats per acre, weighing 36 ?hes per bushel, and plot 3, with ammoniasalts alone, $56 \frac{1}{4}$ bushels, and with nitrate of soda alone, on plot 5 , $62 \frac{1}{4}$ bushels per acre, lootl weighing $38 \frac{1}{2}$ lhs. per bushe l. In other words, $8216 s$. of avalable nitrogen in the salts of ammonia gave an increase of about 20 bushels per acre, and the same quantity of nitrogen in nitrate of soda an increase of 26 bushels per acre.

The next year, the season seems to hive been a very unfavor- 
able one for oats. The no-manure plut produced less than 17 bushels per atere; and the "ashes" amel superphosphate on plot 2 , give an inerease of less than 3 bnsluels per atere. lint it will be seen that on plot 3 the anmonia-silts do as much grood in this unfavorable season ats in the fiborable one. They grive an increase of over 20 bu-hels pere acre.

"I few such facts as this," satid the Deacon, "would almost persuale me that you are right in contemling that it is in the unfatorable s atouns, when prices are sure to be ligh in this country, that al goul farmer stamls the best chance to make money."

"Where mixed alkalies aml superphesphate," said the Doctor, "are abled to the ammonia, the increase from the enmonnie is far greater than where ammonia is used alone. In other words, by eomplaring plot 2 and plot 4 , you will sece that the ammonia gives an increase of $30 \$$ bushels per acre in 1869 , and $31 \frac{1}{2}$ bushels in $18 \% 0 . "$

The truth of the matter prohably is this : $100 \mathrm{lbs}$ of available ammonit per acre is an execsive supply, when used alone. And in fact Mr. Lawes himself only recommends abont half this quantity.

Whether it will pay us to use artificial manures on oats depends on the price we are likely to get for the wats. When the price of oats per lb.anl oat-straw is as high as batrley and harley-straw per $l b$, then it will p:ly al litte better to use manure on oats than on barley. As at rule in this country, however, grood barley is worth more per lb. than groud oats; and it will usually pay better to use artificial mamures oa barley than on oats.

Some years aro Mr. Bath, of Virginia, made some experiments on oats with the following results :

Busleels of outs per acre.

No. 1-300 1bs. Superphosphiste..................2

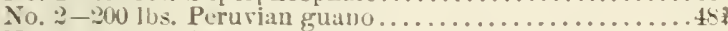

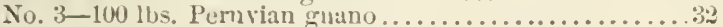

The oats were sown March 13, and the crop barvested July 4.

In 1860, I mule some experiments with gypsum, superphosphate, and sulphate of ammonia as a top-ilressing on oats.

The land was a clover-sod, plowed abrut the middle of MIay, and the oats sown May 20. On the 26th of May, just as the outs were coming up, the manures were sown broalcast. The oats were sown too late to obtain the best results. On another field, where the oats were sown two weeks earlier, the crop was decidedly better. The oats were ent August 28.

The following is the result : 


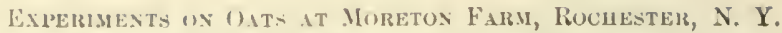

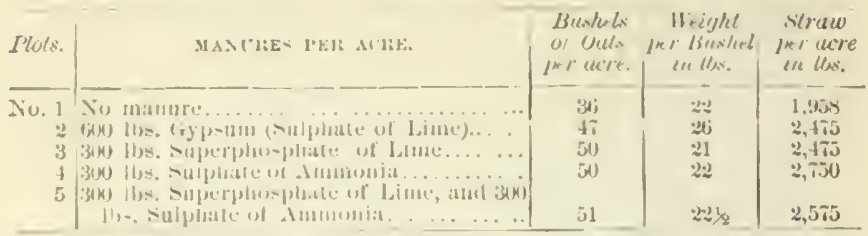

Thuse experiments ware male when my land wils not as clean as it in now. 1 presume che weeds grot more henetit from the ammonia tham the oati. To top-. Iress fonl land with expensive arti-

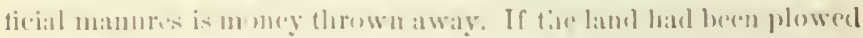

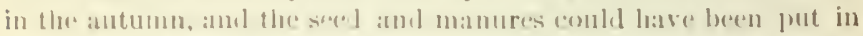
("arly in the spring, I presime we shonlel batse han! more farorable remetlils.

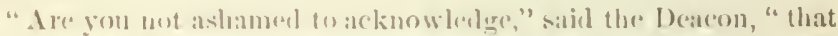

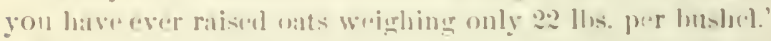

No. I have raind "ven wors:" ropss that this-and so has the De"scon. But l made ap my mind that such farming dicl not pay,

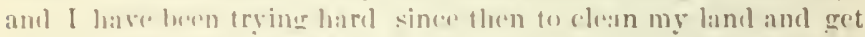
it into !retter condition. Anul until this is done, it is useless to talk muclu of artiticial mamures.

The must strikine result is the effert of the gypsum. It not only gave an increased yild of 11 hishels per acre, hut the gats were of derifledly better quality, and there was nearly half a tom more straw per ace than on the plot alonegide, where no manure was nisiel.

'T'tor superpliospluate was a grood article, similar to that used in Mr. Liawes' experiments. 


\section{II I I'L E I I I I I.}

\section{MANCERLS FOR POTATOES.}

Some time ago, a farmer in P'nusylvania wrote me that he wanted "to ribiec it first-ritle crop of polatues." I answered lim as follows through ilse Ameriren Agriculturist:

"There are many ways of doine thi- Mnt as you only enter on the farm this spring, you will work to elisidvantage. To oltain

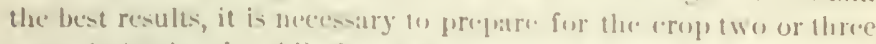

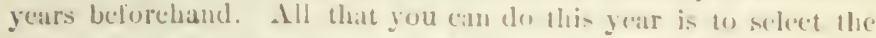

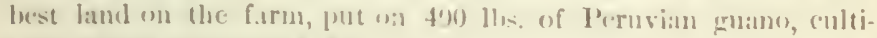
vate thoroughly, and suffer not at wees] to grow. A two or three

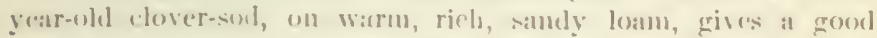
chance for protitoss. Do not plow until you are ready on plant. Sow the gname broa least afur plowing, and latrow it in, or apply

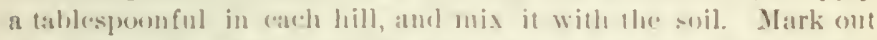
the rows, both ways, three fert apam, and drop at fair-sized potato in each hill. Start the cultivitor as serou as the rows can be distineuishred, and repeat every weels or ten days until there is dauger of disturbing the root. We nsually hill up a little, making a broad, flat hill. I tablespounful of plaster. dusted on the geung plants soon after they come 11 , will usilally do gremel. We recommend guano, heeanse in our experience it does not increase the rot. But it is only fair to alde, that we lave not found even barm-yard manure, if thoroughly rotted and well mixed with the soil the fall previous, half so injurious as some people would have us suppose. If any one will put 2.5 loads per are on onr potato land, we will agree (1) plant and run the risk of the rot. But we would use some guano as well. The truth is, that it is useless to expect a large crop of potatues, say $3 \pi 0$ bushels per acre, without plenty of manure."

This was written before the potatn-beetle made its alpetarance. But I think I should say the same thing non-only put it a little stronerer. The truth is, it will not pay to "fight the bugs" on a poor crop of potatnes. We must select the hest lant we have and make it as rich as possible.

"But why do you recommend Peruvian griano," asked the Doetor, "rather thin superplosphate or aslues? Potatres contain a large amount of potash, and one would expect considerable benefit from an apolication of ashes."

"Ashes, plaster, and hen-dlung," said the Judge, "will at any rate 
pay well on potatnes. I have trick this mixture agitin and again, and always with good eflect."

"I believe in the hen-dune," saitl I, "ant possibly in the plaster, but on $11 \mathrm{y}$ lamt, ashes do not serm to he specially heneficial on potatos, while I lave rarely used Peruvian guano without gond eflect; and sometimes it has proved wonderfully profit ahle, owing to the high prine of potatoes."

Sometime agn, I laad a risit from one of the most enterprising and suceessful farmers in Western New York.

"What I want to learn," he silid, "is how to make manure enough to keep my land in gond condition. I sell nothing but heans, potatoes, wheit, and ipples. I fees out all my corn, oats, stalks, straw, and hay on the farm, and draw into the barn-yard the potato-vines aim everything we that will rot into manure. I make a big pile of it. But the pint witl me is to find out what is the hest stock to feet this staw, stalks, liay, oats, and corn to, so as to make the liest manure and return the lisurest profit. Latet year I bought a lot of steers to feed in winter, and lost money. This fail I hougiat lis luad uf cows to winter, intending to scll them in the spring."

"What did they cust you ?"

"I we'at into Wyoming and Caltarangus Countirs, and picked them up among the dairy farmer; ant scleciol a very fair lot o: cows at an average of \$2 per heal. I expe: 10 sell them as new milel cows in the spring. Such cows last epring would have been worth \$60 to \$ic each."

"That wilı pay. But it is not often the grain-grower gets such a chance to feed out his straw, stalks, an i caher fodder to ad rantage. It canmot he arlopted as a permanest system. It is bat for the lairyman, and no real help to the grain-grower. The manure is not rich enough. Straw and stallis alow ran not lie fed to adrantage. And when you winter eows to sell arain in the spring, it will not pay to feed grain. If you were goingy to keep the cows it we uld pay well. The fat and flesh you put on in the winter would be re. turned in the form of butter and eherse mest summer."

"Why is not the manure gool? I an careful to save ererything, ant expect serin or cight liunded loads of mannre in the spring."

"You hat 60 acese of wheat that vielded 25 bushels per acre, ant hare probably about io tons of wheat straw. You hal also 30 acres oats, that vielded 50 lumshels pere arre, say 3.5 tous of striw. Your 20 acres of enrn producent 40 bushels if sluelled corn per are; syy the stalks weinh 80 tons. And you have 60 tous of 
hay, half clover and half timothy. Jeet us ser what your manure from this amount of grain and folder is wortls.

Manures from

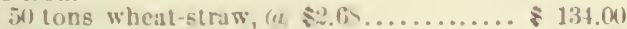

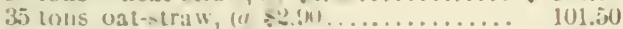

30 luns (rom-lalks, (1) $\$$;i)........... 107.40

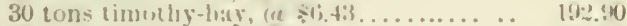

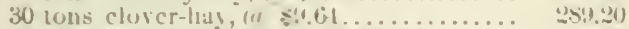

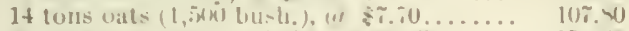

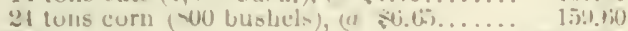

Total. . 21:3 tons

$\$ 1,0.12 .40$

"This is the value of the manure on the lend. Assmung that there are 600 buals, aud that the litbor of chaninge out the statiles, piling, carting, and spreasling the manure is worth :30 eents per

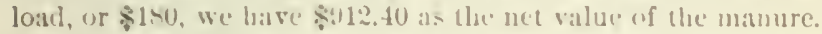

" Now, your 230-acre farm might be so managed that this amount of mautre ambually applied would son greatly incrase its fertility. But you do not think you ean attoril to smmmer-fallow, and you want to raise thirty or forty acres of posatoes every year."

"I propose to do so." he replienl. "Situated am I am, close to a good shippines station, no crop pays me hetter. My potatoes this year have averaged me orer $\$ 100$ per acre."

"Very gonol. But it is perfertly clear to my mind that sonnes or later, you must either farm slower or feed lighlier. And in your case, situated close to a rillage where you can get plenty of help, and with a grod shipping station near by, you hal hetter adopt the latter plan. You must feed ligher, and make richer manure. You now feel out 219, tons of stuff, and make 600 loads of manure, worth \$\$\$12.40. By feeding out one third, or $i 1$ tons more, you can more than deut'le the value of the manure.

50 tons $n !$ bran or mill-feel would gire manure worth...... \& 729.50 :1 tons deeurticated cotton-seed cake....................

$\$ 1,314.51 ;$

"Buy and feed cut this amount of bran and cake, and you would liave 800 loaks of manure, worth on the lind $\$ 2,226.96$, or, estimating as before that it cost 30 cents a load to handle it, its net value would be $\$ 1,936.96 . "$

I am well aware that comparatively few farmers in this section can afford to allopt this plan of enriching their land. We want better stock. I do not know where I could huy a lot of steers that it would pay to fatten in the winter. Those farmers who raise good grade Shorthorn or Deron cattle are not the men to sell them half-fat at low ratcs. They can fatten them as weli as I ean. For some time to come, the farmer who proposes to feed liberally, 
will have in raise his own stock. He can rarely buy well-bred animals to fatten. A good farmer must he a good farmer throughut. IIe can wot be genel in sponts. Jlis land must he drained, wellworked, and free from weeds. If he crops beavily he must manure heavily, and to do this he must feed liberally-and be can not atfurd to feed liberally unless he haw goud stock.

"I have, myself, me doulht hut you are right on this point," said the bocur, "but all this tekes time. Suppese a farmer becomes satisfied that the manure lie makes is not rich moughts. To tell lim, when he is andions to ratise a good erop of putalues next year, that be must gis to work anl improve his stork of cattle, sheep, and swine, and th"'ll by bran and ril-cake (1) mike richer manure, is somew hat tantaliziage."

This is truc, and in such a calse, instead of adding nitrogen and phosplorice acil to his manure in the shape of bran, wileake, ete., he can luy nitrogen :mel phusphoric acid in guame or in nitrate of sola amel superphusulate. This gives him richer manure; which

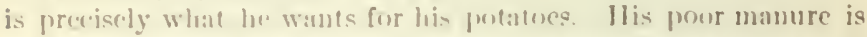
not se much de tiejent in petash as in nitrogen and phosphoric acid, and consequently it is nitrogen and phosplueric acid that he will probalily now to make his soil capalile of producing a large erop of putillues.

I have seen Peruvim Entano (atensively used on potatoes, and

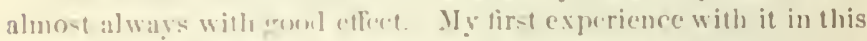
country, wats in 14.? Fen aleres of putatues were planted on a [wo-var-(3], dover-sul, fluwed in the spring. On two aeres,

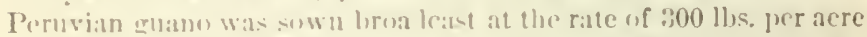
and harrowed in. The putates were flatuted Iat 10. On the ollur two acr s no manure of any kind was used, theugh treated exactly alike in avery other re-spect. The result was as follows:

Vis manur.

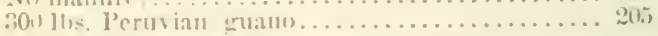

The guano (a)t, here, alkut : cents a lh, and conseruently nine doblars'worth of enanongave st husliels of putatoes. The potatoes were all sombl and grood, but where lhe gu:mo was used, they were l.rger, with seariely a small ome amonget them.

In 185\%, I make the following experiments on potatos, in the same tick on which lise preceling experiment was made in 18.52.

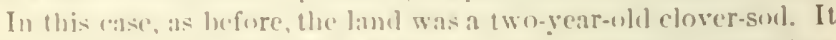
was plowed alume llow first of May, and harrowed until it was in a govel mollow condition. The potatoes were planted iu bills $3 \frac{1}{3}$ 
feet apart each way. The followine table shows the manures used and the yiclel uf puilatin:s pur acre.

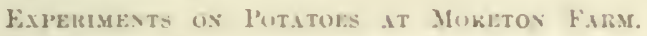

\begin{tabular}{|c|c|c|c|}
\hline $\begin{array}{l}3 \\
3 \\
3 \\
1 \\
\vdots \\
\vdots \\
\vdots \\
\vdots \\
\vdots\end{array}$ & 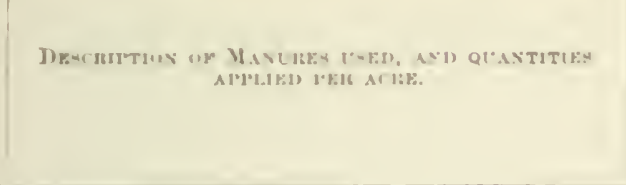 & $\begin{array}{l}3 \\
\vdots \vdots \\
\vdots \vdots \\
\vdots \\
\vdots \\
\vdots\end{array}$ & 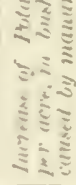 \\
\hline $\begin{array}{l}1 . \\
3 . \\
3 . \\
1 .\end{array}$ & 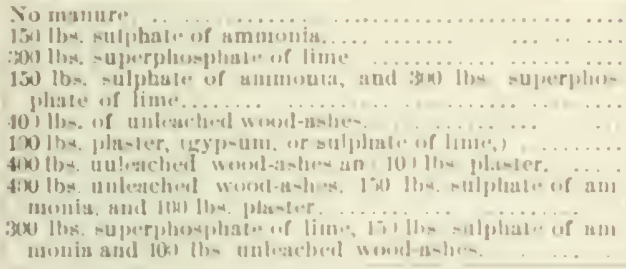 & $\begin{array}{l}4.5 \\
1111 \\
1.22 \\
171 \\
1101 \\
1111 \\
110\end{array}$ & $\begin{array}{c}15 \\
36 \\
4 \\
\vdots \\
6 \\
15 \\
11\end{array}$ \\
\hline
\end{tabular}

The superphusphate of lime was male expres-ly for experimental purposes, from andeined bunce, gromel time, and maxed with

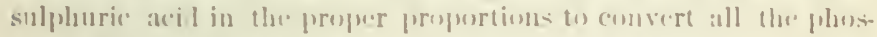
phate of lime of tie loones into the suluble sup rpho-phlate. It war a purely min r.al artible, free from ammoni and other orgatnic matt r. It (c)-t about two and at half eemb- per pomml.

The manures were depusited in lhe hill, covered with an inch or two of stil, and the seed then planted on the top. Where supurphosphate of timeor sulp'bate of ammonia was us.d in conjumeton with ashes, the astars were tir-t deponsted in the hill and eovered with a little sibil, and then the - nperphes-phate or solphate of ammonia placed on the tep and cowered with soil before the seed was planted. Notwith-tanding this preeaution, the ran washed the sulphate of ammonitu uto the a-hes, ancl decomprition, with luss of ammonia, was the renlt. This will aceount for the less yichd on plot 8 than un plot 2 . It would have been better 0 have sostu tue ashes broulcast, hut some previuns expmerunents wulh Peruvan guano on potitoes indicated that ut was best to apply grnano in the hill, carefully corering it with soll to prerent it injuring the seed, than to sew it broadcast. It was for thus reason, and for the greater convenience in sowine, that the manures were applicel in the hill.

The ash of potatoes consists of about 50 per cent of potash, and this fact has induecel many writers to recommenel ashers as a manure for this crop. It will be seen, howeser, that in this instance, at 
least, they have very little effect, 400 lbs. giving an inerease of only five bushels per acre. One humbrel pounds of phaster per acre gave an in. rease of six bushels. I'laster and ashes combined, an increase per acre of 1.5 buslich.

One fact is clearly brought ont by these experiments: that this soil, which has been moler cultivation withont manare for many years, is not, relitively in other constituents of crops, deticient in potash. IIad such been the ease, the sulphate of ammonia and superphosphate of lime-manures which contain no potas'i-would not have given in increase of $8 t$ bushels of potatoes per acre. There was suflicient potash in the soil, in an arailable eondition, for 17 ) hushels of potatoes per aere; and the reas on why the soil withent manure produced only 9.5 bushels per acre, was owing to a deticieney of ammonia and plosiphates.

Since these experiments were made, 1)r. Voeleker an l others have mude similar ones in Englant. The results on the whole all point in one durection. They show that the manures most valuable for potatoes are thos rich in nitrogen and phosphoric acid, and that oceasionally potash is also a useful addition.

"There is one thing I should like $1.2 \mathrm{k}$ (s)," sail the Doctor. "Admittmg that motreren and phopplorie acid and potash are the most important elements of plant-food, how many hushels of potatoes should we be likely to gret from a judicious application of these manures?"

"There is no way," sajd $\mathrm{I}$, "of gretting at this with any legree of certanty. "The numerons experiments that have been mate in England seem to show that a griven cuantity of manure will produce a larger incerease on poor land than on lamel in better condition."

In England potatoes are rarely if crer planted withont mannre, and the land selected for this crop, even without mamre, would usnally be in hetter condition than the average potato land of this section, and consequently a griven amonnt of manure, alplified to potatoes here, would lie likely to do more rood, up to a certain point, than the same amount would in England.

Let us look at some of the expreriments that have been made in Fngland :-

In the Transactions of the Hyliland and A gricultural Society of Seotland for 187:" is a prize essas on "Experiments upon Potatoes, with l'otash Salts, on light Land," hy Charles D. IImuter, F. C. S., made on the fum of Willian Jaw:on, in Cumberland. Mr. Hunter "was (harenel with the manuring of the farm and the purchasine of chemical manures to the annual value of $\mathfrak{L}^{2}, 000$, , or say $\$ 10,000$. 
"Potatoes," says Mr. IIunter, "were largely grown on the farm, and in tle absence of a sullicieney of farm-yard manure, potash naturally suggested itsolf as it meeessury constituent of a chemical potato-manure. The soil was light and gravelly, with an open suboil, and the rainfall from 29 to 38 inche's a year."

The tirst serie's of experiments was made in 186\%. The follow. ing are some of the results:-

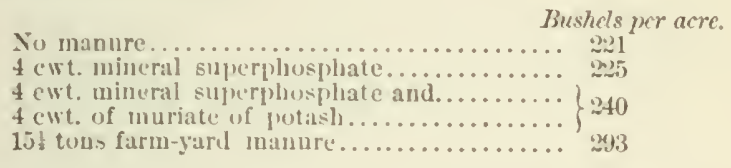

"That does not say much for potash and superphosphate," said the Deacon. "The superphusplate only produced four bushels more than the no manure, and the potash and superphosphate only tifteen bushels more than the superphospliate alone."

It may be wort? while mentioning that one of the experimental plots this year was on a head-land, "where the eattle frequently stand for s!nclter." This plot was dressed with only cight anel a half tons of manure, and the crop was oper 427 bushels per acre, while a plot alongsile, without manure, prouluced only 163 buslicls per acre.

"That shows the importance," said the Deacon, "of planting potatoes on rich land, rather than to plint on poor lind aud try to make it rich hy applying manure directly to the crop."

The following are some of the results in 1868:

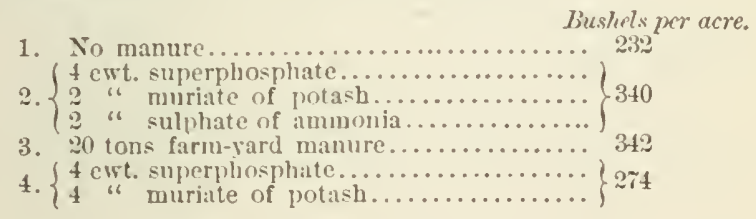

"Here again," said the Doctor, "superplosphate and potash alone give an increas? of only forty-two bushels per acre, while on plot 2 , where two hundre l weight of muriate of potaslı is sulstituted by two hunilre 1 weight of sulphate of ammonia, the increase is 109 bushels per acre. It certainly looks as though a manure for potato's, so far as yield is concerned, should be rich in available nitrogen." 
The following are some of the results in 1869 :

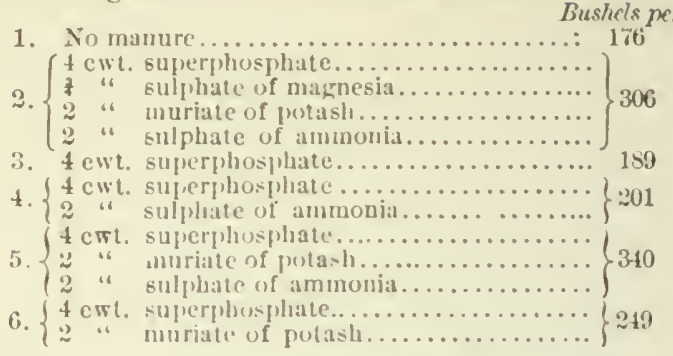

"This is a very interesting experiment," sait the Doctur. "Supurphosphlate alone gives ath inereise of thirteen busheds. Superphospliate and potash an inrrease of seventy-three bushels. The potash, therefure, gives an interease of sixty bushels. Superphusphate and ammonia gise twelve lushels more than superphosphate alone, ant the reasion it deses not produer a better (ropt is owing to a dehoriency of potash. When this is supplied the ammonia gives an increase (plots 5 and 6 ) of nincly-one bushels per acrer."

In 1870 the alkwe experiments were repeated on the same land, with the same general results.

In $18: 1$ some exjuriments were male on a slarp, wravelly soil, which hat loen owerepromel, and was in pour condition. The following are the resilts:-

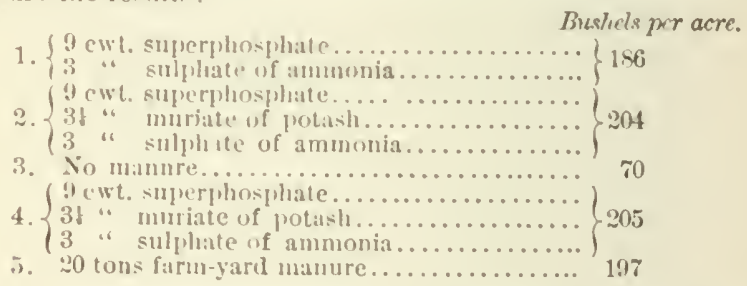

"On this poor soil," sitil the Doctor, "the ammonia and superphosplate gave an incruse of 116 bushels per acre; and $3 \frac{1}{2}$ hundred weight of muriate of potasl an increase, on one plot, of eighteen bushels, and on the other nineteen bushels per acre."

In the same year, 1si1, anolluer set of experiments was made on a hetter aml more liamy soil, which hat been in grass for several years. In 1369 it was sown for hay, anıl in 1870 was broken up and sown to oits, aml the next spring planted with potatoes. The following are some of the results: 
Bushels per acre.

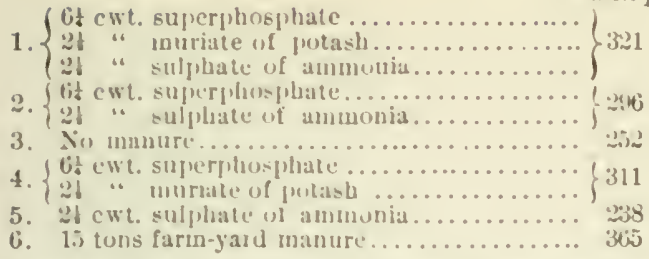

"It is curiuus," said the l)octur, "that the jolot with sulphate of ammonia alone should produce less than the no-manure plot."

"The sulphate of ammonia," saibl I, "may lave injured the seed, or it may have produced tou luxuriant at growth of vine."

Another series of experiments was mole on another portion of the same tielel in 1871. The "no-manure" plot produced :337 bushels per acre. Manures of virious kinds were used, hut the largest yichel, 351 lushels per acre, was from superphospluate and sulplate of ammonia; fourteen tons barn-yarl manure probl ce 340 busliels per acre; and Mr. Ilunter romarks: "It is evident that, when the proluee of the ummanured soil riaches nine tons [336 lusbels] per acre, there is but little seope for manure of any kind."

"I lo not see," said the Doctor, "that you have answered my question, hut I suppose that, with potators at fifty cents a bushel, and wheat at \$1.50 per bushrel, artificial manures can be more profitably used on potatoes than on wheat, and the same is probably true of nats, barley, eorn, etc."

I bave long been of the opinion that artificial manures cin be applied to potatoes with more profit tlaan to any other ordinary farm-erop, for the simple reason that, in this country, potatoes, on the arerage, command relotively high prices.

For instance, if arerage land, withunt manure, will produce fifteen bushels of wheat per acre and 10i) hushels of potatoes, and a giren quantity of manure costing, say \$\$.5, will tlouble the crop, we hare, in the one case, an incretse of :-

15 bushels of wheat at $\$ 1.50 \ldots \ldots \ldots \ldots \ldots \$ 2.50$

$15 \mathrm{cwt}$ of straw................. 3.50

Cost of manure.................. 25.00)

Profit from using manure.............

And in the other:-

10 bushels of potatoes at 50 cents......... 550.00

Cost of manure.................... 25.00

Profit from using manure............ \$25.00 
The only question is, whether the same quantity of the right kind of manure is as likely to (louble the potato crop as to double the wheat crop, when both are raised on average land.

"It is not an easy" matter," said the Deacon, " to double the yield of putatoes."

"Neither is it," said I, "to double the yield of wheat, but both can be done, provided you start low enough. If your land is clean, and well worked, and diry, and only produces ten hushels of wheat per acre, there is no dilliculty in making it produce twenty bushels; and so of potatoes. If the land be dry and well cultivated, and, barring the bugs, produces withont manure if bushels per acre, there onght to be no dilliculty in making it produce 150 bushels.

"But if your land produce's, without manure, 150 bushels, it is not always easy to make it produce 300 bushels. Fortunately, or unfortunately, our land is, in most eases, poor enough to start with, and we ought to he ahle to use manure on potatoes to great advantage."

"But will not the manure," asked the Deacon," injure the quality of the prtatoes?"

I think not. So far a my experiments and experience go, the judicious use of good manure, on dry land, favors the perfect maturity of the tuhers and the formation of sturch. I nerer manured potatoes so highly as I did last year (18\%i), and never had potatoes of such high quality. They eook white, dry, and molyly. We made furrows two and a half feret apart, and spread rich, well-rotted manme in the furrows, and planted the potatoes on top of the manure, and covered them with a plow. In our climate, I am inclined to think, it would be hetter to apply the manure to the land for potatoes the autumn previous. If sod land, spread the manure on the surface, and let it lie cxposed all winter. If stubble land, plow it in the fall, and then spreal the manure in the fall or winter, and plow it under in the spring. 


\section{II A P' ' E R I X I I I.}

\section{WHAT CROPS SHOLLD MANURE BE APPLIED TO.}

"It will not do any harm on any (rop," said the Deacon, "but on my firm it secms bo be most convenient to draw it out in the winter or spring, and plow it under for corn. I do not know any farmer except you who dises it on potateres."

My own ruld is to apply manure (1) these crops which require the most labor pee anere. But I am woll aware that this rule will have many exceptions. For instance, it will often pily well to use manure on barley, and yet barley requires far less labor than corn or potatoes.

P'ople who let out, and those who work forms "on shares" seldom mulerstand this matter clearly. I knew a farmer, who last year let out a fich of aroul land, that hatel heen in corn the previous year, to a man to sow to larley, and afterwarls to wheat on "the halres." Another port of the farm was talken by a man to plant corn and potatoes on similar terms, and another mam put in several acles of callbative, beets, carrots, and onions on halles. It never secmed to oceur to either of them that the conditions were unequal. The expense of dirring and harresting the potato-crop alone was greater than the whole cost of the birly-erop; while, after the barley was off, the land was plowed once, harrowed, and sowed to winter wheat; amb nothing more has to be done to it until the next harrest. With the garden crops, the difference is even still more striking. The labor expentexl on one acre of onions or earrots would put in and liarrest a ten-acre fiell of barley. If the tenant gets pay for his labor, the landiord womld get say \$..5 an acre for his harley land, and \$ุ.jo for his carrot and onion land. I am pretly sure the tenants did not see the matter in this light, nor the farmer either.

Crops which require a large amount of labor can only be grown on rery rich land. Our suceessful market-gardeners, sced-growers, and nurserymen unilesstand this mater. They must get great crops or they cannot pay their labor bill. And the principle is applicable to orlinary farm crops. Some of them require much more labor than others, and should never be grown unless the land is 
capable of producing a maximum yield per acre, or a close approximation to it. As a rule, the least-paying crops are those which require the least libor per acre. Farmers are af rand to expend much money for labor. They are wise in this, unless all the conditions are favorable. But when they lave land in a high state of cultivation-draned, clean, mellow, and rich-it would usually pay them well to grow crops which recpuire the most labor.

And it should never be forgotten that, as compared with nearly all other countries, our labor is expensive. No matter how cheap our land may le, we can not alfore to waste our labor. It is too costly. If men would work for nothing, and board themselves, there are localities where we could perhajes atford to keep sheep that shear two pounds of wool a year; or cows that make 75 los. of butter. We miglat make a protit out of a wheat crop of 8 hushels per acre, or a corn-('a)p of 1.5 bushels, or a potato-crop of 50 bushels. But it camnot be dome with labor eosting from $\$ 1.00$ to $\$ 1.25$ per d.y. And I lo not helieve lahor will cost much less in our time. The only thing we can do is to employ it to the best adrantage. Machunery will help us to some extent, but I (an see no real eseape from our liftienlties in this matter, except to raise larger crops per' arere.

In ordinary farming, "larger crops per acre" means fewer acres planted or sown with grain. It means more summer fallow, more grass, clorer, peas, mustarl, coleseed, roots, and other crops that are consmed on the farm. It means more thorough cultivation. It means clean and rich land. It means husbanding the ammonia and nitric aciel, which is brought to the soil, as well as that which is dereloped from the snil, or which the soil attracts from the atmospldere, and using it to grow a erop every second, thirl, or fouth year, instead of every year. If a piece of land will grow 2.j busluels of corn exery year, we should aim to so manage it, that it will grow 50 every other year, or 75 every thirl year, or, if the climute is capalle of doing it, of raising 100 lumshels per acre every fourth year.

Theoretieally this ean be done, and in one of Mr. Lawes' experiments he did it practically in the case of a summer-fallow for wheat, the one crop in two yours giving a little more than two crops sown in streession. But on sandy land we shoukl probably lose a portion of the liberated plant-food, miless we grew a crop of some kint every year. And the matter orranized in the renovating erop could inot be rendered completely availahle for the next rrop. In the end, however, we onglut to be able to get it with little or no loss. How best to aceomplisl, this result, is one of the 
most interesting and important felels for scicntitic: investigation and practical experiment. We know enough, however, to be sule that there is a great advantage in waling until there is a suflicient ale. cumulation of available plant-food in the soil to produce a latge yield, before sowing a crop' that requires much labor.

If we do not want to wait, we must apply manture. If we have no barn-yarel or stable-manure, we must luy artificials.

\section{HOW AND WHEN MANLRE SHOULD BE APPLIED.}

This is not a merely theoretieal or chemical question. We must take into consideration the cost of application. Also, whether we a]ply it at a busy or a leisure seas(un, I have seen it re(o)mmended, for instance, to spreat manure on meacluw-land jumediately after the hay-erop was remored. Now, I think this may he lleoretically very good astrice. But, on my farm, it would throw the work right into the miclst of wheat and barley larvests; and I should make the theory bent a little to my convenience. The meadows would have to wait mutil we hal got in the cops-or until harvest operations were stopped by rain.

I mention this merely to show the emmplex character of this question. On my own farm, the most lo istre seast)m of the your, except the winter, is immediately aftre wheat harvest. Anu, as alrealy stated, it is at this time that John Johnston draws out his manure an spreads it on grass-land intended to be plowed up the following spring for corn.

If the manure was free from weed-s'eds, many of our best farmers, if they had sume well-rottel manme like this of Joln Johnston's, would traw it out and spread it on their ficlels prepared for winter-wheat.

In this ease, I should draw out the manure in heaps and then spreal it earefully. Then harow it, and if the harrow pulls the manure into heaps, spreat them and harrow again. It is of the greatest importance to spread manure erenly and mix it thoroughly with the soil. If this work is well done, and the manure is well-rotted, it will not interfere with the clrill. And the manure will be near the surface, where the young roots of the wheat can get hold of it.

"You must recollect," said the Doctor, "that the roots can only take up the manure when in solution."

"It must also be remembered," said I, "that a light rain of, say, only half an inch, pours down on to the manures spreat on an acre of land about 14,000 gallons of water, or about 56 tons. If 
you hate put on 8 toms of manure, half an inch of rain would furnish a gallon of water to each pumblef manure. It is not diflicult to understand, therefore, how mamure applied on the surface, or near the surface, ean le taken up by the young roots."

"That puts the matter in an new light to me," sail the Deacon. "If the manure wats plowed under, live or six inches deep, it wonld recpuire an abundant rain 10 reach the manure. And it is not one year in live that wo eret rain enough to thoronghly soak the soil for several wowks after sowing lhe whent in August or Sepermler. Anel when it does come, the season is so far advancel Hat the wheat plant-make little errowth.'

Мy own opinion is, that on clayey laml, mammre will act much quicker if applied on, or mar the surface, than if plowerl muler. ('lyg mixed with manure arrents or cheretise deromplosition. Sand has no such aflet. If anything, it favers a more aretive derompersition, and lience, manure acts mueh more rapidly on sandy land than on clay land. And I lhink, as a rule, where a farmer advorates the applieation of mannre on the surface, it will be

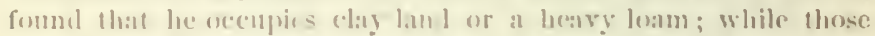
who oppose the practiec, and think manure shonld he plowed under, orempy sandy laml or s:muly losm.

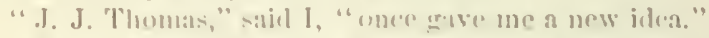

"Is that anything stratuge," remarked tlec Deacon. "Are ideas so scarer among you nericultural writers, that you can recollect wher first sizgesferl them ?"

"Be that as it may," saill I, "thic illea has hasl a decided innuence on my farm practire. I will not say that the idlea originated with $/ 1$ r. Tlommas, but at any rale, it was new to me I hat l always been in the lialit, when spaline in mante in the garden, of putting the manue in the trench and rewe rine it up); and in plowing it in,

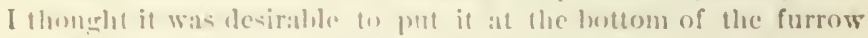
where thre neve furmw woull enerer it up."

"Well," saicl the lueacon, "and what ohjection is there to the practice?"

"I am not objertine to fler prasetice. I do not say that it is not a

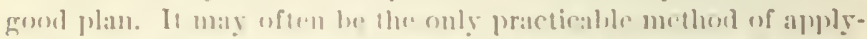
ine manure. But it is well to kouw that there is sometimes a better plan. The i.lea thit Mr. Thomas gave me, was, that it was rery desiralle to lireali up the manure fine, spread it evenly, and thoroushly mix it with the soil.

"After the manure is spreal on the soil," said Mr. Thomas, "and before plowing it in, great lene fit is derisel ly thoroughly harrowing the top-soil, thus breaking finely both the manure and the soil, 
and mixing then well touther. Anesther way for the perfect diffusion of the manure among the particdes of earth, is, to spread the manure in atumun, ses that-all the rains of this sethent maty elissolve the soluble purtions and carry them deswn among the particles, where they are absurbeal atsd retained for the @rowing eroph.

"In experiments," eroutinues Mr. Thomas, "when the manure for coru was thus applied in antum, has atlorded n yield of about 70 bushels fer acre, when the same amount applied in spring, gave only so hu-bels. A thin conting of nanure npplied to winterwheat at the time of suw ing, and was barrowed in, has increased

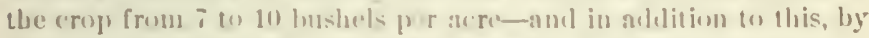
the stronger erowth it lass "aused, as well as by the protection it las aftisriesl in the surface, it has not uufrequently savel the crop from partial or tot:al winter-killing.

"In ('ase: wher it is neetisary to nply enarse manures at onee, much may lo done in lesening lihe evils of coarseness hy artificially grincling it inte the soil. The instrument called the drag-rollerwhich is like the common rollet sut stilf so as not to revolre-lias heen used to great advantagu for this purpose, ly passing it over the surface in connection with the herrow. We have kuown this treatument to cffert a thurough intermixture, and to more than donble the crop ohtained ly common management with common manure."

\section{TOP-DRESAIXG WITH M.AYRE.}

The term "top-dressing" usually refers to sowiug or spreading manures on the growing crop. For instaner, we (n)-dress pastures or meadows ly spreading mamure on the surface. If we sow niIrate of sola, or guano, on our winter-wheat in the spring, that would le top-elresing. We often sow grpsum on clover, and an barley, and peas, while the plants are growing in the spring, and this is toptetresing.

"If the gypsum was sown hroadeast on the land before sowing the seml," said the Deacen, "would not that he top-dressiug also?"

Strietly spenking, I suppose that would not be tup-dressing.

Top dressing in the sence in which I understand the term, is sel lom adopted, exeept on meadows and pastures as a regular system. It is an after-thouglit. We hare sowil wheat on a poor, sandy knoll, and we iran out some manure and spread on it in the winter or early spring; or we top-dress it with hen-manure, or Fuano, or nitrite of soda and superphospluate. I do not say that this is better than to apply the manure at the time of sowing the 
whent, but if we nenlent to den su, then top)-dressing is a commendahlu praction.

Dr. Voelcker rejorts the result of some experiments in top-elress-

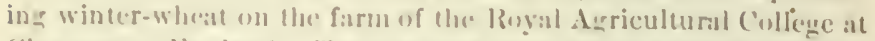
Cireneester, Englanel. The manures were fincly sifted and mixel with ahout tun times their weight of tinc soil, and sown hroalcast wh the growing what, March 22. A the roin uccurred llo following day, anil washerl the manne into the soil. The following is the vicht fier ate: :-

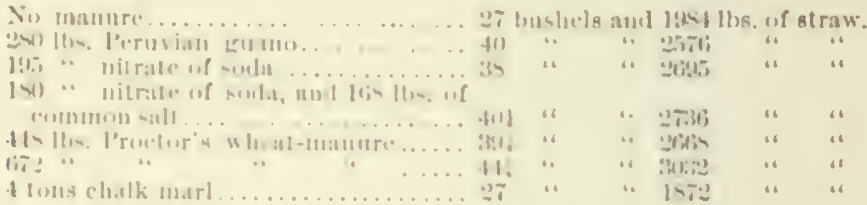

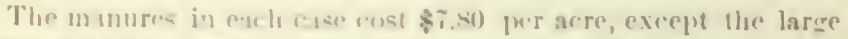

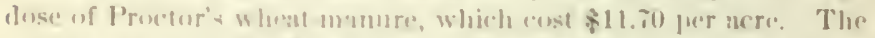

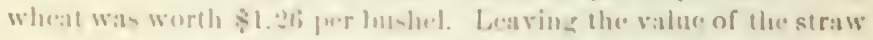

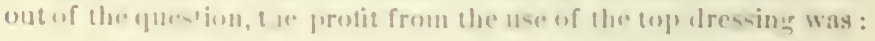

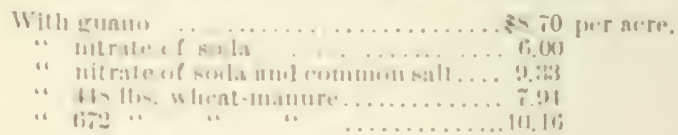

Thue marl did no gand.

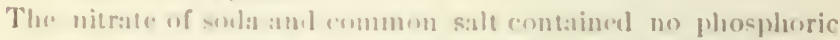
acidl, and yer producel an eveellent effect. The guano and the whe:at monure conteined pho-ple rese acil at well as nitrugen, and

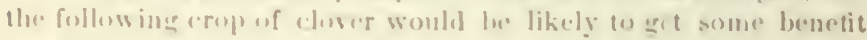
from it

Juhn .John-ion wrote in 1stiq, "I have used manure only as a mop-ifresing for the last 26 y mar, and I lu thiuk one load, llsed in that way, is worth far more th:m ewo losuls pleswed under on our nt itl lancl." 


\section{II A TER IX XIII.}

\section{MANLRES ON MEKMANENT MEAUOWS AND P.ASTLRL:S.}

In this country, whro lidor is comparatively lighlo, and haty

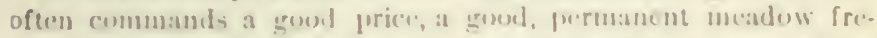
quently notorils as much real protit as any uther portion of the

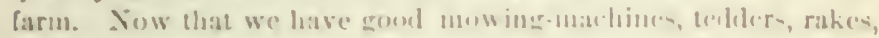

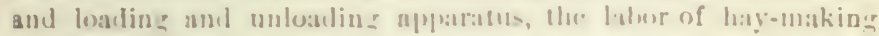

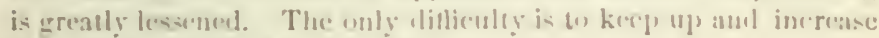
the annual growth of eroot ter is:

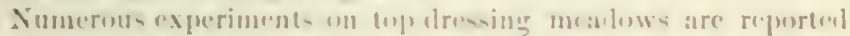

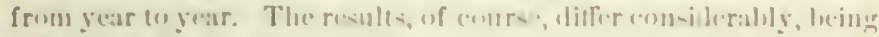
intluenced lye the -oil aud atasus. The protic of the practice depenk very much on the price of hay. In the Eastern States, hay generally comman to a higher relutive prioe than erain, and it not unfrequenty lapplent that we "an ust manure un eras- to decided alvantage.

The erlehrited experiments of Mre-r. Law of fillurt with

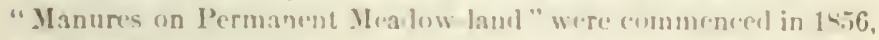
and have been continued on the sabse plots every year since that time.

"You neel not he afridel, Deacon," said I, ae the old erentleman commenced to hutton up his co:tt, "I am mot gengy into the details of these wonderful expriments; but I am sure you will be interested in the results of the thet six or seren years.

The following table explains itself : 


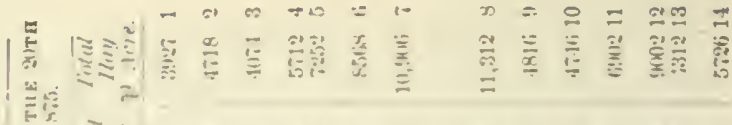

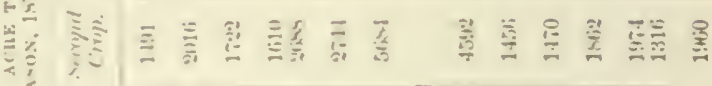

:

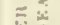

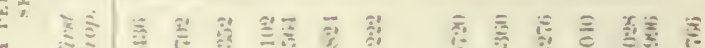

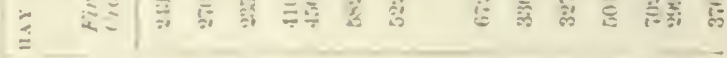

$\approx$ i

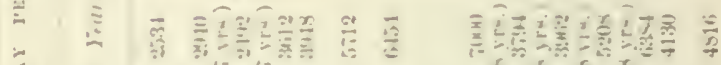
$\leqq$ ह

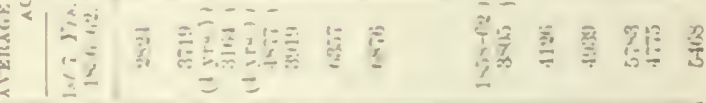
$=1$ y-

势|

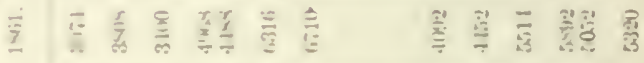

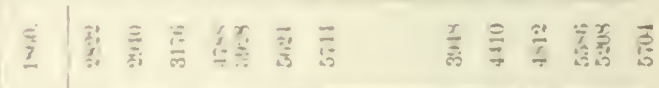

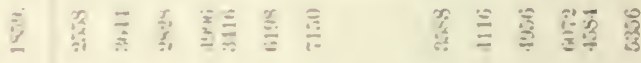

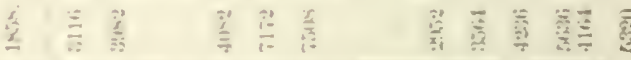

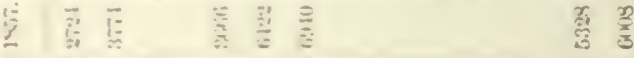

|

:

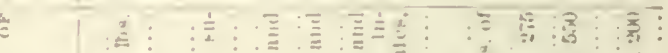

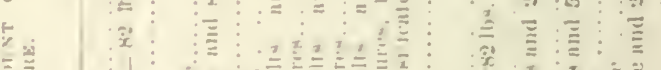

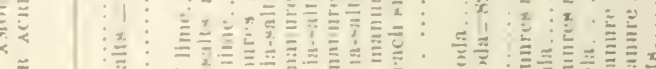

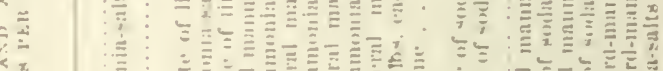

$<x \quad$ 准

|

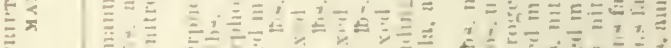

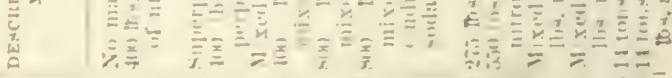


There are all the figure's I will troblut you with. The "mixert

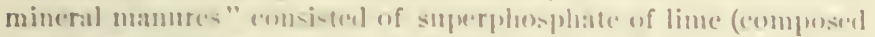

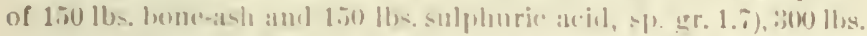

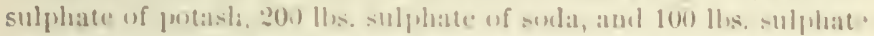

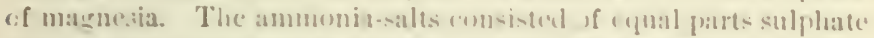

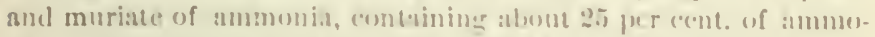
nia. The manures were sum ats arly as posible in the epring, and, if the weather was stitahle, smotimes in Feloruary. The farmyard-manure was -preal on the laml, in the fir-t year, in the spring, aferwares in Nosember or l)cember. The hay was cut from the midelle te the bats of June; and the aftermatli was patstured otl by sheepe in Uctuler.

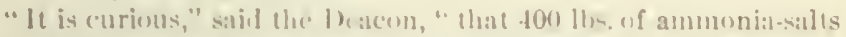

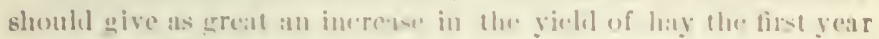

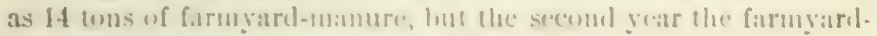

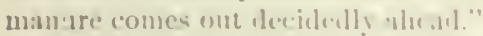

"The farmyari-manure," sild 1, "was applind cory yar, at the

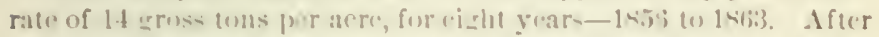
186:3, this plot wat lefe willom monter of any kiml. The average

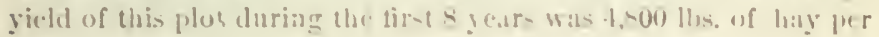
acre.

On the flut dresent with 11 tons of farmyarl-manure and ?00 Ihs. ammonia-silts, the average yiold of hay for 8 years was -5,514 Ubs. per ace. After the eighth year the famyard-manure was discontinued, and during the nexe 2 we lve gears the yillel of hay

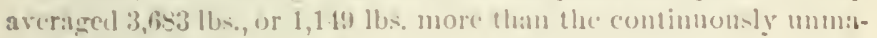
nured plot.

In 1859, superphospluate of lime was i:-cel alone on plot 3, and has been continued ever since. It seemsedear that this land, which had been in pasture or me udow for a humbrel years or more, was nut defieient in phospluates.

"It does not seem," said the Ineacon, "to have heen deficiemt in anything. The twentieth trops, on the amtimumsly unmamured plot was nearly $1 \frac{1}{\text { ton }}$ per acre, the first entting, and nearly gु-ton the second euting. And apparenty the land was just as rich in 18.5 , as it was in 18.50, and yet orer 2.5 tons of hay had been cut ancl remored fron the land, withont any manure being returncd. And yet we are told that hity is a reyg exhaustiug erop."

"Superpliosphate alone," silil the Iluctor, "dirl very litte to increase tive yiald of hay, but superpluseplate and ammonia produered the first pear, 1-59, oser a to: more bay per acre than the supurphusphate alone, and when potesh is addew to the manure, the yield is still further increased." 
"Answer me one question," said the Deacon, "and let us leave the suhject. In the light of these and other experiments, what do you consider the cheipest and hest manure to apply to a permanent meadow or pasture?"

"Rich, well-decompesed farmyand or stahle manure," said I, "and if it is not rich, apply" $200 \mathrm{lbs}$. of nitrate of soda per ace, in aldition. This will malse it rich. Poor manure, made from straw, corn-stalks, hay, ete, is poor in nitrugen, and comparatively rich in potash. The nitrate of soda will supply the defieiency of nitrogen. On the sea-shore fish-serian is a cheaper souree of nitrogen, and may be used insteac of the nitrate of soda."

\section{('HA I'IEli XIIIT. \\ MANURFA FOR SPLCIAL CROPS.}

\section{MINLRES FOR IIOPS.}

"For hope," sathl the Doctor, "there is nothing hetter than rich: well-decomposed farmyari-manure-su l lommre as you are now making from your pies that are belded with stable-m.mure."

"That is so," sitil l, "and the better you feed your loorses and pigs, the bettex will the manure ha for heps. In England, Mr. Paine, of Surrey, mate al series of experiments with different milnures for hope, and, as lhe result of four years trial, reported that meperete', singly, or in combination, invalriably proved the best manure for hops. In this country, cotton-seet, or cotton-sesdcalk, would be at groud substitute for the rape-catie. Whatever manure is used should bo used librally. Hops require a large amount of lathor per ance, and it is, therefore, specially desirable to ohtain a large yeld per acre. This s:m be aromplished only by the most lavish expenditure of manure. And all experience seems to show that it mnst he manure rich in nitrugen. In the hop districts of Enerland, 25 tons of rich farmyarl-mannre are applicd per acre; and in adlition to this, sont and rags, hoth rich in nitrogen, have long been popmlar anxiliaries. The value of soot is due to the fact that it contaius from 1 is to 15 per eent of sulphate of ammonia, and the fact thit it has heen so long used with suecess as a manure for hops, secms to prove that sulphate of ammonia, which 
can now be readily obtained, (onld be used to adrantage by our hop-errowers-sily at the rale, in aldition to farm-yard minure, of 500 lbs. per acre, sown broulcast carly in the spring.

\section{MANLRES FOR TUBACCO.}

When tobacen is grown for wappers, it is desirable to get a large, strong leaf. The richest lamel is sclected for the cropl, and large quantities of the richest and most stimulating manures are userl.

Like cabbates, this eropr requires a laree amount of plant-food per acre; and, liike them, it can only be grown hy constant and liggh manuring. Ifore manure mut be user than the plants can take up out of the soll, and hence it is, that band which has been used for growing tobaeco for some years, will be in high condition for other erops without further manuing.

Farm-yal or stable-manure, must he the mainstay of the tobacco-planter. With this, he ('an $\|$ artificial fertilizers to advantage - such as fi-h-scrilp, woollen-rags; Piruvian guano, dried bluod, slaurhter-house offal, sulphlate of ammomia, nitrate of soda, etc.

For choier, high-flavored smoking-tobacen, the grower aims to get quality rather than quantity. This sems to depend more on the land and the climate thin on the manures used. Superphosphate of lime would he likely to prove advantageoss in favoring the early growth and maturity of the crop. And in raising tobacco-plants in the seed-brel, I should expect good results from the use of superphosphate, raked in to the soil at the rate of three or four lbs. per square rod.

\section{MANURES FOR INDLAN CORN.}

We know less about the manurial requirements of Indian corn, than of almost any other (rop we cultivate. We know that wheat, barley, onts, and grases, require for their maximum growth a liberal supply of arailable nitrogen in the soil. And such facts and experiments as we have, scem to indicate that the same is also true of Indian corn. It is, at any rate, reasonaible to suppose that, as Indian enrn helongs to the same botanical oriler as wheat, barley, onts, rye, timothy, and other grasses, the general manurial requirements would be the same. Sinch, I presime, is the case; and yet there scem to be some facts that wonlel incline us to place Indian corn with the leguminous plants, such as clorer, peas, and beans, rather than with the cereals, wheat, barler, oats, etc.

"Why so," asked the Deacon, "Indian corn does not have much in common with beans, peas, and clover?" 
As we have slown, clover can get more nitrugen out of the soil, than wheat, barley, and oats. Aml the same is true of beans and peas, thumgh probsaluly not to sio wreat an extent.

Now, it wonll] sem that Indian corn cun gret more nitroren out of at soil, than wheat, harley, or uats-and to this extent, at

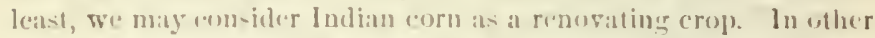

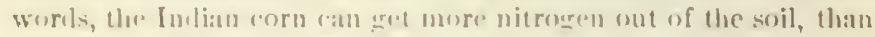
wheat, barley, and oats-and when we feed ont the curn and stalks on the farm, we lave more foud and more manure than if

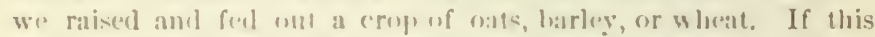

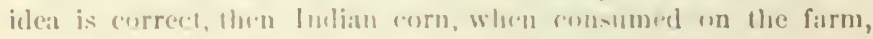

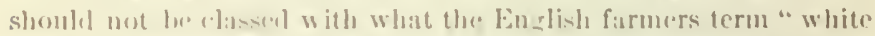

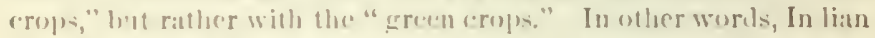

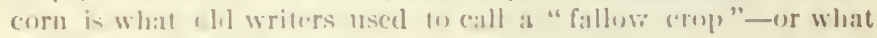
wre r.all a $r$, novaltume (rome.

If this is so, then the erowth and ansiumption of Inclian corn on

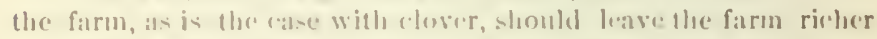
for wheat, rither tham poorer. I do not usean richer absolutely,

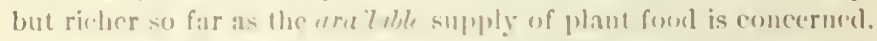

"It may be that you are riglit," sili the boctur, "wlien corn is grown for fuble $r$, hut not when errown for the grain. It is the formation of the sie. w wich exhansts the - gil "

If 1 combl he sure thet it was true of corn-fodder, I should have little doubt that it is true alse of eoru as ordintrily errown for

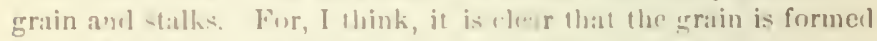
at the experesen of the stalks, and not directly from the soil. The rorn-fordeler will bake from the snil as much nitrogen and phessphorie ateid as l lue erop) of corn, and the more it will take, the more it approvimates in character to clover and uther renovating crops. If comforditer is a renevisting (rop, so) is the ordinary corn-eropl, also, providend it is ronsumed on the f:rm.

"But what make's you think," saicl the Deakn, "that corn can get more nitron a from the soil, than whent?"

"That is the re") point, I) atum," said I, " and I will ask you this question. Suppusery hat a field of whent seeded down to elover, and the elswer failed. After harvect, you plow up laalf of the field and sow it to wheat again, the other half of the ficlil you plow in the spring, and plant with Indian eorn. Now, suppose you get 15 hushels of wheat to the acre, low much corn do you think you would he likely in get ?"

"Well, has ifepends," said the Dracon, "lut I shomld expeet at least 30 bushels of shellem rom prerere."

"Exacty, and I think most farme rs would tell you the same; 
you get twice as much corn amel stalks to the as re at you would of wheat and straw. In other words, while the whe at rannot tind

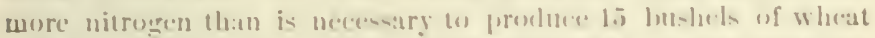
and straw, the com can tind, an l dex- timl, lake up, and organize, at leatst twiec ats much nitrogen an the whe:st."

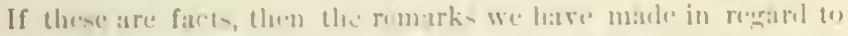
the value of revere as as fertilizing crop, are applicable in mone de-

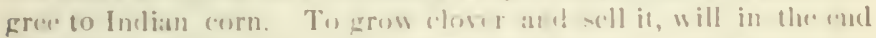

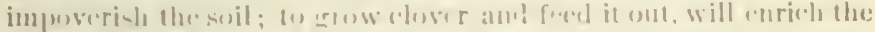

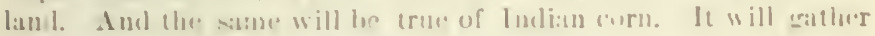

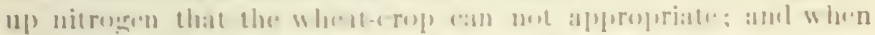

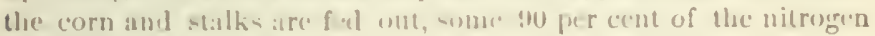
will be left in the mature.

"You do not think, then," sil l the l) x.tur, " Hatt nitregen is sueb an important lemete in manur. for corn, is it is in a manure for wheit."

I lave not sald that. If wo want a larere crople of eorm, we slatll

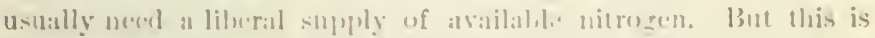

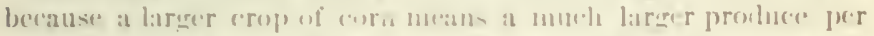

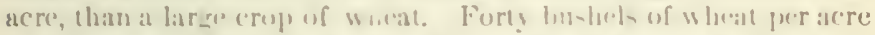

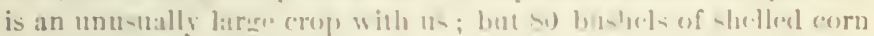

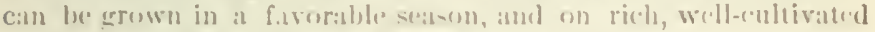

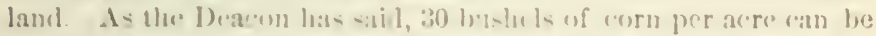

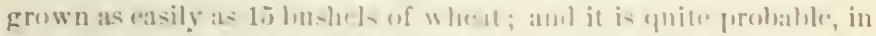

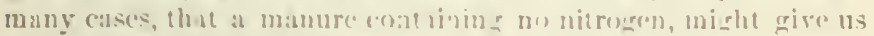

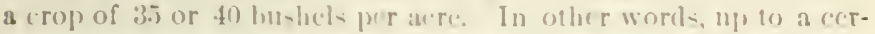

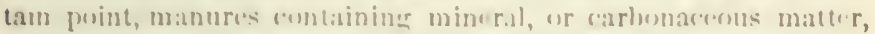
might frequently, in or linery arriculture, increase the viels of fndian corn: while on similar land, steh manures would have little effect on whe.ut.

"That is so," sail the Deneor, "we all know that plofer fre. quently increnses the growtis of curn, while it seldom does much goorl on whent."

But, after you have grot as laree a crop as the land will produce, aided by plaster, aslaes, and superpliosplatie, say 40 busluels of shelled corn per acre, thru if you want to rajec $t 0$ hushels prer arere, you must furnish the soil with manures contaiuing sufficient available nitrogen.

Some years aqo, I made some careful experiments with artificial manures on Indian corn.

"Oh, yes," silil the Deacon, "they were malle nn the south lot, 
in front of iny house, and 1 rerollecet that the $\mathbf{N}$. Y. State $\boldsymbol{\Delta}$ g. Society awa ded you a prize of \$ij, for them."

"And I recollect," sil I 1, "hww you and some other neighbors langhed at me for spending so much time in measuring the land and applying the matnures, and measmring tiec crop. But I wish I conlel have athorded to continue them, A single experiment, however eatrefully mate, can not he dejended on. IIoweser, I will give the results for what they are worth, with some remarks made at the tine:

"The soil on which the exprerinente were mate, is a lizht, sandy

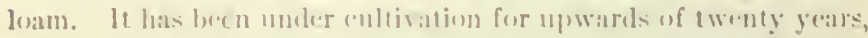

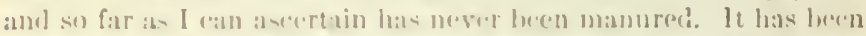
somewlint impurerishent hy the growth of ereal crepse, and it was thonght that for this reason, and on aceount of its light texture and "retive eharacter, which wenld ranse the minures to act immediatrly, it was wrll atlappeel for the purpose of showing the effect

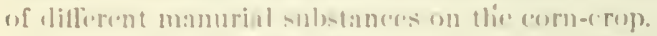

"Th" lamel wise clover-sed, two gears old, pastured the previons summer. It was plowed early in the spriner, and harrowed until

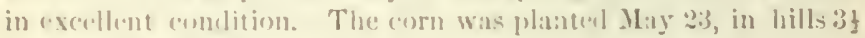
fect apart each way.

"Ther manures were applied in the bill immediately before the secerl wais platisterl.

"With superphosphate of lime, ancl with plaster (eypoum, or

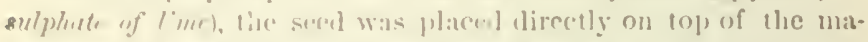
nure, as it is well known that limer manures do not injure the germinating principle of even the s:m-1]le-t sete c!s.

"The ashes were droplud in the hill, and then eovered with soil,

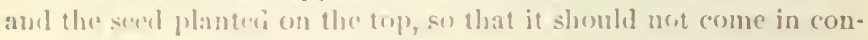
tact with the is:lecs.

" (E)ann and sulphate of ammonia were treate l in the same way.

"()il the plots where ashu's and gurmo, or ashes and sulphate of ammoni: were buth naed, the ashes were tirst gut in the hill, and cosered with soil, and the guano or sulf hate of ammonia placed on the top, and also covered with seil before t?e seced was planted. The ashes and superphorphate of lime wils also trated in the same was. It is well known that unleached ashes, mixed either with guano, sulp'iate of ammonia, or sıperpho-phate, mutually decompose rech other, setting free the ammonia of the suano and sulphate of armmonis, and convertiner the soluble plusplonte of the sug rphusphute of line infor the iasoluble form in which it existed before ireatument with sulphuric acil. All the plots were plantel on the same day, and the manures wi inhed and applied under my 


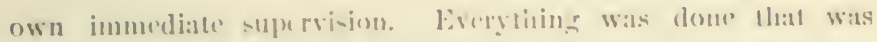

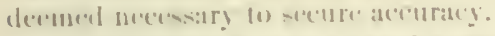

"The folluw ime toble gires the remble of the expriments:

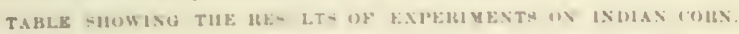

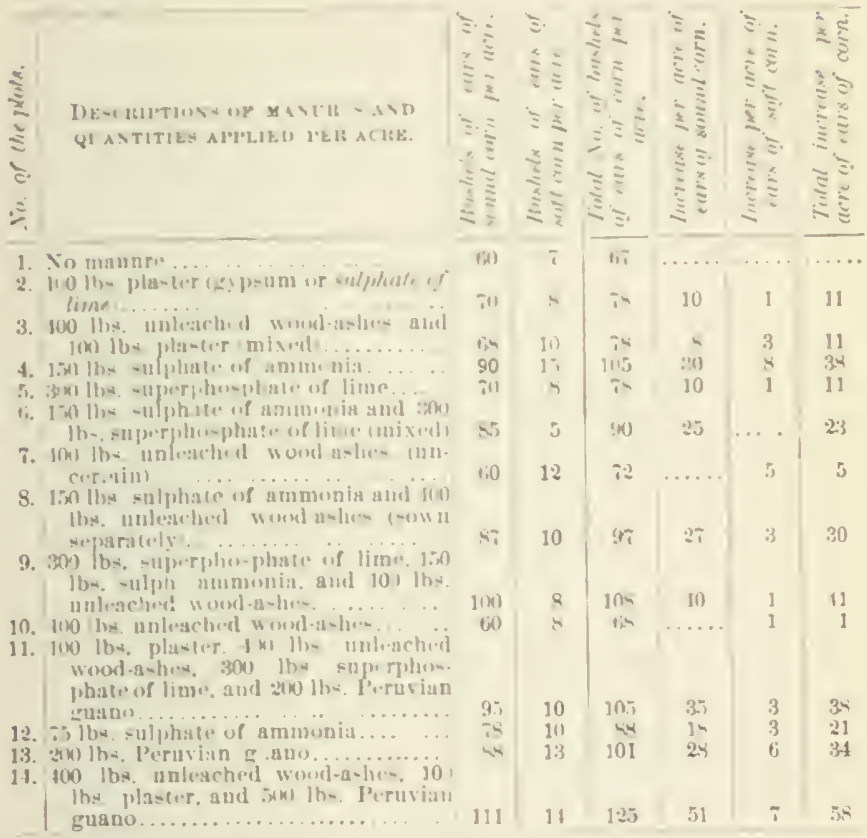

"The superphosplate of lime was made en purpose for these experiments, and was a pure miacral mamure of superior quality, male from calcined lones: il cust about $2 \frac{1}{2}$ chots per pound. The sulpluate of anmonia was a goul, commercial article, obtained from London, at a cost of ahout soven cents per pound. The ashes w-re male from beech and hard maple (Arer siccharinum) wond, and were siftel through a fine sicve hefore heing weighed. The guano was the best Peruvian, costing ahout thre ecents per pound. It was errshed and sifted brefe using. In sowing the ashes on plot $i$, an crror occurred in their application, and for the purpose of checking the result, it was deemed advisable to repeat the experiment on plot 10.

"On plint 5, with 300 lhe. of superphosphate of lime per acre, the plants came up first, and exhibted a heallhy, dark-gruen appear. 
ance, which they retitued for some time. This result was not anticipated, though it is well known that superphosphate of lime has the effect of stimulating the germintition of turnip-secd, and the early growth of the plints to an astonishing degree; yet, as it has no such effect on wheit, it appeared probable that it would not produce this ceffect on Indian corn, which, in chemical composition, is very similar to wheat. 'The result shows how uncertain are all speculations in renard to the manurial requirements of plants. This immediate cifect of sujerpherplate of lime on corn was so marked, that the men (who wrer, at the time of plauting, somewhat inclined to be skeptical, in reigra to the value of sucls small doses of manure), drelared that "superphosphate beats all creation for corn.' The diflience in favor of superphosphate, at the time of horing, was very pereptilhe, even at sume distance.

"Althumple every precaution was taken that was deemed necessary, to prevent the mammes from mixing in the hill, or from injuring the secd, yet, it was found, that those plots dressed with ashes and guano, or with ashes and sulphate of ammonia, were injured to some extent. Shortly after the corn was plinterl, heary rain set in, anil washe l the sulphate of ammonia amel guano, down into the ashes, and mutual deoumpoition tonk plax"c, with more or less loss of ammonit. In adlition to this lu... of ammonia, these manures came up to the surface of the sround in the form of an excrescence, so hard that the plants could with difliculty penetrate through it.

"It will he seen, by examining the table, that althongh the superphospluate of lime hat a gond cffect during the eally stages of the growth of the plints, yet the increase of ears of eurn in the end dill not come up to these early indications. On plot 5, with 300 lhs. of superphosphate of lime per ace, the yield is precisely the same as on plot:, with 100 lbs. of plister (sulphate of lime), per acre. Now, superphosp'ate of lime is composed necessarily of soluble phosphate of lime and plaster, or sulphate of lime, formed from a combination of the sulphuric acid, cmployed in the manufacture of superphosphate, with the lime of the bones. In the 300 lbs. of superphosphiste of line, sown on plot i, there would be about 100 lhs. of plaster; and as the effect of this dressing is no greater than was ohtained from the $100 \mathrm{lbs}$. of plister. sown on plot 2, it follows, that the good effect of the superphosphate of lime was due to the plaster that it eontained.

"A grain, on plot 4 , with 1.50 lhs. of sulpluate of ammonia per acre, we have 90 bushels of ears of sound corm, and 15 bushels of ears of soft corn, ('nubbins,') per acre; or a total increase over the 
plot without manure, of 38 hushels. Now, the suppliate of ammo. nia contains nophosphate of lime, and the fact that snch a manture gives a consiclerable increatse of a rop, contirms the cenclusion we have arrived at, from a (omplarison of the results on plots ? and 5 ; that the increase from the supurphosphate of lime, is not dne to the phosphate of lime which it contains, unless we ar" to conclude that the sulphate of ammonia renderet the phojplate of line in the soil more rendily suluible, and thus furnished an inereased quatuty in an avaliable form for assimilation by the ylantsa conclusion, which the results with superphosphate alone, on plot $\tilde{y}_{\text {, and }}$ with superphosphate and suphate of ammonia, cors. bined, on plot 6 , do not sustain.

"On plot 12, half the quantity of sulpuate of ammonia, was used as on plot 4 , and the iucrease is a litte more than hald what it is where donble the ynantity wats usted. Arain, on plet 13, 200 lba. of Perurian guane juerace, gives nearly as treat an increase of sound corn, as the $150 \mathrm{lbs}$ of sulplate of ammonia. Now, $200 \mathrm{lbs}$. of Peruvian guanu ("outains nearly as mueh ammonia as 150 lbs. sulphate of amnonia, anil the increase in hoth "asc's is eridently due to the ammoniat of these maneres. The 200 lls. of Peruvian guano, contained alwut io lhs. of phesphate of lime; luat as the sulphate of ammonia, which contains mo phosplatle of lime, gives as great an increise as the guamo, it follows, that the phesplate of lime ix the guano, hat little, if any cflect; a result precisely similar to that obtained with superphosphate of lime.

"Vie may conclude, therofore, that on this soil, which has never been manured, and which has bren cultivated for many years with the Ceruliu-or, in other words, with erops which remove a laree quantity of plospluate of lime from the soil-the phosplate of lime, relatively to the ammonili, is not deficient. If such was not the case, an applieation of soluble phosphate of lime would have given an increase of crop, which we have shown was not the case in any ne of these experiments.

"Plot 10, with 400 lbs of unleached wood-ashes per acre, produces the same quantity of sonend corn, with an extra bushel of 'nubbins' per acre, as plot 1 , without any manure at all; ashes, therefore, applied alone, may he said to have had no eflect what. ever. On plot $3,400 \mathrm{lbs}$ of ashes, and $100 \mathrm{lbs}$. of plaster, gire tho same total mumber of busliels per acre, as plot 2 , with 100 lhs. of plaster alone. Plot 8, with 400 lhs. ashes, and 150 lhs. of sulplate of ammonia, yicels three buslıels of sound corm, and fire bushels of 'nubbins' per acre, less than plot 4, with 1.50 lbs. snlphate of 
ammonia alone. 'This result may be ascribed to the faret previously alluded to - the ashes dissipated some of the ammonia.

"Ilot 11, with 100 llos. of plaster, 400 lbs. aslies, 300 lbs. of superphosphate of lime, and $\approx 0 C$ lhs. Peruvian gruano (which contains about as much ammonia ats 1.50 lhs. sulphate of ammonia), proluced precisely the sime mumber of total bushels per acre, at plot 4, with $150 \mathrm{lbs}$ sulphate of ammonia alone, and but 4 bushels more per acre, than plot 13, with 2001 lbs. Peruvian guano alone. It is evident, from theis results, thit neither ashes nor phespliates had mach affect an Indian corn, on this impurerished sonil. Plot 14 re-

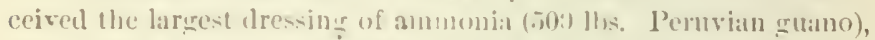

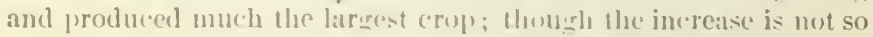
great in proportion to the gratao, as where smaller quantities were used.

"The manue which produced the most profitable result, was the $100 \mathrm{lbs}$ of plist('), on plut :. The $200 \mathrm{lhs}$ of Peruvian guano, on plot 1:3, and which cost albout sili, gave an increase of 14 bushels of shelled corm, and b hushels of 'mubhins.' This will pay at the present price of eorn in liocluester, althengly the profit is not very great. The superphosplatte of lime, althongh a very superior article, and estimated at cost price, in no calse pitid for itsclf. "The same is true of the asices.

"But the olyject of the experiment was not st much to ascertain what manures will pay, but fo ascertain, if pesihle, what comstitu. ents of manures ase recpuresl, in greatest quantity, for the maximum growth of corn. * * Hithelto, no experiments lave been made in this comntry, on Indlim corm, that itforded any certain information on this point. Indered, we helieve no satisfactory experiments have been male on Intian com, in any country, that throw any definte light on this interestin and important question. A few years ago, Mr. Lawes made similar experiments to those given above, on lis farm, at Rothamsted, Eneland; lut owing to the coolness of the English clinate, the (rop dis not arrive at maturity.

"Numerous experiments have heen mate in this country, with guano and superphosphite of lime; but the siperplusphates used were commereial artieles, contining more or less ammonia, and if they are of any benefit to those (rope to which they are applied, it is a matter of uncertainty whether the lonefieial effect of the application is tue to the solnhle phosphate of bime, or to the ammonia. On the other hand, gntumo contuins hoth ammenia and plinsphate; and we are eqtally at a lose (n) determine, whether the effect is attributable to the ammonia or phosphate, or hoth. In order, therefore, to determine satisfacturily, which of the sereral ingredieuts 
of plants is rectumel in erratest proportion, for the maxmmum growth of any partientu crep, wr must ipply these ingredients separately, or in such definite compunuls, as will enable us tu determine to what particular element or compumds the heneficial effect is to be ascribed. It was for this reison, that sulplate of ammonit, and a purely mineral superphosplute of lime, were usel in the above "xperiments. No one would think of using sulphate of ammonia at its price, [sulphute of ammonia is now cheaper, while Peruvian guano is more cuatly and less rich in ammonia], as an ordinary manure, for the reasom, that the same quantity of ammonia can be ohtaned in other sulstances, such as barmyard-manure, Perurian guano, ete., at a unull cheaper rate. But these manures contain all the elements of planti, ansl we can not know whether the effect proluerd by them is clue to the ammonia, phospluates, or any other ingredients. For the purpose of experiment, therefore, we must use a manure that furnishes ammonia without any admixture of plon-phates, potash, soda, lime, magnesia, cte, even though it cost muld more than we could ubtain the same amount of ammonia in other mamures. I make the remarks in order to correct a rery common opinion, that if expriments do not pay, they are useles. The ultiuate ohject, inteed, is to ascertain the most protituble method of manuring; but the means of obtaining this information, can not in all cases be profitable.

"Similar experiments to tlose male ou Indian eorn, were made on soil of a similar claracter, on about an acre of Chinese sugarcane. I do not propose to give the results in detail, at this time, and allude to them merely to meution one very important fact, the superphosphate of lime lud "r ry murked effect. This manure was applied in the hill on one plot (the twentieth of an acre, at the rate of $400 \mathrm{lhs}$. per acre, and the plants on this plut came up first, and outgrew all the others from the start, and ultimately attained the height of ahout ten feet; while on the plot receiring no manure, the plants were not five feet high. This is a result entirely different from what I should have expected. It has been supposed, from the fact that superphosphate of lime had no effect on wheat, that it would probably hare little effect on corn, or on the sugalcane, or other ceralin; and that, as smmonia is so beneficial for wheat, it would probably be beneficial for corn and sugar-cane. The abore experiments inclicate that such is the case, in regard to Indian corn, so far as the production of grain is concerned, though, as we hare statel, it is not true in reference to the earls growth of the plants. The supeppusplaate of limeon Indian corn, stimulated the growtl: of the plants, in a very lecided manner at first, so 
muels so, that we were led to suppose, for some time, that it would give the largest crop'; but at harrest, it was found that it produced no more corn than plaster. These results seem in indicate, that superphosphate of lime stimulates the grow th of stalks and ieaves, and has little effect in increasing the proluction of seed. In raising Indian corn, for fockler or for soiling purposes, superphosplhate of lime may he beneficial, as well as in growing the sorghum for sugarmaking purposes, or for fouldder-tlough, perhaps, not for seed."

"In addition to the experiments given above, I also made the same seatson, on an adjoining fickl, another set of experiments on Indian corn, the results of which are griven below.

"The land on which these experiments were maie, is of a somewhat firmer texture than that on which the other set of experiments was made. It is situated about a mile from the barn-yard, and on this account, has scldom, if ever been manured. It has heen cultivated for many" rears with ordinary farm crops. It was plowed early in the spring, and it was harrowed until quite mellow. The corn was planted May 30, 18.5\%. Each experiment occupied one-tenth of an acre, eonsisting of 4 rows $3 \frac{1}{2}$ feet apart, and the same distance between the hills in the rows, with one row without manure hetween each experimental plot.

"The manure was applied in the hill, in the same manner as in the first set of experiments.

"The barnyard-manure was well-rotted, and consisted principally of cow-dung with a little horse-dung. Twenty two-horse wagon loats of this was applied per acre, and each load would probably weigh about one ton. It was put in the hill and corered with soil, and the secd then planted on the top.

"The following table gives the results of the experiments:

TABISE SIIOWING THE RE-ULT, OF EXPERIMENT ON INDIAN CORN, MADE NEAR ROCIIESTER, $X$. $Y$, IN THE YFAR $155 \%$.

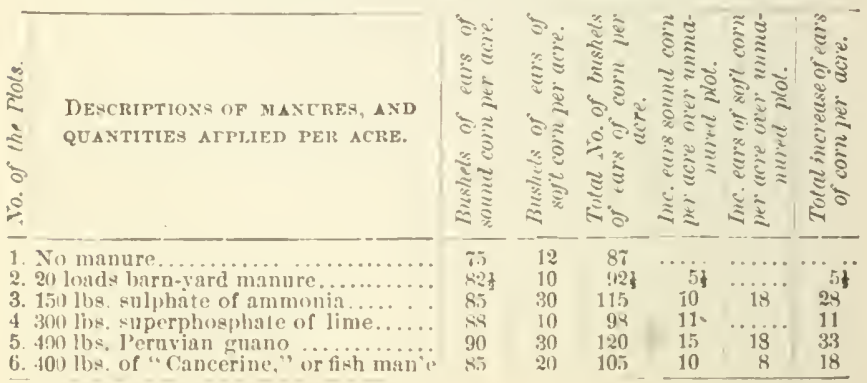


*s before stated, the land was of a strunger mature thatn that on which the tirst sut of experiments wat narle, ancl it was evi. dently in better comelition, ats the plot ly"ving no manure prociuced 20 bushels of ears of corn per acre more than the plot without manure in the other field.

"On plot 4, 300 los. of superpliosphate of 'ime gires a total increase of 11 bushels of ears of corn per acie ower the unmanured plot, agreeing exactly with the increase olutained from the same quantity of the same manure on plot 5 , in the fisst set of experiuents.

"Plot 3, dressed with 150 lbs. of sulphate of ammonia per aere, gives a total increase of 28 hushels of earsof corn per acre, over the unmanured plot; and an incruse of 2.21 buscls of ears per acre over plot 2 , which received 20 loads of goml, well-rotted harnyart-dung per acre.

"Plot 5, with 400 lls. of Peruvian cuano per acre grives the best crop of this scries riz: an increase of 303 lushels of corn per acre over the unmanurul plot, and 2 if $_{2}$ over the plot manured with 20 loats of barnyaril-ilung. The 100 lbs. of 'Cancerine '-an artificial manure male in New Jersey from fish-urives a tolal increase of 18 lushels of ears per acre over the ummanumed plot, and $12 \frac{1}{2}$ bushels more than that manured with barn-yald dung, though 5 bushels of ears of sound corn and 10 hushels of 'nubbins' per acre less than the same quantity of Peruvian sruano."

\section{IINLRES FOR TLRNIPS,}

To raise a large crop of turnips, especially of ruta-bagas, there is nothing better than a liberal application of rich, well-rotted farmyard-manure, and 250 to 300 lbs. of good superplospluate of lime per acre, drilled in with the seed.

I hare seen capital crops of common turnips grown with no other manure except 300 lbs. of superph spluate per acre, drilled with tha seed. Superphosphate has a wonderful effect on the development of the ronts of the turnip. And this is the secret of its great value for this crop. It increases the growth of the young plant, dereloping the formation of the roots, and when the turnip once gets full possession of the soil, it appropriates all the plantfood it can find. A turnip-crop grown with superplosphate, can get from the soil mixch more nitrogen than a crop of wheat. The turnip-crop, when supplied with superphosphate, is a good "scavenger." It will gather up and organize into good food the refuse plant-food left in the soil. It is to the surface soil, what clorer is to the subsoil. 
To the market gardener, or to a farmer who manures heavily, common turnips drilled in with superphosphate will prove a valuable crop. On such lind no other maunre will be needed. I cannot too earnestly recommend the use of superphosphate as a manure for turnips.

For Swelle turnips or rut:-bagas, it will usually be necessary, in order to secure a maximum crop, to use a manure which, in addition to superphosphate, contains avialible nitrogen. A good dressing of rich, well-rotted manure, spread on the land, and plowed under, and then 300 los. of superphosphate drilled in with the seed, would be likely to give a good crop.

In the alseuce of manure, there is probably nothing better for the ruta bagas than 800 lbs. of si-called "rectified" Peruvian guano, that is, guano treatel with sulphuric acid, to render the phosphates soluble. Such a gruano is guaranted to coutain 10 per cent of ammonia, and 10 per ("nt of soluble phosphoric acid, and woull be a good iressing for Swele turnips.

The best way to use guano for turnips is to sow it broadcast on the land, and loarrow it in, and then either drill in the turnip-seed on the flat, or on ridges. The latter is decidedly the better plan, provided you have the necessary injlements to do the work expeditiously. A donble mould-board plow will ridge up four ares a day, and the guano being previously sown on the surface, will be turned up with the mellow surfice-soil into the ridge, where the seel is to be sown. The young plants get hold of it and grow so rapidly as to be soon out of danger from the turnip-beetle.

\section{MANURES FOR MANGEL-TWLRZEL OR SUGAR-BEETS.}

When sugar-beets are grown for feecling to stock, there is probably little or no lifference in the manurial requirements of sugarbeets aud maugel-wurzcl. Our object is to get as large a growth as possible consistent with quality.

"Large roots," saill the Deaenn, "have been proved to contain less nutriment than small roots."

True, but it does not follow from this that rich land, or lueary manuring is the chief cause of this difference. It is much more likely to be due to the variety selected. The seel-growers liave been breeding so'ely for size and shipe. They have succeeded to such an extent that 84 gross tons of roots hare been grown on an acre. This is equal to over 94 of our tons per acre. "That is an enormous "rop," said the Deacon; "and it would require some lahor to p:It 10 acres of them in a "cllar."

"If they were as mutritious as ordinary mangels," sald I, "that 
woull be no argument agrinst tliem. But such is not the case. In a letter just reccived from Mr. Lawes, (May, 1878, he characterizes them as "hludders of water and salts.,"

Had the seed growers bred for quelity, the roots woukl have been of less size, but they would contaim more nutriment.

What: we want is a varicty that has been breal with reference to quality; and when this is secured, we need not fear to make the land rich and otberwise aim to secure great growth and large-sized roots.

It certainly is not good economy to select a variety which las been bred for years to produce large-sized routs, and then sow this seed on poor land for the purpose of obtaining small-sizud rootg. Better take a variety bred for quality, and then malke the land rich enough to produce a guod erop.

We are not likely to err in making the land too rich for mangelwurzel or for sugar-beets grown for stock. When sugar-heets are grown for sugar, we must aiu to u-ce manures favorable for the production of sugar, or raihcr to avoid using those which are unfarorable. But where sugar-bects are grown for food, our aim is to get a large amount of nutriment to the acre. And it is by no means clear to my mind that there is much to be gained ly selecting the sugar-liect insteal of a good raricty of maned-murzel. It is not a difficult matter, by selecting the largest roots for seed, and by liberal manuring, and continuously selecting the largest roots, to conrert the sugar-beet into a mangel-wurzel.

When sugar-bects are grown for food, we may safely manure them as we would mangel-wurzel, and treat the two crols precisely alike.

I usually raise from ten to fifteen acres of mangel-wurzel every year. I grow them in rotation with other crops, and not as the Hon. Harris Lewis ancl some others do, continuously on the same land. Te manure liberally, but not extravagantly, and get a fair yield, and the land is left in almirable condition for future crops.

I mean by this, not that the land is specially rich, but that it is very clean and mellow.

"In 10\%," said the Deacon, "you had potatoes on the Iand where you grew mangels the previous year, and had the best crop) in the neighborhood."

This is true, but still I do not think it a good rotation. A harley crop seeded with elover would be better, especially if the mangels were hearils manured. The elover would get the manure which had been washed into the sulsoil, or left in such a condition that potatoes ar grain could not take it up. 
There is one thing in relation to my mangels of $18 j 6$ which has escaped the I)eacon. The whole piece was manured and well prepared, and ibliled in witl mangels, the rows being $2 \frac{1}{2}$ fect apart, and the seed dropped 15 inches apart in the rows. Owing to poor seed, the mangels failed on about three acres, and we plowed up the land and clrilled in corn for fockler, in rows $2 \frac{1}{2}$ feet apart, and at the rate of over three bushels of seed per acre. We had a great crop of corn-fodder.

The next year, as I said before, the whole piece was planted witl potatoes, and if it was true that mangels are an "enriching crop," while corn is an "exhausting" crop, we onght to have had much better potatoes after the mangels than after corv. This was certainly not the case; if there was any difference, it was in favor of the corn. But I do not plite any confidenee in an experiment of this kind, where the crops were not weighed and the results carefully ascertained.

Mr. Lawes lias mate some most thorough experiments with different manures on sugar-beets, and in 1870 he commenecd a series of experiments with mangel-wurzcl.

The land is a rather stifl clay loam, similar to that on which the wheat and barley experiments werz made. It is better suited to the growth of beets than of turnips.

"Why sn," asked the Deatcon, "I thought that black, bottom land was hest for mangels."

"Not so, Deacon," said I, "we can, it is true, grow large crops of mangels on well-drined and well-manured swampy or hottom land, but the hest snil for mangrels, especially in recrard to quality, is a gond, stiff, well-worked, and well-manured loam."

"And yet," said the Deacon, "you hate a better crop last year on the lower and blacker portions of the field than on the heavy, cliyey land."

In one sense, this is true. We lad dry weather in the spring, and the maned sect on the dre, clayey land dicl not come up as well as on the cooler and moister hottom-land. We land more plants to the acre, hut the ronts on the clayes land, when they onee got fair hold of the soil ind the manue, grew larger and better than on the lighter and moister lind. The great point is to gret this heay lamk into a fine, mellow conclition.

But to Mr. Lawes' experiments. They are remarkably interesting aud instructive. But it is not necessary to go into all the details. Suflee it to say that the experiments seem to prove, very couclusively, that beets recuire a liberal supply of available nitro- 
gen. Thus, without manure, the yield of beets was ahout $7 \frac{1}{2}$ tons of bulbs per acre.

With $550 \mathrm{lbs}$ nitrate of sodil ner acre, the yicld was a little over 22 tons per acre. With 14 tons of farmyard-inanure, 18 tons per acre. With 14 tons of farmyard manure and 550 lbs. nitrate of soda, orer $2 \tau^{t}$ tons per acre.

Superphosphate of lime, sulpliates of potash, soda, and magnesia, and common salt, alone, or with other manures, had comparatirely little effect.

Practically, when we want to grow a good crop of beets or mangels, these experiments prove that what we noed is the richest kind of barnyard-manure.

If our manure is not rich, then we should use, in addition to the manure, a dressing of nitrate of sola-say 400 or 500 liss. per acre.

If the land is in pretty good condition, and we have no harnyard-manure, we maly look for a fair (rop from a dressing of nitrate of soda alone.

"I sce," said the I)eacon, "that 550 lhs. of nitrate of soda alone, gave an increase of $14 \underline{t}$ tons per acre. And the following year, on the same land, it gave an increase of $13 \frac{1}{2}$ tons; and the next year, on the same land, nver 9 tons."

"Yes," saill 1, "the first three years of the experiments (18r1-2-3), 550 liss. of nitrate of sodia alone, applied every year, gave an arerage yield of $19 t$ tons of bulbs per acre. During the same three years, the plot dressed with 14 tons of barnyarl-manure, gave an arerage yicll of $16+$ tons. But now mark. The next year (1874) all the plots were left without any maure, and the plot which had been previously lressed with nitrate of soda, alone, fell off to 3 tons per acre, while the plot which hal been previonsly manured with barnyard-manure, produced $10 \frac{3}{4}$ tons per acre."

"Good," said the Deacon, "there is nothing like manure."

\section{MANURES FOR CABBAGE, PARSNIPS, CARROTS, LETTLCE,} ONIONS, ETC.

I class these plants together, because, though differing widely in many respects, they have one feature in common. They are all artificial productions.

$A$ distinguished amateur horticulturist once said to me, "I do not sec why it is I have so much tronble with lettuce. My land is rich, and the lettuce grow well, but do not lieal. They bave a tendency to run up to seed,and soon get tough and hitter."

I advised him to raise his own seed from the best plants-and especially to rejeet all plants that showed any tendency to go pre13 
maturely to seed. Furthermore, I told him I thought if he would sow a little superphosphate of lime with the seed, it would greatly stimulate the ectrly grow th of the lettuce.

As I lave said before, superphosphate, when drilled in with the seed, has a wonderful effect in developing the root-growth of the young plants of turnips, and I thought it would have the same effect on lettuce, cabhage, cauliflowers, etc.

"But," said he, "it is not routs that I want, lut heads."

"Exactly," said I, "you do not want the plants to follow ont their natural disposition and run up to seed. You want to induce them to throw out a great abundance of tender leaves. In other words, you want then to 'Lead.' Just as in the turnip, you do not want them to run up to seed, but to produce an unnatural development of 'bulb.'"

Thirty years :1go, Dr. Gilbert threw out the suggestion, that while it was evident that turnips required a larger proportion of soluble phosphates in the soil than wheat; while wheat required a larger proportion of available nitrogen in the soil, than turnips, it was quite probable, if we were growing turnips for sced, that then, turnips would require the same kind of manures as wheat.

We want exceedingly rich land for calbage, especially for an early crop. This is not merely because a large crop of cabbage takes a large amount of plant-fond out of the soil, but because the cultivated cablbage is an artificial plant, that requires its food in a concentrated shape. In popular language, the plants have to be " forced."

According to the analyses of Dr. Anderson, the outside leares of cabhage, entain, in round numbers, 91 per cent of water; and the heart leaves, $94 \frac{1}{2}$ per cent. In other worls. the green leaves contain $3 \frac{1}{2}$ per cent more dry matter than the heart leaves.

Dr. Veleker, who analyzed more recently some "cattle-cabbage," found $89 \frac{1}{2}$ per cent of water in the green leares, and 83 ? per cent in the heart and inner leaves-thus confirming previous analyses, and showing also that the comprosition of cabbages varies considerably.

Dr. Tolcker found much less water in the cabbage than Dr. Anderson.

The specimen analyzed by Dr. V., was grown on the farm of the Royal Ag. Collere of Englan', and I infer from some incidental remarks, that the erop was srown on rather poor land. And it is probably true that a large crop of (abbage grown on rich land, contains a higher percentage of wate than cabbage grown on poorer 
land. On the poor lind, the cabbage would not be likely to head so well as on the rich land, and the green leares of cabbage contain more than half as much again real dry substance as the heart leares.

The dry matter of the heart leaves, however, contains more actual nutriment than the dry matter of the green leaves.

It would seem rery desirable, therefore, whether we are raising cabbage for market or for home consumption, to make the land rich enough to grow good heads. Dr. Velcker says, "In orlinary seasons, the arerage produce of Swedes on our poorer fields is about 15 tons per acre. On weighing the produce of an acre of cabbage, grown under similar eireumstances, I found that it amounted to $1 i_{2}$ tons per acre. On good, well-mauured fields, however, we have had a much larger produce."

In a report on the "Cultivation of Cabbage, and its comparative Value for Feeding purposes," ly J. II. M'Laren, of Scotland, the yicld of Swele turnips, was 29 tons per acre, and the yield of cabbage, 4 i⿱ lons per acre.

"It is rery evident," sail the Deaenn, "that if you grow cabbage you should make the lind rich enough to produce a good cropand I tuke it that is all you want to siow."

"I want to show," I replied, "that our market gardeners have reason for applying such apparently excessive dressings of rich manure to the cabbage-crop. They find it safer to put far more manure into the land than the crop can possibly use, rather than run any risk of getting an inferior crop. An important practical question is, whether they ean not grow some crop or crops after the cabbage, that can profitably take up the manure left in the soil."

Prof. E. Wolff, in the last edition of "Praktische Düngerlelıre," gives the composition of cabbage. For the details of which, see Apperdix, page 345 .

From this it appears that 50 tons of cabbage contain 240 lbs. of nitrogen, and 1,600 lbs. of ash. Included in the ash is $630 \mathrm{ll} / \mathrm{s}$. of potash; $90 \mathrm{lbs}$. of soda; $310 \mathrm{lbs}$. of lime; $60 \mathrm{lbs}$. of magnesia; 140 lbs. of phosphoric acid; 240 lbs. of sulphuric acid, and 20 lbs. of silica.

Henderson, in "Gardening for Profit," adrises the application of 75 tons of stable or barn-yard manure per acre, for carly cabbare. For late cabbage, after peas or early potatoes, he says about i0 tons per acre are used.

Brill, in "Farm Garlening and Seed Growing," also makes the same distinction in regard to the quantity of manure used for early 
and late cabbage. He speaks of 70 to 80 tons or more, per acre, of well-rotted stable-manure as not an unusual or excessive dressing every year.

Now, accorling to Wolff's table, ij tons of fresh stable-manure, with straw, contaius $820 \mathrm{lls}$. of nitrogen; $795 \mathrm{lbs}$. of potash ; 150 lbs. soila; $315 \mathrm{lbs}$ of lime; $210 \mathrm{lus}$. of magnesia ; $420 \mathrm{lbs}$. of phosphoric acid ; 105 lbs. sulphuric acid ; $2,6.55 \mathrm{llhs}$. of silica, and $60 \mathrm{lus}$. of chlorine.

"Put the figures side by side," said the Deacon, "so that we can compare them."

Here they are:

\begin{tabular}{|c|c|c|}
\hline & $\begin{array}{l}\text { is tons } \\
\text { Fresh Ilorse } \\
\text { I/unure. }\end{array}$ & $\begin{array}{l}50 \text { tons } \\
\text { Cabbage. }\end{array}$ \\
\hline 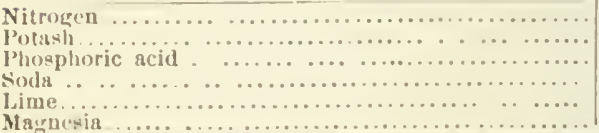 & 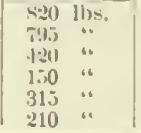 & 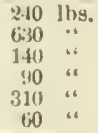 \\
\hline
\end{tabular}

"That is rather an interesting talle," saicl the Doetor. "In the case of lime, the crop takes ahout all that this heary dressing of manure supplies-but I suppose the soil is usually eapable of furnishing a consillerable quantity."

"That may be so," said the Dearon, "but all the authorities on market garlening speak of the impurtanee of either growing eal)batre on lan 1 containing lime, or else of applying lime as a manure. Quinn, who writes like a sensible man, says in h's book, "Money in the Garten,' 'A top-ilressing of lime every third year, thirty or forty busliels per acre, spreal broaleast, and harrowed in, just before planting, pays hamisonncly."

Henderson thinks cabbage can only be grown successfully on land containing abundance of lime. II has used heary dressings of lime on land which did not conticin shelle, and the result was satisfactory for a time, but he found it too expensive.

Experience seems to show that to grow large erops of perfeet cabbage, the scil must be liberally furnished with manures rich in nitrogen and phosphorie acid.

In saying this, I do not orerlook the fact that cabbage require a large quantity of potish. I think, however, that when large quanlities of stable or burn-yarl lianure is used, it will rarely be found that the soil lacks potash.

What we need to grow a large crop of cabbage, is manure from well-fed animals. Such manure can rarely be purchased. Now, the difference between rich minure and ordinary stable or barn- 
yarl-manure, consists principally in this: The rich manure contains more nitronen and phosphoric acil than the orlinary stablemanure-and it is in a more available condition.

To convert common manure into rich manure, therefore, we must add nitrogen and phosphoric acid. In other words, we must use Peruvian guano, or nitrate of sodia and superptusphate, or bonedust, or some other substance that! will furnish avalable nitrogen and phosphoric acil.

Or it may well be, where stable-manure can be bughlut for $\$ 1.00$ per two-horse load, that it will be cheaper to use it in largere quan. tity rather than to try to makc it rich. In this (ase, however, we must emeleavor to follow the cabbige hy sume crop that has the power of taking up the large quantity of nitrogen and other plantfood that will be lett in the soil.

The cabbage needs a large supply of nitrogen in the soil, but removes comparatirely little of it. We see that when 75 tons of manure is used, a crop of $j 0$ tons of cabbiage talies ont of the soil less than 30 per cent of the nitrogen. And yet, if you plant calbbage on this laud, the next y'ar, without manure, gou would get a small (rop.

"It canuot be for want of nitrogen," saicl the Deacon.

"Yes it can," saill 1. "The cabbige, esprecially the early kinds, must have in the soil a much larger quautity of available nitrogen than the plints can use."

I do not mean by this that a large crop of eabhage could be raised, year after year, if furnished only with a large supply of available nitrogen. In such a case, the soil would soon lack the necessary inorganic ingredients. But, what I mean, is this: Where land has been hearily manued for some years, we could oftem raise a good crop of cabbage by a liberal (Iressing of a vailable nitrogen, and still more frequently, if nitrogen and phosploric acid were both used.

You may use what would be considered an excessive quantity of ordinary stable-manure, and grow a large crop of cabbaze; but still, if you plant cablage the next year, without manure of any kind, you will get a small crop; but dress it with a manure containing the necessary amount of nitrogen, and you will, so far as the supply of plant-food is coneerned, be likely to get a grood crop.

In such cireumstances, I think an application of 800 lbs. of nitrate of soda per acre, costing, say $\$ 32$, would be likely to afford a very bandsome profit.

For lettuce, in addition to well prepared rich iand, I should sow 3 lbs. of superphosphate to eac's squiare rod, seattered in the rows 
before drilling in the seed. It will faror the formation of fibrous ronts and stiunulate the growth of the young plants.

In raising onions from seed, we repuire an abundance of rich, well-rotted manure, clean lant, and early sowing.

Onions are often raised year after yeur on the same land. That this cutails a great waste of manure, is highly probuble, hut it is not an easy matter to get ordinary farm-land properly prepared for onions. It needs to be clean and free from stones and rubbish of all kinds, and when once it is in good conclition, it is thought better to continue it in onions, even thourgl it may entail more or less loss of fertility.

"What do you mean," asked the Deacon, "hy loss of manure?"

"Simply this," saidl. "We use a far grenter amount of plantfood in the shape of manure than is removed by the erop of onions. And yet, notwithstanding this fact, it is found, as a matter of experience, that it is absolutely necessary, if we would raise a large and profitah] e crop, to manure it every yar."

A few experiments would throw much linht on this matter. I should expect, when l:and had been heavily dressed every year for \& few years, with stable-manure, and ammully sown to onions, that $800 \mathrm{ll}$ s. of sulphate of ammonia, or of nitrate of soda, or 1,200 lbs. of Peruvian guano would give as groud a crop as 25 or 30 tons of manure. Or perhaps a better plan would be to apply 10 or 15 loals of manure, and 600 llss. of guano, or $400 \mathrm{ll}$ s. sulphate of ammonia.

\section{II $\perp$ P T E IR X X X V. \\ IANURES FOR GARDENS AND ORCIIARDS.}

\section{YANLRE FOR MARKET-GARDENS.}

The chief dependence of the market gardener must be on the stable-manure which he can obtain from the city or village. The chief defect of this manure is that it is sot rich enough in aviliable aitrogen. The active nitrogen exists principally in the urine, and this in our city stables is largely lost. $\Lambda$ ton of fresh, unmixed horse-dung contains about 9 lbs. of nitrogen. A ton of horse-urine, $31 \mathrm{lbs}$. But this does not tell the whole story. The nitrogen in the dung is contained in the rrude, undigested portions of the food. It is to a large extent insoluble and unavalable, while the nitrogen in the urine is soluble and active. 
The matrket-gradedenere, of course, hats to talie surde manure as he can gret, and the only points un be considered are (1), whether he had better continue to use an excessive quantity of the manure, or (2), to buy substances rich in available nitrogen, and either mix them with the manure, or apply them separately to the soil, or (3), whether he ean use this horse-manure as bedeling for pigg to be fed on rich nitrogenous food.

The latter plan I adopt on my own farm, and in this way I get a very rich and active manure. I get avalable nitrogen, plosploric acill, and potash, at far cheaper rates than they can be purchased in the best enmmercial fertilizers.

Pigs soid a large amount of urine, and as pirs are ordinarily kept, much of this liquid is lost for want of suflicient bedeling to absorb it. With the marketerardener or nurseryman, who draws large quantities of horse-mmure from the eity, this need not be the case. The necessary buildings can be constructed at little cost. and the horse-manure can be used frecly. The pigs slonuld be fed on food rich in nitrogen, such as bran, malt-combs, hrowers' grains, the refuse animal matter from the slamithter-houses or butchers' stores, fish scrap, pea or lentil-meal, pahm-nut cake, or such food as will furush the most nitrogenous food, other things being equal, at the cheapest rate.

The market-garilener not only requires large quantities of rich manure, but he wants them to act quickly. The nurseryman who sets out a block of trees which will oceupy the ground for three, four, or five years, may want a "lasting manure," but such is not the ease with the gardener who grows crops which he takes off the land in a few months. As long as he continues to use horse or cow-manure freely, he need not tronble himself to get a slow or lasting manure. His great aim should be to unake the manure as actire and arailable as possible. And this is especially the case if he occupies clayey or loamy land. On sandy land the manure will decompuse more rapilly and act quicker.

"There are many facts," saicl the Doctor, "that show that an artificial appleation of water is equiralent to an applieation of manure. It has been shown that market-gardeners find it necessary to apply a mueh larger amount of plant-food to the soil than the crops can take up. This they have to do year after year. And it may well he that, when a supply of water can be bad at slight eost, it will be cheaper to irrigate the land, or water the plants, rather than to furnish such an excess of manure, as is now found necessary. Even with ordinary farm-erops, we know that they feel the effects of drouth far less on rich laud than on poor land. In 
other words, a liberal supply of plant-fond enables the crops to flourish with less water; aml, on the other hand, a greater supply of water will enable the crops to tlourish with a less supply of plant-food. The market-gardeners should look into this question of irrigation.

\section{MANURES FOR SEED-GROWING FARMS.}

In growing garlen and regetable seeds, much labor is necessarly employed per ace, and consequently it is of great importance to protuce a good yield. The best and cleanest land is necessary to start with, and then manures must be appropriately and freely used.

"But not too freely," said the Doctor, "for I am told it is quite possible to have lind too rich for seed-growing."

It is not often that the land is too rich. Still, it may well be that for some crops too much stable-manure is used. But in nine cases out of ten, when such manure gives too much growth and too little or too poor seed, the trouble is in the quality of the manure. It contains too much carbonacons matter. In other words, it is so pow in nitrogen and phosphoric acid, that an excessive quantity has to be used.

Theremely consists in making richer manures and using a less aunatity, or use half the quantity of stable-manure, and apply the rectified or prepared Peruvian guano, at the rite of 300 lbs. or 400 lbs. per acre, ol suy $200 \mathrm{lbs}$. stuperphosplute and 200 lbs. nitrate of soda per acre.

Where it is very important to have the seeds ripen early, a liberal dressing, say 400 lhs. per acre, of superphosphate of lime, will be likely to prove benricial.

\section{MANURE FOR PRIVATE GARDENS.}

I onee had a small garlen in the city, and having no manure, I depended entirely on thorough cultiration and artificial fertilizers, such as superphosphate and sulphate of ammonia. It was cultivated not for profit, but for pleasure, but l never saw a more produetive picee of lanct. That in almost every ease two crops a year on the same land, and on some plots three crops. No manure was used, except the superphospliate and sulphate of ammonia, and coal and wook ashes from the house.

About is lbs. of sulphate of ammonia was sown broadeast to the square rod, or worked into the soil very thoroughly in the rows where the seed was to he sown. Superphosphate was applied at the sime rate, hut instead of sowing it broadcast, I aimed to get it as near the seed or the roots of plants as possible. 
Half a teaspoonful of the mixture, consisting of erpul parts of superphosphate and sulphate of ammonial, stirred into a large three gallon can of water, and sprinkled on to a bed of verbenas, seemed to have a remarkable effect on the size and brilliancy of the tlowers.

Even to this day, although I have a good supply of rich barnyard-maunre, I do not like to be without some good artificial manure for the garden.

\section{MANURE FOR HOT-BEDS.}

The hest manure for hot-beds is horse or sheep-dung that has been used as bedding for pigs.

When fresh stable manure is used, great pains slould be taken to save all the urine. In other words, you want the horse-dung ihoroughly saturated with urine.

The heat is produced principilly from the carbon in the manure and straw, hut you neel active rilrogenons matter to start the fire. And the richer the manure is in nitrogenous matter, and the more thoroughly this is distributed through the manure, the more realily will it ferment. There is also another advantage in having rich manure, or manure well saturated with urine. You can make the heap more compact. Poor manure has to be made in a loose lieap, or it will unt ferment; but such manure as we are talking about can be trodlen down quite firm, and still ferment rapid enough to give out the necessary heat, and this compact heap will continue to ferment longer and give out a steadier heat, than the loose heap of poor manure.

\section{MANURE FOR NURSERYMEN.}

Our success?ul nurserymen purchase large quantities of stable and other manures from the cities, drawing it as fast as it is made, and putting it in piles until wanted. They usually turn the piles once or twice, and often three times. This favors fermentation, greatly reducirg it in bulk, and renilering the manure much more soluble and actire. It also makes the manure in the heap more uniform in quality.

IIessrs. Ellwanger \& Barrs tell me that they often ferment the manure that they draw from the stables in the eity, and make it so fine and rich, that they get but one loal of rotted manure from three loads as drawn from the stables. For some crops, they use at least 20 loals of this rotted manure per aere, and they estimate that each load of this rotted manure costs at least \$\$.00.

H. E. Hooker places the cost of manure equally high, but seems willing to use all he can get, and does not think we can profitably employ artificial manures as a substitute. 
In this 1 agree with hin. But while I should not expect artificial manures, when used alone, to prove as cheap or as valuable as stable-manure at present prices, I think it may well be that a little nitrate of soda, sulphite of ammonia, and superphosphate of lime, or dissoived Peruvian gruano, might be used as an auxiliury manure to great advantage.

Mr. H. E. IIooker, once sowed, at my suggestion, some sulphate of ammonia and sliperphosplate on part of a block of nursery trees, ancl he erould not perceire that these manures did any good. Ellwanger \& Barry also tricd them, and reported the same negative result. This was sereral year's ago, and I do not think any similar experiments have been made since.

"And yet," said the Deacon, "you used these self same manures on farm-crops, and they greatly increased the growth."

"There are several reasons," said the Doctor, "why these manures may have falled to produce any marked effect on the nursery trees. In the first place, there was considerable prejudice against them, and the nurserymen would hardly feet like relying on these manures alone. They hohbly sowed them on land already well manured; and I think they sowed them too late in the season. I should like to see them fairly tried."

So wonld I. It seems to me that nitrate of soda, and superphosphate, or dissolved Peruvian guano, could he nsed with very great advantage and profit by the uturserymen. Of course, it would hardly be safe to depend upon them alone. They should be used cither in connection with stable-manure, or on land that had previously been frequently dressed with stable-manure.

\section{MANURE FOR FRUIT-GROWERS.}

How to keep up the fertility of our apple-orelards, is liecoming an important question, and is attracting considerable attention.

There are two methods generaliy recommended-I dare not say generally practised. The one, is to keep the orchard in hare-fallow; the other, to keep it in grass, and top-dress with manure, and eitler eat the grass off on the land with sheep and pigs, or else mow it frequently, and let the griss rot on the surface, for mulch and manure.

"You are speaking now," said the Deacon, "of bearing appleorehards. No one recommends liecpirng a young orehard in grass. We all know that young apple trees do far better when the land is occupied with corv, potatoes, beans, or some other crop, which can be cultivated, than they do on land oecupied with wheat, barley, nats, rye, buckwheat, or grass and clover. And even with bearing 
peach trees, I bave seen a wonlerful diflerence in an oredard, half of which was cultivated with corn, and the other half sown with wheat. The trees in the whort were sickly-looking, and bore a small crop of inferior fruil, while the trees in the corn, grew vigorously and hore a fine crop of fruit. And the increased value of the crop of peaches on the cultivated land was far more than we can ever hope to get from a crop of wheat."

"And yet," said the Doctor, "the crop of corn on the cultivated half of the peach-orchard removed far more plint-fool from the soil, than the crop of wheat. And so it is evilent that the difference is not due wholly to the supply of manure in the surface-soil. It may well be that the cultivation which the corn received favored the decomposition of organic matter in the soil, and the formation of nitrates, and when the rain came, it would penetrate deeper into the loose soil than on the adjoining land occupied with wheat. The rain would carry the nitrogen down to the roots of the peach trees, and this will account for the dark green color of the leaves on the cultivated land, and the ycllow, sickly-looking leaves on the trees among the wheat.

\section{HEN-MANURE, AND WHAT TO DO WITII IT.}

A bushel of corn fed to a hen would give no more nitrogen, phosphoric acid, and potash, in the shape of manure, than a bushel of corn fed to a pig. The manure from the pirg, howerer, taking the urine and solid excrement logether, contain 82 per cent of water, while that from the hen contains only 56 per cent of water. Morcover, hens pick up worms and insects, and their food in sucin case would contain more uitrogen than the usual fool of pigs, and the manure would be correspondingly richer in nitrogen. IIence it happens that $100 \mathrm{lbs}$. of dry hen-manure would usually be richer in nitrogen than 100 lihs, of dry pig-manure. But feed pigs on peas, and hens on corn, and the dry pig-manure would be much richer in nitrogen than the dry hen-manure. The value of the manure, other things being equil, depends on the food and not on the animal.

Let no man think he is going to make his farm any richer by keeping hens, ducks, and geese, than be will by keeping sheep, pigs, and horses.

"Why is it, then," asked the Deacon, "that hen-dung prores such a raluable manure. I would rather have a hundred lbs. of hen-dung than half a ton of barnyard-manure?"

"And I presume sou are right," said I, "but you must recollect that your ben-manure is kept until it is almost chemically dry. Let 
us figure up what the half ton of manure and the $100 \mathrm{lbs}$. of henmanure would contain. Here are the figures, side by side:

\begin{tabular}{|c|c|c|}
\hline & $\begin{array}{l}100 \text { lbs. dry } \\
\text { Ilen-Jla- } \\
\text { nure. }\end{array}$ & $\begin{array}{l}\text { llalf ton } \\
\text { Cous- Dung } \\
\text { will stroiv. }\end{array}$ \\
\hline 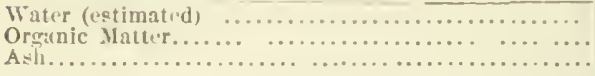 & $\begin{array}{ll}1: 1 \mathrm{lns} \\
51 & \because \\
3 i & " 6\end{array}$ & $\begin{array}{|cc|}76.5 & \text { Ibs. } \\
20: 3 & \text { ". } \\
22 & \text { " }\end{array}$ \\
\hline 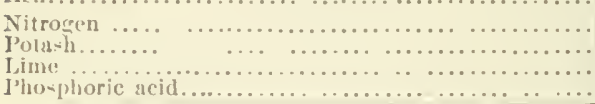 & 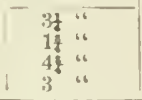 & $\begin{array}{l}32 / 6 " 16 \\
4 \\
3 \\
17 \text { " } 6\end{array}$ \\
\hline
\end{tabular}

I would, myelf, far rather latre 100 lhs. of your dry hen-manure than half at tom of your farmyari-manure. Your hens are fed on richer food than pour enws. The 100 llss. of lien-manure, too, would act much more rapidly than the half ton of cow-manure. It would probuhly do twice as much gond-possibly three or four times as much grool, on the first (rop), as the cow-manure. The nitrogen, b ine olutained from richer and more digestible food, is in a much more asctive and avaibable condition than the nitrogen in the cow-ring.

"If you goo on," said the Deacen, "I think you will prove that I am rierht."

"I have never doulbted," salil I, "the great value of hen-dung, as compared with barnyard-manure. And all I wish to show is, that, notwithstameling its arlinowledgerl value, the fact remains that a given quantity of the same lind of fool will give no greater amount of fertilizing matter when fecl to a hen than if ferl to a pig."

I want those farmers who find so much benefit from an application of hen-minure, ashes, and platster, to their corn and potatoes, to ferl that if they woull liecp better cows, sheep, and pigs, and fecil them better, they would get gond pay for their feed, and the manure would enalie them to grow larger (rops.

While we have been talling, the beacon was looking over the talıles. (See Appendix.) "I see," said he, "that wheat and rye contain more nitroren than hen-manure, but less potash and pliosphoric aciel."

"This is true," said I, "lunt the way to compare them, in orler to see the edlien of passing the wheat through the hen, is to look at the e'omplosition of the air-lried hen-dung. The fresh hen-dung, according to the talle, contilins 56 per ecent of water, while wheat contains less than $14+$ per cent."

Jut us compare the composition of 1,000 lbs. air-tried hen-(lung with 1,000 lls. of air-dried wheat and rye, and also with brin, malt-combs, ete. 


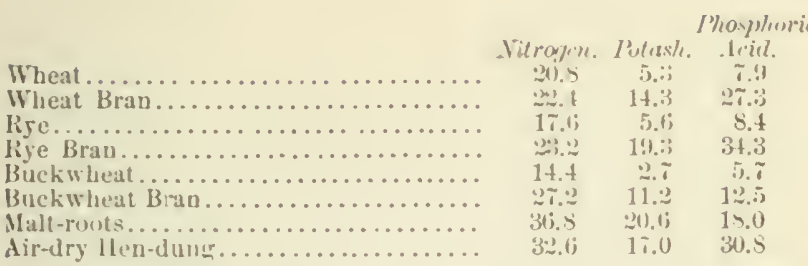

"That tahle," saicl the Dorctor, "is well worth stulying. You see, that when wheat is fut throurh the proess of milling, the miller takes out as much of the stirrel and ghuten ats he wants, and leaves you a pro luct (bran), richar in phosphoric acid, potash, and nitrogen, than gou gave him."

"Ancl the same is true," enotinurel the Doetor, "of the hen. Yon gare her 2,000 grains of wheat, containing 41.6 grains of nit rogen. She puts this throurh the mill, together with some ashes, and hones, that she picks up, and she takes ont all the starch and fat, and nitrogen, and phosphate of lime, that slie neels to sustain life, and to profues flesh, bones, feathers, anıl egges, and leares you 1,000 grains of mantre containing 32.0 grains of nitrogen, 1\%.0 grains of petisli, and 30.8 grains of phosphoric aciel. I do not say," rontinued the Doctur, "that it take's exatly 2,000 grains of wheat to make 1,000 irains of dry manure. I merely give these figures to enable the Ducon to understanl why 1,000 lbs. of hen-lung is worth more for minure than 1,000 lbs. of wheat."

"I must admit," said the Deacon," that I alwars hare been troubled to understand why wheat-bran was worth more for manure than the wheat itself. I sne now-it is berante there is less of it. It is for the same reason that boiled eider is richer than the eider from which it is male. The ciller has lost water, and the bran has lost starel. What is left is richer in nitrogen, and potash, and phosphoric acil. Anil so it is with manure. The animals take out of the food the stureh and fat, and leave the manure richer in nitrogen, phosphoric acid, and pol rsh."

"Exactly," said I, "Mr. Lawes found hy actual experiment, that if you feed 500 lhs. of barley-meal to a pigr, ront:ining 420 lbs. of dry substunce, you get only ic lhs. of dre substance in the manure. Of the 420 lbs. of dry substance, 226.2 lhs, are used to support respiration, ete.; $73.8 \mathrm{lbs}$ are found in the increase of the pig, and 70 lbs in the manure."

The food contains $\tilde{5} 2 \mathrm{lbs}$. of nitrogenons mitter; the increase of pig contains $\boldsymbol{\tau}$ lbs., and consequeutly, if tlıere is no loss, the ma- 
nure shou' I comtisin tij los of uitrugeneus substance=to $7.14 \mathrm{lbs}$. of nitrogen.

"In other workls," said the Doetor, "the $70 \mathrm{lbs}$ of dry iiquid and solit pir-manure eontilins 7.14 lbs. of nitrogen, or 100 lbs. would contain 10.2 Ibs. of nitrogren, which is more nitrogen than we now get in the very best simples of l'mirian guano."

"And thus it will he secu," silid l, "that though corn-fed pigs, leaving out the hedeling and water, produce a very small quantity of munure, it is exceculinsly rich.,"

The talble from which thise facts were obtained, will be found in the Appcudix-pages $34:-3$.

\section{CHAPEL $\mathrm{XXXVl}$}

\section{DIFFEIRENT KINISO OF MANURE.}

\section{COW-MANLRE, AND HOW TO LSE IT.}

"It will do more goud if fermented," sail a German farmer in the mejorhhorhood, whe is noterl for raisiner gooul crops of cabbage, "but I like hon-mamere lecter than cow-dung. The right way is to mix the hog-mianure, cow-thme, and horse-manure together."

"An dould about that," saill I, "lust when you have a grood many cows, aud few other antmals, how worlil you manage the manure?"

"I would gather leaves and swamp-muck, and use them for bedding the cows and pigs. Lawes make splen lit bediling, and they make rich manure, and the "ow-dung and leaves, when made into a pile, will ferment reali!y, and make grand manure for-anythint. I only wish I ham all I coull use."

There is no quation but what enw-manure is better if fermented, but it is not always consenient (o) pile it during the winter in such a way that it will not frees. Ind in this ase it may be the better plan to draw it out on to the land, as opportunity offers.

"l hare hearl," sald Charley, "that pig-manure was not good for rabhage, it prisluess "finger's and toes, or club-font."

Possibly such is the eas when there is a prolisposition to the disease, hut une German fricul says he has never found any ill. effiets from its use. 
"Cows," sail the Inoctor, "when griving a larere equatity of milk, make rather perer manure. 'The manure luses what the milk takes from the foud."

"We have shown what that luss is," said I. "It amounts to less than I think is gencrully supposed. And in the winter, when the cows are ary, the manmre would he as rich as from coxem, provided both were fel alike. See Ippendix, plig. :3:. It will there be seen that oxen take nut only 4.1 lhs. of nitronen from 100 lhs. of nitrogen consumes in the foest. lan other worls, provided there is no less, we shenuld geet in the litguid and solid exerements of the ox and dry cow 9.5.9 per (ent. of the nitroneres furnished in the food, and a still higher per cent of the mineral matter.

\section{SHLEP.MANULE.}

Aceording to Prof. Wollt" table of analyses, sleepl-1nanure, both solit antl liquile, comtain lesi walor than the manture from horses, cows, or swine. With the exeption of swine, the solid dung is also the rielsen in nitrogen, while the urine of sheep is pre. eminently rich in nitmen and potaslı.

These facts are in acordane with the general opinions of farmers. Sluep-manure is an-illered, next to hen-minure, the most valuable manure made on the farm.

I lo not think we have any sitisfactory ericlence to prove that 3 tons of clurer-hay and a ton of cern fed to a lot of fatteninersheep will afford a quantity of manure centaining any toore plantfool than the same kind and amount of foed fed to a lot of fattening-eattle. The experiments of Lawes of (illuert indicate that if there is any difference it is in faror of the wx. See Appendix, page :343. But it may $w / 11$ be that it is much ensier to save the manure from the sheep than from the cattle. And su, practically, sheep may be better manure-makers than cattle-for the simple reason that less of the urine is lost.

"As a rule," said the Doctor, "the dung of slieep contains far less water than the dung of cattle, though when you slop your breeding ewes to make them give more milk, the chung differs but little in appearance from that of cows. Orelinarily, lowever, sheepdung is light and dry, and, like horse-dung, will ferment much more rapidaly than cow or pirr-lung. In piling manure in the winter or spring, special pains should be used to mix the sheep and horse-manure with the cow and pig-manure. And it may be remarked that for any crop or for any purpose where stable-manure is deemed desirable, sheep-manure would be a better substitute than cow or pig-manure." 


\section{MANURE FROM SWINE.}

The dry matter of hog-manure, especially the urine, is rich in nitrogen, but it is mixel with such a large quantity of water that at ton of hog-manure, as it is usually found in the pen, is less valuable than a ton of horse or slieep-manure, and ouly a little more valuable than a ton of cow-manure.

As I bave before said, my own plan is to let the sture-hogs sleep in a basement-cellar, and bed them with horse and sheep-manure. I lave this winter over 50 sows under the horse-stable, and the manure from 8 horses keeps them dry and coinfortable, and we are not specially lavish with straw in badding the horses.

During the summer we aim to keep the logs out in the pastures and orchards as much as possihle. This is not only good for the health of the pigs, but saves labor and straw in the management of the manure. It goes directly to the land. The pigs are good grazers and distribute the manure as evenly over the land as sheep - in fact, during hot weather, slieep are even more inclined to huddle together under the trees, and by the side of the fence, than pigs. This is partieularly the ease with the larger breeds of sheep.

In the winter it is not a diffieult matter to save all the liquid and solid excrements from pigs, provided the pens are dry and no water comes in from the rain and snow. As pigs are often managed, this is the real difficulty. Pigs void an enormous quantity of water, especially when fed on slops frotn the house, whey, ete. If they are kept in a pen with a separate feeding and sleeping apartment, both should he under cover, and the feeding apartment may be kept covered a foot or so thick with the soiled bedding from the sleeping apartment. When the pigs get up in a morning, they will go into the feeding apartment, and the liquid will be discharged on the mass of manure, straw, etc.

"Dried muck," said the Deacon, "comes in very handy about a pig-pen, for absorbing the liquid."

"Yes," said I, "and cren dry earth can be used to great advantage, not merely to absorb the liquid, but to keep the pens sweet and healthy. The three chief points in saring manure from pigs are: 1 , To have the pens under cover; 2 , to keep the feeding apartment or yard corered with a thick mass of strawy manure and refuse of any kincl, and 3 , to scatter plenty of dry earth or dry muck on the floor of the sleeping apartment, and on top of the manure in the feeding apartment."

"You feed most of your pigs," said the Deacon, "out of doors in the yard, and they sleep in the pens or basement cellars, and it 
seems to me to be a good plan, as they get more fresh air and exercise than if confinel."

"We do not lose much manure," said I, "by feeding in the yards. You let a dozen pigs sleep in a pen all night, and as soon as they hear you putting the food in the troughs outside, they come to the door of the pen, and there clischarge the liquid and solicl exerements on the mass of manure left there on purpose to receive and absorb them. I an well aware that as pigs are often managed, we lose at least balf the value of their manure, but there is no neecssity for this. A little care and thought will save uearly the whole of it.

\section{BUYING MANURE BT MEASLRE OR WEIGHT.}

The Deacon and I have just been weighing a bushel of different kinds of manure made on the farm. We made two weighings of each kind, one thrown in loose, and the other pressed down firm. The following is the result:

WEIGHT OF MANLIE PER BUSIIEL, AND PER LOAD OF 50 BCSIELS.

\begin{tabular}{|c|c|c|c|}
\hline No. & KIND AND CONDITION UF MANUEES. & $\begin{array}{l}\frac{\pi}{2 \pi} \approx \\
=\infty\end{array}$ & 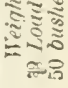 \\
\hline $\begin{array}{l}1 . \\
2 . \\
3 . \\
4 . \\
5 . \\
6 . \\
7 . \\
8 . \\
10 . \\
10 . \\
11 . \\
12 . \\
13 . \\
14 . \\
15 . \\
16 .\end{array}$ & 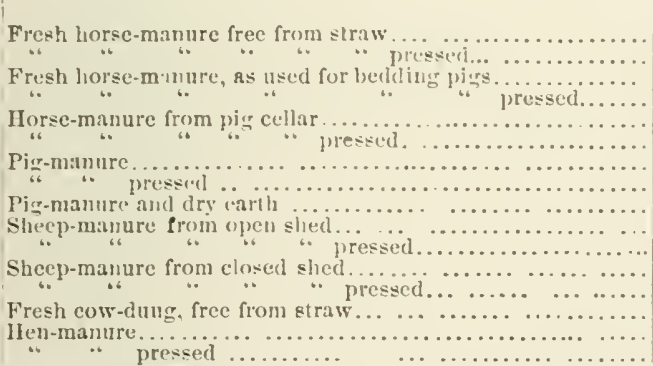 & 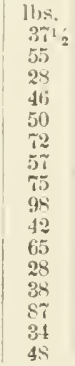 & $\begin{array}{l}16=5 \\
18 \% 5 \\
2750 \\
1100 \\
2: 00 \\
2500 \\
3400 \\
2850 \\
3750 \\
4900 \\
2100 \\
3: 50 \\
1100 \\
1900 \\
4350 \\
1700 \\
24100\end{array}$ \\
\hline
\end{tabular}

"In buying manure," said the Deacon, "it makes quite a difference whether the load is trou down solid or throw $n$ loosely into the box. A load of fresh horse-manure, when trod cown, weighs half as much again as when thrown in loose."

"A load of horse-manure," said Charley, "after it has been used for bedding pigs, weighs 3,600 lbs., and only $2,300 \mathrm{lbs}$. when it is thrown into the pens, and I suppose a ton of the 'double-worked' manure is fully as valuable as a ton of the fresh horse-manure. If so, 15 'loads' of the pig-pen manure is equal to 24 'loals' of the stable-manurc." 
"A ton of fresh horse-manure," said the Doctor, "contains about 9 lbs. of nitrogen; a ton of fresh cow-dung about 6 lbs.; a ton of fresh sheep-(lung, $11 \mathrm{lbs}$, and a ton of fresh pig-manure, 12 lbs. But if the Deacon and you weighed correctly, a 'load' or cord of cow-manure would contain more nitroren than a load of pressed horse-mauure. The figures are as follows:

A load of 50 hushels of fresh horse-dung, pressed and free from straw eontains................. 12.37 lbs, nitrogen,

A load of fresh eow-dung.................... 13.05 "
" "
sheep " ".................... 10.45
" " pig "
" "

"These figures," said I, "show how neeessary it is to look at this subject in all its aspects. If I was bnying manures by aceight, I would much prefer a ton of sheep-manure, if it had been made under cover, to any other manure except hell-dung, especially if it contained all the urine from the sheep. But if buying manure by the load or cord, that from a covered pirs-pen would be preferable to any other."

\section{LIQUID MANURE ON THE FARM.}

I have never had any persoual experience in the use of liquid manure to any crop except grass. At Rothamsted, Mr. Lawes used to draw ont the liquid manure in a water-cart, and distribute it on grass land.

"What we want to know," saicl the Deacon, "is whether the liquid from our barn-yards will pay to draw out. If it will, the proper method of using it can be left to our ingemuity."

According to Prof. Wolff, a ton of urine from horses, cows, sheep, and swine, contains the following amounts of nitrogen, phosplıoric acid, and potash, and, for the sake of comparison, I give the composition of drimase from the barn-yard, and also of fresh dung of the different animals:

TABLE SUOWINO TIE AMOLNT OF NITROQEN, PHOSPHORIC ACID, AND POTASR, IN ONE TON OF TUE FIESII DING AND FIESII TISIR OF MIFFERENT ANIMALS, AND ALSO OF TUE DRANAGE OF TUE BARN-YARD.

\begin{tabular}{|c|c|c|c|c|c|c|}
\hline & \multicolumn{3}{|c|}{1 TON FRESII DUXa. } & \multicolumn{3}{|c|}{1 TON FRESII URINE. } \\
\hline & $\begin{array}{c}\text { Nitro- } \\
\text { gen. }\end{array}$ & $\begin{array}{l}\text { Phas- } \\
\text { phoric } \\
\text { acid. }\end{array}$ & Potash. & $\begin{array}{l}\text { Nifro- } \\
\text { gen. }\end{array}$ & $\begin{array}{l}\text { Phas- } \\
\text { phoric } \\
\text { acid. }\end{array}$ & Potash. \\
\hline 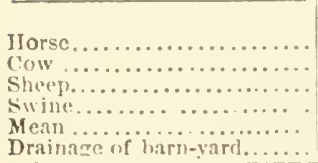 & $\begin{array}{r}115.8 \\
8.5 \\
5.4 \\
11.0 \\
12.0 \\
9.1\end{array}$ & $\begin{array}{l}11,9 . \\
7.0 \\
.01 \\
i .2 \\
8.2 \\
1.2\end{array}$ & $\begin{array}{l}11) . \\
7.0 \\
2.0 \\
3.0 \\
5.2 \\
4.3\end{array}$ & $\begin{aligned} 1130 . \\
31.0 \\
11.6 \\
39.0 \\
8.6 \\
22.5 \\
30\end{aligned}$ & $\begin{array}{l}0.2 \\
1.4 \\
0.4 \\
0.2\end{array}$ & $\begin{array}{r}\text { lb. } \\
30.0 \\
9.8 \\
45.2 \\
16.6 \\
25.4 \\
9.8\end{array}$ \\
\hline
\end{tabular}


The drainage from a barn-yard, it will be seen, contains a little more than half as mucln nitrogen as cow-dung; and it is probalhle that the nitrogen in the liquid is in a much more available condition than that in the dung. It contains, also, nearly fire times as much potash as the duag. It would secm, therefore, that with proper arrangements for pumping and distributing, this liquid could be drawn a short distance with profit.

But whether it will or will not pay to cart away the llainage, it is obviously to our interest to prevent, as far as possible, any of the liquid from running to waste.

It is of still greater importance to guard against any loss of urine. It will be seen that, on the average, it ton of the urine of our domestic animals contains more than twice as much nitrogen as a ton of the dung.

Where straw, leares, swamp-muck, or otler absorbent materials are not sufficiently abundant to prevent any loss of urine, ineans s.jould be used to drain it into a tank so located that the liquid can either be pumped back on to the manure when needed, or drawn away to the land.

"I do not see," said the Deacon, "why horse and sheep-urine should contain sa much more nitrogen and potasli than that from the cow and pig."

"The figures given by Prof. Wolf," said I, "are general arerages. The composition of the urine raries greatly. The richer the food in cligestible nitrogenous matter, the more nitrogen will there be in the dry matter of the urine. And, other things being equal, the less water tie animal drinks, the richer will the urine be in nitrogen. The urine from a sheep fed solely on turnips would contain little or no more nitrogen than the urine of a cow fed on turnips. An ox or a dry cow fed on grass would probably roid no more nor no poorer urine than a horse fed on grass. The urine that Mr. Lawes drew out in a cart on to his grass-lard was made by sheep that had one $\mathrm{Ib}$. each of oil-cake per day, and one tb. of chaffed clover-hay, and all the turnips they would eat. They roided a large quantity of urine, but as the food was rich in nitrogen, the urine was doubtless nearly or quite as rich as that analyzed by Prof. Wolff, though that probably contained less water.

If I was going to draw out liquid manure, I should be very care. ful to spout all the buildings, and keep the animals and manure as much under corer as possible, and also feed food rich in nitrogen. In such circumstances, it would doubtless pay to draw the urine full as rell as to draw the solid manure. 


\section{NIGHTSOIL AND SEWAGE.}

The composition of Luman excrements, as compared with the mean composition of the excrements from horses, cows, sheep, and swine, so far as the nitrogen, phosploric acid, and potash are concerned, is as follows:

TABLE SHOWING THE AMUUXT OF NITROGEN, PHOSPHORIC ACH), AND POTASH, IX OXE TON OF FIBEII MUMAX EXLIEMEXTS, ANU IX UNE TON OF FIESH

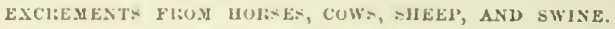

\begin{tabular}{|c|c|c|c|c|c|c|}
\hline \multirow[b]{2}{*}{ One ton (z000 lls:). } & \multicolumn{3}{|c|}{ SOLIDS. } & \multicolumn{3}{|c|}{ UIINE. } \\
\hline & $\begin{array}{l}\text { Ni/ro- } \\
\text { gen. }\end{array}$ & $\begin{array}{l}\text { Phas- } \\
\text { phoric } \\
\text { acid. }\end{array}$ & Potash. & $\begin{array}{l}\text { Nitro- } \\
\text { gen. }\end{array}$ & $\begin{array}{l}\text { Phas- } \\
\text { phoric } \\
\text { acid. }\end{array}$ & P'otush. \\
\hline Human ... . . .......... & 20011 s. & $21.8 \mathrm{lhs}$. & $5.0 \mathrm{Jl}$ s. & $12.0 \mathrm{fbs}$. & 3. $711, s$. & $1.016 \mathrm{se}$ \\
\hline $\begin{array}{l}\text { Meail of horse, cow, slecep. } \\
\text { and swins............... }\end{array}$ & $9.1 \div$ & ii.2 $\cdots$ & $4.3 \cdots$ & 228.5 & $0.4 \cdots$ & 125.4 " \\
\hline
\end{tabular}

One :on of fresh fieces contains more than twice as much nitrogen, and more thau three times as much phosploric acill, as at ton of fresh mixed aninal-(lung. The nitrogen, too, is probably in a more avalable condition than that in common barnyard-dung; and we should not be far wrong in estimating 1 ton of fxees equai to $2 \$$ tons of orlinary dung, or about equal in ralue to carefully preservel manure from liberally-fed sheep, swine, and fattening cattle.

"It is an unpleasan( job," said the Deacon, "but it pays well to empty the valults at least twice a ycar."

"If farmers," sqid the Doctor, "would only throw into the vaults from time to time some lry earth or eall ashes, the contents of the vanlts conld be remored without any disagreeable smell."

"That is so," said I, "and even where a vault has been shamefully neglected, ancl is full of offensire matter, it can be eleaned out without dificulty and without smell. I have cleaned out a large rault in an hour. We were drawing manure from the yares with three teams and piling it in the field. We brought back a load if sand and threw half of it into the vault, and put the other half on one side, to be used as recpuired. The sand and freces were then, with a long-handled shovel, thrown into the wagon, and drawn to the pile of manure in the field, and threwn on to the pile, not more than $t$ wo or three inches thick. The team brought back a load of sand, and so we continued until the work was done. Sand or dry earth is eheap, and we used all that was necessary to prerent the eseape of anr unpleasant gases, and to keep the material from adhering to the shorels or the watron.

"Human urine," said the Doctor, "is richer in phosphoric acid, 
but much poorer in nitrogen and potash than the urine from horses, cows, sheep, and swine."

"Some years amo," said the Deacon, "Mr. Il. E. Ilooker, of Rochester, used to draw considerable quantities of urine from the city to his farm. It would pay better to draw out the urine from farm animals."

"The figures given above," siid I, "showing the composition of human excrements, are from Prof. Woltf, and jrobably are generally correct. But, of course, the composition of the excrements would vary greatly, according to the food."

It bas been ascertained by Lawes and Gilbert that the amount of matter voided by an adult male in the course of a year is-freces, $95 \mathrm{lbs}$; uriuc, $1,049 \mathrm{lbs}$; total liquid and solid excrements in the pure state, 1,144 lbs. These contain:

Dry substance-frecs, $231 \mathrm{lhs}$ : urine, $34 \mathrm{l}$; total, 59 ! lbs.

Mineral matter-fieces, $2 ! 11$ s.; urine, $1: 2$ : total, $14 \frac{2}{1}$ lbs.

Carbon-fxecs, 10 lbs.; urine, 12 ; total $2: 2 \mathrm{lbs}$.

Nitrogen-fxecs, 1.2 lbs.; urine, 10.5 ; total, $12 \mathrm{lbs}$.

Phosphoric acid-freces, 0.7 lbs.; urine, 1.93 ; total, $2.63 \mathrm{lbs}$.

Potash-fieces, 0.24 lbs.; urine, 2.01 ; total, $2.25 \mathrm{lbs}$.

The amount of potash is given by Prof. E. Wolff, not by Lawes and Gilbert.

The mixed solid and liquid excrements, in the condition they leave the body, contain about 95 per cent of water. It would require, therefore, 20 tons of fresh mixed excrements, to make one ton of $d r y$ nightsoil, or the eutire amount roided by a mixed family of 43 persons in a year.

One hundred lbs. of fresh fæces contain 75 lbs. of water, and 25 lbs. of dry substance.

One hundred lbs. of fresh urine contain $96 \frac{1}{2}$ lbs. of water, and $3 \frac{1}{2}$ lbs. of dry substance.

One hundred lbs. of the dry substance of the fæces contain 5 lbs. of nitrogen, and $5+11$ s. of phosphates.

One hundred lbs. of the dry substance of the urine contain 27 'ss. of nitrogen, and 10 los. of phosphates.

These figures are from Lawes and Gilbert, and may be taken as representing the composition of excrements from moderately wellfed persons.

According to Wolff, a ton of fresh human urine contains $12 \mathrm{los}$. of nitrogen. According to Lawes and Gilbert, $18 \mathrm{lbs}$.

The liquid carted from the city by Mr. Hooker was from well-fed adult males, and would doubtless be fully equal to the figures given by Lawes and Gilbert. If we call the nitrogen worth 20 cents a lb., 
and the phosphoric acid (soluble) worth $12 \frac{1}{2}$ cents, a ton of such urine would be worth, on the lind, \$1.06.

"A ton of the fresh freces," said the Deacon, "at the same estimate, would he worth ( 20 Il)s. nitrogen, at 20 cents, $\$ 4 ; 218$ lbs. phosphoric acid, at $12 \frac{1}{2}$ cents, $\left.\$ 2.70\right), \$ 6 . \tau 0 . "$

"Not by a good deal," said the Doctor. "The nitrogen and phosphoric acid in the urine are b th soluble, and would be immediately available. But the nitrogen and phosjohoric acid in the frces would be mostly insoluble. We cannot estimate the nitrogen in the freces at over 15 cents a $1 \mathrm{~b}$, and the phosphoric acid at 5 cents. This would make the value of a ton of fresh faces, on the land, \$4.09."

"This makes the ton of fxecs worth about the same as a ton of urine. But I would like to kcow," said the Deacon, "if you really believe we could afford to pay $\$ t$ per ton for the stuff delivered on the farm?"

"If we could get the genuine article," said the Doctor, "it would be worth st a ton. But, as a rule, it is mixed with water, s.nd dirt, and stones, and bricks, and rubbish of all kinds. Still, it is unquestionably a valuable fertilizer."

"In the dry-earth closets," said I, "such a large quantity of earth has to be used to absorb the liquid, that the material, even if used several times, is not worth carting any considerable distance. Dr. Gilbert fonnd that $\tilde{5}$ tons of absolutely dry carth, before usin:; contained 16.; lbs. of nitrogen.

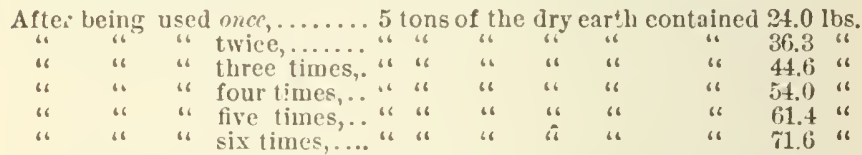

Dr. Vnelcker found that five tons of dry earth gained about 7 lbs. of nitrogen, and $11 \mathrm{lbs}$ of phosphoric acid, each time it was used in the closets. If we consider each lh. of nitrogen with the phosphori : acid worth 20 cents a lb. . j tons of the dry earth, after being used once, would be worth $\$ 1.46$, or less than 30 cents a ton, and after it had been used six times, five tons of the material would be worth $\$ 11.98$, or about $\$ 2.40$ per ton.

In this calculation I have not reckoned in the value of the nitrogen the soil contained before using. Soil, on a farm, is cheap.

It is clear from these facts that any earth-closet manure a farmer would he likely to purchase in the city has not a very high value. It is absurd to talk of making "gutuno" or any concentrated fertilizer out of the material from earth-closets. 
"It is rather a reflection on our scienee and practical skill," said the Doctor, "but it looks at present as though the only plan to adopt in large cities is to use enormous quantities oi water and wash the stuff into the rivers and oceans for the use of aquatic plants and fishes. The nitrogen is not all lost. Some of it comes back to us in rains and dews. Of course, there are places where the sewalge of our cities and villages can be used for irrigating purposes. But when water is used as freely as it ought to be used for health, the sewage is so extremely poor in fertilizing matter, that it must be used in cnormous quantities, to furnish a dressing equal to an application of 20 tons of stable-manure per acre."

"If," continued the Doetor, " the sewage is used merely as vater for irrigating purposes, that is another question. The water itself may often be of great benefit. This aspect of the question has not received the attention it merits."

\section{PERUVIAN GUANO.}

Guano is the manure of birds that live principally on fish.

Fish contain a high pereentage of nitrogen and phosphoric acid, and consequently when fish are digested and the carbon is burnt out of them, the manure that is left contains a still higher percentage of nitrogen and phosphoric acil than the fish from which it was derived.

Guano is digested fish. If the guano, or the manure from the birds living on fish, has been preserved without loss, it would contain not only a far higher percentage of nitrogen, but the nitrogen would be in a much more arailable condition, and consequently he more valuable than the fish from which the guano is made.

The difference in the value of guano is largely dne to a difference in the elimate and locality in which it is deposited by the birds. In a rainless and hot climate, where the bird-droplings would dry rapidly, little or no putrefaction or fermentation would take place, and there would be no loss of nitrogen from the forination and escape of ammonia.

In a damper climate, or where there was more or less rain, the bird droppings would putrefy, and the ammonia would be liable to evaporate, or to be leached out by the rain.

Thirty years ago I saw a quantity of Perurian guano that contained more than 18 per eent of nitrogen. It was remarkably light colored. You know that the white part of hen-droppings consists principally of urie acid, which contains about 33 per cent of nitrogen.

For many years it was not diffeult to find guano containing 13 per cent of nitrogen, and genuine Peruvian guano was the cheap- 
est and best source of arailable nitrogen. But iutterly, not only has the price been advanced, but the quility of the gruano has deteriorated. It has contained less nitrogen and more phosphorie acid. Sce the Chapter on "Value of Fertilizers," Patre 324.

\section{SALTS OF AMMONIA AND NITRATE OF SODA.}

"I wish," said the Deaeon, "yen would tell us something about rhe 'anmonib-salts' and nitrute of soda so long usert in Latwes and Gilbert's experiments. I have never seen any of them."

"You could not invest a little money to better ac'vantage than to send for a few hass of sulphate of amuonit and nitrate of soda. You would then see what they are. and woukt learn more by using tben, than I can tell you in a month. You use them just as you would common salt. As a rule, the better plan is to sow them broadcast, and it is important to di-tribute them erenly. In suwing common salt, if you droy a luandful in a plice, it will kill the plants. Aud so it is with nitrate of sodil or sulphate of anmonia.

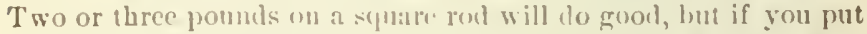
half of it on a square yark, it will hurn up the (rop), and the other half will be apylied in such a small guantity that you will see but little effect, and will conclucie that it is a loumbug. Jutering from over thirty years' experience, I am safe in sayiur that not one man in ten can lie trusted to sow these manures. They should be sown with as much care as you sow grass or clover-secel."

"The best plin," saich the Doetor, "is to mix them with sifted coal-ashes, or with gypium, or sifted earth."

"Perhaps so," silid I, "though tliere is nothing gained by mixing earth or as'ses with them, except in securing a more even distribution. And if I was groing to sow them mysclf, I would much prefer sowing then mumixrl. Any man who can sow wheat or barley ean sow sulphate of ammonia or nitrate of soda."

"Lawes and Gilhert," said the Deacon, "used sulphate and mu. riate of ammoniz, and in one or two instances the carbonate of smmonia. Which is the best?"

"The one that will furnisl a mmonia or nitrogen at the cheapest rate," saitl the Doctor, "is the best to use. The muriate of ammonia contains the most ammonit, hut the sulphate, in proportion to the ammonia, is cheaper than the muriate, and far cheaper than the carbonate.

Carhonate of ammoni:l contains $21 \frac{1}{2}$ per cent of ammonia.

Sulphate of ammonia contains $25 \xi \mathrm{per}$ cent of ammonia $=21^{2} / \mathrm{s}$ of nitrogen. 
Muriate of ammoniat contains 31 per ceut of ammonia=25t of nitrogen

Nitrate of so la ('outains $16^{2}$ s per echt of nitrogen.

Nitrate of potash, 1:3 per cent of nitregen.

From these figures you can ascertain, when you know the price of each, which is the cheapest sourec of nitrogen.

"True," said l, "lut it munt he unlerstond that these figures represent the composition of a pure article. The commercial sulplate of ammonia, and nitrite of sudl.t, would usually contain 10 per eent of impuritie's. Lawes and (Filhert, who haserertainly had much experience, and doululess g t the best commercial articles, state th.te a mixture of equal ports sulphate ant muriate of ammonia contains about 25) per ('nt of ammoma. Aecorling to the figures giren by the Doctor, the mixture would contain, if pure, over 28 per reat of ammuniı. In other words. 90 llss. of the pure article contrins as much as $100 \mathrm{ll}$ s. of the (onmereial article."

As to whether it is beter, when you can buy nitrogen at the same price in nitrate of volil als you can in sulphate of ammonia, to use the one or the other will tepent on rircumstances. The nitrogen exists as nitric acil in the nitrale of sodis, and as ammonia in the sulphate of ammonia. But there are gool reasons to beliere that before ammonia is used by the plants it is eonrerted into nitric acil. If, therefore, we could apply the nitrate just where it is wanted by the crowing crop, and when there is rain enough to thornughly distribute it through the soil to the depth of six or eirfit inches, there can be little doubt that the nitrate, in proportion to the nitrogen, would have a quicker and better effect than the sulphate of ammonia.

"There is another point to be considered," said the Doctor. "Nitric acid is much more easily washed out of the soil than ammonia. More or less of the ammonial enters into chemical combination with portions of the soil, and may be retained for months or years."

When we use nitrate of sola, we run the risk of losing more or less of it from leaching, while if we use ammonia, we lose, for the time being, more or less of it from its hecoming loeked up in insoluble combinations in the soil. For spring crops, such as barley or oats, or spring wheat, or for a meadow or lawn, or for topdressing winter-wheat in the spring, the nitrate of soda, provided it is sown early enough, or at any time in the spring, just previous to a beary rain, is likely to produce a better effect than the sulplate of ammonia. But for sowing in the autumn on winter-wheat the ammonia is to be preferred. 
"Saltpetre, or nitrute of potash," said the Deacon, "does not contain as much nitrogen as nitrate of soda."

"And yet," said the Doctor, "if it could be purchased at the same price, it would be the cheaper manure. It contains $46 \frac{1}{2}$ per eent of potash, and on soils, or for crops where potasin is needed, we may sometimes be able to purchase saltpetre to advantage."

"If I could come across a lot of damiged saltpetre," said I, "that could be got for what it is worth as manure, I should like to try it on my apple trees-one row with nitrate of soda, and one row with nitrate of potask. When we apply manure to apple trees, the ammonia, plosploric acid, and potash, are largely retained in the first fer: inches of surface soil, and the deeper roots get hold of only those portions which leach through the upper layer of earth. Nitric acid, however, is easily washed down into the subsoil, and would soon reach all the roots of the trees."

\section{H A P 'T E R X X X V I I.}

\section{BONE-DUST ANT SUPERPIIOSPIITE OF LIME.}

Bone-dust is often spoken of as a plospliatic manure, and it has been supposed that the astonishing effeet bone-dust sometimes produces on old pasture-land, is due to its furnishing phosphoric aeid to the soil.

But it must be remembered that bone-dust furnishes nitrogen as well as phosphoric acil, and we are not waranted in ascribing the good effect of bones to phosphorie acid alone.

Bones differ considerably in composition. They consist essentially of gelatine and plospliaie of lime. Bones from young animals, and the soft porons parts of all bones, contain more gelatine than the solid parts, or the bones from olker animals. On the average, 1,000 lbs, of good commercial hone-dlust contains 38 lbs. of nitrogen.

On the old dairy farms of Cheshire, where bone-lust produced such marked improvement in the quantity and guality of the pastures and meadows, it was usual to apply from 4,000 to $5,000 \mathrm{lbs}$ per ace, and often more. In other words, a dressing of bone-dlust 
frequently contained $200 \mathrm{lls}$, of nitrogen jer acre-equal to 20 or 25 tons of barn-yard manure.

"It has been supposed," said the Doctor, "that owing to the removal of so much phosphoric acid in the cheese sold from the farm, that the dairy pastures of Cheshire hal bern exhausted of phosphoric acid, and that the wonderful benctits following an application of bone-dust to these pastures, wat clue to its supplying phosphoric acisl."

"I do not doubt," saidl I, "the value of phosphoric acid when applied in eomection with nitrosen of old pasture lands, but I contend that the experience of the Cheshire dairymen with bonedust is no positive prouf that theil soils were particularly deficient in phosplowic acid. There are many instane's griven where the gelatine of the bones, alone prosed of crrat value to the grass. And I think it will be found that the Che hise dairymen do not tind as much benefit from supurphosphate as they did from hone-dust. And the reason is, that the latter, in addition to the phosphoric acid, furnished a liberal trescing of nitrogen. Futhermore, it is not true that dairying specially rols the soil of phosphorie acid. Take one of these old dairy farms in Che-hire, where a dressing of bone-dust, aceorling to a writer in the Journal of the Royal $\mathbf{A g r i}$ cultural Society, has caused a miscrable cosering of pink grass, rusbes, and a variefy of other noxious weets, to gire place to the most luxuriant herlage of will clorer, trefoil, and other succulent and nutritious grasses.' It is evident from this description of the pastures before the bones were used, that it would take at least three acres to keep a cow for a year.

"I have known," says the same writer quoted abore, "many a poor, honest, but half broken-hearted man raised from poverty to comparative independence, and many a sinking family saved from inevitable ruin by the help of this wonderful manure." And this writer not only spoke from olservation and expericnce, but he showed his faith by his works, for he tells us that he had paid nearly $\$ 50,000$ for this manure.

Now, on one of these poor dairy farms, where it required 3 acres to keep a $\mathrm{cnw}$, and where the grass was of poor quality, it is not probable that the cows produced over $250 \mathrm{lbs}$. of cheese in a year. One thousand pounds of cheese enntains, on the arerage, about $45 \frac{1}{2}$ lbs. of nitrogen; $2 \frac{1}{2}$ lbs. of potash. and $11 \frac{1}{2}$ lbs. of phosphoric acid. From this it follows, if $250 \mathrm{lbs}$. of cheese are sold annually from three acres of pasture, less than one lb. of phosphoric acid per acre is exportel from the farm in the cheese.

One ton of timothy-hay contains nearly $14 \frac{1}{2} \mathrm{lbs}$. of phosphoric 
acid. And so a farmer whu ratises a ton of timothy-lay per acre,

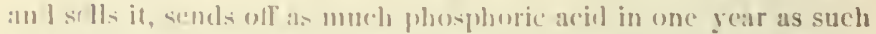
:L Cheshire dairyman as I hatre allunded to dil in fourteen years.

What the dairymen want, and what formers generally want, is uitrogren and phosphorie ardil. Bune-dust furnishes both, and this was the reasom of its womblerful allicts.

It dese not follow from this, that honge-dust is the cheapest and heis manuse we (an use. It is an old and pupular manne, and

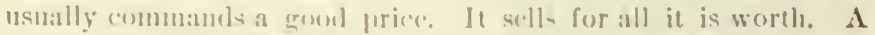

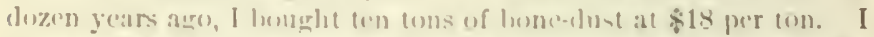
have olfured s:5 per ton siuce for a similar Jot, hut the manufacturery timl a market in New York for all they can make.

Boncelust, lesides nitrogen, contains alwout $2: 3$ per eent of phesplurrie aciel.

"That deres not give me," said the Deacon, "any idea of its value."

"Let us put it in another thaţu", then," satil I. "One ton of good

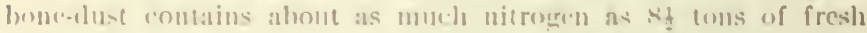
stable-manure, and as muld pho-phorie ared as 110 tons of fresh stable-1uanure. But one ton of manure containe more potash than 5 tons of bone-dust.

Bone-dust, like darnyard-manure, does not immeliately yicld up its nitrogen and phepphorie acid lo plants. The bune phopplate of lime is insolulbe in water, anu bus very sliplitly soluble in water emulanine earlosie acil. Tly endatine of the bones would soon dewompose in a moist, porons, warm soil, provided it was not protected by the wil and by the hard matter of the hones. steaming, lye removing the vil, remuses one of the hindrances to acempusition. Reducing the homs as fine as prosible is another means of increasiner their a vailability.

Another gems] method of increasine lhe availalility of bone-dust is to mix it with barmy:ard-manure, and let beth ferment ingether in a heap. I sm inclinet th thiok this the hest, simplest, and most eromounical method of rendering hone-alust available. The beme-dust callst s the lieap of manure to ferment more realily, and the fermentation of the manure softens the bones. Both the manure and the boues are improved and rendered richer and more arialible by the proces:

Another methed of increasing the arailability of bone-dust is by mixine it with sulpluric arisl. 
The phosplaste of lime in lones is insoluble in water, lhongh rain water containing carlunic acid, and the water in soils, slowly disolve it. By twenting the bumes with suplouric ancid, the phosphate of lime is leecompusinl and rendered soluble. ('onsequently, boue-dust treated whth sulphuric acid will ace much more mpidly than ordinary bone dust. The sulphuric acid does not make it any richer in phusploric acil or nitroner. It simply renders them more avilahte.

"And yet," sain the Doctur, "the use of sulphurie acil for "dissolvings Imnes, ur rather phemplate of lime, introbluced a new rra in agriculture. It is the grand agricultural fart of the uinetecnth century."

"It is perhaps not neersary," sitil I, "to gree any direction for tratin : bones with sulpliuric acid. We have gest beyoul that. We can mew huy supurphosphute cheaper than we can make it frum lones."

"But is it as gooul?" astird the D) aton.

"Soluble plumpliste of lince," s.idl I, "is soluble phosphate of lime, and it makes us difference whether it is made from hurnt bones, or from phosplantir gutano, ormineral phosphate. That question has been fully decibel lyg the must sati-factory experiments."

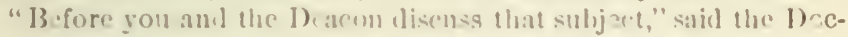
tor, "it wonth be well to tell charley what superpho-phate is."

"I wish you woull tell me," suid Charley.

"Well," said the Doctor, "phospluate of lime, as it exists in bones, is composet of three atoms of lime ant one atom of pliosphoric acid. Chemists rall it the tricalcic phosphate. It is also called the basic phosphate of lime, and not mufreguently the 'bone-earth phospliate.' It is the ordinary or common form of phosphate of lime, as it exists in animals, and plants, and in the various forms of mineral phospliates.

"Then there is another phospliate of lime, ealled the diealcic phosphate, or neutral phosphate of line, or reverted phosphate of lime. It is composed of one atom of water, two atoms of lime, and nne atom of phosphoric acicl.

"Then we have what we call superphosphate, or acid phospluate of lime, or more properly monncalcic phospliate. It is emmposed of 'wo atoms of water, one atom of lime, and one atom of phosplonric acid. This acid phosph te of lime is soluble in urater.

"The manufacture of superphosphate of lime is based on these facts. The one-lime phosplate is soluhle, the three-lime phosphate is insoluble. To conrert the litter into the former, all we have to do is to take areaty taro atums of lime. 
"Sulpluric acil lass a stronger allinity for lime than phosploric acid. And when you mix ennugh sulphuric acid with tinely gromed three-lime phosphate, to take a way two atoms of lime, you get t.ae phosplioric acid united with one atsm of lime aud two atoms of water."

\section{"And what," askel the Deacon, "becomes of the two atoms of lime?"}

"They unite with the smlphuric acill," said the Doctor, "and form plaster, eypsum, or sulphate of lime."

"The molecular weirht of water," (ontinued the Doetor, " is 18; of lime, 5tj; of sulphuric aciul, 80 ; of phusphoric acid, 142.

"An averatere sample of (o)muncreinl hone dnet," (ontinued the

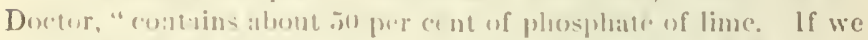

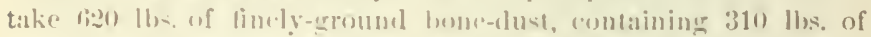
threc lime phosphate, amel mix with it log) lhs. of sulphuric acid

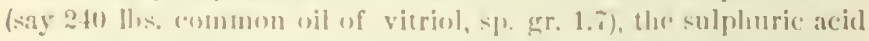
will unite with 11: lhe. of lime, and leave the 14:2 lbs. of plosphoric aced unitul with the remainine 5 th llss. of lime."

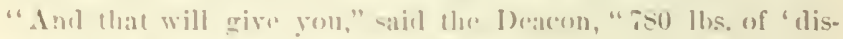
solved bemes, or silju rplimephate of lime."

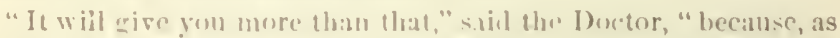
I sail before, the t wo atoms of lime (112 lbs.) are replaced by 1 wo atoms (36 the.) of water. Ancl, furthermure, the two atoms of sulphate of lime produced, contained two atoms (33) \|ls..) of water. The mixture, therefore, contisins, even when perfectly dly, i2 lls. of water."

"Where does this water enme from?" asked the Dracon.

"When I was at Rothamsted," said 1, "the superphexpluste which Mr. Latwe's lsed in his experiments was male on the farm from animal claseoal, or hurne unnss, grombd as fine as possillethe finer the lester. We touk fll llss. of the meal, and mixed it with 20 llse. of water, and then poumel on 30 llse, of rommon sulphuric acidl (*p. r. 1.i), and stirred it up rapidly and thoroughly, and then threw it ont of the veesel into a heap, on the earth-floor in the barn. Then mixed another portion, and so on, until we had the desiret fanamtity, ay two or three toms. The last year I was at Rothamsted, we mixel 40 lhe bene-meal, 30 lls.s. water, and 30 lhes acid; and we thonelit the aldditional water enabied us to mix the acid and meal fugether easiur and better."

"Dr. llabirshaw lolls me," sail the Doctor, "that in making the 'Retifiel Prouvian Guano' no nister is neressary, and none is used. The water in the grumo and in the acid is suffieient to 
furnish the two atoms of water for the phosphate, and the two atoms for the sulphinte of line."

"Such is undoubtedly the cisse," said I, "and when large quantitics of superplousplaste are madr, and the mixing is done by mashinery, it is not neecssary 10 use water. The advantage of using water is in the ereater ense of mixintr."

"Bone-dlest," said the Doutor, "contains alsout 6 per cene of water, and the sulphuric acill (sp. g. 1.i) contalus about sne-third its weight of water. So that, if you take 620 lls. of bone-rlust, and mix with it 24011 s. of common sulphurir acisl, you have in the mixure 117 lls. of water, which is t5 los. more than is needed to furnish the water of combination."

"The superphosphate produed from fir 0 lhs. of bones, therefore," continued the I) uctor, "would eontain:

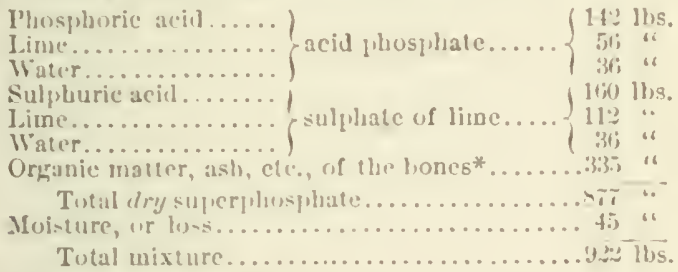

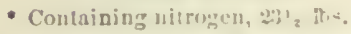

"There is a small quantity of carbonate of lime in the bones," Eail I, "which would take up a litle of the ac.irl, and you will have a remarkably good article if you calculate that the f:20 lbs. of bone-dust furmish you half a $10 \mathrm{n}(1,000 \mathrm{ll}$. $)$ of superphosplate. It will be a letter article than it is practieally poscible to make."

"Assuming that it made hatf a ton," said the Joctor, "it would contain $14 \frac{1}{6}$ per cent of soluble plosphoric acid, and $2 \frac{1}{3}$ per cent of nitrogen."

"With nitrogen at 20 cents per lb., and soluble phosphoric acid at $12 \frac{1}{2}$. per Ib., this half ton of superphosphate, male from $620 \mathrm{lbs}$ of good hone-(lust, wuth be worth $\$ 2.2 .51)$, or $\$ 4.5$ ner ton."

"Or, to lork at it in another light," continued the Doctor, "a ton of bone-dust. m:ade into such a superphospluate as we are tall:in ahout, would be worth si.2.5s."

"How much," asked the Deacon, " would at ton of the bone-dust be consid(re] worth before it was converted into superphosphate?"

"A ton of hone-dusi," replied the Doctor, "contilins $76 \mathrm{lbs}$ of nitrogen, worth, at 19 cents per lh., \$ 13.6 , and 46.4 llhs. phosphoric

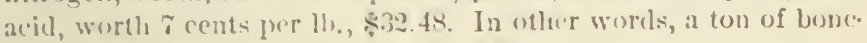
dust, at the usual estimat", is wort's \$16.16." 
"And," said the Deacon, "after it is converted into superphos. phate, the sime ton of bones is worth s.2.58. It thus appears that you pay $\$ 26.42$ per ton for simply making the phosphoric acid in a ton of bones soluble. Is'ut it paying a little too uruch for the whistle?"

"Possibly such is the case," said I, "and in point of fact, I think bone-dust, especially from steamed or boiled bones, ean be used with more economy in its natural state than in the form of superphosphate."

Superphospluate can be made more economically from mineral phosphates than from bones-the nitrogen, if desired, being supplied from fish-scrap) or from some other elicap source of nitrogen.

But for my own use I would prefer to buy a good article of superphosplate of lime, containing no nitrogen, provided it can be ohtained cheapenough. I would buy the aumoniacal, or nitrogenous manure separately, and do my own mixing-unless the mixture could be bought at a liss cost than the same weight of soluble phosphoric acid, aud available nitrogen could be obtained separately.

A pure superplosphate-and by pure I mean a superpbospbate containing no nitrogen-ean be drilled in with the sced without injury, but I should be a little afritid of drilling in some of the ammonizeal or nitrogenous superphosphates with small seeds.

And then, again, the "nitrogen" in a superphosphate mixture may be in the form of nitric acid, or sulphate of ammonia, in one case, or, in another ease, in the form of hair, woollen rags, hide, or leatler. It is far more valuable as nitric acid or ammonia, because it will act quicker, and if I wanted hair, woollen rags, horn-shavings, etc., I would prefer to have them separate from the superplıospliate.

\section{H A P T E R X X X V I I I .}

\section{SPECIAL MANURES.}

Twenty five to thirty years ago, much was said in regard to special manures. Fertilizers were prepared for the different crops with sprecial reference to the composition of the plants.

"Put it was known then, as now," said the Doctor, "that all our atricultural plants were composed of the same clements."

"True, bit what was claimed was this: Some crops contain, for 
instance, nore plospluoric acid than other erops, and for these at manure rich in phosphoric acid was provided. Others contained a large proportion of potash, and these were called ' rotash crops,' and the mamure prescribed for them was r.ch in potash. And so with the other ingreelients of plints."

"I recollect it well," said the Doctor, "and, in truth, for several years I had much faith in the idlea. It was acirocitcd with consummate ability by the lamentel Liebirg, and in fact a patcut was taken out by the Musgraves, of Liverpool, for the mannfacture of Licbig's Special Manures, batwed on this theory. But the manures, though extensively useil by the leading farmers of England, and endorsed by the lighest authorities, did not in the (nd stand the test of actual farm practice, and their manufacture was abandoned. And I clo not know of any experieneed agrieuleural chemist who now adrocates this doctrine of special manures.

")r. Vulcker says: "The ash-analyses of plants do not afford a sufticiently trustwortlyy guide to the practical farmer in selecting the kind of manure which is best applied to each erop.'"

"Never mind the authorities," sild the Deacon; "what we want are lacts."

"Well," replied the Doctor, " lake the wheat and turnip crop as an illustrition.

"We will suppose that there is twice the wriglit of wheat-straw as of grain; anl that to 10 tons of bulls there is 3 tons of turuiptops. Now, 100 lbs. each of the ash of these two erops contain:

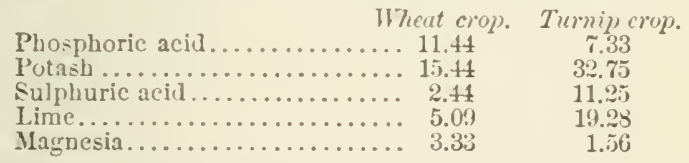

"There are other ingredients," continued the Doetor, "but these are the most important.

"Now, if you were going to compound a manure for wheat, say 100 lbs., consisting of potash and phosphoric acil, what would be the proportions?"

The Deacon figured for a few moments, and then produced the following table:

100 LbS. SPECIAL MaNere FOR WHEAT AND TLRNIPS.

Wheat manure. Turnip manure.

Phosphoric acid.............. $4: \frac{1}{2}$ lbs. $\quad 1 \mathrm{~S}_{\frac{1}{3}} \mathrm{lbs}$.

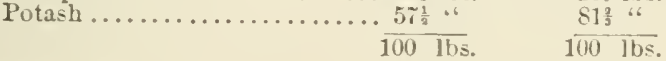

"Exactly," said the Doctor, " and yet the experiments of Lawes 
and Gilbert clearly prove that a soil neels to be richer in available Jhospheric acid, to produce even a fair crop of turuips, than to produce a large crop of wheat. And the experience of farmers everywhere tends in the same direction. England is the greatest turnip-growing country in the world, and you will find that where one furmer applies potash to turnips, or superphosphate to wheat, a hundred farmers use superphospliate as a special manure for the turnip crop.'

"And we are certainly warranted in saying," continued the Doctor, "thit the compusit on of a $p$ unt affords, in practical agriculture, and on ordinary cultivated soils, no sirt of inticution as to the comfors tion of the manure it is best $t$ "pply to the cropp."

"Acrain," (routinued the Doctor, "if the theory was a correct onc, it would follow that these crops which containel the most nitrogen, wonlu require the most nitrogen in the manure. Beans, peas, and cluser would reruire a soil or a manure richer in avalable nitrogen than wheat, harley, or oats. We know that the tery recerse is truc-linow it frum actual, and repentel, and long-continued ex. periments like thos of Liwe's and Gilbert, and from the common experience of farmers cverywhere."

"You neet not get exciteil." said the Deacon, "the theory is a very plausible one, and whule I cannot dispute your facts, I must confuss I camnon see zeliy it is not reasonable to suppose that a plant which contains a large amount of nitrogen should not want a manure sp exilly rich in nitrogen; or why turnips which contain (1) much potash shoull not want a soil or inanure specially ricls in jotasli."

"Do you recullect," said I, "that crop of turnips I raised on a pone hlowing sund ?"

"Yis," saill the I) eacon, "it was the best crop of turnips I efer saw errow."

"That crop of turnips," said I, "was due to a tiressing of superphospluate of lime, will litte or mo potash in it."

"I lnow all that," said the Deneon. "I admit the fact that superpliospliate is a grold manure for turnips. What I want to kunw is the retson why superplusphate is better for turnips than for wheat?"

"Many reasons might be criven," said the Doctor; "Prof. Voleker attributes it to the limiter fee ling range of the roots of turni i'e, : sompared to wheat. 'The roots of whene, says Prof. Virdeler, "as is well known, penctrate the soil to a much inreater hepth than the more leliente fee ling fibres of the ronts of turnips. Wheal, ruaining on the ground t wo or three months longer than 
turnips, can arail itself for a longer periol of the resources of the soil; therefore in wost cas's the phospluoric acid disseminated through the soil is amply suflicient to meet the requirements of the wheat crop; whilst turnips, depending on a thinner depth of soil during their shorter period of growth, cannot assimilate suflicient phosphoric acid, to come to perfection. This is, I believe, the main reasun why the direct supply of readily avialable phosphates is so bencticial to root-('rops, and not to wheat."

"This reanon," said I, "has never becn entirely satisfactory to me. If the roots of the turnip have such is limited range, how are they able to get such a large amount of potarli?

"It is prohable that the turnip, coutainine such a large relative amount of potas! and so little phospluric achil, has roots capable of absurbing potash from a very watak solution, but not so in re. gari to phosphoric acid."

"There is another war of looking at this matter," said the Dontor. "You must recolleet that, if turnips and wlicat were growing in th" same ficld, both plants get the ir fond from the same solution. And instead of supposing that the wheat-plant las the power of taking up more phosphoric acis ihan the turnip-plant, we may suppose that the turnip las the jower of rejecting or excluding a portion of p'osplaoric acil. It tikes up no more potas's than the wheat-plant, but it takes less phosphoric acil."

But it is not necessary to speculate on this matter. For the present we may accept the fact, that the proportion of protash, fhosphoric acid, and nitrogen in the crop is no indication of the proper proportion in which these ingredients should be applied to the soil for these crops in manure.

It may well be that we shoull use special manures for special crops; but we must ascertain what thece minures slould be, not from analyses of the crops to be grown, hut from experiment and experience.

So far as present facts throw light on this subject, we slould conclude that those crops which rontain the leust nitrugen are the most likely to be benefited by its artificial application; and the crops containing the most phosphoric acid, are the crops to which, in ordinary practical agriculture, it will be unprofitable to apply superphosplinte of lime.

"That," said the Doctor, "may be stating the case a little too strong."

"Perhaps so," saicl I, "but you must recollect I am now speaking of practical agriculture. If I wanted to raise a goot (rop of cabbage, I shoulel not think of consulting a chemical analysis 
telligent men engaged in the manufacture and sale of these artificial manures, and owing to more definite knowledge on the part of the manufacturers and of the purchas rs, it is not a diflicult matter to find manures well worth the money asked for them.

"A correct analysis," said I, "furnishes the only sure test of value. 'Testimonials' from farmers and others are pre-eminently unreliable. With over thirty years' experience in the use of these fertilizers, I would place far more confidence on a good and reliable analysis than on any actual trial I could make in the fiell. Testimonials to a patent fertilizer are about as reliable as testimonials to a patent-medicine. In buying a manure, we want to know what it contains, and the condition of the constituents."

In 18i7, Prof. S. W. Johnson gires the following tigures, showing " the trade-values, or cost in market, per pound, of the ordinary occurring forms of nitrogen, phosphoric acid, and potash, as recently found in the New York and New England markets:

Nitrogen in ammonia and nitrates..................... 24

Ceits per pound.

in Peruvian Guano, fine steamed bone, dried and fine ground blood, meat, and fish........... 20

" in fine ground bone, horn, and wool-dust.......... 18

" in coarse bone, horn-shavings, aud fish-serap...... 15

Phosphoric acid soluble in water...................... 12!

" " " "reverted," and in Peruvian Guano....... 9

" " insoluble, in fine hone and tish guano..... 7

" " " in coarse bone, bone-ash, and bone-black................ 5

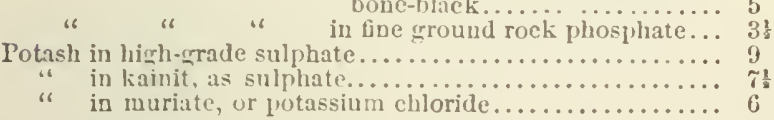

"These 'estimated ralues," says Prof. Jolınson, " are not fixed, but vary with the state of the market, and are from time to time subject to revision. They are not exact to the cent or its fractions, because the same article sclls cheaper at commercial or manufacturing centers than in country towns, cheaper in large lots than in small, cheaper for cash than on time. These values are high enough to do no injustice to the dealer, and accurate enough to serve the object of the consumer.

"By multiplying the per cent of Nitrogen, etc., by the traderalue per pound, and then by 20 , we get the value per ton of the several ingredients, and adding the latter together, we obtain the total estimated ralue per ton.

"The uses of the 'Valuation' are, 1st, to show whether a given lnt or brand of fertilizer is worth as a commodity of trade what it costs. If the selling price is no higher than the estimated value, 
the purchaser may be quite sure that the price is reasonable. If the seiling price is but $\$ 2$ to $\$ 3$ per ton more than the estimated value, it mas still be a fair price, lut if the cant per ton is $\$ 5$ or more over the estimated value, it would be well to look further. 21, Comparisons of the estimated ralues, and selling prices of a number of fertilizers will generally indicate fairly which is the best for the money. But the 'estimated value' is not to be too literally construed, for analysis cannot always decile accurately what is the form of nitrogen, etc., while the m chanical condition of a fertilizer is an item whuse iutluence cannot always be rightly expressed or appreciated.

"The Agriculturul ealue of a fertilizer is measured lyy the benefit recrifed from its use, an 1 depeuls upon its fertilizing etrect, or crop-producing jower. As a broal generil rule it is true that Peruviau gutuno, superphosplıates, tish-scraps, dried blool, potash salts, plaster, etc., have a high agricultural value which is relited to their trade-value, and to a desree determines the latter value. IBut the rule has many exceptions, and in particular instances the trable-value cannot alwars be expected to fix or eren to indicate the anricultural vilue. Fertilizing eflect depends largely upon soil, cropl, aud weather, and as these vary from place in place, and from year to year, it rannot be foretolil or istimated except by the results of past (xperience, and then only in a general and probable manner."

"It will he seen," sail the Doctor, "that Prof. Johnson places a higher value on potash nom than he did 20 years ago. He retains the same figures for solulle phosploric acil, and makes a very just and proper discrimination between the different values of different forms of nitroren and plosplioric acid."

"The prices," said I, "are full as higlı as farmers can afford to pay. But there is not much probability that we shall see them permanently relucel. The teviency is in the other direction. In a public aldress Mr. J. B. Lawes las recently remarked: 'A future generation of British farmers will doubtless bear with some surprise that, at the close of the manure season of $18 \pi 6$, there were 40,000 tons of nitrate of soda in our locks, which could not find jurchasers, although the price did not exreed $£ 12$ or $£ 13$ per ton."

"Ile evidently thinks," said the Doctor, "that available nitrogen is cheaper now than it will be in years to come."

"Nitrate of s da," said I, "at the prices named, is only $2 \frac{1}{2}$ to 28 cents per l', and the nitrogen it contains would cost less than 18 cents per lb., insteal of 21 cents, as giren by Prof. Jolunson."

"No. 1 Perurian Guano, 'guaranteed,' is now sold," said the 
Value per ton of $2,000 \mathrm{lbs}$.

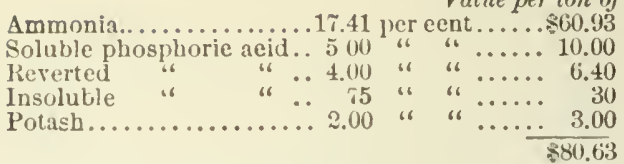

Selling prices per ton of 2,000 lbs.........\$40.00

Irlaboc guano, which was largely imported into England in 1844-5, and used extensively as a manure for turnips, contained, on the average, $7 \frac{1}{2}$ per cent of ammonia, and 14 per cent of phosphoric acid. Its value at the present rates we may estimate as follows :

Ammonia, it per cent.............................. \$26.25

Soluble Phosphoric acid, 4 per cent........................ 8.00

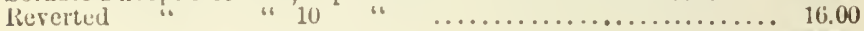

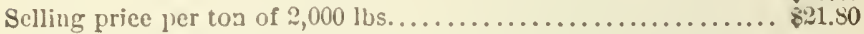

The potash is not giren, or this would probably add four or five dollars to its estimated value.

"All of which goes to show," said the Deacon, "that the Peruvian Gorermment is asking, in proportion to Falue, from two to two and a half times as much for guano as was charged twentyfive or thirty years ago. That first cargo of gruano, sold in New York under the new guarantee, in $18 \%$, for $\$ 56$ per ton, is worth no more than the Ichaboe guano sold in England in 1845, for less than $\$ 22$ per ton!

"And furthermore," continued the Deacon, "from all that I can learn, the guano of the present day is not only far poorer in nitrogen than it was formcrly, but the nitrogen is not as soluble, and consequently not so valuable, pound for pound. Much of the guano of the present day bears about the same retation to genuine oll-fashioned guano, as leacheil ashes do to unleacherl. or as a ton of manure that has heen leached in the barn-yard does to a ton that has been kept unier cover."

"True, to a certain extent," said the Doctor, "but you must recollect that this 'guaranteed' guano is now sold hy analysis. You pay for what you get and no more."

"Exactly," said tlee Deacon, "but what rou get is not so good. A pound of nitrogen in the leached guano is not as a valilable or as valuable as a pound of nitrogen in the unleached guano. An this fact ought to be understood."

"One thing," saill I, "seems clear. The Peruvian Government is charging a considably higher price for guano, in proportion to its actual value, than was charged 20 or 25 years ago. It may 
be, that the guano is still the cheapest minure in the market, but at any rate the price is bigher than formerly-while there has been no corresponding advance in the price of produce in the markets of the world."

\section{POTASH AS A MANURE.}

On land where fish, fish-serap, or guano, has heen used freely for some years, and the crops exported from the firm, we may expect a relative deficiency of potash in the soil. In such a case, an application of unleached ashes or potash-salts will be likely to produce a decilecl benefit.

Clay or loamy lind is usually richer in potash than soils of a more sindy or gravelly character. And on poor sandy land, the use of tish or of gruann, if the crops are all sold, will be soon likely to prove of little benefit nwing to a deficiency of potash in the soil. They may proluce gool crops for a fow years, lut the larger the crops produced and sold, the more woulel the soil become deficient in potash.

We hare given the particulars of Lawes and Gilbert's experiments on barley. Mr. Lawes at a late meting in London, stated that "he had grown 2.; crops of barley one after the other with nitrogen, either as ammonia or nitrate of sola, but witlont potash, and that by the use of potash they bad produced practically no better result. This year (18\%i), for the first time, the potash bad fililed a little, and they hat now produced 10 or 12 bushels more per acre with potash than without, showing that they were coming to the end of the available potash in the soil. This year (1S\%), they obtained 5 t bushels of barley with potash, and 42 bushels without it. Of course, this was to be expected, and they had expected it much sooner. The same with wheat; he expected the end would come in a few years, but they had now gone on between 30 and 40 years. When the end came they would not be sorry, because then they would hare the knowledge they were secking for."

Dr. Velcker, at the same meeting remarked: "Many soils contained from $1 \frac{1}{2}$ to 2 per cent of available potash, and a still larger quantity locked up, in the shape of minerals, which only gradually came into play; but the quantity of potash carried off in crops did not exceed 2 cwt. per acre, if so much. Now 0.1 per cent of any constituent, calculated on a depth of six inches, was equivalent to one ton per acre. Therefore, if a soil contained only 0.1 per cent of potash, a ton of potash might be carried off from a 
depth of 6 inche's. But you had not only 0.1 per cent, but something like $1 \frac{1}{2}$ per cent ancl upwards in many soils. It is quite true there were inany soils from which you could not continuously take crops without restoring the potash."

"In all of which," said the Doctor, "there is nothing new. It does not help us to determine whether potash is or is not deficient in our soil."

"That," saiı I, "can be ascertained only by actual experiment. Put a little hen-manure on a row of corn, and on another row a little hen-manure and ashes, and on another row, ashes alone, and leave one row without any't, ng. On my farm I am satisfied that we neell not buy potash-salts for manure. I do not say they would do no goo l, for they may to gnod on land not deficient in available potash, just as lime will do good on land contiaining large quantities of lime. But potash is not what my land neels to make it produce maximum crops. It needs available nitrogen, and possibly soluble phosphoric acid."

The system of farming adopted in this section, is much more likely to imporerish the soil of nitrogen and phosphoric acid than of potish.

If a soil is deficient in potash, the crop which will first indicate the deficieney, will probably be elover, or beans. Farmers who can grow large crope of red-elover, need not buy patash for manure.

On farms where grain is largely raised and sold, and where the straw, aud corn-stalks, and hay, and the hay from clover-seed are retained on the farm, and this strawy manure returned to the land, the soil will become poor from the lack of nitrogen and phosphoric acil long before there would be any need of an artificial supply of potaslo.

On the other hand, if farmers shonld use fish, or guano, or superphosphate, or nitrate of sola, and sell all the hay, and straw, and potitoes, and root-crops, they could raise, many of our sandy soils would soou become poor in arailable potash. But eren in this case the clover and beans would show the defieiency sooner than wheat or eren potatoes.

"And yet we are told," said the Descon, "that potatoes contain no end of potash."

"And the same is true," said I, "of root-crops, such as mangelwurzel, turnips, ete., but the fact has no other significance than this: If you grow potatoes for many years on the same land and manure them with nitrogenous manures, the soil is likely to be speedily impoverished of potash."

"But suppose," said the Deacon, "that you grow potatoes on the 
same land without manure of any kind, would not the soil become equally poor in potash ?"

"No," said I, " because you would, in such a case, get very small crops-simall, not from lack of potash, but from lack of nitrogen. If I had land which had grown corn, potatoes, wheat, oats, and hay, for many years without manure, or an oceasional dressing of our common barnyird-manure, and wauted it to produce a good crop of potatoes, I should not expert to get it by simply applying potash. The soil might be poor in potash, but it is almost certain to be stıll poorer in nitrogen and phosphoric acid.

Land that has been manured with farm vard or stable manuro for years, no matter how it has been cropped, is not likely to need potash. The manure is richer in potash than in nitrogen and plosphoric acil. And the same may be said of the soil.

If a farmer uses nitrogenous and phosphatic manures on his clayey or loamy land that is usually relatively rieh in potash, and will apply his common manure to the sandy parts of the farm, he will rarely need to purchase manures containing potash. 


\section{II A P ' L E R X L.}

\section{RESTORING FERTILITY TO THE SOIL.}

BY SIR J. 13, LAWLS, B.RT., LL.D., F.16.S., ROTIAMSTED, ENG.

$\Lambda$ relation of mine, who alrearly possessed a very eonsicterable estate, consisting of light land, about twenty years ago purchased a large property auljoining it at a rery high price. These were days when farmers were thourishing, and they no more anticipated what was in storo for them in the future, than the inhabitants of the earth in the days of Noah.

Times have changed sinec then, and hat seasons, low priees of wheat, and cattle-elisease, have swejt off the tenants from these two dstates, so that my relation finds himself now in the position of heing the unhaply owner and oceupier of five or six farms, cxtending over sereral thousanul acres-one farm alone oceupying an areat of two thousanl four hundred acres. Fortunately for the owner, lo prossesses town property in adelitiun to his lauded estates. so that the question with lim is not, as it is with many land owners, how to find the necessary calpital to cultivate the land, but. having fomm the capital, how to expend it in farming. so as to produce a propere return.

It is not rery surprising thit, uncler these eireumstanees, my opinion should have been asked. What, indeed. would have leen the us: of a relation, who not only spent all his time in arricultural experiments. but also pretended to teach our neighlors how to farm on the ofher side of the Atlantic, if he eould not bring his seinento bear on the land of an aljoining county: Ifore is the lami-my rulation might naturally sayhere is the money, and I hare so much eonficlence in your caparity that I will give you cente-blunche to spend as much as you pleast-what an 1 to do?

An inspection of the property hrought out the following faets -that all the lanel was very linht. and that you might walk over the fresh plewed surfice in the wottest weatler without any eliy sticking to your luots : still al portion of the soil was dark in eolor, and therefore prohalily eontained a suffieient amount of fertility to make cultivation profitable, proviled the management coulil be comblucted witl that care an.l economy which are absulute essentials in a business where the expenditure is always pressing closely upon the income. 
Upon land of this deseription meat-making is the hacklone of the system, which must be adopterl, and a large breseling flock of sheep the first essential towards suecess.

Scienee can malie very little improrement upon the fourcourse rotation-ronts, barley, clover, and wheat, unless, perhaps, it may be by keeping the land in clower, or mixed grass and elover, for two or thee years.

A groml de:tl of the land I was inspecting was so light, that, in fact, it was hardly more than sand, and for some years it had been left to grow anything that came up, undisturbed by the plow.

To a practised rye, the chinacter of the natural vegetation is a sure indication of the fertility of the soil. Where herds of butfaloes are to be seen-their sicles shaking with fat-it is quite evident that the pastures upon which they feed cannot be very bat; and in the same way, where a rank growth of weeds is found springing up upom lanel that las been abandonal, it may be taken for certain that the elements of food exist in the soil. This ground was covered with regetation, but of the most inporerished deseription, even the "Quack" or "Couch-grass" could not form a remular carpet, but grew in small, detached bunches; everything, in fact, bore eridence of poverty.

Possibly, the first idea which might occur to any one, on seeing land in this state, might be: Why mot grow the crops hy the ait of artificial manures?

Let us look at the question from two points of view : first, in regarl to the cost of the ingredients; and, secondly, in regard to the growth of the crop.

We will begin with wheat. A crop of wheat, machine-reapel. contains, as carted to the st:sek, about six pounds of soil ingredients in every one humbled pounds; that is to say, each five poumls of mineral matter, and rather less than one pound of nitrogen, which the plant takes from the soil, will enable it to obtain ninety-four pouncls of other substances from the atmosphere. To grow a crop of twenty bushels of grain and two thousand pounds of straw, would require one hundred and sixty pounds of minerals, and about thirty-two pounds of nitrogen ; of the one luundred and sixty pounds of minerals, onehalf would be silica. of which the soil possesses already more than enough ; the remainder, ronsisting of about eighty pounds of potash and phosphate, could be furnished for from three to four dollars, and the thirty-two pounds of nitrogen could be purchased in nitrate of suda for six or elght dollars. 
The actual cost of the ingredients, therefore, in the crop of twenty busleds of wheat, wonld be about ten to twelve dollars. But as this uamure would furnish the ingredients for the growth of luth straw and grain, ambl it is customary toreturn the straw to the land, after the first crop, fully one-third of the cost of the manuremight, in conseryuence, be daducted, which weruld make the ingreelients of the twenty hushels amonnt to six dollars. Twenty lushels of wheat in buglamel would sell fer twenty-exight dollars: therefere, there would he twenty-twe dollars loft for the cost of enltivation aml protit.

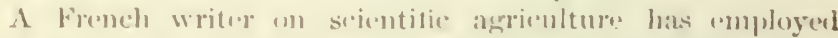
digures very similar to the above, lo show how Foneh farmers maty grow whest at less thatu one desllar per bushol. At this priece they might antainly defy the eompretition of the Uniterl Staters. It is one thinge however, to grow (rop)s in a lecture

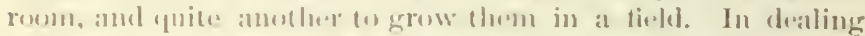

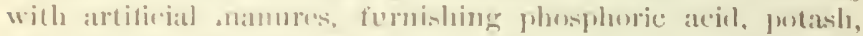

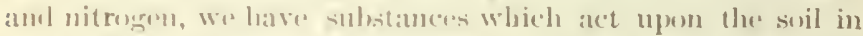
very ditfereuts ways. Plusplate of lime is a very insolubles sulst:moe, and refuires an inormens atmomut of water to disselve it. Salts of putats, oll the other hamul, are very soluble in water, but form very insoluhle rompumuls with the soil. Salts of ammonia anel nitrate uf stula are jerfer.lly solublu in water. When applient to the land, the almumenta of the former sub. stance forms an insoluhle connpumul with the soil, lut in a rery short time is eonverted into nitrate of lime: and with this salt and nitrate of soulat, remains in solntion in the soil water motil they are either taken uj, hy the plant or are washel away into thu drains or rivers.

Crups eviljorate a very large amoment of water, and with this water they attrant the soluble nitrate from all parts of the soil. Very favorable satsons are therefore these in which the soil is meither toos dry nor tex wet: as in one ase the solution of nitrate becomes dried up in the suil. in the other it is ejther washerl away, or the suil lemanins se wet that the plant (anment evaporate the water sulliciently to draw up the nitrates which it iont:iins.

The anount of protasly and phosphoric arid lissolved in the water is far too small to supply the repuilemonts of the plant. and it is probable that what is reepuires for this purpose is dis:olverl by some direet action of the rents of the plant on coming in contate with the insuluble phosphoric acid and potash is the soil. 
In support of this view. I maty mention that wo have cleat evidence in some of our experiments of the wheat croptaking up both phespluates and potash that were applied to the land thirty years agen.

To stepreste, therefore, that, if the sugredients which axist in twenty busheds of wheat and its straw, are simply applied to at barren soil, the (rople will be able to conse in contact with, and take up these substances, is to asistume what certininly will not take place.

I have oftell expresent an opinion that arablo lant, (o)uld not be coultivated protitably by means of atrtificial manures, un! the soil was eapable of promlucing. from its own resourees, a considerable anount of produce: still the yuestion hall mever up to this time come lufore me in at distinet form as one upon which I had to deedele and way or the other. I hat, however. no hesitation in (oming to the (o) never be grown at a profit upon my rolation's land, and that

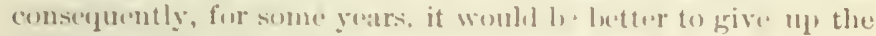
attempt. and ory to impurove the patsture.

After what I has said alout the insulubility of potash and phosphoric acol, it may pusibly lw askinl-why not grive a gousl dose of these substances at omere as they de not wash ont of the soil-say "mough to grow sixt! crops of grain, and apply. the nitrate, or ammonial esery year in just sullicient amounts to supply the want of the (rop)?

The objections to this plat are als follows: assmunge the most farorable comditions of climates, and the largest pousilude produce, the wheat could erertainly not take up the whole of the thirty-two pounds of nitrugen applied, atml the (top) which requires nearly one jement of nitrogen in erery one liundred pounds of gross pronluce, would be cortainly lass than three thousand two humeled pennels, if supplied with only thirty-two pounds of nitrogen. If we take the tostal prouluce of the best and worst wheat crop, grown thring the forty years of our experiments, we shall arrive at a better understamling in the matter. The following are the figures:

Weight of Dry Prodece of Wheat Per ACre.

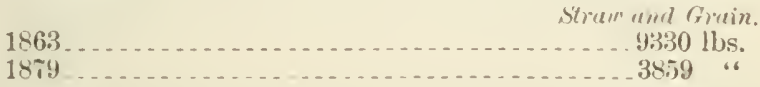

In orler to ascertain the increase due to the nitrogen of the salts of ammonia or nitrate of smla, we must doduct from the 
crop the produce obtainet, where mineral manures without nitrogen were used. In 1863 this amount was three thousand pounds, and in 1879 it was one thousand two hu.elred pounds. Deducting these amounts from the gross produce in each case, leaves sis thousand three hundred and thirty as the produce due to the nitrogen in the season of 1863 , and two thousand six humdred and fifty-uine as the produce due to the nitrogen in 1879.

But in each case we applien the same amount of nitrogen, eimhty-seren pounds: and as the amount of nitrogen in a wheat crop. as earted from th+' fiell, contains less than one per cent. of nitromen. it is evilent that if all that was contained in the manure hat been taken up ly the plant, the increased crop should have wreighe l ei ritt thousand saven hundre- pounds insteal of six thousand threw humlyed and thirty. Thus even in our best year. some of th. nitrogen applied failed to produce growth; and when we come to the bad year we find that only twenty-six and a half punds were taken up out of the eightyseven poumls applied, thus leaving more than two-thirels of the whole unaccountel for.

Seasoms ane only occasionally either very had or very good. What we call an arerage seasun does not differ very much from the mean of the leest and worst years, which in this eaie would he reteresented hy a crop of four thousanl four hundred and ninety-four pounds, eontaining nearly forty-five pounds of nitrogen. I may say that, although I have employed one per cent. to aroid fractions in my calculations, strictly speaking threse-puarters of a per cent. would more nearly represent the real yusutity. If, however, on the average, we only obtain abont forty-five pounds from an application of about eightyseven pumbls of nitrogen, it is evilent that not more than onehalf of the amomt applied entrers into the corp.

Now in dealing with a substance of so costly a nature as ammonia. or nitrate of soda-the nitrogen contained in which substances cannot cost muel less than tweniy-five cents per pound by the time it is spread upon the land, it hecomes a question of importanee to know what beeomes of the other half, or the resilue whatever it may be, which has not been taken up by the crop. Part is maloubterlly taken up by the weeds which grow with the wheat, and after the wheat has been cut. Part sinks into the sub-soil and is washed completely away during the winter.

I, myself, am disposed to think that the very great difference 
in the size of the Indian com crops, as compared with the wheat crops in the states, is partly accounted for by their greater freelom from wends, which are large consumsers of nitric acis, and, in the case of the what crop, frequently recluce the gield by sereral bushels pere ace. It must, howerer, be borne in mind that, thung the wheat is robbed of its food where there are weenls, still if there were no weeds, the amount of nitric acid which the crop could not enet holld of, would, in all probabilty, be washer ont of the soil during the ensuing winter. I cone to the eonchuion, therefore, that the nitrogen alone, which wonld be reepuired to pronluce one bushel of wheat, woulel cost nut much less than lifty cents; and that, in consequence, wheat-growing by means of artiticial manures, will not pay upon very pors lan?.

I have said that the laterl, alout which I was consulted, hai not ben plowed for several rears, and that althumbliture had done all she could to clothe the soil with regretation, the most clisheartening feature in the cisse wats, the poverty of the weeds. I thistle may lwa g giant or a clwarf. acconling to circumstinces; here thy were all dwarfs. The plointain, which I believe is sometims surn in thes districts for foml, has a very deep root: here the plants were abundant, but the leaves were very small and lay so clos's to the grouni, that, as the manager informed $\mathrm{m}$ '. "the sheep were often injured from the ammunt of sand which they swallowed with the leares when feeding."

At Rothamsted. the analyses of the rain water passing through the ordinary soil of one of my fiekls, which has been kept free from regetation, have siown that the amount of nitric acill liberated in a soil, and washeel out each year, is very large. Taking the ten years luring which these special experiments have been in progress. I should think that the loss of nitrogen would be equal to, or pussibly exceel, the amount of that substance removel by the arerage crops grown in the United States.

The results obtained by the rain gauges, are further completely confirmed by those in an adjoining field, where wheat and fallow have been grown alternately for twenty-seven years. The liberation of nitric acis, during the sear of rest, produced for a time a large growth of wheat, but it was done at a very great waste of the fertility of the soil, and the produce is now, in proportion, considerably lower than that grown s the con. tinuously unmauured laud. 
These results, if they are to be accepted as correct, must bring about a very considerable change in the generally received views in regiud to fertility. We not only see more clearly the connection between a former vergetation and the stured up fertility in our soll, lut we also see the importance of vegetation at the present day, as the only means by which the loss of nitrie acid is prevented. The nore completely the land is covereid with veretation, and the mor growth there is, the greater will be the evapration of water, and the less will he the loss of nitric acid by drainage.

I was not at all surprised to find, that the surface soil of a woml on my farm, was poorer in nitrugen than the soil of an old permanent pasture, to which no manure had been applied for twenty-tive years, thomgh duriag the whole period, the crop of hay hat been remored erery year from the land. The wood to which I refer is eoreled with oak, eenturies old, and the foliage is so dense that but little melerwool or uther vegetation ean grow heneath it. If hoth the wool and the pasture were put into arablecultivation, I have no doubt that the pasture would prove much more fortile than the wood land.

In our experiments on permanent pasture, it has been observed that the character of the herbage is mainly dependent on the food supplied. Weeds, and inferior grasses, ean hold their own as hne as poverty exists, but with a liberal supply of manure, the superior grasses overgrow and drive out the bad grasses and weeds. In conseguence of the low price of wheat a good deal of land in Eagland has b en taid down to promanent pasture, and much money has been sput in cleaning the lam preparatory to sowing the grass-seels. I have on more oceasions than one. sugrestral that the money employed in this process womlal be better expended in manure, by which the weeds would be "improved" off the face of the land. Whice walking over the abandoned portion of these estates I explaincd my views upon this proint to the manager. They were, however, received with the usual skepticism, and the rejoinder that "there was only one way of getting rid of the weeds, which was by the plow and fire."

There is nothing that speaks to me su foreibly as color in vegetation; when travelling by rail, I do not require to be told that such il farm is, or is not, in high condition, or that we are passing through a fertile or infertile district. There is a peruliar grecn color in regetation which is an unmistakable sign that it is living upon the fat of the land. I neel hardly say 
that, in this ease, the color of the vegetition gave unmistakahle signs of the porerty of the soil ; hut in the midst of the dingy yellowish-green of the herbage, I (ame upon one spuare of bright green grass. In answer to my enquiry I was told that, a "lambing-fold liad lwen there last year," and my informant added his opinion, " thit the manure would he se strong that it would kill anything !" It lat eertainly killed the woeds, but in their place, some good grasses had taken possession of the soil.

The plan I proposed to arlept was, to spend no more money on tillage operations, but to culleavor to improve the pisture by giving to it the food neerssary to grow gexol gratsses, sowing at the same time a small quantity of the best seeds. I further suggrested that aflock of sherep shonlel he anlowed to run over the whole of the land by dily. and be folded there every night -about one pound of cotton-sored eake pre head being allowed daily. By this means, as the fold would be noved every day, the amount of manure deposited on the soil eould bo estimated.

If there were a hundred sheep, receiving one pound of decorticated cottonsed saks jer head. daily, and the hurdles were arranged to enclose a space of twenty-five hy twenty yards, in the conrse of ten disys an arre of land would have received manure from one tlousand pounds of eake; which amount wonld supply seventy-seven pounds of nitrogen, sixty-eight pounds of phosphate of line. and thirty-two pemmls of potash. This amount of ealke would cost about sixteen dollars.

As regards the vilue of the calie as a fool, it is somewhat difficult to form an estimate; but it takes nine or ten pounds of dry fool-say roots, cake, and hay-to produce an increase of one pound of live wright in sheep. The cake has certainly a hicrer ferding value, than either hay or roots, but I will here give it only the same ralue, and eonsider that one hundred and ten pounts of increase of the animal was obtained by the consumption of the one thousand pounds of cake. The value of the increase of the live weight would be in England fully eleven dollars, leaving five dollars as the eost of the monure. Now the eake furnished seventy-seren pounds of nitrogen alone, which, if purchased in an artificial manure, would have cost nineteen dollars; and the other substances supplied by the cake, would have cost from four to five dollare more. The manures required, therefore, would be obtained much more cheaply by this than by any other process. 
Lalor would be saverl by not eultivating the land. Manure would be savel by sulstituting vegetation which grows under or above ground, almost all the year round. And, by feeding the siock with cake, the necessiry fertility would be obtained at the lowest possible cust.

It is probable that the land would require this treatment to be repeated for several years, before there would be a fair growth of gress. The land might then be broken up and one grain erop be taken, then it might again be laid down to grass.

Hitherto, I have cousidered it rase where fertility is almost absent from the land, this, lowwever, is an exception, as agriculture generally is carried on upon soils which contain large stores of fertility, though they may be rery unequally distributed. By analysis of the soil we can measure the total amount of fertility which it eontains, but we are left in ignoranee in regard to the amount of the ingredients which are in such a form that the crops we eultivate can hiake use of them.

At Ruthamsted, among my experiments on the growth of continuous wheat, at the end of forty years, the soil supplied with salts of ammonia has yiehled, during the whole time, and still continues to yielel, a larger protuce than is obtained by a liberal supply of phosphates and alkaline salts without ammonia.

When we eonsider that "very one hundred pounds of wheat erop, as carted to the stack, contains about five per cent. of mineral matter, and one per eent. of nitrogen, it is inpossible to avoid the eonclusion that nuy soil has a large available balance of mineral substances which the erop eould not make use of for waut of nitrogen. The erol, which has received these mineral manures now anounts to from twelve to thirteen lushels per acre, and removes from the land about sixteen pounds of nitrogen "very year.

Analyses of the soil slow that, even after the removal of more than thirty (erops in sucession, without any applieation of manure containing ammonia, the soil still contains some thousinds of poumls of nitrogen. This nitrogen is in combination with earbon: it is very insoluble in water, and until it becomes separated from the carlom, and enters into eombination with oxyeren, does not appear to be of any use to the crop.

The eomllination of nitrogen with oxyg: $n$, is known as nitric acid. The mitrie acill ('nters mto combination with the lime of the soil, and in this form becomes the food of plants.

From its great importane in regarl to the growth of plants, nitric aed might brealled the main spring of agriculture, but 
being perfectly soluble in water, it is constantly liable to be washed ont of the soil. In the experiment to which I have referred above-where wheat is grown by mineral manures alone -we estimate that, of the amount of nitric acid liberated each year, not much more than one-half is taken up by the crop.

The wheat is ripe in July, at which time the land is tolerably free from weeds; several months, therefore, occur during which there is no vegetation to take up the nitric acid; and even when the wheat is sowr at the end of Octoher, much nitric acid is liable to be washed away, as the power of the plant to take up food from the soil is very limited unt il the spring.

The formation of nitric acid. from the organie nitrogen in the soil, is due to the action of a minute plant, and goe's on quite independent of the growth of our emops. We get, however, in the fact an explanation of the extrenely different results obtained by the use of different namures. One farmer applieslime, or even ground limestone to a soil, and obtains an increase in his erops ; probably lie has supplied the very substance which has enabled the nitrification of the organic nitrogen to increase; another applies potash, a third phosphates; if either of these are absent, the crops cannot make use of the nitric acid, however great may be the amount diffused through the soil.

It may possibly be said that the use of mineral mamures tends to exhaust the soil of its nitrogen: this may, or may not, be true; but eveu if the minerals enable the crop to take up a larger amount of the nitric acil found in the soil year by year, this does not increase the exhaustion, as the minerals only tend to arrest that which otherwise might be washed away.

We must look upon the organic nitrogen in the soil, as the main source of the nitrogen which grows our crops. Whatever may he the amonnt derived from the atmosphere, whether in rain, or dew ; or from eondensation by the soil, or plants, it is probable that, where the land is in arable cultivation, the nitrogen so obtained, is less than the amount washed out of the soil in nitric acid. Upon land which is never stirred by the plow, there is much less waste and much less activity.

The large increase in the area of land laid down to permanent pasture in England, is not due alone to the fall in the price of grain. The reduction of fertility in many of the soils, which have been long under the plow, is beginning to be apparent. Under these circumstances a less exhausting course of treatment becomes nceessary, and pasture, with the protuction of meat, milk, and butter, takes the place of grain fields. 


\section{A P P E N D X.}

\section{LETTER FROM EDWAID JESSOr, YOKK, PA.}

ГокК, PA., March 16, 1876.

Joseph Hurris, E'sy., Horctm Firm, Rewherster, I. I. :

Dear Sir-Yunr faror of the 2:d of last mouth eame safely to hand, and I an truly obligetl to you for the reply to my question.-You ask, can I help you with facts or suggestions, ou the subject of manure? I fear not mucb: but it may be useful to you to know what others need to know. I will louk forwarl to the adreut of "Talks on Manures" with mueh interest, hoping to get vew light on a subject second to none in importance to the Iarner.

I have done a little at e Jmposting for some years, and am now having a pile of about forty coris, made up of stable-manure and carth taken from the wasb of higher lands, turned and fined. The labor of digging and hauling the earth, eomposting in thin layers with manure, turning, and tiniug, is so great, I loubt whether it pays for most farm eropsthis to be used for mangel-wurzel and market-garlen.

The usual plan in this county is to kiep the stable-manure made during winter, and the accumulation of the summer in the barm-yard, where it is soaked by rain, and trampled fine by cattle, and in August and september is hauled upon ground to be seeled with wheat and grass-seeds. I do bot think there is much piling and turning done.

My own cunchsions, not based on accurate experimente, however, are, that the best inanure I have ever apjolied was prepared in a eovered pit on which eattle were allowent to rum, and so kept well trampedsome drainage into a well, secured by jouring water upon it, when necessary, and the Irainage punped and distributed over the surface, at short intervals, partienlarly the parts not well trampel, and allowell to remain until it became a homogeneous mass, which it will do without ha ring undergune so active a fermentation as to have thrown of a considerable amount of ras.

The next best, composting it with earth, as above luseribed, piled about tive or six feet high, turned as often as convenient, and kept moist enourh to secure fermentation.

Or, to throw all the manure as made into a covered pit, until it is thoroughly mixed and made tine, by allowing hogs to run upon it and rout at will; and when prepared for even spreading, apply it as a topdressing on grass-land-at any conrenient time.

As to how many loads of freslı manure it takes to make une of wellrotted manure, it may be answered apjoroximately, lliree to one, but that would depend a groed deal on the manner of loing it, and the amount of rough material in it. If well trodien by ittle under eover. and sufficient draikige joured over it, to prevent any violent fermentation, the 3!:- 
luss of weight, I think, woulh not be very great, nor the bulk lessened over one-lialf.

Many years aro un uhl and sneeessul farmer sajul to me, "if you want to get the full benctit of manure, spread it as a top-elressing on some yrouing crop," and all uy "xperience and observation since tend to confirm the correctness of his advice.

While on this subject, allow me to protest against the practiee of naming the quantity of manure applien to ugiven space, as so many linels, as altogether tou fudefinite. The bushel or cord is a definite quantity. which all can mucterstand

The average price of gool livery stahle horse-mannre at this place has been for several years four diullars it cord.

With two and a half miles to hatul, I an trying whether kecping a flock of 50 breeding ewes, and ferding liberally wilh whent brau. in aldition to bay and pasture, will not probluce the needed manure more eheajply.

$$
\text { Respectfully yours, Euwari) Jissul. }
$$

1. S-You ask fur the alverage reight of a cord of manure, such as we pay four tollars for.

I hud a cord of horse-stable manure from a livery stable in York which had been all the time unler eover, with sev ral figs lauming upon it, and was moist, without any excess of wet, luded intu a wagon-box holding an entirn corl, or 124 cubic feet, trampel by the wagoner three times while loating.

The wagron was weigheil at our hay-scales before loading, and then the wagou and load together, wilh a net result for the manure of $4,400 \mathrm{lbs}$. I considered this manure rather better than the averace. I had another loak, from a diflerent place, which weiglued over 5,000 lhs., but on examination it was found to contain a goold deal of cual ashes. We nerer buy by the ton. IIarrison Bros. \& Co., Manufacturing Chemist., Philadelphia, rate baruyarl-manure as wurth $\$ 5 . \pi$ per ton, and say that would he about \$ิ.21 per corrl, which would be less than $1 \frac{1}{2}$ tons to the eord. If thrown in loosely, and it happened to be tery dry, that might be possible.

Waring, in his " IJandy Book of Husbandry," page 201, says, ha caused a eord of well-trodden livery stable manure eontaining the usual proportion of straw, to be earefully weighed, and that the cord weighed T,, $\mathrm{SO}$ Ibs.

The load I had weighed, weighing 4,400 lbs., was considered by the wagoner and by myself as a fair sample of gond manure. In riew of these wide differences, further trials would be desirable. Dana, in his "Muek Maunal," says a cord of green cow-dung, pure, as dropped, weiglis $9, .289 \mathrm{lbs}$.

Farmers here seldom draw mannre with less than three, more generally with four horses or mules; loading is done by the pnrehaser. From the baru-yard, put on loose boards, from 40 to 60 bushels are about an average load.

In hauling from town to a distance of three to five miles, farmers generally make two loads of a cond each, a day's work. From the barn-yard, 
a very variable number, per day. In ny own ease, two men with three horses lase heen hauling six and seven loads of sisty bushels, fine compost, a distance of from one-half to three-fourths of a mile, up a long and rather bteep libl, and spreading from the wagon, as bauled, upou grass-sud.

Our larger farmers often hare one driver and bis team, two wagons, one lnading, while the other is clrawn to the tield; the driser slips of one of the side-boarls, and with his dung-hook draws off piles at nearly equal distances, to be spre d as eunrenient.

EDWARD JEsSUP.

LETTER FHOM JK. L. L. STCHTLYAT, SOLTI FHMHNGMM, MASS.

\section{Sutrul libamsguan, Mass., April 2, 15\%6.}

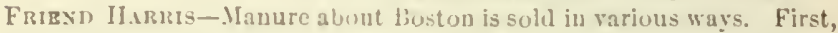
according to the unuber of animals kept; j rice varying so much, that 1 do not renture to name the fierures. Iiy the coril, to be trudelen over while luading; neser by weight, su far as I can learn-priec from 0 to $\$ 12.00$ prer cord. acenrding to seasnn, and rarions aceilental cireumstances. During the jast winter, manure bas been giren awuy in l3oston. Ifandling, hauling to the milroad, and freight costing șt per eorl for carrying 30 uniles unt. Marlet-garileuera usually haul manure as a return freiglat on their journeye to and from market. About South Framingham, price stifr at ș a cord in the vellar, and this may be considered the ruling suburban price. Very friendly yours,

\section{E. I.EWIS StrRteVANT.}

IETTER FROM M. C. WELD.

Уеw Tовк, Nor. 9, 18\%6.

Mr Dear IIARTis- [ don't know what I can write about manures, that would be of use. I hare strong faith in humus, in ashes, leaclicd and unleached, in litwe, gas-lime, flistur, bones, ammonia ready formed, nitrates ready formed, not much in sueat and blond, unless they are chealy. Siertheless, they uften are (heap. and prouluee splendid efiects. I helicre in sulplutuic acil, with organic nitrozenons manures; the eompostiner of meat, blond, hair, ete., with jeat and muck, and wetting it down with dilute sulphuric acis. I beliere in green-manuring, heartils, and in tillage, tillage, tillage. Little faith in superphosphates and compoumled manues, at selling prices. Ilabirshaw"s guano is good enough. So much for my crecd. Truly yours,

M. C. WELD.

\section{LETTER FROM PETEM HENDFRSOS.}

$$
\text { New Tork, Met. :6, 18;6. }
$$

\section{Mr. Therph Marris:}

De.AR Sir-If you will refer to my work "Garlening for Profit," Jew Edition, page 34, rou will gret about all the information 1 possess on Manures, except that I lo not say anglhing about price. In a general way it micht he safe to alrien that whenerer $a$ tom (it is always best to speak of manures by weight) of either eow, horse, hog, or other stablemanure can be laid on the grumnd for \$i?, it is (heaper than eommereial fertilizers of auy kind at their usual market rates. This sิ jer ton, I 
think, would be about the arerige eost in New lurk, Boston, "r l'hila delphia. We never haul it on the gloumel until we are realy to fluw it ln. If it has to be taken from the hore or cistle yarls, wo ilraw it ont into lare heaps, convenient to where it is to be put on the land, turning it, to keep it from birming or "tire-fangring," if necessary. Nume of our farmers or market craldewers lere keep it under eover. The expense of such coveriug and the greater diflieulties in get ting at it, for the innenese quantities we use, would the greater than the brnefits to br ierived from keeping it under cover-benetits, in fact, which, I think, may be greally overrated. Very truly yours,

Piteu liexderson.

LETTER FROM J. M. B. AYNEIRBN, ED, "CANADA FAKMEN," TORONTO. J. Marris, Fisig. :

"Canada Farmeu" Office, Torusto, Mareh 2 ?, $15,6$.

DEAR SiR-Yours of the 2ith inst. Is to hand, and I sliall he most happy to render you ans assistanee in my power. The work you undertake is in uhl hands, and I have every contilence that, when completel, it will form an invaluable acqui-ition to the arricultural literature of the day.

Manure in this city is usually sold hy the two-horse load-about it tons-at the rate of $\$ 1$ per loakl, wr bij cints per ton. The load contains just ubout a coril of mamure, euns."i]uently a corl will wrigh about 1 t tons.

With relerence tw the Eeneral manazenent of maumre in Canada, I may asy that the Eystem filloweil difers in no material respect from that of Nes lork amil the other Eastern states. It is usually kept over winter in the npen barn yari (rarely under enver, I au sorry to say), lajd out on the land about the time of disappearance of last snow, and plowed in. In snme cascs it is not eartel out until the laus is realy for immediate plowing. Witb eome of our more allsunced firmers, the system has latrly been adopter of keeping unanure unler enver and sprinkliug it thoroughig at intervals with jlaster and other substances. Tauks are also hecoming more common than formerly, fur the preservation of liqvid manure, which is usually applied ly means of large, perforated hogslieads, after the manner wf street-materinc.

Tou ask, how the manure is managed at Bow Park, Brantford. That malle daring fall and winter is earefulls liejt in as small bulk as possible, to prevent exposure to the weather. In February and Mareh it is drarn ont and put in licaps 8 fect square, and well packed, to prevent the esseape of ammonia. In spring, as soon as practicable, it is spread, and Ilowed under inmediately. Manure made in spring and summer is spread on the field at onee, and plowed under with a good, deep furrow

Very truly yours, J. M. B. AxDExsox, Eu. Canala Farmer.

\section{MANTRE STATISTICS OF I.ONG ISLAND.}

THE MANTRE TRIDE OF LONG ISLAND-LETTER FROM J. I. RUSHMORF. OLD Westвikx, Long Island, April 6, $16 \% 6$.

Joseph ITarris, Es.. :

Disk Sir-The great number of dealers in manure in New York pre- 
eludes aceuracy, set Mr. Skidmore (who has been testifying voluminously before the $\mathrm{New}$ York buard of llealth in relation to manure and street dirt), assures me that the accompanying figures are nearly correet. I enelose statement, from two roals, taken from their books, and the amount shipped uver the other road I obtained verbally from the General Freight Aqent, and embody it in the slieet of statisties.

The Ash report I know is correet, as I had aceess to the books showing the business, for over ten years. I bare made numerous applieations, verbally, and by letter, to our lirrest market gardeners, but there seems to exist a greneral and strony disinclination to communicate anything worth knowing. I enelose the best of the replies recived. Speaking for some of our largest gardeusers, I may say that they eultivate orer one hundred acres, and use land sulliciently near to the city to enable them to dispense with railroad transportation in bringing manure to their places and marketing crops. I have nuticed that one of the shrewdest gardeners invariahly composts hom-shavings and bone-neal with horsemanure several montlis before expecting to use it. A safe average of mamre used per acre by gardeners, may be statel at ninety (90) tubs, and from two hundred to twenty hundred pounds of fertilizer in addition, aecording to its strengtll, and the kind of crop.

The following railroal manure statisties will give a gener:lly correet idea of the age of manure, when userl:

STATEMExt OF MANURE SENT FroM JAN. 1 TO DEC. 31, $18 \pi 5$.

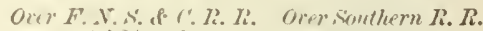

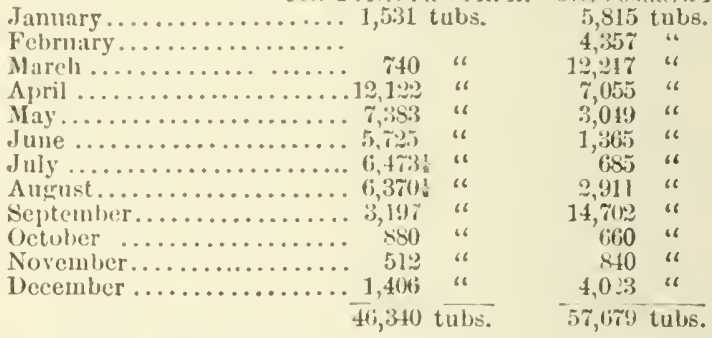

A tub is equal to $1 \mathrm{t}$ bushels.

IJobson, IIurtado \& Co. rejort the amount of Peruvian guano sold in this country last year at thirty thousanel tons.

Estimated number of horses in New York eity, $1100,000$.

Estimated procinet of manure prer horse. Four cords.

Estimated proportion of straw to pure exerement. One-half.

Amount shipped direct from stables. Nearly all.

Anownt shipped on vessels. One-half.

Lengtl of time the unshipped mamure remains in heaps. From three to four mouths.

Average eost per horse, annually. \$3.

Greatest distance of shipment. Virginia. 
Average amount shipped via I. T. R. li. $60,(100)$ tubs.

l'rice of manure per tub delivered on cars or ressel. S0 eents.

A rerage amount jut on car. $\$ 0$ tubs.

Sratistics of Asil Thane.-Time when ashes are lelivered. From middle of June to mildle of Oetoluer.

l'laees from which they are mostly sluipped. Montreal, Belleville, ama Toronto (Canada).

Method of transportation. Canal boats.

Arerage load per boat. Alwut $\$, 000$ bushels.

Average amount anmially solel. 36 ill, 000 bushels.

Arerage cost delivered to farmers. 20, conts foer bushel.

ily Are, about.

Amount used ly farmers for potatoes........ lio tubs.

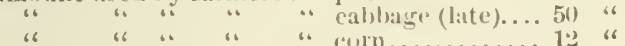

Amount of gruano userl on Lung Island, as rep resented by the books of Chapman ot Vanwyek, and their estimate of sales by other firms, 5,000 tons.

The fertilizers usel on the 1-land are honglit alnost exelusively liy market sardeners or farmers, who do a little market gardening, as it is the general conviction that ordiusy farm-crops will not give a conpunsating return for their application. Must market gardencrs kiep so little stock that the manure malle on the place is very inconsideraible. Onr dairy furmers either eompost home-made manmes with that from the eity, spread it on the land for com in the spring, or rot it separate, to use in the fall for wheat, on land that has been cropped with oats the same year. The manure put on for putatoes is gesserally (estimated to eurich the laud sufticient for it to probuee one crop of winter grain, and from five to seven erops of erass, when it is again pluwed and cultivated in rotation with, first, eorn, second, fotatoes or oats, and is reseeded in autumn of the same year.

Fish and fish guano are largely used on land bordering the water, and adjaeent to the oil-works. The average price for guano in bulk at oilworks is $\$ 12$ per ton. The average price for fish on wharf is \$1.50 per thousand, and it is estimated that, as a general average, 6,000 fish make a ton of guano. The fish, when applied to eorn, are plaeel two at each hill, and plowed under at any time after the corn is large enough to cultivate. Seaweed is lighly prized by all who use it, and it will produce a good erop of eorn when spread thiekly on the land previous to plowing. Very respectfully,

J. II. RusHiore.

LETTER FROM TOHN E. BACKUS.

Newtowx, Long Island, N. Y., Mareh 2nd, 1876.

Mr. G. II. Rushmore:

DEAR SIR. - Some farmers and market-gardeners use more, and some less, manure, aeeorcing to erops to be raised. I use about 30 good twohorse wagron-loacs to the acre, to be applied in rows or broad-easted, as best for certain erojss. I prefer old norse-dung for most all purposes. 
Guano, as a fertilizer, phosphate of bone and blood are very good; they aet as a stimulant on plants and vegetation, and are highly bencicial to some vegetation-more valuable on poor soil than elsewhere, except to produce a thrifty growth in plants, and to insure a large crop.

By wiving you these few items they vary considerably on ditferent parts of the Island; julgment must be used in all eases and all business. Hoping these few lines may be of some avail to Mr. Harris and yourself, I remain, yours, ete., Joun E. Backus.

\section{MANURE IN PHILADELPHIA.}

\section{LETTER FROA JOSEIII HEACOCK.}

Jenkintown, Montgomery Co., Pa., April 18th, 1876.

My Dear Friexd Harris.-Stable-manne in Philadelphia, eosts by the single four-horse-loat, abont $\$$ hanl mueh of it, have it engaged by the year, and then it can be had for from s; to ss pel loul. Mostly, four horses are used, though we frefuently see two and three-horse teams, and occusionally, five or six horses are used. I liave never seen any kind of dung hauled but that of horses. Cow-manure would be thought too heavy to haul so long a distance. Sugar-house waste, spent hops, glue waste, etc, are hauled to a small extent. We live about 9 miles from the conter of the city, and the road is very hilly, though otherwise a good one, being made of stone.

The loads vary from $2 \frac{1}{4}$ to $3 \frac{1}{2}$ or 4 tons for four lorses, according to the dryness of the manure. The wagons are made very strong, and weigh from $1,600 \mathrm{Jbs}$. to 2,300 or $2,410 \mathrm{lbs}$, according to the number of horses that are to be used to then. I cannot say how many cords there are in an average load, but probably not less than two cords to four horses. One of my neighbors has a stable engaged by the year. He pays $\$ 2.50$ fer ton, and arerares about three tons per load, and the listance from the stable in the eity to his place, can not be less than 12 miles. His team goes empty one way and of conrse eun not hanl more than a load a day. In fact, enn not average that, as it would be too laard on his borses. The horses nsed for the purpose are large and strons. Fifteen or twenty years agn, there was hejt on most farms of 75 to 100 acres, a team purposely for lauling manure from the eity. But it is different now, many of the farmers usiner artificial manures, as it eosts so much less; and others are keeping more stock. and so making their own manure. Still, there is a great deal hauled yet. And some of it to a distance of 20 miles. Thourh when hauled to this distance, the teams are loaded both ways. For instance, they will start to the eity with a load of hay (35 to 50 ewt.), on Monday afternoon (Tuesday is the day of the Hay Market); and when they have their load of hay off ou Tuesday, ther load their manure and drive out five or six miles and put up for the night. Next morning they start abont 3 o'elock, arriving home before noon, having been away two days. On Thursday afternoon, they start again. You ean see that manuring in this way is very expensive. But farmers about bere well know that if they do not nanure well they raise 
but little. P'robably about four loads are used por acre on the average. Each load is generally thrown off the wagon in one large heap near where wanted, and is allowed to lie until they use it. I can not tell how much it loses in bulk by lying in the heap.

As to what erops it is used on, farmers do not think that they could go amiss in applying it to anything except oats. But it is probably used more for top-dressing mowing land, and for potatoes, than for auything else.

The usual rotation is corn, potatocs, or oats, wheat seeded to clover and tinothy, and then kept in grass from two to four years. Those who haul stable-manure, usually use bone-(lust or superphosphate to a greater or less extent.

Last December I built a pig-pen, $20 \mathrm{ft} . \mathrm{x} 40 \mathrm{ft}$., $1 \frac{1}{2}$ stories bigh. The upper story to be used for litter, etc. There is a four feet entry on the north side, running the length of the builling. The remainder is divided into five pens, cach $\mathrm{st}$. $16 \mathrm{ft}$. It is made so that in cold weather it can be closed up tight, while in warmer weather it can be made as open as an out-shed. I am very much pleased with it. The pigs make a great deal of manure, and I believe that it can be made much cheaper than it can be bought and hauled from Philadelphia.

$$
\text { JosePH HEACOCK, JR. }
$$

\section{LETTER FRON HERMAN L. ROUTZAHN.}

Middetown, Md., May 11th, $18 \% 6$.

Joseph Harris, Esq. :

I herewith proceed to answer questions asked.

Wheat and corn arc principal crops. Coru is fed now altogether to stock for the manure.

There is but little soiling donc. The principal method of making manure is: Feeding all the corn raised, as well as hay, oats, and roots, to cattle; using wheat straw, weeds, etc., as bedding, throwing the manure in the yard (uncovered), and to cover the pile with plaster (by sowing broadcast), at least (nce a week. To this pile is added the manure from the hog-pens, hen-house, etc., and worked orer thoroughly at least twice before using. It is then applied to corn by plowing under; to wheat, as a top-dressing. For corn it is usually hauled to the field, thrown off in heaps 25 feet each way, a cart-luad making two heaps. Spread just before the plow. For wheat, spread on directly after plowing, and thoroughly harrowed in. Applied broadcast for potatoes. Composts of different kinds are made and used same as in other localities, I presume. Artificial manures are going into disrepute (justly too). This is the plan now adopted by the farmers in this county (Fredericli). Where woods are accessible, leaves and mould are hauled in and added to the manure-heap; in fact, every substance that can be worked into the manure-heap is freely uscd. Well-rotted stable-manure is worth from $\$ 1.50$ to $\$ 2.50$ per cord, according to condition and locality.

Very Respectully Yours,

Herman L. RoctzahN. 


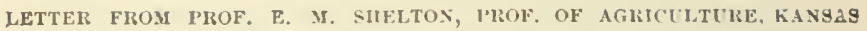
STATE AGRICI LTL RAI, COLLELIE.

Kavisas State Agricllteral Cullege, Masiattan, Kansas, May 5, 1876.

Dear Sir.-In reply to jour firet question, I would scy that stablemanure in this ricinity, is held in very light estimation. Indeed, by the householders of this eity, and quite generally by the farmers, manure is regraded as one of those things-like drouth and crasshoppers-with which a mysterions Providence sees fit to clog the operations of the husbandman. The great bulk of the stable-manure made in this city is, every spring, earted into ravines and vacant luts-wberever, in sloort, with least expense it can be put out of reacl of the senses.

It must not be unlerstood by this that manure has little influence on the growing erop's in Kansas. Sowhere bave I seen such excellent results from application of home-male fortilizers, as un Kansas. For those sterile wast's known as "Alkali lanels," and "Buffalo wallows," manure is a sperely and ecrtain cure. During two years of severe dronth, I bave noticed that wherever manure lad been supplied, the erop withstood the efrects of dry weather mueh better than where no applieation had been male. Four years ago, a strip aeross one of our fichls was heavily manured: this year this ticld is into wheat, and a dark band that nay be seen half a mile shows where this applieation was made.

These fact: the better class of our farmers are beginning to appreeiate. A few days ago, a neighlor, a very intelligent farmer, assured me that from manuriug vicht to ten acres cvery year, lis farm was now in better condition than when be broke un the prairie tifteen years acro.

$\Upsilon$ know of no analysis of stable or farmyard-manure made in Kansis, Concerning the might of mamres, I can gire rou a few facts, haviog had oecasion durine tle past winter to weirh several loals used for experimental purposes. This manuro was wheeled into the harnyard, chictly from the eattle stalls, luring the winter of 18\%t-5. It lay in the open yard until February last, when it was weighed and hauled to the ficlis. I found that a wagou-box, $11 \times 3 \times 9$ feet, into which the manure was pitched, without treadiner, held with slicht variations, when level full. nne ton. At this rate a eord would weigh very close to three tons.

The greatest difliculty that we have to encounter in the management of manure grows out of our ils summers. During our summer months, un!ess suffieient moisture is olitailed, tbe manure dries out rapidly, beermes fire-fanged and practically worthless. My practice upon the Collage farm has been to give the buttom of the barn-yard a "dishing" form, so that it holds all the water that falls upon it. The manure I keep as flat as possible, taking pains to place it where the animals will keep it trod down solicl. I have adopted this plan after having tried composting and piling the manure in the yards, and am satisfied that it is the only practical way to manage manures in this climate.

There is 110 particular crop to which manure is generally applied 
in this State, unless, perhaps, wheat. The practice of applying manure as a top-dressing to winter-wheat, is rapidy gaining groumd here. It is found that the manure thus applicil, acting as a mulch, initigates the effects of drouth, besides improving the quality of the errain.

\section{Very liespectfully Yours,}

E. M. Sheltox.

LETTER FROM PROF. W. H. BHEWER, PROFESSOK OF AGRICULTURE IN SHEFFIELD SCIENTIFIC SCHOOL OF YALE COLLEGE.

SheFfleld SCIENTific School of Yale Collefge, NEW Hates, Conn, Ajril 14h, 1876.

Joseph Hurris, Eso., Ruchester, I. I: :

MY DEAK SIR. - I lave male inquiries relating to "the price of stablemanure in New IIaron, and how far the farmers and trurleners laul it, etc." I have not been to the horse-car stables, but I have to several livery stables, and they are all essentially the same.

They say that but little is sold by the cord or tom, or by any weight or measure. It is sold either "in the lump," "by the month," "by the year," or "per horse." some sell it at a given sum per month for all their horses, on a cenural estimate of their horses-thus, one man says, "I get, this year, sis per month for all my manure, he to remove it as fast as it aceumulates: say one, two, or three tines per week. He hauls it about tive miles and compusts it all before using."

Another says, he sells per horse. "I get, this year, \$13 per horse, they to haul it." The price per horse ranges from \$10 to \$15 per year, the latter sum being high.

From the small or private stables, the manure is generally "lumperl" by private contract, and is largely used about the city. It is bauled sometimes as much as 10 miles, but lisually much less.

But the larger stahles often sell per shipment-it is sent by cars up the Connecticut Valley to Westficld, ete., where it is often hauled several miles from the railroad or river.

Mueb manuie is sent by boat from New York to the Comnecticut Valley tobaceo lands. Boats ("barres") are eren loadel in Albany, go down the Hudson, up the Sound to Commecticut, to various places near Hartford, I an told. Two or thrue years ago, a man cime here and exlibited to us pressed masses of manure-a patent lud been taken out for pressing it, to send by R. R. (stable manure). I never heard anything more about it-and he was confident and enthusiastic about it.

Yours truly,

WY. H. BHEWER. 
FUOD, INCREASE, MANURE, ETC., OF FATTENING ANIMALS.

The following table is griven by Mr. J. B. Iawer, of Rothansted, Englamb, shrwing the relatiun of the increase, manure, and loss by respiratim, to the food consumed by different animals:

OxEx.

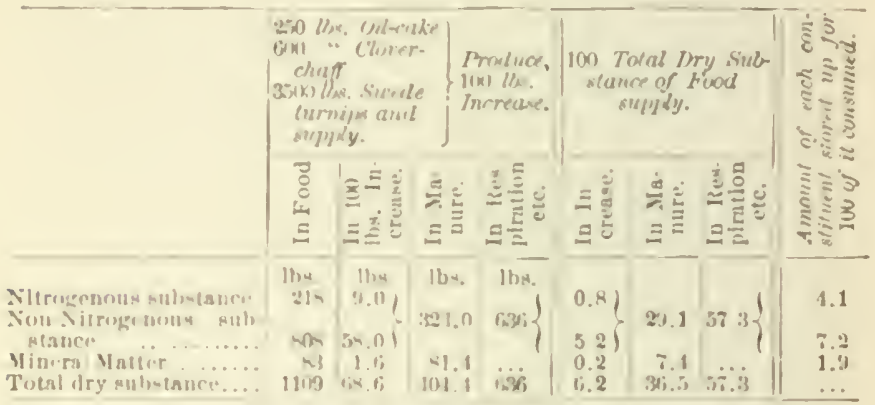

EIEEP.

\begin{tabular}{|c|c|c|c|c|c|c|c|}
\hline & \multicolumn{3}{|c|}{ 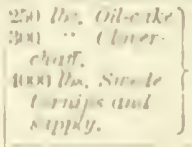 } & $\begin{array}{l}\text { Provines. } \\
\text { liki llas. } \\
\text { Inocretive. }\end{array}$ & \multicolumn{2}{|c|}{ 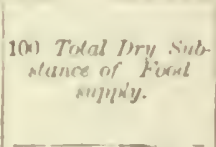 } & $\Sigma$ \\
\hline & $\underset{3}{3}$ & 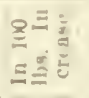 & 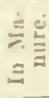 & 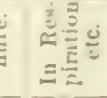 & 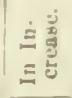 & 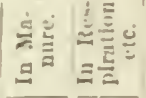 & 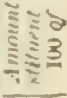 \\
\hline ifrugnome guhatance & $\frac{h o s}{17 \%}$ & ${ }_{7.51}^{11,4}$ & & lbs. & $0.8)$ & & 1.2 \\
\hline $\begin{array}{l}\text { Fon Nitrugenous muls } \\
\text { Atanre }\end{array}$ & & Ris 3 i & & & -.01 & 25. & \\
\hline 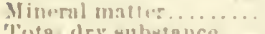 & $\therefore 1$ & & 1,2 & & 0.2 & iis & 3.1 \\
\hline lota dry mubetance. & 912 & .2 .5 & 211 & 514.5 & & 31.9 & \\
\hline
\end{tabular}

PIGS.

\begin{tabular}{|c|c|c|c|c|c|c|c|c|}
\hline & \multicolumn{4}{|c|}{ 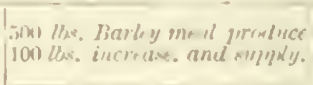 } & \multicolumn{3}{|c|}{ 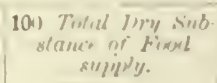 } & \\
\hline & $\begin{array}{l}3 \\
0 \\
0 \\
\Xi \\
\Xi\end{array}$ & 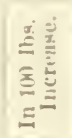 & $\begin{array}{l}\stackrel{\Xi}{\Xi} \\
\Xi \\
\Xi \\
\Xi\end{array}$ & 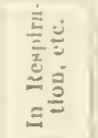 & 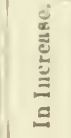 & 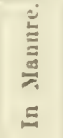 & 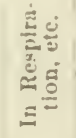 & \\
\hline 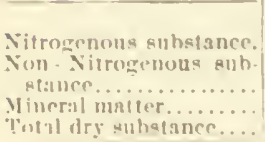 & $\begin{array}{c}\text { lha. } \\
52 \\
3 \% \\
11 \\
121\end{array}$ & 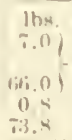 & $\begin{array}{l}\text { Ths. } \\
59.81 \\
10.2 \\
711.0\end{array}$ & $\begin{array}{c}\text { His. } \\
2 \% 6.2\end{array}$ & $\left.\begin{array}{c}1.7 \\
15.7 \\
0.2 \\
17.6\end{array}\right\}$ & $\begin{array}{r}2.1 \\
11 i .7\end{array}$ & fis. is & \\
\hline
\end{tabular}


In ll, la-l alition of his lowk on Mamure, "I'ratitische Inugerlebre," Dr, linil Wuile, grives the fuiluwing lahle.

if 100 116. of ary substance in the foud, there is fomml in the exereneents :

\section{I)Y SI MSTANCE.}

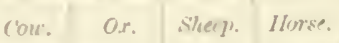

Ireun.

In the Hule.

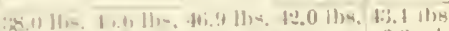

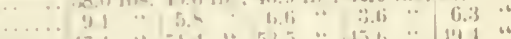

Tutal dry aub-lutere it the Manure..

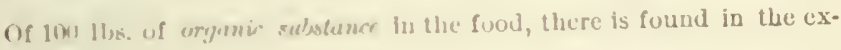
crements:

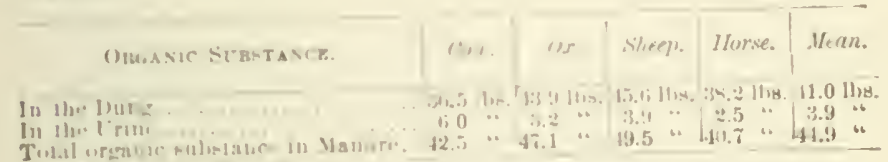

Of $100 \mathrm{lls}$, of nitrup in the foul, there is found in the exerements:

\begin{tabular}{|c|c|c|c|c|c|}
\hline Ẍitroug.5. & rour. & ros. & sheep. & IItorise. & Mecn. \\
\hline 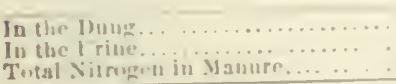 & $\begin{array}{l}15.5113= \\
14.3 \% \\
13.2 \cdots\end{array}$ & $\begin{array}{l}10(1)= \\
.5-16 \cdots \\
-5.15 \cdots\end{array}$ & 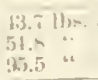 & $\begin{array}{l}51.1 \mathrm{Hhs} \\
27.3 \cdots \\
-3.4 " 4\end{array}$ & $\begin{array}{l}19.1 \mathrm{lhs} . \\
31.0 \% \\
33.1 "\end{array}$ \\
\hline
\end{tabular}

Of $[1 \mathrm{x}]$ !hs. mine ral mutler in the [noul, there is found in the exerements :

MISERAl. MaTTER,

\section{(ine. Or.}

53.9118. $90 . \overline{14 \%}$

In the loung...................

In thic trime....... min in ila nure................. ri,
16. 7 . 13.2.
$117 . .,+10 ; 3,5 ;$

\begin{tabular}{|c|c|}
\hline IJoree. & Mean. \\
\hline $\begin{array}{l}8,1 ; \text { ithe } \\
16.3 \text {." }\end{array}$ & $\begin{array}{l}69.1 \mathrm{lbs} . \\
3 \% .1\end{array}$ \\
\hline 101.9 "6 & 103.5 " \\
\hline
\end{tabular}

The execs of mineral matter is due to the mineral matter in the water drank by the animals.

The following tables of analyses are copicd in full from the list edition (187i)), of Dr. Enil Woltt"s Pratitische Dïngerlehre.

The figures difler materially in many cases from those previously publishel. Tley represent the average results of numerous reliable analyses, and are sufficiently acenrate for all practical purposes connected witb the subjert of manures. In special eases, it will be well to consult actual analyses of the articles to be used. 


\section{I.-TABLES FOI ('ALCI I.ATING THE E.XIIALSTON AND E.S- RICHING OF SUILS.}

A.-HARIE-T JHODCCTS AND I ARIOLS MANLFACTLRED ARTICLES.

Average qunntilg of watur, nitrugen, and total a-h, and the different ingredi-

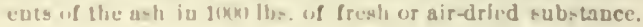

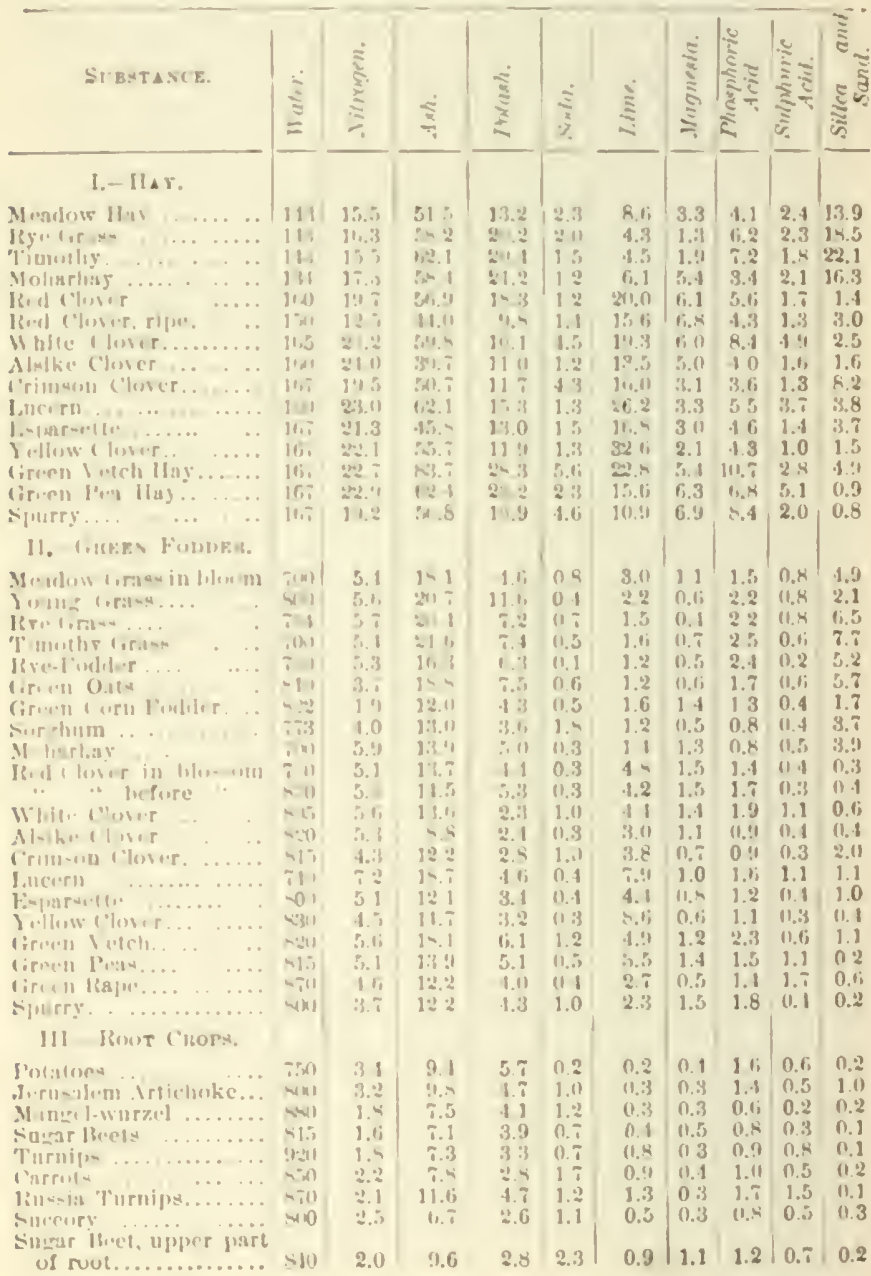




\begin{tabular}{|c|c|c|c|c|c|c|c|c|c|c|}
\hline SERTtaxcz. & $\stackrel{\vdots}{\vdots}$ & है & $\stackrel{\square}{\square}$ & 2 & $\frac{5}{x}$ & $\stackrel{2}{\vdots}$ & 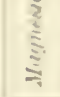 & 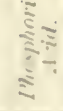 & כ. & $\stackrel{\Sigma}{\approx}$ \\
\hline \multicolumn{11}{|l|}{ 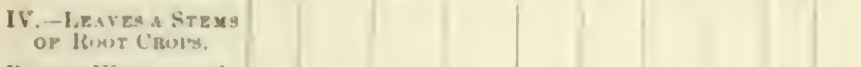 } \\
\hline $\begin{array}{l}\text { Putato Vhuen, nearly } \\
\text { rlype }\end{array}$ & $\pi .11$ & $1 \%$ & 1.7 & $1: 1$ & 0.1 & i. 1 & 3.2 & $1.1 i$ & 1.3 & \\
\hline l'otatu I Inres, unripe & कL" & $6: 3$ & 11.5 & 11 & i1 1 & & $\because 1$ & 1.2 & II. 4 & \\
\hline Jurumalesn Articbine. & Qu1 & (1) 3 & $18 i$ & 31 & $11: 2$ & & 13 & 0.7 & $11,:$ & \\
\hline Mangel warzel ..... & tos & 3.11 & 111 & 11 & $2 ! 4$ & 113 & 13 & 11.". & $11 . \%$ & \\
\hline suzar Hoets ........ & $4 i$ & 311 & $1=1$ & 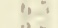 & $2 i$ & $\because 7$ & 25 & 1.3 & 0.9 & \\
\hline Tur ip .......... & $\operatorname{lin}$ & 311 & $11 \%$ & $2=$ & 1) 1 & 3.. 1 & 11.? & 11.1 & 11 & \\
\hline Cirrots $\ldots$ y. & $\because 2$ & 1 & $\because 4,0$ & $\div 9$ & $\therefore$ & $\rightarrow$ & 011 & 1.2 & 20 & \\
\hline$\ldots \ldots$ & (in) & $3 \%$ & 11,5 & 11 & $2 "$ & $1 \because 2$ & (1) 1 & 1.11 & 1.1 & \\
\hline IIIIN- - & 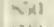 & $10 \mathrm{i}$ & 273 & $3 i$ & $1=$ & Ni & 111 & $\because 11$ & 3.11 & \\
\hline Cablong: "I & (n) & $\div 1$ & 16,11 & 1. 1 & $(1.4$ & 1 & $01:$ & 1.1 & 21 & \\
\hline C'ablisin Flemina $\ldots$. & nat) & 15 & 11.11 & 51 & 0.10 & 1... & 0.5 & 2.1 & $0 ! 3$ & \\
\hline \multicolumn{11}{|l|}{ 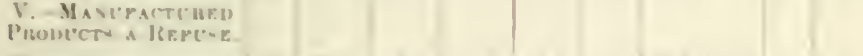 } \\
\hline Wheal Iran ......... & 111 & $\because 2.1$ & i1: & 143 & $0 \div$ & $1 i$ & 34 & 25.3 & 11.1 & \\
\hline & $1: 23$ & 23.2 & i1 1 & 111 & 111 & 2.5 & $11 \mathrm{f}$ & 31.1 & & \\
\hline Murler Bran & $1: 20$ & 237 & 1. 1 & 21 & 117 & Ln & 811 & 4,1 & (1)!) & \\
\hline O.st $\| 131 \%$ & 1111 & $\ldots$ & 317 & $1 !$ & 1) 1 & 11 & 1.0 & $1.6 \mathrm{i}$ & $1: 1$ & 23.3 \\
\hline l'ea lirull. . . 1. & 1111 & & $\because 27$ & 103 & 11.2 & 11 & $2: 3$ & 3.1 & 11.9 & 0.1 \\
\hline Juckwhen liran .. & $1 \mathrm{~min}$ & $\because 7$ & 311 & $11: 2$ & $11:$ & 31 & 111 & 12.7 & 11 & \\
\hline Wherat flos it .... ... & $1 \%$ & 14.? & $7 \geq$ & 21, & 11 & & (1) 1 & 3.7 & & \\
\hline $16 \%$ & 11:? & 1., & 11,11 & 1,5 & 11.3 & 11.2 & 11 & -.5 & & \\
\hline Hurlery IInI]. & 141 & 1,11 & ; 2110 & in & 115 & (1) & $\because i$ & 1) 5 & $(1.6 \mathrm{j}$ & \\
\hline Corn Nival & 111 & 10,11 & $\therefore 1$ & $1 \%$ & $0:$ & J & $0 ! 1$ & 2.1, & ... & \\
\hline Y Malt. & iis & 16) I & $11 . ;$ & $2 ;$ & $\ldots$ & (1) & 1.2 & 5.3 & & \\
\hline Iley Malt ........ & $\therefore$ & $10 \mathrm{ill}$ & $2 t$ & 113 & & & 2.2 & 4.7 & & \\
\hline lirewar \& Graina.... & Int & is & 11.7 & 05 & 01 & & 111 & 1.1 & & \\
\hline Brer $\ldots . .$. & (ant & & 16: 2 & 21 & $0 t_{j}$ & 11.2 & 11. 1 & 2.11 & 112 & \\
\hline M:a I spromit- & $\$ 1$ & $30 \mathrm{i}, 4$ & Wi $i$ & 211 & 12 & & 1. 4 & $1 \mathrm{n}, 11$ & 2.9 & 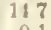 \\
\hline l'ots & 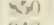 & 1.3 & $1=$ & $0: 3$ & & & $0 !$ & 0.1 & & \\
\hline lofis & & 1.65 & & & 11. 1 & & (1) 1 & 10 & 0.1 & \\
\hline & & 2.9 & II 1 & $; 3$ & 0. & & 0.7 & 1.1 & (9.) 1 & \\
\hline & 915 & 0 - & & 03 & (1). & & 0.2 & 11.2 & 0.1 & \\
\hline & 172 & 12.5 & $-2: 3$ & $5 i: 3$ & 100 & $1 . \bar{i}$ & $0: 3$ & 0.5 & $1 . i$ & \\
\hline 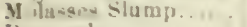 & $(2,1)$ & 3.2 & & 1111 & 1 & (1). & & 11. 1 & 0.2 & \\
\hline & $1 ; 01$ & 42.3 & i1 & 121 & 1. & $t_{1}$ & 70 & 17.2 & 3.2 & \\
\hline & 115 & & & 121 & $0 . \overline{1}$ & & $\therefore 1$ & 11.1 & 1 6 & \\
\hline & & & & & 23 & 270 & 1,2 & 31.2 & $1 !$ & \\
\hline & & & & $1, .5$ & 4.1i & $13:=$ & $3.1 \mathrm{j}$ & 2.7 & 0.6 & \\
\hline & & & & & $\ldots$ & & $5.6 \mathrm{i}$ & 21.2 & 0. & \\
\hline e $\ldots$ & 115 & & & & & & $-! !$ & 25.1 & 0.7 & \\
\hline ...... & 127 & & & & 1.3 & & $1.1 \mathrm{i}$ & 11.9 & 2.1 & \\
\hline I'alm-oil-cake & 10u & 25.9 & $2 ; .1$ & 5.0 & 0.2 & 3.1 & $4 . \bar{j}$ & 11.0 & 0.5 & \\
\hline VII -STRAW. & & & & & & & & & & \\
\hline inser Who & 113 & 18 & & 6.3 & 0.6 & $2 . \bar{t}$ & 11 & 2.2 & 1.1 & \\
\hline & & 10 & & & & & 1. & & 1.2 & \\
\hline & $11: 3$ & +11 & & is & $0 ! 1$ & & 1.1 & 2.1 & 1.1 & \\
\hline whe & 113 & $51 ;$ & & 11.0 & 1.0 & & 0.11 & & 1.2 & \\
\hline Irye $\ldots . . .$. & 113 & 5.6 & & 11 & & & & & 12 & \\
\hline$\ldots \ldots \ldots \ldots$ & 111 & 6.1 & & 3 & & & 1.1 & & $1 . \%$ & \\
\hline & & $\therefore 1$ & & & 1. & & & & & \\
\hline & & 42 & & & & & $2.1 \mathrm{j}$ & 5.3 & 1.2 & 11 \\
\hline vhesst Straw ... & {$[0 \geqslant 1)$} & 1311 & & 212 & 1 & 4. & $1 ! !$ & 6.1 & $2 . i$ & \\
\hline & $1+k\}$ & & & & 1. & 16.2 & $3 . .5$ & 3 & 2. & \\
\hline & $1(x)$ & 16.3 & & & 1. & & 3.3 & 3.2 & $1.1 \mathrm{i}$ & \\
\hline 68 & 19its & & 40 & 12.8 & 3.2 & 111 & 2.5 & 3.24 & $1 . \tau$ & \\
\hline Common V & 160 & 12.0 & 41. & 6.3 & 6.5 & 15.6 & 3.7 & 2.7 & 3.3 & \\
\hline
\end{tabular}




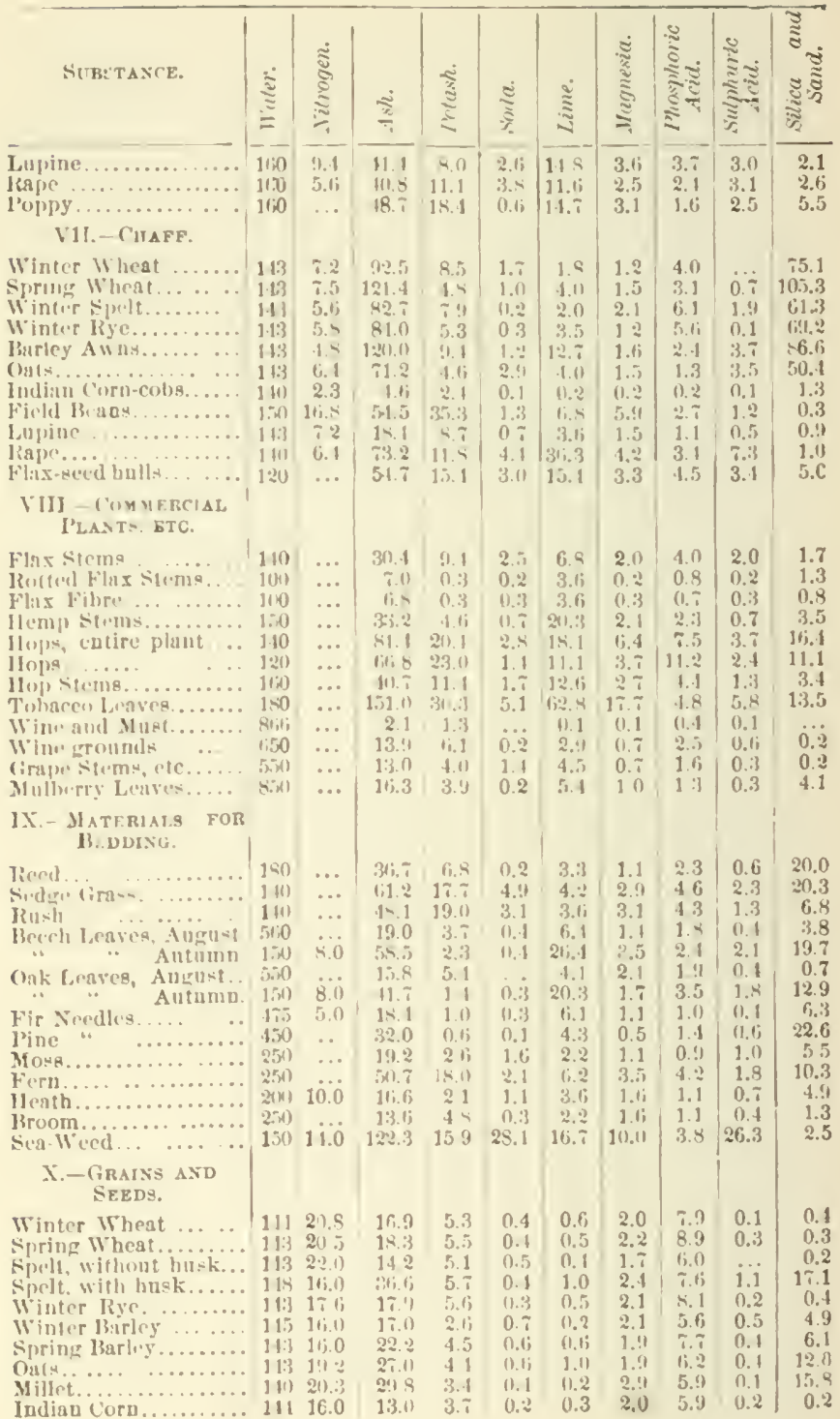




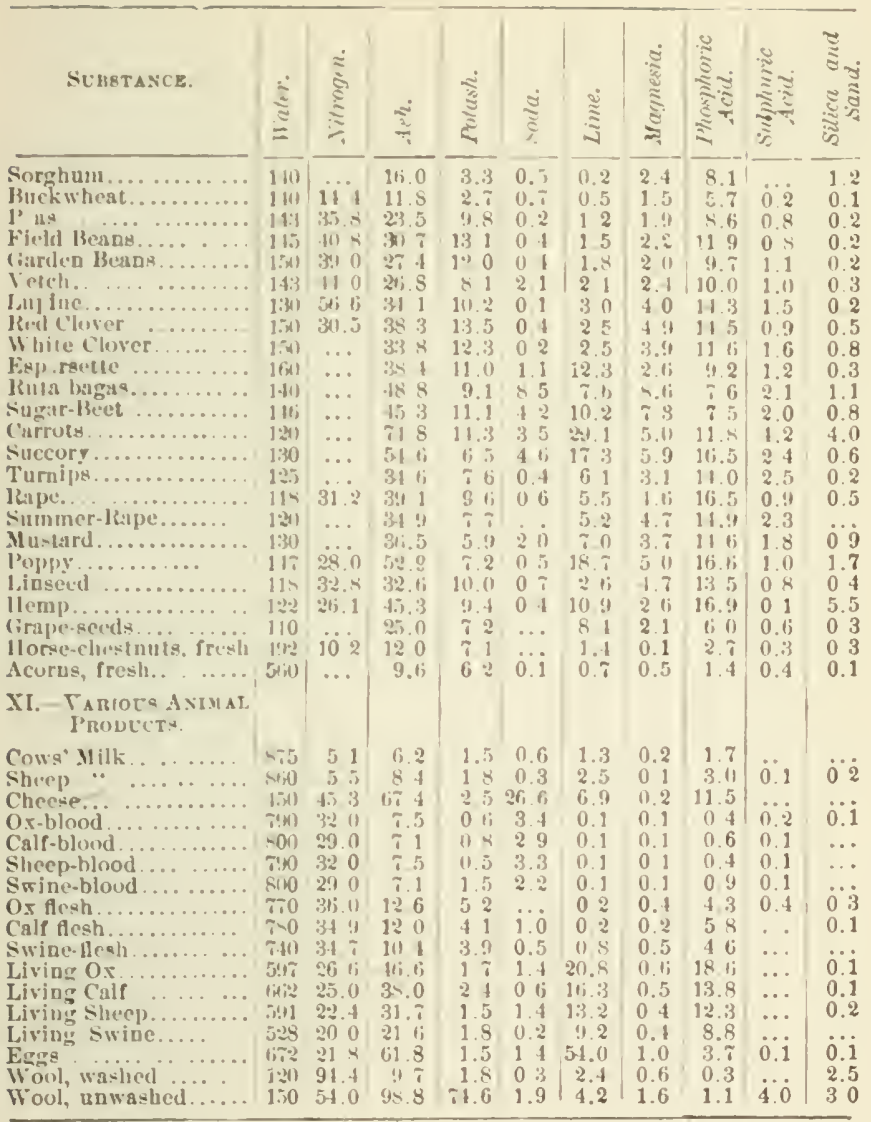




\section{B.-AVERAGE COMPOSITION OF VARIOUS MANURES.}

\begin{tabular}{|c|c|c|c|c|c|c|c|c|c|c|c|c|c|}
\hline VAM OF FERTILIZER. & $\stackrel{\Xi}{\Xi}$ & 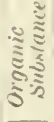 & ङ & $\frac{2}{2}$ & 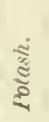 & ङ్ & & $\underset{\text { స }}{\stackrel{\Xi}{\Xi}}$ & 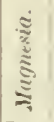 & 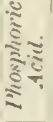 & 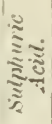 & 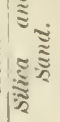 & 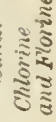 \\
\hline \multicolumn{14}{|l|}{$\begin{array}{l}\text { I. A ANIMAL ExCRE- } \\
\text { MENTs. } \\
\text { (In 100n parts of Ma- } \\
\text { umre.) }\end{array}$} \\
\hline Fresh Fieces: & & & & & & & & & & & & & \\
\hline . & $75 \%$ & 211 & 31,6 & 1.4 & 3.5 & 0 & & 1.5 & 12 & 3.5 & 0.6 & 19.6 & \\
\hline ........ & & & & 2.9 & 10 & & & 34 & 1.3 & 1.7 & & & \\
\hline & $(25)$ & 311 & & (i. & 1.5 & $l_{2}^{1}$ & & $\begin{array}{ll}1 & 6 \\
0 & 4\end{array}$ & 10 & 41 & & 15.5 & \\
\hline \multicolumn{14}{|l|}{$\begin{array}{l}\text { Fresh Irine: } \\
\text { Horke....... }\end{array}$} \\
\hline Horre ...... & (n) & il & 25.0 & 1.55 & 150 & $2:$ & & 15 & 24 & .. & 06 & & \\
\hline - $\cdots \cdots$ & $9: 28$ & .25 & & 54 & $1 ! 1$ & i & & () 1 & 111 & & & & \\
\hline s & $\therefore \div 2$ & $8: 3$ & 4. 2 & $11.5:-5-1-5$ & $\because$ i & 5. & & 1.6 & 3.1 & 0.1 & 30 & 01 & \\
\hline 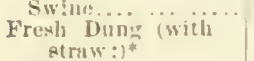 & 967 & 25 & 15.0 & 43 & 8.3 & 21 & & .. & 0.3 & 0 - & $11 \times$ & .. & \\
\hline II & శ1:3 & 25,4 & 32.6 & 58 & 53 & 1 & & $2.1^{1}$ & 14 & 28 & 117 & 17.7 & \\
\hline & $\pi i j$ & 203 & 21. & 3.1 & 10 & & & & 1.1 & it $t_{i}$ & 06 & & \\
\hline & tifli & 315 & 35.6 & 83 & fi $\tau$ & 2 & & 3.3 & 1.8 & 2.3 & 15 & 11.7 & \\
\hline & $7 \pm 1$ & 250 & 25.6 & 4.5 & (ii) & 2 & & $0 . \mathrm{K}$ & 0.9 & 1.4 & 0.5 & 10.8 & \\
\hline \multicolumn{14}{|l|}{$\begin{array}{l}\text { Common Barn-yard } \\
\text { Manure: }\end{array}$} \\
\hline 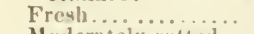 & 710 & $216 i$ & 41.1 & 45 & $5:$ & 1 & & 5.7 & 1.4 & 21 & 1.2 & 12.5 & \\
\hline & 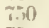 & & & & if 3 & & & Т. 0 & & & & & \\
\hline Thorourbly rutted. & $7 \% 1$ & 145 & 150 & 5.5 & i. 11 & 1 & & S.s & 1.8 & 3.0 & 1.3 & 17.0 & 1.6 \\
\hline $\begin{array}{c}\text { Drainatere froin [3.ırn. } \\
\text { y:trd Manure ...... }\end{array}$ & 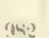 & & & 1.5 & $4 !$ & & & 0.3 & 0.4 & 0.1 & & 0.2 & \\
\hline lluman Fare & $7 \% 2$ & $1 ! 9$ & $\because 1 !$ & 10.0 & 25 & 1 & & $1 i .2$ & 3.6 & 10.9 & 0.8 & 1.9 & \\
\hline $\begin{array}{l}\text { Wrine, } \\
\text { Mixed human excre- }\end{array}$ & $\{M \div\}$ & 34 & & 6.0 & $\because 0$ & & & 0). 2 & 0.2 & $1 . \tau$ & 0.1 & & \\
\hline incre. & 433 & 51 & $11 ; 0$ & 5.0 & 21 & 3. & 8 & 0.9 & 0.6 & 2.6 & 0.5 & 0.2 & 1. \\
\hline $\begin{array}{l}\text { ix liquere. } \\
\text { ly lid }\end{array}$ & 955 & :30 & 150 & 5 & 20 & & & 1.0 & 0.6 & 28 & 0 & & \\
\hline fresh.. & 519 & $30 \mathrm{~K}$ & & 176 & 100 & & & & 5.0 & 17 & & & \\
\hline & itio & $25 \%$ & $14 ; .0$ & 16.3 & ×. 5 & 1 & & & 7.4 & 15.4 & & & \\
\hline $\begin{array}{lll}\text { ack } & \# & \text { ". }\end{array}$ & 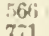 & $21 ; 2$ & $\begin{array}{rl}1720 & 0 \\
950 & 0\end{array}$ & $\begin{array}{r}10.0 \\
5.5\end{array}$ & 62 & & & โ. 0 & & 11.0 & & 25.0 & \\
\hline & & & & & & & & & & & & & \\
\hline
\end{tabular}

\section{I. - Commercial Ma-} NCTES.

(In 100 parta of Fertilizer.)

Peruvian Fuano...... 18.851.1 338 13.0 2.3 1 +11.0 1.2 1301.0 1.7 1.3

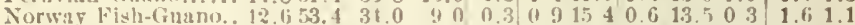

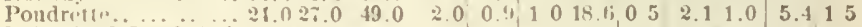

J'ulverized Ilead Ani.

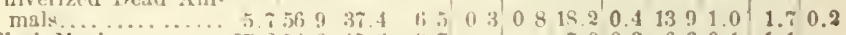

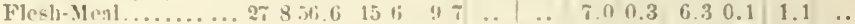

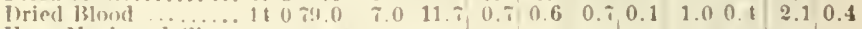
Horn Meal and Shav-

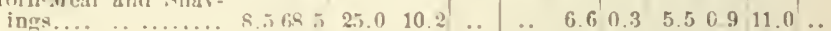

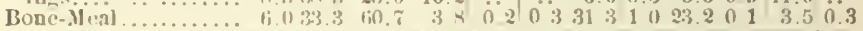

- It is catimated that in the care of horses, cattle, and fwine, one-third of the urine drains awas. The following is the nmonnt of whent-straw used daily as bedding for each animal. Horsc, 6 lbs.; Cattle, 8 lbs.; swive, 4 lbs., and slucep, $0.61 \mathrm{bs}$. 
JaME of Fertilizer.

(In 100 parts.)

Bone Meal from solid

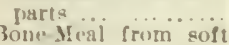
parts................

Bunc-hlack before 11:ird

Bon - lick, speut.

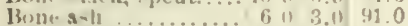

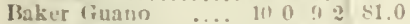

Jarvia (imane)......... 11, $4.2,80.0$

Estremadura Apatite.. (1) 6 ..

Sumbrero Phinephate. \&.5 .. 91.5

Navamea I'losphite... i i 5.1 (12.0

Nassau l'husphorite, rich.

Nassau jhosphorite. medium...

Westphalian Phosphorite ............

Hawover Phosphorite

Coprolites.............

Nitrite of Sod 3 ......

Wool-dust and ofiaj

. 0 . 0 . 31.0

Lime-cake......... 6.5 57.0 46.5

Whale-ojl refuse......23.0 tix.4 ×.6

Common sult........ 5.0 (1) 11

Cispran or liaster... 21.0 ... vi.?

Gas-lime .......... 7.0 1.3. 11.7

Sugar-llouse Scum... 31521.541 .1

Leached wood ashes. $20.0 \quad 5.11 \quad 7 ., 1)$

Wond soot......... 5.0 i1.. $23: 2$

Coal-soot........ 5.0 $70221 \mathrm{~s}$

Ashesfrom Deciduous trees.............

Asbes from Evergreen trees...............

Prrt-a-bes..............

Bleminous coal-ashes

Anthracite cosl-ashes.

\section{III.-STPERPHOS- PHATE, from}

$5.0 \quad 5.0 \mid 90.0$

$\begin{array}{llll}5.11 & 5.0 & 90.0 & 0\end{array}$

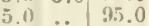

$5.0 \div 95.0$

90.0

Bater Guamo.......... 15.0 6.2 78.8

Estremadura A patite. 15.0 . 85.0

Sombrero Pho-phate. 15.0 .. 85.0

Nava-sa Pbosphate.. $15.0 \quad 2.5$ S:.5

Nassau Phosphorite, \begin{tabular}{|l|l|} 
rich............. $15.0 \quad 85.0$ \\
\hline
\end{tabular}

Nassau Phosphorite,

medium .......... 12.0 KR.0

Bone-blick........... $15.0 \quad \ddot{8} .0$ \%

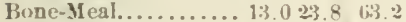

Phospho-guano

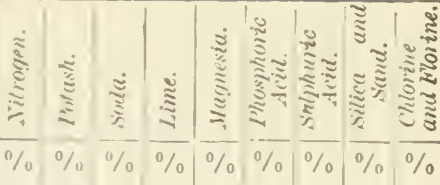

$$
\begin{aligned}
& \begin{array}{llllllllllll}
3.5 & 0.1 & 0.2 & 33 & 0 & 1 & 0 & 25.2 & 0.1 & 3.0 & 0.2
\end{array} \\
& \begin{array}{llllllllllll}
4.0 & 0.2 & 0.3 & 29.11 & 1.0 & 20.0 & 0.1 & 3.5 & 0.2
\end{array}
\end{aligned}
$$

$\begin{array}{lllllllllllll}1.0 & 0 & 1 & 1.3 & 43 & 0 & 1.1 & 32 & 0 & 0.4 & 5.0 & \ldots\end{array}$

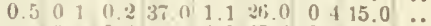
$\begin{array}{lllllllllllllllll}0 & 0.3 & 0.6 & 4 \% & 0 & 1.2 & 35.4 & 0.4 & 8.5 & \ldots\end{array}$ $0.5021 .2-11.51 .531 .4 \quad 150.80 .3$

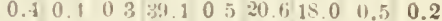

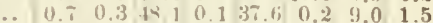

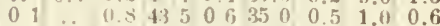

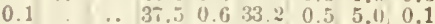
$\begin{array}{lllllllllll}\text {.. } & 0.5 & 0.1 & 4.3 .1 & 0.2 & 33.0 & 0 & 3 & 5.5 & 3.1\end{array}$ \begin{tabular}{llll|llll|l|l|l|l|l}
$\ldots$ & 0.7 & 0.4 & 10.1 & 0.2 & 24.1 & $\ldots$ & 20.5 & 1.5
\end{tabular} . $\quad \ldots \quad \ldots 21 \ldots 0.919 .7 \quad 1.022 .01 .6$

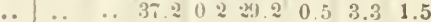
$\begin{array}{lllllllllll} & 1.0 & 0.5 & 45.4 & 1.0 & 26.4 & 0 & 8 & 7.5 & 0.1\end{array}$ $\begin{array}{lllllllllllll}20 & 0 & \ldots & . & 0 & 0.5 & . . & . & 58 & 0 & 3.0 & 1.4\end{array}$ $\begin{array}{lllllllllllll}15 & 5 & \cdots & 35.0 & 0.2 & \ldots & \ldots & 0.7 & 1.5 & 1.7\end{array}$ $\begin{array}{lllllllllllll}5.2 & 0 & 3 & 0.1 & 1 & 4 & 0.3 & 1.3 & 0.5 & 29 & 0 & 0.2\end{array}$ \begin{tabular}{lll|llll|ll|lll}
3.1 & $\ldots$ & $\ldots$ & 20.5 & 2.1 & 3.0 & $\ldots$ & 8.0 & $\ldots$
\end{tabular} $\begin{array}{lllllllllllll}5.7 & \ldots & \ldots & 3.0 & 0 & 2 & 2.3 & \ldots & 3.0 & \ldots\end{array}$ $\begin{array}{lllllllllll} & . & \ldots & 44.3 & 1.2 & 0.2 & \ldots & 1.4 & 2.0 & 18.2\end{array}$

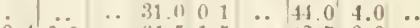
$\begin{array}{llllllllllll}0 & 4 & 0.2 & . . & 61.5 & 1.5 & \ldots & 12.5 & 3.0 & \ldots\end{array}$ $\begin{array}{llllllllll}1.2 & 0.2 & 0.6 & 21.7 & 0.3 & 1.5 & 0.3 & 9.1 & 0.1\end{array}$

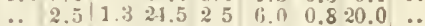
$\begin{array}{lllllllllll}1.3 & 2.4 & 0.5 & 10.0 & 1.5 & 0.4 & 0.3 & 4.0 & . .\end{array}$ \begin{tabular}{lll|l|l|l|l|l|l|l}
2.5 & 0.1 &. & 4.0 & 1.5 & $\cdots$ & 1.7 & 16.0 & $\ldots$
\end{tabular} $\begin{array}{llllllllll}\text { C. } & 10.0 & 2.5 & 30.0 & 5.0 & 6.5 & 1.6 & 18.0 & 0.3\end{array}$ \begin{tabular}{l|l|lll|l|l|l|l}
.. & 6.0 & 2.0 & 35.0 & 6.0 & 4.5 & 1.6 & 18.0 & 0.3
\end{tabular} $\begin{array}{llllllllll}\therefore & 1.5 & 0 & 5\end{array}$ $\begin{array}{lllllllllll}\because & 0.5 & 0.4 ? & 3.2 & 0.2 & 8.5 & \text { ? } & 0.2\end{array}$

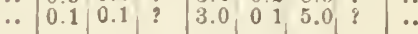

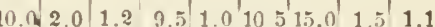
$\begin{array}{lllllllllll}0.3 & 0.1 & 0.8 & 25 & 9 & 0.9 & \geqslant 1.8 & 25 & 5 & 0.9 & 0.2\end{array}$ \begin{tabular}{l|l|llllllll} 
& $\cdots$ & 0.4 & 0.2 & 28.2 & 0.1 & 22.1 & 25.5 & 5.3 & 0.9
\end{tabular} \begin{tabular}{ll|llllllll} 
& $\ldots$ &.. & 0.5 & 26 & 1 & 0.120 & 225.5 & 0.6 & 0.4
\end{tabular} - .. ? 17.0 0.315419 .5223 ? $\begin{array}{llllllllll} & 0 & 0.5 & 0.2 & 26.5 & 0.1 & 19.4 & 25.5 & 3.2 & 1.8\end{array}$ $\begin{array}{lllllllllll} & 0 & 0.3 & 0.1 & 24.2 & 0.1 & 16.6 & 19.5 & 13.5 & 1.3\end{array}$ $\begin{array}{llllllllllll}0 & \because & . & 0.1 & 25.0 & 0 & 7 & 16.2 & 21.0 & 9.3 & \ldots\end{array}$ $\begin{array}{llllllllll}2.0 & 0.1 & 0.2 & 2 & 4 & 0.7 & 16.6 & 19.5 & 2.5 & 0.2\end{array}$

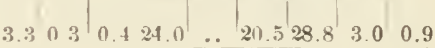


2.-TABLE SIOWING TIIF DISTRIBLTION OF INGREDIENTS IN SUME MANLFACTLRING I'ROCESSES.

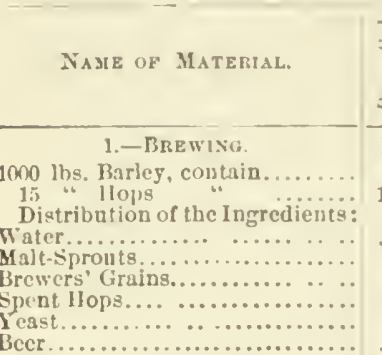

\section{2.-DISTILLERT.}

a. 1000 lbs. Potato a contain.... (1) ". Kilu-Malt........... 20 "Yca+t-1lalt...........

The slump, contaius........... (1). liruill spirits

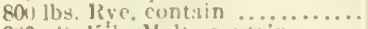

210 " Killu-Malt, contain......

to "Yesst-Malt, " ......

The Slump,

\section{3.-Yeát MaNufactire.}

Ton lbs, hrnised Rye, contsin..... 300 " [B:Irley-yili,

J)istribution of the Ingreditnts: Yerat

Grains and slump............

4.-STAich Maxt"Factete.

Jom lhs Polatues, cuntain........ The remains in the Filre........

$$
\text { 5.-MILlixi: }
$$

Water......

1000 lba. Wheat, crntain...........

1)intribution uf the lugredients:

Flonr $\quad \div .5$ jer cent $). . . . .$.

Mill-feed ( 1.5 " " $). . . . .$.

Bruu (16.0 "....$\ldots$.

\section{6.-CHEege-JAKLNG.}

1000 lhe. Milk, sontain.........

Distribution of the Insredients:

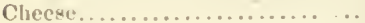

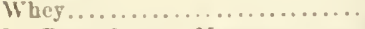

t.-Beet-Sigar Manefactere.

1000 los. Routs, contain..........

Distribution of the huered ents:

Tops and Tuils 112 per cent of

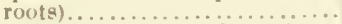

Pomace (15 per cent of roots)....

Skimmings ( 4 fur cent of ronts)..

Molasses (3) prer cent of roots)....

Sugar and lo $\$$..................

$$
\text { S. Flax Drensixt? }
$$

1000 lbs. Flax-stalks, contain...

Distribution of fhe Inoredients:

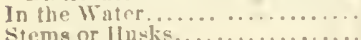

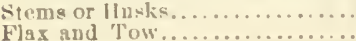

है

E5.

13.:

$\because 3$

23

(!)

3i)

$2: 0$

3

185

$\operatorname{lin} 14$

$141 \quad 2 \quad$ s

119) 0 ता

413 1:

\begin{tabular}{llllllll|l}
59.1 & 12 & 39 & 12.53 & 3.941 & 0.329 & 1 & 411 & 5.876
\end{tabular}

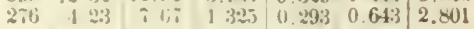

$\begin{array}{lllllllll}\text { 1.5 } \quad 1 \text { fin } & 3.11 & 1 & 273 & 0.162 & 0.36 \% & \mathbf{2} .16 \% 2\end{array}$ $\begin{array}{llllllllll}325 & 11 & 95 & \text { itj } & \text { itt } & \text { 3 } & 9.13 & 0.930 & 1.720 & 6.005\end{array}$

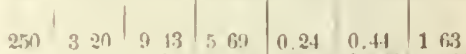

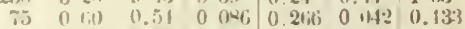

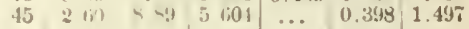

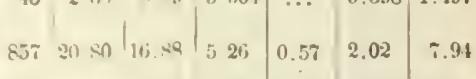

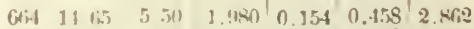

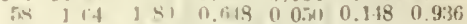

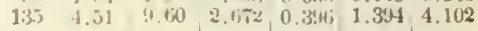
\begin{tabular}{l|l|l|l|l|l|l|l}
125 & & & & \\
4.80 & fi 10 & 1.505 & 1.3333 & 0.186 & 1.735
\end{tabular}

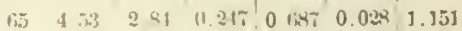

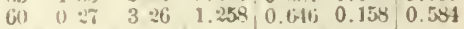

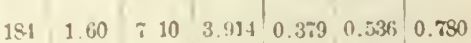

$\begin{array}{lllllllll}19 & 0 & 21 & 1.15 & 0.336 & 0.102 & 0.132 & 0.111\end{array}$ $\begin{array}{lllllllll}46 & 0.11 & 1.61 & 0.5 \div 5 & 0.390 & 0.105 & 0.165\end{array}$

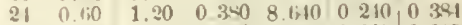

$\begin{array}{llllllllll}25 & 0 & 32 & 2.47 & 1.711 & 0.311 & 0.003 & 0 & 015\end{array}$ $\begin{array}{llllllll}85 & \ldots & 0.57 & 0.872 & \ldots & 0.010 & 0.072\end{array}$ \begin{tabular}{l|l|l|lll|l}
$-t 50$ & $\ldots .$. & 30.36 & 9.426 & 6.751 & 1.595 & 3990
\end{tabular} \begin{tabular}{l|lllllllll}
215 & $\ldots$ & 25 & 15 & 9.175 & 4.100 & 1.850 & 3 & 400
\end{tabular}

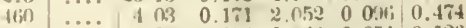

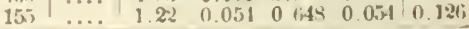




\section{N J) F X.}

Abontive Powers of Sula ......217 Ammonia Aburived by suil frum

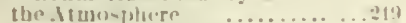
Ammouia and sinperphisplate ...212

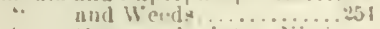
-. C'unverted inte Ditric Achl in the suil......313

“ for (1at8...........253 251

“ fur lotaline ........ . $\$ 61$

“. for Wheat ...........19: : :13

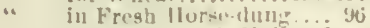

“. iu Limed aud Lnilimed soila In the suil Liberated by Limf...............21 lacked ip in khe suil...221 Lows of by fermenting Manur $\ldots . . . . . . . n$

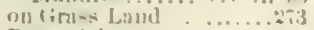
Poteintial .......... 3 ! Quantity of $i$ Promece Une Buslack of Wheat, $211-212$

" Required in Produce a l3u-led of Ba:te.y..2:10-21? Petained by the sisil...2.213 sulto. Lomprosition of ....31: - Iluw to Apjitr.

$$
\text { " for Private Ciar- }
$$
dens .........?

Andirron. J. M. B.. Leller from... Auinals, Compo-ition of Manure from Different .... ....306 What They Remove frum the Fond

Apple Trees. Sitrate of Sudit for ..31 Artiticial 'Ianures, Will They I'ay..211 Asher, Burnt Earth............. i. " Cual...................... 72

* for Barley............... 2i1

“ fur Judisn Corn.............279

" for Oats.................. 253

“ for Potatoes..................259

" of Manure fur irical........ 17.3

" ou Loug Island............ H

“ Plaster and Hed-dung for

. Potaltoes...............255

Barley After T i.n Crops of Turuip......

* a Large lield of...........2 “ and Clower sfter a heavilymanured Ruot-crop. .....2.287

" Best Soil for..............227

* Cost of Raising irith and Without Janure... .....215 361
Barley, Laweg" and Rilbert's Experi-

.. ments on...............227

Potush Imerentecs the Crop of at linthamsted . . . . . . . 3:39

" P'rofits of Raising in pou.r

s(ans(r).............243

. Qnality und i'rice of.........212

.. lield leer Acre............. 11

Burn-ynrd Munnre, Difference in

Quality of $\ldots$............2 .26

lhan-mtraw for Mamure...... is

Beecs, sugar, Lawer and Gilbert's Experiusents on...229 SLauure fur........2.24i

IBlund ......................

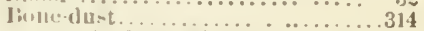

composition of compared with stable Mamure................. 316

". Frmenied with Manure.:316

- Made into Superphos-

" " on ilate F............ 319

Ronee as Manure................. 102

Bran............................

$\because \quad$ fir Manure.............. 10:

" likcher in Plant-foud than W'beat ..............3n1

Brewer, l'ruf. W. I1., Leiter from...311 Cabbage and Barn-yand Maunre, Compusition of ..........2.2 Comprsition of .......290-292 IJog and Cow Manure for.3n? I ime fur................2 Maunre for .......... $24-290$ Manure for Early and

“ Late. Sicds a Large Supply if Nitrogen in the soil. Though it Remuves but Little..............293

" Potach for... . . . .............

“ Special Manure for..........323

" Yield of per Acre........2:291

Cattle vs. Sheep as Mannre-1nakers.303

Cherse, from a Ton of Hay..........111

“ Plant-food in................101

versus $B$ eef...................110

Clay Retnins Ammonia..............219

Clover and Indian Corn...............275

". as a Renorating and Exhausting Crop............277

“ as Manure ..............119-122

“ as Manure for Wheat.........15s

" Does it Get Nitroge $\mathrm{n}$ from the Atmosphere... ...133-138 
Mover, Dr. Vorleker's Experiments

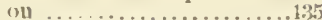

for Whrat.............. 12ti (iathers! i) Banure from the Sinb-soil............. . IIay, Composition of . . . 1:2 13\% IIay, Englisld and (Fermat for Mamine........... 47

How to Huke a Farm lich by (irowiner.......... 13:3-163

Letting it Rut on the surface as Manure...........131

"Nitrogen as a Maimure for...141

" Pasturing by Sheep versis Mowing for llay ..........137

" Plowing fudre versus Feeding ()ut

" Routs, dinouit of jer iere, $143-111-1.5$

"Roots, Composition of..14.5-117

"Seed, Amount of lioots per Acre................... 162

Water Evaporated hy........ 1:32

Why it Enricher latid...... 131

Conl-a-hes to Mix witl Artincial

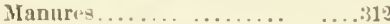
Composting (r)-manure with

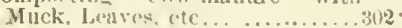
Compost of stable-minure and [iurth

Corn, as a lienovatiug ( $r(0) . . . . . . .27$. Ashes for ..... ....... "r Barn-yurc? Viamure for $\ldots \ldots \ldots$. " Cost if Ratising........... 9 " Crop, Compustion of ...... 25 " Experiments on............2?9 " Fuano for ......... 279-31 " Manure for .............2,5 " Menl for Manure................ 195 “Superphosphite fur....... " Fodder................ 2i " " vo Mangel-wurzels... . 6. " Plisterfor. ......... " "VR. Wheat, Jieli per acre............. $\%$

Crops Rest to Apply Munure to....2 2 is

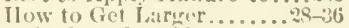
liaised and fold from the Farm................ 2 \% Rotation of ...........116-10is Vle Must Ruise liarrer per Acre...................266

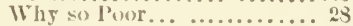

Cotton-secid Cake... ........ 4'i-3039 Cow-manure................ " " and II ow to [ C(mposition of ....... .

Cows, Feeding Grain to........110 113 Feeding in linter for Manure..................256

Dairy Farms, Hune-dust on.......315 I) rainge from Barm-yard...........3n6 Dry Earth for Pig Pens ... .......301

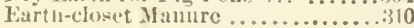
Fallow, Fall ... ..............25 for th heat, ifow to $-\mathrm{Mr}$.

Iaw.' Fixperiments.... 35

* Summer, for $W$ beat...... $15-31$
Farm Dairy, Receipts and Expenses of ....................... 109

“ Ilon. George Geddes"....... 119

“ Ilon. Joseph sliull's......... 109

“Johm Johnston's ......7i-8i-120

“ Mr. Dewey's.............. 39

" Mr. Joseph O. Shclion's..... 15

" to Restore a Worn Out...... 37

Farming. a Pour Business.......... 9 Differcnee Betweeu and Goud .............. 11 Faith in Good............ 14 Goud Does Not Lead to Uver Production....... 14 Slow Hork............... 17

Fermenting Manure to Kill $\mathbf{W}$ eed sieeds.................. 97

Finh as Manure.................347 I"uod, Nuthing Arided to it by the

Animal....................42

(iardeus, Mammre for Privote.........49:

(ieddes, Ifon. George............ 1;-117

Grains, Malt, English and German. 17 (irass a Saving's Bank ........41

.. Importince of Jicl...........113

Manure for.............120

Guano 28 a Top-dressing for Wheat. for Burley................210

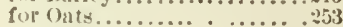

for Peas................ 17

for l'otatoes............. 25j-258

on Whest........... 1:0-180-184

Permian, Compusition of. .311

$$
\text { for Onions.........t. }
$$

Price and Compo sition of Now and 30 Y $\mathrm{rgA}$ iro.327

6. Iiectified for Tur. nips.......... 26

$$
\text { ". Wbat it is.............311 }
$$

Gypanm...............101-116-126

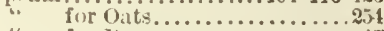

"6 for l'eas................ 17

"6 for Potatoes.......... 25j-253

IIrrison, 'T. L., Letter from.........115 Ilay, Best Manure for ................. ". Plant-food in................101 Iracock, Josmph, Letter from.......318 Ilenderson, Peter, Letter from......344 Heu Manure.............. 13-101-301 " " for Potatoes... ......255 High Farming................ 12 ". versus frood Farming 11 1 ops, Manne for............. 2it Ilorse-munnre, Composition of, ...306 Int-beds. Manure for.............2!r llımal Exerements, Composition

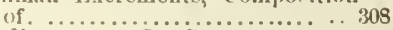

Indian Corn. See Corn .............

Irrieration on Market fardin........29: Jussup, Edward, Letter trom1....... . 342 Johnsan, Prof. S. W., on the Value of Fertilizers................321

Lawes" and Gilbert's Experiments (n) Barley.................. 227

Law es' and (iilbert's Experiments

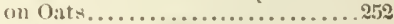

Lawes" and Gilbert's Experimonts ou Permanent Meadow's..........271 
Lawea aud (ijlbert's Experiments on the Amount of lixerements Voided by Mtun.

Law "s" and iilluert's Experiments ou Sugar loect- and Mangel-wnrZels

halles and (ilbelis bxperimento on Wheat ................. 170

Lawes and filbert s Experiments, l'otash Be"neticial for Barley......32!

Lawes' 'Table, filowing Composition and Vilue of Fouds.........

Lettuce, Manure for. . . . . . . . . . . . 2s? silperphespliute for. . . 29(3)-293

Lewis, Hon. IIarris, Letter frowl....103

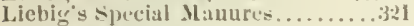

Lime as Maumre................ 215 - Beneficial Effect of for Thirty

Fe:ars.................216

"Changes the Cliemical and Physical Character of the

Soil. .............. 224

" Compu-ting with oid sods...2.4

" for ('abbilge. ... . . ........ 242

* Ilastens the Muturity of the (rop ................222

"Impoverishe. the soil... .....2.2

" in Connecticut.............2.21

. in Delaware. . . . . . . . . . . 223

". in New Jer-ey ................. .

" in Pennsylvania...........22t

"Mired with Bai-uburd Minure...

" $n$ Giras. Land.........

، on Lime--fone Land.... . . . ...217

“ Quantity per Acre.............216

"Sets Free Ammonia in the

Soil..................221

" Silicate Absorbs Ammonia

from Atmosplierc. ......219

6 Then to Apply...........223

"Why Bencticial...........220

Iiquid Minure.................... .

Lowland, I) raining................ 30

Malt-comb. .................. 46

Maigel-wurzels for Manure....... 48 $\because$ " Hanure for $103-286-289$ " Ticld per Acre.... 11

Aranure Absorbing Liquid ..........115 Amount from leced and Bedding ............. is Amount IIade by a llorse

$50-3.16$

- " Made by Horse. Cows, sheep. and Pigs... 51 Amonnt Made on a 250-acre Farm .............. Amonnt of Rain Required to Dissolve..............2 Amount of Straw in Horse.346 and Rotati n of Crops..... 216 Applying Artificial.......312 A pplyine Near the Surface.267 Applying on the Surface...17:3 as Top-dresing..........2.29 Barn-yard for Barley.......210 Barn-yard vs. Artificial fur Indian Corn ..............

(6
Mamure liest for llay............ .

Bunc-du=1 .......311-3it

Brines in livd clover..... 8 \&

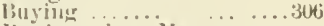
3uying by Measure or II i.ight..............305 Buying by the Load or Ton.306 Cellar...................114 ('hespest a Farmer Can [\$8:. 1:7 ('lover as ............119-122 Clover-seed $a=\ldots . . \ldots \ldots \ldots 127$ Comes from tlie Land.. ... 42 Common sialt as ........200

('omposition of Frosh Barnrard

(ompostion of from j)if. ferent Animals.........306 (') Diffirent Periods........ 57 ('orm-meal for............185) Cost of llauling......... . 312 Cost of Loadincr and D)rawinc.................. ซ7

Cow ...............

1)airy-farm, How to save

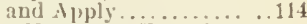

Dr. lalcker's Experiments $01] \ldots \ldots \ldots \ldots \ldots \ldots \ldots . \ldots 1$

Drawing Out to the Field.. 89

Euglisli l'lan of liceping... t? Equivalent to Witcr.......296; Farm-vard for Potatoes . . 261 lermentinuin W int(r.x, $-9: 2-93$ Fermentinir, Slurinkage in..116; Fire-fanc.............41-98 Fislı, as, on loner lsland . 317 boods which Make Rich.... 45 for Cabloge, Parsilips. Onioll:, Carrots, Lettuce, ctc ..............................

for Corn................ so

fur Griss............... 42

for llops......................

for Hlot-beds.............297

for Indiun Corn...........275

for Mangel-wiuzels and Sugar-bects...........257

for .liarket Gurdens... .... 294

for Oats.................252

for Potatoes............. 255

for Seckl-growing Farms. . .296

for sorgbum or Chinese Sigar-cauc.............28?

for Tobacco ........... 275

for Turnips...........285-3*2

for Wheat...................

frow Cows..............30\%

from Earth-cluset..........310

from Oxen .............303

from Pigs, Mr. Lawes' Experiment..............301

from sheep............. 303

Grain Farms, Management

of .................117

Guano price of tow and Thirty Years Ago........328

Guano. Rectified Peruvian.319

Gypsum and Clover as.... 195

Heap, Changes in... ......67 67 
Iannre II ap, Furmentir.g........ as " in Winter......... " Piling in Fic!d.. $8 x-5 !-! n$ "Turning.......... \& IIen............ 43-101-401

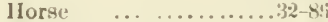

IIorse and Farm-yard ...... 50 IIow and When it should be spplied. .........2\% How Juhn Johinston II anages it ............... 76 Ilow Made and Lowed in Maryland .............319 IIow the Deacon Makes it.. it How to Make ............ t1 Iluw to Mike More..... . . . Ilow (1) Make More and But-

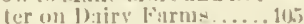
llow to Misk l'vor, Rich, 2. 293

IIuw to Make Ricluer .... 25\% How lluch it Sibrinke by Fermututttion..........3?

Ilow Much Yitrogen in it Load of ...............3ni in Kansa................3tu in Philudrolphin, laterest ing Fuets... ............339

Kerviner Ender cover..... st

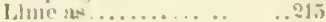

liquirl.......... -.... 36

Man:ogement of in Canmla .335

Mr. Lawes" Experiments with................ 0.5

Lose [rom Lesching....... !y

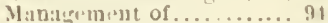

M:irkit Vialne of ............ 101

Mixed wlth Lime............2.

Natural ................23

Night -soil na............3114

Nitrate of solla as......... 13 t

Not A vailalule........... 9.5 on Dairy Farm............101 on P'ormanent Ietoluws nnd listures.

Preserved by the suil .....

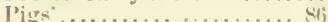

P'iling.................. . 18 ti

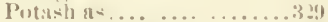

['riec of in Buston ......... it Vlaryland........331 ". ". Nerv II:aven....3I1 " " New York......3 it ". per llorse in Jew

Wrk
(O) (Quantity of lised on loung Jsland. Interesting situ. tiatic .................3.3. Redueed by Fermentation, z:17 Reicher in l'lant-foud than the Food from which it is

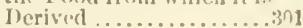
Ser-weed ils.... slyeep. Shonld he liroken lo fine sis soluble l'hosphater in. ... 7* special. .............110 $3: 0$
Manure, Spreific Gravity of from bifferent Animals...... Spread in Open lard.....6.63 stable, Mantegendent... ...250 straw and Chatr as........200 superphosphate, llow IIade................31 Swanp-Ml uck as............ 29 Tauk...................115 the Author's I'lan of Managing................. 83

Tillite as........... $32-121-225$ T'up-dressiug for libent in

$$
\begin{aligned}
& \text { liausan....350 } \\
& \text { on (irowing } \\
& \text { Crops......343 }
\end{aligned}
$$

to That Crops Should it be Applied................265

Value of $\ldots \ldots \ldots \ldots \ldots \ldots$. 78

Value of Irepends in the Food, Notus the Animat. 43

Talue of straw as........123

Witter in................124

11 ceds it ............... 24

Weisht of ..............313 -350

IVell-rutted, Composition of .................... o5

Will-roitide, Luss from l,eaching............... 6.5

That is it y ...........19-2.2

Why 10o 11 e Ferment?

Markct Gurdens, lrierstion in....... 295 .. Matuure for....... $2 y 1$ "I'im-ntanure on.. 2,5

Meadowa, Manure for ............ $2 \% 1$

Niglst soil .................25-308

Nitrible of Inta-h ..... . .......3t?

Nitrate of sinda..................131 Acte (eniclier than Ammonia ......313

" " as a Top-drensing for Wheal........2\%

" " c compostion of....31\%

" $\quad$ " for Apple Trees....314

" " $\quad$ "f for Barley.........213

". $\quad$ " for O.ts ........ 252

.. $\quad$ "for Oniong....... 294

" " " for Sugar-13eets...2s?)

" " sir Wheat....... 159

“" "llow to Apply......312

Vitric Acid...................311

Vitrogen, Amount per icre in the sivil............28-162 as Manure................ 29 in Soil: .....10i-226-336-311 Makes Pour Manure

Rich................. 9.46 Neraerrmen, llanure por............... 1/ats. Experiments on in Virginia..253 Experiments on at Moreton Farm...................254 Iaweq" and Gilbert's Experi.

ments on................252

vanures for...................252

oil eake for shero,................ 6 Onions, Vlanure for..............291 Pitst for Pigs ....................... 17 P'ea-straw for Maure............ 48 
Prat, Composition of............ . 31

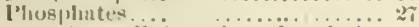
Fibanstion of on batiry Harms............. it)1 Suluble in Barn-yard Manure. .......... 72

Phosphoric Acid in suilo........ 114j-226 * per sere in soils. 16:"Retained by the sioil.

" " Remu ved frum the

Farm by llas, and by Milch Cowe.316 Pig \$ \$nure................. 13-86 * Compusition of . . . . . 30ki

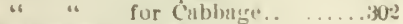

I'jers as Mamure-Makery for Market

Gardeners...................2. . . .

Pigs" Bending. .................. 31

\& for Eurichine janture-Land ....

“ Il ww to Save Manure froba. ...34

“ Nanure frum. .........301-:01

Piling Manure ............. 57

I'hut ford................ . 2i-105

. " $\quad$ Amuant of in an Acre.24 3.5

" $"$ in New aud Cultivited Land................

Master for Indian Curn. ..... . . 27 Juwing in the Full... . ...... 17

Kutash, Amonnt of in the Soil $25-329$ $\because$ แล Manure............. 3:9

“ as Mauure for Wheat.... 215

“ for Cabbages...... . ... . . .

" for Putatoes............25;-260

- for Potiluis and Root. Coins ................330

* Ilow to Ascertaiu wben tbe Suil Needs............3:30

is in Nitrate of Potash..... . 314

". Not a Spccial Munure for Turnipe.......... 3029

“ on Grass Land. . . . . . . . . . 2.3

- oursills nut so likely to be Deficient in, as of Nitrogen and Phosphoric Acirl. 330

" IRetained by the Soil ......219

- Value of iu Artificiul Manures ....

Potatoes, after Root-Crops... . . 257

6. Ammonin for............2til

. Cost of Raising............ 10

6 Experiments on at Horeton Farm........... . 25?

" tor Manure ............. 45

" Jlow to Raise a Large

Crop.................255

"6 Manures for............255

“ Mr.Hunter's Experiments on in England........260

" on Rich Land............. 363

¿6 Profits of Using Artificial Manures on.........263 Will Manure Injure Qual ity of ..............264

Rape-cake ..................46 Roots. Amonnt of Left in Soij by

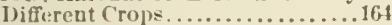

Root-crops................... 17

Rutation of Crops and Manures.....216
Tinalımore, J. II., Letler from.... . 315

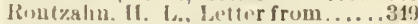

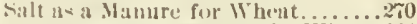

-. ('ommonas Manure for Wheat. 200$)$

". for Mancel-wurka]s .......... . 104

siaw-dinat for Beddiue......... 103

Season, a Punr. l'rolitable for lood Farmers............213

and Nnmure for Oits...... 25:3 Intluence of on the Growth of th hrat............210

Profit in Raising Oats in a Pour .............253

Protit in Ratising [3arley in n pour.............243

Sensons. Intluedee on Crops.......21 seed irowers, Manures for........296; sowate. . . . . . . . . . . . . . . . 308 sheep-Manure........... . 303-33:3-339 Compusition of . . ..306

$\therefore$. Oxen as Mtumre Makers.303 Etelton. Prof. E. M.. Letter from. . 300

Suil, Composition of..........14t-15t Exbaustion of ........2:-2i-3:32

from Warth-closet ............2 Nitromen and P'hosphoris Acid in ...................2. Plast-rood in ................. 105

Weiglt of per Aeir .........221

Suils Abrorb Ammonia from Atmos. phere.................. 219

Ahsorptive Powers of .....217 Sormhim. Hanures for...........28: Special Janures ............... 320 Straw..........20

Amoint if Manure from.....12. and Clunff for Mauure.......200 for iianuris.............. 48

* on Grain Farms..............118

. Selling... ............... 123

Sturtevant. Dr. E. L., Letter from 311 superphospliate.............. 116

\begin{tabular}{|c|c|}
\hline & for Burley.......241 \\
\hline 6 & for Indian Corn. .27! \\
\hline " & for I'otatoes . . . . . 259 \\
\hline ". & $\begin{array}{l}\text { for Private Gar. } \\
\text { dens........... 26; }\end{array}$ \\
\hline “ & for Turnips. .285-322 \\
\hline 6 & for Wheat ..... 168-16! \\
\hline 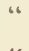 & $\begin{array}{l}\text { from Bones, Com- } \\
\text { position of... } 319\end{array}$ \\
\hline "6 & $\begin{array}{c}\text { Prom Mineral } \\
\text { Phosphaies... } 320\end{array}$ \\
\hline "6 & How Applied... \\
\hline "6 & on Dairy Farms . 315 \\
\hline 6. & on Griss Lind .. 273 \\
\hline 66 & $\begin{array}{l}\text { Talne of as Com } \\
\text { pared with Bune- } \\
\text { Dust.............319 }\end{array}$ \\
\hline 66 & $\begin{array}{l}\text { What Crops Best } \\
\text { for .............243 }\end{array}$ \\
\hline
\end{tabular}

Saperphospate of Lime Doctor Telis How it is Made... .... 317 Superphosphate of Lime, When First Made in the United'States 324 Surface Application of Mauure. .70-268 Swamp-mnck............... an " Swine, see Pigs................. 
Thumne. J T.. Remarka on llir .1 p plientluts of Vianure.

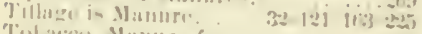

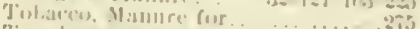

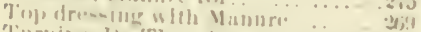

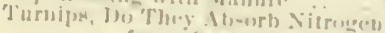
from ibn Aeme-ple ri. .

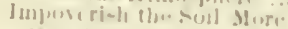

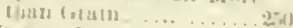

* Mulurefor........... “. and It lieste. Specelaj Ma nures for .......... Mat

Erime from Farm Inimale Rieher than IJ umun .......... v. Sullil Manuie...........

Ialmalion of Firtllzots ...

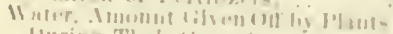

lluring The Ir tirumth.... . 1?

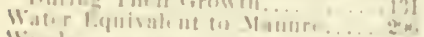

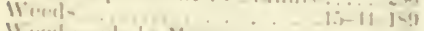

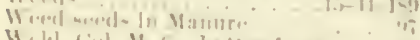

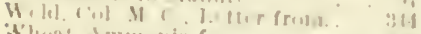

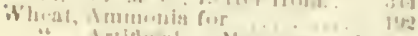

" Arritle asl Vusuria for shoulal ln brillowl in wlets

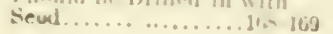

Whan, Cummon Salt an Manure for 2 m

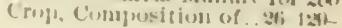

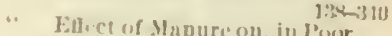
(indr

. In⿴囗十⺝

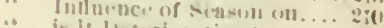

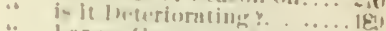

$\because \quad$ larger ('rupk per lers.......

"Lanes and

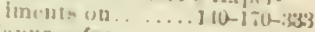

* Manura- for............

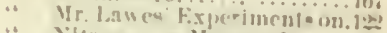

" Xilirigera as Manure for ..1.11

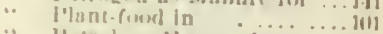

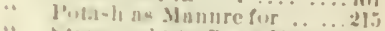

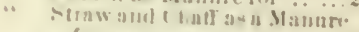
for $\ldots$......

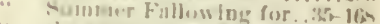

$\therefore$ the sllut rolponsame land :13

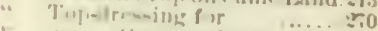

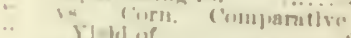

. yl the of .....

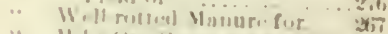

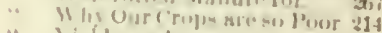

. L iefd per Acre........... 11 
Commended by the Greatest Educators of Germanj, England and the Onited States. Endorsed by Offtclals, and adopted in many Schools

\section{DeW

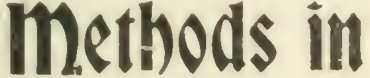 \\ Education}

Art. Real Manual Tralning, Nature Study. Explainlag Processes whereby Band, Eye and Mind are Educated by Means that Conserve Vitallity and Develop a Union of Thought and Action

\section{By J. Cibirty Cadd}

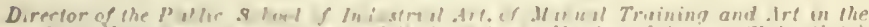

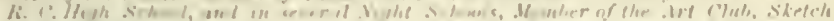

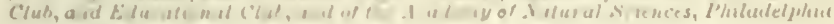

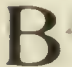

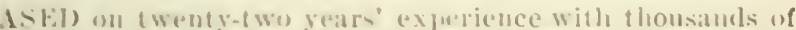

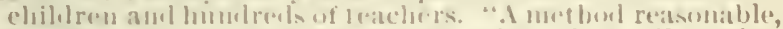

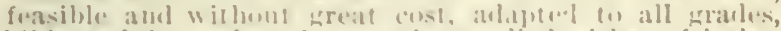

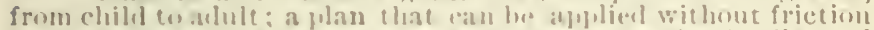
to every kiml of edlutational institution or to the fotmily, and

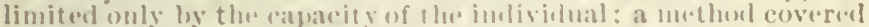
by natural law, workior will the aloulute procision of nature it-

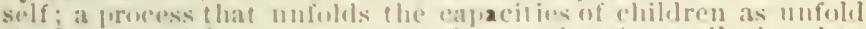

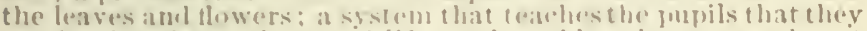
are in the plan amel part if life, amel anahles them to work ont their ow $n$-alvatim on the tros lines of design and work as illıstrated in every matural thimg."

\section{P Wealth of Illustration-478 Pietures and 44 Full-Page Plates}

showinn children and fonelurs fracticing these new methems or their work. A revelation twall insere-ted indrevelogingthe wonderful capabilitios of youmz or olel. 'lihe pictures iustautly fascinate every child, imbuing it wils a olesiro to do likewise.

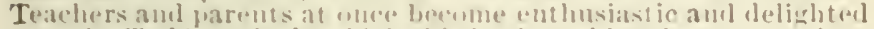

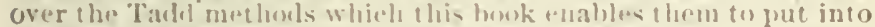
practice. Sut a liackufyenl tlomelit nor a stale pieture. Fresh, new, practical, scintitic, iuspiring

\section{AMONG THOSE WRO ENDORSE THE WORK ARE}

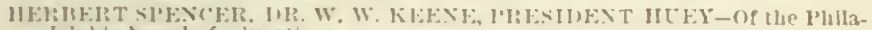

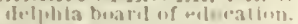

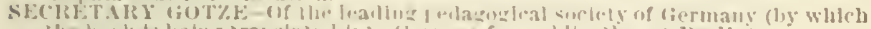

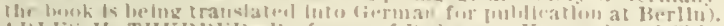

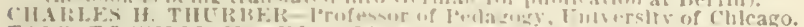

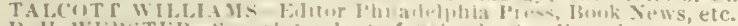

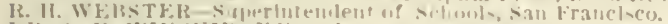

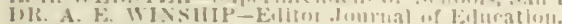

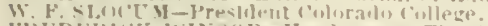

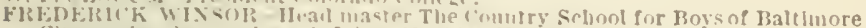

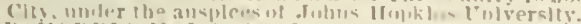

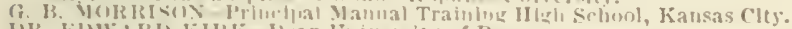

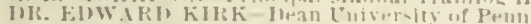

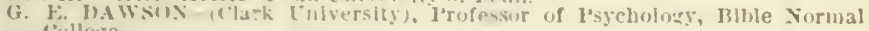
rimllege.

RUMAN STEINER-Baltimore.

SPECIFICATIONS : Size, $7{ }^{\prime}{ }^{\prime} \times n^{1}{ }_{2}$ lmwes, almost a quartn: 456 pages, fine plate

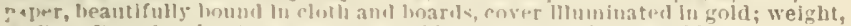
14/2lis. Hoxed, price $\$ 3.00$ get, poitualil th any part of the world.

\section{Orange Judd Company}

New Yor , N. Y., 52-54 Lafayette Place. Springfield, Mass, Homestead Bdg. Chicago, Ill., Marquette Building. 



\section{Greenhouse Construction.}

By Prof. I. I. laft. A complete trontise on Ereenhouse structures and arrangemi-mes of thi" varlous forms anil styles we folat lomses for professional florists as well as gmat, urs. All the best and most afproved structures are so fully and clearly desiribed that angome who desires

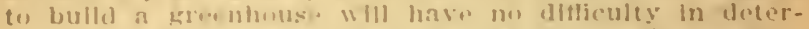
minime the kund bet suftel to hls purjuse. The modern mul most sure.s.a!ul me thods of heathe and ventlluting

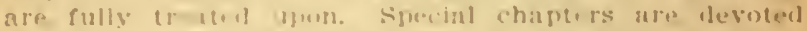

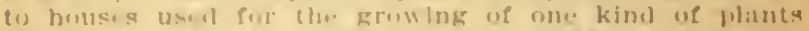
exclusively: Tho comstruetion of hotheds nucl frames

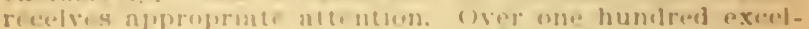

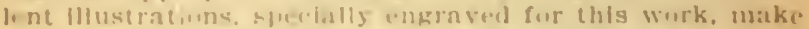

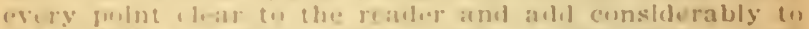
the artiste asple rance of the houk. ('loth, 1:mos. \$1.50

\section{Greenhouse Management.}

Iy" I. T.. Taft. "lihls buok forms an almogt Indigpenga-

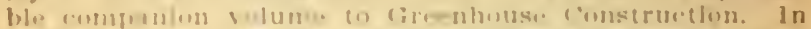

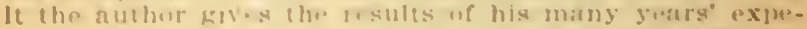
rlente, together bith that of the most sucerssful flurists

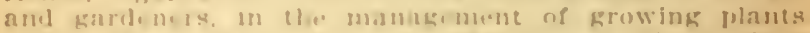

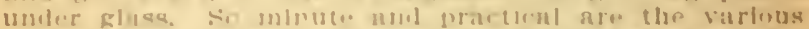

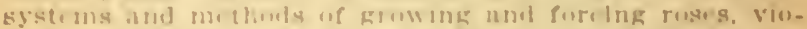
lots. carnations, anl ull the most important florlsts plante, as well ma fruits nmel vergetableg described, thet Ly at careful stuely ut this wurk nnit the following uf Its

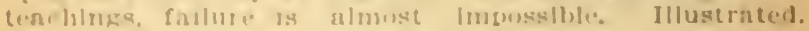
("loth, I:mono.

$\$ 1.50$

\section{Bulbs and Tuberous-Rooted Plants.}

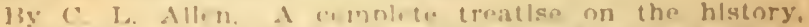

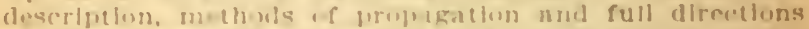

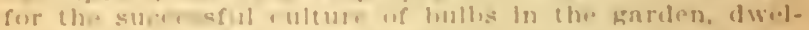

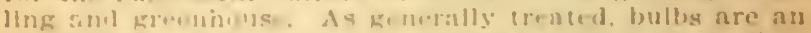
(xpunsi, luxury, whlle when prefuerly managed, thay

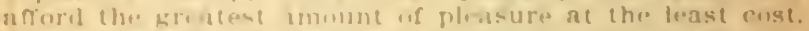
"lhe author of this lukk has for many years mad.. Lulh [erumlng a sperlably, amul is a reconglzed authority on their cultention anid management. The lllustrations whleh +mbelllsh this wark hav. b...n drann frum nature.

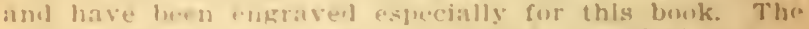
cultural direcinns are plalnly staterl, practical and (1) the point. 1\%uth. 12m110. . . . . \$1.50

\section{Irrigation Farming.}

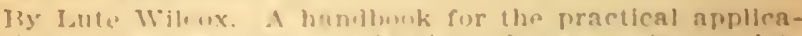
thon of water in the profluction of cropse. A complete

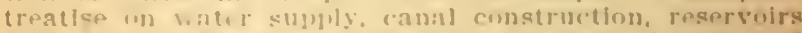

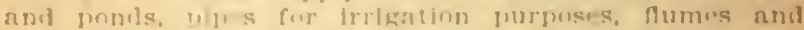
the ir strueture, me thouls uf atpplying water, irrixation of

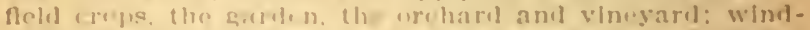
mllis ant fHumb. ajpllamis and "ontrlvances. I'rofuarIs", handsumely" ubustentul. ("luth, 12ro. . . \$1.50 

THE LIBRARY

UNIVERSITY OF CALIFORNIA

Santa Barbara

THIS BOOK IS IUUE ON THE LAST DATE STAMPED BELOW.

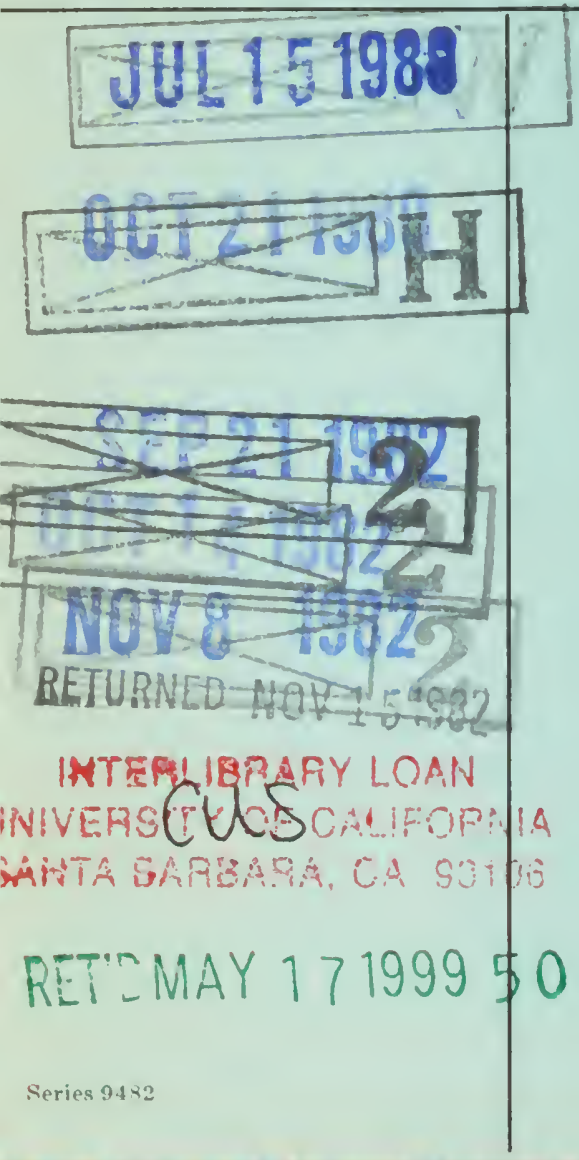




\section{1 prestom

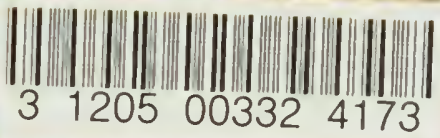

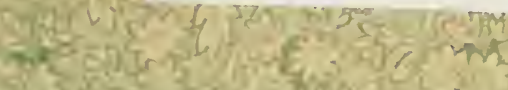

24

ses.

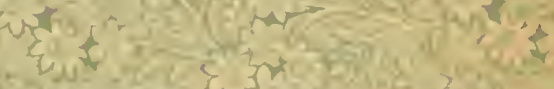

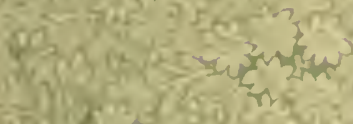
UC SOUTHERN REGIONAL LIBRARY FACILITY
\|\|$\|$ AA 0009915398
th

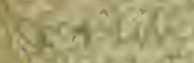 \\ $2 \sqrt{2}+m^{2}$

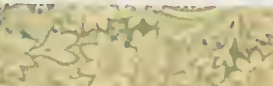

W. $x$ in

$\Rightarrow \cos ^{2}$

$\frac{\pi}{x}$

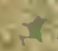

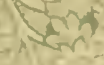

तrd

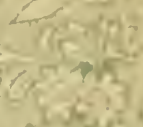

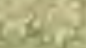

at

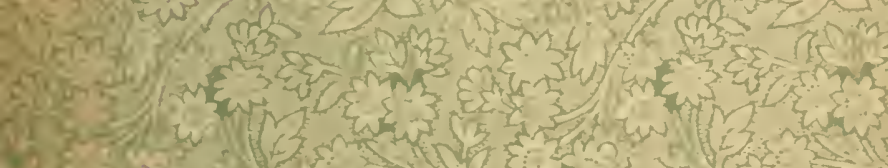

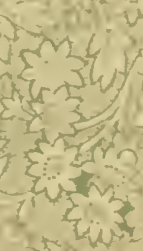

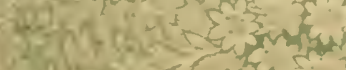

wers

intar

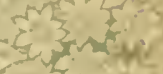


